THIAGO BORGES DE AGUIAR

\title{
Jan Hus: \\ As cartas de um educador e seu legado imortal
}

FEUSP

São Paulo

2010 
THIAGO BORGES DE AGUIAR

\section{Jan Hus: \\ As cartas de um educador e seu legado imortal}

Tese apresentada à Faculdade de Educação da Universidade de São Paulo para obtenção do título de Doutor em Educação

Área de Concentração: História da Educação e Historiografia

Orientadora: Prof. ${ }^{a}$ Dr. ${ }^{a}$ Maria Lúcia Spedo Hilsdorf

FEUSP

São Paulo

2010 
Autorizo a reprodução e divulgação total ou parcial deste trabalho, por qualquer meio convencional ou eletrônico, para fins de estudo e pesquisa, desde que citada a fonte.

Catalogação na Publicação

Serviço de Biblioteca e Documentação

Faculdade de Educação da Universidade de São Paulo

37(09) Aguiar, Thiago Borges de

A282j Jan Hus : as cartas de um educador e seu legado imortal / Thiago Borges de Aguiar ; orientação Maria Lúcia Spedo Hilsdorf. São Paulo : s.n., 2010.

305 p. : il.

Tese (Doutorado - Programa de Pós-Graduação em Educação. Área de Concentração : História da Educação e Historiografia) - - Faculdade de Educação da Universidade de São Paulo.

1. Hus, Jan, 1369?-1415 2. História da educação 3. Cartas - Educação História 4. Boêmia - Educação - História - Século XV I. Hilsdorf, Maria Lúcia Spedo, orient. 
Thiago Borges de Aguiar

Jan Hus: As cartas de um educador e seu legado imortal

Tese apresentada à Faculdade de Educação da Universidade de São Paulo para obtenção do título de Doutor em Educação

Área de Concentração: História da Educação e Historiografia

Aprovado em:

Banca Examinadora

Prof. Dr.

Instituição: Assinatura:

Prof. Dr.

Instituição:

Assinatura:

Prof. Dr.

Instituição: Assinatura:

Prof. Dr.

Instituição: Assinatura:

Prof. Dr.

Instituição: Assinatura: 


\section{DEDICATÓRIA}

Dedico este trabalho à memória de Maria Luiza Canton Cola Francisco, essa grande mulher que com seu exemplo mostrou a todos os que com ela conviveram o verdadeiro sentido de lutar por aquilo que vale a pena, apesar de todos os obstáculos, com um sorriso no rosto. 


\section{AGRADECIMENTOS}

À minha orientadora, professora Maria Lúcia Spedo Hilsdorf, pela confiança, dedicação e presença ao longo destes cinco anos de trabalho. Você foi uma verdadeira mestra nesta caminhada acadêmica.

Ao professor Waldir Cauvilla, pelo apoio, pela amizade e pelas palavras que, em nossos encontros, deixaram marcas indeléveis.

Às professoras Ana Chrystina Venancio Mignot e Juçara Luzia Leite que, em momentos diferentes de elaboração da pesquisa, deram recomendações muito importantes para o aprimoramento do trabalho.

Ao professor Lúcio Kreutz pelas sugestões fundamentais que ofereceu na transição desta pesquisa do mestrado para o doutorado direto.

Ao senhor Renato Emir Oberg, por ter enfrentado o desafio de pesquisar a figura de Jan Hus na década de 1970 e ter provocado uma mudança profunda em minha pesquisa após um domingo conversa e o empréstimo de livros importantes.

Aos queridos companheiros de pesquisa do Grupo de Estudos História da Educação e Religião, pelas oportunidades de aprendizado, estudo e trabalho coletivo banhadas por gostosas risadas.

A toda a comunidade da escola Arraial das Cores, lugar onde tive a oportunidade de crescer pessoal e profissionalmente, vivendo uma experiência educativa única como professor. Um abraço especial para a Michelle e para a Carolina pelo apoio constante nestes cinco anos de convívio.

À Faculdade de Educação da Universidade de São Paulo, professores e funcionários que tanto contribuíram para minha formação e para a realização desta pesquisa.

Ao Ministério das Relações Exteriores da República Tcheca, Consulado Tcheco em São Paulo e União Cultural Tcheco Brasileira pelas oportunidades proporcionadas pelo oferecimento gratuito do curso de tcheco em São Paulo e pelo contato com a comunidade tcheca no Brasil.

À Petra Mocová, minha professora de tcheco, que me ensinou mais do que a conhecer a língua tcheca, ajudou-me a admirar a sua cultura e me incentivou a querer conhecer cada vez mais da história de seu povo. Děkují moc.

A meus grandes amigos Paulo Henrique de Figueiredo, Sueli Righi e Álvaro Antonio de Paula que possuem um lugar reservado em meu coração e nem conseguem imaginar o quanto ajudaram para que este trabalho acontecesse.

À minha família, pela presença indispensável, a começar por minha mãe, Suely, e por todas essas pessoas maravilhosas com quem compartilho a oportunidade de viver a vida: Luiza, 
João, José Eustáquio, José Renato, Rosa, Gerônimo, Eneas, Mirele, Alan e Maria Luiza (in memoriam).

Por fim, que vale como se fosse o início de tudo, à minha amada Marla, que nestes muitos anos de convívio, ensinou-me que compartilhar é, de fato, fazer parte da vida um do outro. Este trabalho não existiria sem você.

Nestes cinco anos de trabalho, aprendi que nada se constrói sozinho. Tive tantas ajudas que nomeá-las todas seria impossível. A todos aqueles que me ajudaram a realizar este projeto, deixo meu forte abraço de agradecimento. Se não tive como escrever seu nome nestas páginas, saiba que ele está escrito em meu coração. 
"Stat rosa pristina nomine, nomina nuda tenemus."

“A rosa do passado é apenas um nome, simples nomes nos são legados.”

Verso de um poema do século II citado por J. Huizinga

"Dávno Čechové ř́kali a př́sloví měli, že podle dobrého pána dobrá jizda bývá"

"Há muito tempo os tchecos diziam e tinham um provérbio [que afirmava] se um líder é bom, boa será a marcha."

Trecho do hino hussita "Ktož jsú boží bojovníci” 


\section{RESUMO}

AGUIAR, Thiago Borges de. Jan Hus: As cartas de um educador e seu legado imortal. 2010. 305 f. Tese (Doutorado). Faculdade de Educação, Universidade de São Paulo, São Paulo, 2010.

Esta tese é um estudo da figura de Jan Hus, tradicionalmente conhecido como reformador religioso da Boêmia do século XV, olhando-o sob a perspectiva da História da Educação. Inspirados nas propostas metodológicas de Carlo Ginzburg para a construção da narrativa histórica a partir do estranhamento das fontes, o paradigma indiciário, analisamos as cartas escritas por Hus. Iniciamos com um estudo de como essas cartas, escritas há quase seiscentos anos, podem ser lidas levando em conta sua historicidade, estrutura retórica, edição e tradução. Identificamos a rede de relações que essa correspondência engendrou e observamos uma intenção educativa da parte do autor das cartas ao escrevê-las. Selecionamos um conjunto de vinte e três cartas que denominamos de "pastorais" e nelas encontramos um padrão de escrita voltado a dar continuidade à tarefa pastoral que Hus realizava na Capela de Belém, constituindo sua ação educativa por meio de cartas. Também analisamos a relação educador-educando que Hus estabeleceu com seu discípulo Martin de Volyně. Por fim, partimos do relato de Petr de Mladoňovice e das edições traduzidas das cartas de Hus para observar a construção, rememoração e recriação do legado educativo deixado por Hus de mártir e mestre defensor da verdade. Concluímos com um questionamento para a História da Educação do lugar que esse personagem ocupa atualmente e como esse lugar é, e pode ser, construído pelo historiador.

Palavras-chave: História da educação, Jan Hus, Cartas, Boêmia, Educadores medievais 


\begin{abstract}
AGUIAR, Thiago Borges de. Jan Hus: The letters of an educator and his immortal

legacy. 2010. 305 f. Tese (Doutorado). Faculdade de Educação, Universidade de São Paulo, São Paulo, 2010.

This thesis is a study of the figure of Jan Hus, traditionally known as the Bohemian religious reformer of the fifteenth century, looking at it from the perspective of the History of Education. Inspired by Carlo Ginzburg's methodological proposals for the construction of historical narrative from the strangeness of the sources, the evidential paradigm, we analyze the letters written by Hus. We begin with a study of how these letters, written nearly six hundred years ago, can be read taking into account its historicity, rhetorical structure, editing and translation. We identify the network of relationships that engendered this correspondence and watch an educational intention of the author of the letters on writing them. We selected a set of twenty-three letters that we called "pastoral" and in them we find a pattern of writing intended to continue Hus' pastoral task that was performed at the Bethlehem Chapel, constituting its educational activities through letters. We also analyzed the relationship between educator-learner that Hus established with his disciple Martin of Volyně. Eventually, based on the report of Petr of Mladoňovice and the translated editions of the letters of Hus we look into construction, remembering and rebuilding the educational legacy left by Hus of martyr and master defender of the true. We conclude with a question for the History of Education concerning the place that currently occupies this character and how this place is and can be constructed by the historian.
\end{abstract}

Keywords: History of Education, Jan Hus, Letters, Bohemia, Medieval educators 


\section{RESUMÉ}

AGUIAR, Thiago Borges de. Jan Hus: Dopisy edukátora e jeho nesmrtelné poselství. 2010. 305 f. Doktorandská práce. Pedagogická fakulta, Univerzita São Paulo, São Paulo, 2010.

Tato doktorandská práce je studií osobnosti Jana Husa, především známého jako českého náboženského reformátora 15 . století, z úhlu pohledu dějin výchovy. Necháme se inspirovat metodologickými návrhy Carla Ginzburga k výstavbě historických vyprávění, která vycházejí z nejrůznějších zdrojů, paradigmatických indicií - takto zkoumáme dopisy napsané Husem. V úvodu práce nalezneme studium toho, jak tyto dopisy, napsané téměř před šesti sty lety, mohou být čteny a chápány $\mathrm{z}$ hlediska historického, řečnického, vydavatelského a předkladatelského. Dále je možné sledovat celou řadu impulzů, které daly vzniknout této korespondenci a vypozorujeme autorův výchovný záměr. Je vybráno dvacet tři dopisů, které lze nazvat jako "kazatelské” a v nich nalézáme určitý způsob psaní, který vlastně pokračuje v jeho kazatelské činnosti, kterou Hus vykonával v Betlémské kapli, a takto potom pokračoval ve své výchovné činnosti např́č svými dopisy. Také je předmětem této práce vztah vychovatele a vychovávaného, který Hus vytvář́ se svým následovatelem Martinem z Volyně. Ke konci práce se opíráme o stat’ Petra z Mladoňovic a o různá přeložená vydání dopisů Jana Husa. To nám slouží $\mathrm{k}$ tomu, abychom vypozorovali stavbu, opětovné připomenutí a předávání výchovného poselství zanechané Husem, mučedníkem, Mistrem a obráncem pravdy. V úplném závěru se zabýváme otázkou vztahující se přímo $\mathrm{k}$ dějinám výchovy. Pokoušíme se dospět $\mathrm{k}$ tomu, jaké místo $\mathrm{v}$ současné době zaujímá tato osobnost a jaké stanovisko k tomuto místu může zaujmout současný historik.

Klíčová slova: Dějiny výchovy, Jan Hus, Dopisy, Čechy, Edukátoři stř̌edověku 


\section{LISTA DE FIGURAS}

Figura 1. Mapa do reino de Venceslau IV no século XIV

Figura 2. Bandeira do Governo da República Tcheca

Figura 3. Principais edições das cartas de Hus - linha do tempo

Figura 4. Cartilha de Hus

Figura 5. Reprodução em diagramação moderna da cartilha de Hus

Figura 6. Percurso aproximado da viagem de Hus à Constança

Figura 7. Monumento a Jan Hus em Constança marcando o local onde ele foi queimado

Figura 8. O rosto de Hus no Jeský Kodex

Figura 9. O rosto de Jerônimo de Praga no Jenský Kodex

Figura 10. Cristo transmitindo seu sacerdócio, detalhe, Jenský Kodex

Figura 11. Detalhe do rosto de Jan Hus num livro de orações hussita de 1563

Figura 12. Detalhe do rosto de Jan Hus em duas imagens da crônica de Ulrich de Richental (1464)

Figura 13. Detalhe do rosto de Jan Hus em duas imagens do Cancioneiro de Litoměřice (século XVI)

Figura 14. Jan Hus na gravura de Theodore de Bry, editado por J. J. Boissard

Figura 15. Detalhe do Rosto de Jan Hus na gravura publicada pela revista Life

Figura 16. Jan Hus, gravura de Hans Guldenmundt

Figura 17. Jan Hus, gravura de Jacques Grandhomme

Figura 18. Detalhe do rosto de Jan Hus nos quadros de Carl Friedrich Lessing e Václav Brožík (século XIX)

Figura 19. Detalhe do rosto de Jan Hus na estátua da Staroměstské Náměstí em Praga

Figura 20. Mestre Jan Hus no Púlpito, Códice de Jena

Figura 21. Imolação de Hus no Códice de Jena

Figura 22. Imolação de Hus no Códice de Jena (xilogravura)

Figura 23. Hus no Concílio de Constança, figura do Cancioneiro de Litoměřice 
Figura 24. Hus no Concílio de Constança, de Carl Friedrich Lessing Figura 25. Hus no Concílio de Constança, de Václav Brožík

Figura 26. Hus indo para a fogueira, Crônica de Ulrich de Richental Figura 27. Hus na fogueira, Cancioneiro de Litoměřice

Figura 28. Jan Hus na Fogueira, num livro de orações hussita de 1563

Figura 29. Estátua de Jan Hus na Staroměstské Náměstí em Praga Figura 30. Capa do fascículo 27

Figura 31. Os pensadores da tradição protestante, gravura do século XVI Figura 32. Jan Hus, do livro de história ilustrada tcheca para crianças Figura 33. "Guerreiros de Deus", no livro História do bravo povo tcheco Figura 34. Detalhes da imagem anterior Figura 35. Jan Hus escrevendo 


\section{SUMÁRIO}

Introdução .......................................................................................... 14

a. O problema da distância na construção da narrativa histórica..........................................22

Capítulo 1. As cartas de Jan Hus ........................................................ 37

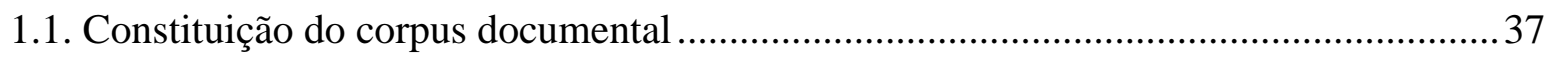

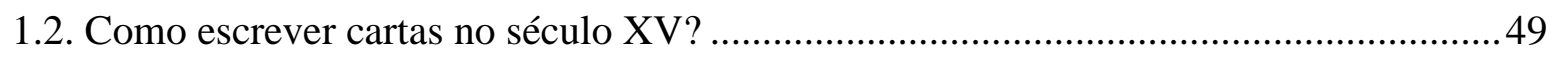

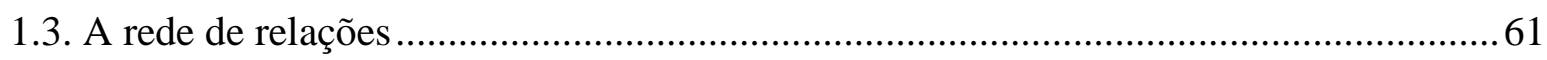

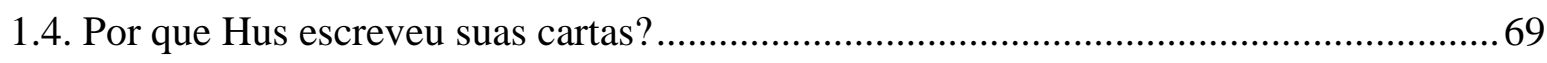

Capítulo 2. A construção de um educador por suas cartas.............. 92

2.1. A construção de um padrão de escrita ..................................................................... 94

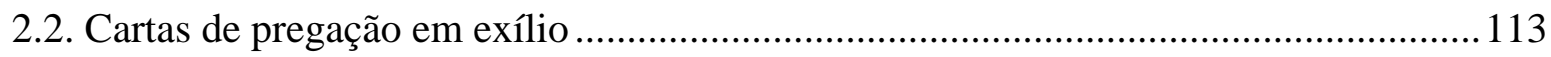

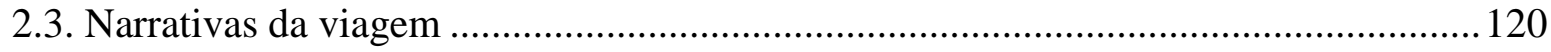

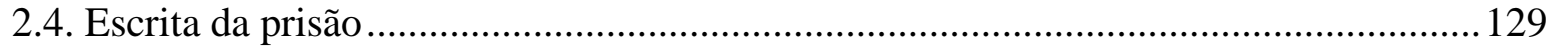

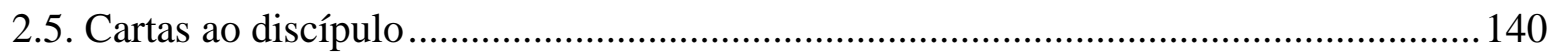

Capítulo 3. A construção de um educador por seu legado ............. 158

3.1. A construção de um legado em seus primórdios: morte e verdade ............................ 159

3.2. A expansão da memória de Hus além da Boêmia ................................................... 178

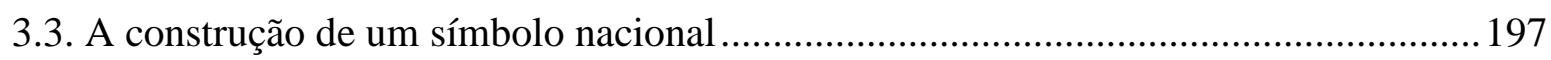

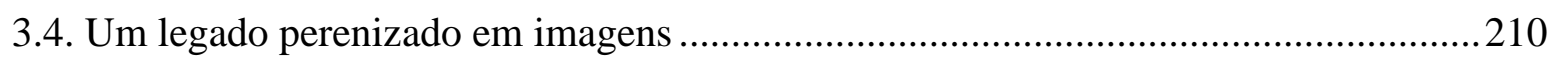

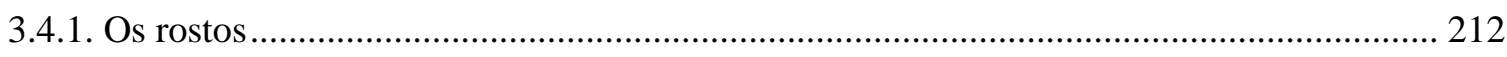

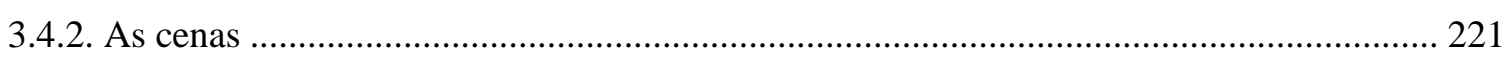

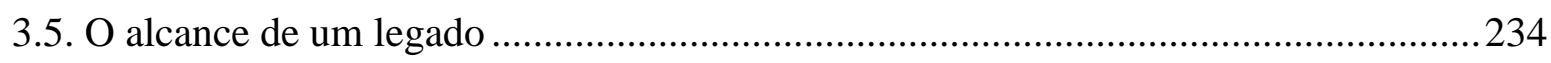

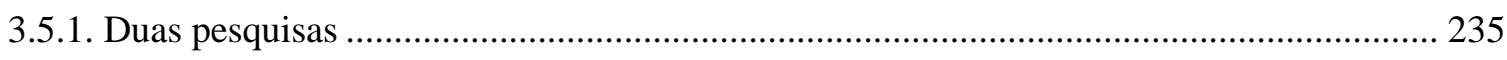

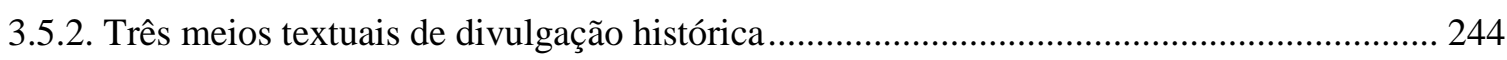

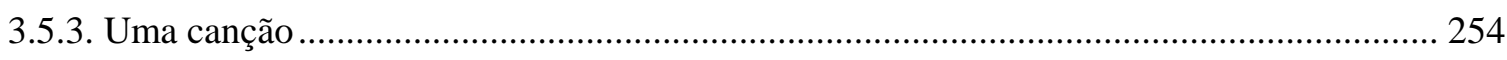

Conclusão: o educador pela História da Educação .................... 257

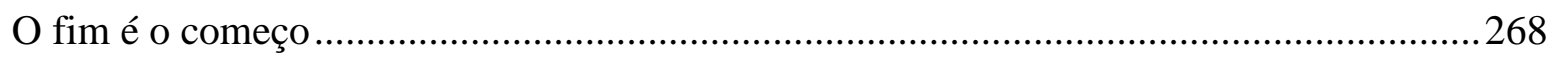

Referências Bibliográficas .................................................... 276

Apêndice 1. Cartas de Hus por edição. ................................... 291

Apêndice 2. Tradução de duas cartas de Hus............................. 295 


\section{Introdução}

Quando eu era um estudante de teologia em Erfurt, aconteceu de chegar às minhas mãos, certo dia, na biblioteca do mosteiro, um volume dos sermões de Jan Hus. Ao ler na capa daquele trabalho as palavras Sermões de Jan Hus, em mim imediatamente acendeu o desejo de apurar, por meio da leitura daquele livro que escapou das chamas e estava conservado numa biblioteca pública, quais heresias ele havia disseminado. Eu me abatia pelo espanto ao ler o livro e estava preenchido por uma surpresa difícil de descrever ao procurar por um motivo pelo qual um homem tão grandioso - um doutor, tão digno de veneração e tão poderoso na exposição das Escrituras - foi queimado até a morte. Mas o nome de Hus era, naquela época, tal objeto de execração que eu acreditava plenamente que se eu falasse qualquer elogio a seu respeito, os céus cairiam sobre mim e o sol ocultaria sua luz. (Martinho Lutero, prefácio às cartas de Hus publicadas por ele em 1537)

Estudando a figura de Jan Hus nos últimos anos, não encontramos melhor expressão da ambiguidade que sua imagem provoca nas pessoas que estas palavras do reformador Martinho Lutero. Muitos nunca ouviram falar nele. Para alguns, concordando com Lutero, ele foi um grande reformador do Cristianismo e da Igreja Católica, "digno de veneração", antes da Reforma Protestante. Para outros, um heresiarca a tal ponto que falar bem dele provocaria “os céus caírem sobre as cabeças e o sol se apagar".

Para seus contemporâneos, ele era "um mestre da vida sem comparação" que "reavivou no clero e no povo a vida correta da igreja primitiva" ou "um pregador errôneo e escandaloso, contrário à Madre Igreja e desviante da fé" ${ }^{2}$. Para a História da Educação ele foi "uma das grandes figuras nacionais tchecas ao defender a figura de Wyclif"3, alguém que "deu uma contribuição concreta à instrução, codificando a ortografia tcheca e redigindo um silabário"4 ou simplesmente ninguém digno de nota ${ }^{5}$.

\footnotetext{
${ }^{1}$ Testemunho da Universidade de Praga sobre Jan Hus, Monumenta, 1:103 apud SCHAFF, David S. John Huss: his life, teachings and death after five hundred years. Eugene, Oregon: Wipf and Stock Publishers, 2001. Publicação original: Nova York: Charles Scribner \& Co, 1915, p. xi.

${ }^{2}$ Esta foi uma das acusações, encaminhadas ao arcebispo de Praga, feitas por clérigos contrários às ideias reformistas de Hus e seus companheiros. Hus respondeu a elas numa carta (número 8) ao arcebispo, escrita entre agosto e setembro de 1408. A acusação é reproduzida por Hus no início da carta.

${ }^{3}$ DENIS, Marcelle. O mundo eslavo. In: MIALARET, Gaston; VIAL, Jean (dir). História mundial da educação. Volume I: das origens a 1515. Porto, Portugal: Rés Editora, s/d, p. 296.

${ }^{4}$ MANACORDA, Mario Alighiero. História da educação. São Paulo: Cortez/Autores Associados, 1989, p. 194.

${ }^{5}$ CAMBI, Franco. História da pedagogia. São Paulo: Editora Unesp, 1999, por exemplo, não cita Hus.
} 
Quem estaria com a razão? Um breve esboço biográfico parece contradizer as avaliações negativas a seu respeito. Hus nasceu em data incerta, entre os anos de 1369 e 1372, na vila de Huscinec, na região da Boêmia, reino do Sacro Império Romano-Germânico, parte de onde se localiza hoje a República Tcheca, na Europa Central (figura 1). No ano de 1402, Jan [João] de Husinec já era um clérigo, isto é, um sacerdote e um "homem de saber"6, estudante de teologia e professor da Universidade Carlos de Praga quando assumiu o comando de uma capela de nome Belém. Essa capela fora construída com apoio de comerciantes e nobres na capital do reino, Praga, para a pregação da "palavra de Deus" na língua tcheca, expressão de um movimento de valorização do vernáculo frente à imposição da língua alemã. ${ }^{7}$

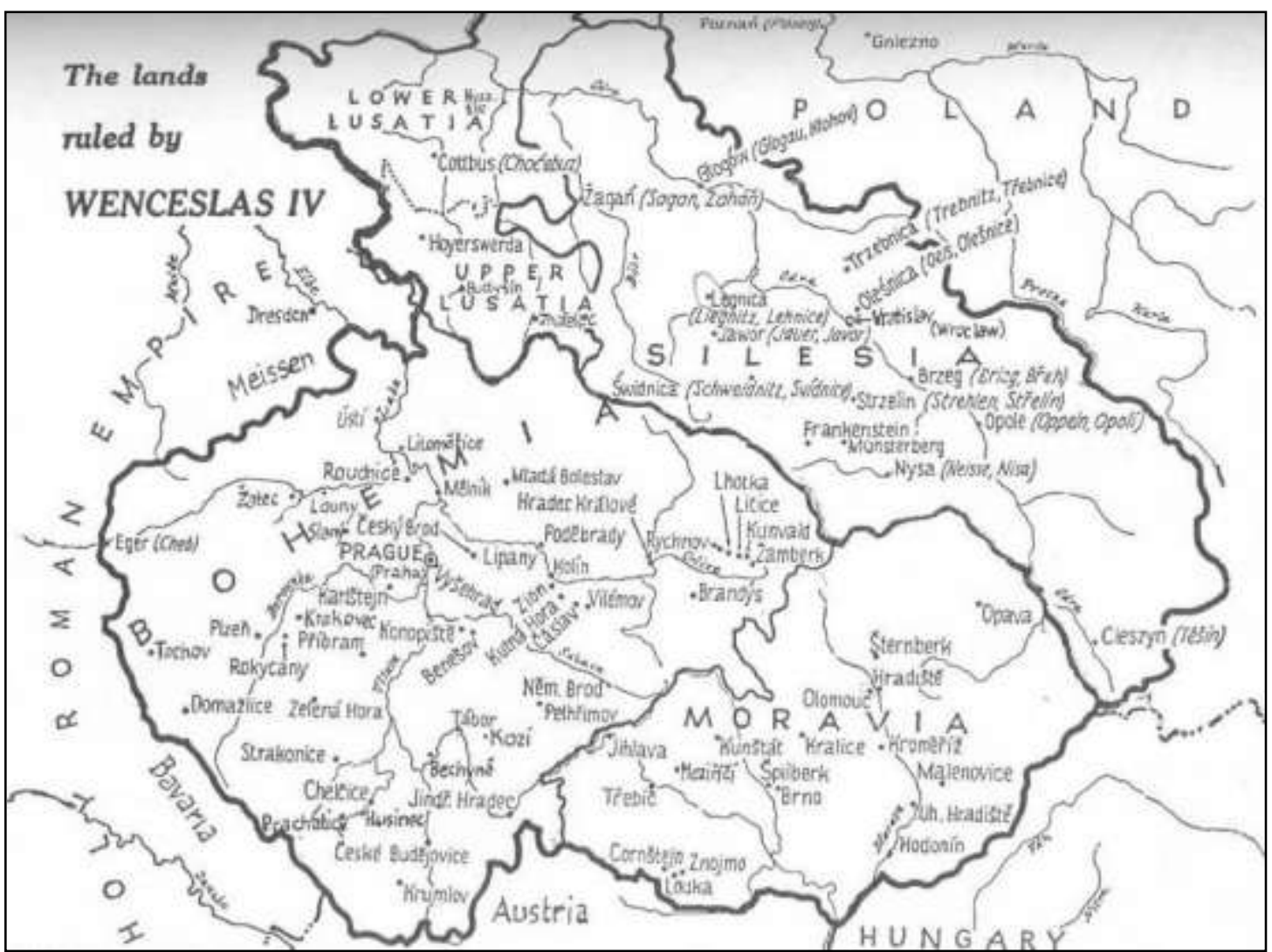
Figura 1. Mapa do reino de Venceslau IV no século XIV
(Fonte: SPINKA, John Hus: a biography)

\footnotetext{
${ }^{6}$ Como utiliza VERGER, Jacques. Homens e saber na idade média. Tradução de Carlota Botto. Bauru, SP: EDUSC, 1999.

${ }^{7}$ Hus, em outra de suas cartas (número 2, de janeiro de 1404), escrita a um professor alemão da Universidade de Praga, afirma ser senso comum a ideia que os alemães são hereges e os tchecos ladrões, confirmando que havia acusações mútuas entre esses povos naquela época. PORTAL, Roger. Os eslavos: povos e nações. Lisboa: Edições Cosmos, 1968, p. 17, trata da relação entre tchecos e alemães como um "antagonismo secular" entre esses povos.
} 
Ao longo de sua vida, conquistou muitos amigos. Da corte real, era confessor da rainha Sofia e amigo do rei Venceslau [Václav] IV. Em sua capela, chegavam nobres, burgueses, artesãos, mestres, estudantes e servos. E lá, já conhecido como Jan Hus, propunha em seus sermões uma vida de retidão, a compreensão das escrituras e a coerência do clero. $\mathrm{Na}$ Universidade, tornou-se líder de um movimento nacionalista que culminou, em 1409, com a saída dos professores e alunos alemães. ${ }^{8}$ Ocupou, então, a reitoria daquela instituição.

Reuniu, porém, inimigos. De alguns clérigos que se sentiam atacados por suas ideias, aos professores alemães que deixaram a Universidade. Mas, principalmente, de alguns professores tchecos e do arcebispo de Praga, Zbyněk, que discordavam das posições de Hus. A Cúria romana passou a persegui-lo, excomungando-o por duas vezes. Opôs-se a uma bula papal e foi obrigado a se exilar. A pedido do rei Venceslau, foi à Constança, cidade beirando o lago com o mesmo nome - localizado hoje ao sul da Alemanha, próximo à fronteira com a Suíça - onde ocorria um concílio. Esse concílio (1414-1418) foi convocado para acabar com os movimentos heréticos e com a crise da Igreja, que estava com três papas simultâneos. Lá, Hus pensava poder expor suas ideias, embora soubesse dos riscos de não mais voltar. Passou cerca de oito meses preso e foi condenado como heresiarca, ou seja, criador e difusor de uma heresia. Foi morto na fogueira.

Sua história foi recontada de diversos modos ao longo dos séculos seguintes, num contínuo movimento de reescrita e rememoração. Por isso, sua imagem se modificou bastante. Foi considerado mártir da Reforma Protestante, precursor de Lutero. Virou símbolo tanto da independência tcheca quanto da imposição do comunismo soviético. ${ }^{9}$ Hoje, na República Tcheca, tem um lugar de destaque como símbolo nacional. A bandeira do presidente da república tcheca (figura 2) exibe um brasão com leões, águias e a expressão "pravda vítězi". Essas palavras em tcheco significam "a verdade vence" e foram atribuídas aos seguidores de

\footnotetext{
${ }^{8}$ A Universidade de Praga seguia o modelo da Universidade de Paris, tendo alunos e professores organizados em quatro nações, a saber, tchecos, poloneses, bavários e saxões. Três nações eram compostas por estrangeiros e os alemães acabaram por se tornar os mais numerosos. Em 1409, o rei Venceslau IV assinou o decreto de Kutná Hora, fazendo com que a nação tcheca tivesse mais poder sobre as decisões na universidade do que as nações estrangeiras. Professores e alunos alemães saíram da Universidade de Praga e fundaram a Universidade de Leipzig. Ver, por exemplo, LE GOFF, Jacques. Os intelectuais na Idade Média. Tradução de Marcos de Castro. Rio de Janeiro: José Olympio, 2003, pp. 102 e 178 e SPINKA, Matthew. John Hus: a biography. Princetown, New Jersey, EUA: Princetown University Press, 1968, pp. 25, 96-98.

${ }^{9}$ CHODAN, Tim. The use and abuse of Jan Hus as an historical figure in czech culture or cooking your own goose: three czech recipes. 1999. 133 f. Dissertação (Master of Arts em História) - Department of History and Classics, Faculty of Graduate Studies and Research, University of Alberta. Edmonton, Alberta, Canadá, 1999.
} 
Hus $^{10}$. Na praça da cidade velha (Staroměstské náměstí) de Praga, importante ponto turístico da cidade e endereço da prefeitura, encontra-se uma estátua de Jan Hus. Num concurso para eleger o "maior tcheco da história", promovido pela TV estatal tcheca, ele foi o sétimo mais votado, ficando à frente de nomes mundialmente famosos como os compositores Dvořák e Smetana e os escritores Karel Čapek, Franz Kafka e Milan Kundera, além de vários reis, políticos, artistas, pensadores e cientistas. ${ }^{11}$

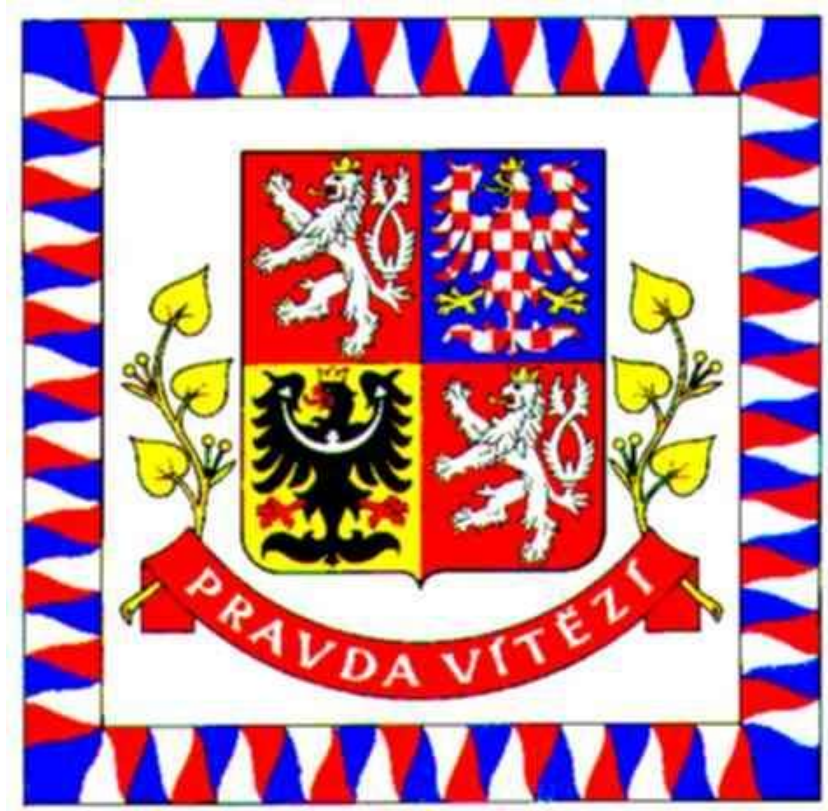

\section{Figura 2. Bandeira do Governo da República Tcheca (Fonte: HISTORY OF THE FLAG OF THE CZECH. Disponível em <http://www.czechgallery.com/flag/index.html>)}

Esta inserção que fizemos de Jan Hus na história, mesmo que apresentada em linhas gerais, recupera a complexidade e a grandeza desse sujeito. No entanto, mostra para um historiador da educação que há uma parcialidade, uma falta. Entendemos que ele foi, além de um expoente religioso, político e cultural, um educador. E, nesta tese, pretendemos demonstrar que ele educou por meio da escrita de cartas e pelo legado várias vezes reconstruído que essas cartas deixaram.

Como suprir essa falta? Como nos aproximarmos dessa figura de um passado tão distante em busca de seu significado educacional? Como ler um educador na história da

\footnotetext{
${ }^{10}$ REPÚBLICA TCHECA. Ministério das Relações Exteriores. The national emblems of the czech republic. Disponível em: <http://www.czech.cz/en/czech-republic/politics/the-national-emblems-of-the-czech-republic>. Acesso em: 02 nov. 2009.
}

${ }^{11}$ V. ČESKÁ TELEVIZE. Největší čech: o projektu. Disponível em

<http://www.ceskatelevize.cz/specialy/nejvetsicech/oprojektu_top100>. Acesso em 06 jun. 2010. 
educação? O que tem por sequência a pergunta: como encontrar o Hus educador, que fontes utilizar e como interpretá-las? Porém, antes de responder a estas perguntas, outra mais imediata tornou-se necessária: por que escrever a história de um personagem tão distante de nosso espaço e de nosso tempo?

A resposta a esta última pergunta passa por duas vertentes: a motivação pessoal para a realização da pesquisa e a contribuição desta à área de História da Educação. Falar de uma motivação pessoal depois de cinco anos de estudo de um tema é muito difícil, visto que quando estudamos algo por tanto tempo mergulhamos num universo conceitual que passa a ser nosso principal foco de investigação intelectual. Nossas questões passam a ser decorrentes desse próprio universo. Se tentarmos reconstruir nossa motivação pessoal, resgatando as perguntas que tínhamos quando iniciamos nossa pesquisa, não conseguiremos. Hoje, essas perguntas nos parecem frágeis, visto que indicavam nosso desconhecimento do objeto de pesquisa. No entanto, foi justamente essa ignorância inicial que nos permitiu o aprofundamento da problematização.

Há cerca de sete anos ganhei de um amigo um exemplar das cartas de Jan Hus em inglês. Estávamos em busca de personagens que defendiam a liberdade de consciência e ele pediu que eu procurasse por esse tema naquela correspondência, visto que eu tinha maior domínio naquela língua. Comecei a traduzir as primeiras cartas, encantando-me com a de número 8, a qual Hus escreveu para o arcebispo de Praga, defendendo-se de acusações que sofria. Aquela defesa parecia tão bem escrita, articulando simplicidade, profundidade e um toque de humor... Quem estava por trás daquelas palavras? Por que ele estava se defendendo? $\mathrm{Eu}$ fiquei intrigado com aquele personagem, e imaginei que, de algum modo, suas ideias poderiam contribuir para o tema que me instigava naquela época: a tolerância religiosa. No entanto, levaria quase dois anos para que eu voltasse àquele livro.

Em meados de 2005, decidi participar do processo seletivo para a pós-graduação na FEUSP. Aquela leitura de anos antes foi marcante para que eu escolhesse o que se tornou tema de minha investigação. O que antes estava voltado para a questão da tolerância religiosa tornou-se a possibilidade de vislumbrar a participação do autor daquelas cartas na construção das ideias pedagógicas. Sabendo da possível influência de Hus na figura do educador Jan Amos Comenius [Komensky], um dos grandes autores da pedagogia moderna que deixaram marcas na minha trajetória formativa, levantei materiais a respeito do primeiro. Passei a ter por objetivo traçar as bases do pensamento comeniano em Hus e as mesmas cartas que eu tinha lido em busca de ideias de liberdade ou de tolerância religiosa apareceram como fonte 
para a pesquisa histórica da educação, pois vislumbrava que aquele personagem nelas se exprimia sobre temáticas educacionais.

Com o desenrolar da pesquisa, percebemos que, antes de tentarmos estabelecer relações entre Hus e Comenius, era necessário conhecer melhor o primeiro, visto que encontrávamos as poucas informações a seu respeito. Centramos, então, nossa investigação no estudo do uso de cartas como fonte para a história da educação para subsidiar uma reflexão sobre a ação educativa hussita. É aqui que entra a segunda vertente da resposta à questão que formulamos sobre o porquê desta tese: de que modo um estudo sobre Jan Hus contribui para a área da História da Educação?

Em primeiro lugar, o estudo aprofundado sobre um personagem histórico traz informações sobre o próprio personagem, permitindo maior divulgação de sua biografia e de suas ideias, especialmente se ele for pouco conhecido, como é o caso de Hus no Brasil. Trazemos aqui, pela primeira vez em nossa língua, materiais escritos por ele e a seu respeito. A maior parte das obras que consultamos está em língua inglesa, havendo também materiais em tcheco e em latim. Mas, em português, encontramos apenas algumas referências em livros históricos e uma tese ${ }^{12}$ escrita na década de setenta, a qual pouco trata das cartas hussitas, de modo que apresentá-las neste trabalho é algo inédito.

Em segundo lugar, esta tese está inserida num movimento inicial, porém crescente, de utilização de cartas como fonte para a história da educação. Na apresentação da obra que organizaram sobre estudos de cartas, Walnice Galvão e Nádia Gotlib ${ }^{13}$ afirmam haver uma "disparidade entre o volume de cartas - escritas por artistas, intelectuais, personalidades históricas - e o número reduzido de estudos". Com essa obra que veio reunir artigos de diversos autores, elas ofereceram uma importante compilação para corrigir a "quase inexistência de estudos de epistolografia". Por outro lado, Francisca Maciel ${ }^{14}$ afirma que "o gênero epistolar vem se consolidando como um campo investigativo na literatura", especialmente depois da abertura da correspondência de Mário de Andrade. Porém, "não se pode dizer o mesmo com relação a outras áreas, entre elas a educação".

\footnotetext{
${ }^{12}$ OBERG, Renato Emir. João Huss, um injustiçado? 1972. 2 vol. 400 p.Tese (Doutorado em História). Faculdade de Filosofia, Letras e Ciências Humanas da Universidade de São Paulo. Departamento de História, 1973, com quem dialogaremos ao longo deste trabalho. Encontramos esta tese a partir de um levantamento de toda a produção acadêmica catalogada nas bibliotecas da Universidade de São Paulo.

${ }^{13}$ GALVÃO, Walnice Nogueira; GOTLIB, Nádia Batella (orgs.). Prezado senhor, prezada senhora: estudos sobre cartas. São Paulo: Companhia das Letras, 2000, p. 9.

${ }^{14}$ MACIEL, Francisca Izabel Pereira. Cartas pedagógicas: fragmentos de um discurso. In: BASTOS, Maria Helena Camara; CUNHA, Maria Teresa Santos; MIGNOT, Ana Chrystina Venancio (orgs.). Destinos das letras: história, educação e escrita epistolar. Passo Fundo: UPF, 2002, p. 206.
} 
A obra de Maria Helena Bastos, Maria Teresa Cunha e Ana Chrystina Mignot, onde está inserido o texto de Francisca Maciel acima citado, procurou dar visibilidade às pesquisas na interface entre história, educação e escrita epistolar, preenchendo essa lacuna. No livro que organizaram,

Debruçados sobre maços de cartas de temporalidades diversas, inéditas ou publicadas em livros, produzidas por missivistas anônimos ou escritores renomados, pesquisadores de diferentes países e tradições disciplinares trazem importantes contribuições para a compreensão da cultura escrita. ${ }^{15}$

Além destes dois trabalhos coletivos, percebemos o crescimento no interesse pelo uso de cartas como fonte histórica, no Brasil, no encontro da Associação Nacional de Pesquisadores em História (Anpuh) realizado em 2009. Além de nossa pesquisa sobre o porquê de Hus ter escrito cartas ${ }^{16}$, do grupo de trabalho "Biografias e autobiografias: escritas, narrativas e invenções de si” ${ }^{\prime 17}$ destacamos outras investigações relacionadas. Carla Gastaud ${ }^{18}$ apresentou as características das cartas de amor guardadas por um casal do início do século XX no Rio Grande do Sul. Deise Schell ${ }^{19}$ retratou o processo de "escrita de si" a partir das cartas de Lope de Aguirre, espanhol do século XVI. Fabiana Fedrigo ${ }^{20}$ trabalhou com as relações, na Grã-Colômbia do início do século XIX, entre Simón Bolívar e Francisco de Paula Santander. Iranilson de Oliveira ${ }^{21}$ retratou as imagens sobre o sertão da Paraíba e do Rio Grande do Norte construídas pelo médico Belisário Penna, no início do século XX, a partir de sua correspondência. Esses trabalhos confluíram para a abertura de novas perspectivas para a escrita (auto)biográfica ao permitir confrontar temporalidades, entrecruzando o tempo da escrita do missivista, o da leitura do destinatário, o da edição de epistolários, o da reedição e o da releitura do historiador. Partilhando desse movimento da área é que pretendemos construir

\footnotetext{
${ }^{15}$ BASTOS; CUNHA; MIGNOT (orgs.), Destinos das letras, pp. 6-7.

${ }^{16}$ AGUIAR, Thiago Borges de. A necessidade de escrever para educar na correspondência de Jan Hus. In: XXV Simpósio Nacional de História da Associação Nacional de História - Anpuh, 2009, Universidade Federal do Ceará, Fortaleza. Anais do XXV Simpósio Nacional de História: por uma est(ética) da beleza na História. Fortaleza: Anpuh, 2009.

${ }^{17}$ Organizado por Juçara Luzia Leite (UFES) e Iranilson Buriti de Oliveira (UFCG).

${ }^{18}$ GASTAUD, Carla Rodrigues. Práticas epistolares: cartas de amor no século XX. In: História e ética: simpósios temáticos e resumos, p. 488.

${ }^{19}$ SHELL, Deise Cristina. 'Yo, rebelde hasta la muerte': as cartas de Lope de Aguirre e a escrita de si. In: História e ética: simpósios temáticos e resumos, p. 488.
}

${ }^{20}$ FEDRIGO, Fabiana de Souza. Francisco de Paula Santander e a exposição de seus projetos para a América independente: entre a memória e a autobiografia. In: História e ética: simpósios temáticos e resumos, p. 489. 
nossa narrativa histórica, utilizando cartas como fonte para nos aproximarmos do educador e seu tempo.

Por fim, no que diz respeito à inserção desta tese na área de História da Educação, analisamos o sentido do que é ser um educador no século XV e como sua ação educativa teve tal impacto que reverberou ao longo dos séculos seguintes. Perguntando "de que maneira podemos pesquisar, compreender e narrar" 22 a vida desse sujeito para alcançar esse entendimento, pensamos, inspirados em António Nóvoa, que é impossível separarmos a vida de um educador de sua prática educativa. Esse autor afirma que

as utopias racionalistas não conseguiram pôr entre parêntesis a especificidade irredutível da acção de cada professor, numa óbvia relação com as suas características pessoais e com as suas vivências profissionais. Como escreve Jennifer Nias: 'O professor é a pessoa; e uma parte importante da pessoa é o professor'. ${ }^{23}$

Também entendemos, tal qual H. Dias ${ }^{24}$, que é possível trabalharmos com histórias de vida não apenas no presente, como propõe Nóvoa em seu trabalho, mas também no passado. Sem o contato direto com os protagonistas, poderemos reconstruir a história deles, como fez essa autora, a partir

da compilação dos dados e informações já produzidos por eles e/ou sobre eles, com o intuito de apresentar as constantes opções que a vida profissional impôs à vida pessoal desses docentes e detectar quais foram as opções pessoais que interferiram em suas realizações profissionais, desvendando, na medida do possível, a maneira de ser e de ensinar de cada um deles. (grifos da autora)

O educador Jan Hus é o clérigo, o homem de saber, o intelectual ${ }^{25}$, o sujeito que escreveu suas cartas por algum motivo que está relacionado com sua história de vida. Mas o aspecto educativo de sua vida foi pouco explorado. Parte importante de sua pessoa foi, portanto, negligenciada. Nesta tese, ao trabalharmos com cartas inéditas como fontes para a construção da narrativa histórica, trazemos a dimensão da relação individual/coletivo para a

\footnotetext{
${ }^{21}$ OLIVEIRA, Iranilson Buriti de. A pena de Belisário: narrativas de nordeste nas correspondências de Belisário Penna. In: História e ética: simpósios temáticos e resumos, p. 490.

${ }^{22}$ V. BORGES, Vavy Pacheco. Desafios da memória e da biografia: Gabrielle Brune-Sieler, uma vida (18741940) In: BRESCIANI, Stella; NAXARA, Márcia. Memória e (res)sentimento: indagações sobre uma questão sensível. Campinas: Editora da Unicamp, 2001.

${ }^{23}$ NÓVOA, António (org.). Vidas de Professores. Porto: Porto Editora, 1992, p. 7.

${ }^{24}$ DIAS, Marcia Hilsdorf. Professores da escola normal de São Paulo (1846-1890): a história não escrita. 2002. 290 f. Dissertação (Mestrado em educação). Faculdade de Educação da Universidade de São Paulo, 2002, p. 10.

${ }^{25}$ Termo usado por LE GOFF, Os intelectuais...
} 
história, porque Hus, ao escrevê-las, também ressignificou seu contexto interpretando os eventos que vivenciava e que, de certa forma, impeliram-no a escrever cartas. Uma carta permite que vislumbremos a expressão do eu em relação ao coletivo.

Quando pesquisamos a ação educativa de Hus aliada aos eventos de sua vida, implicitamente reavaliamos sua figura dentro da história dos sujeitos educadores. Os estudos nessa área permitem observar o ser humano como um "universal singular", que "individualiza a generalidade de uma história social e coletiva". ${ }^{26}$

Como será que os trabalhos sobre educadores tratam desses sujeitos? Estariam eles de acordo com o princípio inspirador de que é impossível separar o educador e sua prática educativa? Partimos em busca de trabalhos que servissem de inspiração para a realização de nossa pesquisa sobre um educador.

No exercício científico característico de uma pesquisa acadêmica, construímos um instrumental teórico que permite observarmos e registrarmos determinado fenômeno que, em nosso caso, é um fato histórico. Esse exercício reúne um levantamento bibliográfico e um conjunto de regras compartilhadas pelos grupos dos quais os sujeitos participam para selecionar um rol de ideias e concepções - um léxico, como diria o historiador da ciência Thomas $\mathrm{Kuhn}^{27}$-, que permitam investigar um objeto.

Para mapearmos esse léxico, realizamos um levantamento das teses e dissertações defendidas nos últimos anos na Faculdade de Educação da Universidade de São Paulo que tratam das relações entre história e educação, ou, mais especificamente, filiam-se à História da Educação. ${ }^{28}$ Nesse levantamento, encontramos alguns trabalhos que tratam de sujeitos educadores. Essas pesquisas permitem conhecer o movimento da área em relação a esses sujeitos ao mesmo tempo em que oferecem inspirações metodológicas para o desenvolvimento de nosso trabalho.

L. $\operatorname{Dias}^{29}$ estudou a educadora anarquista Maria Lacerda Moura, a partir de seus escritos do período de 1918 a 1935, propondo a importância de se considerar o elemento

\footnotetext{
${ }^{26}$ Franco Ferraroti, apud NÓVOA, Vidas de professores, p. 18.

${ }^{27}$ KUHN, Thomas. O caminho desde a estrutura. São Paulo: Editora Unesp, 2006, p. 119.

${ }^{28}$ A partir da base Dedalus, base de dados bibliográficos da USP, fizemos um levantamento das teses e dissertações que partem da figura de um educador ou a analisam, defendidas na Faculdade de Educação da USP, num período de dez anos (1998-2007).

${ }^{29}$ DIAS, Maria Aparecida Lima. O espírito da educação: Maria Lacerda de Moura (1918-1935). 1999. 219 f. Dissertação (Mestrado em Educação). Faculdade de Educação da Universidade de São Paulo, 1999.
} 
religioso na análise de seus escritos, fazendo um contraponto entre estes e sua vida. Morais ${ }^{30}$ estudou o professor Theobaldo Miranda Santos e seus manuais didáticos, buscando caracterizar os principais aspectos de sua obra de construção de uma pedagogia cristã, frente às ideias trazidas pela Escola Nova. Silva ${ }^{31}$ estudou o pensamento do sociólogo Maurício Tragtenberg e sua contribuição para a constituição de uma pedagogia libertária. O autor procura reconstruir as bases do pensamento de Tragtenberg a partir de sua trajetória de vida e de sua obra intelectual, concluindo com um exame das relações entre seus escritos, sua prática como educador e os vínculos com a pedagogia libertária e a pedagogia crítica.

O trabalho de Gonçalves ${ }^{32}$ caracteriza-se por ser uma pesquisa histórica de cunho filosófico-educacional que estuda a contribuição de João Cruz Costa para a Filosofia no Brasil. Parte de pesquisas sobre o mesmo período e depoimentos de pessoas que conheceram o professor Cruz Costa para traçar uma biografia do autor, fazer uma reconstrução do período de formação de seu pensamento e indicar as influências que permeiam sua obra. Na mesma linha de trabalhos que tratam do pensamento de educadores brasileiros está a tese de Zanatta $^{33}$, que estudou o educador católico Jonathas Serrano. A autora parte de uma reconstrução do contexto histórico e das fontes de seu pensamento católico para traçar uma leitura dos fundamentos filosóficos e pedagógicos de sua relação com o movimento da Escola Nova, bem como seus princípios educacionais e representações de vida. Já a tese de Lima ${ }^{34}$ propõe-se a caracterizar a contribuição do intelectual José Mário Pires Azanha para a educação paulista, a partir da descrição e do exame das ideias do autor expressas em seus textos. Ao contrário do que ocorreu em outros trabalhos, a proposta não parte da relação entre vida e obra, mas apenas da produção escrita do autor. A biografia de Azanha que o autor apresenta serve apenas para aproximar o leitor da figura estudada, caso este não o conheça.

A maioria destes trabalhos, bem como daqueles que discutiremos a seguir, apresentam a preocupação de relacionar as ideias do autor com sua biografia e, guardando as

\footnotetext{
${ }^{30}$ MORAIS, Maria Helena de Jesus Silva. Da pedagogia que "pegou de galho" a uma pedagogia cristã nova e brasileira: Theobaldo Miranda Santos (1904-1971) e seus manuscritos didáticos. 2004. 86 f. + anexos. Dissertação (Mestrado em Educação). Faculdade de Educação da Universidade de São Paulo, 2004..

${ }^{31}$ SILVA, Antonio Ozaí da. Maurício Tragtenberg e a pedagogia libertária. 2004. 226 f. Tese (Doutorado em Educação). Faculdade de Educação da Universidade de São Paulo, 2004.

${ }^{32}$ GONÇALVES, Tânia. João Cruz Costa educador: contribuições ao debate sobre a filosofia como formação cultural. 2004. 119 f + anexos. Dissertação (Mestrado em Educação). Faculdade de Educação da Universidade de São Paulo, 2004.

${ }^{33}$ ZANATTA, Regina Maria. Jonathas Serrano e a escola nova no Brasil: raízes católicas na concepção progressista. 2005. 201 f. Tese (Doutorado em Educação). Faculdade de Educação da Universidade de São Paulo, 2005.

${ }^{34}$ LIMA, Raymundo de. A educação no Brasil: o pensamento e a atuação de José Mario Pires Azanha. 2005. 296 f. Tese (Doutorado em Educação). Faculdade de Educação da Universidade de São Paulo, 2005.
} 
especificidades de cada proposta, consideraram a indissociabilidade entre vida pessoal e vida profissional. Isso demonstra que esse princípio que encontramos formulado em Nóvoa é frutífero para a área de História da Educação e é um importante ponto de partida para nossa pesquisa. Contudo, não encontramos uma problematização do modo como a historiografia da educação designa esses personagens. Todos os trabalhos que tratam desses sujeitos afirmam que seus personagens são educadores ou aceitam essa designação feita pela historiografia, sem discutir porque eles são educadores. Percebemos que a simples designação é a característica principal de parte da história dos sujeitos educadores.

Outros trabalhos, no entanto, permitem que avancemos na compreensão desse processo, pois problematizam a designação de seus personagens como educadores. Um primeiro exemplo é a dissertação de Castro $^{35}$ sobre o orador grego Demóstenes. Nele, o autor propõe que esse sujeito seja designado educador, não por causa de sua relação estrita com a educação ou com a instituição escolar, mas a partir de sua preocupação com a formação do indivíduo. Para o autor, "educador no sentido estrito da palavra, tal como é empregada hoje”,36 envolve escrever tratados sobre formação humana e abrir escolas. Mas, não é só isso. Ser um educador implica também "entrever o ideal de homem que tem em vista e o modo de atingir esse ideal. Nesse sentido, ele [Demóstenes] se torna também um educador." A "formação do indivíduo" consiste naquilo que modernamente chamamos de "ideias pedagógicas", de acordo com o autor da dissertação.

Diferentemente do anterior, o trabalho de Loureiro ${ }^{37}$ apresenta a missionária Anna Bagby como educadora principalmente por sua relação com a instituição escolar. A autora, em sua dissertação, afirma que Anna Bagby foi mais do que uma missionária, como foi apresentada na literatura batista. Trata-se de uma educadora "que se ocupa da educação de outras mulheres" e alguém que desenvolveu uma "atividade de escritora", demonstrando amplo "interesse no campo educacional".

Nesse levantamento que fizemos, encontramos uma tese que apresenta uma reflexão específica sobre os critérios para se designar um sujeito como educador. Por ser a única que encontramos que o faz, dedicaremos algumas páginas para analisá-la. Defendida em 2000, a

\footnotetext{
${ }^{35}$ CASTRO, Roberto Carlos Gomes de. Demóstenes educador. 2003. 153 f. Dissertação (Mestrado em Educação). Faculdade de Educação da Universidade de São Paulo, 2003.

${ }^{36}$ ibidem, p. 105, também para a citação da frase seguinte.

${ }^{37}$ LOUREIRO, Noemi Paulichenco. Anna Bagby, educadora batista (1902-1919). 2006. 100 f. + anexos. Dissertação (Mestrado em Educação). Faculdade de Educação da Universidade de São Paulo, 2006.
} 
tese de Cauvilla ${ }^{38}$, possui um capítulo dedicado a responder se Alceu Amoroso Lima foi um educador. $\mathrm{Na}$ introdução, o autor questiona se "Alceu pode, exatamente, ser considerado um educador?"39. Para ele, um educador é aquele que promove mudança em nosso interior. É o que está implícito neste trecho, também da introdução:

Afinal, por mais que influências externas pesem na balança de nossas atitudes, é em nosso interior - 'cabeça' ou 'coração' (provavelmente os dois juntos; e talvez sejamos aqui um tanto rousseaunianos) - é no nosso 'sentimento' que esses processos [de alteração de postura de determinado intelectual] se dão.

Alceu Amoroso Lima posicionou-se diante de questões educacionais, seja em seus escritos, seja em seus cargos na área de educação e, por este motivo, costuma ser citado como educador. Será que essa atuação de Alceu é suficiente para designá-lo como educador? Não, para o autor da tese. Em suas palavras, Cauvilla afirma:

Mas podemos perceber que: a) um professor, mesmo sendo o melhor em sua disciplina, pode não ser, necessariamente, um educador, b) pode-se ocupar cargos na área da educação, como os supracitados, e não se ser um educador; c) e há a recíproca: de se ser um educador sem ocupar nenhuma das posições acima.

Essa "percepção", palavra que reforça nossa interpretação do caráter designativo do conceito de educador, é que leva o autor da tese a afirmar que as intenções de Alceu no exercício de cargos no campo da educação eram políticas e não educativas.

As interpretações dos escritos do intelectual católico sugerem-lhe uma primeira conclusão: "ser professor, reitor ou conselheiro [do Conselho Nacional de Educação e do Conselho Federal de Educação] não torna ninguém educador; se Alceu é considerado educador só por ter ocupado aquelas posições, podemos, então, dizer que ele não o foi." (grifos do autor). Para ele, ser educador é promover uma educação que consista na formação global do indivíduo, incluindo informações e valores. Nas palavras do autor:

\footnotetext{
${ }^{38}$ CAUVILLA, Waldir. Alceu Amoroso Lima e a democracia: em busca da proporção. 2000. $238 \mathrm{f}$. Tese (Doutorado em Educação). Faculdade de Educação da Universidade de São Paulo, 2000. Apresentamos a análise desta tese e sua importância para a compreensão do caráter designativo do educador em 2009. V. AGUIAR, Thiago Borges de. Como se constrói um educador na história da educação. In: VII Semana da Educação - 40 anos da Faculdade de Educação, 50 anos da Escola de Aplicação: conquistas e desafios, 2009, Faculdade de Educação da Universidade de São Paulo. ANAIS. No Prelo.

${ }^{39}$ CAUVILLA. op cit, p. 13 e pp. 17, 156-158, 160, 161, 174, 175, 183 e 184 para as citações seguintes. Exceto quando indicado o contrário, os grifos são nossos.
} 
Entendemos educação como formação global (Alceu diria integral), do indivíduo. Aquela que lhe dá mais do que conhecimento científico, filosófico, literário (o que é específico, justamente, do sistema escolar), mais do que costumamos chamar de informação; educação é aquela que possibilita, além do conhecer, vivenciar, incorporar valores, morais, estéticos, religiosos. (grifos do autor)

A partir dos escritos de Alceu Amoroso Lima, Cauvilla traduz essa educação na transformação de indivíduo em pessoa, seguindo a tradição cristã apresentada nas páginas seguintes (162 a 167). Segue-se uma breve apresentação da ideia de cultura para o intelectual católico, sendo a "formação do homem em sua plenitude" o objeto da cultura. É a partir deste ponto que o capítulo atinge o cerne da designação de Alceu como um educador: a apresentação de um artigo publicado no jornal Folha de São Paulo, intitulado "Na Encruzilhada", de 25/03/1983. Nas palavras de Cauvilla:

Acreditamos, com a apresentação desse artigo, ilustrar de um modo bem significativo a noção de Educação que colocamos no início deste capítulo, a partir da qual, podemos realmente considerar Alceu A. Lima um educador, independentemente dos cargos que exerceu como professor universitário, reitor e conselheiro.

Num primeiro momento, não fica claro para quem lê este trecho por que o intelectual católico pode ser considerado "realmente" um educador. As oito páginas seguintes são dedicadas à leitura comentada do artigo. No entanto, só pudemos realmente perceber os sinais que nos levaram à "ousadia" de afirmar que um educador é designado como tal e que o próprio autor da tese foi educado por seu objeto de estudo, com a frase final do capítulo: “Terminamos, ousando dizer: ler os artigos de jornal de Alceu A. Lima é educar-se”. Esses sinais aparecem nas palavras com as quais o autor analisa o artigo de jornal. Para citarmos alguns exemplos, à página 176, Cauvilla comenta:

Esse artigo é, aliás, um belo exemplo de como em três meias-colunas de jornal (oito parágrafos), Alceu conseguia introduzir várias questões profundas, originais e surpreendentes e, ainda, apresentando a um público de final do século XX as idéias de Santo Tomás de Aquino, um dos grandes filósofos do século XIII.

Neste trecho, às páginas 181 e 182, o autor utiliza recursos típicos da narração:

Muito bem. O artigo começou pela reflexão sobre o evolucionismo, passou pelas noções de instinto, inteligência, cultura, tirou implicações disso na esfera da relação entre massas e elites, desembocou na idéia de democracia e... terminou? Não! na verdade aonde Alceu queria chegar... 
Ou então, neste trecho, ao final da exposição do artigo:

Esse artigo é um exemplo da 'educação amorosiana', ou seja, de Educação no seu sentido pleno. Temos aí uma bela ilustração do que chamaríamos visão global de um problema, unindo o que, à primeira vista, parecia não ter relação nenhuma: eleições e evolucionismo!

Essa "empolgação" expressa nas palavras utilizadas pelo autor da tese trouxe-nos, nas entrelinhas, sua afirmação que se eu fui educado por estas leituras, Alceu é um educador. Esta leitura nos confirmou o indício, que as outras teses também apresentavam, de que a construção da figura de um educador e a manutenção de seu lugar pela historiografia são intimamente atreladas à designação do historiador, pois o lugar do sujeito não existe num vazio, numa neutralidade, ele é dado pelo historiador ao relacionar os personagens entre eles a partir do papel que exerceram em seu contexto.

Se somos nós, os historiadores da educação, que designamos os educadores e seus lugares, pode nosso trabalho contribuir para repensar as designações que Jan Hus recebe? Reconhecemos que Hus exerceu um papel de educador e nos propomos, inspirados nesse levantamento do tratamento dado aos educadores pelos trabalhos na área de História da Educação, a designá-lo como um educador. Propomo-nos a suprir essa ausência historiográfica a partir da análise dos escritos hussitas ${ }^{40}$, mais especificamente suas cartas, e outras fontes, questionando que práticas teria realizado, que ideias teria defendido e quem teria sido educado por ambas. Antes de responder a esta questão, precisamos enfrentar o problema da sua possibilidade, isto é, da distância entre o historiador e as fontes na construção da narrativa histórica que nos propomos realizar.

\section{a. O problema da distância na construção da narrativa histórica}

Das cartas que Jan Hus escreveu em sua vida, chegaram até nós cerca de uma centena, escritas no período de 1404 a 1415, com aproximadamente $80 \%$ delas escritas em latim e o restante em tcheco. Tivemos contato com três edições de traduções dessa correspondência

\footnotetext{
${ }^{40}$ A palavra hussita aqui utilizada pode ser interpretada de duas formas: um adjetivo referente a Hus ou um substantivo referente a seus seguidores, este último, utilizado inicialmente de forma pejorativa. Neste trabalho, todas as vezes que escrevermos hussita, com letra minúscula, seguimos a primeira interpretação. Para a segunda, escreveremos Hussitas, com letra maiúscula. Para essa questão, ver SELTZER, Joel Daniel. Framing faith, forging a nation: czech vernacular historiography and the Bohemian Reformation, 1430-1530. 2005. $309 \mathrm{f}$. Tese (Doutor em Filosofia). Faculty of the Graduate School, Yale University, Yale, EUA, 2005, pp. 43-48. O autor defende o uso da palavra hussita no lugar de utraquista ou calixtino. A primeira refere-se à comunhão dupla (utraque), ou seja, com o pão e com o vinho e a segunda, à comunhão com o cálice (calix). A oferta do cálice aos leigos era uma das práticas defendidas pelos reformadores tchecos. Mesmo não sendo utilizada pelos membros do grupo em questão, Hus não ter fundado nova doutrina (embora fora acusado de heresiarca) e ser de uso pejorativo à época, a palavra hussita é melhor, para Seltzer, em virtude da utilização na historiografia americana e da restrição da abrangência das outras duas.
} 
para o inglês, cada uma apoiada numa edição tcheca diferente. Antes de iniciarmos nossos estudos de língua tcheca (no ano de 2008), toda a leitura que dispúnhamos da língua e cultura na Boêmia dava-se por intermédio da língua inglesa. E, mesmo durante muitos meses de estudo da língua tcheca, nossas traduções das palavras tchecas foram intermediadas por aquela língua. Foi somente após quase dois anos de estudo do idioma de Hus, durante a tradução de alguns termos, que sentimos a necessidade de problematizar a distância linguística e temporal que nos separam de suas cartas. ${ }^{41}$ Precisávamos de referenciais teóricos que nos ajudassem a entender o papel dessa distância na compreensão de nosso objeto de estudo.

Encontramos na obra de Ginzburg ${ }^{42}$ os principais elementos que subsidiam essa reflexão. Ele propõe a construção de uma narrativa histórica que articule elementos em pequena escala com outros mais gerais, num movimento contínuo entre o macro e o micro. Mas esse movimento não tem por objetivo melhor compreender ou até mesmo validar a narrativa macro-histórica. Ele se faz necessário visto que a descontinuidade da realidade impede sua compreensão completa. Nem uma micro-história nem uma macro-história dão conta de explicar a realidade. E como estas duas narrações estão em lugares diferentes, elas não formam um continuum, mas uma sequência de novas perguntas em níveis heterogêneos. É o que explica o historiador italiano, citando o teórico do cinema Siegfried Kracauer:

Segundo Kracauer, a melhor solução é a seguida por Marc Bloch em $L a$ societé féodale [A sociedade feudal]: um contínuo vaivém entre micro e

\footnotetext{
${ }^{41}$ No já citado trabalho de OBERG, única tese em língua portuguesa que encontramos sobre Jan Hus, afirma-se, na página 14: "Reconhecemos, constrangidos, a observação que D. Paul de Vooght nos fez numa das suas cartas, de que é impossível fazer-se um trabalho sobre Huss sem conhecer a língua tcheca mas, estando ela completamente fora do nosso alcance, tivemos que louvar-nos nas referências e traduções que encontramos esparsas por autores vários.” Foi a partir desta afirmação, reforçada pelo próprio Sr. Renato em conversa pessoal, que fomos atrás do estudo da língua materna de Hus.

${ }^{42}$ Carlo Ginzburg é um historiador italiano, que nasceu na cidade de Turim em 1939. Foi professor da Universidade da Califórnia e hoje leciona na Scuola Normale Superiore de Pisa. De sua vasta obra, oito livros foram traduzidos para o português e editados pela Companhia das Letras. Três deles são estudos monográficos e constituem algumas das primeiras obras do autor, a saber, "Os andarilhos do bem" (edição italiana: 1966/edição brasileira: 1988), "O queijo e os vermes" (1976/1987) e "História noturna" (1989/1991). Os outros são coletâneas de ensaios, gênero que caracterizou sua produção histórica nas últimas décadas, a saber, "O fio e os rastros" (2006/2007), "Nenhuma ilha é uma ilha" (2002/2004), "Olhos de Madeira" (1998/2001), "Relações de Força" (2000/2002), e "Mitos, emblemas e sinais" (1986/1989). Fizemos uma análise da inserção da obra de Ginzburg na história da educação. Ver LEONARDI, Paula; BALASSIANO, Ana Luiza Grillo; AGUIAR, Thiago Borges de. Uma leitura da inserção da obra de Carlo Ginzburg em periódicos brasileiros de história da educação. In: IX Congresso Iberoamericano de História da Educação Latino-americana, 2009, Universidade do Estado do Rio de Janeiro. Anais do IX Congresso Iberoamericano de História da Educação Latino-

Americana: Educação, Autonomia e Identidades na América Latina. Rio de Janeiro: Quartet Editora, 2009. Nessa análise, percebemos que da obra do historiador italiano são utilizados quase que exclusivamente os livros O queijo e os vermes e Mitos, emblemas e sinais e, na maioria dos casos, em referências pontuais e sem grande discussão teórica a respeito delas.
} 
macro-história, entre close-ups e planos gerais ou grandes planos gerais [extreme long shots], a pôr continuamente em discussão a visão conjunta do processo histórico por meio de exceções aparentes e causas de breve período. Essa receita metodológica desembocava numa afirmação da natureza decididamente ontológica: a realidade é fundamentalmente descontínua e heterogênea. Portanto, nenhuma conclusão alcançada a propósito de um determinado âmbito pode ser transferida automaticamente para um âmbito mais geral (é o que Kracauaer chama de 'law of levels'). ${ }^{43}$

Essa solução, para Ginzburg, é a base do surgimento da micro-história, movimento ao qual o historiador italiano é associado. Mas sua compreensão de como se constrói a narrativa histórica não pode ser resumida a um rótulo ${ }^{44}$, bem como suas contribuições para a história da educação e, mais especificamente, para este trabalho, precisam de maiores explicações. Iniciemos com sua proposta de um paradigma indiciário.

Marco da obra de Ginzburg, o paradigma indiciário consiste numa produção do conhecimento histórico que parte de elementos normalmente negligenciáveis ordinariamente despercebidos e que não costumamos olhar com atenção. As bases estão apresentadas num ensaio publicado na década de oitenta ${ }^{45}$, mas só se tornaram claramente presentes em seu trabalho vinte anos depois:

Há vinte anos, num ensaio intitulado 'Sinais', lancei uma hipótese, 'obviamente indemonstrável', sobre a origem da narração que suscitou o interesse de alguns teóricos da literatura (...). A própria ideia de narração - conjecturava eu - talvez tivesse nascido numa sociedade de caçadores, a fim de se transmitir por traços infinitesimais um evento que não se podia testemunhar diretamente: 'Alguém passou por ali'. Com esse modelo venatório (ou, se projetado no futuro, divinatório), que defini como 'paradigma indiciário', eu tentava conferir sentido a meu modo de pesquisa, inserindo-a numa perspectiva histórica longuíssima e mesmo plurimilenar. ${ }^{46}$

Sua investigação, a princípio, possuía práticas que o autor julgava "intuitivamente corretas" e só possuíam sentido pela "conjectura" do nascimento da narração nas práticas dos caçadores. E a história busca reconstruir a verdade por meio de uma narração. Esta, porém,

\footnotetext{
${ }^{43}$ GINZBURG, Carlo. O fio e os rastros: verdadeiro, falso, fictício. São Paulo: Companhia das Letras, 2006, p. 269.

${ }^{44}$ V. LIMA, Henrique Espada. A micro-história italiana: escalas, indícios e singularidades. Rio de Janeiro: Civilização Brasileira, 2006, especialmente nas páginas 11 e 15.
}

${ }^{45}$ GINZBURG, Sinais: raízes de um paradigma indiciário. In: Mitos, emblemas e sinais: morfologia e história. São Paulo: Companhia das Letras, 1989.

${ }^{46}$ GINZBURG, Carlo. Nenhuma ilha é uma ilha: quatro visões da literatura inglesa. São Paulo: Companhia das Letras, 2004, pp. 13-14. 
ocorre a partir de perguntas feitas às avessas, utilizando recursos para que a subjetividade do observador e do observado seja problematizada:

Retorno àquele ensaio, que desde então tem continuado a alimentar subterraneamente o meu trabalho, porque a hipótese sobre a origem da narração ali formulada também pode lançar luz sobre as narrativas históricas - voltadas, ao contrário das outras, para a busca da verdade, e contudo modeladas, em cada uma de suas fases, por perguntas e respostas elaboradas de forma narrativa. Ler a realidade às avessas, partindo de sua opacidade, para não permanecer prisioneiro dos esquemas da inteligência: essa ideia, cara a Proust, parece-me exprimir um ideal de pesquisa que inspirou também estas páginas. ${ }^{47}$

O paradigma indiciário, que perpassa a obra de Ginzburg, tem por característica que o observador, a partir de dados aparentemente negligenciáveis, disponha-os para fazer emergir uma narrativa. Ao apontar para esse paradigma, que parte de rastros para reconstruir o fio da narração, o historiador italiano não o toma como excludente de uma "história geral". Esse paradigma não serve para defender uma história que se restrinja a contar episódios. É o que afirma neste trecho:

Se as pretensões de conhecimento sistemático mostram-se cada vez mais como veleidades, nem por isso a ideia de totalidade deve ser abandonada. Pelo contrário: a existência de uma profunda conexão que explica os fenômenos superficiais é reforçada no próprio momento em que se afirma que um conhecimento direto de tal conexão não é possível. Se a realidade é opaca, existem zonas privilegiadas - sinais, indícios - que permitem decifrála. ${ }^{48}$

Esse deciframento requer um trabalho de "rigor flexível", que utiliza tanto a rigidez da técnica quanto a fluidez da intuição. É nesse sentido que sua produção de ensaios parte de elementos surgidos ao "acaso" e interpretados com a premissa da "ignorância" do pesquisador:

$\mathrm{Na}$ origem, há sempre um achado proveniente das margens de investigações inteiramente diversas. (...) Em cada circunstância, tive a súbita sensação de ter encontrado alguma coisa, talvez até alguma coisa de relevante; ao mesmo tempo, tinha consciência aguda de minha ignorância. Às vezes, uma resposta

\footnotetext{
47 ibidem, p. 14.

${ }^{48}$ GINZBURG. Mitos, emblemas e sinais, p. 177.
} 
relampejava (...). Mas não sabia qual era a pergunta. Somente a pesquisa permitiu formulá-la. ${ }^{49}$

Nesta descrição, Ginzburg demonstra como o paradigma indiciário norteia sua produção e apresenta dois elementos que se nos destacam como metodológicos: a ocorrência de sinais que se apresentam à margem da investigação principal e a ignorância como ponto de partida para a pesquisa.

Quando levamos nossas perguntas e interpretações à leitura de nossos documentos, de nossos objetos de investigação, corremos o risco de ver apenas aquilo que "já sabíamos" de antemão. No entanto, como é impossível deixarmos de lado nossa subjetividade ao pesquisarmos, o historiador italiano nos propõe estarmos abertos aos indícios que só aparecem nas margens ou na opacidade da leitura às avessas. Nas suas palavras "contemplar a realidade de um ponto de vista insólito" e "fazer perguntas oblíquas à realidade",50

Mas esse paradigma só fez sentido para nós a partir do conceito de "estranhamento", explicado por Ginzburg. Este "processo intencional de saída da percepção automática" é discutido pelo historiador italiano em outro livro ${ }^{51}$. Partindo de uma reflexão sobre a obra de Marco Aurélio, Tolstoi e o crítico de arte Viktor Chklovski, afirma que "Para ver as coisas devemos, primeiramente, olhá-las como se não tivessem nenhum sentido: como se fossem uma adivinha." 52 As famosas brincadeiras de "o que é, o que é?", presentes em diversas culturas, "talvez em todas" requerem do inquirido uma leitura das coisas na sua mais simples expressão, despida de elementos culturais que interfiram em sua apreensão. A chuva é apenas algo que cai em pé e corre deitado.

Com a expressão "despida de elementos culturais" não afirmamos a possibilidade de estarmos totalmente isentos de cultura na leitura do mundo. Seguimos, apenas, com a proposta de Ginzburg, de que nosso contexto cultural/simbólico é parte integrante de nossa leitura e precisamos de instrumentos que nos permitam dialogar entre nosso contexto e o contexto de produção do documento com o qual interagimos. O processo de estranhamento é o de rompimento com o óbvio, nossos hábitos perceptivos. No trabalho dos historiadores, estranhar passa por não levar um quadro teórico-explicativo pronto para a leitura dos documentos com os quais trabalha.

\footnotetext{
${ }^{49}$ GINZBURG. Nenhuma ilha é uma ilha, pp. 11-12.

${ }^{50}$ ibidem, pp. 41-42.

${ }^{51}$ GINZBURG, Carlo. Olhos de madeira: nove reflexões sobre a distância. São Paulo: Companhia das Letras, 2001.

${ }^{52}$ ibidem, p. 22 e pp. 23,38 e 41 para as citações seguintes.
} 
Citando novamente as ideias de Marcel Proust, Ginzburg afirma que o estranhamento é proteger o frescor das coisas contra a intrusão das ideias. Nas palavras do escritor francês “em vez de nos apresentar as coisas em sua ordem lógica, isto é, começando pela causa, nos mostra primeiro o efeito, a ilusão que nos atrai." Com o olhar para a história, Ginzburg afirma "Parece-me que o estranhamento é o antídoto eficaz contra um risco a que todos nós estamos expostos: o de banalizar a realidade (inclusive nós mesmos).”

O instante do não-reconhecimento abre para o olhar de estranhamento do espectador o caminho da iluminação cognoscitiva. Não é por acaso, observa Kracauer, que os grandes historiadores, de Tucídides a Namier, eram exilados: 'É somente nesse estado de auto-anulação, ou nesse ser sem pátria, que o historiador pode entrar em comunhão com o material que concerne à sua pesquisa. [...] Estrangeiro em relação ao mundo evocado pelas fontes, ele deve enfrentar a missão - missão típica do exilado - de penetrar as suas aparências exteriores, de modo a poder aprender a compreender esse mundo de dentro'. 53

Estranhar é ter consciência que "o mundo todo é nossa casa", o que não quer dizer que sejamos iguais, mas que "todos nos sentimos estrangeiros em relação a alguma coisa e a alguém" "54. É com essa tomada de consciência que convidamos a nós mesmos a estranhar mais e a buscar elementos que não estão óbvios nas cartas hussitas. É agir como a criança que, curiosa, sempre pergunta "por que" ou o nome das coisas.

Estranhamento não consiste em encontrar a diferença entre aquele que lê e o documento lido, mas no exercício de distanciar-se de suas ideias anteriores durante a leitura. A distância é discutida por Ginzburg principalmente no livro "Olhos de Madeira". Ao lermos esta obra, questionamo-nos: por que "olhos de madeira" como metáfora para a distância? Encontramos uma resposta na epígrafe: "Grandes olhos de madeira, por que olham para mim?”, retirada das aventuras de Pinóquio, do escritor italiano Carlo Collodi, publicadas originalmente em um jornal infantil entre os anos 1881 e 1883.

Pinóquio é uma marionete de madeira feita por um carpinteiro chamado Gepeto. No terceiro capítulo, o criador começa a dar forma à criatura. $\mathrm{O}$ carpinteiro inicialmente escolhe $\mathrm{o}$ nome Pinocchio (que significa "olhos de pinha"):

Assim que encontrou o nome para seu boneco, começou a trabalhar com afinco, e logo fez os cabelos, depois a testa, depois os olhos.

\footnotetext{
${ }^{53}$ GINZBURG. O fio e os rastros, p. 238.

${ }^{54}$ GINZBURG. Olhos de madeira, p. 11
} 
Feito os olhos, imaginem a surpresa quando percebeu que eles se mexiam e o fitavam obstinadamente.

Gepeto ficou quase chateado vendo aqueles dois olhos de madeira que o observavam, e disse num tom ressentido:

— Olhões feios de madeira, por que estão olhando para mim?

Ninguém respondeu. ${ }^{55}$

Em seguida, Gepeto faz o nariz, que começa a crescer e não para, mesmo quando cortado. Fez, então, a boca que começou a rir e as outras partes do corpo. Quando terminou a primeira mão, o boneco já agarrou sua peruca. E quanto mais terminava o boneco, mais "maroto" este ficava e mais se chateava Gepeto. O boneco fugiu para a rua e, numa confusão, o carpinteiro foi preso e Pinóquio saiu para viver aventuras. "O que aconteceu depois é uma história que nem dá para acreditar, e vou contá-la a vocês nestes outros capítulos.”, conclui o autor. $^{56}$

Havia um estranhamento mútuo entre Gepeto e Pinocchio, a distância entre o criador e a criatura, entre o ser humano e o boneco de madeira. No entanto, quanto mais Pinocchio se assemelhava a um ser humano, mais ele se movimentava como um. O boneco tornava-se familiar, semelhante.

Essa história ensina-nos o quanto "estranho" não é o mesmo que "diferente", mas o oposto de óbvio, automático. Gepeto não estranha o fato do boneco se movimentar. Mas Pinocchio estranha a si mesmo como um boneco, querendo ser um menino de verdade. Foi o olhar do carpinteiro que fez da marionete de madeira um menino. A cena final da história, na qual Pinocchio, transformado num menino de verdade, olha para a marionete que ele foi, mostra-nos que sua humanidade se construiu no momento no qual se distanciou do que era antes. Ginzburg nos traz, com a metáfora dos olhos de madeira, o exercício de distanciamento e aproximação na narrativa histórica.

A distância que nos separa dos fatos históricos que procuramos pesquisar, compreender e narrar é intransponível e implica noutra importante distância: a da verdade. Sem entrar na questão da existência da verdade como instância ou essência, Ginzburg apresenta-nos uma reflexão do papel da verdade na escrita da história. Os historiadores querem encontrá-la. Para explicar como a buscam, o historiador italiano propõe uma

\footnotetext{
${ }^{55}$ COLLODI, Carlo. As aventuras de Pinóquio. São Paulo: Iluminuras, 1899. Disponível parcialmente em: <http://books.google.com.br/books?id=KmDakW_sISEC>. Acesso em: 15 nov. 2009, p. 17.

${ }^{56}$ ibidem, p. 21
} 
comparação entre duas funções: a do juiz e a do historiador. Ambos utilizam provas em seus trabalhos, mas o estatuto destas provas é diferente em cada um:

Para o primeiro [o juiz], a margem de incerteza tem um significado puramente negativo e pode desembocar num non liquet - em termos modernos, numa absolvição por falta de provas. Para o segundo [o historiador], ela deflagra um aprofundamento da investigação, que liga o caso específico ao contexto, entendido aqui como um lugar de possibilidades historicamente determinadas. ${ }^{57}$

A distância entre o historiador e a verdade "absoluta" do fato histórico é justamente seu espaço do trabalho. A interpretação verossímil aponta para sua possibilidade e oferece recursos para compreender a realidade estudada. É por isso que, para Ginzburg, a história e a narrativa voltam a fazer as pazes: há um espaço para a emergência de possibilidades, sem que elas deixem de ser históricas:

Termos como 'ficção' ou 'possibilidade' não devem induzir a erro. A questão da prova permanece mais do que nunca no cerne da pesquisa histórica, mas seu estatuto é inevitavelmente modificado no momento em que são enfrentados temas diferentes em relação ao passado, com a ajuda da documentação que também é diferente. (p. 334)

É aqui que podemos pensar na abertura para uma reflexão sobre a história da educação. Que documentação e que leitura permitem compreender a figura de um educador que viveu no século XV? Estamos sempre distantes de nosso objeto de investigação histórica. Esse objeto está, por princípio, num tempo cronológico diferente e anterior ao atual. Como nós pensamos no presente, nosso pensar é sempre um processo de olhar o passado a partir dos olhos do presente. Essa distância faz com que nossa leitura do fato histórico que estudamos seja míope: não conseguimos enxergar claramente e precisamos de nossos conhecimentos sobre o que observamos para completar o que vemos.

Assim, a distância temporal está condicionada por uma distância que aqui denominaremos cultural, que engloba elementos como a língua, as experiências e as concepções de quem observa e de quem é observado. Nossa distância das cartas de Hus é muito maior do que a distância que temos, por exemplo, da produção cultural portuguesa do mesmo período. Se lêssemos um documento desconhecido produzido em Portugal no início do século $\mathrm{XV}$, teríamos muito mais saberes prévios a respeito de como ler esse documento do que temos das cartas de Hus. Para quem lê este trabalho que ora apresentamos e nunca ou

\footnotetext{
${ }^{57}$ GINZBURG. O fio e os rastros, pp. 315-316.
} 
pouco ouviu falar sobre esse clérigo da Boêmia e sobre a cultura tcheca, com certeza está tentando encontrar algum elemento em sua própria história que lhe permita compreender o que escrevemos. E é justamente aí que está um dos maiores desafios na escrita da História.

Para reconhecer, à luz de Ginzburg, a figura de um educador num espaço-tempo ${ }^{58}$ tão distante cronológica e culturalmente situado, propomos encontrar nos documentos que utilizamos como fonte primária, a correspondência hussita, "indícios" da sua ação como educador. Se Hus foi um educador e utilizou das cartas para desempenhar sua ação educativa, deve haver rastros de sua intenção nesses documentos. Talvez haja "zonas privilegiadas" que foram pouco ou nada destacados por seus biógrafos ou pela historiografia, que nos permitam observar essa intenção. Elementos como o fato de algumas cartas serem escritas em tcheco e outras em latim, o uso de seu nome como uma metáfora e até mesmo o uso de um vocativo no diminutivo. $\mathrm{O}$ educador pelas cartas pode saltar aos olhos na medida em que reunimos um conjunto de sinais espalhados pelos documentos.

Do mesmo modo, na observação dos comentários dos editores e biógrafos de Hus, das falas de historiadores tchecos ou de textos de divulgação histórica ou religiosa, relacionandoos ao espaço-tempo no qual foram produzidos, podemos encontrar algo ausente na historiografia da educação do período. Podemos reconstruir o legado educativo hussita e o reconhecimento dos educandos da figura educadora de seu mestre. É como se a distância, neste caso, tivesse se tornado o próprio objeto de estudo.

No início do processo, perguntávamo-nos como encontraríamos o Hus educador. Líamos as cartas e nada nos saltava à vista. Estávamos míopes sem dar conta disso. Mas alguns "corpos estranhos" incomodavam nosso olhar. Tentávamos ler cartas do século XV com o olhar do século XXI. Precisávamos de uma nova lente: entender o que significava escrever cartas naquele período. É a partir deste ponto que iniciamos a argumentação desta tese, apresentando no primeiro capítulo um estudo da escrita de cartas no século $\mathbf{X V}$, caracterizando a constituição de nosso corpus documental, levantando questões a respeito de como podemos lê-lo para fomentar nossa pesquisa histórica. Em seguida, apresentamos os

\footnotetext{
${ }^{58} \mathrm{O}$ conceito de espaço-tempo que utilizamos neste trabalho refere-se ao de GUSDORF, Georges. De l'histoire des sciences a l'histoire de la pensée. Les sciences humaines et la pensée occidentale, vol. I. Paris: Payot, 1966, capítulo VI. Neste capítulo, o autor discute a experiência científica como parte da experiência humana, negando a objetividade do conhecimento científico. Este é produzido dentro de uma mentalidade do período, a qual o autor apresenta como o espaço-tempo cultural de uma determinada época. À página 200, o autor utiliza essa expressão nos seguintes termos: "L'experience scientifique n'a pas une existence indépendante; elle se constitue comme un aspect de l'experiénce humaine globale, telle qu'elle existe en un moment donné. La réalité fondamentale est celle de l'espace-temps culturel, qui exerce sa valeur régulatrice sur le hommes d'une époque donnée. Cet horizon global, ou plutôt englobant, apparait comme l'horizon de tous le horizon, la perspective de tout perspectives. Il assure en dernier lieu la correspondance des significations et la coordination des évidences."
} 
destinatários das cartas de Hus, percebendo a rede de relações na qual esse clérigo estava envolvido, pensando-a como um fator de entendimento do conteúdo dessa epistolografia. Concluímos o capítulo refletindo a respeito de por que Hus escreveu cartas, organizando essas cartas em uma classificação baseada na necessidade da escrita.

O segundo capítulo consiste num estudo sobre a correspondência hussita, em busca da construção do educador pelas cartas. Partindo da classificação que elaboramos no primeiro capítulo, selecionamos as cartas que definimos como pastorais, resgatando suas características e os indícios que apontam para a ação educativa de Hus. Concluímos com uma análise aprofundada de duas cartas pessoais escritas para seu discípulo, Martin de Volyně. Estas últimas oferecem material para outro olhar sobre o educador numa relação de maior proximidade e vínculo com um educando específico.

No terceiro capítulo, propomos um estudo da história das edições e traduções das cartas de Hus, em busca da construção do educador por seu legado. Partimos de como Hus estabeleceu as bases de seu legado nas cartas. Seguimos para uma descrição de seu legado educativo a partir da defesa da verdade na correspondência hussita e de seus comentadores. Entramos na reconstrução da história das edições e traduções em relação aos espaços-tempos nos quais elas se inserem. Concluímos dialogando com um conjunto de produções artísticas, literárias e históricas a respeito do clérigo, construídas ao longo dos últimos séculos até a atualidade, que reiteram esse legado.

Dos diversos olhares possíveis para as cartas de Jan Hus partimos de um, aquele que construímos com as bases teórico-metodológicas que sustentam este trabalho. Desse olhar, encaminhamos duas discussões: o educador a partir da sua ação educativa, observando as cartas pastorais e as cartas ao discípulo Martin de Volyně, e o educador a partir do reconhecimento de seu legado, observando as edições das cartas e o impacto delas na cultura tcheca. Esses dois caminhos se encontram na reflexão sobre o caráter designativo da história da educação, comparando as conclusões das duas discussões anteriores com a educação do período, concluindo com a figura de Hus como um educador do século XV. Ao final desta tese, teremos designado Hus como um educador e nos voltaremos para a História da Educação para entender o lugar que esse clérigo nela ocupa. Na busca por um sujeito educador do século XV encontraremos, também, o próprio historiador perante a área que investiga. 


\section{Capítulo 1. As cartas de Jan Hus}

Este capítulo consiste num exercício de compreensão das características das cartas de Hus escritas no século XV e suas potencialidades de uso como fontes para um estudo da figura de um educador. Responderemos à pergunta "quantas são as cartas de Hus e como estão organizadas?", iniciando com a constituição de nosso corpus documental, caracterizando as edições das cartas de Hus e refletindo a respeito do processo de tradução dessas cartas para o português que empreendemos.

Conhecendo a organização dessas cartas, precisamos saber de que maneira podemos lê-las. É o que faremos em seguida, discutindo a escrita de cartas do século XV e analisando os limites e os desafios desse tipo de documento. Partiremos, então, para um mapeamento dos destinatários das cartas hussitas, observando o modo como suas cartas exprimem a constituição da rede de relações em que estava inserido. A partir dessa rede, poderemos levantar indícios da localização da figura de Hus em seu espaço-tempo e dos assuntos que o preocupavam então.

Feito isso, teremos informações que nos permitem lermos e entendermos em linhas gerais as cartas hussitas. No entanto, não basta que possamos entendê-las. Precisamos, como propõe Ginzburg, de um olhar que parta do estranhamento do óbvio. Por isso, perguntaremos por que Hus escreveu cartas? A resposta a esta pergunta permite que estabeleçamos categorias de análise que favorecem uma leitura diferente da cronológica, como as cartas hussitas são normalmente apresentadas. Essas categorias são baseadas na necessidade da escrita pelo seu autor e é com elas que concluiremos este capítulo, preparando o terreno para a construção do educador pelas cartas.

\subsection{Constituição do corpus documental}

A correspondência de Jan Hus que chegou até nós abrange pouco mais de uma década de sua vida, de 1404 até 1415 . As primeiras dentre as cartas que dispomos foram escritas na época em que Hus, com pouco mais de trinta anos de idade, já era professor da Universidade de Praga, onde estudava Teologia, e pároco da Capela de Belém. As últimas foram escritas às vésperas de sua execução.

Mais da metade das cartas (as últimas 65 de um total 102) concentra-se nos dois últimos anos de vida de Hus, abrangendo sua viagem até Constança, no final de 1414 e sua prisão e morte em 1415. 
Parte de sua correspondência foi guardada a seu pedido por Petr de Mladoňovice, secretário de seu amigo nobre Jan de Chlum. Ambos estiveram próximos a Hus durante o período no qual esteve preso e são destinatários frequentes das cartas. É também de Petr de Mladoňovice o documento mais utilizado para retratar o julgamento de Hus, intitulado Relatio $^{59}$, no qual ele narra todos os eventos que acompanhou ao lado do clérigo, desde sua viagem até os momentos seguintes à execução.

As cartas de Hus foram publicadas diversas vezes ao longo dos séculos seguintes à sua execução. Uma primeira edição foi feita pelo reformador Martinho Lutero, em 1536, na cidade de Wittemberg. ${ }^{60}$ Por ocasião da convocação do papa Paulo III para o Concílio de Trento, que ocorreu apenas em 1542, ele traduziu quatro cartas de Hus para o latim e as apresentou junto com outros documentos da época do Concílio de Constança.

No ano de 1537, Lutero publicou uma edição completa das cartas de Hus, intitulada Epistola Qucedam Piissima et Eruditissimae. ${ }^{61}$ Após essa publicação de Lutero, as cartas foram novamente compiladas em outras edições ao longo dos séculos seguintes. Tomamos conhecimento de três delas. A primeira intitula-se Historia et Monumenta J. Hus atque Hieronymi Pragensis Confessorum Christi ${ }^{62}$, a qual nos referiremos posteriormente como Monumenta. Foi publicada em Nuremberg, no ano de 1558, por Johann vom Berg [Joannes Montanus] e Ulrich Neuber [Ulricus Neuberus], e reimpressa em Frankfurt, 1715. Este livro contém, além das cartas, sermões e tratados de Hus, os prefácios de Lutero e diversos outros documentos a respeito da vida do reformador boêmio e de Jerônimo de Praga, amigo de Hus, que compartilhava das mesmas ideias e foi queimado no ano seguinte a Hus. ${ }^{63}$

\footnotetext{
${ }^{59}$ Publicado no original em latim em PALACKÝ, Franciscus. Documenta mag. Joannis Hus: vitam, doctrinam, causam in constantiensi concilio actam at controversias de religione in Bohemia annis 14031418 motas. Praga: Sumptibus Friderici Tempsky, 1869, e traduzido para o inglês na obra SPINKA, Matthew. John Hus at the Council of Constance. New York \& London: Columbia University Press, 1965.

${ }^{60}$ BONNECHOSE, Émile de. (ed.) Letters of John Hus: written during his exile and imprisonment, with Martin Luther's preface and containing a general view of the works of Huss. Tradução para o inglês de Campbell Mackenzie. Edimburgo: William Whyte \& Co, 1846, p.1.

${ }^{61}$ LUTERO, Martinho. Epistolæ quaedam piissimae et eruditissimae Iohannis Hus, quæ solæ satis declarant papistarum pietates, esse Satanæ furias. Wittemberg: Officina Ioannis Lufft, 1537.

${ }^{62}$ HUS, Johannes; HIERONYMUS. Historia et monumenta Joannis Hus et Hieronymi Pragensis confessorum Christi. Frankfurt: Joannes Montanus et Ulricus Neuberus, 1558.

${ }^{63}$ Jerônimo de Praga foi professor leigo da Universidade de Praga de 1407 a 1416. Estudou em Oxford de 1399 a 1401, onde conheceu o trabalho de Wyclif. Copiou dois de seus trabalhos e os trouxe à Boêmia quando retornou em 1401. Entre este ano e 1406 obteve o título de Mestre em Artes nas Universidades de Paris, Colônia e Heidelberg. Defendeu as ideias reformistas de Hus e foi queimado na fogueira, condenado pelo Concílio de Constança, em 30 de maio de 1416, no mesmo local onde Hus fora queimado em julho do ano anterior.
} 
A segunda obra, editada por František Palacký (1798-1876), político, escritor e Real Historiador da Boêmia ${ }^{64}$, intitula-se Documenta Mag. Joannis Hus. 1403-1418. Utilizaremos a palavra Documenta para nos referirmos posteriormente a esta edição. Foi publicada em Praga no ano de 1869 e contém as cartas, o Relatio de Mladoňovice e mais de uma centena de documentos oficiais da época.

A terceira, editada por Václav Novotný, intitula-se M. Jana Husi Korespondence a dokumenty. ${ }^{65}$ Para nos referirmos a ela posteriormente, utilizaremos a palavra Korespondence. Foi publicada em Praga no ano de 1920. Contém além das cartas, documentos da época de Hus. $^{66}$

Sabemos da existência de outras edições tchecas. A primeira, sem data, de Václav Flajšhans, intitulada Listy Husovy ${ }^{67}$, a segunda, de Bohumil Karel Mareš, publicada em 1891, com segunda edição de $1901^{68}$, também com o mesmo nome, e a terceira, de Bohumil Ryba, de 1949, intitulada Sto listů M. Jana Husi ${ }^{69}$. Estas três foram publicadas em Praga. De todas as edições que apresentamos, dispomos do Documenta de Palacký e do Korespondence de Novotný e ambos serviram para nossas consultas aos textos originais em latim ou em tcheco.

Tomamos conhecimento de quatro traduções das cartas de Hus baseadas no Monumenta, no Documenta ou no Korespondence. Embora essas obras não contenham apenas as cartas de Hus, incluindo outros documentos da época, as traduções às quais nos referimos apresentam apenas a correspondência. A primeira é datada de 1846 e foi traduzida para o francês, a partir do Monumenta, por Émile de Bonnechose. Esta tradução de Bonnechose foi posteriormente publicada em o inglês com o título "Letters of John Huss, written during his exile and imprisonment; with Martin Luther's Preface; and containing a

\footnotetext{
${ }^{64}$ František Palacký foi um dos líderes do movimento de panslavismo dentro do Império Austro-Húngaro em meados do século XIX, que valorizava o nacionalismo e a cultura eslavas numa época na qual a língua oficial era o alemão e o poder estava nas mãos do império, em um dos típicos momentos de "antagonismo secular" entre tchecos e alemães, conforme expressão de Roger Portal que citamos na introdução. Em seus trabalhos históricos, destacou a época hussita como um dos momentos mais importantes da história tcheca. Sua publicação mais famosa intitula-se Dejiny národa českého v Čechách a na Moravě [História da nação tcheca na Boêmia e na Morávia], obra em cinco volumes escrita entre os anos de 1836 e 1867. Seu rosto está impresso na cédula de mil coroas tchecas.

${ }^{65}$ NOVOTNÝ, Václav. M. Jana Husi Korespondence a dokumenty. Praga: Komise pro vydávání pramenů náboženského hnutí českého, 1920.

${ }^{66}$ Fomos informados por Blanka Zylinska, professora de história da Universidade de Praga, via e-mail em 24 de maio de 2010, que esta obra de Novotný é hoje considerada a mais completa e a autoridade mais confiável dentre as edições das cartas hussitas.

${ }^{67}$ FLAJŠHANS, Václav. (ed.) Listy husovy. Praga: J. Otto, s/d.

${ }^{68}$ MAREŠ, Bohumil Karel. Lisy husovy. 2a ed. Praga: Samostatnost, 1901.

${ }^{69}$ RYBA, Bohumil. Sto listů M. Jana Hus. Praga: Jan Laichter, 1949.
} 
General View of the Works of Hus". O tradutor do francês para o inglês, Campbell Mackenzie, não é muito citado e esta obra é normalmente referenciada ao seu autor francês ${ }^{70}$. Por esse motivo, sempre que nos referirmos a este livro, utilizaremos o nome de Bonnechose.

A segunda é datada de 1904 e foi traduzida a partir do Documenta. O título original é “The letters of John Hus" e foi traduzida do latim para o inglês por R. Martin Pope, com notas explicativas escritas por Herbert B. Workman. ${ }^{71}$ Esta obra também está disponível em nossas mãos.

A terceira, a mais recente, é datada de $\mathbf{1 9 7 2}$ e foi traduzida a partir do Korespondence. O título original é "The Letters of John Hus", traduzido do latim e do tcheco para o inglês por Matthew Spinka ${ }^{72}$. Esta edição também está em nossas mãos.

Workman e Pope citam a tradução de HÖFLER para o alemão, da qual não dispomos, intitulada Geschichtschreiber der husitischen Bewegung in Böhmen In: Fontes rerum Austiacarum e publicada em Viena no ano de 1865 . Eles afirmam ${ }^{73}$ que esta edição foi submetida a "severa crítica" por Palacký. A figura 3 apresenta uma "linha do tempo" que localiza as principais edições das cartas de Hus.

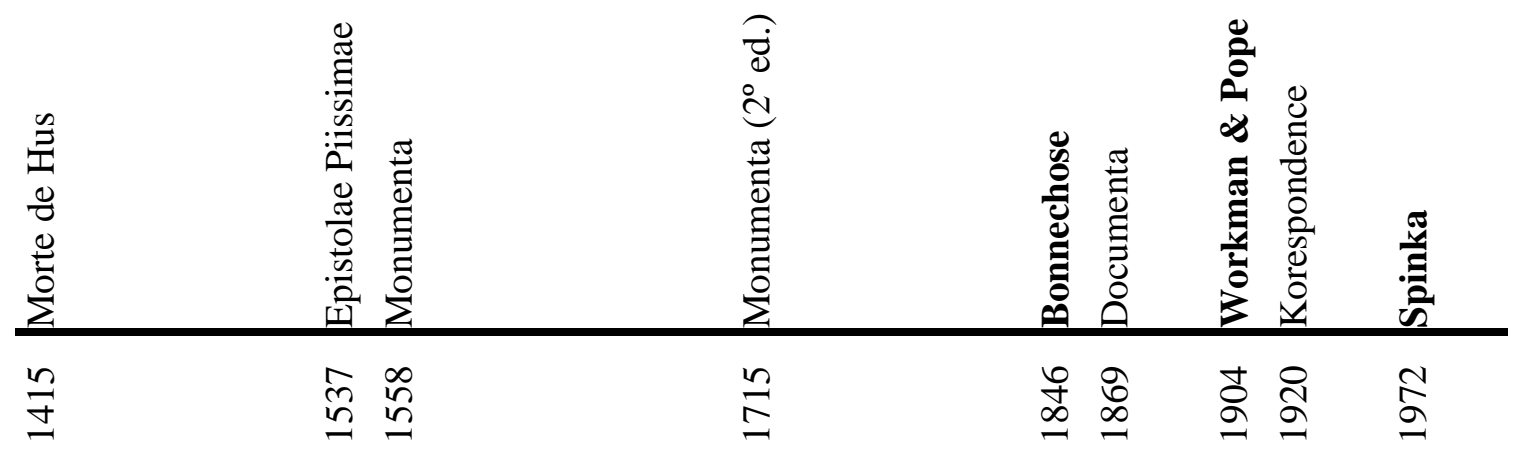

Figura 3. Principais edições das cartas de Hus - linha do tempo

Para esta tese trabalhamos com o Documenta, o Korespondence e com as traduções de Bonnechose, Workman e Pope e Spinka. Todos estes três autores afirmam que a sua tradução é a primeira em sua língua. Workman e Pope justificam isso afirmando ${ }^{74}$ que

\footnotetext{
${ }^{70}$ Assim o fazem, por exemplo, Workman e Pope na citação que apresentaremos na sequência quando justificarão o ineditismo de sua tradução.

${ }^{71}$ WORKMAN, Herbert B.; POPE, R. Martin. The letters of John Hus: with introductions and explanatory notes. Londres: Hodder and Stoughton, 1904.

${ }^{72}$ SPINKA, Matthew (ed.). The letters of John Hus. Manchester, USA: Manchester University Press, 1972.

${ }^{73}$ WORKMAN; POPE. op. cit., p. vi.

${ }^{74}$ ibidem, pp. v-vi
} 
As cartas de Hus ainda não foram adequadamente traduzidas para o inglês. A única tradução existente é a de Mackenzie e publicada em Edinburgh no ano de 1846. Ela foi realizada a partir da edição francesa das cartas, de Bonnechose, e não a partir dos originais. Infelizmente, o trabalho de Bonnechose é baseado na edição bem imperfeita de 1558 - Historia et Monumenta J. Hus et Hieron. Pragens. (também com diferente paginação e material adicional no ano de 1715). Não houve, até o momento, nenhum trabalho a partir do texto de Palacký, que, além de ser mais completo, possui também o mérito de apresentar as cartas organizadas por sua aproximação cronológica.

A crítica de Workman e Pope à tradução de Bonnechose compreende desde a ordem "confusa" da apresentação das cartas até apontamentos de dificuldades do tradutor com algumas expressões tchecas deixadas sem tradução e algumas cartas "tristemente confusas". Lendo a tradução de Workman e Pope, constatamos uma preocupação em comparar as diferenças entre o Documenta e o Monumenta, bem como apontar variações que consideram importantes nas traduções de Bonnechose e Höfler. Pope, porém, não traduziu dos originais tchecos. Para essas cartas, valeu-se da tradução para o latim existente no próprio Documenta, comparando-a "cuidadosamente" com a versão de Höfler.

Spinka não faz qualquer menção às outras publicações das cartas de Hus, exceto sua própria publicação anterior ${ }^{75}$. No entanto, os editores, na orelha do livro, afirmam que "é a primeira vez que as cartas de Jan Hus, este importante reformador religioso medieval, apareceram em tradução para o inglês". Ao longo de toda a obra, o tradutor apresenta poucos comentários ao processo de tradução e não menciona as possíveis diferenças entre o Korespondence e as outras edições. Entretanto, na bibliografia as três compilações dos originais estão presentes, bem como a tradução de Workman e Pope, o que nos traz indícios que Spinka tenha trabalhado com essas obras.

As três traduções oferecem suportes por parte dos tradutores à leitura das cartas, apresentando contextos de produção, explicação de nomes e termos bem como a inclusão de textos explicativos. Bonnechose traduziu, além das cartas, os prefácios e comentários de Lutero. Escreveu apontamentos a respeito da obra de Hus e uma análise de seu Tratado sobre a Igreja.

Workman e Pope produziram uma compilação com uma contextualização mais extensa, se comparada com as outras duas. Para cada pequeno grupo de cartas, eles apresentam comentários e narrativas dos eventos que subsidiam a compreensão do contexto

\footnotetext{
${ }^{75}$ SPINKA, John Hus at the Council of Constance.
} 
de produção. Apresentam, também, uma breve introdução sobre as edições das cartas e uma tabela comparativa entre o Documenta e o Monumenta.

Spinka apresenta diversas notas explicativas sobre os personagens históricos citados nas cartas, os destinatários, os eventos históricos relacionados e as citações bíblicas e de outros livros. No entanto, para o aprofundamento no contexto de produção das cartas, remete o leitor a sua biografia de Hus, intitulada John Hus: a biography. ${ }^{76}$

Com relação ao volume de cartas que compõem a correspondência que está a nossa disposição e que tomamos por nosso corpus documental, ela é composta por 107 cartas. Destas, 102 foram escritas por Hus (constituindo sua correspondência ativa), 4 tiveram-no por destinatário (constituindo sua correspondência passiva) e uma, a de número $48 \mathrm{a}$, foi escrita por um apoiador de Hus para seus amigos na Boêmia e foi incluída nesta lista por fazer parte das edições de Bonnechose e de Workman e Pope, o que atesta sua relevância na compreensão de eventos ligados à vida do clérigo. Quase todas as 107 cartas estão presentes na edição de Spinka, que reúne 105 cartas (todas da correspondência ativa e três da passiva). As outras duas cartas não presentes na edição de Spinka estão ambas presentes nas edições de Workman e Pope e de Bonnechose. Workman e Pope reúnem 88 cartas (83 ativa, 4 passiva e a carta 48a) e Bonnechose, 56 (51 ativa, 4 passiva e a carta 48a). ${ }^{77}$ Entendemos que cada uma destas edições baseou-se numa edição tcheca ou alemã anterior.

Temos por hipótese que as cartas que Petr de Mladoňovice guardou a pedido de Hus foram parte daquelas escritas de Constança. Observemos que o número de cartas da correspondência ativa apresentado por Bonnechose (51) e, por consequência, extraídas das primeiras edições alemãs das cartas hussitas, é menor que número de cartas escritas de Constança (65). Outra corroboração a esta hipótese é o fato de que a maioria das cartas que Bonnechose apresenta está concentrada nesse período final da vida de Hus. Entendemos que cada nova edição da correspondência pôde reunir novos documentos por meio de um trabalho histórico e/ou arqueológico empreendido ao longo dos anos pelos historiadores tchecos. As

\footnotetext{
${ }^{76}$ Spinka é autor de diversos livros sobre Jan Hus, sendo as cartas e a biografia os dois últimos que publicou, respectivamente em 1968 e 1972. Ele também escreveu trabalhos sobre Jan Amós Comenius (Komensky) na década de 40, época na qual publicou sua primeira obra sobre Hus, John Hus and the Czech Reform. Foi professor de história da igreja no Hartford Seminary Foundation, em Connecticut, nos Estados Unidos. Ele morreu no mesmo ano da publicação das cartas de Hus, 1972.
}

${ }^{77}$ OBERG, João Huss, um injustiçado?, p. 14, afirma que as publicações de Bonnechose e de Workman e Pope possuem "uma série quase igual das mesmas cartas", o que não concordamos, tanto no que diz respeito à sequência, quanto à quantidade, o que é facilmente perceptível no Apêndice 1, especialmente nas primeiras cartas. O Apêndice 1 desta tese apresenta a correspondência da numeração neste trabalho, nas três compilações de originais e nas três traduções para o inglês. Essa tabela foi montada a partir da nossa comparação das cartas nas traduções e no Documenta, das notas de rodapé na edição de Spinka e do Apêndice B na edição de Workman e Pope. 
cartas descobertas mais recentemente, se compararmos as cartas presentes no Korespondence de Novotný com as edições anteriores na lista apresentada no Apêndice 1 desta tese, são em sua maioria as mais antigas. Não temos informações a respeito de onde estas cartas foram encontradas, o que inviabiliza qualquer certeza a respeito de como elas foram guardadas. No entanto, essas informações sugerem que outras pessoas, além de Petr de Mladoňovice, também guardaram as cartas escritas por Hus. Quem seriam essas pessoas? Seriam outros discípulos ou seguidores do clérigo da Boêmia, o que indicaria certa amplitude de seu círculo de influência e de seguidores? Seriam seus opositores, que eventualmente interceptaram alguma carta e a incluíram na documentação da condenação de Hus? Seria algum de seus destinatários que guardou a carta recebida em meio à sua correspondência?

No que diz respeito à questão das cartas em sua maior parte terem sido escritas da prisão (as cartas de Constança), temos outro problema histórico a considerar. Como já afirmamos, não dispomos de todas as cartas escritas por Hus e esse imperativo da documentação condiciona nossa leitura do sentido de haver uma maioria da certas escritas de Constança. Hus pode ter escrito mais cartas porque estava preso. No entanto, essa maior quantidade de cartas pode ser um indício de que elas foram consideradas as mais importantes pela pessoa que as guardou. Ou então, especificamente Petr de Mladňovice preservou todas as cartas que passaram por ele durante o período no qual era o secretário do nobre que acompanhava Hus. O fato das primeiras cartas hussitas terem sido publicadas por Lutero também pode ser um indício de uma seleção. O reformador alemão pode ter publicado, daquelas que estava à sua disposição, apenas as relativas ao julgamento do clérigo da Boêmia. Como a publicação de Lutero foi fundamental para a preservação da correspondência hussita, parte das outras que ele não publicou pode ter sido perdida. Este é outro problema que não podemos resolver com a documentação que dispomos e toda conclusão que tirarmos dela está restrita à sua abrangência.

Com relação à numeração das cartas, para este trabalho, decidimos seguir a de Spinka, por ser a edição mais completa e apresentar as cartas em ordem cronológica. No entanto, as quatro cartas que aparecem no apêndice do livro desse autor, bem como as duas cartas ausentes em sua tradução mas presentes nas obras dos outros tradutores, incluímos por aproximação cronológica ao longo da numeração, seguidos da letra "a", como fizemos acima ao citarmos a carta 48a. Seguir a numeração de Spinka também implicou em aceitar que algumas cartas (por exemplo, 34, 61, 97 ou 100) não estão divididas em duas, conforme apresentaram Workman e Pope ou Bonnechose. 
Apenas Workman e Pope e Spinka apresentaram datações para as cartas. Estas, porém, divergem quando não indicadas explicitamente no texto. A carta 28, por exemplo, Workman e Pope afirmam ser de "outubro de 1412" enquanto Spinka propõe "outono" do mesmo ano. Igualmente ocorre na carta 33, com as datações "final de abril de 1413 " ou "antes de 25 de abril de 1413". Em outras, há distâncias temporais grandes, como é o caso da carta 11, datada de "outono de 1408", para Workman e Pope, e "cerca de agosto de 1410", para Spinka. No caso desta carta, a distância não interfere tanto na compreensão do curso dos eventos, porém, não ocorre o mesmo com a de número 101.

Para Spinka, e também para Novotný, o editor tcheco da correspondência hussita, a carta 101 é a última que Hus escreveu, tendo-o feito na véspera de sua execução, em 5 de julho. Se assim o for, ela marca a audiência de 5 de junho como decisiva para a condenação do reformador boêmio, pois Hus a relembra no dia antes de ir à fogueira. Por outro lado, se ela tiver sido escrita em 7 de junho, como propõem Workman e Pope, ela é apenas um relato dessa audiência, não atribuindo a esse evento a força que ele teria se tivesse sido relembrado no dia 5 de julho. Assumimos a datação de Spinka.

Para apoiar nossa leitura das cartas, utilizamos principalmente três trabalhos biográficos. O primeiro e mais utilizado é a biografia de Spinka, que mencionamos há pouco, publicada em 1968. Do mesmo autor, utilizamos também a obra John Hus at the council of Constance, publicada em 1965. Nela, Spinka traduziu para o inglês o Relatio de Petr de Mladoňovice, fonte primária importante e utilizada por todos os estudiosos de Hus. Igualmente retiramos diversas informações da biografia escrita por David S. Schaff, em 1905, intitulada John Huss: his life, teachings and death after five hundred years. Foi este biógrafo que traduziu para o inglês o mais famoso tratado escrito por Hus, seu De Ecclesia, publicado em inglês como Treatise on the Church em $1915^{78}$. Também tivemos acesso a duas publicações de textos de Hus em tcheco e latim. A primeira é seu tratado sobre a ortografia tcheca (De ortographia bohemica) ${ }^{79}$ e a segunda é seu texto devocional escrito a mulheres religiosas intitulado A filha $(\text { Dcerka })^{80}$.

Em suma, nosso corpus documental é constituído por 102 cartas escritas por Hus e 5 cartas escritas por outras pessoas, traduzidas para o inglês em três edições diferentes

\footnotetext{
${ }^{78}$ HUSS, John. The Church. Trad. David Schaff. Nova Iorque: Charles Scribner's Sons, 1915. Reimpressão Westport, Connecticut: Greenwood Press, 1976.

${ }^{79}$ HUS, Jan. Ortographia bohemica (Ortografie česká). Edição de Aloys Vojtěch Šembera. Tiskem Leopolda Sommra, 1857.

${ }^{80}$ DE VOOGHT, Paul; PILNY, Josepha. Um classique de la littérature spirituelle: la "Dcerka" de Jean Huss.

Revue d'histoire de la spiritualité. Tomo 48, v. 3, n. 191, p. 275-314, 1972.
} 
(Bonnechose; Workman e Pope; Spinka), a partir de três edições diferentes das cartas de Hus em latim e/ou em tcheco (Monumenta, Documenta, Korespondence). Cada edição mais nova contém as cartas da edição anterior acrescidas de outras, sendo a tradução de Spinka a mais completa à nossa disposição. Como material de apoio à leitura dessas cartas, usamos as notas das traduções e duas obras biográficas. Três outros escritos de Hus, citados, ajudam-nos a contextualizar a obra, o pensamento e as práticas do autor.

O ineditismo da existência de textos de Jan Hus em português compeliu-nos a enfrentar a construção de uma versão em português para suas cartas. Recorremos a alguns estudos sobre o processo tradutório de modo a subsidiar nosso trabalho. O livro de Alves, Magalhães e Pagano ${ }^{81}$, trata de estratégias de tradução e propõe um modelo didático do processo tradutório. Ele permitiu-nos compreender sua complexidade e de que maneiras conduzi-lo para assegurar sua qualidade.

Os autores, em sua obra, revisam um conjunto de crenças sobre a tradução e o tradutor. Destas, destacamos a antiga afirmação que o tradutor é um traidor e que sempre há certo grau de traição ao original quando se traduz um texto. Essa afirmação parte do pressuposto equivocado que as línguas possam ser automaticamente transpostas umas para as outras, distanciando-se dos contextos histórico-culturais nos quais os discursos se processam. As pesquisas a respeito do processo tradutório revelaram a complexidade desse ato. Desse modo, por exemplo,

podem ser realizadas diferentes traduções de um mesmo original de acordo com os objetivos pretendidos, o público-alvo, a função que se busca atribuir ao texto traduzido e outros fatores mercadológicos ou não que participam das decisões a serem tomadas na recriação de um texto numa nova língua e cultura.

Eles também realizam um estudo e uma descrição de estratégias de busca e de análise e como estas atuam durante a tradução de um texto. Fazem parte desse processo: a definição de unidades de tradução, a busca de subsídios internos (cognitivos referentes principalmente à memória e a mecanismos inferenciais) e externos (fontes textuais e computacionais), e a análise macro (gênero, texto e contexto) e microtextual (palavras e estruturas gramaticais).

Definir qual o tamanho ideal das Unidades de Tradução (UTs) num texto é posicionarse perante a dicotomia "fidelidade versus liberdade". Quanto menor for a UT, no nível lexical, por exemplo, maior é a fidelidade que busca o tradutor. A partir do advento das pesquisas

\footnotetext{
${ }^{81}$ ALVES, Fábio, MAGALHÃES, Célia, PAGANO, Adriana. Traduzir com autonomia: estratégias para o tradutor em formação. $2^{a}$ edição. São Paulo: Contexto, 2003.
} 
linguísticas das décadas finais do século XX, especialmente a Análise do Discurso e a Teoria da Funcionalidade, a UT ideal seria todo o texto, o que garantiria a total liberdade. Para tentar romper com essa dicotomia, os autores propõem uma definição de UT na qual

suas características individuais de delimitação e sua extrema mutabilidade contribuem fundamentalmente para que os textos de chegada tenham formas individualizadas e diferenciadas. $\mathrm{O}$ foco de atenção e consciência é o fator direcionador e delimitador da unidade de tradução e é através dele que ela se torna momentaneamente perceptível.

Alves, Magalhães e Pagano propõem um modelo de fluxo que descreve possíveis caminhos que percorremos ao traduzir. Analisamos e refletimos sobre esse modelo durante as atividades práticas sugeridas no livro. Em seguida, realizamos a tradução de algumas cartas de Hus, de modo a não apenas aproximarmo-nos ainda mais de seus escritos e de suas ideias, mas também a observar nossas próprias estratégias de tradução, permitindo uma maior consciência do processo que realizávamos. O modo mais fácil de explicar como isso ocorreu é apresentando um registro do trabalho de tradução inicial e de como tomamos nossas decisões.

Iniciamos montando um quadro comparativo das edições, procurando nas cartas por elementos que nos permitissem encontrar o mesmo documento com suas três traduções. Para cada carta traduzida, fizemos uma leitura completa na edição de Spinka para apreender o sentido geral da carta.

A cada parágrafo, procuramos definir UTs que fossem comparáveis nas três edições. Como há diferenças de voz e de pontuação, por vezes trabalhamos com frases, em outras com orações e houve ainda momentos com os quais operamos a partir de expressões ou palavras. Às UTs não disponíveis para tradução automaticamente, a partir de recursos internos, oferecemos um tratamento no qual utilizamos os recursos externos disponíveis para encontrar a melhor tradução.

Deparamo-nos com as seguintes situações, diante das quais tomamos os caminhos descritos a seguir:

1. As UTs são idênticas nos textos. Procedemos à tradução, observando a coerência com os trechos precedente e posterior, os sentidos que determinadas palavras assumem em inglês e a adequação vocabular em português. Analisamos, então, qual a melhor colocação da voz, apostos e palavras conectivas em português.

2. As UTs são semelhantes, porém contendo palavras diferentes. Procedemos à redução das UTs temporariamente ao nível lexical, comparando os sentidos. Caso essas palavras tenham sentidos próximos e estes não modifiquem a possível ideia original do autor, 
a melhor palavra em português é escolhida para o texto. Caso essas palavras tenham sentidos diversos, retornamos à UT original e tomamos decisões com base no contexto que se encontra para selecionar qual será mantida no texto final. Estas escolhas foram registradas em notas de tradução ${ }^{82}$.

3. As UTs são semelhantes, porém escritas em ordem ou em voz diferente. Procedemos à tradução escolhendo a ordem ou a voz melhor adequada à versão em língua portuguesa.

4. As UTs são semelhantes, porém com palavras que só existem em uma ou duas das versões. Procedemos à tradução, analisando se o sentido dessas palavras está implícito nas palavras das outras versões ou pode ser traduzido numa única palavra. Caso não esteja implícito ou não possa ser traduzido, ambas são traduzidas. Em todos os casos, anotamos no rodapé a diferença.

5. Toda a UT só existe em uma das versões. Procedemos à tradução e anotamos essa circunstância no rodapé.

Após traduzirmos cada parágrafo, relemos o trecho traduzido, realizando pequenas alterações para aperfeiçoá-lo: seja uma palavra, seja a transformação de duas frases em uma ou vice-versa, seja a divisão do parágrafo em dois entre outras ações pontuais. O mesmo fizemos ao final da tradução de toda a carta. Ao longo do processo, algumas dúvidas foram esclarecidas a partir da comparação do trecho nas versões em latim ou em tcheco.

Esse registro pode parecer um tanto pragmático, ainda mais de um processo tão carregado de subjetividade como é o da tradução. É o que percebemos ao interagirmos com outros trabalhos, como os artigos de Oliveira ${ }^{83}$, que trata de diversas correntes de tradução, e o de Moraes $^{84}$, que estuda as relações entre a tradução e a subjetividade. Por meio destes textos encontramos elementos para refletirmos acerca de diferentes conceitos de língua e de sujeito e o modo como estes conceitos contribuem para uma leitura menos carregada de nossos sentidos subjetivos.

Arrojo, citada por Oliveira ${ }^{85}$, afirma que, na linha teórica da Desconstrução:

\footnotetext{
${ }^{82}$ Optamos por não incluir essas notas de tradução nas citações de trechos ao longo do trabalho, com vistas a oferecer maior legibilidade, excluindo notas que poderiam desviar o leitor do raciocínio que apresentamos. No Apêndice 2 desta tese, apresentamos a tradução de duas cartas de Jan Hus (números 27 e 28) com as notas referentes às diferenças entre as versões dos tradutores dessas cartas para o inglês.

${ }^{83}$ OLIVEIRA, Alessandra Ramos. Equivalência: sinônimo de divergência. Cadernos de Tradução. Universidade Federal de Santa Catarina. jan-jun 2007, nº 19, pp. 97-114.
}

${ }^{84}$ MORAES, Maria Rita Salzano. O que (se) passa na tradução? O que (ultra)passa a tradução? Literal. Escola de Psicanálise de Campinas. jan-jun 2002, nº 5, pp. 169-178.

${ }^{85}$ A. R. OLIVEIRA, op. cit, p. 109. 
O leitor de um texto não pode proteger os significados originais de um autor porque, a rigor, nem o próprio autor poderia estar plenamente consciente de todas as intenções e de todas as variáveis que permitiram a produção e a divulgação de seu texto. Da mesma forma, no momento da leitura, o leitor não poderá deixar de lado aquilo que o constitui como sujeito e como leitor - suas circunstâncias, seu momento histórico, sua visão de mundo, seu próprio inconsciente. [...] somente poderá estabelecer uma relação com o texto [...], que será sempre mediada por um processo de interpretação, um processo muito mais 'criativo' que 'conservador', muito mais 'produtor' do que 'protetor'.

O texto lido como um escrito desprovido de sentido único possibilita a construção do leitor sobre ele. Essa construção consiste na elaboração de novos sentidos por quem lê. É por isso que a autora apresenta a tradução, vinculada à linha teórica da Desconstrução ${ }^{86}$, como um ato não de equivalência, mas de "transformação de um texto em outro"

Estas reflexões despertaram em nós uma preocupação com as atribuições de sentido que nós fazemos quando lemos um texto e que na tradução podem resultar num texto esquecido de seu contexto de produção. Nesse processo, por não nos prendermos somente às palavras, pudemos imergir nas ideias de Hus e "discuti-las" com seus tradutores, percebendo o quanto num trecho um deles estava preocupado em ser "literal" enquanto o outro estava preocupado em compreender o sentido. As notas dos tradutores para a língua inglesa também foram importantes por apontarem dificuldades na tradução do latim de alguns trechos.

Diante de um trecho, apresentado por vezes com até cinco versões diferentes (três em inglês, uma em latim e uma em tcheco), quão objetiva e "literal" pode ser nossa tradução? Quão rígida pode ser a descrição do processo? Cada tradutor e editor fez um esforço de compreensão da escrita hussita para atribuir-lhe um sentido. Não foi diferente para o nosso caso. Reescrevemos as palavras de Hus em nossa língua, depois de muitas horas de conversa com Palacký, Novotný, Bonnechose, Workman, Pope, Spinka e o autor das cartas. O resultado dessa conversa é o que apresentamos nesta tese.

\footnotetext{
${ }^{86}$ A autora afirma que a Desconstrução é uma linha teórica contemporânea, ligada ao pós-estruturalismo, que tem como representantes teóricos Jacques Derrida, Stanley Fish e Jacques Lacan.

${ }^{87}$ ibidem, p. 108.
} 


\subsection{Como escrever cartas no século $X V$ ?}

Os séculos finais do período que se convencionou chamar de medieval ${ }^{88}$ assistiram a uma mudança qualitativa no significado e na extensão das práticas de cultura escrita. Essa mudança foi caracterizada por uma inclusão dos iletrados no mundo escrito e a formação de uma cultura literária mais laica entre os séculos XI e XIII. ${ }^{89}$

Ela foi acompanhada pela lenta porém progressiva utilização das línguas vernaculares nos processos administrativos urbanos e a difusão dessas línguas com as traduções de textos bíblicos, especialmente a partir do século XII na Inglaterra e na França. ${ }^{90}$ Duas fortes instituições do período mantiveram o uso do latim, a Igreja e a Universidade ${ }^{91}$, mas esse uso não foi suficiente para frear a consolidação do vernáculo como língua escrita difundida socialmente. ${ }^{92}$ Prova está que Jan Hus, cerca de dois séculos depois, escreve parte

\footnotetext{
${ }^{88}$ NUNES, Ruy Afonso da Costa. História da Educação na Idade Média. São Paulo: Editora Pedagógica e Universitária Ltda. Editora da Universidade de São Paulo, 1979, pp. 9-10 afirma que o termo "Idade Média" é impróprio, mas já se tornou convencional e que pode ser usado "desde que nos tenhamos desembaraçado da ignorância e das prevenções que outrora se lhe associaram.” Já BARRACLOUGH, Geoffrey. Europa: uma revisão histórica. Tradução de Affonso Blacheyre. Rio de Janeiro: Zahar Editores, 1964, pp. 78-79, não concorda com esse uso, afirmando que "trata-se de um conceito apenas, uma categoria mental conveniente, e não uma realidade. (...) não existiu uma Idade Média. Ela foi apenas a ideia de um medíocre erudito alemão de três séculos atrás, que dispunha de muito menos dados históricos para trabalhar do que as pessoas comuns de nossos dias." LE GOFF, Jacques. Para um novo conceito de Idade Média: tempo, trabalho e cultura no ocidente. Lisboa: Editorial Estampa, 1980, p. 12 afirma trabalhar com uma "Outra Idade Média" que é "uma longa Idade Média, em que todos os aspectos se estruturam num sistema que, no essencial, funciona desde o Baixo Império Romano até a Revolução Industrial dos séculos XVIII e XIX."
}

${ }^{89}$ CASTILLO GÓMEZ, Antonio (coord.). Historia de la cultura escrita: del próximo oriente antiguo a la sociedad informatizada. Gijón, Astúrias, Espanha: Ediciones Trea, S. L., 2001, p. 183.

90 ibidem, p. 184.

${ }^{91}$ A bibliografia sobre ambas as instituições é vasta e foi utilizada, na medida da necessidade, ao longo deste trabalho. Para o leitor interessado, apontamos aqui algumas obras que foram importantes para nossa compreensão dessas instituições, especialmente no início de nossa pesquisa. Jacques LE GOFF, Os intelectuais na Idade Média, pp. 93-198 apresenta as características da universidade, sua história e fortuna nos séculos XIII em diante. Igualmente, em outra obra, o mesmo autor apresenta a presença da Igreja no cotidiano: LE GOFF, Jacques. Maravilhoso e o quotidiano no ocidente medieval. Lisboa: Edições 70, 1985. MIALARET; VIAL, História mundial da educação, p. 267 aponta, por exemplo, para o surgimento da Universidade como resultante da conciliação entre o desejo de liberdade intelectual e a vontade de manutenção da autoridade por parte da Igreja. TUCHMAN, Barbara W. Um espelho distante: o terrível século XIV. Tradução de Waltensir Dutra. Rio de Janeiro: José Olympio, 1990, ao estudar o século XIV, este século que "nasceu sob o signo do sofrimento", trata em diversos momentos o papel social e cultural da Universidade e da Igreja. Também podemos citar duas obras de um importante medievalista francês. DUBY, Georges. Europa na idade média. São Paulo: Martins Fontes, 1988. DUBY, Georges. Tempo das catedrais: a arte e a sociedade, 980-1420. Lisboa: Editora Estampa, 1979. Este último trata mais especificamente das relações entre a Igreja e a arte no período medieval. Não podemos deixar de citar o clássico HUIZINGA, Johan. O declínio da Idade Média. Tradução de Augusto Abelaira São Paulo: Verbo; EDUSP, 1978, além de vários tratados de história da educação, muitos dos quais estão presentes na bibliografia.

92 CASTILLO GÓMEZ. op. cit., pp. 186, 203, 218, 219 e 238 para este e os próximos parágrafos, exceto na citação de Brocchieri, extraído de BROCCHIERI, Mariateresa Fumagalli Beonio. O intelectual. In: LE GOFF, Jacques (dir.). O homem medieval. Tradução de Maria Jorge Vilar de Figueiredo. Lisboa: Editorial Presença, 1989 , p. 136. 
de suas cartas e de seus textos em tcheco, participando de um movimento de valorização da língua tcheca. Esse movimento, porém, não se consolida apenas no campo cultural, mas também no político, como destaca Mariateresa Brocchieri a respeito do clérigo da Boêmia e de Wyclif:

Para Huss, como para Wycliff, um aspecto não marginal da actividade intelectual é a utilização da língua nacional (no seu caso, o checo), que se torna sinal de consciência de uma oposição social (contra os ricos), política (contra os alemães) e religiosa (contra a Igreja romana). Assim se conclui verdadeiramente o percurso do intelectual que, no clima turbulento de finais da Idade Média, optou pelo empenhamento político e alinhou ao lado da divergência e da reforma contra a tradição: Wycliff e Huss decidem abandonar o latim, a língua que os definia e distinguia como intelectuais. Ambos desejam a tradução do texto bíblico e a pregação em língua vulgar, 'para mudar as coisas' e não apenas para se fazerem compreender por um público mais vasto.

Outra mudança importante no significado e na extensão das práticas de cultura escrita no final do período medieval é o lugar do manuscrito reunido no formato do in-folio na difusão da cultura escrita. Ele deixa de ser um objeto sagrado, suporte para a palavra revelada e se torna um veículo de transmissão do saber e fonte de conhecimento para os mestres e estudantes das universidades do século XII. Surge uma nova gramática da legibilidade, com novidades como a segmentação das palavras; os resumos encabeçando os capítulos; a disposição do texto em colunas, deixando espaços nas margens para as diversas possibilidades de glosas, comentários e anotações durante a leitura; o aperfeiçoamento dos sinais de pontuação e dos sistemas de abreviação; o emprego de iniciais adornadas e em cores distintas, rubricas e letras marginais; e a numeração dos cadernos, colunas e linhas, que proporcionava uma ordenação sequencial do texto.

Também nesse período ocorre o crescimento da escrita pessoal ou privada, manifesta em livros de contas, diários e cartas, por exemplo. Destas últimas, caras a este trabalho, sabemos que serviam como recurso escrito para estabelecer laços de união à distância e um lugar propício para confidências e informalidades, resguardadas as diferenças de formalidade da escrita de acordo com o remetente. Embora não fosse um gênero textual essencialmente feminino, a escrita de cartas guardava estreita relação com a escrita privada por parte de mulheres. Encontramos muitas mulheres escrevendo cartas, visto que essa prática, por se tratar de uma atividade privada, não alterava as convenções sociais impostas por uma mentalidade patriarcal. Castillo Gómez afirma, também, que na correspondência entre o rei Jaime II de Aragão (rei de 1291 a 1327) e seus filhos, há diferenças com relação à 
formalidade da escrita. $\mathrm{O}$ rei escreve empregando uma linguagem mais formal que a utilizada por seus filhos, escrevendo sobre detalhes e recomendações políticas enquanto os filhos, em especial as filhas, escreviam a respeito de aspectos sentimentais e pessoais. Esse autor apresenta ainda uma carta de julho de 1374, ditada por uma mulher analfabeta de nome Antonia, na qual encontramos um texto bem diferente das cartas formais medievais que lemos de Hus. Para uma pessoa como Hus, clérigo e professor universitário, mesmo a escrita privada era feita com um maior grau de formalidade. Percebemos com isso que a escrita, mesmo privada, estava submetida a regras e convenções de acordo com a condição sócio-cultural dos autores ou o lugar que ocupavam na sociedade.

Hus trabalhava sob essas regras e convenções em virtude de sua formação universitária, impregnando-se delas em seus estudos dentro do currículo medieval. Formado Mestre em Artes na Universidade de Praga, Hus vivenciou os estudos do trivium e do quadrivium $^{93}$. Como não temos referências de como era organizado esse currículo em Praga, podemos fazer apenas aproximações a partir de outras universidades do período. $\mathrm{Na}$ Faculdade de Artes de Paris estuda-se mais a lógica e a dialética além das ciências matemáticas e astronômicas, enquanto em Bolonha insiste-se mais na retórica. ${ }^{94}$

Com relação a esta última disciplina, sua abrangência é ampla por tratar da linguagem humana. Originada na antiguidade greco-romana, ela ganha desde o século XII "novos tons" a partir da força das artes poéticas (literatura). ${ }^{95}$ Nos séculos seguintes, os tratados de retórica passam a ser mais específicos em relação ao objeto que tratam, especializando-se em tratados de arte oratória, de arte poética e de ars dictandi, o estudo da retórica da escrita de cartas. ${ }^{96}$

A tradição da adaptação do discurso clássico às peculiaridades da carta começou no norte da Itália no século XI, tendo um grande desenvolvimento da ars dictandi em Bolonha no século seguinte. ${ }^{97}$ Diversos tratados foram escritos nessa época e são todos muito

\footnotetext{
${ }^{93}$ O trivium consiste nas disciplinas de Gramática, Retórica e Dialética, enquanto o quadrivium engloba Aritmética, Geometria, Música e Astronomia.

${ }^{94}$ LE GOFF. Os intelectuais na idade média, pp. 105-106.

${ }^{95}$ MONGELLI, Lênia Márcia. Retórica: a virtuosa elegância do bem dizer. In: MONGELLI, L. M. (coord.) Trivium e quadrivium: as artes liberais na Idade Média. Cotia: Íbis, 1999, p. 74.

96 ibidem, pp. 74 e 93-94. TIN, Emerson (org.). A arte de escrever cartas. Campinas: Editora da Unicamp, 2005, p. 35 afirma que na França, o estudo sobre cartas era ensinado em conjunto com a Gramática. Este é um período no qual a escrita não é de domínio de todos. Os autores utilizam-se de secretários para os quais ditam o conteúdo de suas cartas ou de outros textos (como leis, tratados etc.), sendo a ars dictandi uma arte retórica do ditado. Ditar para outra pessoa não era o caso de Hus, que escrevia seus próprios textos, mas é provável que o seja para o nobre Jan de Chlum, correspondente frequente do clérigo, que levara um secretário consigo durante a viagem para Constança.

${ }^{97}$ TIN. op cit, p. 32 e seguintes.
} 
semelhantes com relação ao seu conteúdo. Em 1135, em Bolonha, um autor, cuja identidade nos é desconhecida, escreveu um tratado sobre as regras para a escrita de cartas (Rationes dictandi $)^{98}$. Foi somente após a leitura desse texto que, reconhecendo nas cartas de Hus as características presentes nessas regras, conseguimos entender a escrita do clérigo da Boêmia e, por meio dela, sua figura de educador. Dediquemos, portanto, algumas páginas para entender a formalidade da escrita epistolar medieval.

O autor anônimo de Bolonha inicia seu texto apresentando-o como oriundo de pedidos de professores para uma breve exposição sobre as regras para escrever cartas. O opúsculo está dividido em treze partes. A primeira é o prefácio. Na segunda, o autor aponta como um texto escrito deve ser, definindo-o como "uma adequada e conveniente exposição escrita sobre alguma coisa, ou memorizada ou enunciada em discurso ou por escrito". Diferencia textos métricos, rítmicos e prosa e afirma que o último deve ser "conveniente e simples (...) porque as palavras de um escritor poderiam alcançar até o menos educado ou as mais ignorantes pessoas" e "em conformidade com as circunstâncias". Em seguida, na terceira parte, define o que é uma carta:

Uma epístola ou carta, então, é o adequado arranjo das palavras assim colocadas para expressar o sentido pretendido por seu remetente. Ou, em outras palavras, uma carta é um discurso composto de partes ao mesmo tempo distintas e coerentes, significando plenamente os sentimentos de seu remetente.

Estrutura, então, o autor de Bolonha, a carta em cinco partes: saudação (salutatio), captação da benevolência (captatio benevolentiae), narração (narratio), petição (petitio) e conclusão (conclusio). E segue, nas partes 5 a 9 do texto, com um detalhamento delas. Destacamos o espaço dedicado à saudação no tratado desse autor anônimo do século XII. Ele utilizou quase metade do texto visível na edição consultada com essa explicação. Por que o fez? A definição do autor pode nos dar uma pista: “A saudação é uma expressão de cortesia que transmite um sentimento amistoso compatível com a ordem social das pessoas envolvidas." (grifo nosso) Numa sociedade que valoriza o lugar que o indivíduo ocupa na sociedade e estabelece regras para a relação entre aqueles que o ocupam ${ }^{99}$, a carta precisa apresentar claramente o lugar de quem escreve e para quem escreve.

\footnotetext{
${ }^{98} \mathrm{O}$ texto foi traduzido e está publicado em TIN, op cit, pp. 81-109, de onde foram retiradas as citações seguintes.

${ }^{99}$ V. LE GOFF, Jacques; SCHMITT, Jean-Claude (coord.). Dicionário Temático do Ocidente Medieval. Coordenação da Tradução Hilário Franco Júnior. Bauru, SP: Edusc, 2006, pp. 237, 297 e 447, por exemplo, nos quais os autores mostram a hierarquização da sociedade, as diferenciações entre os indivíduos e a importância
} 
A saudação pode ser de três tipos: prescrita, com o nome do destinatário escrito primeiro, seguido por suas qualificações; subscrita, com o nome do destinatário ao fim, com todas as suas qualificações; circunscrita, com o nome do destinatário "escrito em vários lugares". Para este caso, o autor oferece um exemplo explicativo:

A Inocêncio, venerado em Cristo Nosso Senhor, pela Graça de Deus, o Sumo Pontífice e universal Papa de toda a Sagrada igreja, Fulano, o bispo de Verona, presta a devida reverência em Cristo

Para escolher qual delas utilizar, o critério é justamente a ordem social, de modo que, quando alguém escreve cartas e

a diferença entre os estados das pessoas envolvidas é conhecida, ele deve levá-la em consideração primeiramente se o propósito é de um homem escrever para outro homem, ou de um escrever para vários, ou de vários para um, ou de vários para vários; e se de um igual para outro igual, de um inferior a um superior ou de um superior a um inferior.

Com essa preocupação, aquele que for superior deve aparecer primeiramente na saudação. Em seguida, o autor dá exemplos e regras de saudações a diversos tipos de pessoas, dentre os quais apresentaremos aqueles que oferecem elementos para compreensão das saudações nas cartas de Hus.

Na saudação ao papa, termos como "reverência, lealdade, devoção, obediência, servitude e submissão" são costumeiros. Entre eclesiásticos, devem ser usadas expressões como

'Fulano, pela graça de Deus, bispo da Sagrada Igreja de Bolonha, embora indigno, envia incessantes bons votos em Cristo' ou 'cumprimento no eterno Cristo', 'fraternais cumprimentos e preces no senhor', 'desejos crescentes de fraternal boa vontade e amor', 'expressa um sentimento de fraternal afeição', ou 'envia cumprimentos e sinceras preces no Senhor'.

De prelados para seus subordinados é costume enviar uma bênção. Desde que eles sejam párocos, a amigos, deve-se enviar "cumprimentos com um sentimento de amizade". Se eles não forem párocos, "amizade" modifica-se para "estima". Em cartas de excomunhão ou severa reprovação deve ser simples, como "Fulano, pela graça de Deus, bispo de Faventia, a Beltrano, um clérigo". Se for uma advertência, deve acrescentar algo como "cumprimentos de acordo com o mérito". Os subordinados devem utilizar aos prelados superiores palavras

dada à aparência na sociedade. TIN, op. cit., p. 86, no texto do Anônimo de Bolonha está a seguinte afirmação "É claro, entre todas as pessoas, algumas são proeminentes, outras são inferiores, e ainda outras estão entre ambas". 
como: lealdade, reverência, obediência, devoção, servitude e submissão, podendo acrescentar algo como "em Cristo" ou "no Senhor".

Entre amigos, há uma lista grande de sugestões que incluem expressões como "A Fulano, o mais íntimo dos amigos", "o mais amado dos companheiros" etc. Palavras como afeição, doçura, camaradagem, fraternidade também estão presentes.

Entre alunos e professores, as fórmulas valorizam a relação com o conhecimento, como esta, de um professor a seu aluno:

Fulano, promotor da carreira escolástica, deseja ver Beltrano, seu mais querido amigo e companheiro, adquirir os ensinamentos de toda a literatura, possuir plenamente toda a diligência da carreira filosófica, seguir não a loucura, mas a sabedoria de Sócrates e Platão.

De um aluno a um professor, a fórmula é semelhante à de um subordinado a seu superior. Também é comum utilizar os significados do nome do destinatário para levá-lo a uma maior boa vontade em ler. Conclui a parte sobre saudações o autor de Bolonha com uma consideração da importância de conhecer diversas saudações de modo que elas estejam adequadas ao tema da carta.

Após o estudo da saudação, o autor apresenta a captação da benevolência que é "uma certa ordenação das palavras para influir com eficácia na mente do destinatário”. A boa disposição para ler a carta pode ser assegurada por cinco modos: pela pessoa que envia a carta, se menciona humildemente alguma coisa sobre seus negócios, obrigações ou razões; pela pessoa que a recebe se, além da humildade do remetente, os louvores ao destinatário estiverem presentes; por ambas, imediatamente; pelo efeito das circunstâncias, se alguma coisa é acrescida que seja apropriada a ambas as pessoas envolvidas, ou que esteja no propósito das coisas, ou poderia ser adequadamente ou razoavelmente associada à boa disposição (com palavras como intimidade, afeição, companheirismo, familiaridade, senhorio e serviço, sentimento paternal e sentimento filial etc.); pela matéria em questão, destacando-se o grau de sua importância. Ao longo das cartas, palavras que exprimam boa disposição devem ser repetidas, como nomes que indiquem a honra ou a glória do cargo do destinatário.

A narração é a apresentação dos fatos da carta e deve ser breve e clara. Será simples se tratar de apenas uma matéria e complexa se compreender a exposição de várias matérias. Após a narração, o autor apresenta a petição, na qual "se tenta pedir alguma coisa". Ele apresenta nove tipos de petição: suplicatória (súplica), didática (o que deve ou não ser feito, por preceitos), cominativa (ameaças), exortativa (o que deve ou não se feito, por insistência), incitativa, admonitória (advertência), de conselho autorizado (aconselhamento), reprovativa 
(reprovação) e direta (simplesmente enunciando o pedido). Elas podem ser, também, simples ou complexas.

A conclusão é o término da carta e pode ser usada para afirmar ou negar, referir-se às vantagens ou não da matéria tratada, resumindo o que foi apresentando na narração. A carta é finalizada, então, sem se remeter à sua matéria, na primeira pessoa ("Eu saúdo Pedro e Paulo"), na segunda pessoa (“Adeus, Pedro e Paulo, meus amigos e irmãos”) ou na terceira pessoa ("Possa a boa fortuna ser cada vez maior para Pedro e Paulo").

Dos últimos quatro itens das regras para escrever cartas, os de número 10 e 11 tratam dessa estrutura, considerando quais dessas partes podem ser omitidas e como a sequência pode ser alterada. Com relação ao primeiro, o autor considera possível, para tornar uma carta breve, omitir a conclusão (por inutilidade ou inconveniência) e até mesmo a petição (se não houver nada a pedir). Porém, a omissão da narração impede a carta de estar completa. Para escrever uma carta abreviada é possível omitir também a saudação. Porém, se esta for omitida, também deve sê-la a captação da benevolência.

Ao discutir a ordem das partes, o autor defende a sequência na qual as apresentou, mas reconhece algumas possibilidades de variações: inversão da narração e da captação da benevolência (os sentimentos receptivos do destinatário antecedem a petição); a captação da benevolência após a narração e a petição, com ausência da conclusão (assegurar maior efeito nas cartas de resposta); a petição antes da narração (se feita com cuidado); articulação entre narrações e petições simples e complexas (podendo ser apresentadas partes de uma seguidas de partes da outra). Conclui suas regras o autor de Bolonha com uma discussão gramatical, antes afirmando que "toda carta deve ser arranjada dentro de um formato conveniente, como dito anteriormente, ou em conformidade com as circunstâncias".

Não temos informações para afirmar que Hus tenha lido este texto. Podemos, no entanto, levantar hipóteses a respeito da influência dessas regras na escrita hussita. Não nos esqueçamos, como já afirmamos, que ele estudou as artes do trivium na Universidade de Praga e que havia grande semelhança entre os tratados de ars dictandi no período em que estes foram escritos. Uma nova epistolografia, que retoma as cartas romanas (inicialmente de Cícero) e busca romper com a rigidez das regras retóricas medievais surgirá com o humanismo dos séculos XIV e XV, tendo como Petrarca (1304-1374) um dos fundadores desse novo movimento. No entanto, durante o século XV ainda havia convivência das regras medievais com a nova epistolografia. ${ }^{100} \mathrm{E}$ se olharmos para as cartas hussitas, encontraremos

${ }^{100}$ TIN, op. cit., p. 43. 
a estrutura presente na Rationes dictandi. Selecionamos uma carta escrita por Hus que consideramos exprimir mais claramente essa estrutura. Sem querermos antecipar as discussões que ela suscita, e que veremos no capítulo 2, vale a pena, neste momento, fazer um primeiro contato com um dos documentos que utilizamos como fonte deste trabalho.

Hus inicia a carta de número 28, destinada aos praguenses, com a saudação, colocando seus destinatários em primeiro lugar, mostrando a importância que lhes dá. Coloca-se numa posição de humildade, não apenas por apresentar o remetente após o destinatário, mas também pelos adjetivos que utiliza:

Para todos os fiéis e zelosos pelo Senhor Jesus Cristo e por Sua palavra que vivem na cidade de Praga. Mestre Jan Hus, servo de Deus, um sacerdote inútil, deseja-lhes perseverança no amor a Deus.

Segue para a petição, destacando a importância da matéria que trata na carta:

Meus bem-amados, suplico-lhes, com toda a força de meu coração, que não abandonem a verdade que aprenderam e cujo conhecimento lhes foi generosamente concedido pelo misericordioso Salvador.

Apresenta, então, com a captação da benevolência, por meio de uma disposição esperada da parte dos destinatários e da apresentação de como se sente. Utiliza uma citação de Paulo de Tarso, associando-se aos sentimentos expressos pelas palavras deste. Tocando nos sentimentos do leitor, Hus visa despertar uma boa disposição para ler a carta:

Tenho certeza que o senhor levará à perfeição a obra que iniciou em vocês, seus escolhidos, e dará a perseverança perante as tentações. Eu mesmo dependo da misericordiosa bondade de nosso Salvador, embora posso, neste momento, dizer com o apóstolo: "pois para mim o viver é Cristo e o morrer é lucro. Mas, se o viver na carne me dá a ocasião de trabalho frutífero, não sei bem o que escolher. Sinto-me num dilema: o meu desejo é partir e ir estar com Cristo, pois isso me é muito melhor, mas o permanecer na carne é mais necessário por vossa causa." Isto escreveu o apóstolo Paulo para os Filipenses, quando confinado a uma prisão em Roma.

Segue, então, sua narração, apresentando o motivo de sua escrita, o fechamento da Capela de Belém e sua posição perante esse evento:

Da mesma maneira, digo-lhes, meus bem-amados, embora eu não esteja preso, preferia morrer com Cristo e estar com ele. No entanto, eu anseio trabalhar com vocês pela sua salvação. "O que escolher, não sei”, espero pela misericórdia de Deus. De fato, temo que muitos males sejam cometidos contra vocês, que os fiéis sofram e os maus, por isso, percam suas almas. Estes se alegram enquanto exigem não apenas que a Palavra de Deus seja 
silenciada em mim, mas também que o lugar dessa palavra, Belém, seja fechada com barras de madeira. Permitirá o Deus onipotente que eles levem a cabo sua intenção? Porém, se Ele permitir que os criminosos causem sofrimento com seus atos, tal qual fizeram em Belém, onde ele nasceu, e em Jerusalém, onde ele nos redimiu, vamos, ainda assim, louvá-lo em sua graça, fazendo-nos humildes perante seu poder. Esse poder, que está com aqueles que o amam, liberta os que sofrem em seu nome e reserva o fogo eterno para aqueles que o insultam.

Retoma a petição inicial em forma de súplica, seguindo com uma nova captação da benevolência. Aqui, ele toca nos sentimentos do leitor apresentando-se como exemplo de perseverança a ser seguido:

Portanto, meus bem-amados, suplico-lhes que não se entreguem ao cansaço, mas rezem para que o Salvador nos dê a perseverança para seguir o que for bom. Confiemos em sua imensa bondade, para que ele liberte Sua palavra e nos ajude contra o Anticristo, que eu guerrearei com a ajuda de suas preces e, se o Cristo assim desejar, tendo a Palavra de Deus como minha arma.

Conclui sua carta, com uma frase que "nada contém que remeta diretamente à matéria da própria carta", conforme propõe em uma de suas fórmulas o anônimo de Bolonha ${ }^{101}$ :

A paz e o amor, o progresso em tudo o que for bom e a vida eterna em glória no outro mundo são o que desejo, de nosso Senhor Jesus Cristo, a vocês. Amém.

Lermos uma carta como esta sem conhecermos as regras retóricas que a estruturam, faz com que nos percamos no nosso próprio discurso, impedindo que compreendamos o discurso do século XV. Sem conhecermos estas regras, nós lemos a carta com a lente do século XX, no qual há uma distância cada vez maior entre a escrita de cartas e nossas práticas de escrita cotidianas no atual mundo digital. ${ }^{102}$ Ao mesmo tempo, aproximar-se de uma carta

\footnotetext{
${ }^{101}$ TIN, op. cit., p. 101.

${ }^{102} \mathrm{Na}$ imprensa temos dois exemplos dessa distância. O primeiro é de um comentário, datado de 10/09/2006, do então governador de São Paulo, Cláudio Lembo, sobre uma carta do ex-presidente Fernando Henrique Cardoso aos eleitores de seu partido. A reportagem dá destaque à fala de Lembo que escrever cartas é "coisa de velho", de "gente antiga": "As pessoas na minha idade, na idade dele [FHC] ainda escrevem cartas. Quando eu deixar o governo, no dia $1^{\circ}$ de janeiro, escrevo uma carta também, já que sou velho”, afirmou o então governador. (CATÃO, Andrea; Folha Online. Lembo ironiza FHC e diz que escrever cartas é "coisa de velho". Disponível em <http://www1.folha.uol.com.br/folha/brasil/ult96u82810.shtml>. Acesso em 02 nov. 2009) O segundo está relacionado ao papa Bento XVI. Em 17 de julho de 2009, ele sofreu uma fratura no pulso direito após uma queda no quarto de uma casa de veraneio no norte da Itália, onde passava férias. Informações de agências internacionais de notícia, apresentam a seguinte afirmação do chefe de traumatologia do hospital que operou o pulso do papa: "ao final da reabilitação, o papa poderá usar normalmente a mão direita, tocar piano um de seus passatempos preferidos - e escrever cartas." (FOLHA ONLINE. Vaticano diz que escuridão e perna da cama foram causas de queda do papa. Disponível em <http://www1.folha.uol.com.br/folha/mundo/ult94u600926.shtml>. Acesso em 02 nov. 2009, grifo nosso).
} 
como esta, com poucas informações a respeito do contexto de sua escrita, suscita muitas perguntas. Por que ele se preocupa com o "abandono da verdade"? Por que está vivendo um dilema? Por que ele teme problemas na capela de Belém? O que está fazendo o Anticristo, de modo que ele se propõe a guerrear contra ele? Respostas a estas perguntas só são possíveis com um conhecimento da biografia hussita e seu contexto sócio-cultural. E para utilizarmos cartas como fonte para encontrarmos o Hus educador, além de conhecermos suas regras de escrita e seu contexto de produção, precisamos saber com quais perguntas nos aproximaremos delas, de modo a obtermos respostas que nos permitam elaborar nossa narrativa histórica.

As cartas cumpriam a função de "moverem-se entre presença e ausência, ao mesmo

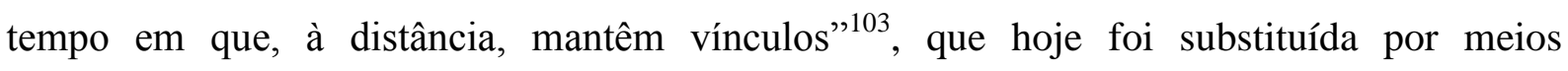
tecnológicos de grande velocidade, causando a ilusão da simultaneidade. No entanto, elas possuem um ritmo diferente, para alguns de nós, difícil de compreender:

Escrever cartas exige tempo, reflexão e disciplina, pois é uma forma de
compartilhar vivências mais pessoais, íntimas e até mundanas. Escrevem-se
e mandam-se cartas pelos mais variados motivos: conversar, seduzir,
desabafar, agradecer, pedir, segredar, informar, registrar, vender, comprar,
desculpar e desculpar-se, falar da vida, enfim! As cartas seguem um
protocolo, obedecem a um outro ritmo de tempo: levam um tempo para
chegar, muitas vezes demoram para ser respondidas e, não raro, demoram
para retornar.

Quando lemos uma coletânea de cartas organizadas num livro, o ritmo de nossa leitura é muito diferente do tempo da escrita, da demora da resposta, do que aconteceu no intervalo das cartas. O que para nós consiste num simples virar de página pode ser para o autor daquelas palavras uma imensidão de acontecimentos. Por exemplo, nas cartas de Hus escritas à véspera de sua execução, chega a haver uma distância de 6 dias entre a carta 97 e a de número 99, que estão na tradução de Spinka separadas por uma simples página. Não há indicações, pelo menos na correspondência, sobre o que aconteceu nesses dias, nem se houve respostas. Quando escrevemos nossa narrativa histórica, esses saltos são muitas vezes inevitáveis. Ginzburg, comentando sua obra "O queijo e os vermes", discute a possibilidade de preencher as lacunas existentes na documentação para construir uma narração uniforme. Suas palavras inspiram nossa proposta de análise:

Os obstáculos postos à pesquisa eram elementos constitutivos da documentação, logo deviam tornar-se parte do relato (...) Desse modo, as

${ }^{103}$ BASTOS; CUNHA; MIGNOT, Destinos das letras, p. 5 . O mesmo para a citação seguinte. 
hipóteses, as dúvidas, as incertezas tornavam-se parte da narração; a busca da verdade tornava-se parte da exposição da verdade obtida (e necessariamente incompleta). ${ }^{104}$

O fato de haver lacunas não é impeditivo de lermos as cartas. Nós preenchemos esses vazios da correspondência levantando perguntas a partir do que encontramos na documentação. $\mathrm{O}$ estranhamento desses vazios permite o levantamento de pistas para a construção nossa narrativa histórica. Mas não apenas na ausência de respostas do destinatário encontramos pistas. Se olharmos para a carta que apresentamos, percebemos uma nova pista pela ausência de elementos que pressuponham uma resposta esperada da parte de Hus. Ela foi escrita para um destinatário coletivo, os praguenses, e por isso pode ser referida como uma carta pastoral:

As Cartas Pastorais têm uma singularidade própria cuja característica primeira a ser revelada é a da epistolografia 'sem resposta'. (...) A Carta Pastoral quer existir ainda que corra o risco de nunca ser lida e de nunca se deparar com um leitor responsável por sua significação, ou seja, é um empreendimento que arrisca não (ob)ter sentido. Trata-se, todavia, de um exemplo de pré-suposição do significado a ser dado pelo leitor; por isso, o autor da Carta Pastoral sempre prescinde da resposta porque supõe a posse da significação inscrita na autonomia do outro, o leitor. (...) Opera-se, então, com a elaboração de um texto que, por abrir mão de quem lhe confere significado e sentido, abre mão também da comunicação multilateral. Comunicar-se passa a ser ouvir, e as Cartas Pastorais são escritas para serem lidas em público; destinam-se, então, à comunidade 'como um todo'. O 'outro', o indivíduo par na epistolografia, é suposto a priori mais como um ouvinte do que como leitor. Um ouvinte, cumpre assinalar, imaginado em assembleia, o que quer dizer, em silêncio. Essa procedência de ouvir sobre o ler aproxima a Carta Pastoral da forma retórica dos Sermões. ${ }^{105}$

Esse modelo de carta pastoral é apresentado com outra nomenclatura no texto de Hansen. ${ }^{106}$ Este autor, discutindo uma diferenciação proposta por Deissmann para os escritos bíblicos de Paulo de Tarso, reflete a respeito da diferença entre carta e epístola. A primeira teria por característica possuir um destinatário determinado enquanto a segunda seria endereçada a uma coletividade. Mas não apenas o destinatário diferencia uma da outra, também seu conteúdo que seria, no primeiro caso, mais particular e, no segundo caso, questões gerais, teóricas ou doutrinárias escritas de modo dissertativo. No entanto, essa

\footnotetext{
${ }^{104}$ GINZBURG, O fio e os rastros, p. 265.

${ }^{105}$ FREITAS, Marcos Cezar. Por quem os sinos dobram? In: BASTOS; CUNHA; MIGNOT, op. cit., pp. 61-62.

${ }^{106}$ HANSEN, João Adolfo. O nu e a luz: cartas jesuíticas do Brasil. Nóbrega - 1549-1558. Revista do Instituto de Estudos Brasileiros. 1995, n. 38, pp. 87-119, pp. 88-90 para as citações.
} 
diferenciação não é adequada em todos os casos, visto que "o mesmo discurso pode mudar de estatuto conforme as apropriações, que produzem valores de uso distintos do inicial". Optamos, contudo, pela expressão "cartas pastorais", dada a pouca utilização do termo epístola nos outros autores com os quais trabalhamos.

Se essa carta de Hus foi escrita para um público, uma coletividade, que está suposta na posição de ouvinte, como num sermão, por que ela foi escrita? Seria ela um registro, uma preparação de algo que seria dito posteriormente, uma antecipação de um encontro? Ou estaria ela substituindo um sermão presencial que não poderia ser proferido?

Essas cartas pastorais possuem um "sentido do mundo" numa visão autorreferenciada a respeito de outras visões de mundo ${ }^{107}$. Ao apresentar esse "sentido de mundo", as cartas pastorais possuem um "tom didático" e podem significar uma intenção educativa da parte de quem as escreveu. Se olharmos a tradição da epistolografia ocidental, percebemos que ela é devedora em parte também aos gregos Epicuro, Isócrates e Platão. Muitas de suas cartas foram destinadas ao ensino, sendo que eles inauguraram por meio de temas de interesse para toda a comunidade a prática das "cartas abertas" $" 108$. De que maneira cartas como essa de Hus, que apresentamos há pouco, apresentam sua síntese de "sentido do mundo"? O que o motivou a escrevê-las? Possuem esse "tom didático" que Freitas atribui às cartas de Antônio Vieira ${ }^{109}$ ?

As cartas pastorais, contudo, representam cerca de um quarto da correspondência hussita disponível. Dentro deste universo de 107 cartas, a maioria consiste de cartas pessoais, escritas esperando por uma resposta. As respostas, contudo, não temos, fazendo com que tenhamos apenas um lado da história e fiquemos sem saber o que o outro disse. Estudar cartas não consiste numa atitude de bisbilhotice na intimidade alheia, embora não possamos deixar de considerar que essa leitura desperte a curiosidade de saber o que acontecia entre os interlocutores. Mas o trabalho de escrita da história por meio da correspondência não se resume a "matar a curiosidade alheia". Ele pressupõe um olhar antropológico. O historiador "propõe uma leitura que não visa tanto desvendar a intimidade suposta, mas compreender as razões e a lógica que presidem essas práticas de escritura e de conservação." ${ }^{110}$ Esse olhar antropológico, que nos leva "a identificar e a isolar fragmentos do texto que se reportavam às

\footnotetext{
${ }^{107}$ FREITAS, op. cit., p. 58.

${ }^{108}$ MIRANDA, Tiago C. P. dos Reis. A arte de escrever cartas: para a história da epistolografia portuguesa no século XVIII. In: GALVÃO; GOTLIB, Prezado senhor, prezada senhora, p. 42.

109 ibidem, p. 62, nota 4.

${ }^{110}$ DAUPHIN, Cécile; POUBLAN, Daniéle. Maneiras de escrever, maneiras de viver: cartas familiares no século XIX. In BASTOS; CUNHA; MIGNOT, op. cit., pp. 82 e 83 para a citação seguinte.
} 
noções de tempo, de espaço, de finalidade da escritura e de efeitos nos correspondentes", também nos levou, inspirados pelas ideias de Ginzburg citadas anteriormente, a buscar indícios de uma intenção educativa em Hus.

Portanto, para lermos as cartas hussitas e nelas encontrar esses indícios, precisamos conhecer a retórica da escrita de cartas que o autor utilizou, o contexto no qual ele as escreveu e a função da carta (de acordo com a expectativa de resposta ou não de seu autor). São decorrentes destas características duas importantes perguntas que agora fazemos para a correspondência hussita: para quem Hus escreveu suas cartas e por que as escreveu?

\subsection{A rede de relações}

O historiador, poderíamos assim dizer, é um segundo leitor, que ao trabalhar com cartas pode "compreender itinerários pessoais e profissionais de formação, seguir a trama de afinidades eletivas e penetrar em intimidades alheias" $"$. Por isso, apresentamos um esboço da trama de afinidades que as cartas hussitas exprimem, identificando os destinatários delas.

Mignot, estudando a correspondência recebida na prisão pelo educador brasileiro do início do século XX Eduardo Sussekind de Mendonça, conclui sua reflexão com uma ideia que se assemelha ao que observamos na correspondência hussita:

Ele esteve preso, mas seus familiares e amigos também: foram presos de uma rede de ideias e afetos. Desafiando o arbítrio, foram escritas, lidas e guardadas como prova de amizade entre pessoas unidas por laços de sangue ou amalgamadas pela crença na importância da educação, da democracia e da liberdade. ${ }^{112}$

Igualmente, os personagens com que Hus se correspondeu formaram uma rede de relações, compartilhando ideias e afetos, ou, em alguns casos, conflitos e desafetos. Como a correspondência que aqui dispomos é parte da totalidade das cartas escritas por Hus, visto que existem cartas perdidas sobre as quais não temos nenhuma informação, o mapeamento dos destinatários não caracteriza os montantes nem as regularidades no envio de cartas. No entanto, esse mapeamento oferece-nos uma ideia de quem eram as pessoas com as quais Hus se correspondia. Por exemplo, o nobre Jan de Chlum é o destinatário mais frequente na correspondência que dispomos. Porém, não podemos afirmar a partir desta informação que ele foi o maior correspondente de Hus, visto que há um número para nós incalculável de cartas

\footnotetext{
${ }^{111}$ MIGNOT, Ana Chrystina Venâncio. Artesãos da palavra: cartas a um prisioneiro político tecem redes de ideias e afetos. In: BASTOS; CUNHA; MIGNOT, op. cit., p. 115.

112 ibidem, p. 135.
} 
escritas pelo clérigo para outras pessoas e que se perderam no tempo. É provável que a conservação de grande quantidade de cartas escritas a Chlum deve-se ao fato da maioria das cartas hussitas que chegaram até nós terem sido guardadas pelo secretário desse nobre. Como não é possível estabelecer a correta frequência dos destinatários, os exemplos que dispomos permitem traçarmos um panorama de quem são os correspondentes de Hus e do papel deste naquela sociedade.

A identificação dos destinatários não é uma tarefa simples. Ela só foi possível pelo aproveitamento das notas eruditas de Spinka e Workman e Pope, bem como os apontamentos biográficos de Schaff. ${ }^{113}$ Há trinta e duas cartas com um destinatário coletivo ${ }^{114}$ como "povo da Boêmia", "senhores e mestres em Praga", "nobres reunidos na corte do reino da Boêmia", "membros da universidade de Praga" ou vocativos um pouco mais detalhados como este da carta de número 27: "todos os que amam a Deus verdadeiramente, confessam sua lei, esperam que o Salvador apareça e com ele desejam viver para sempre.”

Outras oito ${ }^{115}$ possuem destinatários anônimos (clérigos, nobres, monges e uma dama da nobreza), ocupando períodos muito diversos da correspondência, sendo a primeira delas de 1404 e a última do ano de 1414.

Dois personagens são destacados pelo papel que exerceram na vida de Hus, diretamente relacionados ao período no qual o clérigo ficou preso. São eles Jan de Chlum e Petr de Mladoňovice. O primeiro foi um cavaleiro da nobreza da Boêmia, da corte do rei Sigismundo, convocado por este para acompanhar Hus em sua viagem a Constança. Chlum parece ter sido um membro de confiança de Sigismundo, pelos cargos que ocupou nas ações militares precedentes. Transformou-se de protetor a grande amigo, sendo uma das pessoas mais presentes ao lado de Hus durante o período em que esteve preso. Fez discursos e pregações em nome do clérigo e, por sua eloquência, foi confundido, na cidade de Biberach, com um doutor em teologia, fato a partir do qual recebeu de Hus e seus amigos o apelido de “doutor de Biberach". Cuidou de diversas "questões práticas" referentes à prisão de Hus e esteve presente acompanhando o Concílio.

Petr de Mladoňovice foi o secretário de Jan de Chlum. Nasceu na região da Morávia e foi estudante da Universidade de Praga. Como um bom secretário, durante toda a viagem de Hus a Constança até seu julgamento e morte fez anotações para um relato detalhado dos

\footnotetext{
${ }^{113}$ SPINKA, The letters of John Hus; WORKMAN;POPE, The letters of John Hus; SCHAFF, John Huss.

${ }^{114}$ Cartas de número 6, 19, 25, 26, 27, 28, 29, 31, 32, 34a, 37, 38, 39, 40, 41, 42, 46, 47, 48, 50, 51, 52, 58, 66, $73,87,91,93,94,98,100$ e 101.

${ }^{115}$ Cartas de número 1, 3, 5, 10, 14, 21, 22 e 49.
} 
eventos. Lidava com cartas e tratados de Hus, tendo um papel importante no julgamento, apresentando documentos para contrapor às acusações contra Hus. Tornou-se amigo íntimo de Hus e este o recomendou à Universidade. Virou professor desta instituição e, após a morte de seu amigo e mestre, fez parte do grupo de hussitas conservadores, junto de Christian de Prachatice. Vinte e oito cartas foram escritas para Petr e/ou Chlum ${ }^{116}$, contendo pedidos referentes à sua situação de preso, comentários em relação ao concílio e exortações morais. Embora por vezes um ou outro seja o destinatário explícito de algumas das cartas, entendemos que, em geral, era para ambos que Hus escrevia.

Christian de Prachatice foi benfeitor de Hus, tendo-o conduzido às vidas universitária e clerical. Hus sempre o considerou como seu benfeitor, mesmo depois de Christian não poder mais sê-lo. Isso ocorreu durante o período no qual Hus estava na Universidade e Christian, por ter apenas o título de mestre, não possuía titulação suficiente para permanecer nessa condição. Foi chefe da igreja de St. Michael, na Cidade Velha de Praga, desde 1405 e em sua casa ocorreram importantes conversas dos partidários da dupla comunhão (com o pão e o vinho) para leigos. Foi reitor da Universidade de Praga até 25 de abril de 1413 e representou os interesses daquele grupo nos debates sobre o conceito de Igreja. Foi à Constança com a comitiva real e chegou a ser preso, porém foi logo solto após assinar uma confissão de fé e receber a intercessão do rei Sigismundo. Foi, de Hus, um importante interlocutor. Continuou defendendo as ideias da dupla comunhão após a morte de Hus e foi um dos chefes do grupo dos hussitas conservadores de Praga, mantendo as práticas de adoração tradicionais, desde que não ferissem as escrituras, e oferecendo a dupla comunhão aos leigos. Cinco $\operatorname{cartas}^{117}$ da correspondência que dispomos hoje foram escritas para ele.

Quatro cartas ${ }^{118}$ tiveram por destinatários reis da época. As duas primeiras datam, respectivamente, de 1411 e 1412 e são dirigidas ao rei da Polônia. As duas últimas datam de 1414 e têm por destinatários os reis tchecos Venceslau e Sigismundo. Wladislaw Jagiello foi rei da Polônia. Sua esposa abriu uma moradia para estudantes lituanos em Praga. Ele deu forças para o desenvolvimento da Universidade de Cracóvia, reinstalando-a em 1400, e venceu os Cavaleiros Teutônicos em 1410. Na primeira carta, Hus suplica por um acordo de

\footnotetext{
${ }^{116}$ Cartas de número 53, 54, 56, 57, 59, 60, 61, 62, 63, 64, 65, 68, 69, 70, 72, 75, 77, 81, 82, 85, 86, 88, 89, 90, 95, 96, 97 e 99.

${ }^{117}$ Cartas de número 30, 33, 34, 35 e 92.

${ }^{118}$ Cartas de número 13, 24, 43 e 44.
} 
paz entre os reis Wladislaw e Sigismundo e, na segunda, afirma estar feliz pela concretização desse acordo e exorta ao rei da Polônia que atue para a correção dos vícios do clero.

Venceslau IV foi o filho primogênito de Carlos IV e se tornou chefe do Sacro-Império Romano Germânico e rei da Boêmia logo após a morte de seu pai. Nunca foi, no entanto, coroado. Assumiu o trono com 17 anos e foi considerado pelos historiadores como um rei fraco e ligado aos prazeres da vida real. Nos anos finais do século XIV, chegou a ser preso por seu irmão, Sigismundo, por ocasião de uma tentativa de destroná-lo. Após esse evento, num conflito com os arcebispos alemães, foi destronado em 1400, assumindo Ruprecht do Palatinado. No entanto, opondo-se a esse ato, manteve-se no poder em disputa com Ruprecht havendo, então, dois reis. Morreu em 1419, de ataque cardíaco. O rei e sua esposa foram apoiadores de Hus, assumindo uma postura contrária ao arcebispo Zbyňek quando este se voltou contra aquele.

Sigismundo, irmão mais novo de Venceslau, recebeu de seu pai, Carlos IV, após sua morte, o reino da Hungria. Nos primeiros anos do século $\mathrm{XV}$, liderou uma revolta para destronar seu irmão do império. Na tentativa de aumentar seu prestígio, convocou o Concílio de Constança, obtendo o apoio do papa de Pisa, João XXIII. Aceitou oferecer a Hus um salvoconduto que o permitiria apresentar-se em Constança e voltar sem que nada lhe acontecesse. Porém, durante o Concílio, em uma reunião secreta, pediu aos juízes que condenassem Hus, ele retratando-se ou não. Isso lhe trouxe prejuízos após a morte de Hus. Após o fim do Concílio e a morte de seu irmão, não conseguiu o trono da Boêmia e tentou por dezessete anos investidas militares e políticas contra a região para assumir o controle. Os conflitos só terminaram com um acordo, em 1437, no qual Sigismundo prometeu defender perante o Concílio de Basileia um documento, intitulado Compactata, que estabelecia os princípios da crença "reformada" dos hussitas. Embora o concílio aprovasse o documento, Sigismundo combateu os que aceitavam a dupla comunhão na Boêmia, o que provocou uma revolta. Foi obrigado a fugir e morreu nessa fuga, em 9 de dezembro de 1437. Ele é um personagem importante no julgamento de Hus e está presente em diversas de suas cartas, em momentos com pedidos de ajuda e com palavras de esperança, em outros com a perda da confiança na palavra real. Há diversos momentos nas cartas nos quais Hus apoia Venceslau contra Sigismundo.

Três $\operatorname{cartas}^{119}$ foram escritas a Henry Škopek de Dubá. Ele foi um membro da nobreza, que provavelmente apoiava Hus financeiramente e ouvia suas ideias. Possuía um

${ }^{119}$ Cartas de número 67, 71 e 74. 
castelo em Auscha e morreu em 1417. Hus demonstra grande estima por Henry Škopek, dado que para ele escreveu um conjunto de versos exortando-o a permanecer firme perante as adversidades. Na carta número 100, que designamos carta de despedida, Hus agradece a ele e a outros nobres "pelo trabalho e outras gentilezas" que lhe mostraram. Importante não confundi-lo com Venceslau de Dubá, um dos protetores de Hus durante a viagem, membro da corte de Sigismundo, que pertencia a uma divisão da casa de Dubá diferente da de Henry Škopek. Venceslau de Dubá aparece como um destinatário de Hus apenas no trecho final da carta número 97 escrita a Jan de Chlum, recebendo do clérigo felicitações por seu desejo expresso de se casar, exortando-o a viver uma vida que rejeite as coisas da terra, servindo a Deus em sua casa.

Outro personagem que foi destinatário de três $\operatorname{cartas}^{120}$ é o Arcebispo de Praga, Zbyněk. Ele ocupou o arcebispado no período de 1403 a 1411. Filho de nobres, teve uma ação militar importante antes de ser arcebispo, liderando tropas contra a invasão de Sigismundo. Ao assumir o ofício, posicionou-se a favor dos reformistas e estudiosos de Wyclif. No ano que assumiu esse cargo, 45 artigos de Wyclif foram proibidos na Universidade. Em 1405, o papa Inocêncio solicita a Zbyněk uma atitude para eliminar os erros wyclifistas da Boêmia. O mesmo faz Alexandre V em 1409. Zbyněk muda de posição. Em 1406, o arcebispo convoca um sínodo, a partir do qual afirmou que a Boêmia estava livre de heresias. Em 1408, Hus escreveu-lhe três cartas nas quais se defendia das acusações que sofria e sustentava a posição da neutralidade em relação aos papas. Em 1410 reuniu evidências contra Hus e em 1411 acusou-o de herege, excomungando-o. Promoveu a queima dos livros de Wyclif. Tornou-se impopular, fugiu de Praga e proclamou o interdito sobre a cidade, o que foi ignorado pelo rei e pelo povo. Escreveu para Venceslau, afirmando que este não lhe deu atenção e apoio e que se dirigia a Sigismundo para obter apoio e proteção. Morreu no caminho da viagem. Não se sabe a causa de sua morte.

O papa João XXIII foi um personagem importante no início do século XV e recebeu duas $\operatorname{cartas}^{121}$ de Hus. Ele foi eleito em 1409, no Concílio de Pisa, quando, então, era o Cardeal de Bolonha, Balthasar Cossa. O Concílio de Pisa depôs os dois papas, porém estes recusaram a deposição, passando a haver três papas. Até o concílio de Constança era considerado, na Boêmia, o papa verdadeiro, pois aceitaram o concílio de Pisa. Durante a discussão com Zbyněk, Hus apelou ao papa em dois momentos. No primeiro, em prol das obras de Wyclif, o que culminou numa comissão escolhida pelo pontífice para estudar a

\footnotetext{
${ }^{120}$ Cartas de número 7,8 e 9.

${ }^{121}$ Cartas de número 12 e 18.
} 
questão que concluiu não encontrando motivos para queimá-las. No segundo, em defesa de si próprio, pedindo ao papa que lhe absolvesse sem que ele fosse obrigado a ir até Roma, o que culminou em sua excomunhão e no interdito contra Praga. João XXIII abriu o Concílio de Constança com uma missa em 6 de novembro de 1414. Alguns dias após sua chegada, recebeu a visita de Jan de Chlum e lhe prometeu que Hus estaria a salvo "mesmo que tivesse matado seu [do papa] irmão”. Algumas semanas depois, porém, Hus foi preso. Jan de Chlum questionou o papa, que disse que os Cardeais pediram a prisão de Hus insistentemente. Para que o Concílio o definisse como único papa, tendo o apoio dos cardeais italianos, João XXIII nomeou diversos prelados in camera. As outras nações articularam-se para que a votação fosse feita por nação e não por "cabeça". Sendo essa a melhor maneira de não continuar o cisma, esse processo foi aceito. João XXIII foi acusado de diversos crimes (alguns dos quais não foram registrados, pois causariam escândalo). Depois de diversas tentativas de fazê-lo de forma menos oficial, aceitou abdicar seu trono se os outros papas o fizessem. Porém, fugiu escondido e, após se estabelecer em Schaffhausen, convocou os cardeais. Estes resolveram que continuariam o Concílio de facto, mesmo tendo dúvidas se o poderiam fazê-lo de jure. Por fim, João XXIII foi acusado, deposto e preso por dois dias no mesmo castelo, Gottlieben, onde estava Hus.

Havlík foi pastor da Capela de Belém e um dos que ficaram no lugar de Hus em sua ausência. Recebeu uma carta, a de número 83. Jan de Chlum provavelmente disse a Hus que Havlík opôs-se a introduzir a dupla comunhão na capela, este o motivo da carta. Havlík parece ter um papel importante em Belém, pois Petr de Mladoňovice narrou que ele lera uma carta de Hus na capela, comentando que este estava sem papel para escrever. Outro elemento que corrobora esta hipótese é a atribuição, por parte de Hus, de Havlík como seu substituto na Capela de Belém após sua morte. No entanto, quem assumiu o lugar de Hus foi Jakoubek de Stř́ibro, um dos líderes dos hussitas e o primeiro a instituir a dupla comunhão.

Há outros sujeitos que receberam pelo menos uma carta de Hus. São eles: um membro anônimo do concílio que tentou convencer Hus a abjurar. Este o chamou de Pater ${ }^{\mathbf{1 2 2}}$, provavelmente porque era perigoso deixar sue nome registrado; Martin de Volyně, discípulo de Hus; o povo das cidades de, Louny, Krumlov e Plzeň ${ }^{123}$, bem como Jan Barbatus (habitante da segunda cidade) amigo leigo partidário de Hus; Jan Chudoba ${ }^{\mathbf{1 2 4}}$, nobre "adepto fervoroso" de Hus, acusado de roubo, que recebe do clérigo uma exortação de boa conduta

\footnotetext{
122 Cartas de número 78 e 80.

${ }^{123}$ Cartas de número 16, 17 e 20, respectivamente.

${ }^{124}$ Carta de número 4.
} 
por meio da carta; John [Johann] Hübner ${ }^{\mathbf{1 2 5}}$, professor silésio-alemão da Universidade de Praga; Leonard Statii de Datis ${ }^{\mathbf{1 2 6}}$, dominicano, provavelmente um membro da comissão para investigação da heresia do Concílio de Constança; Štěpán de Dolany ${ }^{\mathbf{1 2 7}}$, superior da ordem cartusiana da cidade tcheca de Dolany, amigo do passado de Hus que se tornou um combatente das ideias de Wyclif e, consequentemente, do clérigo da Boêmia; John Sywort de Siebengergen ${ }^{128}$, na Transilvânia, professor da Universidade de Viena; Rychard Wyche $^{129}$, clérigo inglês, seguidor de Wyclif; Záviš de Zapy ${ }^{130}$, cônego pluralista de Prachatice, que recebeu de Hus uma admoestação escrita por tê-lo chamado de herege.

Hus era professor da Universidade de Praga e pregador da Capela de Belém. Esses dois lugares marcam os espaços a partir dos quais ele participou de uma rede de relações por meio da correspondência. Escreveu de Praga para cidades como Louny, Prachatice, Krumlov e Plzeň que cobriam várias regiões da Boêmia, bem como para outras regiões de fora da Boêmia como Áustria, Inglaterra, Polônia e para a Cúria Romana. Quando se exila de Praga, a correspondência faz o caminho inverso e Hus passa a escrever para a cidade sede da Capela de Belém e da Universidade, além das cartas que escreveu para seus amigos Jan de Chlum, Venceslau de Dubá e Petr de Mladoňovice, que estavam com ele em Constança. Prioritariamente, escrevia em latim, embora tenhamos cerca de um quinto das cartas escritas em tcheco. Estes foram os caminhos que as cartas fizeram se olharmos pelo critério geográfico-cultural.

Se seguirmos o esquema clássico de Georges Dumézil ${ }^{131}$, que propõe uma estrutura trifuncional nos fundamentos da cultura indo-europeia: os que rezam, os que combatem e os que trabalham, Hus correspondeu-se com todas as camadas sociais da época.

Entre "os que rezam", encontramos desde os superiores na hierarquia da Igreja, o papa e o arcebispo, a clérigos seculares tchecos, como Záviš, Havlík e Martin e ingleses, como Richard Wyche. Também correspondeu-se com monges, como o dominicano Leonard Statii e o cartuxo Štěpán de Dolany. Com estes, discutiu questões doutrinárias, defendeu suas posições, propôs normas de conduta moral ou aconselhou.

\footnotetext{
${ }^{125}$ Carta de número 2.

${ }^{126}$ Carta de número 84. Esta carta é apenas um fragmento.

${ }^{127}$ Carta de número 23.

${ }^{128}$ Carta de número 36.

${ }^{129}$ Carta de número 15.

${ }^{130}$ Carta de número 11.

${ }^{131}$ apud LE GOFF, Jacques (dir.). O homem medieval. Tradução de Maria Jorge Vilar de Figueiredo. Lisboa: Editorial Presença, 1989, p. 15.
} 
Entre "os que combatem", Hus teve contato com diversos membros da nobreza, como Jan de Chlum, Jan Chudobá, Henry Škopek e Venceslau de Dubá. Também escreveu para uma dama da nobreza e um nobre anônimo. Com eles, assumiu uma postura de conselheiro espiritual, analisando as situações que viviam e propondo formas de viver adequadamente dentro dos preceitos cristãos. Alguns foram seus apoiadores e receberam pedidos de ajuda e calorosos agradecimentos da parte de Hus.

Também foi importante a relação entre Hus e os reis da época. Embora seguindo os padrões retóricos de devida reverência na escrita a reis e imperadores, seus escritos, em especial para Venceslau IV e Wladislaw Jagiello, mostram proximidade suficiente para que ele se sinta à vontade para aconselhá-los, sustentar suas posições doutrinárias e se defender perante as acusações. A carta para o rei Sigismundo exprime maior submissão da parte do clérigo, assemelhando-se a um pedido de ajuda a alguém de pouca intimidade, apontando para uma relação difícil entre os dois, que se tornou num posicionamento em lugares opostos durante o Concílio de Constança.

Entre "os que trabalham", encontramos muitas cartas escritas para o povo de Praga, em especial àqueles que frequentavam a Capela de Belém, bem como para o povo de outras cidades tchecas, como Louny, Plzeň e Krumlov. Hus exerceu, por meio delas, o papel do clérigo que aconselha, exorta a uma vida correta dentro de preceitos morais que defendia na capela e atribuía aos eventos que ambos vivenciavam um "sentido de mundo" compartilhado.

De seu lugar de homem de saber, Hus escreveu para membros de universidades. Não há lugar para estas pessoas nas categorias de Dumézil, visto que no século XV muitos universitários estão ligados à Igreja ou o Estado, embora tenham um espaço que lhes reserva certa autonomia dentro da Universidade. Esse esquema trifuncional não dá conta da especificidade de tipos humanos que encontramos em nossa própria documentação, como o trabalhador intelectual. Hus escreveu para professores da Universidade de Praga, como um de seus reitores, Christian de Prachatice, e um professor alemão seu opositor, Hübner, e para professores de outras universidades, como Jonh Sywort, da Universidade de Viena.

Quando olhamos para nossa fonte e encontramos Hus referindo-se às pessoas com quem se correspondeu, observamos que ele trata dos tipos humanos de forma mais diversificada do que fez Dumézil em seu esquema. Na carta 73, escrita em 10 de junho de 1415 de Constança para os habitantes de Praga, ele exorta as pessoas a cumprirem diligentemente cada um o seu papel: 
Suplico aos nobres que lidem misericordiosamente com seus pobres e os guie com justiça. Suplico aos burgueses que conduzam seus comércios com justiça. Suplico aos artesãos que façam seu trabalho fielmente e obtenham seu sustento dele. Suplico aos servos que sirvam seus senhores e senhoras fielmente. Suplico aos mestres que, vivendo merecidamente, ensinem seus pupilos fielmente (...). Suplico aos estudantes e outros pupilos que obedeçam e sigam a seus mestres no bem e que estudem diligentemente pelo propósito do louvor a Deus e pela sua salvação e a dos outros. (grifos nossos)

Identificamos nesta citação seis tipos, isso sem considerar o rei e os clérigos que são citados em outros trechos da mesma carta. Le Goff já tinha percebido a incompletude do esquema de Dumézil quando propôs na obra que organizou, "O homem medieval", retratar essa figura a partir dos vários tipos humanos em que se concretiza. Ele abandona esse esquema clássico e, elaborando perfis desse homem, propõe o desenvolvimento de dez desses tipos. $^{132}$

Essa nossa leitura da rede de relações criada a partir da correspondência hussita vai ao encontro dos critérios necessários, segundo Peter Burke, para se responder à pergunta "para quem" se destinava uma tradução. Este autor afirma que essa pergunta exige uma resposta social além de geográfica. A primeira mostra os grupos sociais com os quais o sujeito se relaciona enquanto a segunda mostra o espaço geográfico-cultural dos destinatários. ${ }^{133}$

Foi essa ampla base sócio-cultural que favoreceu a Hus tratar de temas diversos em sua correspondência e, por meio deles, defender seus posicionamentos perante um amplo espectro de leitores. Esse clérigo tem a intenção de influenciar seus correspondentes por meio de sua escrita. Caso haja a aceitação dessa influência, essa rede de relações transformará a figura de Hus num educador da nação tcheca. Vejamos como ele exerce essa influência.

\subsection{Por que Hus escreveu suas cartas?}

Ao nos aproximarmos de nossa documentação, a pergunta título deste item se fez presente. $\mathrm{O}$ conceito de cartas como meio de estabelecer laços e manter vínculos à distância foi o primeiro que iluminou nossa leitura. Hus escreveu cartas por causa da distância que apresentava de seus interlocutores ou porque esse era um meio de comunicação privilegiado da época. Talvez tenha escrito cartas por qualquer outra motivação mais prosaica. Esta é a resposta mais óbvia.

\footnotetext{
${ }^{132}$ ibidem. Sobre os perfis, ver p. 9-24.

${ }^{133}$ BURKE, Peter; HSIA, R. Po-chia. (orgs.) A tradução cultural nos primórdios da Europa moderna. São Paulo: Editora Unesp, 2009, pp. 29, 80.
} 
O óbvio, no entanto, pode ganhar novas cores quando observado numa singularidade. Se questionássemos os motivos que levaram esse clérigo a se distanciar de seus interlocutores e precisar se comunicar com eles, poderíamos encontrar as especificidades da correspondência hussita. Enquanto líamos um ensaio sobre as cartas do escritor brasileiro do século XX Mário de Andrade, deparamo-nos com a expressão "projeto inicial do primeiro modernismo [brasileiro], transformando carta em artifício de ensino"134 . O autor demonstrou em seu texto que o escritor e poeta da Semana de 22, quando dos seus cinquenta anos de idade, trabalhava pela formação intelectual e artística dos moços utilizando a epistolografia como um dos meios para fazê-lo, sem nelas "jamais aconselhar". Em nossas primeiras anotações da leitura desse ensaio escrevemos: "haveria alguma intenção educativa nas cartas de Hus?"

Até aquele momento, preocupávamo-nos apenas com os assuntos sobre os quais ele escrevia, como Igreja, vida sacerdotal, obediência, verdade, moral cristã e comentários sobre seu contexto de vida particular e pública. Foi questionando sua intenção em escrever, que procuramos por mais do que uma lista de temas. Identificamos um rol de motivações, construindo outro olhar sobre a documentação.

As primeiras pistas encontramos na organização que os editores fizeram das cartas de Hus. Cada uma das obras organiza as cartas por um critério. Bonnechose ${ }^{135}$ dividiu-as em duas séries: "cartas escritas no período da interdição de Jan Hus e de seu exílio de Praga em 1411; algumas podem ter sido escritas em 1410" e "cartas escritas por Jan Hus e outras pessoas no período do Concílio de Constança”.

Workman e Pope ${ }^{136}$ organizam as cartas em seis partes: I. "cartas escritas antes da morte do arcebispo Zbiněk"; II. "da morte de Zbiněk ao exílio de Hus"; III. "cartas escritas durante o exílio de Hus"; IV. "cartas escritas durante a viagem à Constança"; V. "cartas escritas durante a prisão no mosteiro dominicano" e VI. "cartas escritas do mosteiro franciscano".

Spinka ${ }^{137}$ apresenta as cartas organizadas em três partes: I. "cartas escritas antes do exílio de Hus (1412)”; II. “cartas escritas no exílio (1412-1414); III. “cartas de Constança (1414-1415)".

\footnotetext{
${ }^{134}$ MORAES, Marcos Antonio de. "Orgulho de jamais aconselhar": Mário de Andrade e os moços. In: GALVÃO; GOTLIB, op. cit., p. 289.

${ }^{135}$ BONNECHOSE, Letters of John Hus.

${ }^{136}$ WORKMAN; POPE, The letters of John Hus.

${ }^{137}$ SPINKA, The letters of John Hus.
} 
Os marcos mais significativos das separações que esses autores fizeram na correspondência de Hus são o exílio deste de Praga, que ocorreu em 1412 e sua viagem para Constança, entre 1414 e 1415. Eles são suficientes para Bonnechose e Spinka. Já Workman e Pope apresentam outras subdivisões, separando as cartas anteriores ao exílio no período anterior e posterior à morte do Arcebispo Zbyněk e as cartas de Constança em dois lugares diferentes: o mosteiro dominicano e o franciscano.

O que aparenta, com relação a estas divisões, é que Hus tinha, pelo menos, dois motivos para escrever cartas. O primeiro, evidenciado nas leituras de todos os compiladores, é sua ausência de Praga. A carta torna-se, portanto, o melhor meio disponível para a comunicação à distância, afinal, esse tipo de escrita serve, como apontamos, para compensar distância e ausência de sua tarefa religiosa, pois lhe haviam retirado seu púlpito. O segundo, suscitado pela subdivisão de Workman e Pope, é sua querela com o Arcebispo Zbyněk, personagem que conhecemos a partir do estudo de sua rede de relações, causada pela acusação contra Hus de criticar de modo severo a conduta moral do clero. No entanto, ao olharmos para as cartas hussitas, para o Relatio de Petr de Mladoňovice e ainda para as biografias posteriores sobre Hus, percebemos que estas motivações não são suficientes para dar conta das razões da escrita em toda a correspondência hussita. Ao nos aprofundarmos em sua leitura, encontramos pistas da existência de outras motivações. Percebemos o quanto também seu lugar de professor da Universidade de Praga, sua relação próxima com a nobreza e seu papel como clérigo e chefe da Capela de Belém marcam sua escrita.

Organizando esses "rastros", chegamos a cinco categorias para as motivações da escrita. A primeira, partindo do lugar de professor da Universidade de Praga, é seu trabalho intelectual. A segunda, a partir de seu lugar de clérigo e em especial da sua relação próxima com a nobreza, é o aconselhamento. A terceira, a partir das ideias que defendeu perante a oposição liderada pelo arcebispo de Praga, Zbyněk, e por colegas da universidade, é a necessidade de elaborar uma refutação às acusações que lhe foram imputadas. A quarta, que surge em consequência do desenrolar dos acontecimentos referentes às acusações que recebeu, é a defesa da verdade. Por fim, a quinta, presente em boa parte da correspondência e desencadeada por seu exílio de Praga, a continuidade da tarefa pastoral por meio de cartas. O modo como podemos construir essas categorias a partir das cartas hussitas é o que nos propomos apresentar neste item. Aqui começa nossa resposta à pergunta "por que Hus escreveu cartas?".

Hus era um intelectual, professor da Universidade de Praga e, portanto, tinha na escrita um de seus instrumentos de trabalho. Não podemos afirmar que era o principal, visto que a 
cultura medieval que nos parece "erudita" nunca esteve totalmente nas bibliotecas. A “atividade universitária não comportava nenhum exame escrito, estando inteiramente baseada em cursos e exercícios orais, para os quais os manuscritos eram apenas dossiês e testemunhos."138 Mas, como professor universitário, ele era leitor e escritor. É o que percebemos pela apresentação dos instrumentos necessários aos clérigos no dicionário do mestre parisiense Jean de Garlande:

livros, uma escrivaninha, uma lâmpada noturna com sebo e um castiçal, uma lanterna, e uma peça de boca ampla com tinta, uma pena, um fio de prumo e uma régua, uma mesa, e uma férula, uma cadeira, um quadro-negro, uma pedra-pomes com uma raspadeira e giz. ${ }^{139}$

A produção escrita de Hus é extensa e inclui sermões, cartas e trabalhos de cunho devocional, teológico e/ou linguístico. São mais conhecidos seu Comentário sobre as sentenças de Pedro Lombardo (Super IV Setentiarum), o Tratado sobre a Igreja (Tractatus de Ecclesia), seu Da ortografia tcheca (De ortographia bohemica) e Filha (Dcerka).

O primeiro, apresentado na Universidade de Praga como um conjunto de aulas ministradas entre 1407 e 1409, foi publicado pela primeira vez em 1905 numa obra de cerca de oitocentas páginas comentando os quatro livros das Sentenças de Pedro Lombardo (século XII), utilizando teólogos como Durandus, Bradwardine e Wyclif. ${ }^{140}$ Durante a realização de nossa pesquisa, não tivemos acesso a esta obra.

O segundo é considerado o mais famoso escrito de Hus, pois dele foram retirados os $\operatorname{artigos}^{141}$ utilizados em sua condenação pelo Concílio de Constança. Os primeiros capítulos do tratado são dedicados ao conceito de Igreja e à afirmação que o papa não é o chefe da Igreja Universal. Apresenta, em diversos capítulos, as consequências dessa afirmação e justifica, nos últimos, suas posições e atitudes perante sua excomunhão e o interdito à cidade de Praga. Foi escrito em 1413 e está publicado na obra Historia et Monumenta J. Hus, sobre a qual escrevemos no item 1.2. A tradução para o inglês é de $1915 .^{142}$

\footnotetext{
${ }^{138}$ LE GOFF; SCHMITT, Dicionário Temático do Ocidente Medieval, p. 389.

${ }^{139}$ LE GOFF, Os intelectuais na Idade Média, p. 113.

${ }^{140}$ A fonte para esta frase é SCHAFF, op. cit., p. 305.

${ }^{141}$ A palavra artigos aqui, como no restante da tese, refere-se à seguinte acepção do dicionário: "assunto, ponto, matéria que é objeto de discussão" (V. HOUAISS, Antônio. Dicionário eletrônico Houaiss. Rio de Janeiro: Objetiva, s/d.) e é tradução do inglês articles.

${ }^{142}$ HUSS, The Church. As informações seguintes a respeito do tratado podem ser encontradas na introdução escrita pelo tradutor, nas páginas X-xlii, de onde foram retiradas as citações seguintes.
} 
A escrita deste tratado foi motivada pelo aparecimento de um documento assinado por oito doutores da Faculdade de Teologia da Universidade de Praga, datado de 6 de fevereiro de 1413. Esses doutores apoiavam o papa de Pisa, João XXIII, e a publicação de sua bula no ano anterior, a qual promulgava a venda de indulgências para quem o apoiasse contra o príncipe Ladislau de Nápoles. A posição desses oito doutores pode ser resumida nos seguintes itens:

- Dever de absoluta submissão aos comandos do papa e de autoridades eclesiásticas.

- Condenação de 45 artigos supostamente retirados das obras de Wyclif, apresentados à Universidade de Praga em 1403. Eles são considerados escandalosos e heréticos.

- Exigência de limpeza da heresia de dentro do reino da Boêmia, se necessário com as mais severas punições eclesiásticas e civis.

- O clero e a nação boêmia estão em total acordo com a Igreja Romana, cuja cabeça é o papa e seus cardeais.

- "Herege" é o nome mais detestável possível.

- Nada falarão a respeito de Hus, dado que não compete ao clero de Praga fazêlo.

Hus escreve, então, sua resposta para esses autores, num texto conhecido como Resposta aos oito doutores, além de escrever textos específicos para dois deles: Štěpán Páleč e Stanislav de Znojmo. ${ }^{143}$ Também escreve uma carta (número 34a, escrita entre os meses de abril e maio de 1413), na qual afirma que esses doutores deveriam apontar os erros e provar, não apenas difamar. De acordo com Hus, como lemos na carta, eles fazem falsas afirmações a respeito da Boêmia e quem acreditar ao contrário é considerado herege, mas não apontam quem são os hereges. Eles condenam os 45 artigos de Wyclif, mas muitos destes foram defendidos por Stanislav e Páleč, antes deles se deixarem levar pelo medo. Os doutores afirmam que dado que Hus foi excomungado pela autoridade papal, a excomunhão é válida, mas eles sabem que ela foi feita em bases falsas. É o que aponta Hus, concluindo, portanto, que o Consilium de doutores deve ser rejeitado.

No entanto, sua resposta mais completa ao documento é o Tratado sobre a Igreja, o qual se torna, de acordo com o tradutor para o inglês, a "apologia pro su vita de Hus". Foi nesse tratado que ele defendeu suas principais visões a respeito da Igreja e a partir das quais foi condenado. Nesse texto, ele inicia definindo a Igreja. Ela é uma em todo o mundo, unida

${ }^{143}$ ibidem, p. xi. 
pela predestinação ou, como também propõe, pela fé, esperança e amor. Seguindo Agostinho, afirma que ela é um corpo misturado, contendo os predestinados e os condenados. Salienta que é diferente estar na igreja e ser da igreja e a Igreja Romana não é a Igreja Universal, pois nenhuma igreja regional pode ser toda a Igreja. Ela é apenas a principal dentre as igrejas militantes.

Em seguida, afirma que os papas e os prelados não têm autoridade pelo simples fato de o serem. O pontífice romano não é o chefe da Igreja na terra, visto que a cabeça da igreja é o Cristo e ele é a pedra sobre a qual a Igreja está construída e não Pedro. De acordo com a argumentação de Hus, a palavra papa não está nas escrituras e é possível que um papa seja um herege, como ocorreu em vários momentos da história. Portanto, a igreja poderia funcionar muito bem sem papas e seus decretos nem sempre devem ser obedecidos. Devemos obedecer primeiro a Deus, sustenta Hus em seu tratado.

Continua o tratado, discutindo o poder das chaves ${ }^{144}$, ou seja, o poder de perdoar ou manter os pecados. Para Hus, nem o papa e nem qualquer sacerdote pode absolver alguém dos pecados, exceto onde Deus já o fizera antes. Para ele, as duas chaves colocadas nas mãos da Igreja são o conhecimento e a autoridade. O poder maior dado aos apóstolos e seus sucessores não foi o de remir os pecados, mas o de pregar e evangelizar.

As Escrituras, para o autor do tratado, são apresentadas como autoridade máxima, padrão suficiente para a fé e a conduta. Portanto, antecipa, com essa afirmação, o direito individual de julgamento a partir das escrituras, sem a necessária mediação clerical, um dos princípios elementares da Reforma Protestante do século seguinte.

Feita essa argumentação, Hus finaliza o tratado defendendo-se da acusação de insubordinação às ordens de seus superiores eclesiásticos. Para ele, o dever supremo do cristão é com Deus e as Escrituras e não com a hierarquia da Igreja Romana. Uma de suas principais frases, que resume o espírito de sua argumentação, é "nós devemos obedecer a Deus em vez de obedecer aos homens".

O terceiro trabalho de Hus que aqui citamos é um tratado sobre a ortografia da língua tcheca, apresentando uma reforma para simplificá-la. Nele, o autor propõe a substituição de dígrafos por letras com sinais diacríticos como o caron (háček, ` $)^{145}$, o uso do acento agudo para indicar vogais longas, entre outras simplificações. Nesse sentido, czyezzta torna-se cesta

\footnotetext{
${ }^{144}$ V. Mateus 16:18-19: “Também eu te digo que tu és Pedro, e sobre esta pedra edificarei minha Igreja, e as portas do Inferno nunca prevalecerão contra ela. Eu te darei as chaves do Reino dos Céus e o que ligares na terra será ligado nos céus, e o que desligares na terra será desligado nos céus." (grifo nosso)

${ }^{145}$ Utilizamos o exemplo do háček, que é o sinal utilizado no tcheco dos dias de hoje. Na época de Hus, a reforma proposta utilizava um ponto acima da consoante. A palavra háček significa "ganchinho".
} 
(caminho) ou Wyerzy vboha otczye torna-se Vieri wbuoh otcie ("Creio em Deus pai", escrito no tcheco da época de Hus). No início desse trabalho, Hus apresenta uma cartilha ${ }^{146}$ para o ensino das primeiras letras. Foi escrito entre $1411-1414^{147}$. A figura 4 apresenta uma reprodução dessa cartilha.

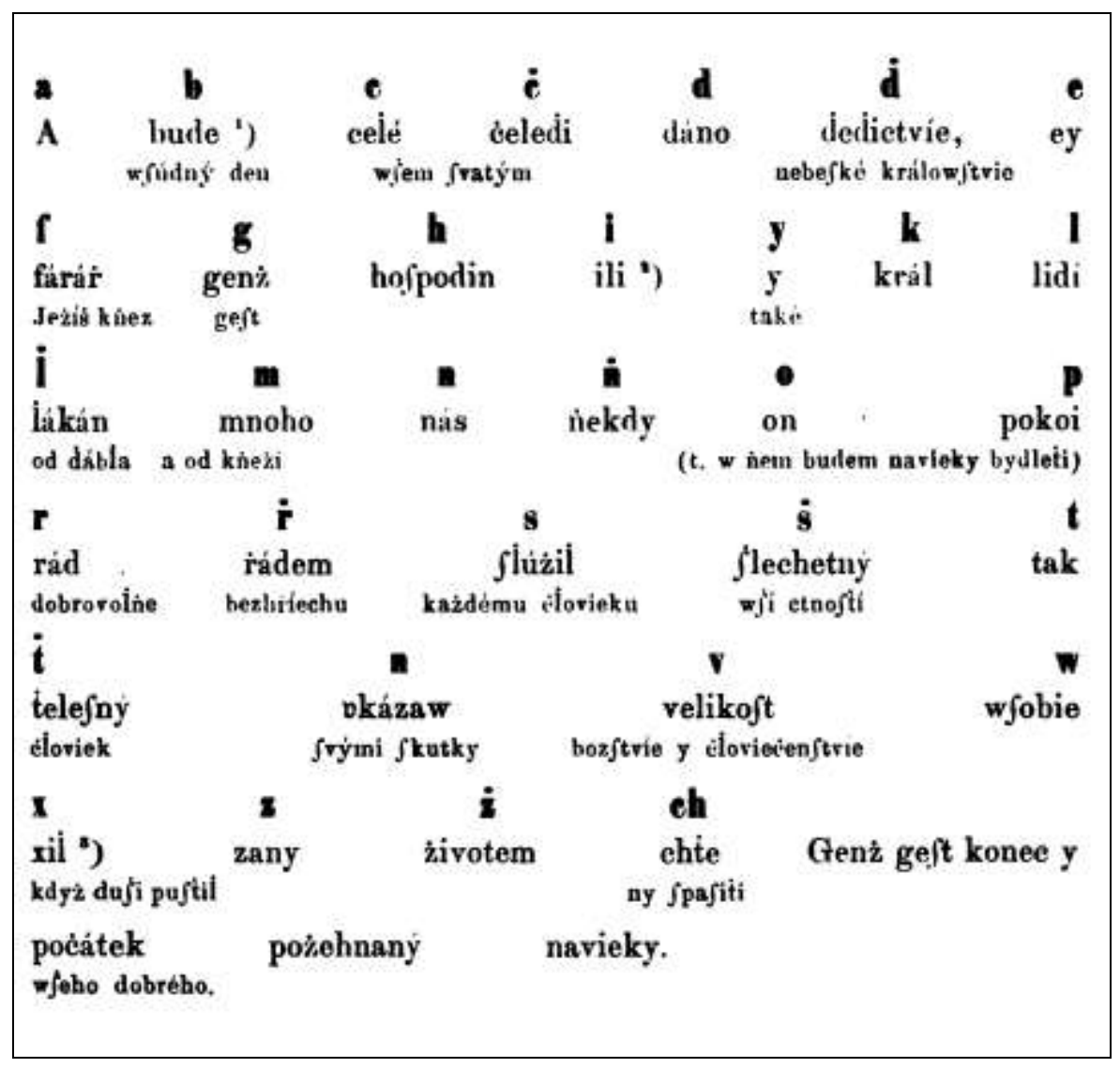

\section{Figura 4. Cartilha de Hus \\ (Fonte: ŠEMBERA, Ortographia bohemica)}

A versão desta cartilha, publicada em 1857, não apresenta o alfabeto inicial e o texto está escrito em tcheco mais próximo à escrita do século XV do que a versão publicada nas Obras Completas de Jan Hus (1985), que se assemelha mais ao tcheco contemporâneo, como podemos ver na figura 5.

\footnotetext{
${ }^{146}$ Citada por MANACORDA, História da educação, p. 194 e por CAGLIARI, Luiz Carlos. Alfabetizando sem o bá-bé-bi-bó-bu. São Paulo: Scipione, 1998, p. 20, provavelmente a partir do primeiro.

${ }^{147}$ A data exata não é conhecida. Mesmo a autoria está sujeita a dúvidas. A certeza que os estudiosos tchecos possuem a respeito é que em 1411 Hus produziu a cartilha que inicia a obra. O professor Robert Adam da Universidade Carlos de Praga afirmou-nos, via e-mail, em 20 de novembro de 2009 que "a autoria de Hus não é certa mas é bastante provável, no que diz respeito ao documento, mas ele com certeza escreveu o texto mnemônico que usou a nova ortografia". O texto em latim que segue à cartilha foi escrito entre 1413-1414, conforme a introdução da edição bilíngue de Šembera: ŠEMBERA, Aloys Vojtěch (ed.) Ortographia bohemica (Ortografie česká). Tiskem Leopolda Sommra, 1857. Šembera traduziu o texto para o tcheco a partir da edição Pálacký de 1827.
} 


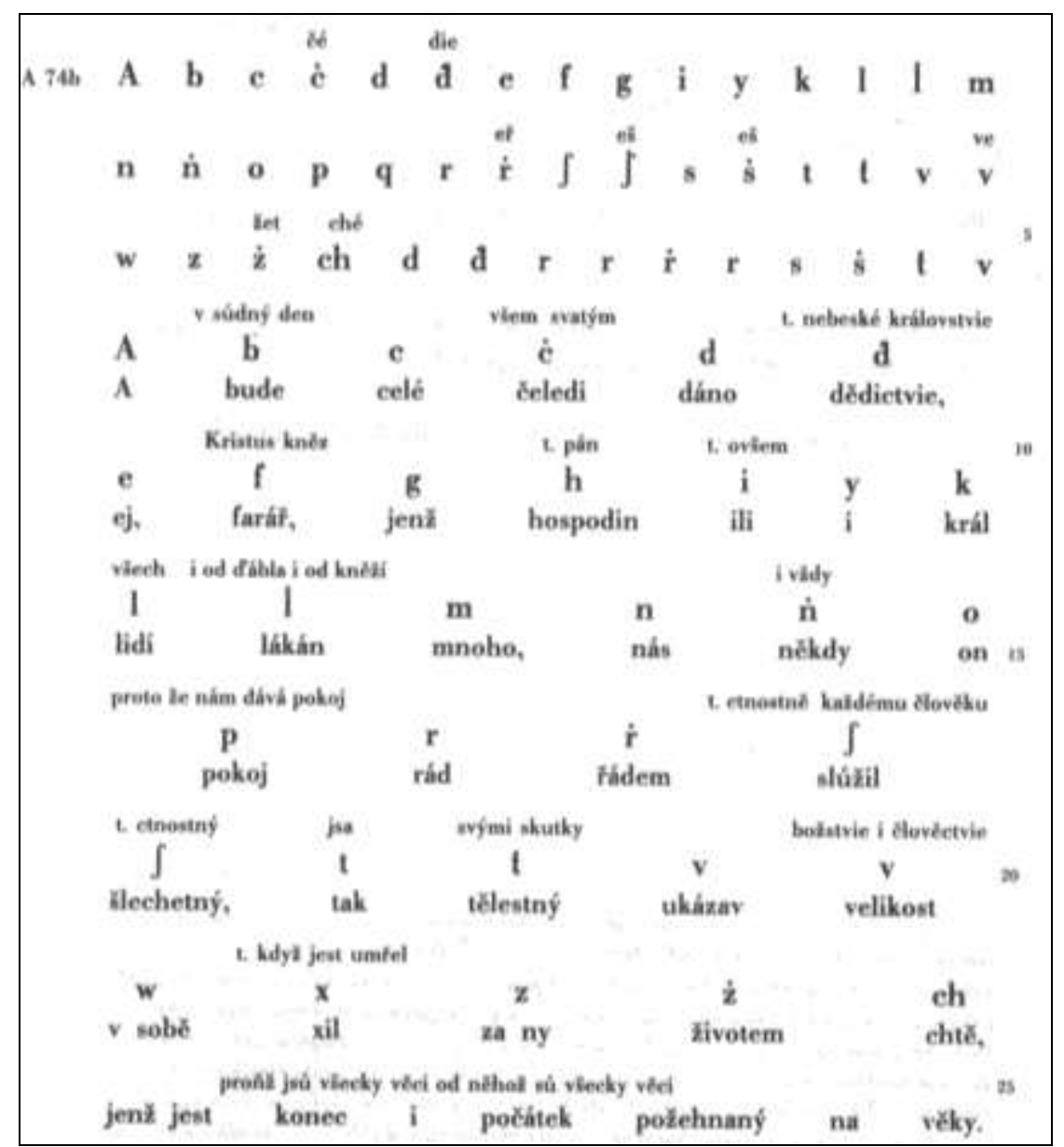

\section{Figura 5. Reprodução em diagramação moderna da cartilha de Hus}

\section{(Fonte: Hus, Opera omnia)}

Composta por 26 linhas de texto ${ }^{148}$, a cartilha ${ }^{149}$ inicia com um alfabeto da língua tcheca e apresenta frases de conteúdo religioso. Utiliza os símbolos latinos e insere um ponto redondo como sinal diacrítico sobre algumas consoantes para substituir os então utilizados dígrafos. O motivo da repetição de algumas letras ao final, após o ch, não nos está claro até o momento.

Em seguida ao alfabeto, encontramos uma lista de palavras abaixo de cada letra. São palavras, em geral, simples e voltadas para o universo religioso cotidiano da época. Alguns exemplos nos mostram isso: faráŕ (pároco), hospodin (Deus), král (rei), pokoj (tranquilidade).

\footnotetext{
${ }^{148}$ A numeração das linhas encontra-se à direita. Contatamos a biblioteca da Universidade de Praga e fomos gentilmente atendidos pela bibliotecária da Faculdade de Teologia Evangélica (Evangelická teologická fakulta) Natasha Rückl, que nos enviou esta reprodução em 17 de abril de 2007.

${ }^{149}$ Para cartilhas espanholas em fac-simile do período dos séculos XV e XVI ver INFANTES, VÍCTOR. De las primeras letras: cartillas españolas para enseñar a leer de los siglos XV y XVI: preliminar y edición facsímil de 34 obras. Salamanca: Ediciones Universidad de Salamanca, 1998. Tivemos acesso a essa obra por intermédio da professora Diana Gonçalves Vidal, da FEUSP, a quem agradecemos por essa oportunidade. Estando situadas, porém, cerca de cem anos à frente da cartilha de Hus elas são mais extensas e elaboradas. No entanto, a grande maioria inicia-se com um alfabeto e apresenta textos de cunho religioso, características semelhantes à cartilha de Hus. Como não tivemos acesso à materialidade da cartilha de Hus, outros elementos de comparação ficaram dificultados.
} 
Entre as letras e palavras aparecem frases de cunho religioso, com palavras de uso corriqueiro na época. O texto todo é uma referência à grandiosidade divina do Cristo e à salvação no juízo final. As frases compostas pelas palavras logo abaixo de cada letra, utilizadas como recurso mnemônico para ensino da leitura, são acompanhadas por apostos ou pequenas explicações logo acima. A tradução que apresentamos serve para dar uma ideia do conteúdo do texto:

E será, no dia do julgamento, dada a herança, o reino celeste, para todas as criaturas, a todos os santos. Eis o pároco (Cristo sacerdote) o qual senhor Deus, mas também rei das pessoas (de todas as pessoas, também dos demônios e dos párocos) que são atraídas por ele. Sempre nos deu a ordem e a tranquilidade, generoso, com seus atos mostrou sua grandeza (divina e humana) dentro de si e quando morreu por nós. Assim é no final e início bendito para todos os tempos.

A versão retirada das obras completas de Hus apresenta as palavras e frases que ele utilizou transcritas para a ortografia atual. Por exemplo, a letra $\int$ (longo s) hoje não é mais utilizado na ortografia tcheca e as palavras que com ela se iniciam flúżil e flechetný foram apresentados na ortografia moderna slúžil e šlechetný. Outro elemento que comprova que a edição é moderna é a presença do ponto redondo sobre as letras no alfabeto e do caron ( ${ }^{*}$ ) nas palavras, tal qual ocorre na letra $r^{\cdot}$ e na palavra $\check{r}^{\prime}$ dem. ${ }^{150}$ A edição da obra editada por Šembera apresenta o ponto redondo tanto sobre as letras quanto sobre as palavras e mantém nas frases o uso da letra $\mathrm{W}$ e do longo $\mathrm{S}$. Todos estes são elementos pouco usados no tcheco contemporâneo, porém presentes no tcheco do século XV.

Foi grande o impacto do tratado De Ortographia Bohemica no desenvolvimento da língua tcheca. ${ }^{151}$ Esse texto contribuiu para a codificação da língua, favorecendo seu uso pelos tchecos nos séculos XV e XVI, viabilizando a tradução completa da Bíblia para o tcheco, a Bíblia de Kralice, nas décadas finais do século XVI, e a apropriação da língua tcheca como língua litúrgica pelos luteranos eslovacos na mesma época. ${ }^{152}$ No entanto, o impacto dessa produção na educação ainda não foi explorado. ${ }^{153}$

\footnotetext{
${ }^{150} \mathrm{O}$ ponto redondo não é mais utilizado hoje em dia como sinal diacrítico, exceto na vogal u longa não localizada no início da palavra. Foi substituído pelo háček.

${ }^{151}$ Confirmado pessoalmente por Petra Mocová, formada em Letras na República Tcheca, e pelo professor Robert Adams via e-mail.

${ }^{152}$ KOWALSKÁ, Eva. A língua como meio de transferência de valores culturais. In: BURKE; HSIA, op. cit. A autora também afirma, à página 73 , que a tradução da Bíblia de Kralice continuou a ser utilizada pela comunidade luterana eslovaca até meados do século XX.

${ }^{153}$ Nós apresentamos no Simpósio Internacional Livro Didático: Educação e História, em 2007, as primeiras informações que levantamos naquela época sobre esta cartilha. A tradução que apresentamos nesta tese, feita por Petra Mocová e revisada por mim, consideramos mais adequada que aquela que foi utilizada como base para o
} 
O quarto texto que aqui estamos apresentando, único em tcheco desta lista ${ }^{154}$, é um texto devocional, tido como um de seus mais belos escritos ${ }^{155}$, enviado para um grupo de mulheres que formaram um círculo devocional não oficial. Consiste numa exortação ao autoconhecimento e à vida pia. O nome se origina da expressão inicial de cada capítulo: "Slyš, dcerko!" (ouça, filha) e tem por subtítulo “O poznání práve cesty k spasení” (sobre o conhecimento do caminho certo para a salvação). Esse texto foi publicado em tcheco em $1865^{156}$ e traduzido para o francês em $1972 .^{157}$

Esse trabalho intelectual por meio da escrita aparece nas cartas em poucos exemplos. Um deles é a carta de número 2. Nela, Hus escreve a John Hübner, um professor silésio-alemão colega de universidade, em $1404^{158}$, antes da saída dos professores alemães. Em janeiro desse ano, Hübner defendeu em seu Quodlibet que um conjunto de quarenta e cinco artigos, supostamente extraídos dos escritos de Wycliff, era herético. O Quodlibet era um exercício intelectual da Escolástica na qual um mestre dispõe-se a tratar de um tema levantado por qualquer pessoa. ${ }^{159}$ A Universidade de Praga reuniu-se em 28 de maio de 1403 para julgar uma lista de artigos extraídos por esse professor dos textos de Wycliff. Como os alemães possuíam maioria de votos, os artigos foram considerados heréticos. Esses artigos negam a transubstanciação, a missa, a posse de bens pelos clérigos e afirmam coisas como que a eleição do papa foi instituída pelo diabo. Hus apresentou sua argumentação contrária apenas após o Quodlibet. A título de ilustração, extraímos o seguinte trecho desta longa carta, no qual ele afirma que um dos artigos não está de acordo com os escritos de Wycliff:

Você também declarou que Wyclif denomina a santa madre Igreja de sinagoga de Satã. Exceto por sua referência, isso não é verdade. Se talvez isso esteja assim escrito em sua cópia, é um erro; ou você não a leu cuidadosamente, ou a tendo examinado, você não registrou bem na memória. Pois se a cúria Romana for a sinagoga de Satã, isso não resulta que a santa madre Igreja seja a sinagoga de Satã. E se ele disse 'Igreja', sem adicionar

texto do simpósio. A referência para o trabalho de 2007 é a seguinte: AGUIAR, Thiago Borges de. O abecedário de Hus: o passo tcheco no caminho para as primeiras cartilhas européias. In: Simpósio Internacional "Livro Didático: Educação e História", 2007, São Paulo. Anais do Simpósio Internacional "Livro Didático:

Educação e História", São Paulo: Faculdade de Educação da Universidade de São Paulo, 2007.

${ }^{154}$ Embora o Ortographia Bohemia citado anteriormente trate de uma reforma da ortografia do tcheco ele foi escrito em latim. Somente o texto inicial, o ABC, foi escrito originalmente em tcheco.

${ }^{155}$ SPINKA, John Hus: a biography, p. 20.

${ }^{156}$ SPINKA, John Hus: a biography, p. 194.

${ }^{157}$ DE VOOGHT; PILNY, op. cit..

${ }^{158}$ Como afirmamos na introdução, a datação das cartas não é precisa.

${ }^{159}$ LE GOFF, Os intelectuais na Idade Média, pp. 122 e 123. 
'santa', isso está de acordo com o que Davi diz: 'Eu odeio a igreja dos maus'.

Outro exemplo de Hus escrevendo a partir do lugar de professor universitário aparece numa carta escrita nove anos depois desta. Na carta 36, escrita em $1^{\circ}$ de julho de 1413 a John Sywort de Siebenbergen, Transilvânia, professor da Universidade de Viena, Hus repreende seu destinatário por ter, conforme lemos no texto, acusado Jerônimo de Praga e dois estudantes croatas de heresia. Utilizando diversas citações bíblicas, o professor da Universidade de Praga escreve em termos como estes:

Você é um professor da lei do Cristo quando difama tão mentirosamente seu vizinho? Com certeza, o Anticristo o ensinou a declarar tais insanidades! Onde está a lei do Cristo, 'Não julgueis para não serdes julgados'! Onde está 'Se seu irmão pecar contra você, repreende-o'? ${ }^{160}$ Por que, ao invés de primeiro dar a seu irmão a correção pelo amor, você emitiu publicamente uma difamação prejudicial?

Com relação ao aconselhamento, postura característica de sua posição de clérigo, encontramos logo nas primeiras cartas seus conselhos a respeito da conduta moral das pessoas. Enquanto o escritor brasileiro Mário de Andrade orgulhava-se de jamais aconselhar, poderíamos dizer que Hus poderia orgulhar-se de jamais perder uma oportunidade de aconselhar. Suas cartas mostram uma autoridade educativa que aconselha e, por vezes, é consultado pelos outros que lhe pedem conselhos. Essa relação é explícita na admoestação inicial da carta de número 1 (sem data), escrita a um clérigo que acabara de aceitar um ofício secular: "Contra o meu conselho, não sei se correto, você já aceitou um ofício bastante perigoso" (grifo nosso).

De modo semelhante, ele procede na carta 3 (sem data), para uma mulher da nobreza: “Ouvi dizer que você está levando bem sua viuvez, mas que não está sendo cuidadosa ao permitir jogos e danças em sua casa, o que é uma clara transgressão dos mandamentos de Deus."

Vemos reaparecer esse cuidado com a conduta moral das pessoas na carta (número 4) escrita antes de agosto de 1406 a um nobre acusado de cometer roubos durante as guerras de 1405. No trecho que selecionamos, Hus apresenta-se preocupado com um nobre que já foi seu discípulo, Jan Chudoba, exortando-o, na petição ao final do trecho, a parar de roubar.

\footnotetext{
${ }^{160}$ SPINKA, The letters of John Hus, pp. 104 e 105, notas 6 e 7, refere essas citações como de Mateus 7:1 e Lucas 17:3.
} 
Também vemos uma menção que poderia passar despercebida, mas que marcará boa parte das cartas seguintes de Hus: as acusações das quais ele próprio foi vítima:

Com grande tristeza no coração fiquei sabendo que algumas pessoas espalharam a informação que Vossa Nobreza voltou a roubar, agora, confiscando as propriedades das pessoas, desapropriando os donos e roubando suas posses. Se isso tudo o que dizem de você é verdade eu não sei e gostaria que não fosse. Ai de mim! É com frequência que me repreendem face a face, dizendo 'Cuidado, seu filho devoto Chudoba, que você esperava que subisse aos céus e cuja penitência você ousou declarar publicamente, é, agora, um ótimo penitente! O que antes ele não podia roubar, agora rouba. Ele recebeu o título de cavaleiro para poder roubar com mais audácia.' Esse tipo de fala crava-se em meu coração.

Não obstante, essa fala em nada me ofenderia se eu soubesse que não é verdadeira. Pois coisas piores são ditas a meu respeito, mas eu me regozijo de consciência tranquila, negando as acusações de meus inimigos, ao saber que elas são indubitavelmente falsas. Por isso, nobre e amado senhor em Cristo, humildemente exorto-lhe, pelo amor da compaixão, misericórdia e justiça de Deus, que poupa os pecadores penitentes, mas pune aqueles que irremediavelmente cometem o mal: lembre-se da glória e da punição perpétuas, considere sua honra, permaneça firme em suas boas intenções anteriores e não roube. (grifos nossos)

Uma das mais longas cartas hussitas (número 5) é escrita em cerca de 1407 e endereçada a um nobre. Este, a quem Hus se dirige como "amigo", pede-lhe instruções sobre como proceder com relação a heranças sem que ele "erre ou manche sua alma, sem ofender a Deus, perder o reino eterno e receber a condenação de corpo e alma”. O clérigo, escrevendo em tcheco, afirma que não há menções claras na escritura a esse assunto, mas apresenta sua argumentação sobre o modo correto de fazê-lo e um rol de citações bíblicas e patrísticas para sustentar sua posição referente à avareza e à opressão. Desta carta, extraímos este trecho como ilustração:

...encontro poucas pessoas que se recusam completamente de receber os impostos de morte e as heranças. Pois nesta última era do mundo eles seguiram muito na avareza, conforme a profecia da sagrada escritura. Eu não encontro instrução na sagrada escritura sobre receber direitos de morte como eles fazem. Do mesmo modo, eu não ouso aconselhar quando eles devem ou não recebê-los. De todos os casos, eu não vejo um mais claro do que quando o camponês diz "O modo como o nobre dispor de minha propriedade, assim deve sê-lo!" Também, quando o camponês morre sem deixar testamento, não mencionando qualquer amigo. Tais modos deveriam ser publicamente declarados nas cortes, nos mercados ou nas igrejas, como fazem aqueles que não querem sujar suas almas e suas propriedades pela cobiça. No entanto, 
tais declarações são amplamente abominadas pelos avarentos, mesmo sendo melhor para a salvação e riqueza que o dever de morte. Pois o senhor Deus dá sua fiel prosperidade mesmo aqui, como afirmam as escrituras. Portanto, quem quer que não deseje sujar sua alma pela cobiça e deseje ser agradável a Deus, salvar sua alma e obter prosperidade pelo serviço divino mesmo aqui, observe as instruções acima citadas. (grifo nosso)

Hus aconselha um monge a respeito da posse de propriedades e o voto de pobreza na carta 22, de 28 de fevereiro de 1412. Explica-lhe que a regra básica para clérigos é "possuir todas as coisas em comunidade (in communi)" e analisa o direito à propriedade a partir de grandes nomes da Igreja como Agostinho, Gregório, Bento de Núrsia, Basílio, Cassiano, Francisco de Assis, Jerônimo e Tomás de Aquino. Em seguida, diz: "Mesmo que nenhum desses mestres (istorum) tivesse dito qualquer coisa, um monge está atado a seus votos." Conclui sua carta afirmando que a escrevera com o que "tinha à mão" e que escreverá mais depois.

Aconselhamento é uma das grandes motivações para a escrita desse clérigo da Boêmia. Diversas cartas possuem essa característica, indicando a preocupação com a conduta moral de seus interlocutores, sejam eles clérigos ou nobres, amigos ou discípulos. Hus é ao mesmo tempo o intelectual que tem as informações necessárias sobre as regras morais e o pastor que cuida de seu rebanho por meio de conselhos, fossem orais, como nos sermões, fossem escritos, como pelas cartas.

Igualmente significativa na correspondência de Hus é a presença da refutação perante as acusações que lhe foram imputadas. O arcebispo de Praga, Zbyněk, teve um papel central perante elas num primeiro momento, o que dá sentido à separação das cartas de Hus feita por Workman e Pope. Ao assumir o arcebispado da região de Praga em 1403, ele estava em posição favorável às ideias reformistas de Hus. Nesse mesmo ano, porém, os 45 artigos de Wyclif foram julgados e condenados pela faculdade de teologia, ficando proibidos de serem ensinados. Em janeiro de 1404 Hübner condenou-os novamente em seu Quodlibet, como mencionamos acima. Ao longo dos anos seguintes, houve um aumento da disputa entre os partidários de Hus e seus opositores e diversas acusações foram apresentadas contra ele. As primeiras não foram de heresia, mas por criticar de modo severo a conduta moral do clero. Entre agosto e setembro de 1408 diversas reclamações foram entregues a Zbyněk e, em defesa, Hus escreve-lhe uma carta, número 8 de sua correspondência, na qual assume uma 
postura por vezes mais sarcástica do que séria ${ }^{161}$. O início segue a tradição retórica de posicionar-se com humildade perante um superior:

Eu fui acusado por meus adversários perante a graça de Vossa Paternidade de ser um pregador escandaloso e errôneo, contrário à Santa Madre Igreja e, assim, me afastar da fé. Mas isso foi feito de forma frívola e mentirosa. Portanto, com a ajuda de Deus, gostaria de, humilde e fielmente, refutar as acusações frívolas de meus inimigos, declamadas perante vossa mais graciosa Paternidade, para dar razão à minha fé e esperança.

Depois inicia sua argumentação refutando a palavra "toda":

Então, para o primeiro artigo, que diz 'Mestre Jan Hus perante toda a multidão de pessoas de ambos os sexos disse, e não se envergonhou de dizer, ser contrário aos decretos da Santa Madre Igreja e às regras dos Padres,' etc., eu digo que o nego e que é falso. Primeiramente, porque eu não disse nada perante toda a multidão de pessoas, porque naquele dia, quando eu preguei, não estava em Praga toda a multidão de pessoas. Pois eu não disse nada perante a multidão de pessoas de ambos os sexos que estava em Roma e nem disse nada perante a multidão que estava em Jerusalém e assim sucessivamente.

E segue com outros argumentos contra as acusações que lhe foram imputadas por membros do clero praguense e da Universidade de Praga. Mais à frente, no mesmo ano, Hus escreve outra carta ao arcebispo, sustentando sua obediência à Igreja e neutralidade perante o cisma papal. Antes de apresentar esta carta, precisamos entender o cisma, com a existência de mais de um papa simultaneamente.

Desde quando Clemente V levara o papado de Roma para Avignon, em 1309, houve diversos descontentamentos e disputas políticas com relação aos papas que se sucederam. As questões envolviam o poder papal e a relação da Igreja com o dinheiro. O imperador Carlos $\mathrm{V}$, tentando resolver essas questões trazendo a sede papal para mais perto do Império, insistiu para que o papado voltasse para Roma, o que fez Urbano V de 1367 a 1370. De lá, os estados pontificais poderiam ser mais bem controlados do que de Avignon. Porém, a instabilidade na Itália e a pressão dos cardeais franceses o fizeram retornar a Avignon. Seu sucessor, Gregório XI, também francês (como foram todos os papas de Avignon), sob a pressão de Catarina de Sena, retornou à Roma em 1377. Com saúde frágil, morreu pouco mais de um ano depois, em março de 1378.

${ }^{161}$ SPINKA, The letters of John Hus, p. 24, nota 1 confirma textualmente essa afirmação. 
Reuniu-se, então, um conclave em Roma. Dos dezesseis cardeais presentes, onze eram franceses. A população de Roma enviou representantes para pressionar pela eleição de um papa romano, "digno da nação italiana":

A agitação pública aumentou, e multidões ameaçadoras reuniram-se quando os cardeais, cercados por 'muitos soldados fortes e nobres belicosos', entraram no Vaticano para o conclave. Sob as janelas, podiam ouvir o povo gritando: 'Romano lo volemo! (Queremos um romano!) Romano! Romano!' (...) Tremendo por suas vidas, os cardeais recorreram ao artifício de vestir o trêmulo [idoso e doente] cardeal Tebaldeschi, apesar de seus protestos, com a mitra e a capa de asperges para ser mostrado no trono como papa eleito, por tempo suficiente para permitir-lhes escapar do Vaticano para lugares fortificados, fora da cidade. Quando os sinos de São Pedro tocaram em meio aos choques e à confusão, correu a notícia da farsa. A multidão passou a gritar: 'Non le volemo!' e 'Morte aos cardeais!' Espadas foram desembainhadas e os beberrões, que tinham arrombado as adegas papais, tornaram-se violentos e barulhentos. ${ }^{162}$

No dia seguinte, elegeram o arcebispo de Bari como Urbano VI, uma pessoa que era considerada "manobrável" pelos franceses e poderia levar de volta o papado para Avignon. Mostrou-se uma pessoa de temperamento forte, combateu a simonia, malquistou-se com os cardeais franceses, inclusive utilizando agressões verbais. Tomou partido em assuntos seculares e, a seu respeito, levantou-se até a ideia que enlouquecera por causa do poder.

Os cardeais franceses reuniram-se em Avignon e, em agosto de 1378, lançaram uma "Declaração a Toda a Cristandade", que considerava nula a eleição de Urbano por ter sido feita num ambiente "com temor pelas próprias vidas", ao som de "vozes tumultuosas e horríveis". Em setembro fizeram um novo conclave e elegeram Clemente VII. Os dois papas excomungaram um ao outro e afirmaram sua legitimidade. Os países se dividiram no apoio a cada um deles, por exemplo, com França apoiando Clemente, Inglaterra e o Império RomanoGermânico apoiando Urbano. Iniciou-se o Grande Cisma Ocidental ${ }^{163}$, o segundo grande cisma na Igreja, tendo sido o primeiro aquele que dividiu a Igreja em Ocidental e Oriental ${ }^{164}$.

\footnotetext{
${ }^{162}$ TUCHMAN, Um espelho distante, p. 302.

${ }^{163}$ As principais fontes para a descrição do cisma são TUCHMAN, op. cit. e MCBRIEN, Richard P. Os papas: de São Pedro a João Paulo II. Tradução Barbara Theoto Lambert. São Paulo: Edições Loyola, 2000. Este último é professor de teologia da Universidade de Notre Dame (Indiana, EUA), especialista em eclesiologia. Sua obra percorre a lista de todos os papas até João Paulo II. Barbara Tuchman é historiadora e escritora norte-americana. Seu livro é uma narrativa detalhado dos acontecimentos do século XIV.

${ }^{164}$ Esta relação de sequência não é exata. O cisma entre as Igrejas do ocidente e do oriente começou no século V, mas não terminou até os dias de hoje e teve repercussões mesmo depois do Concílio de Constança (1414-1418), como explica MCBRIEN, op. cit. em seu glossário: “Cisma entre Oriente e Ocidente rompimento dos laços de comunhão eclesiástica entre Roma e Constantinopla, já iniciado com as controvérsias cristológicas do século V, mas que chegou ao auge em 1054, com a mútua excomunhão entre o patriarca de Constantinopla, Miguel
} 
Os desentendimentos, banhados a incursões bélicas e acusações de todos os lados, só aumentaram. Urbano morre, “provavelmente envenenado", em 1389. Rapidamente, um conjunto de cardeais italianos elegeu Bonifácio IX. Este

nada fez para lidar com o cisma da Igreja. Cultivou seus laços com a Alemanha $^{165}$ e a Inglaterra, ao mesmo tempo que ignorou todos os apelos para solucionar a divisão. Todavia propôs nomear o antipapa Clemente VII núncio para a França e a Espanha e permitir que ele e seus cardeais conservassem a posição cardinalícia - em troca da abdicação de Clemente. Clemente VII morreu em 1394 sem concordar com as condições de Bonifácio. O rei da França, Carlos VI, exortou os 21 cardeais de Avignon a não eleger um sucessor para Clemente VII, mas eles foram avante e, antes de abrir a carta do rei, elegeram o cardeal Pedro de Luna [Bento XIII]. ${ }^{166}$

Houve algumas tentativas de reconciliação por parte de Bento XIII, mas Bonifácio morreu sem fazer um acordo. Foi eleito em Roma um novo papa, Inocêncio VII, que recusou conversar com Bento e morreu com um pouco mais de um ano de ocupação do trono. Em 1406, Gregório XII foi eleito e quebrou seu juramento de não nomear novos cardeais.

Quando Jan Hus, no final de 1408, comenta essa situação em sua carta, de número 9, ao arcebispo de Praga, havia, então dois papas Bento XIII, de Avignon, e Gregório XII, de Roma:

Eu não posso, no entanto, entrar na controvérsia de quem [dentre os dois papas] deve ser honrado, pois o Salvador o proibiu a seus discípulos em Lucas 12. ${ }^{167}$ Nem posso aprovar a falha de meu senhor com relação à observância de seu juramento, o que é sabido em quase toda a cristandade. Nesta questão, ele agiu contrariamente ao Cristo que disse em Mateus 5 'seja o seu falar sim, sim, não, não', e que disse pelo profeta 'Faça seus votos ao senhor Deus e os siga ${ }^{168}$. Portanto, com relação a estas duas coisas, a saber, a controvérsia entre o papa e o anti-papa e o não cumprimento do juramento, eu sou neutro.

Entendemos que essa postura de neutralidade, apoiada pelo rei Venceslau, da Boêmia e do Império, recaía como acusação de desobediência sobre Hus, visto que o arcebispo

Cerulário, e o bispo de Roma, Leão IX. O cisma foi selado pelas cruzadas (1095-1221) e pela rejeição ortodoxa do Decreto de União, do Concílio de Florença, em 1439."

$165 \mathrm{O}$ autor, provavelmente para facilitar sua síntese, utilizou o nome contemporâneo. Na época, era o Sacro Império Romano-Germânico e que abrangia uma área maior que a atual Alemanha.

${ }^{166}$ MCBRIEN, op. cit., p. 257.

${ }^{167}$ SPINKA, The letters of John Hus, p. 36, nota 10 afirma ser mais provável Lucas 22: 24-5 do que Lucas 12:58.

${ }^{168}$ ibidem, p. 37, nota 13 afirma ser Salmos 76:11. 
apoiava Gregório XII. Antes de se declarar neutro na carta, seu autor afirma "Em qualquer questão que o pontífice romano, Gregório XII, ou a Santa Madre Igreja e Sua Paternidade, legalmente impuserem, eu desejo humildemente obedecer”. Parece não ser contraditória a Hus a posição de neutralidade com relação ao cisma e a obediência ao papa e considera as acusações como habitual de seus adversários. Mais ao final da carta, na petição, ele afirma, em defesa própria:

Além disso, caro e reverendíssimo Pai, meus adversários dizem insultos a
meu respeito, como há muito tempo estão acostumados a fazer, e deles
poderia muito escrever. Agora, porém, que apenas isso seja suficiente: se
Vossa Paternidade encontrar alguma culpa em mim, submeter-me-ei
humildemente à punição. Apenas rezo humildemente a Deus para que Vossa
Paternidade não acredite em todos os meus inimigos, e não me suspenda do
ofício da pregação, visto que agora recebeu meu testemunho escrito que eu
não abandonei a obediência ao pontífice romano, Gregório XII.

Não houve muito tempo para que essa declaração de obediência surtisse algum efeito, visto que novos eventos ocorriam no âmbito da hierarquia da Igreja. Com exceção de três, todos os cardeais abandonaram o papa Gregório XII e fizeram um novo concílio em Pisa, no ano de 1409. Neste, os dois papas foram acusados de má-fé e conspiração, a Santa Sé foi declarada vaga e Alexandre V foi eleito. Este morreu repentinamente, menos de um ano após sua eleição, e em 1410 foi eleito João XXIII. Desde o Concílio de Pisa, a eleição de Alexandre V e o agravamento do cisma papal, Zbyněk e Hus ocuparam, definitivamente, lados opostos. Enquanto o primeiro insistia na obediência ao papa romano, Gregório XII (supostamente deposto em Pisa), o segundo preferia a neutralidade, seguindo a posição do rei Venceslau. Ainda nesse ano, Hus recebeu novas acusações e foi examinado pelo inquisidor Maurice Rvačka, que esteve satisfeito com sua defesa, absolvendo-o.

No entanto, Zbyněk ampliou o ataque aos livros de Wyclif que anos antes sustentara. O papa de Pisa, no contexto de um apelo de cinco alunos da Universidade para que não precisassem entregar suas cópias, decidiu apoiar o arcebispo e sua intenção de formar uma comissão para analisar os livros do teólogo inglês. Em 1410, após a súbita morte do papa de Pisa, quinze livros de Wyclif foram considerados heréticos e as cópias deles, a partir do decreto papal, deveriam ser entregues ao arcebispo.

Zbyněk ordena a queima dos livros de Wyclif, o que ocorre a portas fechadas. Logo em seguida, sentindo-se sem segurança ou com medo das consequências desse ato ${ }^{169}$, ele foge

${ }^{169}$ SPINKA, John Hus: a biography, p. 112. 
para seu castelo em Roudnice. Dois dias depois, 18 de julho de 1410, declara a excomunhão de Hus, o que foi por este ignorada, pois continuou a pregar. Hus opõe-se a queima dos livros, pede apoio ao povo na Capela de Belém ${ }^{170}$ e apela para o novo papa, João XXIII numa carta de 12 de setembro de 1410 (a de número 12):

... nós imploramos ajoelhados, Vossa Beatitude, humildemente vos suplicando, como um pai piedoso e afetuoso, que Vossa Santidade remova de seus filhos esta calúnia ilegal, anulando a sentença que foi falsamente apropriada pelos inimigos: pois eles foram profundamente perturbados pela proibição da santa pregação e pela queima dos livros, o que não trouxe bons resultados mas a discórdia, disputas, ódio e homicídios. Estes não cessarão de surgir até que a beneficência de Vossa Santidade liberte a Palavra de Deus e anule a sentença de queima dos livros, visto que alguns dos filhos de Vossa Santidade são, agora, considerados hereges. Mas nós esperamos que vossa mais piedosa e paterna Santidade nos trará cheio de graça de volta a honra a seus filhos obedientes.

Os protestos cresceram na Universidade. Alguns estudantes compuseram pequenas músicas provocativas que foram cantadas também pelas pessoas na rua. A mais famosa era algo como:

Zbyněk, o bispo $\mathrm{ABC}$

queimou livros sem saber

o que tinha dentro deles. ${ }^{171}$

O papa João XXIII ordenou uma investigação da queima dos livros de Wyclif. A comissão foi formada por dois professores de teologia de Bolonha (João XXIII fora Cardeal dessa cidade), um de Paris e outro de Oxford. Eles, ao final, decidiram que a queima estava errada e apenas algumas ideias selecionadas de Wyclif não poderiam ser ensinadas na Boêmia.

Como Hus havia feito um segundo apelo ao papa com referência às ações de Zbyněk, o pontífice entregou o caso às mãos do cardeal Odo de Colona, que mais tarde se tornará o papa Martinho V. Apesar do resultado da comissão e dos apelos do rei e da rainha da Boêmia, dos nobres e da universidade para que não parassem as pregações na Belém, o cardeal aprovou o procedimento do arcebispo em 25 de agosto de 1410. Com esta aprovação,

\footnotetext{
${ }^{170}$ ibidem, p. 113 cita que o sermão está na obra Historia et Monumenta, 11, pp. 85 e seguintes.

${ }^{171}$ Esta pequena música aparece em SPINKA, John Hus: a biography, p. 114, como "Bishop Zbyněk $\mathrm{ABC}$ /burned books although he/knew not what they contained" e em WORKMAN; POPE, The letters of John Hus, p. 27 e SCHAFF., John Huss, p. 92 como "Zbynek, Bishop ABC/burned the books, but never knew he/what was in them written". Não temos qualquer referência à sonoridade original da música, nem se ela era cantada em tcheco ou em latim. Portanto, traduzimos com mais liberdade, de modo a exprimir a ideia e a sonoridade das versões em inglês. OBERG. op. cit., p. 154, traduziu, a partir de uma versão alemã, da seguinte forma: "Zbynek, o medroso e protetor do A B C,/ queimou os livros/ sem saber/ o que dentro deles estava".
} 
confirmou a excomunhão de Hus e o cita a comparecer à cúria de Bolonha. Em 24 de setembro, o arcebispo declarou que Hus estava "sob grave excomunhão".

O rei Venceslau se posicionou favorável a Hus e apelou ao papa. O caso tomou proporções maiores. Há indícios que os Lolardos ingleses ${ }^{172}$ tenham enviado novas cópias de livros do reformador inglês à Boêmia para repor aqueles que formam queimados. Hus não foi à cúria. Zbyněk distribuiu presentes e dinheiro para representantes, cardeais e o próprio papa, ação que era comum na cúria. Consequentemente, o cardeal de Colona excomungou Hus por contumácia e não aparecimento em fevereiro de 1411. Spinka ${ }^{173}$ destaca que "a excomunhão foi imposta não porque Colona considerou Hus culpado de heresia, nem mesmo porque ele examinou cuidadosamente as desculpas de Hus e o apelo real e as considerou falhas, mas unicamente porque Hus não apareceu."

Zbyněk ordenou, então, que a excomunhão fosse lida em todas as igrejas, o que não ocorreu em apenas duas, de apoiadores de Hus. Nesse período, ele foi acusado de heresia por partidários do arcebispo. O papa nomeou o arcebispo de Florença, Francesco Zabarella, para intervir em busca de uma solução pacífica, o que não foi bem sucedido.

O rei agiu contra o arcebispo de Praga e ordenou a interrupção dos pagamentos dos sacerdotes e pastores das igrejas da cidade, porque tinham espalhado mentiras. Zbyněk excomungou os oficiais reais em 2 de maio de 1411. O rei declarou o sequestro dos tesouros da catedral. $\mathrm{O}$ arcebispo, então, em 20 de junho, declarou a cidade de Praga e duas milhas de seu entorno sob interdito, o que interrompe todos os serviços das igrejas e sacramentos, como batismos, casamentos e funerais. $\mathrm{O}$ interdito é uma sanção que impede a realização de ofícios divinos na região. Talvez não consigamos, hoje, perceber o que isso significava para o povo boêmio da época. A historiadora Barbara Tuchman oferece-nos a medida da influência da Igreja no cotidiano, quando descreve o Cristianismo como

a matriz da vida medieval: até mesmo receitas de cozinha determinavam que um ovo fosse cozido 'durante o tempo em que se pode dizer um Miserere'. Ele governava o nascimento, casamento e morte, sexo, comida, estabelecia as regras do direito e da medicina, dava à filosofia e à erudição sua matéria.

\footnotetext{
${ }^{172}$ Os Lolardos foram os seguidores de Wyclif que, nos séculos XIV e XV, defendiam a pobreza do clero e criticavam a opulência da igreja. Um dos pontos controversos da visão dos lolardos é o questionamento do dogma da transubstanciação (transformação do pão e do vinho no corpo e no sangue do Cristo). Eles traduziram a bíblia para o inglês no final do século XIV. Um lolardo famoso foi Sir John Oldcastle, nobre defensor das ideias wyclifistas, que foi condenado como herege e queimado em 1418, apenas três anos após Jan Hus.

${ }^{173}$ SPINKA, John Hus: a biography, p. 120.
} 
A participação da Igreja não era uma questão de escolha, mas compulsória e sem alternativa, o que lhe dava uma influência que não era fácil desalojar. ${ }^{174}$

O rei Venceslau proibiu a obediência ao interdito e após alguns conflitos entre partidários opostos, o interdito foi ignorado.

Nova tentativa de reconciliação foi infrutífera. Representantes da Universidade de Praga, Hus e Zbyněk assinaram um acordo de paz em 3 de julho de 1411. Zbyněk não cumpriu sua parte e, após diversas tentativas de uma audiência com o rei, procurou o adversário deste último, Bispo Jan, "o Ferro", que em Litomyšl o recomendou procurasse o irmão de Venceslau, Sigismundo.

Em 1 de setembro de 1411, Hus escreve novamente ao papa (carta 18), reafirmando sua confissão de fé e defendendo-se das acusações de Zbyněk:

Menciono, além do mais, que eu apelei contra a sentença do reverendíssimo pai em Cristo, Senhor Zbyněk, à Sé Apostólica, e também que procedimentos legais baseados em informações errôneas vieram da Santa Sé Apostólica. Pois os inimigos da verdade, desconsiderando sua honra e salvação, sugeriram maliciosamente à Sé Apostólica que erros e heresias se espalharam no reino da Boêmia, na cidade de Praga e no margraviato da Morávia e que os corações de muitos foram infectados por lá e pela multidão de pessoas infectadas por tais erros tornou-se necessária a aplicação de um remédio para sua correção.

Além disso, eles falsamente sugeriram que a Capela de Belém era um local privado, apesar de ter sido confirmado pelo ordenado [o bispo] como um benefício eclesiástico, e sua destruição não diminuiria em nada a honra de Deus entre as pessoas...

O arcebispo morreu subitamente enquanto viajava para se encontrar com Sigismundo, poucos dias após esta carta de Hus, em 5 de setembro de 1411. O historiador tcheco Bartoš ${ }^{175}$ sugere a possibilidade de assassinato. A proximidade da data de ambos os eventos (a morte do arcebispo e a escrita da carta de Hus) parece-nos apenas uma coincidência. A morte do arcebispo de Praga, principal opositor de Hus naquele momento, não melhorou a situação deste. O clérigo chefe da capela de Belém se envolverá em querelas maiores que exigirão constantes refutações de sua parte, mas estas não serão suficientes para livrá-lo da morte na fogueira.

Os exemplos que aqui apresentamos são suficientes para observarmos expressões da motivação de escrita que categorizamos como refutação de acusações. Se voltarmos um

\footnotetext{
${ }^{174}$ TUCHMAN, op. cit., p. 32.

${ }^{175}$ SPINKA, John Hus: a biography, p. 129.
} 
pouco no tempo dessa história da qual tentamos nos aproximar, encontraremos uma carta que nos dá indícios do início de outra motivação para a escrita, aquela que fará a fama de Hus no seu aspecto mais emblemático: a defesa da verdade.

Em cerca de 1410, pouco tempo após Zbyněk ter proibido a pregação por parte de Hus, este escreve uma carta, de número 10, a um nobre, cuja identidade desconhecemos, defendendo-se da acusação de heresia:

De muitas pessoas confiáveis eu soube que muitos, que não temem ao Senhor Deus, acusaram-me de herege a Vossa Nobreza, embora nenhum deles tenha a coragem de se declarar publicamente meu adversário. De fato, nem mesmo o arcebispo, que, por meio de seus companheiros e se utilizando de um sagaz subterfúgio e uma falsa acusação, denunciaram-me ao papa, ousam fazê-lo. Assim, presumo que eles devem ter, igualmente, incitado Vossa Nobreza contra mim.

Logo em seguida, anuncia numa pergunta o mote que perpassará boa parte de sua correspondência e, ao mesmo tempo, lança um ataque direto à proibição imposta pelo arcebispo:

Devo ter medo disso ao me manter firme na verdade do evangelho? Claro que não, visto que eles próprios se opõem ao evangelho de Jesus Cristo, desejando restringi-lo de modo que ele não possa ser livremente pregado, como o misericordioso senhor ordenou. $\mathrm{Na}$ verdade, os prelados assumiram agora o espírito dos pagãos e dos Fariseus proibindo a pregação do evangelho em capelas e em outros locais apropriados.

E a base de seu conceito de verdade aparece algumas linhas a seguir na mesma carta:

Devo obedecer ao arcebispo quando uma ordem sua é contrária à ordem de Deus? Longe de mim! 'Pois devemos obedecer antes a Deus que aos homens ${ }^{176}$, disseram os apóstolos, mesmo que o clérigo chefe os proibissem de fazê-lo.

É justamente sua sustentação da verdade perante as acusações que levam Hus a ser acusado de heresia: ao defender a obediência ao evangelho e não à estrutura da Igreja, ao exigir a compreensão da verdade em detrimento de seguir o que os seus superiores lhe obrigam, ao denunciar práticas que considerava erradas ao invés de praticá-las como muitos o faziam. É assim que a verdade aparecerá em sua correspondência em oposição aos adversários do evangelho, ao Anticristo ou aos membros do Concílio que o acusam.

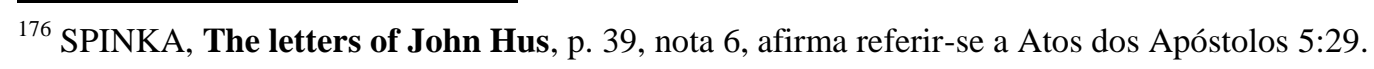


Nas cartas pastorais, escritas para o povo da Boêmia, há diversas menções à verdade. A de número 27, por exemplo, contém esta frase: “A verdade que eles quiseram eliminar tem a propriedade de brilhar mais forte, sempre que se tenta apagá-la, e de subir mais alto, sempre que se tenta rebaixá-la." Na carta 32, ele afirma que, embora tenha precisado fugir de Praga, ele não fugirá da verdade, preferindo morrer por ela:

Além disso, caros bem-amados, tenham certeza que, tendo eu fugido em
conformidade com os ensinamentos de Cristo, eu não serei o motivo da
danação eterna para os maus e nem a causa de sofrimentos e tribulações para
os bons. Tenham certeza também que os loucos não impedirão o serviço
divino. No entanto, quanto a fugir da verdade, confio que o Senhor me dará a
oportunidade para morrer por ela.

Hus também utiliza a verdade como tema de suas discussões teológicas, como na carta de número 21. Escrita a um clérigo cuja identidade desconhecemos, em cerca de 1412, ele utiliza citações do Novo Testamento, de Aristóteles (o "Filósofo") e de Agostinho para sustentar a verdade:

Naquele lugar onde o Salvador diz 'seja seu falar sim, sim, não, não', entenda que de acordo com o Filósofo e com Santo Agostinho 'é verdade que o que é, é e o que não é, não é'. Quando, no entanto, o Salvador diz 'seja seu falar sim, sim, não, não', ele deseja que a verdade positiva seja afirmada sem um juramento. Se alguém me perguntar: 'É Deus trino?' eu devo responder 'ele é'. Igualmente 'É verdade que você pecou?' eu devo responder 'sim'. Quando Cristo diz 'seja seu falar sim, sim, não, não', ele deseja que a verdade negativa seja afirmada negativamente. Se alguém me perguntar 'Não é Deus mau?' eu devo responder, 'ele não é'. Do mesmo modo, se alguém disser 'Não é você culpado de um ato?' se eu souber que eu não sou culpado de um ato, devo dizer, 'eu não sou'. A intenção de Cristo ali é clara, a verdade deve ser afirmada sem um juramento e a falsidade deve ser negada sem um juramento. ${ }^{177}$

E mais à frente, conclui sua argumentação:

Em Cristo, portanto, não havia 'sim' e 'não', ou seja, a afirmação e a negação da mesma coisa, pois neste caso uma mentira seria encontrada em sua boca, o que não é verdade. Pois Pedro disse: 'Ele não cometeu pecado e nenhuma mentira foi encontrada em seus lábios ${ }^{178}$. Portanto, qualquer pessoa que, sabendo a verdade, diz 'não', nega a verdade; aquele que, no

\footnotetext{
177 ibidem, p. 67, notas 9, 10 e 11, afirma serem as citações as seguintes: Mateus 5:37; Aristóteles, Sobre o homem no universo, Metafísica, V. p. 53; Agostinho, Solilóquios, II, 5, 8.

178 ibidem, p. 68, nota 16, sugere esta citação como I Pedro 2:22.
} 
entanto, souber que uma inverdade foi dita e disser 'sim', afirma uma falsidade. Não é o Cristo.

Não é possível ler estas palavras escritas em 1412 e deixar de relacioná-las àquelas escritas às vésperas de sua morte, em 1 de julho de 1415. Apresentadas como carta 98 por Spinka, elas consistem na declaração final escrita por Hus ao Concílio de Constança, concílio este que condenara diversos artigos retirados de seus livros como heréticos e o obrigara a negá-los. A perspectiva na qual "saber a verdade" impele a pessoa a dizer a verdade, permanece num dos últimos textos escritos por Hus, só que agora como decisão pessoal de manter-se firme nela. Mesmo que o leitor não conheça o caminho trilhado por ele desde sua querela com Zbyněk até sua condenação em Constança, a permanência do mesmo princípio nos dois escritos mostra uma antecipação, em 1412, do que estaria por vir ou uma manifestação honesta (verdadeira, em termos hussitas) de suas intenções. Em sua última declaração, afirma:

... a respeito dos artigos extraídos de meus livros, pelo menos aqueles que foram escritos corretamente, eu declaro que, se qualquer um deles contiver um sentido falso, eu o repudio. Mas, temendo ofender a verdade e falar contra a opinião dos santos, não desejo abjurar qualquer um deles.

Defender a verdade tornou-se, para Hus, muito mais do que uma estratégia para defender-se diante das acusações que sofria. Ele a assume como um dos principais conteúdos de sua prática educativa, como "pastor de seu rebanho", por meio das cartas. O trecho a seguir, extraído da carta 27, do final do ano de 1412, é representativo dessa intenção:

Escrevo-lhes esta carta, meus queridos irmãos e amadas irmãs, para que vocês se mantenham firmes na verdade que aprenderam. Não temam as intimações e não venham menos do que antes para ouvirem a Palavra de Deus por causa das ameaças cruéis que eles fazem. Pois "o Senhor é fiel, e há de fortalecer-vos e vos guardar do mal'.

Eis aqui a base da quinta motivação para a escrita epistolar: a continuação da sua tarefa pastoral de educador, conselheiro, defensor de ideias e testemunho da verdade por meio de cartas. Cartas que apresentam em elementos de seus conteúdos, indícios que nos permitem reconstruir, para além das intenções educativas de sua tarefa pastoral, a própria ação educativa hussita. É o que veremos na sequência. 


\section{Capítulo 2. A construção de um educador por suas cartas}

Desde o início de nossa pesquisa sobre Jan Hus, tínhamos por hipótese que ele era um educador e que realizou sua ação educativa de duas formas: por meio de seus escritos e por meio de seus sermões na Capela de Belém. Isso pode ser inferido a partir da leitura das biografias que consultamos, como as de Matthew Spinka ${ }^{179}$ e de David Schaff ${ }^{180}$. No entanto, precisávamos de fontes que embasassem historicamente essa inferência e a principal fonte à disposição eram as cartas hussitas, que descrevemos no capítulo anterior. Elas não dão conta de toda a vida desse clérigo da Boêmia, nem descrevem detalhes de sua atuação como pregador na Capela ou como professor na Universidade. Porém, consistem em documentos que preservam uma intenção educativa, como observamos a partir da rede de relações e das necessidades de escrita para Hus, uma ação educativa, representada pela construção de um padrão de escrita que visava continuar a tarefa pastoral por meio de cartas e, por fim, um legado educativo reconstruível a partir da história das edições. É no segundo destes itens que concentramos nossa atenção neste capítulo.

Iniciaremos com um estudo mais aprofundado das cartas que denominamos de pastorais. Estas foram escritas sem ter uma pessoa específica como destinatário, mas o "povo", os "amigos" ou os "irmãos” da Boêmia ou de Praga. Eram lidas no púlpito da Capela de Belém e dão continuidade aos sermões presenciais que Hus lá realizava. ${ }^{181}$

Em seguida, aproximando nosso olhar ainda mais dos detalhes, como propõe Ginzburg, podemos atingir uma escala ainda menor de observação, encontrando outros indícios talvez não disponíveis num conjunto abrangente como o das cartas pastorais. Lembrando-nos da descontinuidade entre os planos de observação proposta por Ginzburg a partir da obra de Kracauer, dedicaremos um espaço para o estudo de duas cartas pessoais escritas para seu discípulo Martin de Volyně. Elas apresentam um diálogo mais próximo entre o mestre e seu discípulo e, ao mesmo tempo, constroem uma nova relação educativa entre os correspondentes, produzindo as figuras do educador e do educando. Nossa leitura detalhada destas cartas oferece elementos adicionais à leitura das cartas pastorais, mais públicas e mais

\footnotetext{
${ }^{179}$ SPINKA, John Huss, a biography.

${ }^{180}$ SCHAFF, John Huss.

${ }^{181}$ OBERG, João Huss, um injustiçado?, p. 72, afirma que a Capela de Belém era o "meio popular de comunicação".
} 
visíveis, para a compreensão da figura educativa de Hus, de sua escrita e de seu contexto cultural.

Iniciemos com as cartas pastorais. Das pouco mais de cem cartas hussitas que dispomos, 23 apresentam como destinatários o povo da Boêmia ou os praguenses, mencionando ou não algum nome específico ao longo da saudação. Há outras cartas que não possuem destinatários específicos ou são cartas abertas, mas não parecem ter sido escritas especificamente para serem lidas do púlpito da Capela de Belém. Afirmar, por oposição, que essas 23 cartas que denominamos aqui pastorais foram escritas especificamente para serem lidas na capela é perigoso, pois indicaria uma certeza não condizente com a produção histórica. Há uma distância, impossível de ser superada, entre o fato "verdadeiro" e nossa leitura, conforme explicitamos na introdução. O que podemos, então, fazer é levantar os indícios que nos levam a argumentar que essas cartas tiveram essa finalidade.

Em primeiro lugar, as cartas pastorais foram escritas do exílio. As outras semelhantes a estas, escritas antes de Hus sair de Praga, têm por destinatários cidades diferentes. A primeira carta escrita aos habitantes de Praga, a de número 25, consiste justamente numa reflexão sobre sua ausência, justificando-a a partir de citações bíblicas e de uma carta de Santo Agostinho.

Em segundo lugar, o destinatário é um ser coletivo, característica dos sermões proferidos pelos clérigos e das cartas pastorais, conforme apontamos na introdução. As outras cartas hussitas que possuem por destinatários seres coletivos são notas públicas ou declarações abertas, como as de número 47 e 98. Para efeito de comparação, a carta 27 apresenta em sua conclusão um vocativo com uma clara menção a um destinatário coletivo (grifo nosso): "Eu lhes escrevo esta mensagem, caros irmãos e amadas irmãs, para que..."

Em terceiro lugar, a Capela de Belém era um lugar para sermões em língua vernacular. Das cartas hussitas que dispomos, 20 foram escritas em tcheco. Destas 20, 14 encontram-se neste grupo de cartas pastorais. Deste grupo, duas outras (números 38 e 39), cujo original está em latim, foram consideradas por Novotný como escritas originalmente em tcheco. O que significa que das 23 cartas pastorais, cerca de dois terços (16) foram escritas em tcheco.

Por fim, há detalhes nas cartas que mostram um Hus preocupado em escrever para compensar sua ausência ${ }^{182}$. Na carta 26 , do final de 1412, escrita em defesa da Capela de

\footnotetext{
${ }^{182}$ Matthew Spinka e František M. Bartoš afirmam que durante seu exílio, Hus substituiu seus sermões por escritos, como tratados, coletâneas de sermões e cartas. SPINKA, Matthew; BARTOŠ, František M. Jan Hus. Encyclopaedia Britannica. Disponível em <http://www.britannica.com/eb/article-9041616>. Acesso em 01 dez.
} 
Belém, Hus afirma "Eu lhes escrevi isto, já que não posso convenientemente ir até vocês". Ou também na carta 29, de 18 de outubro de 1412, na qual inicia sua argumentação com "Suplico-lhes que não se entreguem ao cansaço porque eu não estou com vocês ou por causa de minha excomunhão". Ou ainda, esta afirmação da escrita da carta para compensar a ausência de um sermão presencial, que aparece na "captação da benevolência" da carta número 39, de 25 de dezembro de 1413: "Embora eu esteja separado de vocês, de tal maneira que se torne, talvez, inadequado que eu lhes pregue muito, o amor que tenho por vocês impele-me a dizer pelo menos algumas poucas palavras para seu amor”.

Para manter seu lugar de pregador, educando por meio dos sermões, ao mesmo tempo em que precisava compensar a distância causada por seu exílio forçado, Hus passa a escrever cartas pastorais. Atuando dentro do modelo da ars dictandi, ele desenvolve aos poucos um padrão de escrita próprio dessas cartas.

\subsection{A construção de um padrão de escrita}

Pouco tempo após a morte do arcebispo Zbyněk, Hus entra em nova querela, agora por causa do papa João XXIII. A oposição de Hus à bula do papa João XXIII foi um dos mais decisivos eventos de sua vida. Workman e Pope ${ }^{183}$ a consideram "uma controvérsia de ampla importância" e Spinka ${ }^{184}$ "o agravamento mais sério" da situação de Hus, um conflito que se provou "fatal". Emitida em 9 de setembro de 1411, a Bulla indulgentiarum Pape Joannis XXIII prometia indulgências a quem lutasse contra os adversários de João XXIII: o papa de Roma, Gregório XII, e o rei de Nápoles, Ladislau, que apoiou Gregório. Eis uma síntese do conteúdo da bula, segundo Spinka:

Ele ordenou a todos os patriarcas, arcebispos, bispos e outros prelados, sob a pena da excomunhão, que 'publicamente, e em voz alta e inteligível', declarassem Ladislau 'excomungado, mentiroso, cismático, blasfemo, um herege relapso, protetor dos hereges, culpado do crime de lèse majesté, um conspirador contra nós e contra a Igreja.' Incluídos nesta condenação um tanto ofensiva 'os cúmplices ligados a ele e seus seguidores'. (...) O papa, então, implorou 'pelo sangue derramado pelo Salvador', que todos os imperadores, reis, príncipes seculares, eclesiásticos e monásticos, bem como os prelados, universidades e indivíduos de ambos os sexos tomassem a espada, 'em defesa da Igreja e de nós', para exterminarem Ladislau e seus cúmplices. O papa prometeu 'a todos os verdadeiros penitentes e que

2007. OBERG, op. cit., p. 185 corrobora essa interpretação. Ele afirma que Hus "Usou a língua tcheca para escrever, porque o seu grande púlpito sendo agora a pena, empunhou-a para se comunicar com o povo."

${ }^{183}$ WORKMAN; POPE, op. cit., p. 67.

${ }^{184}$ SPINKA, John Hus: a biography, p. 132. 
confessam' que pegarem a cruz (ou seja, as armas) às suas próprias despesas ou equiparem e sustentarem um soldado por um mês, 'a remissão de todos os pecados dos quais eles estivessem arrependidos de coração e que tivessem confessado. $^{185}$

O rei Venceslau apoiou a venda das indulgências, participando delas em suas terras. Hus posicionou-se contrário ao modo "sacrílego" "186 pelo qual a venda era feita e a guerra era promulgada. Seus amigos não o apoiaram, com destaque para seu companheiro de estudos universitários Štěpán Páleč e seu professor Stanislav de Znojmo. Hus afirma, em seu tratado Contra Pálec ${ }^{187}$, que o evento da bula papal foi decisivo para o rompimento da amizade com eles e utiliza uma frase que vai ao encontro de sua defesa da verdade "Páleč é um amigo, a verdade é uma amiga. Sendo ambos amigos, é sagrado preferir a verdade.” Dos poucos que o apoiaram, destacam-se Jerônimo de Praga e Jakoubek de Stř́ibro.

Páleč, quando diretor da faculdade de teologia, acusou Hus de ter chamado o papa de Anticristo num Quodlibet que lá ocorreu em janeiro de 1412, o que não foi verdade, pois fora Jakoubek quem fizera a acusação. Mas poucos da faculdade o sabiam. Hus defendeu-se de modo irônico às acusações da faculdade, afirmando que o rei deveria criar uma prisão acadêmica se ele quisesse impor sua vontade ${ }^{188}$. Isso o afastou também do apoio real.

O conflito a respeito da bula papal reforçou o debate sobre os artigos de Wyclif, com reuniões da Universidade para definir uma posição perante eles e respostas escritas de Hus a essas posições. Em julho de 1412, ele foi novamente excomungado por não-obediência e deveria apresentar-se perante a cúria ou haveria interdito sobre Praga. Todos os fiéis estavam proibidos de se comunicar com ele

por meio da comida, bebida, cumprimentos, discursos, compra e venda, conversação, abrigo ou qualquer outro meio. Em qualquer lugar que ele procurasse por abrigo, todos os serviços e administrações das igrejas deveriam ser interrompidos e mantidos em suspensão por três dias após sua saída. Se ele morresse, ele não deveria ser enterrado; se ele fosse enterrado, seu corpo deveria ser exumado. ${ }^{189}$

\footnotetext{
${ }^{185}$ SPINKA, John Huss: a biography, pp. 132-133.

${ }^{186}$ ibidem, p. 134.

${ }^{187}$ ibidem, p. 135

188 ibidem, p. 151

${ }^{189}$ ibidem, p. 161.
} 
Dado que não havia possibilidade de qualquer apelo ao papa, pois seria inútil, Hus apelou, então, para Deus e Cristo. Essa carta, que numeramos como $28 \mathrm{a}^{190}$, apresenta uma longa justificativa com trechos bíblicos, a maioria extraída do livro dos Salmos, para a possibilidade de se entregar sua causa nas mãos de Deus. Na sequência, escreve seu apelo:

Eu apelo a Deus pela opressão terrível, sentença injusta e falsa excomunhão do pontífice, os escribas e os fariseus e os juízes sentados no trono de Moisés. A Ele eu entrego minha causa, seguindo os passos do salvador Jesus Cristo, como fez o santo e grande patriarca de Constantinopla, João Crisóstomo, nos dois sínodos de bispos e clérigos.

Ele, então, critica a recusa do papa em recebê-lo ou a algum de seus procuradores e apresenta uma breve argumentação do motivo pelo qual não foi considerado herege na querela com Zbyněk. Afirma que não possui segurança para aparecer em Roma e, por isso, Deus o perdoará. Conclui com uma renovação de seu pedido inicial, apresentando seu lugar naquela sociedade:

$\mathrm{Eu}$, Jan Hus de Husinec, mestre em artes e formatus bacharel em sagrada teologia na Universidade de Praga, clérigo e pastor designado para a capela chamada Belém, faço este apelo a Jesus Cristo, o mais justo Juiz, que conhece, protege e julga, declara e recompensa sem erro a causa justa de cada homem.

Hus se identifica como o homem de saber, o clérigo e o pregador da verdade ao povo que, por uma circunstância extrema, corre o risco de não estar mais presente. E se não puder pregar presencialmente, ele o fará por escrito pelas cartas. Continuar a pregar, mesmo que por meio de cartas é, contudo, uma escolha que vai ainda além de uma vontade pessoal. Ela é condizente com o espaço-tempo no qual Hus atua. No século XV, o pregador é uma figura que tem o apoio do povo, entusiasmado com a atuação desse tipo humano, como afirma Vauchez:

no século XV (...) em todo o Ocidente, os únicos religiosos, à excepção dos eremitas, que suscitaram o entusiasmo das multidões são pregadores que consagraram sua vida e as suas forças ao ministério da palavra. Percorrendo o Ocidente, desde Aragão até a Bretanha e desde a Itália até a Polônia e à Croácia, esses religiosos distinguiam-se claramente do clero a que os fiéis estavam habituados: iam de cidade em cidade, viviam na maior pobreza, mas tinham tempo para se fazer conhecer pelos seus auditores, dado que, muitas vezes, lhe dedicavam um ciclo completo de sermões - por exemplo, durante

\footnotetext{
${ }^{190}$ Como afirmamos no capítulo 1, as cartas que, na edição de Spinka, foram apresentadas como apêndice, nós as inserimos em nossa numeração, seguidas da letra "a".
} 
a Quaresma -, o que lhes dava a possibilidade de se familiarizarem com os problemas desta ou daquela cidade e dos seus habitantes. ${ }^{191}$

A despeito de sua excomunhão, Hus não se apresentou à cúria e continuou a pregar. $\mathrm{O}$ papa chegou até a ordenar a destruição da Capela de Belém, o que nos mostra o papel simbólico que esse lugar possuía para a atuação de Hus, o que não foi levado a cabo pelos tchecos, confirmando a influência do clérigo e a importância daquele lugar.

Vinte dias após a sentença de excomunhão, novo interdito foi imposto sobre Praga e Hus questiona-se a respeito de permanecer ou sair. Após os conselhos de seus assistentes na Belém, a ordem do rei e a oferta de abrigo por parte de nobres do sul da Boêmia (em Kozí situa-se o principal castelo onde ficou), ele deixa Praga em outubro de $1412^{192}$. Workman e Pope não apresentam certeza da data de saída de Hus da cidade, afirmando que ele talvez tenha saído em 12 de agosto e retornado para pregações ${ }^{193}$. Atestam, também, que em outubro ele, com certeza, estava fora. Mas sua saída definitiva foi em dezembro de 1412. Schaff afirma que Hus esteve ausente de outubro de 1412 a outubro de $1414^{194}$. Ironicamente, no mesmo mês de outubro de 1412, chegou à cidade a notícia de que o papa concluíra um acordo de paz com o rei Ladislau quatro meses antes e, portanto, o principal motivo que levou Hus a entrar em conflito com o papa e que desencadeou seu exílio já não existia mais.

$\mathrm{Na}$ primeira carta pastoral, escrita logo após sua partida no outono de 1412, a de número 25, Hus expressa seu ponto de viragem, um momento de grande dúvida para ele:

Refleti longamente, também, a respeito da carta de Santo Agostinho ao Bispo Honoratus ${ }^{195}$, que procurou por seus conselhos em uma situação semelhante. Em sua resposta, Agostinho conclui: 'Aquele que fugir de tal modo que sua fuga não prive sua igreja do ministério evangélico faz o que o Senhor lhe recomendou e permitiu. Mas aquele que fugir de tal modo que o rebanho do Cristo seja privado de seu alimento espiritual é como o mercenário que, vendo o lobo se aproximar, foge, porque não se preocupa com as ovelhas.' (...)

Avisem-me, portanto, se vocês concordam com o conselho de Agostinho, pois minha consciência adverte-me da ofensa que minha ausência pode causar, embora não esteja faltando ao rebanho o alimento necessário da

\footnotetext{
${ }^{191}$ VAUCHEZ, André. O santo. In: LE GOFF, O homem medieval, p. 222.

192 ibidem, p. 165.

${ }^{193}$ WORKMAN; POPE, op. cit, p. 80.

${ }^{194}$ SCHAFF, John Huss, p. 133.

${ }^{195}$ Spinka afirma que esta é a carta de número 228 do volume de Epistolas de Agostinho, número 33 da Patrologia Latina de Migne. A única informação que dispomos da carta de Agostinho é o comentário que Hus fez logo em seguida na citação que transcrevemos.
} 
palavra de Deus. Por outro lado, temo que minha presença, durante o período do interdito execravelmente obtido, possa causar a suspensão desse alimento, privando o rebanho do santo sacramento da comunhão e de outros recursos para a salvação.

Deixar o "rebanho" para acabar com o interdito à Praga, correndo o risco de não poder oferecer a "palavra de Deus", o "sacramento da comunhão" e "outros recursos para a salvação" ou permanecer, oferecendo esses elementos? O que é mais prejudicial, a sua ausência ou a sua presença nestas circunstâncias? Ao compor sua carta, Hus busca uma autoridade que lhe sirva de referência tanto para encontrar uma solução para seu problema, quanto para lhe indicar uma maneira de se comunicar na situação de exilado: escrever cartas.

As referências à "palavra de Deus" e às epístolas de "São Paulo" no final da carta são indícios que reforçam nossa percepção do exemplo paulino na correspondência escrita do exílio:

O apóstolo Paulo, dos teólogos o mais avançado, exortou seus discípulos convertidos a orarem o tempo todo, no espírito, por ele (...) como encontramos em Efésios 6, Tessalonicenses 3 e Colossenses 4.(...)

Suplico-lhes, portanto, em nome do Senhor, que lhe despejem súplicas em espírito e verdade, para que "a palavra viva de Deus seja-me dada ao abrir minha boca e eu possa falar como devo", tal qual foi dada a São Paulo por causa das orações de outros.

Neste momento, por ser talvez a primeira carta pastoral escrita por Hus, parece que ele começa a elaborar seu padrão de escrita e, por isso, parte de modelos como as epístolas de São Paulo e autoridades como Agostinho. Esta é uma carta que embora apresente as características de uma carta pastoral, também cita nomes de destinatários. Os três nomes citados, Mikulaš (Nicolau) de Miličín, Martin de Volyně e Havlík, são também pregadores. Há indícios de uma resposta esperada por Hus da parte deles ("avisem-me se vocês concordam com a resposta de Agostinho"), mas a inclusão de um quarto destinatário coletivo ("aos outros irmãos na sagrada Belém"), aponta para um padrão de escrita pastoral que ele está experimentando, misturando o coletivo com o individual, diante das questões prementes que ele precisa resolver.

Na mesma época em que escreveu a carta 25, outono de 1412, escreve aos "nobres e mestres” em Praga, carta número 26, pedindo-lhes apoio e apresentando seus argumentos para não abjurar. O destinatário, por ser coletivo, não dará uma resposta escrita. O que Hus espera é um apoio dos membros da nobreza e dos intelectuais para sua causa. Além disso, escreveu a carta em tcheco ao invés do latim, como fizera na anterior. Essas características começam a 
compor o padrão de escrita das cartas pastorais hussitas. Hus explica que a abjuração pode servir tanto para a verdade quanto para a mentira. Inicia com seus pedidos:

Suplico-lhes, em primeiro lugar, que apóiem a causa de Deus, pois um grande erro está sendo feito a Ele. Eles querem suprimir sua santa Palavra, destruir a capela tão útil para a pregação da palavra de Deus, e, assim, obstruir a salvação das pessoas. Em segundo lugar, considerem a desgraça de vossas terras e de vossa nação ou povo ${ }^{196}$. Em terceiro lugar, considerem a vergonha e o erro que são cometidos contra vocês sem motivo. Em quarto lugar, considerem e aceitem alegremente o fato que o demônio está se enfurecendo contra vocês e o Anticristo está fazendo caretas para vocês. Mas, como um cachorro acorrentado ele não lhes fará mal se vocês amarem a verdade de Deus.

E segue, apresentando sua explicação sobre abjurar:

Além disso, vocês devem saber que 'abjurar' é renunciar às suas crenças. Deste modo, aquele que abjura, ou renuncia a uma crença que ele realmente acredite ou a heresias e erros que ele acredite. (...) Vocês devem saber, portanto, que se qualquer um de vocês abjurar - como eles escrevem na carta - essa pessoa irá abjurar tanto a verdadeira fé e a verdade quanto uma heresia ou um erro. Desse modo, após abjurar, ela acreditará tanto numa heresia ou erro, quanto naquilo que ele está abjurando.

Entendam disso que na carta eles lhes consideram hereges e exigem que vocês abjurem das heresias que vocês supostamente acreditam. Segue-se disto que cada um de seus filhos ou amigos pode ser interpelado e reprimido - se qualquer um de vocês abjurar - por ter um pai ou um amigo herege. Em segundo lugar, significa que a todos os que abjurarem pode-se dizer corretamente 'você abjurou uma heresia que acreditara e não é digno de mim'. Em terceiro lugar, se alguém abjurar, mas não manter no coração a verdade que ele renunciou sob coerção, ele é perjuro.

Próximo ao fim desta carta, Hus apresenta uma definição de vida eterna como recompensa por viver na verdade e correção:

Considerando estas coisas, colocando em primeiro lugar a verdade e o louvor a Deus e vivendo corretamente, permaneçamos no amor para terminar com a mentira do Anticristo, tendo o Grande Salvador em nossa ajuda. Ninguém pode superá-lo e ele não nos abandonará jamais se nós não o abandonarmos. Ele nos dará a recompensa eterna, que consiste na satisfação

\footnotetext{
${ }^{196}$ Palavra de difícil tradução, visto que o original em tcheco (pokolení) pode significar geração, gênero (humano) ou raça. Spinka e Workman e Pope traduziram por race. A palavra "povo" foi uma escolha que nos pareceu mais próxima do sentido original, especialmente porque é antecedida de terras e nação. Hus está se referindo, aqui, às pessoas que compõem a nação tcheca. Mas sabemos da insuficiência desta palavra para exprimir o sentido.
} 
de nossa vontade, razão, memória e todos os sentidos do corpo sem economia.

Como lembramos anteriormente, trabalhar com cartas é lidar com temporalidades bem diferentes e um protocolo de escrita que segue outro ritmo. O que para nós está aqui distante apenas alguns parágrafos, para Hus há uma gama de eventos interpostos dos quais não temos informações. Não temos nenhuma escrita epistolar no período de um mês após a escrita deste pedido de apoio. Não sabemos se houve mudanças na relação com a nobreza e com os intelectuais da Boêmia. Sabemos apenas que ele continuou a escrever e a consolidar seu padrão de escrita de carta pastoral.

Em cerca de novembro de 1412, Hus escreve uma carta (número 27), também em tcheco, para o povo de Praga, na qual ensina as pessoas a reconhecerem o que denominou de "armadilhas do Anticristo e de seus mensageiros". Neste trecho, justifica ter se exilado para proteger seus fiéis e defender a verdade:

Tenham certeza de que eu não hesito entregar minha pobre vida pela verdade de Deus perante o perigo ou a morte, pois nada falta para nós em Sua palavra e, dia após dia, a verdade evangélica se espalha mais. No entanto, eu desejo viver por aqueles que sofrem a violência e precisam da pregação da Palavra de Deus, para que a maldade do Anticristo possa ser exposta e os devotos escapem dela. É por isso que eu estou pregando em outros lugares e exercendo o ministério para todos, sabendo que assim a vontade de Deus se realiza em mim, mesmo que eu morra ou caia doente pelas mãos do Anticristo. Se eu for para Praga, os meus inimigos, que não servem a Deus e impedem os outros de servi-lo, com certeza, prepararão armadilhas para mim e perseguirão a vocês. Contudo, rezemos a Deus para que, se houver entre eles alguns dos escolhidos, que estes se voltem para o conhecimento da verdade.

Enquanto na carta 26 Hus utiliza de uma argumentação lógica a respeito da abjuração e da verdade, a carta 27 é escrita como uma exortação pela verdade. Hus defende-se das acusações que sofreu, cita diversas autoridades bíblicas e dá conselhos a respeito da conduta moral de seus destinatários que ouvirão a leitura daquela carta na Capela de Belém. Estes elementos farão parte do padrão de escrita de suas cartas pastorais deste momento em diante. No entanto, eles já estavam presentes na correspondência anterior ao exílio, em cartas escritas para habitantes de outras cidades. É o caso de uma carta (número 16) escrita para os habitantes da cidade de Louny.

Louny é uma cidade localizada a noroeste de Praga, local que Hus considera um lugar no qual "a harmonia e unanimidade" pela "fé, paz, caridade e atenção à palavra do Salvador" são maiores do que em qualquer outra cidade. Hus escreve a seus habitantes exortando-os a 
permanecerem no caminho correto que já seguem. Não sabemos por que Hus escreveu-lhes essa carta, mas o tipo de escrita tendo por destinatário um sujeito coletivo e o tom de sermão assemelham-se às cartas pastorais que estamos analisando.

Ao povo dessa cidade propõe uma postura perante os cismas e conflitos entre as pessoas:

Caso haja ali alguém perturbador e obstinado em disseminar a discórdia, admoesta-o como um irmão. ${ }^{197}$ Não leve a questão perante um tribunal, pois isso trará para ambos grandes prejuízos para sua alma, seu corpo e seus bens. Prefiram vindicar o mal causado a Deus ao mal causado a vocês mesmos.

O clérigo afirma que a humanidade está errando, preocupando-se em vindicar as coisas pessoais mais do que as divinas. Escreve, então, como o clero está incoerente com as recomendações das escrituras, mostrando os erros que combatia, bem como a perseguição que ele próprio estava sofrendo:

Um clérigo, monge ou prelado pode ser um fornicador ou um adúltero e sair livre de sua falta, mas se ele ensinar algo segundo sua vontade, isso será visto como um motivo para o anátema. Acontece o mesmo com os leigos: se alguém desonrar a Deus, eles não o punirão, mas se alguém lhes disser 'Padres designados, vocês me condenaram injustamente', o que acontece com frequência, imediatamente eles o punem com a espada, porque afirmam que ele acusou injustamente aos juízes clericais.

Voltando-se a seus destinatários, afirma acreditar que eles não seguirão esse caminho e discorre, como um tema para reflexão, sobre a Justiça Divina. Nela, aparece a ideia da obediência antes a Deus do que aos homens no início do trecho:

Eu tenho fé em Deus que Ele irá livrá-los desses males, de modo que vocês poderão observar Sua lei mais do que as normas humanas. Observando sua lei, ninguém poderá causar-lhes mal. Portanto, meus bem-amados, reflitam profundamente sobre estas duas coisas que são eternas e imperecíveis: condenação e vida. Na primeira, há o fogo perpétuo, escuridão, sofrimento martirizante e um queimar sem fim junto dos demônios. Já na vida eterna, há alegria perfeita, luz, ausência de qualquer angústia ou sofrimento e comunhão com o próprio Deus e Seus anjos.

E apresenta, em termos simples, o caminho para a salvação, escrevendo: "seremos, então, abençoados se perseveramos no caminho do bem até o fim”. Termina sua carta com uma exortação para que eles vivam devotamente:

${ }^{197}$ Referência a II Tessalonicenses 3:15, conforme apontamentos de Spinka. 
Saibam, meus bem-amados, que o mundo está ruindo, a morte está batendo à porta e logo partiremos daqui. Vivam, portanto, devotamente, renunciando aos seus pecados, empenhando-se pelas alegrias celestes e amando a Deus de todo o seu coração, acreditando que Ele, pelos méritos de Jesus Cristo, irá adorná-los com Sua glória e fará de vocês participantes de Seu reino. Amém.

Num período próximo ao envio dessa carta, Hus escreve (carta número 17) a seu amigo Jan Bradáček (algo como "João Barbado") e ao povo da cidade de Krumlov (situada ao sul da Boêmia, próxima à fronteira com a Áustria). Ele retoma o tema da obediência, que parece estar premente das discussões das quais participava naquela época. Apresenta diversos argumentos para obedecer antes a Deus. Novamente recorre a citações bíblicas (Atos, Gálatas, Salmos, Deuteronômio e I Pedro) e aos Padres da Igreja e comentadores, como Agostinho, Gregório, Jerônimo, Bernardo e Beda e os utiliza para oferecer autoridade a sua posição contrária à hierarquia e à obediência cega aos homens da Igreja. Workman e Pope ${ }^{198}$ dão uma dimensão de quem era Bradáček e de como essas citações permitem-nos compreender o aprendizado medieval:

John Barbatus, também conhecido por Bradáček, ou Železna Brada ("barba de ferro"), a quem esta carta é dirigida, foi um grande amigo de Hus. Ele era leigo, como sua "barba" mostra, um "sujeito rústico e robusto" - como foi chamado por uma nota escrita por alguém à margem. Sabemos que ele esteve em Constança durante o julgamento e a execução de Hus, cujas últimas cenas ele nos deixou um testemunho terno e vívido (Documenta 556). Parece que morava, nessa época em Krumlov. Muitas das citações desta carta encontramos repetidas por Hus em seu De Sex Erroribus, c. 4, 'De Obedientia' (Monumenta i. 192b) e também em seu De Ecclesia, c. 19 (Monumenta i. 238-9). Elas são um exemplo claro do pequeno aprendizado medieval, tão comum em Hus, pois a maior parte foi extraída - como nossas notas apresentam - na ordem em que aparecem de uma ou duas páginas do Decretum de Graciano - trabalho que Hus utilizou como uma mina de referências patrísticas. A consciência medieval a respeito de plágio era curiosamente indulgente.

Ao comentar do "pequeno aprendizado medieval", apresentando um valor ao acesso às obras escritas, os tradutores das cartas de Hus oferecem outro indício importante: ele estava utilizando as fontes que considerava terem autoridade e as selecionou com base nos critérios de sua época. ${ }^{199}$ E se o fez, foi com a intenção de garantir o oferecimento do melhor para os

\footnotetext{
${ }^{198}$ The letters of John Hus, p. 45.

${ }^{199}$ O monge Graciano, em cerca de 1140 , foi o primeiro a tentar estabelecer de forma sistemática um direito canônico, publicando o seu Decretum, no contexto da reforma gregoriana do século XII. Este texto é a primeira parte do que depois se tornou o Corpus juris canonici. O Decretum de Graciano, junto das Sentenças de Pedro
} 
seus discípulos, visto que o destinatário é um amigo seu. Mais um importante detalhe que mostra que a prática educativa estava presente em suas cartas. A ideia um tanto pragmática do conhecimento como instrumento para saber como agir no mundo, presente na conclusão desta carta, é a confirmação disso:

Baseando-me nisso [na argumentação sobre obediência], eu prefiro, no que diz respeito à pregação, obedecer a Deus e não ao papa, ao arcebispo e ao resto dos sátrapas ${ }^{200}$ que se opõem às palavras do Cristo: 'Ide por todo o mundo...' Subscrevo-me com estas palavras para que vocês saibam como fazer oposição aos cães do demônio.

Também representativa desse início de uma ação pastoral por meio de cartas é a carta de número 20, escrita mais para o final do mesmo ano de 1411, para os habitantes da cidade de Plzeň, localizada a sudoeste de Praga. Ela é uma resposta a uma carta perdida na qual Hus foi informado de discórdias na cidade e dos abusos de um dos clérigos locais.

Essa carta se destaca logo na saudação, um tanto diferente das outras: “Aos bons, a perseverança na virtude; aos pecadores, o santo reconhecimento de nosso senhor Jesus Cristo". Observamos que é justamente essa oposição entre os bons e os pecadores que norteia a "captação da benevolência":

Ouvi com grande pesar que há entre vocês a desunião e a discórdia na verdade de Deus. Começando bem, vocês seguiram mal e provocaram a ira de Deus, destroem suas almas, dão maus exemplos para os outros, ferem sua honra e por um ganho insignificante neste mundo vocês pouco consideram a vida eterna.

Por que vocês não se lembram do que disse o Salvador: 'O que vale ao homem ganhar o mundo todo e perder sua alma? Ou o que ele dará em troca de sua alma?' Oh, porque vocês não se lembram que sempre foram um bom exemplo para toda a terra da Boêmia por sua concórdia, por ouvir a Palavra de Deus e por evitar o mal? Oh, como vocês esqueceram que sua unidade no bem era santa, que ela thes defende contra os inimigos, enriquece-lhes e lhes fizeram estimados perante Deus e os homens!

Lombardo e da Dialética de Abelardo constituem as principais sínteses do saber oriundo da tradição dos Padres da Igreja no currículo escolástico. V. LE GOFF; SCHMITT, op. cit. p. 343 e 369.

${ }^{200}$ De acordo com o dicionário HOUAISS, sátrapa é o governador de uma satrapia, na antiga Pérsia, e, por derivação, um indivíduo muito poderoso e arbitrário, um déspota, ou ainda uma pessoa que leva uma vida muito faustosa. WORKMAN; POPE. op. cit., p. 50 diz “'Sátrapas' é a palavra preferida por Wyclif para denominar o alto clero. Cf. Dialogues, 25 1,20; 32 1,22; 113 1,33; Cruciata (Polemic Works II,620) et passim. 
Inicia, então, Hus sua argumentação de como isso aconteceu. Volta-se a um dos importantes temas morais de suas cartas: o combate às festas e aos jogos. Relembra-lhes de sua reputação:

O que vocês querem fazer com sua boa reputação, que no passado soava assim: O povo de Plzeň é o mais unido. Eles administram bem a cidade, amam a Palavra de Deus, expelem as concubinas e sedutoras dos clérigos, pararam de jogar dados e são um bom exemplo para as outras cidades.

Termina com uma exortação ao caminho do bem, descreve uma boa cidade e faz um pedido ao "Pai, Filho e Espírito Santo, pela morte do Senhor Jesus e com a ajuda da Virgem Maria e de todos os santos, que ajudem a transformar Plzeň, hoje perturbada, em tal cidade”. Mas a carta não termina aí. Hus a expande com um texto sobre o uso da língua vernacular e sobre os erros dos clérigos. Spinka ${ }^{201}$ afirma que esse adendo foi depois ampliado num tratado "Contra praedicatorem Pilznensem" [Contra os pregadores de Plzeň]. Eis um trecho de sua argumentação, apontando os erros e utilizando o aprendizado e a compreensão como alternativas a esses erros:

Após escrever esta carta, eu recebi outra na qual se afirma que alguns clérigos proibiram a leitura da escritura em tcheco ou alemão vernaculares. Segundo, que alguns clérigos pregaram que ninguém, mesmo que tenha cometido um pecado mortal, é servo ou filho do demônio. Terceiro, que à missa nova [primeira após a ordenação] ele pregou 'Este clérigo, que até aqui não foi oficiado, foi um filho de Deus, mas de hoje em diante, quando for oficiado, será o pai de Deus e o criador do corpo de Deus.' Quarto, que o mesmo clérigo pregou que o pior clérigo é melhor que o melhor leigo.

Se for isso mesmo e ninguém se opor a estes erros, é num grande pecado que vocês caíram, longe da verdade, especialmente aqueles dentre vocês que aprenderam e possuem a compreensão.

E, mais à frente, apresenta sua argumentação para o aprendizado da verdade em vernáculo:

Muitos de vocês conhecem a verdade e a aprenderam que cada um pode falar, confessar e - se ele puder - até mesmo ler a lei de Deus em Latim, como São Marcos escreveu seu evangelho, ou em Grego, como São João compôs seu evangelho, as canônicas, ou cartas. Ou em Hebraico, como São Mateus o escreveu, ou em Siríaco, como São Lucas o escreveu, ou em Persa, como São Simão pregou e o escreveu; ou em Judaico ${ }^{202}$ como São

\footnotetext{
${ }^{201}$ SPINKA, The letters of John Hus, p. 61, nota 11.

202 ibidem, p. 62 apresenta, entre colchetes, “Aramaico?” e, em nota (número 15), que Bartoš corrigiu a frase, substituindo "Indiano" por "Judaico".
} 
Bartolomeu o escreveu e assim sucessivamente em outras línguas. Como é possível que vocês permitam clérigos que proíbem as pessoas de ler a lei de Deus em Tcheco ou em Alemão?

Segue com argumentação contra os outros erros, afirma que precisaria de mais espaço para provar as questões que afirma e faz nova exortação:

Oh, bravos cristãos! Todos vocês morreram, já que permitiram os erros serem espalhados e a Palavra de Deus ser restrita? Acordem e não deixem o mal governá-los! Que o Senhor Deus, Aquele que unicamente pode ser e é o Criador, ajude-os nisto. Amém.

No início de 1415, já preso, Hus escreve conjuntamente aos habitantes de Louny, Plzeň, Praga e Žatec. Essa carta, de número 66, foi escrita em tcheco e só aparece na edição tcheca das cartas hussitas de 1949, por B. Ryba. ${ }^{203}$ Apresentamos, a seguir, sua tradução integral, como um exemplo de uma carta escrita aos mesmos destinatários em outro momento bem diferente da vida do clérigo da Boêmia. Hus atribui um sentido ao sofrimento que vive na prisão:

Para os amigos em Praga, Žatec, Louny e Plzeň.

Rezem ardentemente por mim para Deus, pedindo-Lhe que me dê a perseverança. Eu não sou melhor que São Pedro: dado que ele negou o Senhor Jesus por três vezes, se eu também negar, não sigam meu exemplo, caros tchecos, ficando sem desculpas perante Deus e os homens.

Se nós compartilharmos no sofrimento de Cristo, nós nos alegraremos com Ele: não como assassinos e ladrões, que sofrem por seus débitos, mas como aqueles que sofrem inocentemente com Cristo, que nós possamos obter a vida eterna. Pois Salomão diz que Deus trata os homens como crianças: 'Ele reprova aqueles que ama' ${ }^{204}$, como um pai faz com seus filhos, não desejando ver neles a danação.

Ele condescende gentilmente a olhar por nós

E para nos doar seus dons maravilhosos:

Prisão estreita, cama dura, comida escassa,

tábuas duras, dor de dente, vômito e febre.

Como todo o corpo pecou e portanto fez Deus sofrer,

\footnotetext{
${ }^{203}$ RYBA, op. cit. Nesta edição, é a carta de número 65.

${ }^{204}$ SPINKA, The letters of John Hus, p. 156, nota 2, indica Provérbios 3:12.
} 
Todo o corpo, ao receber a punição, chega até Deus com sua alma.

As três cartas escritas antes do exílio aqui apresentadas (números 16, 17 e 20) apontam para um padrão de escrita que se estabelecerá durante o exílio de Hus. Cerca de um quarto de sua correspondência seguirá esse padrão, com as características que identificaremos a seguir a partir da análise mais detalhada de duas cartas escritas no final do ano de 1412.

A carta 27, que comentamos há pouco, foi escrita originalmente em tcheco, conforme apontou Spinka na sua tradução para o inglês ${ }^{205}$, embora seja conhecida apenas na versão em latim da edição de Palacký ${ }^{206}$. Esse detalhe da escrita destaca a importância do uso do vernáculo para Hus, que textualmente já apareceu na carta aos habitantes de Plzeň (número 20). Usar a língua vernacular, no caso o tcheco, para facilitar a compreensão do povo, que não conhece o latim, do conteúdo bíblico é uma das mais importantes características educativas dos movimentos de reforma da Igreja. ${ }^{207}$

Outra característica desse padrão de escrita é o uso da autoridade teológica das citações bíblicas e dos comentadores e Padres da Igreja. Com grande frequência na correspondência hussita nós encontramos citações, especialmente do Novo Testamento, utilizadas como fonte de autoridade para conduta moral dos destinatários ou como base interpretativa para os eventos contemporâneos à escrita. Na carta 27 nós encontramos ${ }^{208} 21$ citações diretas ou paráfrases de livros bíblicos, com trechos de Mateus (4 citações), Tiago (3), João, Gálatas (2), Provérbios, Salmos, Isaías, Filipenses, Tito, Hebreus, Romanos, I Tessalonicenses, II Timóteo e I Pedro. No exemplo a seguir, retirado da carta 27, Hus alude aos Provérbios de Salomão e aos Salmos de Davi para justificar o sofrimento que ele e seus amigos estão passando:

Não se aflijam, portanto, meus bem-amados, nem sintam medo se alguns de vocês são testados por Deus que permite que os ministros do Anticristo lhe aterrorizem com sua tirania. Pois Deus Pai diz a cada um de seus filhos nos provérbios de Salomão, terceiro capítulo: 'Não te assustará o terror imprevisto, nem o ataque dos maus sobre você. Pois o senhor ficará ao teu lado e guardará o teu pé da armadilha.' E, por meio do profeta Davi, ele diz a respeito de cada um de Seus servos que sofrer por Sua causa: 'na angústia estarei com ele, eu o livrarei e o glorificarei'. ${ }^{209}$

\footnotetext{
205 ibidem, p. 79, nota 1.

${ }^{206}$ PALACKÝ, Documenta, pp. 36-41.

${ }^{207}$ V. MANACORDA, História da educação, p. 194 e seguintes.

${ }^{208}$ A partir das notas de SPINKA, op. cit., pp. 79-84.

${ }^{209}$ Provérbios 3:25-6 e Salmos 91:15 apud SPINKA, op. cit., p. 80, notas 6 e 7.
} 
Das citações bíblicas, oito são retiradas de alguma das cartas de Paulo de Tarso. Citar uma epístola paulina na correspondência é mais do que utilizar uma autoridade importante da teologia católica, é uma aproximação a uma prática educativa com os mesmos princípios. Hus, ao citar Paulo de Tarso, utiliza um texto bíblico originalmente escrito como uma carta que visava à formação cristã de seus destinatários. ${ }^{210} \mathrm{O}$ clérigo da Boêmia transcreveu em suas cartas trechos escritos originalmente por Paulo para educar por meio de cartas. Na carta 27, os trechos seguem o mesmo princípio de uso da autoridade, como neste exemplo:

Os maus, portanto, não pararão de perseguir e os fiéis membros de Jesus não deixarão de sofrer enquanto continuar, neste mundo, a batalha entre o Cristo e o Anticristo. Pois disse São Paulo: 'todos os que quiserem viver com piedade em Cristo Jesus serão perseguidos. Quanto aos homens maus e impostores, eles progredirão no mal, enganando e sendo enganados.' São Paulo quer dizer que todos os homens bons sofrerão em nome do Cristo Jesus, mas os homens maus continuarão a errar e a seduzir aos outros, satisfazendo, assim, seus desejos de agirem no mal para sua própria destruição. $^{211}$

A relação da prática hussita com a prática paulina reaparece na carta 28 , escrita na mesma época que a 27. Durante o trecho da carta que, de acordo com as regras retóricas para a escrita de cartas, pode ser tida como a captação da benevolência, Hus utiliza um trecho da epístola de Paulo aos Filipenses a qual, semelhante ao clérigo da Boêmia, o apóstolo escrevia por estar distante:

\footnotetext{
${ }^{210}$ CAVICCHIOLI, Maria de Lourdes Silva Barros. A cultura clássica e o magistério de Paulo de Tarso. 2005. 118 f. Dissertação (Mestrado em Educação). Universidade Estadual de Maringá, 2005, p. 101-102, ao demonstrar a influência estóica no pensamento de Paulo de Tarso, afirma: "Para transmitir os seus ensinamentos e manter os seus discípulos persistentes na busca da perfeição, Sêneca também utilizou cartas. Nelas, revela um ardor apostólico, que resume a tarefa de um professor ou de médico, que aconselha a virtude e o bem aplicável a todos os homens. Dessa forma, a carta se tornou o principal instrumento para educar e levar a tranqüilidade da alma. Paulo de Tarso adotou a mesma solicitude e o mesmo desvelo pastoral para com os cristãos das comunidades por ele fundadas, reanimando-as na fé por meio das suas cartas e visitas, quando possível e/ou se fazia necessário (...). A partir desse expediente, Paulo de Tarso procurou manter com seus discípulos uma intensa comunicação, para transmitir suas mensagens e manter doutrinariamente as comunidades unidas." FARIA, Vera Lúcia Boechat. Combati o bom combate: retórica nos discursos de Paulo. 2008. 84 f. Dissertação (Mestrado em Letras). Universidade Vale do Rio Verde, Três Corações, 2008, p. 30, ao analisar a retórica nos escritos de Paulo de Tarso, afirma: "Um dos métodos de evangelização utilizados por Paulo era o discurso, constituído de ensinamentos ministrados a líderes e membros leais do Cristianismo, que retransmitiam aos grupos, nas evangelizações, ou a outras pessoas a quem o apóstolo buscava converter. Paulo ainda fazia o acompanhamento e o controle desses líderes missionários por meio de cartas em formato de discurso argumentativo e retórico. Tais cartas eram recheadas de orientações, palavras de conforto e, principalmente, evangelização e propagação da "palavra de Deus". A epistolografia (prática de escrita e envio de cartas) e a arte retórica eram práticas comuns na Antiguidade greco-romana. As cartas, portanto, acabaram por se constituir em instrumento valoroso de transmissão de orientações e procedimentos para a propagação do evangelho de Jesus Cristo."

${ }^{211}$ II Timóteo 3:12-13 apud SPINKA, op. cit., p. 81, nota 17.
} 
Eu mesmo dependo da misericordiosa bondade de nosso Salvador, embora possa, neste momento, dizer com o apóstolo: 'pois para mim o viver é Cristo e o morrer é lucro. Mas, se o viver na carne me dá a ocasião de trabalho frutífero, não sei bem o que escolher. Sinto-me num dilema: o meu desejo é partir e ir estar com Cristo, pois isso me é muito melhor, mas o permanecer na carne é mais necessário por vossa causa.' Isto escreveu o apóstolo Paulo para os Filipenses, quando confinado a uma prisão em Roma. ${ }^{212}$

Tanto esta carta 28 quanto a 27 possuem referências diretas ao reconhecimento da aprendizagem por parte do educador e essa aprendizagem está relacionada ao conhecimento da verdade. Na carta 27 , a captação da benevolência relaciona o desejo de aprender a lei de Deus ao conhecimento "perfeito" da verdade:

Meus bem-amados, fiquei sabendo do zelo e do progresso de vocês na palavra de Deus, o que agradeço a Ele com alegria. Rezo para que nosso pai lhes dê a perfeita compreensão, de modo que, reconhecendo os artifícios e fraudes do Anticristo e de seus mensageiros, vocês não se permitam o desvio da Sua verdade.

Próximo ao final da carta, na petição, Hus reconhece nos destinatários a aprendizagem da verdade e pede orações para que ele possa continuar a escrever e a pregar a verdade. Em outras palavras, pede para que ele possa continuar a educar por meio da escrita de cartas:

Escrevo-lhes esta carta, meus queridos irmãos e amadas irmãs, para que vocês se mantenham firmes na verdade que aprenderam. Não temam as intimações e não venham menos do que antes para ouvirem a Palavra de Deus por causa das ameaças cruéis que eles fazem. Pois 'o Senhor é fiel, e há de fortalecer-vos e guardar-vos do mal. ${ }^{213}$

Por último, suplico-lhes, meus bem-amados, que rezem por aqueles que proclamam a verdade de Deus em sua graça. Rezem, também, por mim, para que eu possa escrever e pregar ainda mais contra as maldades do Anticristo e, quando for necessário, que Deus me coloque na frente de batalha para defender sua verdade.

Igualmente, no início da carta 28 , o tema do aprendizado da verdade volta a aparecer na frase "Meus bem-amados, suplico-lhes, com toda a força de meu coração, que não abandonem a verdade que aprenderam e cujo conhecimento lhes foi generosamente concedido pelo misericordioso Salvador."

O conhecimento da verdade e a importância da escrita das cartas para a continuidade de seu aprendizado já apareceu no final da carta 27. Mas eles estão associados a outra

\footnotetext{
${ }^{212}$ Filipenses 1:6 apud ibidem, p. 85, nota 2.

${ }^{213}$ II Tessalonicences 3:3 apud ibidem, p. 83, nota 26.
} 
importante característica da defesa da verdade nas cartas hussitas, o que funciona como um forte exemplo de conduta moral: morrer pela verdade seguindo o exemplo do Cristo:

Tenham certeza que eu não hesito entregar minha pobre vida pela verdade de Deus perante o perigo ou a morte, pois nada falta para nós em Sua palavra e, dia após dia, a verdade evangélica se espalha mais. No entanto, eu desejo viver por aqueles que sofrem a violência e precisam da pregação da Palavra de Deus, para que a maldade do Anticristo possa ser exposta e os devotos escapem dela. É por isso que eu estou pregando em outros lugares e exercendo o ministério para todos, sabendo que assim a vontade de Deus se realiza em mim, mesmo que eu morra ou caia doente pelas mãos do Anticristo. Se eu for para Praga, os meus inimigos, que não servem a Deus e impedem os outros de servi-lo, com certeza, prepararão armadilhas para mim e perseguirão a vocês. Contudo, rezemos à Deus para que, se houver entre eles alguns dos escolhidos, que estes voltem-se para o conhecimento da verdade.

Que Deus lhes dê a compreensão e a perseverança naquilo que eu lhes escrevi e que Ele realize seus desejos em todo o bem, pelos méritos de Jesus Cristo, que sofreu por nós a morte mais vergonhosa e cruel. Ele nos deixou seu exemplo para que nós soframos igualmente de acordo com Sua vontade. Amém.

Em outros trechos da argumentação, a comparação com o Cristo já havia aparecido. No primeiro, o argumento é "se eles perseguiram o Cristo, imaginem o que fazem conosco". Percebemos um diálogo entre a história evangélica e o que viviam Hus e seus contemporâneos, como um efeito retórico de retomar a captação da benevolência:

Ele, o criador, o rei e o senhor de todo o mundo, sem que fosse necessário à sua divindade, fez-se humilde na humanidade. Isento de pecados, ministrou fielmente a nós pecadores mesmo suportando fome, sede, frio, calor, cansaço, falta de sono, trabalho duro na pregação. Sofreu grandes insultos nas mãos dos bispos, sacerdotes e escribas que o chamaram de 'glutão e beberrão', um louco possuído pelo demônio, um sedutor e blasfemo, afirmando 'este homem não vem de Deus'. Declararam-no culpado de heresia, excomungaram-no, conduziram-no para fora da cidade e o crucificaram como um homem maldito.

Se os sacerdotes fizeram isso com aquele que curou todas as doenças por suas palavras, que sem dinheiro e sem preço, expulsou os demônios, ressuscitou os mortos, ensinou a lei de Deus em nada lhes prejudicando e que não pecou, a não ser pelo fato de ter exposto as maldades dos que o perseguiram, por que vocês estranham que os mensageiros do Anticristo de hoje, que são mais avarentos, mais tendentes à fornicação, mais cruéis e astutos do que os Fariseus, perseguem Seus servos com calúnias, excomunhões, prisões e mortes? 
E, como era de se esperar, Jesus é comparado com a Verdade neste outro trecho:

Os altos sacerdotes, os sacerdotes, os escribas, os fariseus, Herodes, Pilatos e os cidadãos de Jerusalém condenaram a verdade, crucificaram-na e a puseram no túmulo. Mas ela ressurgiu e conquistou a todos eles. E, no lugar de um único pregador, enviou doze e mais outros.

Hus traz a figura dos doze apóstolos do Cristo para, em seguida, relacioná-los aos “defensores da Verdade” em Praga. E, para se referir a estes últimos, chama-os por nomes de aves:

Essa mesma verdade deu a Praga, no lugar de um fraco e medroso ganso, muitas águias e falcões ${ }^{214}$, que possuem olhos aguçados, voam grandes alturas pela graça de Deus e habilmente capturam todos os outros pássaros para o rei, senhor Jesus, que lhes dará a força e a todos os seus fiéis. Pois ele disse: 'E eis que eu estou convosco todos os dias, até a consumação dos séculos!'

Por que essa metáfora das aves? Se olharmos para alguns parágrafos antes, talvez tenhamos novas informações para ampliarmos nossa compreensão. Ao condenar os ataques que ele e a Capela de Belém estão sofrendo, a saber, excomunhão, interdito e destruição, Hus utiliza pela primeira vez essa metáfora:

Primeiro, eles atacaram todas as capelas e locais de adoração para evitar que a Palavra de Deus fosse pregada nesses lugares, mas o Cristo não permitiu tal crime. Agora, eu soube que eles decidiram destruir a Capela de Belém e proibiram a pregação nas igrejas onde sua iniquidade é denunciada. Mas eu confio em Deus que eles não obterão sucesso. Eles já espalharam suas armadilhas, com intimações e excomunhões, contra o Ganso e já pegaram muitos outros. Mas, mesmo sendo o ganso um pássaro preguiçoso, doméstico e que não voa alto, suas redes já começaram a rasgar. Portanto, muitos outros pássaros que voam mais alto até Deus, com suas palavras e com suas vidas, irão, agora, despedaçá-las. Eles lançaram suas ameaças e suas excomunhões como a imagem de uma ave de caça e atiraram uma flecha da aljava do Anticristo quando impediram os serviços divinos e a adoração. No entanto, quanto mais eles tentam esconder sua maldade, mais eles a revelam. Quanto mais eles desejam ser livres, mais trabalho eles têm. Quanto mais eles se esforçam por espalhar suas tradições como redes, mais elas se rompem. E, na busca pela paz no mundo, eles a perderam junto com a paz espiritual. Querendo prejudicar aos outros, eles se machucam ainda mais.

${ }^{214}$ Spinka, The letters of John Hus, p. 83, nota 23 afirma que as águias e falcões referem-se a Jakoubek de Střibro, Nicholas e Petř de Dresdren e outros reformistas. 
Este trecho é mais preciso ao dizer que o ganso foi excomungado. Jan Hus é o ganso, como seu próprio nome diz: Husa em tcheco significa ganso. E a utilização de seu nome como metáfora foi um recurso diversas vezes utilizado por ele, embora nas cartas pastorais encontremos apenas uma ocorrência. Um exemplo da repercussão desse recurso à época encontraremos numa carta (número 48a) de Jan Cardinalis de Rejnstejn, vigário de Janovice, apoiador de Hus e de seus amigos tidos como reformadores, escrita dois anos depois (em 1414) a amigos na Boêmia. Ele envia notícias sobre o Concílio e a prisão de Hus. Embora não tenha Hus por destinatário, ela foi incluída nas edições de Bonnechose e Workman e Pope, provavelmente por ser de alguém que estava ao lado de Hus e deu importantes notícias suas de Constança. O trecho final, com uma referência ao ganso, é bastante significativo da importância dessa metáfora:

Escrito em Constança no sábado antes do dia de São Martin. O Ganso ainda não foi cozido e não tem medo de sê-lo, porque neste ano a noite de São Martin cai num sábado, dia em que não se come gansos. ${ }^{215}$

Na carta 57 (janeiro de 1415), escrita a seu amigo Jan de Chlum, Hus termina dizendo "lembre-se do Ganso". Em outra, de número 63 (março de 1415), afirma que a única preocupação que o ganso tem com relação à ausência de resposta escrita de Chlum é a de que ele esteja fisicamente bem. Por fim, na mesma época da carta 63, escreve em outra, número 65, "se você ama o pobre ganso, faça com que o rei me dê guardas de sua corte ou me liberte da prisão nesta noite".

Essa utilização de animais como metáforas para o aprendizado moral era comum naquela época. Os bestiários, livros que apresentavam animais e suas “características morais", consistiam numa leitura de sucesso. ${ }^{216}$ Para termos uma ideia do sentido dessa utilização de animais na Idade Média, observemos este trecho escrito pelo monge beneditino Pedro Damiano (século XI) em sua obra De naturis animalium:

Assim como Deus criou todas as coisas terrestres para o uso dos homens, Ele teve igualmente o cuidado de moldar sadiamente o homem, com auxílio das mesmas forças naturais e dos mesmos impulsos incontroláveis que introduziu nos animais inferiores, para que o homem pudesse aprender com os próprios animais o que deve imitar, o que deve evitar, o que pode saudavelmente emprestar deles e o que deve corretamente desdenhar.

\footnotetext{
${ }^{215}$ Tradicionalmente na República Tcheca e países vizinhos, na noite de São Martin (ou São Martinho), 11 de novembro, come-se ganso.

${ }^{216}$ LE GOFF; SCHMITT, Dicionário temático do ocidente medieval, p. 264. O mesmo para a citação de Pedro Damiano no parágrafo seguinte.
} 
Hus estava inserido numa tradição que considerava as atitudes dos animais como exemplares do que se devia ou não fazer. Seguindo essa tradição, o clérigo utilizou de um recurso educativo comum da época para transmitir sua mensagem nas cartas.

Finalmente, encontramos nessa mesma carta de cerca de novembro de 1412, escrita do exílio, uma referência à Capela de Belém. Belém é central, por se constituir no espaço do encontro passado entre Hus e seus discípulos no encontro presente entre suas cartas e seus ouvintes. O trecho no qual ocorre essa referência nós já citamos acima, quando observamos a metáfora do Ganso. A carta 28 possui a capela como tema preponderante. Na argumentação desta, Hus medita a respeito do sofrimento que ele e os fiéis estão passando por causa da perseguição. Percebemos que aqui ele faz referência à cidade de Belém, onde se atribui o nascimento de Jesus, ressaltando, assim, duplamente a importância do local:

Da mesma maneira, digo-lhes, meus bem-amados, embora eu não esteja preso, preferia morrer com Cristo e estar com ele. No entanto, eu anseio trabalhar com vocês pela sua salvação. 'O que escolher, não sei', espero pela misericórdia de Deus. De fato, temo que muitos males sejam cometidos contra vocês, que os fiéis sofram e os maus, por isso, percam suas almas. Estes se alegram enquanto exigem não apenas que a Palavra de Deus seja silenciada em mim, mas também que o lugar dessa palavra, Belém, seja fechada com barras de madeira. Permitirá o Deus onipotente que eles levem a cabo sua intenção? Porém, se Ele permitir que os criminosos causem sofrimento com seus atos, tal qual fizeram em Belém, onde ele nasceu, e em Jerusalém, onde ele nos redimiu, vamos, ainda assim, louvá-lo em sua graça, fazendo-nos humildes perante seu poder. Esse poder, que está com aqueles que o amam, liberta os que sofrem em seu nome e reserva o fogo eterno para aqueles que o insultam.

As cartas 25, 26, 27 e 28 foram escritas no final de 1412. Cronologicamente, elas representam os primeiros exemplos em nossa documentação do trabalho pastoral hussita por meio de cartas após seu exílio e contêm os elementos que nos permitem afirmar o caráter educativo das cartas pastorais de Hus, que, em síntese, são os seguintes:

- uso do vernáculo;

- uso da autoridade teológica das citações;

- referência às epístolas de Paulo de Tarso;

- reconhecimento da aprendizagem por parte do educador;

- conhecimento e defesa da verdade;

- aconselhamento e vivência de uma conduta moral cristã;

- uso de metáforas de animais para propor uma interpretação de conduta moral; 
- uso da metáfora do Ganso, a partir de seu nome;

- referência à Capela de Belém como um local do ensino da verdade.

Hus, em virtude de seu exílio, mobilizou seus saberes para trazer para as cartas a tarefa pastoral que realizava presencialmente na Capela de Belém. Uniu a retórica da escrita de cartas, sua interpretação do contexto político e cultural, seus conhecimentos teológicos e sua prática de pregador para escrever cartas que apresentam os elementos acima citados. As regras que impregnaram seus estudos na Universidade aparecem, agora, impregnando seus escritos do exílio.

\subsection{Cartas de pregação em exílio}

Retomando a questão da indissociabilidade entre vida pessoal e vida profissional, podemos dizer, inspirados em Nóvoa, que esse padrão de escrita das cartas pastorais hussitas é uma construção da vida de Hus. Escrever para pregar foi uma das opções que sua vida pessoal impôs para que ele continuasse sua atividade de clérigo designado para uma capela. E sua história de vida norteará essa continuação.

O exílio de Hus torna-se cada vez mais sem volta. Sua posição em relação às autoridades da Igreja coloca-o em crescente situação de conflito com elas. Ele precisa escrever para pregar e defender seus princípios. As cartas pastorais são, agora, parte de sua tarefa e o acompanham até as vésperas de sua morte.

Por não ter comparecido ao chamado da Cúria, Hus foi excomungado por desobediência. Até este momento, ele não havia sido acusado de cometer uma heresia. Se ele não aparecesse, Praga sofreria interdito. O papa enviou a sentença de excomunhão maior, que foi tornada pública em 18 de outubro de 1412. A publicização dessa sentença é acompanhada por um ritual que consiste, de acordo com Spinka ${ }^{217}$, em "tocar os sinos, acender e apagar velas, elevar a cruz e jogar pedras em direção à casa do excomungado."

Hus escreve para o povo da Boêmia, entre outubro e novembro de 1412, uma carta (número 29) comentando sua excomunhão. Exorta-lhes para que se mantenham firmes e, no comentário sobre as "pedras na porta", apresenta sua visão contrária à força dos rituais:

Suplico-lhes que não se entreguem ao cansaço porque eu não estou com vocês ou por causa de minha excomunhão, se eles a cumprirem. Confio, de verdade, na clemência do Salvador que irá cooperar em tudo para meu e para o seu bem. Temos apenas que tomar cuidado com os pecados e nos preocuparmos com aqueles que se opõe a Deus e a Sua palavra, achando que

\footnotetext{
${ }^{217}$ SPINKA, John Hus: a biography, pp. 161-2.
} 
estão agindo certo, como os Judeus fizeram quando crucificaram Jesus e apedrejaram Santo Estevão. Deles, o Cristo e Santo Estevão disseram que eles não sabiam o que estavam fazendo. Machucar-me-ia se eles, com blasfêmia, carregassem a cruz como antigamente, lamentassem sobre Judas, jogassem pedras contra a porta, causando-lhes a fadiga? Que Deus não permita que eles se excomunguem a si próprios!

Segue com um confronto entre a prática dos rituais para provocar medo e o conhecimento para diferenciar o que é de Deus e o que é invenção dos homens:

Eles pensaram nessas práticas de um jeito que aterrorizasse os simples e permitisse que estes fossem conduzidos de acordo com a vontade deles. Mas o senhor todo poderoso dará a seus fiéis o conhecimento necessário para compreender isso, de modo que eles possam entender que tudo isso é uma mera invenção da cabeça deles e não um mandamento do Senhor.

E, mais para frente, mostra a diferença entre uma excomunhão no sentido bíblico e o ritual que muitos seguem sem saber por quê:

Eles pegam pedras sem saber o porquê, mas jogam-nas, como está escrito em seus pergaminhos, em memória da eterna danação de Datã e Abiram, que forçaram sua entrada no sacerdócio, mesmo não sendo dignos. Com esse ato de atirar pedras eles indicam quais sacerdotes que adentraram ao sacerdócio por meio de riquezas, bem-estar e honrarias. Eles lamentam os filhos de Judas porque eles são inseguros. Todos os simoníacos são os filhos de Judas, excomungados por Deus que os observa: neles próprios cairão as excomunhões que impuserem aos outros.

Nesta interpretação da excomunhão, Hus destacou a importância do conhecimento em relação aos rituais e se posiciona claramente contrário à obediência das regras inventadas preferindo a obediência à lei de Deus. Conclui a carta com sua costumeira referência à obediência a Deus e não à Igreja. Também apresenta uma interpretação um tanto milenarista da realidade, típica daquele período ${ }^{218}$, mostrando que muitos estão no caminho errado:

Visto que uma multidão de homens está excomungada por Deus, fujamos, meus bem-amados, de Sua excomunhão e imploremos por Sua graça. Que seja de Sua vontade manter-nos em sua bênção. Qualquer outra excomunhão não pode nos fazer nenhum mal. O mais eminente dos bispos irá, sem

\footnotetext{
${ }^{218}$ TUCHMAN, op. cit., p. 25, afirma que o século XIV, tanto por causa das mudanças climáticas quanto pelos atos humanos estava "sob o signo do sofrimento". Ela menciona como exemplo desses atos humanos, à página 26, que "a excomunhão e o anátema, as medidas mais extremas a que a Igreja podia recorrer, supostamente reservadas para a heresia e os crimes horríveis (...) eram agora usadas para arrancar dinheiro de pagadores recalcitrantes. Num certo caso, foi negada a um bispo a sepultura cristã até que seus herdeiros concordassem em responsabilizar-se pelas suas dívidas, para escândalo da diocese, que viu seu bispo permanecer insepulto e sem esperança de salvação. $\mathrm{O}$ abuso de poder com essas finalidades provocou a indiferença pela excomunhão e diminuiu o respeito pelos líderes religiosos."
} 
dúvida, nos oferecer Sua bênção, dizendo: 'Vinde, benditos de meu Pai, recebei por herança o Reino preparado para vós desde a fundação do mundo.'

O que Hus fez foi uma apologia por um futuro melhor em oposição a uma leitura pessimista da realidade, que podemos resumir neste trecho de Huizinga:

Mau governo, extorsões, cobiça e violência dos grandes, guerras, assaltos, escassez, miséria e peste - a isto se reduz, quase, a história da época aos olhos do povo. O sentimento geral de insegurança causado pelas guerras, pela ameaça das campanhas dos malfeitores, pela falta de confiança na justiça, era ainda por cima agravado pela obsessão da proximidade do fim do mundo, pelo medo do Inferno, das bruxas e dos demônios. O pano de fundo de todos os modos de vida parecia negro. Por toda a parte as chamas do ódio se alteiam e a injustiça reina. Satã cobre com as suas asas sombrias a Terra triste. Em vão a Igreja militante combate e os pregadores fazem sermões; o mundo permanece inconvertido. ${ }^{219}$

Mesmo que porventura sua pregação fosse "em vão" e Hus partilhasse dessa interpretação pessimista, ele aproveitava as oportunidades para ajudar seus destinatários a retirar algo de bom dos eventos ruins que lhe afligiam. Numa carta escrita em data próxima ao natal de 1412 (número 32), ele apresenta uma reflexão sobre a data comemorativa do nascimento de Jesus e justifica, com citações do Novo Testamento, sua saída de Praga para evitar maiores sofrimentos. Inicia com a captação da benevolência seguida de uma argumentação que apresenta exatamente essa justificativa:

Meus caros bem-amados. Está próximo o dia no qual comemoramos o nascimento do Senhor. Portanto, limpem dos pecados sua casa interior, o máximo que puderem. Ouçam à Palavra de Deus com zelo e alegria. Não se importem com os detratores que proíbem a vocês de assistirem à pregação em Belém. Antes, eles tentaram dissuadi-los a meu respeito. Agora, eles não precisam mais fazê-lo, mas afirmam que eu sou um fugitivo. Fi-lo com alegria, para confirmar a palavra e o exemplo do Cristo. Escrevi "palavra" porque ele disse: 'E se algum lugar não vos receber nem vos quiser ouvir, ao partirdes de lá, sacudi o pó de debaixo dos vossos pés em testemunho contra eles.' E mais à frente, disse, 'Quando vos perseguirem numa cidade, fugi para a outra. E se vos perseguirem nesta, tornai a fugir para a terceira.' Quando eles o expulsaram de seu meio e quiseram matá-lo, Jesus fugiu diversas vezes. Especialmente, como João escreve no capítulo 10, quando 'procuraram novamente prendê-lo, ele lhes escapou das mãos. Ele partiu de novo para o outro lado do Jordão, para o lugar onde João tinha anteriormente batizado, e aí permaneceu.' Mais além, no capítulo 13, João escreve que quando eles resolveram matá-lo, 'Jesus, por isso, não andava em público,

${ }^{219}$ HUIZINGA, O declínio da Idade Média, p. 30. 
entre os Judeus, mas retirou-se para a região próxima do deserto, para a cidade chamada Efraim, e aí permaneceu com os seus discípulos. Os judeus, então, procuraram por Ele e falaram entre si, estando no Templo: 'Que pensais? Que ele não virá à festa?' Os chefes dos sacerdotes e os fariseus tinham ordenado que quem soubesse onde Jesus estava, o indicassem, para que o prendessem.' Assim escreveu João.

Não é surpreendente, portanto, que eu tenha seguido seu exemplo e fugido e que os sacerdotes e os outros como eles estejam por aí perguntando e falando a respeito de meu paradeiro.

Além da citação dos evangelhos e da utilização do Cristo como exemplo da moral cristã, Hus também retoma a defesa da verdade nesta carta, ao afirmar "No entanto, quanto a fugir da verdade, confio que o Senhor me dará a oportunidade para morrer por ela." E ironiza com sua ausência os erros dos outros clérigos, retomando em seguida a confirmação da necessidade de sua ausência:

Talvez eles gostassem de me ver de volta na cidade de Praga, para que aqueles que se sentem provocados pela santa pregação contra a avareza, a devassidão e o orgulho pudessem parar as horas, as missas e outros serviços. Mas vocês, que são zelosos pela Palavra de Deus e agem em sua conformidade, adorariam, em seu amor e para seu bem, ter-me por seu vizinho. Eu também gostaria de vê-los e de pregar-lhes a palavra de Deus.

$\mathrm{O}$ ano de 1413 foi muito importante na vida de Hus. Nos primeiros meses ele volta algumas vezes para Praga e se esconde na Capela de Belém. Seu exílio principal foi o castelo de Kozí, a sudeste de Praga. De lá, escreve textos sobre a Igreja em resposta a um sínodo de membros do clero convocado em janeiro pelo rei Venceslau para "extirpar a heresia da Boêmia". O sínodo falhou em conseguir um consenso e uma comissão de doutores em teologia da Universidade de Praga trabalhou nesse sentido, mas também não obteve sucesso na conciliação. Há poucas cartas hussitas nesse período. As principais são suas respostas às propostas do sínodo e da comissão de doutores. Em maio desse ano, completou seu tratado $D e$ Ecclesia (Sobre a Igreja), que mencionamos no trecho inicial deste capítulo.

Em julho de 1413, Hus escreve uma carta pastoral, de número 37. Spinka considera que ela foi escrita provavelmente antes de sua nova saída de Praga. Se sua suposição estiver correta, Hus a escreveu de seu esconderijo na Capela de Belém. Nesta carta, ele destaca seu esforço para que as pessoas aprendessem a "Palavra de Deus" e diz claramente que lhes "ensinou". O fato que as pessoas aprenderam traz-lhe grande conforto. Esse aprendizado, ele reconhece por meio da "penitência verdadeira e sincera" que ele "observou". Ensinar, 
reconhecer o aprendizado por meio de sua observação e se alegrar com o aprendizado dos educandos: eis a temática da captação da benevolência nesta carta:

Bem-amados, desejo fervorosamente e de todo o meu coração que vocês estejam livres de todos os pecados por Jesus Cristo e que, não dando importância às vaidades deste mundo, possam vencer a carne, o mundo e o demônio. Que vocês, pela graça de Jesus Cristo, possam sofrer a tudo com boa-vontade e perseverar perante as aflições até o fim por sua salvação. É este o conteúdo de minhas preces por vocês, meus bem-amados. Foi para isso que eu trabalhei entre vocês por mais de doze anos na Palavra de Deus, tendo Ele por minha testemunha. Experimentei grande consolação neste trabalho quando soube de sua diligência em ouvir a Palavra de Deus e quando observei a verdadeira e sincera penitência de muitos de vocês.

Por isso, meus bem-amados, suplico-lhes, pela paixão do Cristo, que guardem e agarrem firmemente Seu evangelho, cresçam e floresçam em tudo o que eu lhes ensinei.

Mais à frente, deixa como pedido que eles estudem para manter a fé verdadeira e a esperança, apresentando citações do Novo Testamento para explicar o momento que estão vivendo. Esta carta possui vinte citações, sendo metade do evangelho de Mateus, destacando, por meio da citação de trechos da vida de Jesus, o exemplo moral do Cristo. Eis o trecho no qual fala do estudo e explica como seus ouvintes poderiam, a partir da observação dos vícios dos clérigos de sua época, reconhecer os falsos profetas:

Portanto, caros bem-amados, estudem para terem a fé verdadeira e a esperança segura. Mantenham-se firmes no amor pela Palavra de Deus e se apeguem a ela com a máxima vontade, ouvindo àqueles que o Senhor enviou para pregar Seu evangelho sem medo, resistindo, com perseverança, aos lobos ferozes e aos falsos profetas. Destes, o Cristo disse a seus fiéis: 'E surgirão falsos profetas em grande número e enganarão a muitos. ${ }^{220}$ Ele ordena aos fiéis tomarem cuidado com eles e os ensina como os falsos profetas podem ser reconhecidos: por seus frutos, que são o orgulho, a fornicação, a avareza, a simonia, desprezo pela Palavra de Deus, perseguição dos fiéis, difamação, ambição, zelo pelas tradições humanas etc.

E, no trecho seguinte, reúne diversas metáforas evangélicas com animais:

Estes homens possuem "disfarces de ovelha". Eles assumem o nome e o ofício de Cristão, mas, já que eles são "lobos ferozes por dentro", eles dilaceram e despedaçam as ovelhas do Cristo. A respeito desses lobos, Ele disse a Seus discípulos: "Eis que eu vos envio como ovelhas entre lobos. Por isso, sede prudentes como as serpentes e sem malícia como as pombas." Ele

\footnotetext{
${ }^{220}$ Mateus 24:11, apud SPINKA, The letters of John Hus, p. 107, nota 10.
} 
disse "sede prudentes" para que eles não se deixassem ser pisados e, por conseqüência, destruírem dentro deles a cabeça de Cristo. E disse, "sem malícia como as pombas", para que eles suportassem pacientemente a crueldade dos lobos. ${ }^{221}$

Mais próximo ao final, cita da segunda epístola de Paulo de Tarso a Timóteo, um trecho no qual afirma que surgirão mestres que desviarão as pessoas da verdade para fábulas, para confirmar o momento no qual estão vivendo:

'Pois virá um tempo em que alguns não suportarão a sã doutrina; pelo contrário, segundo os seus próprios desejos, como que sentindo comichão nos ouvidos, se rodearão de mestres. Desviarão os seus ouvidos da verdade, orientando-os para as fábulas.' Esta profecia de São Paulo, como vocês podem ver com seus próprios olhos, já está se realizando.

No final de 1413 e no início de 1414, Hus escreve quatro cartas semelhantes, no que diz respeito ao seu conteúdo e à sua estrutura, às anteriores que aqui citamos. Spinka ${ }^{222}$ considera que as duas primeiras, números 38 e 39, podem ter sido escritas de Kozí e afirma que Novotný sugere que o autor as escreveu em tcheco, dadas algumas incorreções na versão latina. É possível que outra pessoa as tenha traduzido para o latim. A terceira, número 40 foi com certeza escrita em tcheco a partir de Kozí enquanto a quarta, número 41, também em tcheco, pode ter sido escrita de Kracovec. Para esta cidade localizada ao sul de Praga ele foi convidado por Henry Lefl de Lažany, chefe do conselho real do rei Venceslau, visto que Hus precisou fugir de Kozí, onde não estava seguro, e se escondeu em algum lugar próximo a Sezimovo Ústí.

Como um sermão de preparação ao Advento de 1413, Hus escreveu a carta 38. O Advento é um "período de quatro semanas, iniciado a partir do primeiro dos quatro domingos que antecedem o Natal, destinado à preparação espiritual e à purificação diante da expectativa quanto à vinda do Salvador." 223 Foi escrita, portanto, próximo ao final de novembro daquele ano. Hus parte do advento do Cristo para destacar sua condição de juiz supremo no final dos tempos. Na conclusão associa o entendimento ao fortalecimento dos corações na fé perante o sofrimento:

Então, caros bem-amados, considerando estes dois lados - a dignidade de seu primeiro Advento e a justiça e o terror de seu segundo Advento fortaleçam seus corações na graça e no sofrimento. Se vocês sofrerem de

\footnotetext{
${ }^{221}$ Os trechos evangélicos citados neste trecho, apud ibidem, p. 107, são Mateus 7:15 e 10:16.

222 ibidem, pp. 109-112.

${ }^{223}$ HOUAISS, Dicionário eletrônico Houaiss.
} 
algum modo, considerem estas palavras: 'erguei-vos e levantai suas cabeças', isto é, seu entendimento, 'pois está próxima a sua libertação', libertação de toda desgraça, de onde o justo Juiz chamar-lhes-á, dizendo: 'Vinde, benditos de meu Pai, recebei por herança o Reino'.

No natal do mesmo ano, Hus escreveu nova carta (número 39). Seu texto possui uma escrita um tanto diferente das outras cartas, visto que nesta utiliza frases que iniciam por "alegrem-se" (gaudete, em latim) e concluem com "glória a Deus nas alturas e paz na terra aos homens de boa vontade". No início da carta ele diz que embora distante, o amor que sente por eles impele-o a escrever, conforme citamos algumas páginas atrás.

$\mathrm{Na}$ Quaresma de 1414, escreveu a carta de número 40, destinada a "todos os eleitos e zelosos pelo Senhor Jesus Cristo e por Sua Palavra que moram em Praga". Hus diz estar alegre "em saber que vocês ouvem constantemente a Palavra de Deus e que o Salvador misericordioso oferece-lhes bons líderes na verdade”. A Quaresma é o período de quarenta dias anterior à Páscoa. Por isso, Hus reflete a respeito da crucificação de Jesus e dá destaque ao desejo pela paz. O destaque para a prudência de comportamento e o silêncio é novidade nesta carta e um indício que entendemos como uma preocupação da parte do clérigo com relação aos ataques que ele está sofrendo e que seus amigos podem vir a sofrer:

A Seu modo, caros bem-amados, desejo-lhes Sua paz. Desejo-lhes Sua paz, para que, vivendo virtuosamente, vocês possam superar seus inimigos, o demônio, o mundo e a carne. Desejo-lhes Sua paz, para que vocês amem-se uns aos outros, inclusive seus inimigos. Desejo-lhes a paz para que vocês ouçam Sua palavra pacificamente. Desejo-lhes a paz, para que vocês falem com prudência e se protejam perante seus inimigos. Desejo-lhes a paz, para que vocês saibam conservar o silêncio em seu favor. Pois aquele que humildemente ouve não discute com malícia. Aquele que fala prudentemente supera o contencioso. Aquele que conserva o silêncio em seu favor não fere sua consciência com facilidade. (grifos nossos)

A carta 41 foi escrita no final do verão de 1414 (ao redor do mês de agosto). Definindo qual é o "caminho de Deus", Hus pede-lhes para seguirem esse caminho por meio da audiência à pregação, sua compreensão e conhecimento de si mesmo para conhecer a Deus e amá-lo. Conclui pedindo-lhes a correta penitência e a prática do bem. No trecho que selecionamos, ele define e propõe seguir o caminho de Deus. Observemos a menção aos astros (sol, lua e outros astros), que pouco é feita nas cartas hussitas:

'Fique nos caminhos, perguntando com dedicação qual deles afasta da morte eterna e leva para a vida eterna, afasta de toda a miséria e leva para a alegria eterna. Esse caminho é o evangelho de Deus Todo Poderoso, as epístolas apostólicas, o Antigo Testamento, bem como a vida dos santos que 
encontramos na lei de Deus. Eles brilham com suas vidas como o sol, a lua e outros astros. Portanto, meus caros irmãos e irmãs no senhor Deus, peço-lhes pelo martírio do Filho de Deus, que vocês estejam presentes à pregação, ouvindo-a com atenção e, ao ouvi-la, compreendendo-a e, ao compreendê-la, conservando-a e, ao conservá-la, aprendendo a conhecer a si mesmos e, ao aprender a conhecer a si mesmos, conhecer corretamente seu querido salvador (para saber que Deus é a suprema justiça). Ao conhecê-lo, amá-lo de todo seu coração e de toda sua vontade, e seu próximo como a si mesmo. E amando-o, alegrar-se com ele sem fim.

As cartas escritas entre o final do ano de 1412 e meados de 1414 (números 29, 32, 37 , 38, 39, 40 e 41) dão continuidade ao padrão de escrita das cartas pastorais hussitas, buscando substituir o sermão presencial na Capela de Belém. Esse padrão começa a sofrer pequenas modificações na medida em que mudam as condições de sua escrita. O exílio de Hus toma um novo rumo e sua escrita o acompanha.

\subsection{Narrativas da viagem}

Em Krakovec, Hus preparou-se para viajar para Constança, onde logo começaria um Concílio. O Concílio de Constança foi convocado pelo rei Sigismundo da Hungria, irmão mais novo de Venceslau, que havia sido eleito imperador poucos anos antes, 1411, e, com essa convocação obteria maior prestígio. De fato, ficou sendo conhecido como o rei que ajudou a acabar com o cisma papal. ${ }^{224}$ Venceslau, que foi imperador até o ano de 1400, continuou como rei da Boêmia até sua morte, em 1419.

Segundo Spinka, Sigismundo escolheu a cidade de Constança, ao norte dos Alpes e próxima à fronteira da Suíça, para evitar que houvesse um comparecimento de um número muito grande de partidários italianos de João XXIII. Dessa forma, o papa eleito no Concílio de Pisa, que viria a ser acusado de diversos crimes, não teria como ter o benefício da maioria dos presentes no Concílio de Constança. Ele poderia, portanto, mais facilmente ser deposto.

O édito de convocação afirmava que o rei "faria tudo o que estivesse em seu poder para garantir a segurança e a liberdade a toda e qualquer pessoa que estivesse no Concílio"225. O rei Venceslau exortou Hus a comparecer voluntariamente ao concílio que foi aberto para, entre outras coisas, eliminar as heresias. Sigismundo enviou dois cavaleiros tchecos para acompanhar o clérigo boêmio até Constança, prometendo um salvo-conduto para a viagem e para que sua integridade fosse preservada a despeito da decisão do concílio. Os cavaleiros eram Venceslau de Dubá e Jan de Chlum. Hus escreveu um sermão, De pace [Sobre a Paz], e

\footnotetext{
${ }^{224}$ SPINKA, John Hus: a biography, p. 219. O mesmo para o parágrafo seguinte.

${ }^{225}$ ibidem, p. 220 e seguintes para as informações referentes à viagem.
} 
uma breve exposição, De sufficientia legis Christi [Sobre a suficiência da lei do Cristo], que apresentaria no concílio, pois tinha a certeza que teria uma audiência pública garantida.

Em 26 de agosto de 1414, Hus anuncia publicamente sua decisão de aceitar o convite real e ir à Constança, como vemos em duas cartas (42 e 43) para "todo o reino da Boêmia" e para "a Graça real [Venceslau] e a rainha, seus conselheiros, mestre da corte real e toda a corte real". Em ambas defende a verdade e acusa seus opositores caso algo dê errado. Em 1 de setembro, escreve ao rei Sigismundo (carta 44) confirmando a viagem e agradecendo por seu apoio.

Em 11 de outubro de 1414, Hus iniciou sua viagem a Constança, passando por diversas cidades alemãs. Antes de sair, enviou uma carta, número 45, para seu discípulo Martin de Volyně que havia ficado em Praga. Acompanhavam Hus os cavaleiros, Petr de Mladoňovice, bacharel em artes, trazido como secretário pelo cavaleiro de Chlum, Jan Cardinal de Rejnštejn, amigo de Hus e representante da Universidade, Oldřich de Znojmo, outro bacharel em artes, e alguns servos. Eles viajaram em diversas carroças e Hus ia em seu próprio cavalo.

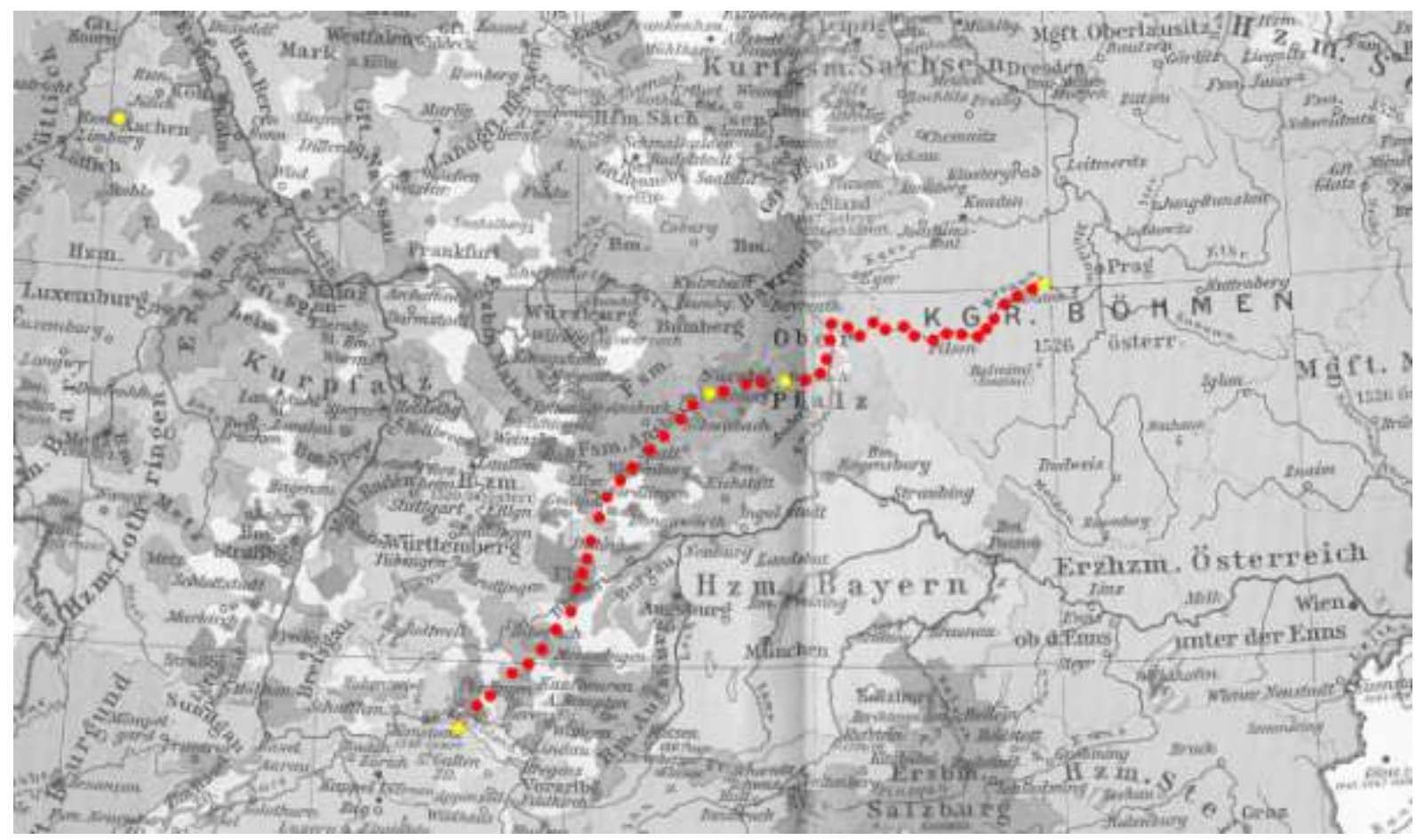

\section{Figura 6. Percurso aproximado da viagem de Hus à Constança}

(Fonte: Adaptado de F. W. PUTZGER, Historischer weltatlas, pp.66-67)

Em Nuremberg, Venceslau de Dubá deixou a comitiva para acompanhar a coroação de Sigismundo como Rei dos Romanos, em Aachen (ver mapa na figura $6^{226}$ ). Ele traria, então, o

\footnotetext{
${ }^{226}$ O percurso saindo da cidade de Krakovec e chegando até Bärnau (cidades não presentes no mapa) foi provavelmente realizado beirando o rio Berounka (Mies, em alemão). O ponto inicial em amarelo é uma
} 
salvo-conduto. $\mathrm{O}$ restante da comitiva seguiu para Constança, para não aumentar demais o caminho e os gastos da viagem indo ao encontro de Sigismundo.

Alguns dias após o início da viagem, em 19 de outubro, Hus escreve nova carta pastoral em tcheco (número 46). Nesta, bem como na que escreveu no dia seguinte, então em Nuremberg, faz um relato da viagem e uma análise dos motivos para ir à Constança. Logo no início da argumentação, apresenta-se como um fraco pastor que tentou ensinar a verdade, afirma ter trabalhado por um bom tempo entre seus fiéis e diz possuir registros que apontam os ataques que sofreu como mentirosos:

Vocês sabem que por muito tempo eu trabalhei fielmente entre vocês, pregando-lhes a Palavra de Deus, sem heresias ou erros, como vocês estão cientes, e que sua salvação foi, é agora e continuará a ser o meu desejo até a morte. Quis pregar-lhes antes de minha jornada, antes de minha partida para o Concílio de Constança e, em especial, informá-los a respeito dos falsos depoimentos e dos nomes das testemunhas que falaram contra mim. Eu tenho todos os seus nomes e os registros de seus depoimentos e os anunciarei a vocês para que, caso eles me difamem ou me condenem à morte, vocês, sabendo de tudo, não temam, como se eu tivesse sido condenado por alguma heresia por mim cometida. Também o farei para que vocês permaneçam sem medo e sem hesitação na verdade que o Senhor Deus lhes deu a saber por intermédio de fiéis pregadores e por mim, um fraco. E, terceiro, o farei para que vocês aprendam se proteger dos pregadores enganadores e hipócritas.

Deste trecho, Workman e Pope ${ }^{227}$ fazem dois importantes destaques. Sobre a menção aos nomes das testemunhas, apontam que o conhecimento por um prisioneiro da Inquisição 228 dos nomes das testemunhas era uma vantagem pouco comum. Com relação à frase que termina com as palavras "como se eu tivesse sido condenado por alguma heresia por mim cometida", afirmam que ela foi utilizada contra ele no Concílio, embora traduzida erroneamente como se ele afirmasse ter cometido heresias.

$\mathrm{Na}$ mesma carta, Hus menciona mais de uma vez a possibilidade de sua morte. Escreve aqui sobre a morte como algo tão simples que, mesmo que ele morra, todos se encontrarão na "alegria celeste". A frase final do trecho, ao iniciar com a expressão "além do mais", mostra esse caráter de simplicidade:

localização aproximada de Krakovec. O segundo ponto amarelo corresponde à cidade de Sulzbach e o terceiro à de Nuremberg. O caminho de Nuremberg até Constança (ponto amarelo do final da viagem) é uma aproximação, pois não temos informações a respeito. A cidade de Biberach, na qual Jan de Chlum ficou famoso por seus discursos, está no caminho, pouco acima de Constança. No topo do mapa, à esquerda, está marcada a cidade de Aachen, na qual Sigismundo foi coroado.

${ }^{227}$ WORKMAN; POPE. op. cit., p. 147.

${ }^{228}$ Lembremos, apenas, que Hus não foi levado ao tribunal da Inquisição, mas foi julgado pelos membros do Concílio de Constança. 
Talvez vocês não me vejam em Praga antes que eu morra. Se, no entanto, Deus Todo Poderoso quiser me trazer de volta a vocês, nós nos encontraremos mais alegremente. Além do mais, nos encontraremos, é claro, na alegria celeste. ${ }^{229}$

Já em Nuremberg, Hus conta um pouco mais de sua viagem numa carta (número 48), escrita em 20 de outubro de 1414. Cita as diversas cidades por onde passou e as pessoas com quem encontrou. $\mathrm{O}$ tom narrativo diferencia esta carta das outras pastorais, apontando para a adequação de seu padrão de escrita ao contexto da viagem. Inicia dizendo que não viajou disfarçado e que foi bem recebido em todos os lugares:

Saibam que eu nunca viajei encapuzado, mas sem disfarces e com o rosto descoberto. Quando eu deixei a Boêmia, antes mesmo de chegar à primeira cidade, Bärnau, o pastor local com seus vigários esperavam por mim. Quando eu entrei na sala, ele imediatamente serviu-me uma grande taça de vinho, recebeu, com seus companheiros, todos os meus ensinamentos de forma muito gentil e declarou que sempre foi meu amigo. Mais tarde, em Neustadt, todos os alemães ficaram muito felizes em me ver. Nós passamos por Weiden, onde uma grande multidão de pessoas me observava com admiração. E quando eu cheguei a Sulzbach, nós entramos numa hospedaria na qual uma corte, landgericht, se reunia. Lá eu disse aos conselheiros e aos anciãos sentados ao salão de jantar: "Olhem! Eu sou o Mestre Jan Hus, de quem, suponho, vocês ouviram muitas maldades. Questionem-me, à vontade." E conversando a respeito de muitas coisas, eles receberam tudo com boa vontade. Nós, então, passamos pela cidade de Hirsweld, onde eles também me receberam com grande gentileza. Então, nós passamos pela cidade de Hersbruck e passamos a noite na cidade de Lauff. Lá, o pastor, um grande jurista, chegou com seus vigários, e com eles conversei. Ele também recebeu tudo com grande boa vontade.

Na cidade de onde escreveu a carta, Hus também participou de um debate e conclui com alguma surpresa:

Saibam que até agora eu não encontrei nenhum inimigo. Em cada hospedaria, eu dava ao hospedeiro como um presente de despedida, os Dez Mandamentos ${ }^{230}$, e em alguns lugares eu os aplicava com pasta de farinha. ${ }^{231}$

\footnotetext{
${ }^{229}$ LAUAND, Luiz Jean. Et Pilo sua Umbra... Inscrições em Relógios de Sol. Disponível em <http://www.hottopos.com/mirand5/et_pilo_sua_umbra.htm>. Acesso em 28 ago. 2010, lembra que há "fontes 'menores', que na verdade podem ser decisivas para a captação do 'outro', que se manifesta - por vezes de modo único e especial - em formas aparentemente irrelevantes como as inscrições em pára-choques de caminhão no Brasil ou - em seu equivalente medieval e antigo - as inscrições em relógios de sol." A leitura deste trecho lembrou-nos, justamente, de uma frase de pára-choques de caminhão que guarda semelhante simplicidade em relação à morte: "Com Deus eu vou, com Deus eu volto e se não voltar estarei com Ele."

${ }^{230}$ WORKMAN;POPE, op. cit., p. 154, acreditam que Hus refere-se a seu tratado sobre os Dez Mandamentos, embora sua data de publicação que consta no Monumenta seja de algumas semanas depois.
} 
Todas as esposas dos hospedeiros e seus maridos receberam-me em todos os lugares com grande gentileza. Eles não impuseram o interdito em qualquer lugar. Todos elogiam minha nota escrita em alemão. Eu afirmo, portanto, que não há aqui maior inimigo do que entre os habitantes do reino da Boêmia. (grifo nosso)

Hus surpreende-se provavelmente porque supunha haver uma visão negativa a seu respeito entre os alemães, especialmente após a saída deles da Universidade de Praga. Percebemos ao longo da correspondência que os principais acusadores de Hus foram seus compatriotas e o quanto ele se lamenta por isso. Continuando a leitura da carta, encontramos Hus levantando uma dúvida inédita em sua correspondência “o que mais escrever?”, outro indício de uma mudança no padrão de escrita em virtude da viagem:

O que mais eu devo escrever? Tanto o senhor Venceslau [de Dubá] e o senhor Jan [Chlum] tratam-me com grande gentileza e finura. Eles são como se fossem arautos da verdade, ou melhor, para dizer mais verdadeiramente, defensores da verdade. Com eles, pela ajuda do Senhor, tudo corre bem.

Podemos observar nesta carta um Hus preocupado em nunca parar de pregar, não importa onde estivesse, e defender constantemente a verdade. Considera a ajuda dos cavaleiros como parte dessa defesa.

A comitiva de Hus chegou à cidade de Constança em 3 de novembro. Dois dias mais tarde, Venceslau de Dubá trouxe o salvo-conduto que garantia, apenas, livre passagem e não a audiência e o livre retorno. Segundo Spinka, Hus e seus companheiros de viagem trataram o documento como se ele contivesse tudo o que fora acordado, ou seja, entenderam que Hus teria seu retorno garantido. No dia seguinte, Jan de Chlum e seu tio Henry de Lacembok avisaram o Papa João XXIII, que chegara a Constança em 28 de outubro, que Hus lá estava. O papa garantiu que Hus permaneceria intocado "mesmo que ele tivesse matado meu próprio irmão". ${ }^{232}$

A carta 50, escrita a 4 de novembro de 1414, é um relato dessa chegada. Seguindo a intervenção em seu padrão de escrita causada pela viagem, Hus faz uma narrativa interpretativa das condições e expectativas referentes à sua vinda para Constança. Inicia com uma breve saudação e conta de sua chegada:

\footnotetext{
${ }^{231}$ No original: et allicubi applico in farina. WORKMAN; POPE, op. cit, p. 154, afirmam ser esta uma referência a um ditado italiano que significa "ter uma mente disponível". SPINKA, The letters of John Hus, p. 126, afirma que esse trecho é traduzido de formas diferentes por outros tradutores e considera sua tradução "I post them with flourpaste" (divulgava-os com pasta de farinha) mais razoável. Aproximamo-nos desta última.

${ }^{232}$ SPINKA, John Hus: a biography, p. 232, a partir de PALACKÝ, Documenta, n. 246 (Relatio de Mladoňovic).
} 
Salvação de Jesus Cristo! Nós chegamos a Constança no sábado após a Festa de Todos os Santos, sem qualquer contratempo. Ao passarmos pelas cidades, publicávamos notícias tanto em Latim quanto em Alemão. Residimos em Constança numa rua perto da residência do papa, tendo chegado aqui sem o salvo-conduto.

Segue com uma menção a Michal de Causis, clérigo de Praga que estava, naquele momento, como procurador papal e o encontro dos nobres de Chlum com o papa:

No dia seguinte, Michal de Causis publicou na igreja os procedimentos contra mim e posicionou acima deles um grande sobrescrito para os efeitos que estes procedimentos eram contra o excomungado e teimoso Jan Hus, suspeito de heresia e muitas outras coisas além. Não obstante, com a ajuda de Deus, eu não presto atenção e isso, sabendo que Deus o enviou para dizer coisas maldosas contra mim por causa de meus pecados, como um julgamento se eu sei e se estou disposto a sofrer um pouco em Seu nome. O senhor Lacembok e o senhor John Kepka foram recebidos pelo papa e falaram com ele a meu respeito. Ele disse que não desejava fazer nada pela violência.

Apresenta, então, algumas notas de eventos que estavam por acontecer, como a vinda do papa Bento XIII, o que não ocorreu. Hus prevê a chegada de Sigismundo para próximo do Natal e a conclusão do Concílio na Páscoa do ano seguinte. De fato, Sigismundo chegou em 24 de dezembro, mas o Concílio de Constança terminou quatro anos depois, em 1418:

Há rumores, embora vagos, que o papa espanhol, Benedito, está a caminho do Concílio. Hoje nós recebemos notícias que o duque de Burgundy com o duque de Brabant deixou o campo e que o rei Sigismundo deveria chegar em, no máximo, três dias em Aachen e ser coroado e que o papa e o Concílio deveriam esperar por ele. Como Aachen é setenta milhas distante de Constança, eu suponho que o rei provavelmente não chegará para o Natal. Do mesmo modo, suponho eu, o Concílio, se não for dissolvido, terminará por volta da Páscoa.

Segue com sua preocupação perante as necessidades materiais e financeiras do grupo e o custo da viagem. Essa preocupação aparece outras vezes nas cartas escritas de Constança. O preço dos cavalos em Constança era cerca de um terço o preço na Boêmia ${ }^{233}$ :

A comida é muito cara: uma cama custa meio florim por semana. Os cavalos são baratos: um custando seis sexagenae na Boêmia é comprado aqui por sete florins. Nós enviamos os cavalos com o Senhor John para a cidade quatro milhas distante, chamada Ravensburg. Eu acho que logo terei

${ }^{233}$ apud SPINKA, The letters of John Hus, p. 130, nota 14. 
necessidades. No que diz respeito a elas, peça ajuda aos amigos cujos nomes seria muito demorado citar e oneroso para lembrar de memória.

Hus, então, demonstra a esperança de uma audiência e conta quais pessoas já chegaram por lá, com destaque para os cardeais. Esse destaque se dá por uma expressão em tcheco associada a eles. O fato de a carta ser escrita em latim e de possuir este trecho em tcheco é um indício que podemos estranhar, nos termos de Ginzburg. Por que colocar um trecho em tcheco numa carta em latim? Entendemos que isso talvez signifique que seu autor quis deixar uma fala nas entrelinhas, ou seja, dizer algo que apenas os mais próximos entendam. Tal qual uma piscadela quando falamos com alguém. Hus afirma que os cardeais andam em mulas e acrescenta "ale gsú laczni", que entendemos como, no tcheco atual, "ale jsou lačný". Isso pode significar tanto que "as mulas estão famintas" quanto que "os cardeais são gananciosos". Com base no que discutimos acima, a última interpretação parece-nos mais adequada. Workman e Pope ${ }^{234}$ entendem como "as mulas estão famintas" e apontam que Hus utilizou o tcheco para exprimir seus sentimentos a respeito disso. Spinka ${ }^{235}$ entende que os cardeais são gananciosos e aponta que a expressão latina traduzida à margem da tcheca, "sed valde ieiuni", pode significar ambos:

O senhor Lacembok está se dirigindo ao rei. Ele me recomendou não tentar nenhuma ação antes da chegada do rei. Eu espero ter uma audiência pública para minha resposta.

Há muitos parisianos e italianos por aqui, mas até o momento poucos arcebispos e até mesmo bispos. Os cardeais são numerosos, eles cavalgam mulas, mas são gananciosos. (grifo nosso)

Conclui retomando a questão das necessidades materiais, cumprimenta a todos e termina com a "constância na verdade":

Muitos de nossos tchecos gastaram todo o dinheiro que eles tinham no caminho e já estão necessitados dele. É uma grande pena, mas não dá para se ajudar a todos. O cavalo do senhor Pribyslav foi levado pelo senhor Lacembok, mas meu cavalo Rabštýn ainda os vence todos em força e espírito elevado. É o único que eu tenho comigo se eu tiver a oportunidade de sair da cidade, em algum momento, [para encontrar com] o rei.

Cumprimentem a todos os nossos amigos, não fazendo exceção de ninguém etc. Esta é a quarta carta escrita de locais estrangeiros, enviada no domingo à noite depois da Festa de Todos os Santos, em Constança.

\footnotetext{
${ }^{234}$ WORKMAN; POPE, op. cit., p. 159.

${ }^{235}$ SPINKA, The letters of John Hus, p. 130.
} 
Nenhum dos cavaleiros boêmios está em Constança, a não ser o senhor Jan Kepka, que me trouxe e me protegeu como um cavaleiro real. Ele prega por todo lugar, mais do que eu, declarando minha inocência.

Dada em Constança. Rezem a Deus pela constância na verdade.

Em 6 de novembro, Hus escreve nova carta (número 51) semelhante à anterior. Menciona o salvo-conduto que não chegou, a perseguição de Michal de Causis e de Venceslau Thiem de Mikulov, decano da cidade Passau, que vendia indulgências em Praga em 1412. Cita, então, uma importante fala do papa que afirma que Hus é perseguido pelos tchecos, retomando a impressão da carta 48. Afirma que o rei Sigismundo ficou feliz em saber de sua viagem à Constança, embora saibamos hoje que o motivo dessa alegria era outro, visto que Sigismundo foi um importante articulador da prisão e condenação de Hus:

O papa não quer anular os procedimentos e disse ' $\mathrm{O}$ que posso fazer? No final das contas, seus próprios compatriotas é que o estão fazendo!' Dois bispos e um doutor disseram ao senhor Jan Kepka que eu deveria chegar a um acordo ficando quieto. Assim sendo, eu sei que eles estão com medo de minha resposta e pregação públicas, o que eu espero que, pela graça de Deus, estejam seguros quando o rei Sigismundo chegar. O Senhor Venceslau de Leštno disse-me a seu respeito [de Sigismundo], que ele estava muito feliz quando ele, o senhor Venceslau, disse-lhe que eu estava me dirigindo diretamente para Constança, sem o salvo-conduto.

Em seguida, narra o fato de um bispo, que foi cânone de Praga, ter espalhado o boato que Hus "lia a mente das pessoas", mas quando elas se aproximavam, ficavam felizes por ouvir sua pregação sobre a verdade:

Eu tive um arauto no caminho, o bispo de Lebus, que sempre nos precedeu com um noturno ${ }^{236}$ e espalhou o rumor que eles estavam trazendo-me acorrentado numa carroça e que o povo deveria tomar cuidado porque eu era um leitor de mentes! Consequentemente, assim que nos aproximávamos das cidades, multidões corriam para me conhecer, como se fosse um espetáculo. Mas o inimigo estava destruído por sua própria mentira, pois o povo se alegrava quando ouvia de mim a verdade. Com certeza, 'Cristo Jesus está comigo como um forte guerreiro'. Portanto, não tenho medo do que o inimigo possa fazer.

Conclui a carta apontando que precisará de recursos materiais e de orações. No dia 16 de novembro, dia da abertura do Concílio, Hus escreve uma carta em tcheco, número 52, num padrão de escrita muito semelhante às suas primeiras cartas pastorais. Finda a viagem e as

\footnotetext{
${ }^{236}$ Noturno é o tempo que leva um clérigo para recitar três salmos e três passagens das escrituras. SPINKA, The letters of John Hus, p. 132.
} 
narrativas a seu respeito, Hus volta a se preocupar prioritariamente com a pregação por meio de cartas, voltando ao padrão de escrita de suas cartas do exílio. É o que percebemos desde a saudação da carta: "Para todos os fiéis e amados no Senhor Deus, irmãos e irmãs, que amam a verdade do Senhor Jesus Cristo." Na passagem da captação da benevolência para a argumentação, apresenta os modos pelos quais os "mensageiros do Anticristo" atuam e, citando o evangelho de Mateus, pede-lhes para tomarem cuidado com os falsos profetas:

Eu rezo para que vocês, vivendo em conformidade com a lei de Deus, sejam diligentes com sua salvação, ouvindo a Palavra de Deus com circunspecção para não sejam enganados pelos mensageiros do Anticristo. Eles iluminam os pecados dos homens, não os punem, bajulam seus superiores, não previnem as pessoas com relação aos pecados, enaltecem-se ao ostentarem suas ações aumentando seu poder. Mas eles não desejam seguir o senhor Jesus Cristo na humildade, pobreza, paciência e trabalho. Deles, o gracioso Salvador profetizou, ao dizer 'Surgirão falsos profetas que irão desviar muitos do caminho'. E, prevenido os fiéis, Ele disse 'Cuidado com os falsos profetas que vem a vós vestidos com roupas de ovelhas, mas internamente são lobos devoradores. Por seus frutos vocês os reconhecerão.

Pede-lhes, então, que "disciplinem seus corpos, não temam a morte, amem uns aos outros e permaneçam firmes em Deus na lembrança, razão e vontade". Lembra do Dia do Julgamento, pedindo-lhes firmeza na verdade. Pede também que ele mesmo possa permanecer firme na verdade de Deus. Cita que nenhum serviço foi interrompido por sua presença nas cidades, como impunha o interdito, e mesmo o papa rezou a missa de abertura do Concílio, em 5 de novembro, sabendo de sua presença por lá $^{237}$ :

Ele [Deus] já me trouxe à Constança sem qualquer obstáculo. Em todo o caminho, vindo abertamente como um clérigo e me anunciando em voz alta ao público, não encontrei nenhum inimigo em nenhuma cidade. Nem encontrarei em Constança, se o clero tcheco, que circula pedindo benefícios, na avareza, não desviou as pessoas.

Mas eu espero que o misericordioso Salvador, a querida Mãe de Deus e todos os santos e todo o sagrado reino, bem como em suas preces, que eu me mantenha firme na verdade de Deus até a morte. Vocês devem saber que em nenhum lugar os serviços foram interrompidos por minha causa, nem mesmo em Constança, onde o próprio papa realizou um serviço enquanto eu estava lá.

Esta foi a última carta que Hus escreveu em liberdade. No entanto, seu exílio já era o prenúncio de seu cativeiro. Desde a abertura do Concílio, os dois professores tchecos, Stěpán

${ }^{237}$ V. ibidem, p. 134 , nota 5. 
Páleč e Michal de Causis, que antes apoiavam os reformadores, mas que deles se separaram durante a querela com a bula da venda de indulgências, trabalharam na seleção de artigos do tratado De Ecclesia de Hus para fazerem diversas acusações contra ele. Distribuíram as acusações entre os presentes no concílio e pediram a sua prisão. Em 28 de novembro, o emissário enviado para Sigismundo solicitando a permissão para a prisão voltou com a resposta afirmativa.

Nesse mesmo dia, uma delegação chegou à casa onde Hus estava hospedado, convidando-o para uma entrevista com os cardeais. Ele e Jan de Chlum foram. Ao chegarem, os cardeais acusaram-no de erros e heresias que ele havia ensinado na Boêmia. Ele negou as acusações. À noite, disseram ao cavaleiro para ir embora e a Hus para ficar. Jan de Chlum, numa demonstração de raiva, acusou o papa de romper com a promessa de manter Hus intacto. Este, contudo, foi preso. O papa exigiu que os cardeais jurassem que ele nunca ordenara a prisão e que ela havia ocorrido por insistência deles. Eles o fizeram. Meses depois, João XXIII admitiu que a ordem de prisão partiu dele. Em 6 de dezembro de 1414, Hus foi encarcerado no mosteiro dominicano de Constança. ${ }^{238}$

\subsection{Escrita da prisão}

Moraes $^{239}$ afirma que "para um prisioneiro, talvez mais do que para qualquer outro homem, as cartas se rendem forçosamente ao seu sentido primeiro: o de abolir distâncias." Mignot $^{240}$ aponta que em documentos como cartas de/para prisioneiros "as dificuldades ficam potencializadas (...) na medida em que o remetente tem clareza de que a correspondência tem como leitor, além do destinatário, o censor." Essas duas afirmações são claramente percebidas, por exemplo, na correspondência de Vaclav Havel ${ }^{241}$, escritor e dramaturgo tcheco do século XX, que se tornou o primeiro presidente da República Tcheca (1993). Quando esteve preso, durante parte da ocupação comunista na Tchecoslováquia, escreveu cartas para sua esposa, Olga. Sendo sua correspondência censurada, Havel utilizou diversos subterfúgios para que suas cartas fossem liberadas, como o comentário de seus estados de humor ou a escrita de reflexões sobre o teatro, dado que não poderia descrever sua situação na

\footnotetext{
${ }^{238}$ SPINKA, John Hus: a biography, p. 234.

${ }^{239}$ MORAES, Elaine Robert. A cifra e o corpo: as cartas de prisão do marquês de Sade. In: GALVÃO; GOTLIB, Prezado senhor, prezada senhora, p. 55.

${ }^{240}$ MIGNOT, Artesãos da palavra, p. 134.

${ }^{241}$ HAVEL, Václav. Cartas a Olga. São Paulo: Estação Liberdade, 1992.
} 
prisão e nem tecer quaisquer comentários políticos. ${ }^{242}$ Essas três leituras trouxeram-nos como questão o impacto da prisão na correspondência hussita. Houve mudanças em sua prática de escrita? Suas cartas foram censuradas? Como suas cartas chegavam a seus destinatários? O que aconteceu no período no qual nada pôde escrever? Ele produziu alguma escrita cifrada?

Nossas respostas são positivas, mostrando que houve repercussão de sua prisão no seu padrão de escrita, como houve nas cartas de viagem. A primeira grande repercussão é o impacto desse evento na temática de suas cartas. Desse momento em diante, Hus escreve algo próximo a 50 cartas, boa parte delas a Jan de Chlum, seu secretário Petr de Mladoňovice ou, mais genericamente, a seus amigos em Constança. Entendemos que quando Hus escreve para "seus amigos em Constança", ele está, de fato, escrevendo para esse nobre e seu secretário, visto que há uma continuidade dos assuntos tratados nas cartas com o destinatário genérico "amigos" e naquelas escritas explicitamente para apenas um deles.

É a Chlum a primeira carta escrita da prisão, número 53, em algum dia entre 25 de dezembro e 3 de janeiro. Ele se prepara para escrever cartas e respostas às suas acusações, como sugere suas primeiras palavras: "Adquira-me uma Bíblia e a envie por este bom homem. Se seu escriba, Petr, tiver um pouco de tinta, peça-lhe que me mande um pouco, bem como várias canetas e um pequeno tinteiro." Conclui com a frase: "Escrito por minhas próprias mãos, o que seu escriba Petr sabe bem". O adendo "o que seu escriba Petr sabe bem" abre espaço para várias interpretações. Numa delas, entendemos que Hus pode estar preocupado com falsificações e, portanto, Petr seria alguém que poderia confirmar sua caligrafia. Noutra, Hus talvez esteja afirmando que ele não precisa de um secretário para escrever suas cartas, como o nobre precisa.

A frase anterior assemelha-se às conclusões de diversas cartas hussitas. Esperávamos, portanto, que a carta encerrasse nela. Hus, porém, em seu primeiro escrito da prisão, adiciona outra frase: "Mementote aucae vos amici mei" [Lembrem-se do ganso vocês, meus amigos] Spinka $^{243}$ afirma que o fato do clérigo ter escrito seu nome em latim é um provável recurso criptográfico para esconder o real significado daqueles que não sabem o significado tcheco de seu nome. Para as pessoas que não soubessem que husa em tcheco significa "ganso", uma frase como "lembrem-se do ganso" não faz sentido algum. Este é um exemplo de escrita cifrada logo na primeira carta escrita da prisão.

\footnotetext{
${ }^{242}$ ibidem, p. 406 apresenta um relato de seu colega de prisão Jiří Dienstbier, que detalha os mecanismos que Havel utilizou para fugir à censura, como a escrita de cartas contendo seus "quinze tipos de humor", dado que não poderia escrever sobre qualquer outro assunto que não fosse sobre ele mesmo.

${ }^{243}$ SPINKA, The letters of John Hus, p. 135, nota 6.
} 
Hus ficou preso no mosteiro dominicano até março de 1415. Dessa prisão, escreveu apenas uma carta que não fosse para Jan de Chlum ou Petr de Mladoňovice, a de número 58, datada de 19 de janeiro de 1415, a primeira carta pastoral após sua prisão. Escrita em tcheco, ele a inicia pedindo por preces para que permaneça firme na verdade até a morte, com a presença de Deus. Afirma que ficou doente e se curou. Considera a morte como iminente, embora ainda passariam quase seis meses até ser queimado. Os temas da prisão e da morte passam a marcar sua correspondência:

Peço-lhes, aqui da prisão, da qual não me envergonho, pois sofro na esperança do amor de Deus, que peçam ao Senhor Deus por mim, para que Ele me mantenha com ele. Ele me visitou misericordiosamente com uma doença grave e, em seguida, me curou. Ele permitiu [o ataque de] meus inimigos muito determinados, homens para quem fiz muito de bom e a quem amei sinceramente. Nele apenas eu tenho a esperança e em suas preces que Ele possa me manter firme em Sua graça até a morte. Se Ele quiser me levar para junto de si agora, que sua santa vontade seja feita, mas se ele quer me levar de volta, igualmente, que seja feita sua santa vontade. Com certeza, eu preciso de grande ajuda.

Em outro trecho, afirma que uma de suas cartas, que ele não indica, mas é provavelmente a de número 46 , foi falsificada na tradução para o latim e que está trabalhando muito para responder às acusações de seus inimigos. Diz que a única pessoa que pode lhe dar qualquer conselho neste momento é Jesus, citando o evangelho de Lucas. Com relação à falsificação, já mencionamos quando apresentamos a carta 46, que o trecho no qual Hus escreveu "como se eu tivesse sido condenado por alguma heresia por mim cometida" foi utilizada para dizer que ele afirmou ter cometido heresias:

Saibam que a carta que eu deixei para vocês foi, na sua tradução para o latim, amplamente falsificada por meus inimigos. Eles estão produzindo tantos artigos e acusações contra mim que eu tenho tido muito trabalho de escrita para fazer, frequentemente respondendo da prisão. Não há homem que possa me aconselhar a não ser o senhor Jesus misericordioso, que disse a seus fiéis 'Eu lhes darei eloquência e sabedoria as quais todos os seus adversários serão incapazes de resistir’.

Conclui procurando estabelecer uma relação de vínculo afetivo com seus destinatários, destacando seu trabalho pastoral mesmo quando preso:

Oh, meus bem amados! Lembrem-se do quão arduamente eu trabalhei por vocês e sempre desejei sua salvação, mesmo agora enquanto estou na prisão e sofro grandes tentações. 
Em março de 1415, o papa João XXIII foge de Constança, em busca de escapar de sua condenação. Todas as atenções do Concílio se dirigiram para a questão dos três papas ${ }^{244}$ e a comissão que cuidava do caso de Hus foi dissolvida. Com a fuga do papa, diversos guardas do mosteiro dominicano também se retiraram e Hus foi transferido para os cuidados do bispo de Constança, que o prendeu numa torre em seu castelo, em Gotlieben, às margens do rio Reno, no dia 24 de março.

Como a comissão julgadora do caso de Hus perdeu sua jurisdição, nova comissão foi formada em 6 de abril pelo Cardeal D'Ailly, Jean Gerson e o Cardeal Zabarella. Os três o consideravam herege. Durante os meses de abril e maio, essa comissão avaliou o caso de Hus e o acusou de ser heresiarca. Diversos membros da nobreza tcheca intercederam com o rei Sigismundo para tentar ajudá-lo a ter uma audiência.

Hus obteve a possibilidade de uma audiência pública a ser realizada no mosteiro franciscano próximo à igreja de Santo Estéfano. Em 3 de junho foi transferido de Gotlieben para a prisão desse mosteiro. ${ }^{245}$ A primeira audiência ocorreu em 5 de junho. A respeito desta, Hus escreveu no mesmo dia para seus amigos em Constança (carta 68). Ele inicia afirmando "Deus todo poderoso deu-me hoje um coração firme e corajoso." Apresenta explicações sobre quais textos deveriam ou não ser apresentados e como ele espera que os eventos se sigam. Conclui esperando melhores oportunidades em sua próxima audiência, marcada para 7 de junho, no refeitório do mosteiro, o mesmo local onde ocorrera a primeira. Na carta seguinte (número 69), escrita no mesmo dia da segunda audiência, afirma que supunha encontrar mais cortesia e disciplina no Concílio. Também diz que estava com dor de dente e que vomitara sangue, teve dor de cabeça e cálculo.

Em 8 de junho ocorreu seu julgamento. A comissão julgadora apresentou 39 artigos contra Hus e o impeliram a abjurá-los. O clérigo da Boêmia recusou-se a fazê-lo e pediu nova audiência para poder defender-se explicando os erros dos artigos. Seu pedido foi negado e o levaram de volta à prisão. No dia seguinte, escreveu outra carta (número 70) a seus amigos em Constança. Nela, demonstra perceber que não voltará mais à Boêmia:

\footnotetext{
${ }^{244}$ João XXIII foi deposto em 29 de maio e permaneceu por dois dias preso no mesmo castelo onde estava Hus. Gregório XII renunciou em 4 de julho, sob a condição de ser considerado o papa legítimo. Bento XIII perdeu o apoio da Espanha e de Portugal e se refugiou numa região espanhola. Foi deposto pelo Concílio de Constança em 26 de julho de 1417, embora continuasse aclamando ser o papa verdadeiro. Por ter poucos aliados, foi desconsiderado. O novo papa foi eleito, pelo Concílio, em 11 de novembro de 1417.

${ }^{245}$ Hus estava inacessível em Gotlieben. SCHAFF, op. cit., p. 195, afirma que nenhuma carta foi escrita por Hus enquanto estava preso no castelo. SPINKA, The letters of John Hus, p. 159, levanta a possibilidade da carta de número 67, escrita em tcheco para Henry Škopek de Dubá ter sido escrita de lá.
} 
Agora eu me lembro das palavras do Mestre Jerônimo, que disse 'se eu for ao Concílio, suponho que não voltarei'. Um bom alfaiate, Andrew, o Polonês, que me disse quando se despedia de mim 'Deus esteja com você. Parece-me que você não vai voltar'.

No dia seguinte, escreveu para Henry Škopek de Dubá e, no dia 10, para Chlum e para o povo da Boêmia. Esta carta (número 73) foi redigida na expectativa de uma sentença de morte a ser dada no dia seguinte e, nela, Hus inclui, do nosso ponto de vista, uma síntese de sua concepção de ensinar. A saudação da carta é a seguinte:

Mestre Jan Hus, na esperança de ser um servo de Deus, para todos os tchecos fiéis que amam ao senhor Deus e o amarão, envia seu desejo que o Senhor lhes ofereça habitar e morrer em sua graça e viver para sempre na alegria do paraíso. Amém. Fiéis e queridos em Deus, nobres e damas, tanto ricos quanto pobres.

Hus dirige-se à sua ampla rede de relações, que inclui todos aqueles que são "fiéis em Deus" sendo eles da nobreza ou não. Coloca-se no lugar daquele que ensinou a verdade por meio de suas pregações e de seus escritos:

Peço e suplico que vocês obedeçam ao senhor Deus, exaltem sua palavra e a ouçam e sigam alegremente. Peço para que vocês acreditem na verdade de Deus que eu retirei da lei de Deus e as preguei e escrevi a partir dos ensinamentos dos santos. Peço-lhes, também, que caso alguém tenha ouvido em minhas pregações ou particularmente qualquer coisa contrária à verdade de Deus, ou se eu o escrevi em algum lugar - o que eu confio em Deus não há nada - que ele não o siga.

Além de colocar-se no lugar de mestre, Hus pede para que um ajude o outro e cada um faça aquilo que lhe compete, dando destaque aos estudantes, exortando-os para que sigam seus mestres e estudem com diligência. Igualmente, dirige-se aos mestres, suplicando para que eles

vivendo merecidamente, ensinem seus pupilos fielmente, primeiramente a amarem a Deus e a estudarem pelo propósito de Seu louvor e pelo benefício da comunidade, bem como pelo propósito de sua salvação - mas não pelo propósito da avareza ou da prosperidade no mundo.

Sua concepção de ensino está diretamente relacionada à salvação. Tanto o mestre quanto o pupilo devem ensinar/estudar "pelo louvor a Deus" e "para sua salvação e a dos outros”. Depois de fazer seus pedidos a pessoas que fazem parte de sua rede de relações, Hus agradece aos nobres que o ajudaram durante o concílio, como "defensores e sustentadores divinos da verdade". Ressalta que seus principais acusadores eram os tchecos e não os 
alemães, mas que "todo o concílio gritou contra ele". Pede pela graça de Deus ao rei Venceslau, sua rainha e seus nobres. Reza por seu "trabalhador amado e companheiro" Jerônimo de Praga, pois nada sabe a seu respeito. ${ }^{246}$ Conclui dirigindo-se a todos os praguenses, em defesa da Capela de Belém e pedindo que todos aprendam a verdade:

Eu também suplico, em especial a vocês, praguenses, a serem gentis com a Belém visto que o senhor Deus ficará feliz se a Palavra de Deus foi pregada lá. Pois o demônio começou a ficar enfurecido naquele lugar e incitou pastores e cânones contra ele, percebendo que seu reino foi lá arruinado. Confio no senhor Deus que Ele preservará aquele lugar conforme Sua vontade e aumentará seus benefícios em outros, mais do que ele fez por mim, este servo inútil. Suplico-lhes também que amem uns aos outros e não permitam que os bons sejam oprimidos pela violência e desejo que cada um de vocês aprenda a verdade.

Hus recebeu a formulação final de sua sentença em 18 de junho. Escreveu sua resposta por escrito, tendo utilizado dois dias para elaborar seus argumentos contrários. Nesse período entre 18 de junho, quando recebeu a versão final de suas acusações, até 6 de julho, quando ocorreu seu julgamento, condenação e morte, encontramos vinte e cinco cartas escritas por Hus. Diante da morte cada vez mais iminente, o clérigo concentra-se na sua defesa e na sua despedida. Esta é uma mudança importante no padrão da escrita das cartas hussitas causada pela prisão. Cinco dessas cartas, semelhantes entre si, são pastorais.

Em 24 de junho de 1415, Hus escreve para o povo da Boêmia em tcheco uma carta (número 87) na qual retoma o tema da verdade e da perseverança nela até a morte. Utilizando diversas citações bíblicas e referências a São Gregório e São João Crisóstomo, Hus exorta o povo a não temer a ordem do concílio de queimarem os livros que ele escreveu. Afirma que antes do Dia do Julgamento haverá grandes tribulações e, portanto, não devem desistir de ler o que ele escreveu. Além disso, as ordens do Concílio vão demorar muito para chegar até eles e muitos homens do Concílio morrerão antes de lhes retirarem os livros, como vemos neste trecho que selecionamos:

Lembrando disso [que os dias de tribulações acabarão], caros bem amados, permaneçam firmes. Pois eu tenho esperança em Deus que a escola do Anticristo terá medo de vocês e lhes deixará em paz. O Concílio não virá de Constança para a Boêmia. Pois eu acho que muitos daquele Concílio morrerão ao redor do mundo antes de arrancarem os livros de suas mãos. Eles se espalharão do Concílio pelo mundo como cegonhas e, quando o inverno chegar, eles perceberão que cometeram um crime durante o verão.

${ }^{246}$ Jerônimo estava preso na época e foi queimado em 30 de maio de 1416. 
E, em seguida, lança uma provocação à ideia do papa ser o cabeça da Igreja, que Hus combateu em seu livro De Ecclesia e em outros escritos. Apresenta, aqui, sua principal crítica ao comportamento do clero, retomando o que já escrevera nas suas primeiras cartas. Referindo-se à condenação de João XXIII, escreve:

Atentem para o fato que eles condenaram sua cabeça como um herege. Respondam agora, seus pregadores, que pregam que o papa é o deus terreno, que ele não pode pecar e não pode cometer simonia. Os juristas dizem que o papa é a cabeça de toda a santa Igreja, que ele governa muito bem, que ele é o coração da santa Igreja, que ele nutre espiritualmente, que ele é a fonte de onde brota todo o poder e bondade, que ele é o sol da santa Igreja, que ele é o refúgio infalível onde todo cristão deve se abrigar.

Bem, essa cabeça já foi cortada, o deus deste mundo está amarrado e seus pecados já são públicos. A fonte já secou, o sol escureceu, o coração está rasgado e o refúgio fugiu de Constança e é repudiado de tal modo que ninguém procurará abrigo lá. O Concílio o condenou como herege porque ele vendeu indulgências, bispados e outros benefícios e muitos dos que o condenaram os compraram dele e traficaram nele. (...) Esses homens condenaram e anatematizaram o vendedor enquanto eles mesmos permaneceram compradores e intermediários e continuam a vender em seus lares. (...)

Oh, se o senhor Jesus tivesse dito ao Concílio 'aquele que dentre vocês estiver sem o pecado da simonia, condene o papa João' parece-me que eles correriam para fora um depois do outro. Por que, então, eles ajoelharam perante ele, beijaram seus pés e o chamaram de santíssimo Pai, quando eles sabiam que ele era um herege, um assassino e um sodomita, pecados que eles mesmos trouxeram a público mais tarde?

Segue com outras perguntas semelhantes a esta última e discorre sobre a abominação e vergonha que foram estes atos. E, perante estes, Hus gostaria de descrevê-los para que os fiéis de Deus tomem cuidado. Assim conclui sua carta:

Eu gostaria de fazê-lo [descrever as maldades], mas acredito em Deus que ele fará surgir, depois de mim, homens mais corajosos, que eles já existem agora e que eles irão declarar as maldades do Anticristo e arriscarão suas vidas com a morte pela verdade do senhor Jesus Cristo, que dará a vocês e a mim a alegria eterna.

Esta carta foi escrita no [dia de] João Batista, lembrando que João também foi decapitado na prisão e nas amarras pela verdade de Deus.

Na carta 91, escrita em 26 de junho, em tcheco, retoma a questão dos livros da carta 87, de dois dias antes. Afirma que eles não leram porque não entendiam tcheco. Menciona 
como exceção o bispo de Litomyšl que estava presente ao concílio, mas não apoiava Hus. Nesse trecho inicial, menciona que a Boêmia é a terra da melhor fé:

Eu tentei mais de uma vez chamar a atenção de vocês que o Concílio orgulhoso e avarento, cheio de abominações, condenaram meus livros tchecos, sem nem ao menos os terem ouvido ou visto. E mesmo que os tivessem ouvido, não os teriam entendido, visto que havia italianos, franceses, ingleses, espanhóis, alemães e [falantes] de outras línguas naquele Concílio, exceto talvez o Bispo Jan de Litomyšl tenha entendido meus livros de algum modo. Pois ele estava entre os outros tchecos, os provocadores, com os capítulos de Praga e Vyšehrad de onde se originaram as calúnias contra a verdade de Deus e de nossa terra da Boêmia. Eu acredito que essa terra, na esperança de Deus, é a terra da melhor fé, sabendo de seu desejo pela Palavra de Deus e pela moral.

Além disso, condena os pecados do Concílio, apresentando uma fala corrente dos habitantes daquela cidade:

Oh, vocês viram que o Concílio se proclama o mais santo e que não pode errar. Vocês com certeza viram a grande abominação. Pois eu ouvi que é dito pelos suábios que Constança ou Kostnice ${ }^{247}$, sua cidade, não vai se livrar por pelo menos trinta anos dos pecados que aquele Concílio cometeu na cidade.

Hus, então, narra como foi recebido em sua audiência e descreve uma discussão que parece calorosa, com todos gritando, inclusive ele mesmo:

Eu digo a vocês que quando em cheguei perante o Concílio no primeiro dia, vendo que não havia qualquer ordem por lá, disse alto, quando eles estavam todos quietos: 'Eu supunha que haveria maior reverência, bondade e melhor ordem no Concílio do que está havendo!' Naquele momento, o cardeal presidente disse 'O que você está dizendo? Você falou com mais humildade no castelo!' Ao que eu respondi, dizendo 'Porque no castelo ninguém gritou comigo e aqui todos estão gritando!' (grifos nossos)

Mais à frente, cita outra de suas falas ao concílio. Hus pede por uma explicação, uma compreensão do que estava acontecendo. A palavra tcheca que ele usa, porém, é naučenie, que tem por raiz o verbo učit, ensinar/aprender. A tradução para o inglês de Spinka é "instruction". Workman e Pope omitem uma parte da frase "peço explicação" e traduzem as outras ocorrências como "information". Essa omissão da primeira parte da frase também ocorre na tradução do tcheco para o latim feita por Palacký em seu Documenta. Neste trecho,

\footnotetext{
${ }^{247}$ Este é o nome tcheco de Constança.
} 
Hus apresenta um modelo do oposto de sua concepção de ensino, a saber, a imposição da autoridade:

Eles [Venceslau de Dubá e Jan de Chlum] estavam presentes quando eu disse: 'Eu peço pela explicação, se eu escrevi algo errado peço que me expliquem'. Então, o cardeal presidente disse: 'Como você quer que the expliquemos, eis sua explicação: você deve abjurar, como cinquenta mestres das sagradas escrituras concluíram'. Oh, que bela explicação!

Conclui sua carta dizendo que a escreveu para mostrar que eles tentaram fazê-lo abjurar mas não conseguiram. Suas últimas palavras são: "mas pelos misteriosos desígnios de Deus eu não posso dizer se esta é minha última carta, pois o Deus todo poderoso ainda poderá me libertar."

No dia seguinte, 27 de junho, Hus escreve nova carta pastoral, número 94, que começa retomando o final da carta anterior. Nesta carta, ele explicita seu gosto em escrever cartas para eles, utilizando esse meio como uma conversa:

Tendo muitos motivos para acreditar fortemente nisso, escrevi-lhes como se fosse morrer amanhã. Mas visto que eu novamente soube do adiamento de minha morte, escrevo-lhes mais uma vez, amigos graciosos e fiéis em Deus, para mostrar minha gratidão o máximo possível, e até mesmo sentindo prazer em poder conversar com vocês por carta. (grifo nosso)

Segue com uma explicação de que o adiamento de sua morte e o da morte de Jerônimo de Praga é para que eles dois possam redimir melhor seus pecados e se lembrar do exemplo de Jesus e dos santos que entraram no reino dos céus sofrendo:

Quem pode descrever todas as torturas pelas quais os santos do Novo e do Antigo Testamentos sofreram pela verdade de Deus, especialmente aqueles que foram contra as maldades do clero e pregaram contra ela. Seria estranho se hoje alguém não sofresse por uma corajosa posição contrária à maldade, especialmente a dos clérigos que não se deixam ser tocados.

E conclui com uma ironia: seus acusadores tiveram que ler seus livros atentamente. "Fiquei feliz que eles foram obrigados a ler meus livretos, que claramente revelam suas maldades. Eu sei que eles os leram mais atentamente do que lêem as sagradas escrituras, tentando encontrar erros neles."

Finalmente em $1^{\circ}$ de julho, Hus escreve sua declaração final ao Concílio (carta 98), afirmando que não irá abjurar, pois isso significaria cair em perjúrio e não voltará atrás em nenhum deles, temendo ofender a verdade. Depois daquela, escreve suas últimas cartas em 5 de julho, véspera de sua morte, desta vez inevitável. A de número 99 é endereçada a seus 
amigos em Constança confirmando sua declaração contra a abjuração. Nela pede que cuidem de suas cartas cautelosamente, pois elas podem ser perigosas às pessoas nelas citadas, indício de que sua correspondência poderia estar sob censura ou vir a ser interceptada.

Escreve, então, a carta de número 100, em tcheco. Agora, preocupado com seus próximos, deixa um recado para cada pessoa que considera importante. Pede para que nada falte a Jan de Chlum, designando um nobre para cuidar disso. Agradece à rainha e sua corte. Pede a todos que rezem por ele, pois ele logo se encontrará com Deus. Afirma estar preso, "no aguardo da sentença de morte, que eu sofrerei, espero, na lei de Deus”. E pede para que não permitam que os bons clérigos sejam destruídos. Assina como "Mestre Hus, na esperança de ser um servo de Deus", epíteto muito recorrente em suas cartas. Acrescenta a essa carta um adendo com recados para diversas pessoas, o qual apresentamos a seguir. Na lista, vemos nobres, professores da universidade, amigos e discípulos:

Petr, caro amigo, fique com meu casaco de pele em minha memória.

Nobre Henry Lefl, viva uma boa vida com sua esposa. Agradeço-lhe por seus benefícios. Que Deus lhe recompense.

Senhor Lidher, amigo fiel, com Senhora Margaret e Nobre Škopek e mestre Mikeš e outros, que Deus lhes de a eterna recompensa pelo trabalho e outras gentilezas que me mostraram.

Fiel e querido mestre Christian, que Deus esteja com você.

Mestre Martin, meu discípulo, lembre-se do que eu lhe ensinei fielmente.

Mestre Mikulaš, Petr, capelão da rainha e o resto dos mestres e clérigos, sejam diligentes na Palavra de Deus.

Clérigo Havlík, pregue a Palavra de Deus!

Suplico a todos que permaneçam firmes na verdade de Deus.

Hus chama Martin de seu discípulo e afirma que lhe ensinou algo. Ao olharmos para as palavras tchecas deste trecho percebemos um destaque para o lugar de Martin para Hus. Dirige-se a ele no diminutivo (Martínku), mostrando maior intimidade e o considera um učedlniče, palavra que possui em sua raiz o mesmo verbo učit (ensinar) mencionado anteriormente. Martin é seu aprendiz, aquele a quem Hus ensinou.

A última carta hussita que dispomos (número 101) também foi escrita em 5 de julho. Hus afirma escrever um "memorial" da audiência de 7 de junho para "todo o mundo cristão". 
O clérigo afirma, em sua argumentação, que não recebeu qualquer explicação (instrução/ensino) referente ao que escreveu:

Primeiro, que em muitas audiências particulares e, posteriormente, nas públicas do Concílio, eu protestei por minha vontade de submeter-me às explicações e direções, revogações e punições, desde que eu recebesse a explicação de qualquer coisa que eu tenha escrito, ensinado ou dito em resposta fosse contrário à verdade.

Escreve, em seguida, que eles lhe disseram "você deve ceder à decisão do Concílio". E cada vez que utilizava alguma citação das escrituras ou dos Padres da Igreja, eles ou zombavam dele ou diziam que ele citava erroneamente. Cita um momento no qual o cardeal presidente pede-lhe argumentos perante a questão da essência comum de Deus existente nas coisas e ele os apresenta. O cardeal, claramente "reduzido ao máximo de sua falta de conhecimento sobre o argumento, ficou quieto". Outro doutor inglês tentou emendar e não conseguiu:

Falhando em sua argumentação, quando eles [os outros membros do Concílio] pediram-lhe para se calar, ele disse 'Olhem! ele [Hus] astutamente engana ao Concílio! Tomemos cuidado para que o Concílio não seja enganado como ele o foi por Berengar ${ }^{248}$.

Segue, Hus, com a sequência daquele debate, tentando mostrar o quanto estava desorganizado e não lhe davam crédito às suas palavras:

Quando ele se calou, alguém começou a argumentar em voz alta sobre a essência comum criada, mas a multidão gritou com ele. Eu, no entanto, levantei-me e pedi que ele pudesse ser ouvido, dizendo-lhe 'Argumente com coragem que eu alegremente lhe responderei'. Mas, igualmente, desistiu e acrescentou mal-humorado 'é uma heresia'.

Hus, então, repete o que escrevera na carta 91, sobre a desordem do Concílio, citando novamente a fala do cardeal presidente de que ele, Hus, exprimira-se mais humildemente em Gotlieben. Conclui com as palavras do cardeal e do rei, afirmando que ele teria a explicação dos doutores a respeito de seus erros por escrito e que ele deveria responder a elas:

E ele [o cardeal presidente] disse 'Oh, isto consiste sua explicação, que os doutores declararam os artigos retirados de seus livros como errôneos. Você deve revogá-los e abjurar aqueles que foram depostos contra você pelas testemunhas'. O rei disse 'Eles serão em breve escritos para você e você

\footnotetext{
${ }^{248}$ SPINKA, The letters of John Hus, p. 210, nota 5 explica que Berengar, no Concílio de Roma, em 1059, abjurou suas afirmaç̃ôs sobre a transubstanciação, o assunto da discussão, mas voltou a ensiná-las logo que retornou para Tours.
} 
poderá respondê-los'. E o cardeal disse 'Isso será feito na próxima audiência'. E, imediatamente, o Concílio se levantou. Só Deus sabe as grandes tentações que eu sofri em seguida!

Hus deixava, como disse, um "memorial" do que pensou ser o elemento mais importante de sua condenação: ninguém debatia com ele ou lhe ensinava em que estava errado, ao passo que ele via-se como alguém que ensinava apenas a verdade. Desta forma, uma carta narrativa marca sua despedida. E o que parece querer Hus, no limiar de sua morte, com essa escrita? O que fez ao longo de suas cartas da prisão: defender-se. Além disso, deixar um memorial diante da morte iminente é legar para a posteridade o julgamento de seu caso e a busca pela verdade de sua condenação. Como não conseguiu preservar sua vida, tentou, então preservar sua memória. É o que fará nas cartas a seu discípulo Martin de Volyně.

Em 6 de julho, Jan Hus foi morto na fogueira, condenado como heresiarca pelo Concílio de Constança.

\subsection{Cartas ao discípulo}

Quando Jan Hus estava prestes a partir para Constança, ele deixou escrita uma carta pessoal, lacrada, com instruções para que fosse aberta apenas caso chegasse, de uma fonte segura, a notícia de sua morte. Essa carta (número 45) foi destinada a Martin de Volyně. Volyně é uma pequena cidade situada no sul da Boêmia.

Mas quem foi Martin, essa pessoa para quem Hus deixou uma carta que deveria ser aberta apenas em condições especiais? Por que nele Hus depositava tanta confiança a ponto de deixar-lhe conselhos espirituais e orientações pragmáticas a serem tomadas após sua morte? Para responder a estas perguntas, em primeiro lugar, podemos observar como Martin aparece nas próprias cartas para, em seguida, consultar na historiografia outros indícios de sua identidade.

Martin é destinatário exclusivo de duas cartas pessoais, números 45 e 76 . No entanto, ele aparece também em outras ocasiões. A carta 25, pastoral, analisada no item anterior deste capítulo, possui a seguinte saudação: “Aos queridos irmãos em Cristo, Mestres Nicholas, Martin e Havlík, companheiros de trabalho na Palavra de Cristo, e aos outros irmãos da sagrada Belém”. Ele também é citado nas cartas 95, 96 e 100. Na carta 100, analisada anteriormente, Hus afirma textualmente que Martin era seu discípulo. Esses indícios apontam para uma proximidade entre Hus e Martin. 
Uma pista a respeito de ambos exercerem funções semelhantes encontra-se na expressão "companheiros de trabalho na palavra do Cristo". Na carta 76, encontramos a exortação para que Martin "esforce-se com diligência na pregação da palavra de Deus", confirmando sua atuação como clérigo.

A carta 45 permite-nos entender, entretanto que, embora fosse clérigo, ele ainda não tinha nenhum encargo paroquial, visto que Hus dá conselhos a Martin utilizando expressões como "se você for chamado ao ofício pastoral" e "se você se tornar um pastor". Nas biografias sobre Hus e nos comentários às cartas não encontramos muitas informações adicionais, o que sustenta nossa hipótese de que a principal fonte para conhecermos Martin é a própria correspondência de Hus. Matthew Spinka faz seis menções em dois livros, atribuindo-lhe as alcunhas de "discípulo"249, "fiel discípulo"250, "ex-discípulo"251, "amigo e ex-discípulo" 252 e duas outras um pouco diferentes e mais reveladoras, a saber, "estudante"253 e "assistente em Belém" estudante da Universidade de Praga e a segunda, que ele era um clérigo assistente de Hus. Workman e Pope confirmam a posição de discípulo ${ }^{255}$ e de membro da universidade ${ }^{256}$. David Schaff refere-se ao mesmo destinatário como Martin de Praga, talvez se referindo à localidade onde ele se encontrava quando recebeu a carta. Afirma ser ele o "discípulo favorito" 257 de Hus.

A denominação de Martin como "estudante", feita por Matthew Spinka, abre espaço para entendermos a atuação educativa de Hus. Estudantes morarem junto a igrejas era comum na época e foram justamente dessas moradias que surgiram, nas décadas seguintes, os futuros colégios secundários. ${ }^{258}$ A menção aos estudantes na carta 73 , citada anteriormente, o fato das cartas pastorais serem escritas para serem lidas na Capela de Belém e a história do surgimento dos colégios secundários compõem um forte indício que havia estudantes presentes na Capela

\footnotetext{
${ }^{249}$ SPINKA, John Hus: a biography, p. 30.

${ }^{250}$ ibidem, p. 276.

251 ibidem, p. 229.

${ }^{252}$ SPINKA, John Hus at the council of Constance, p. 30.

${ }^{253}$ SPINKA, John Hus: a biography, p. 74.

${ }^{254}$ ibidem, p. 163.

${ }^{255}$ WORKMAN; POPE, op. cit., p. 80.

${ }^{256}$ ibidem, p. 149. "Junior member" no original.

${ }^{257}$ SCHAFF, op. cit., p. 168.

${ }^{258}$ V. HILSDORF, Maria Lúcia Spedo. O aparecimento da escola moderna. Belo Horizonte: Autêntica, 2006.
} 
de Belém e que Hus atuou com eles. Segundo Spinka ${ }^{259}$, na vizinhança da capela, foi montada uma moradia para estudantes, intitulada "Colégio de Nazaré", que hospedava estudantes pobres da universidade. Também afirmou que Hus dedicava especial atenção a essa moradia, encaminhando e promovendo estudantes. Aqueles que ele apresentava para os exames recebiam dele uma preparação adicional.

Hus também realizava discursos para formandos na Universidade. Num desses discursos, proferido em 1405, ele se dirigiu ao único membro da nobreza que fazia parte do grupo de alunos que moravam no pensionato nos fundos da capela. Spinka atesta a existência de uma relação muito próxima entre professor e aluno ${ }^{260}$, perceptível pelo tom jocoso com que Hus afirmou ser esse membro da nobreza, Zdislav de Zvířetice, uma pessoa preguiçosa, que dormia demais.

Esse mesmo tom de intimidade e cuidado paterno está presente na carta 45 , como afirma Spinka: "Nada ilustra melhor a relação próxima e íntima de Hus com seus alunos do que esta carta!"261. Workman e Pope consideram esta carta "um dos tesouros da coleção, incalculável por sua introspecção no espírito meigo, um tanto autorrepreensível, do escritor,"262.

O início da carta 45 é um conselho, no qual Hus exorta Martin para que preserve sua virgindade, tomando cuidado para não se envolver com as mulheres:

Mestre Martin, caro bem-amado irmão em Cristo, exorto-lhe, no Senhor, a temer a Deus, a guardar Seus mandamentos, a fugir do convívio das mulheres e a ser cuidadoso quando ouvir à confissão delas, para que o Satã não lhe engane por meio da hipocrisia das mulheres. Pois Agostinho disse: 'Não acredite na devoção delas, porque quanto mais devota mais lasciva é, e sob o pretexto de piedade esconde-se o visgo ${ }^{263}$ da concupiscência., 264 Portanto, esteja alerta para que você não perca sua irrecuperável virgindade, que eu espero que você a preserve.

\footnotetext{
${ }^{259}$ SPINKA, John Hus: a biography, p 39.

${ }^{260}$ SPINKA, John Hus: a biography, p. 73.

261 ibidem, p. 74. Afirmação semelhante na sua tradução da carta em The letters of John Hus, p. 120.

${ }^{262}$ WORKMAN; POPE, op. cit., p. 146.

${ }^{263}$ De acordo com o dicionário HOUAISS, visgo é o mesmo que erva-de-passarinho, a saber, “designação comum a diversas plantas hemiparasitas (...) de pseudofrutos com substância viscosa, us. como goma de mascar, em armadilhas para pássaros etc., e muito procurados por estes animais, que os disseminam esp. pelos excrementos; (...)".
}

${ }^{264}$ SPINKA, The letters of John Hus, p. 120, afirma que esta não é uma citação de Agostinho, mas de uma carta do Papa Alexandre III ao Arcebispo de Canterbury. 
Não é de se estranhar que esta seja a primeira recomendação de Hus a seu discípulo. A concupiscência $^{265}$ é o apetite pela satisfação dos sentidos do corpo, contrários à razão ${ }^{266}$. Começar com uma referência à preservação da virgindade segue o padrão de educação moral do período no qual Hus escreve, visto que a sexualidade é um dos principais temas desse período:

A palavra, a sexualidade, o dinheiro são os três temas que no fim da Idade Média retornam, com insistência quase obsessiva, aos tratados morais, aos sermões, aos primeiros catecismos: elementos de uma cultura do pecado profundamente modificada, mas longe de estar exaurida, e destinada a influir com todo seu peso nos acontecimentos culturais e religiosos que marcam a passagem à era moderna. ${ }^{267}$

Vejamos as consequências dessa "cultura do pecado". A Igreja atribui ao sexo um espaço apenas para procriação. Santo Agostinho advertiu que "Também é adúltero quem ama com demasiado ardor sua mulher" e essa advertência ecoou nos séculos que lhe seguiram ${ }^{268}$. "A mulher era a rival da Igreja, a tentadora, a desencaminhadora, o obstáculo à santidade, a isca do Diabo." 269 Ela é vista como insaciável, particularmente sujeita ao desejo, mais próxima da animalidade. Ao homem competia não ceder a essa volúpia ${ }^{270}$. O imaginário medieval expresso na Divina Comédia de Dante coloca no inferno o casal que se deixou levar pelo desejo. Os luxuriosos, no segundo círculo, sentem-se presos pelo amor:

\section{Amor, que a amado algum amar perdoa, tornou-me, pelo seu querer, tão forte, que como vês ainda me agrilhoa. ${ }^{271}$}

O discurso medieval sobre as mulheres está na mão dos clérigos que impõem sua palavra e constroem imagens tão mais estigmatizadas quanto mais distantes estão delas ${ }^{272}$. A

\footnotetext{
${ }^{265}$ O original em latim, na carta, apresenta a palavra "libidinis".

${ }^{266}$ MING, John. Concupiscence. The Catholic Encyclopedia. Vol. 4. New York: Robert Appleton Company, 1908. Disponível em <http://www.newadvent.org/cathen/04208a.htm>. Acesso em 19 dez. 2009.

${ }^{267}$ LE GOFF; SCHMITT, Dicionário Temático do Ocidente Medieval, p. 350.

268 ibidem, p. 480.

269 TUCHMAN, Um espelho distante, p. 194.

270 ibidem, p. 479.

${ }^{271}$ ALIGHIERI, Dante. A divina comédia. Tradução e notas de Italo Eugenio Mauro. São Paulo: Editora 34, 1998, canto V, v. 103-105.

${ }^{272}$ KLAPISCH-ZUBER, Christiane. Introdução. In: DUBY, Georges; PERROT, Michelle (dir.). História das mulheres no ocidente. Volume 2: A Idade Média. Porto: Edições Afrontamento, 1990.
} 
castidade é, no final da Idade Média, o melhor remédio para a concupiscência, recomendada a homens e principalmente a mulheres:

A virgem é virgem não tanto e não só pela integridade do seu corpo, mas sobretudo pela pureza dos seus pensamentos, afastados de toda a concupiscência graças à escolha meditada que soube fazer e manter; (...) A viúva vive virtuosamente a sua condição não apenas graças a um evento casual que libertou o seu corpo da obrigação das relações sexuais, mas sobretudo se, a partir desse acontecimento, sabe libertar a sua mente de todo o desejo carnal. A mulher casada vive virtuosamente a sexualidade no interior do matrimônio porque as suas intenções se mantêm puras e castas, voltadas como estão para o cumprimento do dever conjugal e para a propagação da espécie. ${ }^{273}$

Essa valorização da virgindade Hus já havia feito numa carta (número 6) escrita em algum momento após 1408, em tcheco, a um grupo de mulheres que vivem em retiro. O texto trata quase que exclusivamente desse tema. Exorta-lhes a preservarem sua virgindade, lembrando o exemplo da virgem mãe de Cristo, pois vivendo no celibato e na virgindade elas serão abençoadas por Deus. Ao final, afirma que está mandando uma música, a qual não tivemos acesso, cantada na capela de Belém nas tardes dos serviços das santas virgens.

No entanto, não bastam a castidade e a virgindade. Para que estas virtudes tenham valor espiritual, são necessárias ainda outras ${ }^{274}$. É o que fará Hus na continuação da carta para Martin. Ele parte de um dos principais temas da educação moral do período para fortalecer a relação com seu discípulo:

Lembre-se que, desde sua juventude, eu lhe ensinei a servir ao Cristo Jesus, e eu gostaria, se tivesse sido possível, de ter lhe ensinado em um dia tudo o que eu sabia. Você sabe, igualmente, que eu denunciei a avareza e a vida irregular de sacerdotes, e por isso, na graça de Deus, estou sofrendo perseguição, a qual logo levará a cabo minha destruição. Eu também não tenho medo de enfrentar a humilhação em nome de Jesus Cristo.

Este trecho diz muito a respeito de Hus e de sua relação com Martin. A primeira frase aponta para uma relação educativa de muitos anos entre mestre e discípulo, bem como para a impossibilidade de se ensinar tudo. Porém, mais importante na análise desta carta do que uma lista das coisas que Hus ensinou a Martin é o estabelecimento dessa relação entre eles. É no

${ }^{273}$ CASAGRANDE, Carla. A mulher sob custódia. In: ibidem, p. 112. Sobre a viuvez ver OPTIZ, Claudia. O quotidiano da mulher no final da Idade Média (1250-1500). In: ibidem, p. 415 e seguintes.

${ }^{274}$ LE GOFF; SCHMITT, op. cit., p. 482 afirmam: “A castidade - a fortiori a virgindade - não tem grande valor espiritual quando não é acompanhada por outras virtudes, e sua forma mais valorosa é a castidade voluntária vivida no matrimônio." 
momento em que o educador diz segue-me e o discípulo o aceita que está a principal marca da educação, como explica Gusdorf:

Segue-me: a afirmação da personalidade é uma mobilização da personalidade. Até aí o discípulo era um entre os outros. Vivia na inconsciência, na ignorância e na imobilidade. A adesão ao mestre, uma vez que é consentimento a si mesmo, nada tem de uma escravatura. Ela implica para o discípulo servir ao mestre, mas apenas na medida em que esse serviço é a consagração à verdade. ${ }^{275}$

Lembremos que Hus escreveu essas palavras para serem lidas apenas após sua morte. Elas só possuem esse valor afirmativo, ou seja, só educam porque foram acompanhadas da ação. Se Hus tivesse voltado atrás no que disse, se tivesse aceitado os pedidos para que abjurasse, nenhuma dessas palavras significaria algo. Não são nelas que está o educador, mas no seu exemplo (as palavras não ditas). "O mestre ensina, mas ensina algo diferente do que ensina. O mais alto ensinamento do mestre não está no que ele diz, mas no que ele não diz."276 É nesse sentido que os conselhos na sequência da carta propõem uma adesão a um padrão de vida coerente com uma das principais preocupações de Hus, que é agir motivado pela honra a Deus:

Eu lhe imploro, de todo meu coração, que não cobice os benefícios. Entretanto, se você for chamado ao ofício pastoral, esteja motivado pela honra a Deus, pela salvação das almas e pelo trabalho, ao invés da posse de semeaduras ou um pedaço de terra ${ }^{277}$. Mas se você se tornar um pastor, cuidado ao ter uma mulher como sua cozinheira, para que você não edifique sua casa mais do que sua alma. Seja você um construtor de edifícios espirituais, sendo gentil com os pobres, e humilde, não gastando seus bens em banquetes.

Hus apresenta, aqui, dois dos principais temas da educação moral medieval: a sexualidade e o dinheiro, retornando o tema do cuidado com a mulher, mostrando que o simples fato de estar próximo de uma é um grande risco, neste caso, o de edificar mais a casa do que a alma. Resume essas duas preocupações em uma frase: ser o construtor de edifícios espirituais e ser humilde. Segue com o aconselhamento perante o uso de roupas finas, o que, parece-nos, Martin gostava de usar:

\footnotetext{
${ }^{275}$ GUSDORF, Georges. Professores para quê? Tradução de João Bénard da Costa e António Ramos Rosa. 2.a edição. Lisboa: Moraes editores, 1970, p. 241.

276 ibidem, p. 147.

${ }^{277}$ Trecho com versões muito diferentes entre os tradutores. É “sows or a plot of land”, para Spinka (tradução que adotamos), "fine clothes or lands", para Workman e Pope e "riches", para Bonnechose. No original em latim está "non habitio (ou ambiti, como em um dos manuscritos) scropharum vel praediorum".
} 
Temo, também, que se você não corrigir sua vida, desistindo de roupas finas e supérfluas, você será severamente repreendido pelo Senhor. E o será do mesmo modo que eu, um infeliz miserável, estou sendo por ter usado essas coisas, por ter sido seduzido pelos hábitos e elogios maléficos dos homens. Por elas, eu fui ferido pelo espírito do orgulho contra Deus.

Hus aproxima-se de Martin ao afirmar que também viveu as experiências que ele está vivendo. Em diversos trechos das cartas escritas de Constança, Hus retoma essa ideia de ser punido por seus erros passados. Na carta 69, por exemplo, escrita a seus amigos em Constança, em 9 de junho de 1415, ele termina dizendo: "Estou sofrendo de dor de dente e, no castelo, eu sofri com vômito de sangue, dor de cabeça e a pedra. Estas foram as punições pelos pecados como sinal do amor de Deus por mim." Do trecho que citamos da carta 45, a palavra "elogio" pode ser um indício da preocupação com o uso da palavra, a terceira das maiores preocupações medievais. ${ }^{278}$ Essa aproximação de Hus a Martin, apresentando-se como alguém cheio de faltas, ele continua na sequência, incluindo um novo item: o jogo de xadrez:

Já que você conheceu bem minha pregação e minha conduta em público desde sua juventude, não considero necessário escrever-lhe mais sobre isso. Imploro-lhe, no entanto, pela misericórdia de Jesus Cristo, que não me siga em qualquer leviandade que você tenha visto em mim. Você sabe que, ai de mim, antes de eu me tornar um clérigo, eu gostava de jogar xadrez e o fazia com frequência. Desperdicei meu tempo, e por causa desse jogo provoquei, com tristeza e por diversas vezes, a cólera em mim e nos outros.

Logo no início deste trecho, Hus comenta a respeito de algo que já apresentamos como seu principal meio de educar: a pregação evangélica e o exemplo de vida pública. Nesta carta, na qual o clérigo apresenta suas principais preocupações a respeito da educação de seu discípulo, temos a confirmação de sua principal prática. E por que ela é a principal? Porque ela é a mais eficaz a tal ponto que não é necessário escrever mais sobre isso. Esta frase inserida nesta carta é o indício que corrobora a hipótese que desenvolvemos nos itens anteriores deste capítulo: a de que Hus educava pelos sermões e que passou a educar pelas cartas a partir do momento em que não podia mais estar presente.

Continua com a apresentação de seus erros, ressaltando o fato que gostava de jogar xadrez, fazia-o com frequência e isso provocou tristeza e cólera nele e nos outros. Já em outro lugar ele faz referência aos jogos como motivos de discórdia e avareza. Na já mencionada carta 3 a uma dama da nobreza, ele afirma:

\footnotetext{
${ }^{278}$ A expressão et applausu aparece apenas na edição de Novotný (Korespondence) e, portanto, está presente unicamente na tradução de Spinka.
} 
Eu ouvi que você conduziu bem sua viuvez, mas que não está cuidadosa por permitir jogos e danças em sua propriedade, o que é uma clara transgressão ao mandamento de Deus. Pois no jogo cobiçam a propriedade alheia, basicamente insultam e batem uns nos outros, às vezes insultando até mesmo Deus e os santos, enganam um ao outro, negligenciam trabalhos úteis, não observam os dias santos e, quando eles perdem, eles roubam seus patrões, amigos e pais. Às vezes eles saqueiam nas estradas e assassinam pessoas de fé e outras mais. Se eles são camponeses, às vezes abandonam seus povoados e suas famílias e fogem para estarem mais livremente aptos a jogar os dados e outros jogos, e para mentir dia e noite nas tavernas. Muito prejuízo vem disso para eles próprios, seus patrões, ou suas crianças (...)

Este trecho deixa clara a relação que o clérigo faz entre jogos e dinheiro, levando a diversos pecados. No entanto, a menção ao xadrez traz um contraponto com papel dos jogos na educação medieval. No período entre os séculos XII e XV, esse jogo possuiu grande difusão e popularidade na Europa ${ }^{279}$. Os jogos eram parte importante da educação medieval e o xadrez, especificamente, possuía uma forte carga moral no final da Idade Média. Em dois textos do século XIII, encontramos exemplos disso. O primeiro, Moralitas de Saccario, utiliza o xadrez como metáfora para a explicação da vida humana:

Este mundo é como um tabuleiro de xadrez: uma casa é branca, outra é preta, e assim representa o duplo estado de vida ou morte, de graça ou pecado.

A família que habita esse tabuleiro é formada pelos homens deste mundo, que - tal como as peças saídas todas da mesma bolsa (sacculus) - procedem todos de um só ventre (sacculus) - materno. (...)

E com frequência acontece que, quando se devolvem as peças, o Rei fica por baixo, no fundo do saco; e assim também acontece com os grandes que ao sair deste mundo são sepultados no inferno; enquanto os pobres são levados ao seio de Abraão.

Neste jogo, o diabo diz: xeque! incitando ao mal e ferindo com o dardo do pecado. E se o atingido não sai rapidamente dizendo: livre!, pela penitência e compunção do coração, o diabo lhe diz: mate!, levando sua alma ao inferno de onde não se poderá livrar de modo algum. ${ }^{280}$

O segundo exemplo está na introdução do Libro del Acedrex, de D. Alfonso o Sábio. Vale a pena destacar que D. Alfonso foi rei de Castela e Leão e, portanto, não sendo membro do clero, sua argumentação pode não possuir as mesmas bases. Nos dois primeiros parágrafos,

\footnotetext{
${ }^{279}$ LAUAND, Luiz Jean. O xadrez na Idade Média. São Paulo: Perspectiva; Editora da Universidade de São Paulo, 1988, p. 23.

${ }^{280}$ apud ibidem, p. 48-49.
} 
ele associa o jogo a uma invenção do homem para realizar com plenitude a alegria que Deus lhe deu:

Deus quis que os homens naturalmente tivessem todas as formas de alegria para que pudessem suportar os desgostos e tribulações da vida, quando lhes sobreviessem.

Por isso os homens procuraram muitos modos de realizar com plenitude tal alegria e criaram diversos jogos que os divertissem. ${ }^{281}$

O lúdico é parte fundamental da educação medieval ${ }^{282}$ e D. Alfonso, como um grande educador medieval, ressalta a importância do xadrez. Seria a oposição de Hus ao jogo uma oposição à ludicidade característica do homem medieval? Huizinga ${ }^{283}$ pode iluminar esta questão quando se refere às "lágrimas abundantes" nos eventos públicos do final da Idade Média. Em virtude da tensão e violência que marcavam a vida naquele período, havia nas pessoas um grande grau de excitação:

Um simples exemplo bastará para mostrar o grau de excitação que distingue a Idade Média do nosso tempo. Dificilmente conceberemos jogo mais pacífico do que o xadrez. No entanto, tal como a propósito das canções de gesta, alguns séculos antes, Olivier de la Marche menciona frequentes querelas em consequência desse jogo; 'o mais sensato perde a paciência ao jogá-lo’.

Entendemos que Hus, vivendo nesse período de grande excitação emocional, tenha se exaltado quando jogou xadrez. Por isso, quando em sua correspondência ele se opôs à cólera, à avareza e à luxúria não estava em oposição ao riso e à diversão. Ele mesmo faz algumas brincadeiras no meio de suas cartas, especialmente na correspondência com pessoas próximas, como com o cavaleiro Jan de Chlum, que é chamado por Hus (carta 65) de doutor de Biberach $^{284}$.

O clérigo da Boêmia utiliza o jogo de xadrez como um símbolo de seus erros passados, que Martin deve evitar para não cair no pecado. Não é simplesmente o jogo, mas todos os males que ele carrega e que podem levar a pessoa a um prejuízo em sua salvação. Desses males, os principais são a carne, o mundo e o demônio, como continua Hus em sua carta para Martin:

\footnotetext{
281 apud ibidem, p. 65.

${ }^{282}$ V. LAUAND, Luiz Jean. Deus Ludens - o lúdico no pensamento de Tomás de Aquino e na pedagogia medieval. Disponível em <http://www.hottopos.com/notand7/jeanludus.htm>. Acesso em 22 dez. 2009.

${ }^{283}$ HUIZINGA, O declínio da Idade Média, p. 18.

${ }^{284}$ SPINKA, The letters of John Hus, p. 150, nota 2.
} 
Portanto, por causa de minhas incontáveis outras faltas ${ }^{285}$ que cometi, entrego-me, por suas preces, ao mais misericordioso Senhor, pedindo Seu perdão. Não demore a apelar para Sua misericórdia, que Ele queira dirigir minha vida e, depois de superar os males desta era, a carne, o mundo e o demônio, colocar-me, pelo menos no Dia do Julgamento, na morada celeste.

Essa tríade de males (ou inimigos) também encontramos na Suma Teológica de Tomás de Aquino. Ele afirma ${ }^{286}$ que a tentação possui fonte trina: a carne o mundo e o demônio. São Francisco de Assis também utilizou essa tríade como os inimigos que deixam cegos aqueles que não vivem em espírito de penitência e nem recebem o corpo de Nosso Senhor Jesus Cristo. ${ }^{287}$ Embora não haja referência a nenhum deles, ambos são anteriores a Hus. Mas todos podem ter se inspirado na primeira epístola de João, especialmente os versículos de 12 a 17 do segundo capítulo que associam a vitória da concupiscência como a vitória contra o demônio, o mundo e a carne. ${ }^{288}$ Eis o trecho bíblico:

Eu vos escrevo, filhinhos, porque os vossos pecados foram perdoados/ por meio do seu nome./ Eu vos escrevo, pais,/ porque conheceis aquele/ que é desde o princípio./ Eu vos escrevo, jovens,/ porque vencestes o Maligno./ Eu vos escrevi, filhinhos,/ porque conheceis o Pai./ Eu vos escrevi, pais,/ porque conheceis aquele/ que é desde o princípio./ Eu vos escrevi, jovens,/ porque sois fortes,/ porque a Palavra de Deus permanece em vós,/ e porque vencestes o Maligno./ Não ameis o mundo/ nem o que há no mundo./ Se alguém ama o mundo,/ não está nele o amor do Pai./ Porque tudo o que há no mundo/ - a concupiscência da carne,/ a concupiscência dos olhos e/ o orgulho da riqueza - / não vem do Pai,/ mas do mundo./ Ora, o mundo passa/ com suas concupiscências;/ mas o que faz a vontade de Deus/ permanece eternamente. ${ }^{289}$

Hus despede-se de Martin deixando instruções a respeito da distribuição de alguns de seus bens. É a primeira vez que o faz e o repetirá nas cartas 76 (para Martin), 95, 96 (Petr de Mladoňovice) e 100 (carta pastoral):

\footnotetext{
285 "fault" para Spinka e "sin" paraWorkman e Pope e Bonnechose. A versão latina apresenta "culpis".

${ }^{286}$ AQUINO, Tomás de. The summa theologica of St. Thomas Aquinas. 2a. ed. Traduzido para o inglês pelos Fathers of the English Dominican Province, 1920. Edição Online de 2008. Disponível em <http://www.newadvent.org/summa>. Acesso em 26 dez. 09, parte III, questão 41, artigo 1, objeção 3. Em inglês está "temptation is from a threefold source--the flesh, the world, and the devil".

${ }^{287}$ ASSIS, Francisco de. Carta aos fiéis II. Disponível em 〈http://www.franciscanos.org.br/v3/carisma/fontesfran/word/CARTA\%20AOS\%20FIÉIS\%20I.doc >. Acesso em 26 dez. 09, capítulo XI.

${ }^{288}$ Agradecemos a Ivanilson Bezerra da Silva, pastor presbiteriano e mestre em educação, por esta referência.

${ }^{289} 1$ João II: 12-17. Transcrição de A BíBLIA DE JERUSALÉM. 6a impressão. Nova Edição, Revista. São Paulo: Edições Paulinas, 1993.
} 
Adeus, em Cristo Jesus, junto com todos os que guardam Sua lei. Você pode ficar com a túnica verde, se você quiser, como uma lembrança. Mas, como eu acho que você detesta verde, dê-a para quem você achar melhor. Dê a túnica branca para meu aluno ${ }^{290}$, "o Pastor". Para o Georgio ou Girzikoni, dê sessenta grossi $^{291}$ ou a toga verde, pois ele me serviu fielmente.

É, no mínimo, curiosa a suposta contradição entre este último trecho e o restante da carta. Afirmamos suposta contradição visto que parece haver uma disparidade entre a insistência do desapego dos bens materiais que marca a carta e a destinação das túnicas de Hus. Mas é justamente neste final que temos a confirmação da proximidade e confiança que ele possui em Martin a ponto de deixar com ele o cuidado da distribuição de seus pertences. Mais ainda, ele apresenta a extensão dessa relação com outros discípulos, no caso, o "pastor" e George, este que o serviu fielmente. Deles não temos outras informações, mas podemos supor $^{292}$, seguindo Spinka, que eles habitavam o Colégio da Capela de Belém, seja como estudantes, seja como criados.

Podemos relacionar o conteúdo da carta 45 ao da outra que Hus enviou para Martin (número 76), considerando as diferenças de contexto no qual cada uma foi enviada. Enquanto a carta 45 data do início de outubro de 1414, começo da viagem de Hus a Constança, a de número 76 é datada de 16 de junho de 1415, quando Hus já estava preso e discutia os termos de sua defesa perante a proposta de abjuração do Concílio.

A carta 76 possui conteúdo semelhante à 45 . Hus escreve novamente a seu discípulo Martin, só que, desta vez, na prisão. Por que ele escreveu outra carta para dizer, basicamente, as mesmas coisas? Em primeiro lugar, é provável que Martin não tivesse aberto a outra ${ }^{293}$, se seguiu as instruções de seu mestre. Em segundo lugar, como perceberemos, Hus é mais detalhado em sua lista de instruções e em seus ensinamentos. Poderemos, então, levantar a hipótese que ele, tomando a morte como cada vez mais próxima, tomou mais cuidado ao distribuir sua herança. E, o que tentaremos mostrar aqui, é que essa herança não é apenas material.

\footnotetext{
${ }^{290}$ Para Workman e Pope a palavra aluno está relacionada ao nome seguinte, George. Para Spinka, confirmado pela carta 76, "Pastor" e Gerogio/Girzikoni [Jorge/Jorginho] são ambos servos de Hus. O último era também estudante.

${ }^{291}$ Spinka afirma que sessenta grossi totalizam uma sexaginta (em tcheco, kopa). Workman e Pope afirmam esta quantidade ser um guinéu. Bonnechose utiliza sessenta "groschen" de prata. Workman e Pope também afirmam que três moedas sexagenae de Praga valiam doze florins. A despeito destas informações, não sabemos precisar se esta era uma quantia grande ou pequena.

${ }^{292}$ SPINKA, John Hus: a biography, p. 73-74.

293 ibidem, p. 276.
} 
Hus inicia sua segunda carta a Martin, retomando os mesmos conselhos da primeira: evitar roupas luxuosas e conversas com mulheres, além de preservar sua virgindade:

Mestre Martin, o mais amado pupilo e irmão em Cristo. Viva de acordo com a lei do Cristo e se esforce com diligência na pregação da Palavra de Deus. Eu lhe peço, pelo amor de Deus, que não ame roupas ilustres, como eu, ai de mim, amei e usei e, assim, negligenciei em viver um exemplo de humildade ao povo para quem eu preguei. Leia a Bíblia alegremente, especialmente o Novo Testamento, e, onde você não entender, busque imediatamente pelos comentadores enquanto você puder tê-los. Evite conversas com mulheres e seja especialmente cauteloso na escuta de confissões para que você não seja capturado pela armadilha da volúpia. Pois eu espero que você seja um virgem puro preservado para Deus.

Aqui ele é mais explícito no cuidado com o uso da palavra, pedindo a Martin que pregue a palavra de Deus com diligência e estude o Novo Testamento e seus comentadores. Aqui Hus estabelece a autoridade da Bíblia com a valorização do Novo Testamento ${ }^{294}$.

Na sequência, Hus ensina Martin a escapar dos acusadores:

Não tema morrer por Cristo se você desejar viver com Cristo. Pois ele disse 'Não tema àqueles que matam o corpo, pois eles não podem matar a alma'. Se eles o acusarem de ser meu partidário, diga 'Eu espero que o Mestre tenha sido um bom cristão, mas o que ele escreveu e ensinou sob protesto nas escolas, eu não entendi completamente nem li com atenção.' Pois eu suponho que seja isso mesmo.

Até as escolas apareceram neste trecho. Mais importante do que a explicitação que ele ensinou nas escolas, é o fato de Hus apresentar-se como alguém que ensinou e formou discípulos, neste caso, partidários. Ele também destaca que os ensinamentos que foram alvos de protesto, ou seja, promoveram debates e o levaram à prisão, não são os principais. Ao mesmo tempo, este trecho apresenta um indício de outra coisa: Hus estava preocupado com a vida de Martin, não querendo que ele fosse acusado e condenado por ser seu partidário. Propõe, então, um modo dele escapar dessa condenação: Martin deveria explicar que não entendera nem lera com atenção as palavras de Hus. Então, ele completa:

\footnotetext{
${ }^{294}$ LE GOFF; SCHMITT, op. cit., p. 116, afirmam que embora haja uma tendência para o Novo Testamento a partir dos séculos XI e XII, o Antigo não fora esquecido. A título de nota, os Hussitas foram responsáveis pela tradução da Bíblia para o tcheco. Após os ingleses e os alemães, eles foram os pioneiros nessa tradução das Escrituras para a língua vernacular. A Bíblia de Kralice foi publicada na Boêmia em 1579-1594, preparada por teólogos da União dos Irmãos (Unitas fratrum) e foi utilizada não apenas pelos Hussitas como pelos luteranos eslovacos, que, pela proximidade linguística e condições políticas da região, assumiram o tcheco como língua litúrgica. V. LE GOFF; SCHMITT, Dicionário Temático do Ocidente Medieval, p. 115; CZECH
}

LANGUAGE. Encyclopaedia Britannica. Disponível em <http://www.britannica.com/eb/article-9028459>. Acesso em 01 dez. 2007 e KOWALSKÁ, A língua como meio de transferência de valores culturais. 
Mas eu espero, na misericórdia de Deus e na ajuda dos bons homens, que eles te deixarão em paz, embora Páleč e seu grupo façam de tudo para condenarem todos os meus partidários. Tenha certeza que o Senhor ainda faz viver aquele que consegue preservar tudo de si em Sua graça, mas, os inimigos da verdade, leva à morte e destrói em Geena. (grifo nosso)

Na sequência da carta, uma grande lista de nomes recebe os cumprimentos de Hus:

Eu entrego em suas mãos, caro bem amado, meus irmãos. Faça-lhes o melhor que você souber. Cumprimente - espero santamente - Petra, Důra e família e todos os companheiros que fazem parte de Belém: Kateřina chamada Hus ${ }^{295}$ - eu espero uma virgem santificada - Jiř́ík ${ }^{296}$, o Pastor, a senhora Zderaz, Michal de Prachatice, Maurice Kačer, e todos os amigos da verdade, Ješkova, dominus Gregório, todos os mestres, Jesenic, Kuba, ambos os Simons, Nicholas e Havlík.

O educador transfere sua tarefa educativa para seu discípulo, entregando-lhe seus irmãos ${ }^{297}$ para que ele cuide. Da lista de cumprimentos, destacamos o aparecimento das figuras de Michal de Prachatice, destinatário de algumas cartas de Hus e notário frequentemente contratado por ele ${ }^{298}$, Jakoubek de Stř́bro, um dos principais defensores da dupla comunhão e pregador na Capela de Belém sucedendo Hus após sua morte. Nicholas de Miličín e Havlík eram pregadores na capela enquanto Hus estava fora. A carta ainda segue com alguns cumprimentos mais genéricos:

Aquele que estiver ou vier a estar com os livros, que tenha cuidado com eles. Cumprimente também os doutores, meus queridos irmãos em Cristo, os sapateiros, os alfaiates e os escribas e lhes diga para serem solícitos com a lei do Cristo e pensarem humildemente, não usando suas próprias explicações, mas aquelas dos santos professores.

Aqui está o Hus preocupado com o uso que pode ser feito de seus livros. A expressão "ter cuidado" possui duplo sentido e a escolhemos propositalmente para tentar preservar a ambiguidade das diferentes traduções para o inglês ${ }^{299}$. Ela pode significar tanto cuidar para preservar quanto cuidar para evitar que sejam mal utilizados e venham a público contra aquele que possuir os livros.

\footnotetext{
${ }^{295}$ Não encontramos informações sobre por que ela era chamada de Hus. A única informação que temos a seu respeito, em NOVOTNÝ, Korespondence, p. 277, nota 6, é que Kateřina morava próximo à Capela de Belém.

${ }^{296} \mathrm{O}$ mesmo citado em latim como Gerogio na carta 45 , que deveria receber sessenta grossi.

${ }^{297}$ ibidem, p. 277, nota 3 afirma que provavelmente Hus refere-se à audiência da Capela de Belém e não a irmãos de sangue.

${ }^{298}$ SPINKA, The letters of John Hus, p. 171.

${ }^{299}$ Spinka utilizou "be cautious", Workman e Pope, "be careful" e Bonnechose "be prudent". Na versão em latim encontramos "erit cautus".
} 
Cuidar de seus escritos, nos dois sentidos acima, é uma prática comum de correspondentes $^{300}$ e também o foi para Hus durante a prisão. Ele cita essa preocupação em diversas ocasiões em sua correspondência. Por exemplo, na carta a Jan de Chlum número 61, de 5 de março de 1415, ele pede para seu destinatário entregar o tratado sobre os mandamentos de Deus para que Petr de Mladoňovice o copie. Na carta 83, de 21 de junho de 1415, escrita para Havlík a respeito da dupla comunhão, recomenda-lhe a leitura de um de seus escritos sobre o assunto para maiores esclarecimentos. Ou então, na carta pastoral número 94, de 27 de junho de 1415, como já mencionamos anteriormente, ele afirma estar feliz com o fato que os membros do concílio tiveram que ler seus escritos, pois estes expõem os erros daqueles.

Hus preocupa-se, no trecho citado, também com o uso da palavra e recomenda a todos, dos doutores aos sapateiros, a serem humildes no pensamento, usando não suas próprias palavras, mas as explicações dos santos professores. Indiretamente, essa recomendação é ao próprio Martin na medida em que este passa a ser o intermediário entre o clérigo preso e as pessoas na Boêmia. Hus está transmitindo para Martin seu legado, mostrando-lhe não apenas o caminho como o que e para quem dizer.

Com relação ao uso de suas próprias explicações, Hus não está fazendo uma restrição ao livre pensar, mas valoriza a autoridade dos Padres da Igreja em relação às glosas ${ }^{301}$. Há uma grande força das bíblias glosadas entre o século IX e o XIV, ocorrendo nos dois últimos séculos desse período uma grande presença da exegese na Universidade, com uma ligação entre os sermões e a prática exegética. Após 1340, a exegese diminui e os sermões assumem um caráter moralizante. ${ }^{302}$

Hus continua na carta com as disposições dos bens materiais e conselhos de conduta, atribuindo-lhe responsabilidades de uma pessoa de confiança:

Não deixe de pedir ao Lord Henry Lefl para dar ao escriba Jacob sessenta grossi que ele lhe prometeu. Cumprimente Matthew, antes de Belém, e, em particular, dominus Mathew, o Pobre, que ele ore por mim, um pecador, e ao fiel Jan Vitlínov. Os filhos de meu irmão, se você considerar como o melhor, que aprendam uma arte, pois temo que se eles entrarem na carreira espiritual eles não a observarão como deveriam. Meus credores, para quem

\footnotetext{
${ }^{300}$ MIGNOT, Artesãos da palavra, p. 134 cita exemplos de como a correspondência foi guardada para "preservar para a posteridade provas do exercício do autoritarismo contra intelectuais, mulheres, estudantes e organizações sindicais do qual havia sido uma das vítimas."

${ }^{301}$ SPINKA, The letters of John Hus, p. 171, nota 14 sugere isso. As glosas são anotações marginais de comentário ao texto original, no caso, a Bíblia.

${ }^{302}$ LE GOFF; SCHMITT, op. cit., p. 110-112.
} 
eu devo, pague o máximo que você puder. Se, no entanto, eles de bom grado perdoarem a dívida em nome de Deus e por amor a mim, Deus lhes pagará muito mais. (grifos nossos)

Dos citados, Henry Lefl foi o nobre protetor de Hus no castelo de Krakovec ${ }^{303}$, um dos lugares em que ele se abrigou durante o exílio. O primeiro Mathew é Mathew de Tupčany, que foi clérigo na capela de Belém em 1412. O segundo foi um clérigo que Hus admirava por sua caridade aos pobres. Hus entrega a Martin os cuidados educativos de seus sobrinhos e lhe deixa a responsabilidade da escolha do que fazer com eles. E segue, após pedir que pague suas dívidas, para o trecho final da carta:

Guarde tudo aquilo de bom que você aprendeu de mim. Se você encontrou qualquer coisa desordenada, rejeite-a e ore a Deus por mim para que ele tenha misericórdia de mim. 'Pense sobre o que você é, o que você foi e o que você será'.

Chore pelo passado

Melhore o presente

Cuidado com o futuro, ou seja, com os pecados.

Que Deus de toda a graça lhe fortaleça junto de todos os acima mencionados e os outros irmãos em Sua graça e que lhes conduza à glória na qual - espero em Sua misericórdia - nós nos regozijaremos juntos, antes que trinta anos tenham passado. Despeço-me em Cristo Jesus, querido irmão, junto com todos os que amam o nome de nosso senhor Jesus Cristo. Escrito na prisão, domingo antes da festa de São Vito.

Aqui, Hus retoma seu reconhecimento que realizou um trabalho educativo, explícito no início da carta. Mas pede a oração de Martin para que seus erros sejam perdoados. É o momento em que, semelhante ao que fez na carta 45, Hus aproxima-se de seu discípulo em posição de humildade, pedindo-lhe ajuda. É o momento no qual ambos se alinham perante a verdade, como iguais. Nas palavras de Gusdorf:

O encontro do mestre e do discípulo aparece, em verdade, como numa relação de pessoa a pessoa, mas não numa solidão partilhada, no comprazimento exclusivo de um pelo outro. Numa bela frase, afirma Saint Exupéry que o amor não consiste, para aqueles que se amam, em olhar um para o outro, mas em olharem ambos na mesma direcção. O mesmo acontece com o mestre e o discípulo: na realidade, alinham-se ambos em função de uma perspectiva que lhes é comum. ${ }^{304}$

\footnotetext{
${ }^{303}$ Esta e as informações seguintes a respeito dos citados neste trecho estão nas notas de SPINKA, op. cit., p. 171.

${ }^{304}$ GUSDORF, op. cit., p. 247.
} 
Utiliza de um provérbio medieval ${ }^{305}$ para transmitir um ensinamento fundamental: pensar a respeito de sua própria vida, passado, presente e futuro. A beleza sonora da versão latina desse provérbio merece destaque: "quid sis, quid fueris, quid eris, semper mediteris",306. A utilização de provérbios para a educação moral na Idade Média é muito comum, visto que erudição não era uma preocupação medieval. Era muito comum a autores medievais eruditos utilizarem formas informais e lúdicas de se dirigirem a seus leitores ${ }^{307}$. Os provérbios, em especial, possuem a característica de chamar a atenção para algo que poderia passar desapercebido, como mostra Lauand comentando um livro de provérbios portugueses antigos:

Quando se tem em conta que a educação - mais do que no âmbito oficial da escola - exerce-se na interação social informal e que a moral pressupõe, antes e acima de tudo, conhecimento sobre o ser do homem, torna-se imediatamente evidente que a tradição viva de provérbios populares é poderosa instância de educação moral (que, naturalmente, valerá o que valerem os conteúdos veiculados...). No caso, essa educação se faz, antes de mais nada, pela possibilidade de circunscrever, de configurar uma atitude que passaria despercebida, se os provérbios não chamassem a atenção para ela: especialmente para a educação moral vale a intuição contida na acumulação semântica da palavra castelhana enseñar: ensinar e mostrar! ${ }^{308}$

O mesmo autor afirma que há afinidade entre os provérbios e o filosofar de Tomás de Aquino:

É natural que haja afinidade com provérbios nesse filosofar, em que o centro da vida moral é ocupado pela virtude da prudentia: a arte de decidir de acordo com o reto conhecimento da realidade e do homem. Os provérbios enquanto condensação da experiência - informam principalmente a dimensão cognoscitiva da prudentia. ${ }^{309}$

Os provérbios permitem, ao condensar uma experiência, indicar um caminho, propor uma reflexão e uma análise sobre si mesmo. Extrapolamos isso para Hus. Este, ao propor essa reflexão sobre si mesmo no passado, presente e futuro, retoma o final da carta 45 em sua preocupação com os três males: a carne, o mundo e o demônio, na medida em que eles são a

\footnotetext{
${ }^{305}$ A frase é considerada um provérbio por SPINKA, The letters of John Hus, p. 172, nota 18.

${ }^{306}$ Frase idêntica está presente na carta 74 ao nobre Henry Škopek de Dubá, acrescida de "quid loqueris et ubi, de quo, cur, quomodo, quando" (o que falares e onde, de quem, por que, como, quando). Esta carta foi escrita em tcheco, mas este trecho está em latim, mostrando a força deste provérbio.

${ }^{307}$ LAUAND, Luiz Jean (org.). Oriente \& ocidente: Idade Média: cultura popular estudos e traduções. Vol. 7. São Paulo: Centro de Estudos Árabes/DLO-FFLCH-USP; Edix edições, 1995, p. 5.

${ }^{308}$ LAUAND, Luiz Jean. 500 provérbios portugueses antigos: educação moral, mentalidade e linguagem. Disponível em < http://www.hottopos.com/vdletras4/jeans2.htm>. Acesso em 25 dez. 2009.

${ }^{309}$ idem. Medievália: filosofia, teatro e pedagogia. Série Acadêmica. São Paulo: Hottopos, 1997, p. 85.
} 
síntese das tentações do corpo, da sociedade e do espírito, que também podemos resumir nas preocupações medievais da sexualidade, do dinheiro e da palavra. Por isso, na carta 76, a recomendação "cuidado com o futuro, ou seja, com os pecados"

Ao analisarmos detalhadamente as cartas escritas para Martin de Volyně (45 e 76), procuramos estabelecer o modo como Hus sustentou por meio delas sua relação mestrediscípulo com ele. Mais do que educar por meio das cartas, como fez com as cartas pastorais, as cartas a Martin são o indício de um início da transmissão de seu legado ao discípulo que continuará sua tarefa de educar. Elas exprimem o conteúdo moral da educação medieval, com as principais preocupações daquele tempo, o vínculo e a proximidade entre mestre e discípulo e sustenta a defesa da verdade com base na humildade e na autoridade da fé e da razão. ${ }^{310}$

Aqui terminamos o primeiro eixo de nosso trabalho de construção de um educador pelas cartas. Partimos de um universo de pouco mais de uma centena de cartas, organizadas em epistolários que as apresentam em latim, tcheco e inglês. Buscando ir além de uma ordem cronológica, inspirados nas reflexões históricas de Carlo Ginzburg, procuramos por indícios de uma intenção educativa e do estabelecimento de uma relação educador-educando. Do total da correspondência hussita disponível, analisamos mais detidamente vinte e cinco cartas. Vinte e três destas nós denominamos pastorais e duas são cartas pessoais escritas a um de seus discípulos, Martin de Volyně.

As cartas pastorias são educativas para a comunidade da Capela de Belém, a qual Hus chefiou até o momento em que foi para o exílio. A principal hipótese que aqui desenvolvemos é que ele tenha continuado seu trabalho pastoral, que antes realizava presencialmente na capela, por meio de cartas e desenvolveu um padrão de escrita que manteve até sua última carta. Confirmam esta hipótese o conjunto de sinais que reunimos em nove elementos. As cartas 27 e 28, como explicamos, concentram todos esses elementos, que arrolamos aqui: uso

\footnotetext{
${ }^{310}$ Antes de seguirmos, vale a pena uma nota sobre a carta 49. Spinka supõe que ela pode ter sido escrita a Martin de Volyně. Novotný, editor tcheco das cartas de Hus de 1920, supõe ser Havlík (V. SPINKA, The letters of John Hus, p. 128, nota 1). Workman e Pope, seguindo a interpretação de Palacký, editor das cartas de Hus de 1869, afirmam (V. WORKMAN; POPE, The letters of John Hus, p. 281 e PALACKÝ, Documenta, p. 149) que esta carta é, muito provavelmente, uma fraude, por diversos indícios, em especial o fato de nela haver uma exortação à dupla comunhão, tema que, segundo eles, só foi assumido por Hus quando estava na prisão em Constança (a carta 83 é dedicada a este tema). Bonnechose não faz qualquer menção a essa questão. Parece-nos que esse questionamento é exclusivo de Palacký. O conteúdo da carta assemelha-se em alguns pontos às outras dirigidas a Martin. No entanto, não há qualquer expressão que indique a proximidade que há naquelas. O texto completo restringe-se a aconselhamentos. A hipótese de interpolação de cartas diferentes, de Workman e Pope, é coerente. Caso a carta seja verdadeira, a hipótese de Novotný dela ser dirigida a Havlík parece-nos mais coerente que a de ser dirigida a Martin. De qualquer modo, seu conteúdo não traz nenhuma novidade em relação ao que vimos nas cartas 45 e 76 e, por isso, limitamos nossos comentários a esta nota.
} 
do vernáculo, uso da autoridade teológica das citações, referência às epístolas de Paulo de Tarso, reconhecimento da aprendizagem por parte do educador, conhecimento e defesa da verdade, aconselhamento e vivência de uma conduta moral cristã, uso de metáforas de animais para propor uma interpretação de conduta moral, uso da metáfora do Ganso a partir de seu nome, referência à Capela de Belém como um local do ensino da verdade.

O trabalho educativo de Hus, porém, não se limitava a uma ação pastoral com a comunidade tcheca que frequentava a Capela de Belém. Ela também ocorria na relação educador-educando entre o clérigo e seus discípulos. Esta é mais difícil de ser encontrada, visto que há poucas cartas pessoais escritas para discípulos e termos a disposição essas duas cartas a Martin é contingencial. Martin de Volyně foi um sujeito sobre o qual, se não fossem as cartas conservadas que recebeu de Hus, pouco ou nada saberíamos a respeito, pois não há outros documentos que permitam localizá-lo historicamente. Sabemos apenas que Hus considerava-o como discípulo. Mas a intimidade, a confiança e a dedicação que eles compartilharam permanecem registradas na escrita hussita. Analisando com mais detalhes as duas cartas que com certeza foram escritas a Martin, encontramos elementos semelhantes aos das cartas pastorais, com detalhes adicionais (como no caso do conteúdo da educação moral medieval e da defesa da verdade) e um novo elemento que caracteriza a relação entre eles como educativa: a transmissão do legado.

Abrimos, então, o espaço para um novo questionamento: de que é constituído esse legado e como ele foi retransmitido ao longo dos séculos seguintes? Uma resposta a esta pergunta é o que nos propomos a dar no terceiro capítulo. 


\section{Capítulo 3. A construção de um educador por seu legado}

No segundo capítulo desta tese, procuramos demonstrar como Jan Hus educou por meio das cartas e explicitou nelas sua intenção educativa. Das características que apontamos, destacamos, pelo uso que delas faremos neste capítulo, duas: a defesa da verdade e a transmissão de seu legado educativo. A primeira aparece mais claramente nas cartas pastorais e a segunda nas cartas para seu discípulo Martin de Volyně. Propomo-nos a demonstrar como Hus deixou as bases de seu legado de defesa da verdade em suas cartas e como aqueles que se sentiram educados por Hus reelaboraram seu legado ao longo dos anos.

Apenas uma pequena parte da correspondência que dispomos é de cartas escritas por outras pessoas. Não é possível, portanto, tentarmos reconstruir a visão dos educandos a partir das respostas dos interlocutores de Hus. Porém, entendemos que a variedade de traduções e edições dessas cartas constitui-se num campo de pesquisa muito fértil e a própria reedição das cartas hussitas em diversos espaços-tempos é um indício do reconhecimento de um legado a ser preservado. Propomos um estranhamento, no sentido utilizado por Ginzburg, do próprio ato de republicar a correspondência de Hus.

Para isso, faremos uma leitura sobre a construção da figura de Hus como um educador a partir de seu legado educativo, com destaque para a defesa da verdade. Iniciamos com a questão da morte de Hus e a necessidade de guardar sua correspondência. Veremos como ele mesmo percebeu que era fundamental preservar sua memória e solicitou nas suas cartas que isso fosse feito. Nessa etapa, resgataremos a descrição da morte de Hus que foi veiculada a partir do relato de Petr de Mladoňovice.

Seguimos para a história das edições das cartas hussitas, partindo de uma análise do prefácio de Martinho Lutero, o primeiro a publicá-las, passando pelas edições inglesas dessas cartas como exemplos da preservação desse legado ao longo dos anos.

Depois, estabeleceremos um diálogo com a hipótese de Tim Chodan, autor de uma tese sobre Jan Hus ${ }^{311}$, de que haveria diferentes imagens de Hus ao longo dos anos, observando a presença das edições da correspondência hussita nos momentos que ele estabeleceu.

\footnotetext{
${ }^{311}$ CHODAN, The use and abuse of Jan Hus...
} 
Concluímos analisando um apanhado de imagens contemporâneas de Hus que vão desde a tese de Renato Oberg defendida na Universidade de São Paulo na década de $1970^{312}$ até o discurso do papa João Paulo II a respeito de Hus em 1999, passando por elementos da cultura popular tcheca.

Acompanharemos diferentes imagens que vão registrando a memória de um legado constantemente repetido, porém reelaborado a cada nova repetição.

\subsection{A construção de um legado em seus primórdios: morte e verdade}

Um dos principais documentos utilizados pela historiografia para elaborar suas narrativas a respeito da condenação e da morte de Jan Hus é um relato escrito por Petr de Mladoňovice que cobre uma série de eventos anteriores à viagem à Constança, a prisão, o julgamento e a morte de Hus. A fonte para sabermos mais sobre este personagem é a introdução à tradução deste texto feita por Spinka ${ }^{313}$. Petr, conforme apontamos no capítulo 1 desta tese, foi aluno da Universidade de Praga, tendo obtido seus títulos de Bacharel em Artes no ano de 1409 e de Mestre em Artes no ano de 1416. Morou no Colégio estabelecido junto da Capela de Belém, o que sugere a possibilidade de um contato anterior com Hus. Spinka afirma que esse contato foi grande e que a devoção de Petr pelo clérigo de Belém é explícita em seu relato.

Esteve com este em Constança, sendo o secretário designado pelo nobre Jan de Chlum para fazer o registro da viagem. Após a morte de Hus, tornou-se professor da Universidade de Praga e progressivamente assumiu um papel central no grupo "moderado" dos Utraquistas ${ }^{314}$, opondo-se a Jan Žižka, líder dos Taboritas ${ }^{315}$. Morreu em 7 de fevereiro de 1451, como um dos principais membros dos Utraquistas.

Esse relato que Petr intitulou Historia de sanctissimo martyre Johanne Hus foi publicado em Nuremberg, por influência de Martinho Lutero, no original em latim, em 1528,

\footnotetext{
${ }^{312}$ OBERG, João Huss, um injustiçado?

${ }^{313}$ SPINKA, John Hus at the Council of Constance, p. 79 e seguintes.

${ }^{314}$ Utraquistas é um dos nomes atribuídos ao grupo dos Hussitas, posteriores à morte de Jan Hus, que defendiam o oferecimento da comunhão com o pão e com o vinho (sub utraque specie) também para os leigos. Também eram chamados de Calixtinos. O utraquismo foi condenado como heresia pelos Concílios de Constança, Basileia e Trento.

${ }^{315}$ Taboritas é o nome de outro grupo Hussita, liderado por Jan Žižka, membro da nobreza inferior que liderou um exército de combatentes utraquistas contra as ações do exército do rei Sigismundo e as cruzadas enviadas pela Cúria Romana. Esse grupo foi considerado mais radical pelo uso da força militar. Em 1434, os Taboritas, já distantes dos Utraquistas em virtude dos acordos políticos para a elaboração da Compactata no ano anterior, foram derrotados na Batalha de Lippau. Em 1457, um novo grupo dissidente dos poucos taboritas remanescentes começa a se formar. Este grupo ficou conhecido como Unitas Fratrum (Irmãos Morávios ou Irmãos Boêmios).
} 
e traduzido para o alemão em 1529. Não temos informações a respeito de quem fez a tradução. Sabemos, apenas, que Lutero esteve envolvido com a publicação, podendo ter participado dela. Foi incluído por Jean Crespin, juntamente com as cartas de Hus, em 1554 em seu Le livres de martyr, cuja versão em latim surgiu dois anos depois com o nome Acta matyrum. Influenciou o Book of Martyrs de John Foxe, que surgiu inicialmente em 1554 e foi diversas vezes ampliado até atingir a versão publicada em Basileia no ano de 1559 . O relato de Petr foi publicado na Boêmia apenas em 1869 por Palacký (Documenta), sendo posteriormente revisto, a partir de novas fontes, em 1932 por Novotný. Esta última é base para a tradução de Matthew Spinka de 1965 que aqui utilizamos. Foi Palacký que deu a organização em cinco capítulos e o nome atual do texto: Relatio de Mag[ister] Johannis Hus causa in Constantiensi consilio acta.

Estas informações sobre a circulação do texto de Petr de Mladoňovice são suficientes para atestarmos que sua narrativa e as cartas de Hus, juntas, foram fundamentais para a construção de um imaginário a respeito do clérigo da Boêmia. Um imaginário que o colocou como mártir (martyre) e mestre (magister), defensor da verdade, um dos símbolos da reforma protestante, resgatado como tal por três importantes figuras da Reforma: Martinho Lutero, Jean Crespin e John Foxe.

Isso, porém, ocorreu mais de um século depois da morte de Hus. Nos anos seguintes à sua morte, o impacto desse evento estava restrito à Boêmia. Sabemos ${ }^{316}$ que nos dias 6 de julho de cada ano, provavelmente nas igrejas que apoiavam os Hussitas, além dos trechos do Evangelho eram lidas a parte final do Relatio (que narra a morte de Hus) e as cartas de despedida de Hus. E isso continuou a ocorrer por cerca de duzentos anos ${ }^{317}$. Mesmo que estas informações sejam exageradas e careçam de outras fontes que a corroborem além dos livros de Spinka, elas são um forte indício da manutenção da memória da vida de Hus que o transforma em mártir defensor da verdade.

Petr de Mladoňovice, no parágrafo final de seu texto, deixa claras as suas intenções de preservação da memória de Hus:

Assim, eu descrevi, então, claramente e em detalhes a sequência da morte e da agonia do celebrado Mestre Jan Hus, o eminente pregador da verdade evangélica, de modo que, no curso do tempo, sua memória possa ser lembrada vividamente. Meu princípio não foi o de enfeitar a descrição com um amontoado de palavras bonitas, carecendo do que foi central no fato e no

\footnotetext{
${ }^{316}$ SPINKA, John Hus at the council of Constance, p. 80.

${ }^{317}$ Spinka não afirma a fonte para esta informação, mas supomos estar na edição de Novotný do texto de Petr.
} 
feito, de modo a fazer cócegas aos ouvidos desejosos desse prazer. Pelo contrário, foi o de falar daquilo que é essencial da substância dos procedimentos do julgamento acima mencionado, o qual eu conheço claramente a partir do que eu mesmo vi e ouvi. Aquele que sabe todas as coisas é minha testemunha que não menti. Eu prefiro ser culpado de ter usado palavras ineptas e estranhas de modo que reconheçam que eu dei o testemunho da verdade, para que a memória do Mestre, sua mais leal defensora, possa assim viver no futuro.

Não há palavras mais claras que estas para indicar que a intenção de Petr é preservar a memória de Hus para que, no futuro, ele possa ser lembrado como o defensor da verdade. Também vemos neste trecho o reconhecimento de Hus como um mestre além de um adjetivo que o coloca num lugar diferenciado: o eminente pregador da verdade. Eis o início do legado hussita fora das mãos de Hus. É este o documento que inicia, para além das cartas, seu legado educativo.

Preservar a memória e a verdade por meio do fiel registro do que aconteceu durante o Concílio de Constança foi uma intenção e um pedido do próprio Hus. Na carta escrita a seus amigos em Constança em 22 de junho de 1415 (número 85), ele se preocupa com o conteúdo de suas cartas parar em mãos erradas:

Ele [Páleč] também me disse que eles têm uma carta que foi escrita para a Boêmia, na qual está mencionado que eu cantei dois versos sobre a prisão no castelo na melodia de 'Deus Todo-poderoso'. Pelo amor de Deus, guarde as cartas. Não deixe que elas sejam carregadas por qualquer pessoa. Faça com que os senhores as guardem cuidadosamente entre outros documentos seculares.

Hus estava preocupado com o fato de uma carta ter chegado às mãos de seus opositores e nela conter algo que pudesse ser usado contra ele, como ter modificado a letra de uma canção litúrgica para incluir palavras suas a respeito de sua prisão em Gottlieben ${ }^{318}$. Por isso, pede que as cartas sejam transportadas apenas por pessoas de confiança e sejam guardadas pelos nobres que o apoiavam, junto com outros documentos seculares. Este é um indício que Hus solicitava a guarda de sua correspondência em virtude do conteúdo. Se Hus não quisesse que suas cartas fossem guardadas, ele pediria que elas fossem destruídas. Na que

\footnotetext{
${ }^{318}$ SPINKA, The letters of John Hus, p. 185, nota 7, afirma que não está claro porque isso seria uma ofensa. Entendemos, conforme apontamos, que a ofensa seria modificar a letra de uma canção litúrgica, o que poderia se configurar numa blasfêmia. Se Hus realmente parodiou um hino litúrgico, utilizou de certa ludicidade presente em outras de suas cartas. Percebamos que ele não criticou sua ação de fazê-lo, como em outros momentos criticou seus erros, mas pediu que as cartas fossem guardadas com cuidado. Como já afirmamos, Hus não era contra o brincar mas contra os vícios do excesso envolvidos nos jogos e danças. E, embora ele vivesse numa época de pessimismo, herdava uma valorização do lúdico na vida humana, como encontramos em Tomás de Aquino, que afirma: "o brincar é necessário para a vida humana”. V. LAUAND, Deus Ludens.
} 
escreveu em 13 de junho (número 75), por exemplo, ele afirma que destrói as cartas recebidas de Petr de Mladoňovice imediatamente após sua leitura. Meses antes, em 3 de janeiro, ele pede que a carta, de número 54 , seja rasgada imediatamente.

Antes mesmo do que escreveu em 22 de junho, Hus já se preocupava com o vai-e-vem de sua correspondência. Na carta escrita em 9 de junho para os mesmos destinatários (número 70), ele pede "não carregue cartas". Em janeiro de 1415 (número 60), ele pede para Jan de Chlum para esconder uma de suas cartas (pastoral número 58), caso ela ainda não tivesse sido enviada à Boêmia, pois ela poderia causar problemas. Embora ele não explique o motivo, entendemos que a carta 58 poderia causar problemas por afirmar que não há homem nenhum que possa aconselhá-lo a não ser Jesus. Pensamos que essa afirmação talvez pudesse ser usada para indicar que ele era obstinado em suas ideias.

Na carta de 24 de junho de 1415 para Petr e Jan Cardinal de Rejnštejn (número 88), percebemos que a circulação de sua correspondência era vigiada e Hus estava bastante preocupado com o impacto que ela poderia causar em seus fiéis:

Visto que eles [o Concílio] condenaram apenas os tratados, eu lhe peço que corrija a última carta tcheca que eu mandei hoje, para que o povo de Deus não suponha que todos os meus livros tenham sido condenados, como eu supunha pela carta de ontem. Eu ficaria feliz em ver que nenhuma carta escrita nesta prisão tenha sido mostrada a qualquer pessoa, pois ainda não está definitivamente certo o que Deus fará comigo. Eu temo que qualquer carta minha seja enviada por Ulrich. Ainda peço, pelo amor de Deus, que preserve cautelosamente suas cartas, palavras e ações. Ah, quanto consolo recebi por suas cartas que, junto das minhas, irão, espero, pela graça de Deus, beneficiar as pessoas.

Além da preocupação com as cartas que envia e recebe, Hus mostra que as escreveu para "benefício das pessoas", reforçando o caráter educativo da correspondência. Sobre o nome citado neste trecho, Ulrich, não temos qualquer informação ${ }^{319}$. Mais próximo de sua morte, já com a certeza de que não haveria volta para sua condenação, Hus preocupa-se em preservar sua memória. Escreve, além das suas duas últimas cartas para o povo da Boêmia (números 100 e 101), no mesmo dia 5 de julho de 1415, véspera de sua morte, uma carta para seus amigos em Constança (número 99). O conteúdo dessas três cartas dá uma visão de como foram seus últimos dias, suas decisões finais e sua intenção de preservar sua memória.

\footnotetext{
319 ibidem, p. 191, nota 5 afirma que ele talvez seja um dos servos de um nobre thceco, mas não está claro o motivo do aviso de Hus a seu respeito. Seria ele um inimigo?
} 
Percebemos que Hus escreve o mesmo texto, sua despedida, em três formatos diferentes: o pragmático, o íntimo e o formal.

O início da carta 101, com a saudação e a captação da benevolência, mostra que ele quis deixar o registro de sua audiência como um "memorial da verdade":

Eu, mestre Jan Hus, na esperança de ser um servo de Jesus Cristo, desejando de todo o coração que os fiéis do Cristo, após minha morte, não tenham ocasião de serem ofendidos por causa de minha morte, julgando-me como se eu fosse um herege obstinado. Tomando o Cristo Jesus como minha testemunha, por cuja lei eu desejei morrer, eu escrevo isto para os amigos da verdade como um memorial.

Em outras palavras, Hus diz que não era um herege, pelo contrário, defendia a verdade e, como sua condenação como herege poderia interferir na compreensão que as pessoas tinham de sua figura, ele escreveu a carta contando como foi sua audiência. Entendemos que essa carta e a número 91 procuram registrar a injustiça que Hus viu nas ações do Concílio. Esse procedimento de registrar a injustiça será retomado por Petr em seu relato.

A carta 100, como já apontamos, mostra o Hus mais íntimo, preocupado com os seus amigos mais próximos. A carta 99 apresenta, mais formalmente, sua posição final e o pedido explícito de preservar a memória dos eventos que viriam a acontecer, o que Petr, como o provável destinatário desse pedido, afirmou cuidar de fazer. Eis o texto integral da carta 99:

Amanhã, na hora sexta, devo responder, em primeiro lugar, se eu estou disposto a declarar que cada artigo retirado de meus livros é errôneo e se eu vou desmenti-los e pregar o oposto. Em segundo lugar, se eu estou disposto a confessar que eu preguei tais artigos, como foi provado pelas testemunhas. Em terceiro lugar, se eu vou abjurar.

Se ao menos Deus em Sua graça trouxesse o rei [Sigismundo] para a audiência! Eu gostaria de vê-lo ouvindo as palavras que o mais gentil Salvador colocará em minha boca!

Se eles me derem uma pena e um papel eu responderei por escrito, espero, com a ajuda de Deus, da seguinte forma:

'Eu, Jan Hus, na esperança de ser um servo de Jesus Cristo, não estou disposto a declarar que cada artigo retirado de meus livros é errôneo, para não condenar a opinião dos santos doutores, especialmente de Santo Agostinho. Segundo, a respeito dos artigos atribuídos a mim por falsas testemunhas, não estou disposto a confessar que os afirmei, preguei e acreditei. Terceiro, eu não estou disposto a abjurar, para não cometer perjúrio.' 
Pelo amor de Deus, preserve as cartas cuidadosamente e as envie para a Boêmia com precaução similar, para não causar grande perigo às pessoas. Caso eu não escreva a vosso amor por causa de alguma contingência, imploro-lhe que preserve, junto de meus amigos, a minha memória e reze para que eu receba a constância junto de meu amado irmão em Cristo, Mestre Jerônimo. Suponho que ele também sofrerá a morte pelo que entendi dos delegados do Concílio.

Esta carta resume todos os principais pontos para a construção no imaginário da figura de mestre e mártir. Em primeiro lugar, sabemos que ele foi condenado por artigos, extraídos de seus livros, que ele supostamente afirmou nas pregações na Capela de Belém. Para ele, os testemunhos foram falsos e os artigos que são verdadeiros, estão corretos de acordo com as escrituras e, principalmente, com Santo Agostinho, que aqui aparece, pelo destaque, como uma das principais influências de seu pensamento.

Com relação a Santo Agostinho, há indícios que ele tenha fortemente influenciado as ideias de Hus. Nas cartas, ele é citado como autoridade para o clérigo da Boêmia afirmar que devemos obedecer em primeiro a uma autoridade maior, ou seja, a Deus em relação às ordens dos homens (carta 17) e para validar a opção deste de se exilar para salvar seu rebanho (carta 25). No tratado De Ecclesia, Agostinho foi citado diversas vezes por Hus no que diz respeito ao conceito de Igreja, destacando, nesse tratado, o papel do Bispo de Hipona:

Portanto, não há dúvidas que Santo Agostinho contribuiu muito mais para a
igreja do que muitos papas e, no que diz respeito à doutrina, muito mais do
que todos os cardeais, desde o primeiro até aqueles que estão hoje no ofício.
Pois, no governo da igreja, ele conhecia as Escrituras do Cristo melhor do
que eles e também definiu a natureza da fé católica melhor ao limpar a igreja
dos erros heréticos e corrigi-los. ${ }^{320}$

Também percebemos pela carta 99 que, de todos os seus inimigos, um dos mais importantes é o rei Sigismundo. Petr de Mladoňovice em seu relato narrou que o rei demonstrou apoiar Hus, mas, na verdade, foi o principal articulador de sua condenação. Ao contrário de Páleč e Stanislav de Znojmo, que abertamente mudaram de posição, de apoiadores para opositores, o rei garantiu um salvo-conduto e, além de não fornecê-lo, pediu privadamente aos arcebispos do Concílio que condenassem Hus, mesmo que ele abjurasse, visto que isso seria uma mentira ${ }^{321}$. É curioso observar que a percepção de Sigismundo a respeito de uma possível abjuração de Hus era verdadeira, visto que, caso este voltasse atrás em suas ideias, seria uma mentira, um perjúrio, como o último afirma na carta.

\footnotetext{
${ }^{320}$ HUSS, The Church, p. 149-150.

${ }^{321}$ SPINKA, John Hus at the concil of Constance, p. 221-222 (Relatio, parte IV).
} 
E, na conclusão, Hus dirige-se a seu interlocutor com um vocativo de forte vínculo, "ao vosso amor", e pede, caso algo aconteça com ele, que guarde as cartas e preserve sua memória. É provável que esse pedido seja a Petr. Unindo as três últimas cartas, temos a solicitação de Hus para preservar sua memória, por meio de suas cartas, seus objetos e do relato verdadeiro dos acontecimentos.

Como afirmamos, a partir de Ginzburg, todo relato histórico busca a verdade, embora seja impossível atingi-la na plenitude em virtude da distância que separa o narrador do fato. Neste momento, mais importante do que reconstruir o relato da condenação e morte de Hus por meio da análise de diferentes fontes, queremos observar a imagem que Petr de Mladoňovice ajudou a construir ao longo dos séculos. Pela abrangência de seu documento, é a fonte mais utilizada pelos biógrafos de $\mathrm{Hus}^{322}$ no que diz respeito ao ano de 1415. Para compreendermos essa imagem, vamos apresentar uma síntese da última parte da narrativa, a que conta o último dia de vida de Hus, ou seja, o dia seguinte à escrita das cartas 99, 100 e 101.

Relata Petr ${ }^{323}$ que dois nobres, Václav de Dubá e Jan de Chlum, e mais quatro bispos foram até Jan Hus, no dia 5 de julho de 1415, para ouvirem sua palavra final. Hus foi, então, retirado da prisão e levado para a audiência no Concílio. Nesse momento, Jan de Chlum disselhe que não sabia como aconselhá-lo, mas que ele seguisse "os ditados de sua consciência" e permanecesse firme naquilo que ele sabia ser a verdade. Foi, então, que Hus, "chorando, respondeu com humildade":

Nobre Jan, tenha certeza que se eu soubesse que escrevi ou preguei algo errôneo contra a lei e contra a madre Igreja, eu desejaria humildemente revogá-lo. Deus é minha testemunha. Eu sempre quis que me mostrassem Escrituras melhores e mais relevantes do que aquelas que eu escrevi e ensinei. E se elas fossem mostradas para mim eu abjuraria de muito boa vontade. $^{324}$

Momentos depois, um dos bispos presentes no Concílio chamou Hus e lhe perguntou se ele queria ser mais sábio que o Concílio. Ele, então, respondeu: "Eu não quero ser mais sábio que o Concílio, mas eu peço, dê-me ao menos alguém do Concílio que possa me instruir

\footnotetext{
${ }^{322}$ Basta observarmos as notas de rodapé dos livros de Matthew Spinka e David Schaff para perceber o quanto é citada essa fonte quando se trata do relato das audiências, da condenação e da morte.

${ }^{323}$ Esta síntese foi feita com base na tradução para o inglês da parte V do Relatio de Petr de Mladoňovice presente em SPINKA, op. cit., p. 224-234.

${ }^{324}$ ibidem, p. 224.
} 
com Escrituras melhores e mais relevantes e eu estarei pronto para abjurar." ${ }^{325}$ Com essa resposta, os bispos disseram que ele continuava obstinado em sua heresia e o mandaram de volta para a prisão.

Neste trecho, bem como em todo o texto, Petr refere-se a Hus como Mestre Jan Hus e, às vezes, apenas como Mestre. Ao citar essas palavras do chefe da Capela de Belém, o narrador ajuda a construir a imagem do mestre que ensina. A palavra mestre, quando lida em nosso século, traz um caráter de líder, que deixou discípulos como nos mostra em diversas passagens Gusdorf. ${ }^{326}$ Mesmo que originalmente o uso da palavra mestre por Petr de Mladoňovice não seja o mesmo de Gusdorf, a constante repetição dessa palavra ao longo dos séculos favoreceu o deslocamento de sentido para o de "mestre que ensina". Le Goff nos mostra que o intelectual medieval, aquele que trabalha "com a palavra e a mente" e não "com as mãos", era chamado por vários nomes como "magister (mestre), doctor (doutor), philosophus (filósofo), litteratus (literato)",327. Hus era um intelectual.

No dia seguinte, 6 de julho de 1415, “o sábado após São Procópio”, modo comum de se referir às datas naquela época, utilizando como referência os dias dos santos, Hus foi levado pelo arcebispo de Riga para a catedral da cidade de Constança. Montaram com um banco um pedestal no qual colocaram os trajes e ornamentos sacerdotais que seriam, depois, retirados de Hus. Ele se aproximou do pedestal, ajoelhou-se e rezou. O bispo de Lodi iniciou um sermão a respeito das heresias e de como elas afetaram à Igreja, além do fato de ser dever do rei extirpá-las, especialmente a simonia (comércio de bens espirituais). Lembremos que esta não era uma das acusações contra Hus, pelo contrário, a perseguição deste iniciou justamente quando ele se opôs à bula da venda de indulgências do papa João XXIII. Enquanto isso, o procurador do Concílio, Henry de Piro, fez uma moção para que continuassem o julgamento de Hus até atingirem a decisão final.

Foram lidos o processo e os artigos contra ele. O acusado, então, na tentativa de responder a cada um deles foi silenciado pelo cardeal Pierre d'Ailly, presidente da comissão de julgamento e cardeal de Cambrai, que o impeliu a responder a todos os artigos juntos e ao final. Hus, então disse, "como posso responder a todos eles juntos se eu não consigo refletir a respeito de todos juntos?". Francesco Zabarella, um dos membros da comissão e cardeal de

\footnotetext{
${ }^{325}$ ibidem, p. 225.

${ }^{326}$ GUSDORF, Professores para quê?, passim.

${ }^{327}$ LE GOFF, O homem medieval, p. 20.
} 
Florença, ordenou-o ficar em silêncio, pois “já ouvimos bastante de você". Insistiu novamente e novamente foi silenciado, ao que se sentou e rezou.

Foram lidos, então, os artigos contra ele atestados por testemunhas, que incluíam a negação da transubstanciação e a declaração que ele se dizia a quarta pessoa da divindade. Ele negou a todos. Os cardeais disseram que ele apelou a Deus e condenaram esse tipo de apelo. Hus, então, respondeu: "Eu continuo a declarar que não há apelo mais seguro do que ao Senhor Jesus Cristo, que não se sujeita ao suborno perverso e nem se deixa levar por falso testemunho, mas dará a cada um o que ele merece.”328

Depois, acusaram-no de contumácia, por não ter comparecido à convocação da cúria, o que ele respondeu que enviou diversos representantes que não foram recebidos, alguns sendo até mesmo presos. E afirmou que foi ao Concílio por sua própria vontade e com um salvo conduto do rei, querendo provar sua inocência e sua fé.

A sentença contra ele foi lida e ele respondeu, em alguns pontos falando mais alto. Novamente reafirmou que não estava obstinado por sua visão, mas que esperava pela instrução a partir das Escrituras.

Seus livros foram utilizados como prova de acusação contra ele e o resto da sentença foi lida. Hus pediu a Jesus Cristo, em voz alta, que perdoasse aqueles que o acusaram falsamente e que produziram falsos artigos e testemunhas contra ele. Muitos clérigos zombaram dele. Então, Hus vestiu os paramentos sacerdotais como se fosse celebrar uma missa. Quando vestiu a alva, disse que Jesus, quando foi levado de Herodes a Pilatos, usava trajes brancos. Quando estava todo paramentado, os bispos exortaram-no a abjurar e revogar suas ideias. Hus, "chorando tristemente", subiu no banco, virou-se para a multidão e disse:

Eis, os bispos exortam-me a revogar e abjurar. Mas eu temo fazê-lo, pois caso o fizesse seria um mentiroso aos olhos do Senhor e ofenderia a minha consciência e a verdade de Deus. Pois eu nunca acreditei nesses artigos que são testemunhados falsamente contra mim. Pelo contrário, eu escrevi, ensinei e preguei o oposto. Se o fizesse, eu também ofenderia a multidão para quem eu preguei e os outros que pregam a Palavra de Deus. ${ }^{329}$

Este trecho apenas sustenta as observações que fizemos anteriormente a respeito da importância da defesa da verdade e da construção da imagem de educador. Aqui, Hus se coloca como alguém que defendeu a verdade, utilizando uma tríade que sintetiza a ação educativa de sua época: escrever, ensinar e pregar. Considerando que estas palavras não foram

\footnotetext{
${ }^{328}$ SPINKA, op. cit., p. 228.

${ }^{329}$ ibidem, p. 229-230.
} 
escritas por Hus, mas atribuídas a ele por Petr de Mladoňovice, temos aqui um exemplo de como este último contribuiu em seu relato para construir a imagem do educador. Não estamos negando ou afirmando que estas palavras sejam de Hus. Sendo uma transcrição exata ou não do que ele disse durante seu julgamento, elas representam o destaque que o autor do relato quis dar a elas.

Ao ouvirem essas palavras de Hus, alguns prelados disseram que, naquele momento, percebiam o quanto ele estava obstinado em sua heresia. Seguiram, então, para a cerimônia de deposição do ofício sacerdotal. Retiraram o cálice de suas mãos, amaldiçoando-o. Tiraram a estola, a casula e todos os paramentos, amaldiçoando-o a cada peça retirada. Quando todas as vestes estavam retiradas, os bispos começaram a discutir como cortariam a tonsura, com lâmina ou com tesoura. Hus disse para o rei que eles ainda não concordavam no modo de fazer sua difamação. Cortaram-na em quatro partes: direita, esquerda, frente e trás. Os bispos disseram "entregamos sua alma ao diabo" e Hus respondeu "e eu a entrego ao mais misericordioso senhor Jesus Cristo". Colocaram-lhe uma coroa de papel, arredondada de cerca de cerca de quarenta e cinco centímetros de altura ${ }^{330}$, com desenhos de demônios prestes a agarrar e rasgar uma alma com suas unhas. Nela estava escrito "este é um heresiarca".

Aqui, lembramos da carta 29, que analisamos no capítulo anterior, no qual Hus afirma que o ritual da excomunhão foi feito para "assustar aos simples e conduzi-los segundo a vontade de quem o executa". Não encontramos qualquer comentário sobre essa afirmação de Hus em nossas fontes, o que nos abre espaço para uma questão: o que será que ele pensou durante o ritual de sua deposição? Teria ele olhado para aquele ritual como algo feito apenas para "assustar aos simples"?

Hus foi, então, entregue ao Duque Ludwig do Palatinado que o entregou aos executores. A Igreja condena, mas quem executa é o braço secular. Ao sair da igreja, viu que no cemitério anexo seus livros eram queimados e sorriu. Exortou as pessoas para não acreditarem na acusação e, como afirmou Petr, "quase todos os habitantes da cidade, com armas na mão, acompanharam-no para a morte". 331

Durante a Idade Média, mas especialmente a partir do século XIV, como apresentam as obras de arte do período, a morte é um espetáculo e um momento no qual as pessoas buscavam vencê-la como o Cristo fizera. É nesse sentido que o historiador francês Duby

\footnotetext{
${ }^{330}$ No original, em latim, "ad quantitatem fere unius cubiti in altitudine" (PALACKÝ, Documenta, p. 321). Cubitum ou cubitus é a medida do cúbito até a ponta do dedo médio. SPINKA, John Hus at the council of Constance, p. 231, traduziu o trecho como "almost eighteen inches high". Dezoito polegadas medem, aproximadamente, $45,7 \mathrm{~cm}$.

${ }^{331}$ ibidem, p. 231.
} 
prepara-nos para o caráter da execução que se segue: "Morrer é, de certa forma, pregar. Cumpre então morrer em público, para distribuir, para dar a todos os que, ao redor de si, se acham ainda vivos uma lição de renúncia." 332 É a lição que dará o clérigo da Boêmia.

O lugar da execução estava no caminho de Constança para Gotlieben, num pequeno prado entre os portões e o fosso desta última. Chegando ao local, Hus "cantou devotamente" alguns salmos, especialmente os de número 51 e 31. Petr destaca as frases "Tem piedade de mim, ó Deus", "eu me abrigo em ti" e "em tuas mãos eu entrego meu espírito"333. É clara, especialmente nesta última frase, a qual Hus repetiu ${ }^{334}$, a relação da cena de execução de Hus e a execução do Cristo de acordo com o evangelho de Lucas "e Jesus deu um grande grito: 'Pai, em tuas mãos eu entrego o meu espírito'. Dizendo isso, expirou." ${ }^{335}$ Seja por uma inspiração no sofrimento da paixão de Cristo da parte de Hus ou por uma associação entre os eventos da parte de Petr, o fato é que este registro ajuda na construção da imagem de mártir.

Enquanto rezava, a coroa de papel caiu de sua cabeça e ele sorriu. Um dos soldados correu para recolocá-la dizendo que ele deveria ser queimado junto com os demônios. Hus, então, disse em voz alta "para que os seus pudessem ouvi-lo: 'Senhor Jesus Cristo, estou disposto a enfrentar com muita paciência e humildade esta morte horrenda, ignominiosa e cruel por teu evangelho e pela pregação de tua palavra." ${ }^{, 336}$ Retiram suas roupas e o amarraram e acorrentaram na estaca. Um dos espectadores observou que ele estava virado para leste e pediu que ele fosse virado para oeste, dado que era um herege. ${ }^{337}$

A estaca possuía cerca de quinze centímetros de diâmetro e estava fixada no chão. Colocaram dois fardos de lenha aos seus pés, que ainda estavam calçados e acorrentados. A lenha foi empilhada ao redor de seu corpo chegando até a altura de seu queixo. Novamente, pediram-lhe que abjurasse e Hus disse:

Deus é minha testemunha (...) que essas coisas que são falsamente atribuídas a mim e das quais falsas testemunhas me acusam eu nunca ensinei ou preguei. Mas que a principal intenção de minha pregação e de todos os meus outros atos ou escritos foi apenas que eu pudesse afastar os homens do pecado. E, pela verdade do Evangelho, que eu escrevi, ensinei e preguei de

\footnotetext{
${ }^{332}$ DUBY, Europa na idade média, p. 146. HUIZINGA, O declínio da Idade Média, p. 129 já apontava para um "imperecível apelo de memento mori [que] ressoa através da vida" no final da Idade Média, destacando que em nenhuma outra época se atribuiu tanto valor ao pensamento da morte.

${ }^{333}$ Salmos 51:3 e 31:2,6.

${ }^{334}$ SPINKA, op. cit., p. 231.

${ }^{335}$ Lucas 23:46.

${ }^{336}$ ibidem, p. 232.

${ }^{337}$ Este é um simbolismo cujo significado não encontramos.
} 
acordo com o que disseram e explicaram os santos doutores, estou disposto a morrer alegremente neste dia. ${ }^{338}$

Quando acenderam o fogo, narra Petr, Hus imediatamente começou a cantar em voz alta "Christe fili dei vivi miserere nobis", "Christe fili dei vivi miserere mei" e "Qui natus es ex Maria virgine ${ }^{339}$. Estas frases, presentes no ritual litúrgico da época, são conhecidas como o Kyrie Eleison (Senhor, tende piedade), correspondendo à litania (momento de oração no qual o sacerdote faz curtas invocações a Deus, a Jesus Cristo, à Virgem Maria etc. e a audiência responde). Elas também aparecem em alguns salmos, como o já citado $51 .^{340} \mathrm{O}$ fogo atingiu seu rosto e ele continuou a mover seus lábios. Morreu no tempo em que uma pessoa pudesse recitar o "Pai Nosso" rapidamente por duas ou, no máximo, três vezes.

Enquanto alguns restos ainda faltavam para queimar, os executores puxaram tudo para o chão, adicionaram mais lenha e quebraram os ossos para que estes queimassem mais depressa. Quando encontraram o coração entre os intestinos, espetaram-no com uma lança e dedicaram um "cuidado especial” para queimá-lo até virar cinzas. Por ordem do duque, jogaram suas roupas no fogo para que nenhum tcheco pudesse guardá-las como relíquias. "Então, eles colocaram todas as cinzas num carrinho e as jogaram no rio Reno, que corria por perto."341

E por que alguém guardaria as roupas de Hus como relíquias? A veneração das relíquias, conta-nos Huizinga ${ }^{342}$, era permitida pela Igreja e fazia parte da cultura popular e religiosa da época:

A concepção material dos santos era acentuada pela veneração das suas relíquias e não era somente permitida pela Igreja mas também formava parte integral da religião. Era inevitável que este piedoso apego às coisas materiais arrastasse toda a hagiolatria para uma esfera de idéias brutas e primitivas e conduzisse a extremos surpreendentes. Em matéria de relíquias a fé profunda e linear da Idade Média nunca temeu a desilusão ou a profanação devida a um contato grosseiro com coisas sagradas. $\mathrm{O}$ espírito do século XV não diferia muito dos camponeses da Úmbria que, por volta do ano 1000, pretenderam matar S. Romualdo, o eremita, a fim de se assenhorearem dos seus ossos preciosos; ou dos monges de Fossanova que, depois da morte de S. Tomás de Aquino no seu mosteiro, não hesitaram em

\footnotetext{
338 ibidem, p. 233.

${ }^{339}$ PALACKÝ, Documenta, p. 323.

${ }^{340}$ V. FORTESCUE, Adrian. Kyrie Eleison. The Catholic Encyclopedia. Vol. 8. New York: Robert Appleton Company, 1910. Disponível em: <http://www.newadvent.org/cathen/08714a.htm>. Acesso em 17 mar. 2010.

${ }^{341}$ SPINKA, op. cit., p. 234.

${ }^{342}$ HUIZINGA, op. cit., p. 154.
} 
decapitá-lo e cozinhá-lo e pôr-lhe o corpo em conserva, com receio de perderem as relíquias. Em 1231, enquanto Santa Isabel da Hungria não foi enterrada, uma multidão de devotos cortou e rasgou o pano de linho que lhe cobria a face; cortaram-lhe o cabelo, as unhas e até os bicos dos peitos. Em 1392 o rei Carlos VI de França, por ocasião de uma festa solene, foi visto a distribuir costelas do seu antepassado, o rei S. Luís.

Temia o Duque Ludwig do Palatinado que Hus fosse visto como um mártir ou um santo e suas roupas se transformassem em relíquias, passando a ser objetos de adoração, que eram tão comuns naquela época? O duque era filho de Ruprecht, o rei que disputou a coroa do Sacro Império com Venceslau, este um apoiador de Hus. Sabia, portanto, do papel que Hus exercia na Boêmia e a rede de relações que o clérigo mobilizava. Além disso, podemos reconhecer na atuação do duque comandando a queima de Hus o conflito entre tchecos e alemães. O filho de Ruprecht, o alemão, queimando o protegido de Venceslau, o tcheco, garantiu que nada restasse do condenado para servir como relíquia.

Isso não impediu, porém, a santificação de Hus. É o que vemos no trecho conclusivo do Relatio, que apresentamos no início deste item e repetimos aqui:

Assim, eu descrevi, então, claramente e em detalhes a sequência da morte e da agonia do celebrado Mestre Jan Hus, o eminente pregador da verdade evangélica, de modo que, no curso do tempo, sua memória possa ser lembrada vividamente. Meu princípio não foi o de enfeitar a descrição com um amontoado de palavras bonitas, carecendo do que foi central no fato e no feito, de modo a fazer cócegas aos ouvidos desejosos desse prazer. Pelo contrário, foi o de falar daquilo que é essencial da substância dos procedimentos do julgamento acima mencionado, o qual eu conheço claramente a partir do que eu mesmo vi e ouvi. Aquele que sabe todas as coisas é minha testemunha que não menti. Eu prefiro ser culpado de ter usado palavras ineptas e estranhas de modo que reconheçam que eu dei o testemunho da verdade, para que a memória do Mestre, sua mais leal defensora, possa assim viver no futuro.

Este é o começo da construção da imagem do mártir, "santo e reverendo mestre Jan

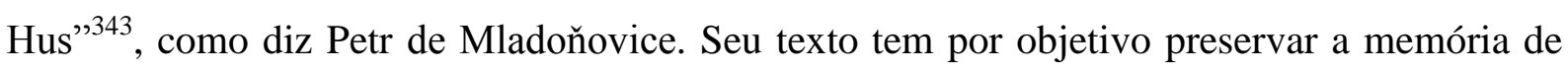
Hus para o futuro. Mas não é uma mera lembrança de sua existência, é a manutenção da imagem do mártir, que foi defensor da verdade até a morte, da consciência, da razão, do evangelho, que ensinou por meio de seus escritos, palavras e pelo exemplo de como viver e morrer pela verdade. O historiador francês Vauchez fornece-nos uma explicação a respeito do símbolo de mártir e santo:

${ }^{343}$ SPINKA, op. cit., p. 224. 
Na Antiguidade clássica, a morte constituía uma fronteira intransponível entre os homens e os deuses. Ora, na perspectiva cristã, foi precisamente por terem morrido como seres humanos, seguindo Cristo e empenhados na fidelidade à sua mensagem, que os mártires tiveram depois acesso à glória do paraíso e à vida eterna. O santo é um homem através do qual se estabelece um contacto entre o céu e a terra. $\mathrm{O}$ dia do seu aniversário comemora o seu nascimento ao lado de Deus, para além da morte, e é a festa cristã por excelência dado que renova o sacrifício salutar do único medianeiro. ${ }^{344}$

Hus seguiu o exemplo dos mártires e deixou o seu próprio exemplo. Para os membros do Concílio, de contumácia na mentira. Para Petr de Mladoňovice de constância na verdade. Há uma intenção da parte desse secretário de um nobre e aluno da Universidade de Praga em fazer o educador ser reconhecido pelos que viriam a ler seu texto. Ele assumiu a responsabilidade de atender ao pedido de Hus de preservação de sua memória.

Essa memória, hoje, deixa sua marca no local onde Hus foi queimado. Lá, existe um pequeno monumento em sua homenagem. Ele está situado na rua Alten Graben, fronteira oeste de Constança.

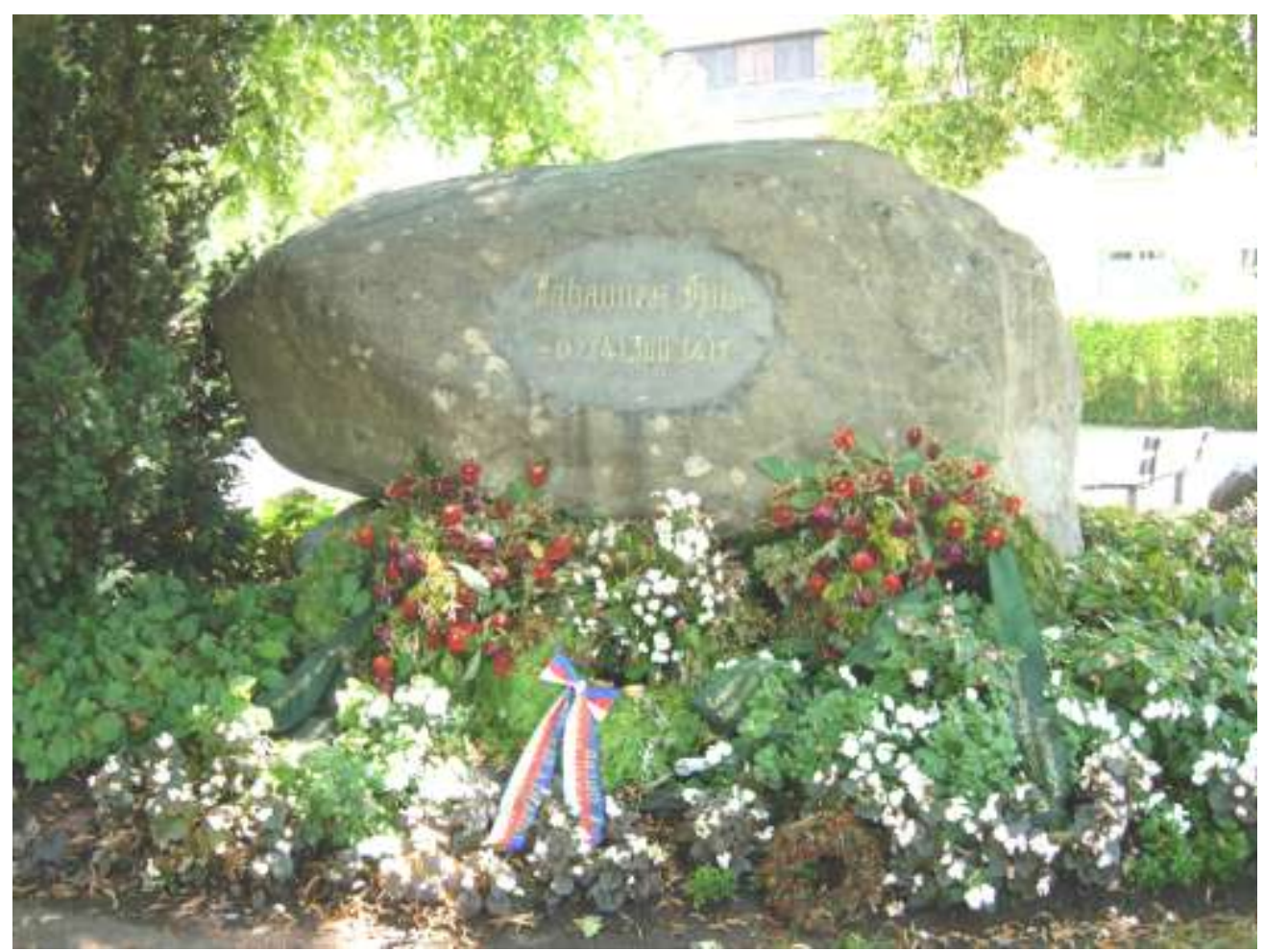

Figura 7. Monumento a Jan Hus em Constança marcando o local onde ele foi queimado (Fonte KARLSSON, Hussenstein.)

\footnotetext{
${ }^{344}$ VAUCHEZ, O santo In: LE GOFF, O homem medieval, p. 212.
} 
O texto de Petr serviu de base para todas as imagens que surgiram no século seguinte. Porém, se todo documento "sempre guarda uma relação altamente problemática com a realidade", mas, como afirma Ginzburg ${ }^{345}$, a realidade existe, uma leitura diferente do documento influenciará na narrativa histórica. A leitura que nos propusemos acima não foi a de tentar entender o que aconteceu, mas observar como a própria narrativa escrita por Petr construiu a imagem de mártir que morreu pela verdade. Voltando, agora, para as cartas, poderemos observar como o próprio autor delas ao escrevê-las participou diretamente dessa construção. Além disso, a publicação dessas cartas contribuiu para difundir essa imagem.

O clérigo Richard Wyche de Londres, discípulo de Wyclif, escreveu uma carta (número 11a) para Hus em 8 de setembro de 1410. O intercâmbio entre os Lolardos e os reformistas tchecos, que esta carta e a resposta de Hus comprovam ${ }^{346}$, já estava baseado no conceito de verdade. Os Lolardos foram os seguidores e discípulos de John Wyclif, os primeiros a traduzir a Bíblia para sua língua vernacular, o inglês, no século XIV. O Lolardismo difundiu-se entre leigos (camponeses, cavaleiros e membros da nobreza) e clérigos mais humildes. Eles eram chamados de laici litterati (leigos letrados), por sua apropriação da cultura letrada associada a uma valorização do vernáculo. Os Hussitas são, de certo modo, herdeiros dessa tradição. ${ }^{347}$ Com sua valorização da interpretação não mediada da sagrada escritura, a verdade evangélica era mais importante que as hierarquias e poderes da Igreja na Terra. Richard, no início de sua carta, estabelece o vínculo entre ele e Hus na verdade:

Caríssimo amigo no Senhor, que eu amo na verdade e, não apenas eu, mas todos os que aprenderam a verdade como verdade, que, pela graça de Deus, sobrevive em você e com você para sempre. Eu fiquei muito feliz quando meus caríssimos amigos vieram e me trouxeram o testemunho de sua verdade, como você também andou na verdade.

E, mais ao meio da carta, complementa:

\footnotetext{
${ }^{345}$ GINZBURG, O fio e os rastros, p. 229.

${ }^{346}$ OBERG, op. cit., p. 156 é contrário a este entendimento. "Há os que queiram ver neste incidente motivos para afirmar a existência de uma forte correspondência entre os lolardos da Inglaterra e o movimento de Huss, mas esta carta não oferece razões suficientes para isto." (grifo nosso) O próprio fato dele utilizar a palavra "incidente" mostra que há uma intenção do autor em minimizar essa correspondência. No entanto, o intercâmbio entre ingleses e tchecos era forte, veja na própria carta a menção a amigos que levam e trazem as notícias e o fato de Jerônimo de Praga ter trazido textos de Wyclif de Oxford para Praga, para dar alguns exemplos. Se havia uma conjunção de interesses entre os lolardos e os partidários das visões reformistas que Hus dava continuidade, por que não supor uma correspondência intensa entre eles? Se não foi “forte”, podemos supor que, pelo menos, ela ocorreu com mais do que algumas poucas cartas, mesmo que não as tenhamos para comprovar.
}

${ }^{347}$ TUCHMAN, Um espelho distante, p. 266 e LE GOFF; SCHMITT, Dicionário Temático do Ocidente Medieval, p. 244. 
Portanto, você, Hus, caríssimo irmão em Cristo, embora de face desconhecida para mim, mas não desconhecido na fé e no amor, visto que a distância das terras não pode separar aqueles que o amor de Cristo efetivamente uniu, seja forte na graça que lhe é dada. Trabalhe como um bom soldado de Cristo Jesus. Pregue, seja diligente na palavra e no exemplo, e lembre-se do caminho da verdade o máximo que puder. Pois a verdade do evangelho não pode ser asfixiada pelas censuras frívolas e fulminações do Anticristo.

Esta carta foi escrita no contexto da queima dos livros de Wyclif e da citação de Hus a Roma. Percebemos que o clérigo da Inglaterra está dando para o clérigo da Boêmia conselhos que este último seguiu até o fim. O próprio Richard Wyche seria queimado na fogueira em $1440^{348}$. As condições desta morte não estão explícitas em nenhuma das referências que encontramos a respeito deste personagem. Workman e Pope, por exemplo, consideram que caso ele realmente tenha sido queimado em 1439 (as datas divergem, embora estejam próximas), ele seria um homem bastante idoso, velho demais para ter convivido com Wyclif como Hus afirma. Sabemos apenas que ele foi um lolardo, foi acusado de heresia, abjurou e tornou-se vigário de Deptford, próximo a Greenwich. ${ }^{349}$

A resposta de Hus, na carta 15, sai cerca de seis meses depois da carta de Wyche. Nela, entre diversas citações bíblicas e notícias dos eventos que estão ocorrendo na Boêmia, Hus valoriza a coragem de "pregar o evangelho", em oposição ao "demônio que o persegue". Entendemos que ele se refere à perseguição dos seus adversários que em 1411 já estava acirrada, o que o levaria ao exílio no ano seguinte. Neste trecho, a morte aparece como parte da luta contra as tribulações:

Isto [a coragem] nós desejamos de nossos corações, por isso nós trabalhamos, como seu caro amor escreve, por isso nós estamos humildemente prontos para sofrer a morte. Não devemos falhar na confiança na ajuda do Senhor Todo-Poderoso, porque o mais misericordioso senhor diz 'estou com ele na tribulação, vou resgatá-lo e glorificá-lo.'

Perante as acusações que sofre, embora ainda alguns anos distante de sua condenação, Hus já apresenta a ideia da morte pela verdade. Isto é um elemento da imagem dos mártires, que morrem seguindo Cristo e empenhados na fidelidade à sua mensagem ${ }^{350}$, e é comum para aqueles que se colocam numa posição de defesa da verdade a todo custo. Mas ela só se confirma na hora derradeira. Se Hus tivesse escrito nesta e, como veremos a seguir, em outras

\footnotetext{
${ }^{348}$ SPINKA, The letters of John Hus, p. 45, nota 1.

${ }^{349}$ WORKMAN; POPE, The letters of John Hus, p. 31, 38-39.

${ }^{350}$ VAUCHEZ, op. cit..
} 
cartas que estava disposto a morrer pela verdade, mas renegasse suas ideias diante do tribunal, estas palavras de nada significariam. Mas, como ele sustentou esta posição até a fogueira, esta reconstituição de como ele defendeu essa ideia ajuda-nos a traçar o modo como ele próprio construiu sua imagem de mártir.

Repete-o em várias outras cartas, como naquela que escreveu aos habitantes de Plzeň (número 20). Nela, Hus sustenta o conhecimento e a defesa da verdade, aprendida pela língua vernacular, e afirma, com base nas palavras de São João Crisóstomo:

Agora, vocês têm o argumento daquele grande santo da palavra do Cristo 'Não tema aqueles que matam o corpo'. Todo aquele que, seja clérigo ou leigo, conhece a verdade deve defendê-la até a morte, caso contrário, ele é um traidor da verdade e, portanto, também do Cristo.

E em várias outras passagens como, na carta pastoral 32, "quanto a fugir da verdade, confio que o Senhor me dará a oportunidade para morrer por ela”. Na de número 46, escrita antes da viagem para Constança, na mesma época da carta-testamento a Martin de Volyně, ele fala da verdade que ensinou e "se minha morte for a Sua vontade e nossa vantagem, que a Ele agrade que eu encontre o sofrimento sem o medo excessivo". A carta pastoral 50 termina com "Rezem a Deus pela constância na verdade".

Na 52, pede a Deus para que ele possa ter "sabedoria, paciência, humildade e coragem para permanecer firme na sua verdade", bem como aconselha seus leitores (e sua audiência, visto que é uma carta pastoral), inspirados no sofrimento de Cristo, a "se você mantiver seu sofrimento na mente, você passará alegremente pela oposição, injúria, difamação, violência e prisão e, se for da vontade Dele, até mesmo a morte do corpo por Sua santa verdade”.

No total das trinta e quatro cartas escritas em seu último mês de vida, de 5 de junho a 5 de julho de 1415 , o tema da verdade aparece em onze ${ }^{351}$, exortando seus destinatários a permanecerem firmes nela, chamando seus opositores de "inimigos da verdade" ou considerando como verdade aquilo que escreveu e ensinou.

Das poucas cartas que dispomos da correspondência passiva de Hus, dois destaques são importantes para observarmos como a verdade estava associada à sua imagem. $\mathrm{O}$ primeiro, na carta 62a, escrita por Jan de Chlum no mês de março de 1415, que inicia com a seguinte frase: "Caro amigo, você deve saber que o seu caso e a causa da verdade nunca andaram tão claramente quanto agora, embora outros assuntos externos e irrelevantes intervieram, causando certo atraso." Mostrando, talvez, um otimismo em relação ao

${ }^{351}$ As de número 70, 72, 73, 76, 80, 82, 92, 93, 97, 98 e 100. 
julgamento de Hus pelo Concílio, Jan de Chlum escreveu esta carta ao clérigo confortando-o em relação às possibilidades de absolvição. Os "assuntos externos e irrelevantes" estavam ligados ao debate dos três papas que ocupava o Concílio no início do ano de 1415.

Em cerca de 20 de junho de 1415, Hus escreveu (carta 78) a um prelado do Concílio, chamando-o apenas de "Pater", provavelmente porque seria perigoso identificá-lo na carta ${ }^{352}$. Agradece por sua "graça gentil e paternal", mas recusa a fórmula de retratação que seu correspondente lhe sugerira por escrito ${ }^{353}$ porque

assim eu teria que condenar muitas verdades que eles chamam de escandalosas, como ouvi deles mesmos, ou cairia em perjúrio se eu me retratasse e confessasse que acreditei nos erros. Desse modo, eu escandalizaria a muitas das pessoas de Deus que me ouviram pregar o contrário.

E, mais para frente, complementa:

De fato, para mim seria mais vantajoso morrer do que, para evitar uma punição momentânea, cair nas mãos do senhor e depois, talvez, no fogo e na desonra eternos. Porque apelei para o Cristo Jesus, o juiz mais poderoso e justo, entregando a ele minha causa, eu me submeto à sua mais santa decisão e sentença, sabendo que ele irá julgar e recompensar a cada homem não de acordo com o falso testemunho ou com os conselhos errôneos, mas de acordo com a verdade e com o mérito.

Em resposta à carta de Hus, esse membro do Concílio tenta convencê-lo a abjurar (carta 79), apelando para a inteligência de Hus, mostrando-lhe que julgar a verdade a partir do pensamento de uma só pessoa pode levar ao erro:

Com relação ao primeiro [item], caro e amantíssimo irmão, não se perturbe como se você estivesse condenando a verdade, pois quem está julgando são eles, seus e nossos superiores, e não você. Preste atenção a estas palavras 'Não dependa da sua sabedoria'. Há muitos homens inteligentes e conscienciosos no Concílio. (...) não existe heresia se você cessar com a obstinação. Agostinho, Orígenes, o Mestre das Sentenças etc. erraram, mas alegremente voltaram. Eu muitas vezes acreditei que tinha entendido bem algo que eu errara, mas sendo corrigido, voltei regozijando-me. Além disso, eu escrevo brevemente porque escrevo para um homem inteligente. Você não irá fugir da verdade, mas render-se à verdade. Você não fará pior, mas melhor. Você não causará ofensa, mas edificação.

\footnotetext{
${ }^{352}$ SPINKA, The letters of John Huss, p. 173, nota 2.

353 OBERG, op. cit., p. (235) considera essa troca de correspondência com o Pater "linda e comovente", e que "tudo leva a crer que era sem malícia alguma" que pedia a retratação.
} 
A carta deste membro do concílio mostra que o debate da verdade era parte importante do julgamento de Hus. Ambas as partes consideravam-se estar próximas a ela. Mas suas visões eram diferentes. Hus esperava por uma explicação enquanto o Pater recomendava uma submissão. No entanto essa submissão não era pela obediência, mas pela sabedoria dos membros do Concílio. Ele apelou para a consciência do clérigo da Boêmia, insistindo que poderia haver algo que estava errado no seu pensamento, bastava que ele deixasse de ser obstinado em sua posição. É justamente essa obstinação que o levou à condenação, mas também é por ela que se construiu a imagem de mártir defensor da verdade.

Para Spinka ${ }^{354}$, não está claro se outra carta que Hus escreveu também em cerca de 20 de junho (número 80) é uma continuação ou não desse diálogo, visto que nela Hus retoma os mesmos argumentos. Concordamos com ele, mas, mesmo que não seja uma resposta direta ao Pater, pensamos que o trecho final lhe responderia claramente:

... lembro-me de São Eleazar, que, como está escrito ${ }^{355}$, recusou-se mesmo a dizer que tinha comido a carne proibida pela lei, para não deixar um mau exemplo à posteridade, mas preferiu enfrentar o martírio. Como, portanto, tendo esses exemplos diante de meus olhos e de tantos santos homens e mulheres da Nova Lei, que se ofereceram ao martírio ao invés de consentir com o pecado, posso eu, que por tantos anos preguei a paciência e a constância, cair nas mentiras e no perjúrio e ofender a tantos filhos de Deus? Bem longe de mim!

Hus não apenas escreveu estas palavras como pensou a respeito do sentido de escrevêlas e guardá-las. O remetente referir-se ao conjunto de sua correspondência, pedindo para que ela seja preservada ou destruída, exprimindo, assim, sua visão da importância dessa documentação é prática comum. Igualmente comum é o exercício de guardá-la, como afirma Malatian:

Reveladoras da verdade fugaz de um momento perdido após sua composição, as cartas sempre suscitaram em seus autores ou destinatários sentimentos ambivalentes de desejo de preservação ou destruição. Proteger a intimidade de olhares indiscretos, sobretudo os momentos de entrega mais espontânea do eu, unido pela conversação escrita a um olhar distante, não poucas vezes inspirou recomendações de destruição dos papéis após a leitura, de sua conservação em cofres trancados, de promessas de segredo e discrição. Mas outro interesse, mais poderoso, permitiu que as cartas sobrevivessem silenciosas em arquivos pessoais, por vezes cuidadosamente

\footnotetext{
${ }^{354}$ SPINKA, op. cit., p. 176 , nota 1.

${ }^{355}$ De acordo com a indicação de SPINKA, op. cit., p. 176, nota 3, a referência bíblica é do segundo livro de Macabeus, 6:17-31 e 7:1-42.
} 
atadas com fitas: o desejo de salvar vestígios de vidas, de laços estabelecidos, de afetos experimentados. ${ }^{356}$

É por esse desejo de preservação que Hus pediu e Petr guardou as cartas. Para além de guardar para o futuro um rol de laços e afetos - tão difíceis de serem percebidos mesmo nos momentos mais dramáticos da correspondência desse homem tão obstinado - Hus exprimia querer a garantia de uma leitura futura da verdade dos fatos. Deste ponto em diante, não há no clérigo da Boêmia a ambivalência do desejo de guardar ou destruir as cartas. Para garantir essa leitura futura da verdade dos fatos, Hus apresenta o desejo de preservar sua correspondência. Mas Petr não apenas guardou as cartas hussitas como escreveu seu relato da viagem à Constança. Ambas as ações foram fundamentais para a construção do legado hussita de defesa da verdade.

\subsection{A expansão da memória de Hus além da Boêmia}

A memória de Hus segundo a visão de Petr foi aquela a que deram continuidade os amigos e seguidores do clérigo, com seu trabalho de difusão das ideias reformistas e de pregação nas igrejas e capelas. Jerônimo de Praga foi condenado pelo mesmo Concílio em 30 de maio de 1416. Petr já havia narrado, em seu relato, que os arcebispos comentaram que condenar Jerônimo seria muito fácil após a condenação de Hus, visto que ele era seu discípulo. Portanto, eles deveriam condenar primeiro a Hus. Jerônimo foi morto na fogueira, queimado no mesmo lugar em que Hus foi supliciado. Essa era uma forma dos membros do Concílio sustentarem a condenação de Hus como heresiarca: ele formou discípulos que foram também queimados por serem obstinados em sua heresia. Ao mesmo tempo, esse ato colaborou para a construção da imagem de Jerônimo como discípulo de Hus.

A morte de ambos, porém, não levou à "extirpação da heresia" esperada pelos membros do Concílio. Dois grupos se formaram: os Utraquistas, ou Calixtinos, defensores da comunhão dupla e os Taboritas, liderados por Jan Žižka, tidos como "rigorosos, indo até um extremo de fanatismo" 357 .

Cinco cruzadas foram enviadas à Boêmia pelo papa Martin V, eleito em 1418 com o término do Concílio de Constança, entre 1420 e 1431 para combater a heresia na região, sendo derrotados pelos Hussitas. Jan Žižka, líder dos Taboritas, morreu em uma batalha no

\footnotetext{
${ }^{356}$ MALATIAN, Teresa. Cartas: narrador, registro e arquivo. In: PINSKY, Carla Bassanezi; LUCA, Tania Regina de (orgs.). O historiador e suas fontes.São Paulo: Editora Contexto, 2009, p. 200.

${ }^{357}$ SCHAFF, John Huss, p. 329.
} 
ano de 1424. Seu continuador foi Procópio [Prokop], o Grande. O exército cruzado foi derrotado pelos Hussitas em 1431. Em 1433, o Concílio de Basileia tenta chegar a um acordo com os Hussitas, e os dois lados constroem um documento, Compactata, que garantiu os direitos da fé reformada utraquista. Esse documento foi, no entanto, anulado pelo papa Pio II, em 1462.

Em 1457 surge, com apoio dos Valdenses ${ }^{358}$, um terceiro grupo Hussita, os Irmãos Morávios (ou Boêmios), também conhecidos como União dos Irmãos (Jednoty Brátrské, em tcheco e Unitas Fratrum, em latim). Ele se desenvolveu na Boêmia e na Morávia por cerca de dois séculos, sendo Jan Amos Komensky (Comenius, 1592-1670) um dos últimos e mais famosos de seus bispos. O ideal desse grupo foi resgatado pela Igreja Morávia, liderada pelo Conde Zinzerdorf, em 1722, igreja que existe até os nossos dias. ${ }^{359}$

Nossa hipótese é que a memória de Hus ficaria restrita a um grupo dissidente da Igreja, ligado aos descendentes da União dos Irmãos, e não teria o impacto internacional que possui se não fosse pela rememoração de sua figura pelo reformador alemão Martinho Lutero $^{360}$. Ele leu os escritos hussitas e encontrou neles ideias que considerou verdadeiras. Mais do que isso, porém, ele encontrou nas cartas um exemplo de "mártir e verdadeiro cristão".

O reformador alemão publicou o "Tratado sobre a Igreja" (De Ecclesia) de Hus em Wittemberg, em 1520, um ano após declarar que o clérigo da Boêmia não deveria ter sido condenado e que os concílios e os papas não eram infalíveis. ${ }^{361}$ Influenciou para a publicação, em 1528, do Relatio de Petr de Mladoňovice (e sua tradução para o alemão no ano seguinte $)^{362}$ e publicou as cartas de Hus em 1536 e $1537^{363}$.

\footnotetext{
${ }^{358}$ Movimento religioso do final da Idade Média, iniciado pelo comerciante Pedro Valdo de Lyon nas décadas finais do século XII. Foi considerado herético pela Igreja. O movimento se espalhou por vários lugares da Europa, conquistando adeptos também na Boêmia e na Morávia. V. FALBEL, Nachman. Heresias medievais. São Paulo: Editora Perspectiva, 1976.

${ }^{359}$ SPINKA, John Hus: a biography, p. 321, considera os Irmãos Morávios como "o mais puro resultado da Reforma Tcheca" e que Comenius "conservou e desenvolveu grandemente a herança espiritual de sua Igreja".

${ }^{360}$ SELTZER, Framing faith, forging a nation, apresenta, no terceiro capítulo, as tensões que ocorreram entre os Utraquistas da Boêmia e os Luteranos, mostrando que houve momentos de conciliação e momentos de conflito entre eles. A imagem de Lutero como divulgador e defensor de Hus deve ser olhada com cautela, pois transmite a falsa impressão que o convívio entre tchecos e alemães foi tranquilo. Pouco mais de cem anos depois do decreto de Kutná Horá, em 1409, no qual os alemães foram expulsos da Universidade de Praga, ainda havia divergências.

${ }^{361}$ SCHAFF, op. cit., p. 294.

${ }^{362}$ SPINKA, John Hus at the council of Constance, $\mathrm{p} 80$.

${ }^{363}$ BONNECHOSE, Letters of John Hus, p. 1-2.
} 
Isso mostra que a publicação de Lutero das cartas de Hus ocorreu quando ele já estava, há algum tempo, em contato com as ideias do clérigo da Boêmia. Mas se ele já havia publicado outros textos hussitas, por que publicar suas cartas? Em oposição ao movimento da Reforma Protestante, o papa Paulo III convocou a realização de um concílio na cidade de Mantua em 1537. Esse concílio só se realizou, de fato, a partir de 1545, na cidade de Trento, sendo um dos mais famosos da Igreja. Por ocasião da convocação de 1536, Lutero selecionou quatro cartas tchecas de Hus, encaminhou-as para tradução ao latim e juntou a elas mais algumas cartas escritas por nobres da Boêmia e da Morávia por ocasião do Concílio de Constança e as publicou em Wittemberg. ${ }^{364}$ No prefácio da edição de 1536 a essas cartas, ele explica seus motivos:

Meu motivo para publicar estas cartas, se Deus permitir que o dito concílio se reúna, é prevenir seus membros a cuidarem para não seguirem o exemplo do Concílio de Constança, no qual a Verdade foi exposta a ataques tão grandes e violentos. E ainda, não obstante, agora triunfa e, erguendo sua cabeça vitoriosa, mostra essa reunião indigna sem roupas e despida de sua autoridade tirânica. ${ }^{365}$

Eis Hus aparecendo como símbolo da verdade que foi atacada. As cartas de Hus são publicadas para mostrar o contra-exemplo, aquilo que não pode ocorrer no Concílio que viria a se reunir. Lutero espera

que reis, príncipes e bispos reúnam todas as suas energias para que calamidades como estas [causadas pelo concílio] e outras ainda mais assustadoras não aconteçam como resultado do novo concílio recém convocado. (...) Eu publico estas cartas, portanto, com o propósito de dar um aviso salutar. Aquele que for avisado e não ouvir ao aviso perecerá terrivelmente, mas não por minha falta.

Após esse "aviso salutar", o reformador alemão faz nova publicação das cartas de Hus, porém, do conjunto completo, que, na época, consistia de 56 cartas, intitulando-o Epistolae Qucedam Piissima et Eruditissimee. ${ }^{366}$ O prefácio a esta edição de 1537 é consideravelmente maior que o primeiro e oferece diversos outros elementos históricos a respeito da primeira publicação das cartas de Hus.

\footnotetext{
364 ibidem, p. 1.

365 ibidem, p. 217. Bonnechose publicou os dois prefácios de Lutero às edições de 1536 e 1537.

${ }^{366}$ Essa obra foi incluída na primeira compilação dos trabalhos latinos de Hus, intitulada Historia et Monumenta J. Hus atque Hieronymi Pragensis Confessorum Christi (Monumenta), publicada em Nürenberg no ano de 1558 e republicada em Frankfurt no ano de 1715. A primeira publicação tcheca foi a de Pálacký, em 1869. O Monumenta possui os três prefácios de Lutero a escritos de Hus. Não possuímos informações a respeito de quem o publicou.
} 
O início do prefácio à segunda edição possui uma riqueza de elogios da parte de seu autor em relação à figura de Hus. Esse recurso estilístico é uma marca de todas as publicações das cartas hussitas que tivemos acesso:

Qualquer homem que ler, ou ouvir alguém ler, estas cartas (...) não hesitará, estou convencido, em reconhecer que a Jan Hus foram dados os dons preciosos do Espírito Santo. Observe, de fato, como ele se une, em seus escritos e palavras, às doutrinas do Cristo. Com que coragem ele lutou contra as agonias da morte. Com que paciência e humildade ele sofreu cada indignidade. E com que grandeza de alma ele, no fim, enfrentou uma morte cruel na defesa da verdade. Fazendo tudo isso sozinho e sem ajuda, diante de uma congregação imposta dos homens mais poderosos e eminentes, como um cordeiro no meio de lobos e leões. Se a tal homem for considerado um herege, nenhuma pessoa sob o sol pode ser visto como um verdadeiro cristão. Por quais frutos, então, reconheceremos a verdade se ela não for mostrada pelos que tão ricamente adornaram Jan Hus?

Não apenas Lutero atribui a Hus, utilizando ainda mais referências elogiosas que Petr de Mladoňovice, a imagem do mártir que lutou pela verdade até a morte, mas afirmou que se Hus fosse um herege, ninguém seria um verdadeiro cristão. No imaginário bíblico, a verdade deve ser reconhecida pelos frutos que a adornaram. Em Hus, esses frutos são suas ideias a respeito da Igreja e da vida cristã, seu martírio corajosamente sofrido e a permanência dos escritos hussitas como precursores da Reforma Protestante.

Em especial, está mais do que solidificada a associação da imagem de Hus com a defesa da verdade. Se na carta 63, Hus afirma que começava a entender o Livro dos Salmos que propõe pensar sobre o sofrimento do Cristo e dos mártires, Lutero marca-o definitivamente com o signo de mártir: devemos aprender com seu exemplo. O mártir é um educador pelo seu exemplo, pelo legado que deixa para a posteridade. Mas só o é porque há pessoas que o reconhecem. Assim começou Petr de Mladoňovice e consolidou Martinho Lutero. Eles o designaram como tal: mestre e mártir da verdade.

O reformador alemão produz aqui dois movimentos. No primeiro, alimenta a religiosidade popular de uma tradição de mártires e santos. No segundo, apresenta uma argumentação erudita teológica para validar as ideias hussitas. É o que faz na continuação de seu prefácio, explicando que o maior crime de Hus foi afirmar que um homem de vida ímpia não poderia ser a cabeça da Igreja Universal e, como consequência, o papa não era a cabeça da Igreja. Os membros do Concílio se esforçaram para provar ao clérigo da Boêmia que o papa era infalível e santo: 
Todos os homens do Concílio de Constança, sábios como eram considerados, (...) quando destronaram três pontífices culposos, não deram a ninguém o direito de condená-los ao fogo. Mas quando Jan Hus disse as mesmas coisas, eles o arrastaram imediatamente para a estaca! ${ }^{367}$

Segue Lutero com a justificativa de porque o papa era falível, comparando a falibilidade do papa João XXIII (condenado pelo Concílio de Constança) com o evento da venda de indulgências para financiar a construção da Basílica de São Pedro no período do papa Leão X (1513-1521). Ele aparece, então, com nova exaltação a Hus. "O erro extraordinário [de considerar o papa infalível] desses homens tão importantes, por um lado, e os ultrajes evidentes que Jan Hus sofreu deles só serviram para animá-lo de uma coragem ainda maior." Ele, então, cita dois trechos evangélicos ${ }^{368}$ para mostrar que o clérigo da Boêmia tinha a ajuda do Espírito Santo e alguns relatos de outras pessoas a respeito de Hus:

Eu ouvi de algumas pessoas dignas de fé que o imperador Maximiliano disse, a respeito de Jan Hus, 'eles cometeram uma grande injustiça para aquele excelente homem'. Erasmo de Roterdã, em seus primeiros escritos, agora em minha posse, declarou que Jan Hus tinha sido queimado, mas não convencido. E a opinião geral entre os homens pios daquela época era que ele tinha sido oprimido por ultraje e violência. ${ }^{369}$

Tenta Lutero, nesse trecho e na sequência, apresentando um debate entre Hus e certo doutor Zacharias a respeito de uma passagem bíblica, mostrar que além de ter sido injustiçado ele foi assim reconhecido ao longo dos anos que se seguiram. Lutero, aqui, mostra que há um lugar que ele ocupa na história que deve ser registrado, em virtude do conhecimento e da erudição de Hus. Confronta isso com as concepções que ele ouvira quando estudante: ${ }^{370}$

Trinta anos atrás, eu ouvi vários teólogos competentes declararem que 'Jan Hus era um doutor sumamente superior e que ele superou em erudição e conhecimento todas as pessoas que participavam do concílio.' Seus escritos, como o Tratado sobre a Igreja, e seus Sermões confirmam este elogio.

Quando eu era um estudante de teologia em Erfurt, aconteceu de chegar às minhas mãos, certo dia, na biblioteca do mosteiro, um volume dos sermões

\footnotetext{
${ }^{367}$ BONNECHOSE, op. cit., p. 4-5.

${ }^{368}$ Mateus 10:20 "porque não sereis vós que estareis falando, mas o Espírito de vosso Pai é que falará em vós" e Lucas 21:15 "pois eu vos darei eloquência e sabedoria, às quais nenhum de vossos adversários poderá resistir, nem contradizer".

369 ibidem, p. 7.

${ }^{370}$ Parte deste trecho já foi apresentada na introdução deste trabalho. Repetimo-lo, agora, estendido, num contexto mais definido.
} 
de Jan Hus. Ao ler na capa daquele trabalho as palavras Sermões de Jan Hus, em mim imediatamente acendeu o desejo de apurar, por meio da leitura daquele livro que escapou das chamas e estava conservado numa biblioteca pública, quais heresias ele havia disseminado. Eu me abatia pelo espanto ao ler o livro e estava preenchido por uma surpresa difícil de descrever ao procurar por um motivo pelo qual um homem tão grandioso - um doutor, tão digno de veneração e tão poderoso na exposição das Escrituras - foi queimado até a morte. Mas o nome de Hus era, naquela época, tal objeto de execração que eu acreditava plenamente que se eu falasse qualquer elogio a seu respeito, os céus cairiam sobre mim e o sol ocultaria sua luz. Tendo fechado o livro, eu saí triste de coração e disse para mim mesmo, como um consolo, 'Talvez ele tenha escrito essas coisas antes de cair na heresia. ${ }^{371}$

Por vezes, lendo o texto de Lutero e das outras pessoas que reforçaram essa imagem de mártir e de sábio associada a Hus, esquecemos que ele falava de um personagem considerado como heresiarca. Em sua juventude, Lutero deparou-se com duas posições divergentes: Hus caiu na heresia, mas era mais sábio do que os membros do Concílio de Constança. Como era possível um herege ser mais sábio que aqueles que o acusaram? A única explicação razoável era que aquele texto ainda não estava contaminado pela heresia. O lugar que a Igreja ocupava na sociedade ou, pelo menos, na universidade era um obstáculo ao questionamento da ideia de falibilidade das suas instituições. Isso era com certeza ainda mais forte no que diz respeito ao questionamento de um concílio como o de Constança, que fícou famoso por dar fim ao Cisma Papal. Diante, porém, do papa Leão X e sua venda de indulgências para pagar a construção da Basílica de São Pedro e financiar suas campanhas militares, Lutero opõe-se escrevendo as famosas 95 teses de Wittenberg. ${ }^{372}$ A lembrança do período de sua juventude serve tanto como argumento para confirmar os erros da Igreja quanto para associar ambos os momentos da história como semelhantes. A Igreja precisa de reforma e deve cuidar disso. Esse é o aviso de Lutero, visto que tem por leitores intencionados desse prefácio os membros do Concílio de Trento, aquele que consolidaria o movimento de Contra-Reforma.

\footnotetext{
${ }^{371}$ ibidem, p. 9

${ }^{372}$ MCBRIEN, Os papas, p. 280. FRITZER, Gottfried. O que Lutero realmente disse. Rio de Janeiro: Editora Civilização Brasileira, 1971, p. 1, afirma que "Nunca houve a propalada exposição pública das teses de Lutero; trata-se apenas de uma lenda histórica, inventada pelas Igrejas Protestantes, segundo a qual Martinho Lutero, monge agostiniano e professor de Teologia da Universidade de Wittenberg, pregou noventa e cinco teses, aos 34 anos, na porta da igreja do Castelo de Wittenberg, abrindo, com essas 'ressonantes marteladas', uma nova era na história da Igreja e do mundo europeu. (...) O fato fora de questão, e que pode ser comprovado inequivocamente nas fontes, é que Lutero, no dia 31 de outubro de 1517, enviou as noventa e cinco teses sobre as Indulgências, por ele redigidas, ao Arcebispo Albrecht von Hohenzollern, de 27 anos, então em exercício de suas funções na cidade de Magdeburgo. O manuscrito foi acompanhado de uma respeitosa carta."
} 
Até os seus inimigos testemunham pelo caráter elevado de Hus. É o que diz o autor do prefácio, citando frases das atas do Concílio de Constança atribuídas ao clérigo da Boêmia. São as mesmas cenas narradas por Petr de Mlandoňovice, como a repetição da invocação "Jesus, filho de Deus, tenha piedade de mim" por parte daquele que estava prestes a ser supliciado. Mas Lutero também acrescenta uma frase que não está no Relatio, o que, segundo Bonnechose $^{373}$, indica que o reformador confundiu-se e a cena ocorreu na morte de Jerônimo de Praga. Schaff ${ }^{374}$ afirma que, embora Lutero tenha escrito a cena em seu prefácio, é uma tradição que não pôde ser verificada. Eis o trecho: "Diante de uma camponesa ${ }^{375}$ trazendo um pouco de madeira para alimentar as chamas, ele novamente sorriu com delicadeza, e exprimiu estas palavras de São Jerônimo 'oh, santa simplicidade!’.”376 Rememorar é acrescentar.

Caminhando para a conclusão do prefácio, Lutero repete sua consideração de Hus como um verdadeiro cristão, sem igual no mundo e, opondo-se ao papa, coloca-o no paraíso:

O homem que, diante da agonia da morte, invocou com um coração tão firme a Jesus, o filho de Deus, que, por tal causa, entregou seu corpo às chamas com tamanha fé e tão firme constância, se tal homem, eu repito, não merece ser considerado um mártir generoso e intrépido e um verdadeiro seguidor do Cristo, será difícil para qualquer pessoa ser salva. O próprio Jesus Cristo declarou: 'Aquele que me confessar diante dos homens eu o confessarei diante de meu Pai.' O que mais posso dizer? O pontífice romano eleva ao lugar de santo muitos homens que são difíceis de dizer se estão entre os eleitos ou entre os demônios e ele precipita para o inferno um homem como este, quando, a partir da análise de sua vida, percebe-se que seu lugar é no paraíso. ${ }^{377}$

Lutero conclui retomando o "aviso salutar" que fizera na primeira edição das cartas e eleva Hus para um lugar acima de todos os que estariam no Concílio de Trento:

Nossos teólogos, fortes em sua autoridade, não antecipam qualquer perigo. Eu admito que eles possuem um poder igual ao que possuíam no tempo de Jan Hus. Porém, não é menos correto dizer que aquele que esteve diante do tribunal deles agora senta num lugar no qual seus juízes devem abrir caminho diante dele.

\footnotetext{
${ }^{373}$ BONNECHOSE, op. cit., p. 10.

${ }^{374}$ SCHAFF, op. cit., p. 258.

375 Para Schaff, “an old woman”.

${ }^{376}$ BONNECHOSE, op. cit., p. 10. Além desta, outra frase foi atribuída a Hus: "Hoje, vocês estão queimando um ganso, mas de minhas cinzas nascerá um cisne que vocês não queimarão". SCHAFF, op. cit., p. 258 afirma que ela não é uma profecia dita por Hus, mas uma invenção tardia.
}

${ }^{377}$ BONNECHOSE, op. cit., p. 11. 
Eis o Hus de Lutero: alguém tão importante que as pessoas que o julgaram e condenaram devem abrir caminho para sua passagem. Mártir e teólogo, homem de coragem e seguidor de Cristo, Hus é o exemplo a ser seguido pelos cristãos e sua condenação é o contra-exemplo para o concílio vindouro.

Na geração seguinte à de Lutero, encontramos um dos primeiros escritos sobre Hus em língua inglesa, o "Livro dos Mártires" de John Foxe. ${ }^{378}$ Este foi um escritor protestante que nasceu na Inglaterra e estudou em Oxford. Ele viveu de 1516 a 1587. Escreveu seu livro quando estava no exílio em virtude da perseguição da rainha Mary Tudor contra os lolardos. A primeira edição, em latim, foi publicada em 1559 e a primeira em inglês no ano de 1563. Spinka afirma que “depois da Bíblia, sua martirologia continua a ser a leitura favorita dos membros da igreja na Inglaterra até o final do século XIX"379.

Hus já era conhecido na Inglaterra, como sabemos pela correspondência que trocou com Richard Wyche. O que não sabemos é se antes do Livro dos Mártires, Hus já era considerado um mártir religioso na região. No entanto, o sucesso dessa obra fixa nessas terras a imagem do mestre e mártir defensor da verdade.

O capítulo do livro de Foxe sobre Jan Hus, intitulado "A história do Mestre Jan Hus", é praticamente uma síntese do Relatio de Petr de Mladoňovice, com inúmeras transcrições diretas desse texto, acrescidas de pequenas frases com a opinião do autor inglês. Sua síntese a respeito do cisma papal, ao apresentar cada um dos três papas como pertencente a uma nação e este fato como causador do conflito entre as nações no Concílio de Constança é restrita, visto que ele se limita a citar a existência de três papas sem mencionar os contextos e os antecedentes que culminaram na convocação do concílio. No entanto, a imagem que ele constrói para apresentar os erros desse concílio em relação a Hus é reveladora da perpetuação do legado do clérigo da Boêmia:

Os três papas eram: João, eleito pelos italianos; Gregório, eleito pelos franceses e Benedito, nomeado pelos espanhóis. Nesse conflito cismático provocado pela ambição todos defendiam o seu Papa, para grande perturbação das nações cristãs. O concílio durou três anos e cinco meses. Muitas coisas importantes e úteis para a glória de Deus e vantagem do povo poderiam ter sido concluídas, se a carne podre dos homens da Igreja tivesse tolerado o sal do Evangelho, e se eles tivessem amado a verdade. ${ }^{380}$

\footnotetext{
${ }^{378}$ FOXE, John. O livro dos mártires. Tradução de Almiro Pizetta. São Paulo: Mundo Cristão, 2005, p. 93.

${ }^{379}$ SPINKA, John Hus at the council of Constance, p. 80.

${ }^{380}$ FOXE, op cit., p. 93. As citações seguintes foram retiradas das páginas 117, 88 e 120.
} 
Hus estava com a verdade, ele trazia o sal do Evangelho. Foi um mártir porque sofreu "a censura dos bispos" e porque estava "mais disposto a ensinar o Evangelho do Cristo do que as tradições dos bispos". E, seguindo a proposta de Hus de preservação da sua memória, Foxe assim termina seu texto:

O coração, que foi encontrado entre as vísceras, depois de batido com varas e paus, foi por fim espetado na ponta aguda de uma estaca e assado no fogo até consumir-se. Em seguida, recolheram as cinzas com grande diligência e as jogaram no rio Reno, para que não ficasse sobre a terra o menor vestígio desse homem. Todavia, sua memória não pôde ser apagada das mentes piedosas nem pelo fogo, nem pela água, nem por qualquer outra tortura. Esse piedoso servo e mártir de Cristo foi queimado em Constança, no dia seis de julho de 1415, d.C. ${ }^{381}$

Nem o fogo, nem a água ou qualquer outra tortura apagaram a memória de Hus. Isso porque seu legado estava não em seu corpo, mas no seu exemplo de vida e em suas palavras. Essa imagem se forma numa Inglaterra protestante por meio da difusão dessa obra de grande circulação no período em que foi publicada. O livro de John Foxe, se não podemos garantir que foi a primeira obra a circular na Inglaterra com esse propósito, foi aquela que ajudou a consolidar essa imagem. Sendo uma das leituras favoritas da igreja na Inglaterra até o século XIX, pode ter sido uma das obras lidas por estudiosos que tiveram sua formação religiosa nesse espaço-tempo, como Herbert B. Workman e R. Martin Pope.

Em 1904, Workman e Pope, professores do Westminster Training College, de Londres, instituição acadêmica e religiosa de formação teológica protestante, publicaram uma tradução das cartas de Hus para o inglês. A primeira coisa que chama a atenção quando viramos a folha de rosto do livro são as epígrafes. Duas frases, em latim, de Hus foram selecionadas para abrir a obra. Quais são as palavras-chaves dessas frases?

A verdade sempre vence, pois ela tem a propriedade de brilhar mais forte sempre que se tenta apagá-la e de subir mais alto sempre que se tenta rebaixá-la.

Eu sei que só vence quem morre. ${ }^{382}$

Morte e verdade. Somente a seleção destas frases como epígrafe já nos confirma que, quase trezentos e cinquenta anos depois do Livro dos Mártires, na Inglaterra, a imagem de

\footnotetext{
${ }^{381}$ ibidem, p. 120.

${ }^{382}$ No original, "Veritas semper vincit, cum haec sit ipsius proprietas et natura, ut, quo magis obscuratur, eo magis illucescit, etquo magis deprimitur, eo magis elevatur", adaptado da carta 27 e "Scio, quod vincit qui occiditur", da carta 30.
} 
Hus é a do mártir defensor da verdade, a mesma construída pelas cartas, por Petr de Mladoňovice e Martinho Lutero e repetida por John Foxe. Não podemos ignorar, contudo, nestas epígrafes a repetição do verbo “vencer". É esta a palavra que liga morte à verdade. Em oposição aos membros do concílio, morrer pela verdade é vencer, que aqui carrega tanto um caráter de salvação da alma (“Cristo venceu a morte, também nós venceremos”), quanto de salvação da memória (“a verdade de tudo o que eu ensinei é a que permanecerá”).

Essa imagem que as epígrafes constroem não é desenvolvida em boa parte do prefácio, que apresenta uma maior natureza técnica, apresentando a organização do livro, as fontes utilizadas e as dificuldades encontradas na tradução e localização das citações. Eles fizeram sua tradução com base da edição de Palacký ${ }^{383}$, comparando-a com a edição alemã de Höfler $^{384}$. Foi uma edição que, embora "possa ser de algum uso para o estudante mais sério, foi pensada, inicialmente, para o leitor em geral" ${ }^{385}$. O objetivo que eles se propõem é "fazer o próprio Hus, o homem, como ele viveu e trabalhou, mais real. Apresentar uma imagem do Reformador como somente as cartas podem oferecer, pintada pelo próprio sujeito."

Com certeza as cartas permitem um olhar sobre seu autor, algo que possamos dizer: "pintado pelo próprio sujeito". No entanto, a organização dessa correspondência diz também a respeito de quem a fez. Encontrar as citações bíblicas ou dos Padres da Igreja e buscar suas referências são adições às cartas, são leituras. Igualmente o são as traduções. Ler as cartas de Hus por meio das edições é ler as leituras de outras pessoas. E, não podemos negar, a leitura que fazemos neste trabalho é totalmente dependente das leituras dos editores. Mais ainda, nós construímos nossas próprias versões das cartas nas traduções para o português. Cada nova publicação das cartas de Hus é uma nova leitura, acrescentando interpretações e propondo mudanças na compreensão dessa correspondência. Porém, cada nova publicação é, também, uma rememoração das imagens que historicamente recebemos. É nesse movimento contínuo de rememoração/interpretação que ocorre a transmissão e a propagação do legado educativo.

Workman e Pope, por exemplo, entendem, no prefácio às cartas de Hus, que o autor delas dependia da compilação de Graciano, Decretum, para suas referências patrísticas (como já mencionamos no segundo capítulo). Mas, para eles, essa dependência é uma das

\footnotetext{
${ }^{383}$ PALACKÝ, Documenta.

${ }^{384}$ HÖFLER, K Geschichtschreiber der husitischen bewegung in Böhmen In: Fontes rerum austiacarum. Viena, 1865.

${ }^{385}$ WORKMAN; POPE, op. cit., p. x e pp. ix-xi, 1 e 2 para as citações seguintes.
} 
justificativas para afirmar que ele não dependia exclusivamente de Wyclif: ambos usavam a mesma fonte:

Qual era a conexão entre Hus e o original? Loserth, em sua valorosa monografia (Wyclif e Hus, 1884), estabeleceu a profunda dependência de Hus do grande Reformador Inglês [Wyclif]. Nós estamos inclinados a pensar que nossas notas estabelecerão uma dependência igual de Hus do grande manual medieval, Decretum de Graciano, e, em alguns casos nos quais Loserth acredita que o boêmio copiava o inglês, nós suspeitamos que ambos estavam copiando de Graciano.

Atentemos para a expressão "que nossas notas estabelecerão". Ela deixa claro que a compilação que eles apresentam não apenas retrata a imagem de Hus como ele a pintou, mas também com as pinceladas adicionais dos organizadores. Eles também, na sequência do prefácio, propõem uma leitura diferente da cronológica:

Aqui e lá, o leitor poderá se sentir fora de contato. Ele pode reclamar que tem muito som de trombeta, a voz das palavras e os ecos de lutas que já morreram faz tempo. Até certo ponto, isso é verdade para as cartas escritas durante o exílio (parte III).

Para o historiador da Educação, pelo contrário, as cartas escritas do exílio são riquíssimas, pois estabelecem o trabalho educativo de Hus. Continuam os editores:

Ao leitor que se aproxima do estudo de Hus pela primeira vez, talvez seja melhor começar estas Cartas pelo meio, a partir da viagem para Constança (parte IV) e ler até a cena final. ${ }^{386}$ Nós estamos muito errados se, desse modo, ele não ficar com tanto interesse no autor desse conjunto imortal de cartas escritas da prisão que vai, com alegria, voltar para as cartas menos fascinantes, dado que mais polêmicas, da parte inicial. Apesar de tudo, a morte de um homem não pode ser entendida separadamente de sua vida e a imagem extraordinária que Hus nos dá na prisão da Inquisição em Constança não pode ser isolada do resto. Somente pelo estudo da totalidade das cartas nós podemos entender a totalidade do homem em toda a sua força, ternura e, podemos acrescentar, sua fraqueza. (grifo nosso)

Por que a leitura das cartas de Constança, que são a maioria daquelas que dispomos, é o ponto de partida para entender Hus? Concordamos em parte com os editores: somente pela totalidade das cartas podemos entender alguns aspectos da totalidade do homem ${ }^{387}$, visto que

\footnotetext{
${ }^{386}$ Foi exatamente isso que fez Spinka com suas publicações sobre Hus. A primeira foi a tradução do Relatio e das cartas de Constança. A versão completa das cartas só foi publicada sete anos depois.

${ }^{387}$ GOLDMANN, Lucien. Dialética e cultura. São Paulo: Paz e Terra, 1967, p. 8, afirma "Uma ideia, uma obra só recebe sua verdadeira significação quando é integrada ao conjunto de uma vida e de um comportamento." e às pp. 13-14, "se bem que nunca se possa chegar a uma totalidade que não seja ela mesma elemento ou parte, o
} 
elas são apenas uma parte das ações e da história do sujeito que as escreve. Mas iniciar a leitura pelos escritos da prisão favorece a construção de uma imagem de mártir. Afinal, um dos objetivos de Workman e Pope, implícito nesse trecho, é entender a morte desse homem, sua "imagem extraordinária".

Na conclusão do prefácio, eles afirmam que a leitura da correspondência hussita pode trazer mais do que um conhecimento histórico, uma experiência espiritual:

Também não deixamos de ter a esperança que este fragmento de história-daalma, pois é justamente isso que as cartas de Hus nos mostram, possa se entregar nas mãos de alguns, não apenas do ponto de vista mais estreito da história, mas também do panorama mais amplo da unidade e continuidade da experiência espiritual, que permeia todas as épocas sob diferentes formas e em maneiras diversas, e é, além disso, a manifestação e o trabalho do único Senhor e Doador da Vida.

Mais à frente, na introdução às cartas, Workman e Pope retomam Lutero, afirmando que elas marcam o desenvolvimento espiritual do reformador e citam trechos do prefácio deste último. Esses trechos, todos já citados nesta tese, são os que mostram o Lutero jovem descobrindo a correspondência hussita e o seu elogio a Hus como um verdadeiro e incomparável cristão. Eles também citam uma carta de Lutero a George Spalatin, outro personagem importante da Reforma Protestante, escrita antes mesmo de ele ter acesso às cartas de Hus. Eis o trecho: “Até aqui eu ensinei e acreditei em todas as opiniões de Hus sem sabê-lo. Com similar desconhecimento Staupitz as ensinou. Nós somos todos Hussitas sem sabê-lo. Eu não sei o que pensar de tanto espanto."

Workman e Pope confirmam e sustentam, com essa introdução, a linha que os liga às cartas de Hus passando por Martinho Lutero. E, mais do que isso, adicionam um importante elemento histórico à imagem de Hus: ele é precursor da Reforma, exercendo um importante papel no desenvolvimento das ideias do reformador alemão. Citar um trecho no qual Lutero diz que ele e os seus contemporâneos reformadores são todos Hussitas é carregar a imagem de Hus com a força histórica da imagem de seu sucessor "que deu certo". É uma justificativa

problema do método nas ciências humanas é o do corte do dado empírico em totalidades relativas suficientemente autônomas para servir de quadro a um trabalho científico." Idem. Correspondance de Martin de Barcos, abbé de Saint-Cyran, avec les abbesses de Port-Royal et les principaux personnages du groupe janséniste. Paris: Presses universitaires de France, 1956, pp. 48 e 49, afirma que a vida humana é uma realidade total, em que todos os processos de consciência tem consequiências práticas e, inversamente, qualquer comportamento prático traz um impacto emocional, intelectual, artístico, teológico, etc. Para ele, é de grande interesse para a pesquisa histórica a ideia de se rastrear e reconstruir o passado, investigando uma vida social como uma verdadeira imagem total. 
para ler as cartas hussitas. O clérigo da Boêmia é o mestre, mártir, defensor da verdade e precursor da Reforma Protestante.

É claro que essa imagem de precursor não é uma invenção de Workman e Pope. A publicação do Monumenta nos séculos XVI e XVIII e a tradução de Bonnechose em meados do XIX, ao trazerem o prefácio de Lutero, procuraram legitimar a escrita de Hus a partir de uma autoridade já legitimada, a do reformador alemão. É isso que fazem os prefácios escritos por outras pessoas. Mas, é claro, a publicação de uma frase como "nós somos todos Hussitas" traz um elemento adicional: dizer-se Hussita é filiar-se a Hus. Este se torna um precursor.

O historiador francês Émile de Bonnechose (1801-1875) publicou dois livros sobre Hus. O primeiro, uma biografia intitulada Os Reformadores Antes da Reforma: Século $\mathrm{XV}^{388}$, no qual narra a vida do clérigo da Boêmia desde sua atuação na Universidade até sua condenação, com detalhes do Concílio de Constança e os Hussitas. O segundo é a compilação das Cartas de Hus, acrescida dos prefácios escritos por Lutero, uma síntese da obra De Ecclesia (o Tratado sobre a Igreja) e uma lista dos escritos hussitas. Sua visão a respeito de Hus pode ser sintetizada nestas palavras com que conclui sua introdução à biografia de Hus:

Como historiador de Jan Hus e do Concílio de Constança ${ }^{389}$, eu sei que, ganhando a admiração de muitos deste justo que o Concílio imola, eu o exponho a novos ultrajes. Mas a qualquer pessoa que tentar insultar a sua memória, eu direi: Jan Hus foi condenado porque se recusou a acreditar que o homem, por qualquer motivo, abafasse a voz de sua consciência e agisse contra sua persuasão interna. O que ele não acreditou, você acredita? ? $^{390}$ Medite a respeito da vida dele, leia suas cartas - suas cartas tocantes onde se manifestam a alma mais cândida e o fervor mais santo. Veja que amor pelo bem, que horror pelo mal, que devoção pela verdade! Veja como ele viveu e como ele morreu. Feito isso, coloque a mão em seu coração e diga 'eu sou mais cristão que esse homem'. Aí, então, você pode insultá-lo. ${ }^{391}$

Os elogios de Bonnechose a Hus são semelhantes aos de Workman e Pope, levando-o ao status de grande cristão e mártir, pelo exemplo de sua vida e de sua morte. Candura e

\footnotetext{
${ }^{388}$ BONNECHOSE, Émile de. The reformers before the reformation: the fifteenth century, John Hus and the Council of Constance. Tradução para o inglês de Campbel Mackenzie. New York: Harper and Brothers, 1844. Também tivemos acesso à versão original em francês, a saber: idem, Les réformateurs avant la réforme (XVe siècle): Jean Hus et le Concile de Constance. 2a ed. Paris: Au Comptoir des Imprimeurs-Unis, 1847.

${ }^{389}$ A expressão "e do Concílio de Constança” está presente no original em francês e ausente na tradução para o inglês, bem como a expressão "eu o exponho a novos ultrajes".

${ }^{390}$ Neste trecho, de difícil compreensão, Bonnechose parece tentar colocar o suposto interlocutor que é contrário a Hus em oposição a ele, mas num lugar que ninguém ousaria estar. Quem seria contra "agir de acordo com sua consciência"?

${ }^{391}$ BONNECHOSE, The reformers before the reformation, p. 7-8; BONNECHOSE, Les réformateurs avant la réforme, p. 24-25.
} 
fervor para o primeiro, ternura e força para os segundos, Hus é um exemplo a ser seguido por sua devoção à verdade. Repete a afirmação de Lutero que se Hus não é um verdadeiro cristão, ninguém será. ${ }^{392}$ A palavra diferente aqui, no texto de Bonnechose, é "consciência". A liberdade de consciência é valorizada pelo historiador francês como um dos principais legados hussitas. Após apresentar as cartas e exemplos da vida do clérigo da Boêmia, Bonnechose, na sua introdução à correspondência de Hus, conclui dizendo que ele trouxe para parte da Europa "a compreensão do direito sagrado daquela liberdade de consciência que, quando corretamente empregada, constitui o cristão igualmente no trono como nas correntes" ${ }^{393}$. Pois, "nenhum outro fez mais para restaurar à Consciência, no coração do homem, aquele trono ao qual ela nunca poderia ter abdicado." 394 Hus torna-se aquele que ensinou às pessoas a compreensão do direito à liberdade de consciência.

Bonnechose foi um historiador francês que se tornou protestante e publicou seus livros sobre Hus na década de 1840. Foi convertido e age com a paixão dos neo-conversos. Escrever sobre o clérigo da Boêmia não era, para ele, apenas um trabalho de historiador, era incentivar um movimento de liberdade de consciência na França, meio século após a Revolução Francesa, durante realeza burguesa de Luís Filipe de Orléans, às vésperas da revolução de 1848. Período de forte cunho nacionalista e embates políticos e, como afirma Bonnechose, de despertar do Cristianismo. Ele escreve seu texto em oposição a uma Igreja Católica cada vez mais próxima do Concílio Vaticano I (1869/1870), que reforçará a ortodoxia do Concílio de Trento e estabelecerá definitivamente o dogma da infalibilidade papal. Sua proposta em retratar Hus é de

inspirar nossos leitores [com] o respeito por todas as convicções que são verdadeiramente cristãs (...) e gratidão para com todos aqueles que, durante dezoito séculos, contribuíram com uma pedra para o edifício cristão. Estes são os sentimentos que, acima de tudo, é importante difundir diante da aproximação do movimento religioso que, atualmente, dá indicações de sua chegada. ${ }^{395}$

Seu prefácio à sua biografia de Hus consiste numa proposta de "elevação da fé" num lugar no qual "há na mente dos homens uma vontade de acreditar, ao invés da própria

\footnotetext{
${ }^{392}$ BONNECHOSE, Letters of John Huss, p. xvi.

393 ibidem, p. xxi.

394 ibidem, p. xxiii.

${ }^{395}$ BONNECHOSE, The reformers before the reformation, p. 1.
} 
crença", com o objetivo de "servir à Igreja universal" dentro de uma religião maior que todas as formas particulares de adoração: o Cristianismo. ${ }^{396}$

Bonnechose afirma não querer discutir questões doutrinárias do catolicismo, mas “contesta veementemente dois princípios (...) que são regidos pela autoridade sacerdotal e que nenhum defensor da liberdade religiosa pode admitir", a saber, a "infalibilidade sacerdotal" e a possibilidade de os sacerdotes "fecharem o paraíso contra todo aquele que não reconhecer neles o poder de abri-lo". 397

Para esse autor, quanto mais o evangelho é estudado, melhor podemos ver a unidade de espírito existente entre os cristãos e a fé comum nas doutrinas que são verdadeiramente essenciais. E, estudar Jan Hus, bem como estudar qualquer um dos mártires da história da religião, é estar acima das disputas entre nações e religiões. O exemplo desses sujeitos leva “as nações a avançar pela inteligência e liberdade em direção à unidade espiritual". E inteligência e liberdade significam uma convicção religiosa digna de uma nação livre, ou seja, não ligada à Igreja católica:

A França não se conhece (...) eles rejeitaram a fé antiga e não terão outra;
eles odeiam aquela igreja, agora envelhecida, na qual eles nasceram, e
esperam por sua queda (...) e, vendo-a ainda em pé, eles estão perdidos em
espanto; eles não sabem que, na ordem das ideias, nada é destruído que não
seja substituído e que uma religião só é substituída por outra. Se uma fé cega
e imposta pode ser suficiente para um povo escravizado, uma nação livre
precisa de uma convicção; sem ela, a liberdade de consciência é uma
nulidade e nenhuma nação quer essa liberdade mais do que a França,
especialmente quando o horizonte está se tornando sombrio. ${ }^{398}$

Render um tributo a Jan Hus, como propõe Bonnechose, é declarar que a "França não é suficientemente orgulhosa de seus mártires" e que apesar de ter conseguido a "liberdade religiosa, ela não ousa usá-la”. Ele falava do lugar dos protestantes franceses. É o que percebemos na leitura de seu obituário, publicado no Bulletin historique et littéraire da Société de l'histoire du protestantisme français [Boletim histórico e literário da Sociedade de história do protestantismo francês] de 1875, escrito pelo filósofo francês Charles Waddington:

Emile de Bonnechose não só honrou o protestantismo francês pela nobreza de seu caráter e as virtudes modestas que são o traje de um cristão, ele derramou sobre a Igreja Reformada uma grande luz com suas publicações históricas. Para mencionar apenas aqueles que se relacionam mais

\footnotetext{
396 ibidem, p. 2.

397 ibidem, p. 3.

398 ibidem, p. 6.
} 
diretamente a nossos estudos, todo mundo conhece sua Histoire de France, onde a verdade sobre a Reforma foi exposta com tal tato e moderação, e esta biografia tocante de Jan Hus, onde o autor nos mostra, segundo sua expressão genial, os reformadores antes da Reforma. É no prefácio desta última obra que o $\mathrm{Sr}$. Bonnechose, recentemente convertido ao protestantismo, dispôs o testemunho público de sua fé e a tocante expressão de tristeza que era, dizia ele, 'a maior garantia de sua sinceridade'. A França perde em Emile de Bonnechose, um bom cidadão, a Igreja Reformada um membro ilustre e devotado, nossa Sociedade, enfim, um amigo esclarecido, um aliado precioso, a quem ela renderá logo uma homenagem das maiores e mais adequada a seus méritos. ${ }^{399}$

Este historiador francês, recém convertido ao protestantismo, defensor de um cristianismo separado das estruturas da Igreja católica, resgatou a imagem de Jan Hus, sob a crença que "depois da conclusão de grandes eventos, o trabalho mais útil é, talvez, perpetuar a sua lembrança e é prestar um bom serviço à humanidade discutir ao longo do tempo a memória daqueles que honra."

Essa crença de Bonnechose é a mesma crença de todos os editores das cartas de Hus. A figura desse clérigo vai se construindo ao longo dos séculos, ganhando novos contornos à medida que novos autores e editores o lêem: de verdadeiro cristão e defensor da verdade até a morte torna-se precursor da Reforma Protestante e restaurador do direito à liberdade de consciência. Matthew Spinka, historiador protestante norte-americano da atualidade, ao reconstruir a vida e o período no qual viveu o clérigo da Boêmia, insere-o num movimento mais amplo de reforma da Igreja anterior à Reforma Protestante, o Conciliarismo. Esse movimento consistia na busca pela unidade da Igreja, no período de Cisma, a partir do princípio que um Concílio teria mais poder e autoridade que o papa. Spinka afirma que só é possível compreender a figura de Hus e seu julgamento no Concílio de Constança a partir da compreensão desse princípio pelo qual o papa não seria o chefe da Igreja, mas seu servidor. Sustenta que um dos principais motivos para sua condenação tenha sido a oposição entre uma visão hussita baseada nas escrituras e uma visão legalista dos juízes que o condenaram. Todos buscavam uma reforma da igreja, porém com visões que se tornaram opostas naquele julgamento. ${ }^{401}$

Spinka foi professor do The Central Theological Seminary, em Dayzon, Ohio, do Hartford Seminary Foundation, em Connecticut, e Claremont School of Theology, na

\footnotetext{
${ }^{399}$ WADDINGTON, Charles. Nécrologie: M. E. de Bonnechose. Bulletin historique et littéraire. Paris: Société de l'histoire du protestantisme français. 1875, ano 24, p. 144.

${ }^{400}$ BONNECHOSE, The reformers before the reformation, p. 1. Página 5 na versão original em francês.

${ }^{401}$ SPINKA, John Hus at the Council of Constance, passim.
} 
California. Também foi secretário da American Society of Church History. ${ }^{402}$ Seu sobrenome sugere uma ascendência eslava e os lugares onde trabalhou são indícios de uma formação protestante e de historiador. Publicou textos sobre a história do cristianismo entre os povos eslavos desde a década de 1920, escrevendo inclusive a respeito dos Hussitas e de Comenius. ${ }^{403}$ Publicou seu primeiro trabalho sobre Hus em 1965, mesmo ano no qual terminou o Concílio Vaticano II. Nessa obra ${ }^{404}$, na qual traduziu o Relatio de Petr de Mladoňovice e as cartas que Hus escreveu de Constança, ele dá o tom de sua leitura sobre Hus:

Destas cartas pode-se derivar a melhor prova da personalidade e do caráter do reformador tcheco. Elas revelam suas convicções profundas a respeito da autoridade suprema das escrituras a partir da interpretação dos Padres da Igreja, em oposição às visões legalistas de seus juízes, associadas à sua profunda humildade e prontidão em ser instruído a respeito de qualquer coisa que pudesse conflitar com a compreensão de sua fé. Elas também são o testemunho de sua determinação por morrer ao invés de trair a verdade. Elas ilustram melhor do que qualquer outra fonte disponível o conflito trágico entre seu desejo fiel e sincero de reformar a Igreja de acordo com o padrão apostólico primitivo, interpretado pelos doutores da Igreja, especialmente Agostinho, e a igreja contemporânea sua, bem longe desse padrão. Elas manifestam sua suprema devoção ao ideal de uma igreja como corpo do Cristo que existe a despeito da corrupção da sociedade secular 'sem mancha ou ruga', uma irmandade dos redimidos, 'imaculada do mundo'. 405

Spinka não atribui explicitamente à Hus a imagem de verdadeiro cristão, mas sustenta a de precursor da Reforma Protestante e defensor da verdade até a morte. $O$ que Bonnechose via como uso da "liberdade de consciência", Spinka vê como um uso mais racional das Escrituras como base para a reforma da Igreja. Hus foi o símbolo da suprema devoção a uma visão de Igreja sem máculas. Em outra obra, Spinka deixa claro que o clérigo da Boêmia pode ser considerado como “o estágio de transição entre o período medieval

\footnotetext{
${ }^{402}$ Spinka assina como secretário a ata de algumas das reuniões dessa sociedade. V. SPINKA, Matthew. Fiftieth (Thirty-Fourth Annual) Meeting of the American Society of Church History. Church history. Cambridge University Press; American Society of Church History. mar. 1941, vol. 10, n. 1, pp. 60-67.

${ }^{403}$ Para citarmos alguns deles: SPINKA, Matthew. Religious movements in Czechoslovakia. The journal of religion. Chicago: University of Chicago Press. nov 1923, vol. 3, n. 6, pp. 616-631. Idem. Slavic Translations of the Scriptures. The journal of religion. Chicago: University of Chicago Press. out 1933, vol. 13, n. 4, pp. 415432. Idem. Peter Chelčický: The Spiritual Father of the Unitas Fratrum. Church history. Cambridge University Press; American Society of Church History. dez. 1943, vol. 12, n. 4, pp. 271-291. Idem. Comenian Pansophic Principles. Church history. Cambridge University Press; American Society of Church History. jun. 1953, vol. 22, n. 2, pp. 155-165. Idem. Paul Kravař and the Lollard-Hussite Relations. Church history. Cambridge University Press; American Society of Church History. mar. 1956, vol. 25, n. 1, pp. 16-26.

${ }^{404}$ SPINKA, John Hus at the Council of Constance.

${ }^{405}$ ibidem, p. 85-86.
} 
anterior e a Reforma, assim oferecendo uma ligação entre os movimentos antigo e novo de reforma." ${ }^{406}$ Igualmente, o Concílio Vaticano II, ao estabelecer ${ }^{407}$ que ninguém pode ser condenado e executado por suas crenças e convicções, associaria, de certa forma, seu programa de reforma ao programa conciliar dos séculos XIV e XV, do qual Hus é importante representante $^{408}$. Spinka atribui, por esta conexão, um lugar para Hus na História, afirmando que ele possui "influência amplamente desconhecida no mundo contemporâneo" 409 . O clérigo da Boêmia é um dos precursores do Concílio Vaticano II. O legado de Hus é desconhecido porém fundamental.

Outro elemento da imagem de Hus que Spinka traz ${ }^{410}$ é a quantidade "extraordinária e até mesmo monumental" de produções da historiografia tcheca a respeito da Reforma na Boêmia no final do século XIX e na primeira metade do século XX. Ele cita quatro vertentes de pensamento a respeito de Hus. Uma primeira, liderada por Johann Loserth, que aponta, no final do século XIX, o clérigo da Boêmia como um plágio de Wyclif. Essa visão foi combatida por historiadores como Václav Novotný e Vlastimil Kybal no início do século XX, elogiados por Spinka. O segundo é o dos "liberais católico-protestantes" como os já citados Novotný e Kybal além de Kamil Krofta, F. M. Bartoš e Tomáš G. Masaryk. Formam o terceiro grupo Josef Pekař, católico liberal, Jan Sedlák, teólogo ortodoxo e um frei beneditino belga Paul De Vooght, reelaborando a visão católica romana sobre Hus. O quarto grupo, de inspiração comunista, é representado por Milan Machovec, Robert Kalivoda, e Josef Macek. Este último grupo é considerado por Spinka, pelo fato de serem marxistas, como "não qualificados para uma pesquisa genuína e imparcial".

Esse levantamento do autor norte-americano aponta para a confirmação de uma afirmação que ouvimos recentemente de um diplomata tcheco quando lhe falávamos a respeito deste trabalho: "existiram muitos Hus, dependendo da época que se escreveu dele".

\footnotetext{
${ }^{406}$ SPINKA, John Hus: a biography, p. 3.

${ }^{407}$ Confirmando a encíclica Pacem in Terris do papa João XXIII de 11 de abril de 1963. V. JOÃO XXIII, Papa. Pacem in terris: carta encíclica do sumo pontífice papa João XXIII a paz de todos os povos na base da verdade, justiça, caridade e liberdade. Disponível em <http://www.vatican.va/holy_father/john_xxiii/encyclicals/documents/hf_jxxiii_enc_11041963_pacem_po.html>. Acesso em 16 jan. 2010. Um importante documento do Concílio Vaticano II que pode ser usado como fonte para esta afirmação é a declaração Dignitatis Humanae, que trata da liberdade religiosa. CONCÍLIO VATICANO II. Dignitatis humanae: declaração sobre a liberdade religiosa. Disponível em <http://www.vatican.va/archive/hist_councils/ii_vatican_council/documents/vatii_decl_19651207_dignitatis-humanae_po.html >. Acesso em 16 jan. 2010.

408 ibidem, p. 3-4.

${ }^{409}$ ibidem, p. 4.

${ }^{410}$ SPINKA, John Hus at the Council of Constance, p. x-xi.
} 
Até aqui apresentamos os principais tradutores das cartas de Hus nos séculos XIX e XX. Cada um deles realizou sua tradução a partir de seu espaço-tempo. Traduzir as cartas de Hus para esses sujeitos não foi simplesmente um trabalho de reescrita de um texto em outra língua. Cada um deles divulgou e reiterou a memória do legado hussita, atribuindo variações a esse legado, mas conservando o lugar de ícone de defesa da verdade, o mártir que deixou seu exemplo.

Nenhum historiador, partindo das mesmas fontes, escreverá a mesma história, visto que a seleção que ele fizer será influenciada por sua leitura. Estabelecemos uma linha geral de historiadores que reiteram o legado hussita a partir da morte pela verdade e as decorrentes imagens de Hus como defensor da liberdade de consciência e como precursor da Reforma Protestante. No entanto, também vislumbramos as diferenças na ênfase nos detalhes e nas escolhas de cada um, de modo a construir seu projeto pessoal, e de seu espaço-tempo, de representação de um mártir.

Para Lutero, Hus foi o exemplo de um verdadeiro cristão. Bonnechose o considerou o defensor da liberdade de consciência. Para Workman e Pope, ele foi o precursor da Reforma Protestante. Já Spinka o colocou no lugar de ligação entre o pensamento medieval e a Reforma. Partindo dos mesmos documentos, essencialmente o Relatio de Mladoňovice e as cartas de Hus, eles reforçaram o mesmo legado, porém com variações de ênfase.

Reconstruir um legado passado é restabelecer uma proposta de ação futura. Nesse sentido, ele é educativo ao colocar o discípulo no lugar de mestre, reafirmando a verdade a ser ensinada. ${ }^{411}$ Quando transmitimos um legado nós o estamos propondo como ação para nossos interlocutores (ou leitores). Quando Bonnechose, por exemplo, afirma que Hus é um defensor da liberdade de consciência ele reconhece o legado educativo hussita e tem a intenção de divulgá-lo para que mais pessoas lutem pela liberdade de consciência. Bonnechose, discípulo torna-se educador.

Ao apresentarem diferentes interpretações, os historiadores trazem diferentes perspectivas. Ao lermos seus trabalhos, poderemos procurar por aquilo que os diferencia ou pelo que os assemelha. Mas elas oferecem um "lugar de encontro, uma praça onde se pode conversar, discutir, dissentir" como propõe Ginzburg ${ }^{412}$. Justamente o que diferencia é a leitura que o historiador faz dos documentos que utiliza. Mesmo que a fonte seja a mesma, "uma leitura diferente da documentação disponível influi imediatamente sobre a

\footnotetext{
${ }^{411}$ GUSDORF, Professores para quê?, passim.

${ }^{412}$ GINZBURG, Olhos de madeira, p. 198.
} 
narração. ${ }^{413}$ É por causa dessa influência que a leitura proposta neste trabalho para cartas de Hus é necessariamente diferente da dos tradutores citados.

Não encontramos novos tradutores dessas cartas cujos trabalhos foram publicados após o de Spinka. Sabemos, apenas, que há pesquisas contemporâneas ${ }^{414}$ a respeito de Jan Hus ligadas à Igreja Católica, bem como investigações acadêmicas ${ }^{415}$ nas universidades tchecas a respeito do período no qual Hus viveu.

Há, no entanto, espaço em outras universidades ao redor do mundo para pesquisas a respeito do clérigo da Boêmia e de seu espaço-tempo. Um desses estudos, datado de 1999, foi apresentado como dissertação de mestrado na Universidade de Alberta, no Canadá. A análise que o autor apresenta a respeito do uso de Jan Hus como figura histórica na cultura tcheca permite que, não apenas, conheçamos um pouco mais do lugar do clérigo da Boêmia na história moderna de seu povo, como também possamos estabelecer um diálogo entre seus estudos e nossa investigação. É o que faremos na sequência.

\subsection{A construção de um símbolo nacional}

Escrito por Tim Chodan e apresentado ao Departamento de História da Universidade de Alberta, no Canadá, o trabalho "O uso e o abuso de Jan Hus como figura histórica na cultura tcheca ou cozinhando seu próprio ganso: três receitas tchecas" ${ }^{\text {"16 }}$ propõe uma leitura da imagem de Hus complementar à que apresentamos até aqui. Chodan publica seu trabalho sobre Hus no mesmo ano em que Jan Hus foi objeto de estudo e discussão na Igreja Católica $^{417}$, embora não tenhamos encontrado qualquer referência a este evento na tese ou indícios de relação entre ambos. Em sua conclusão, o autor estabelece um diálogo em forma

\footnotetext{
${ }^{413}$ idem, $\mathrm{O}$ fio e os rastros, p. 229, grifo do autor.

${ }^{414}$ O papa João Paulo II discursou em um simpósio sobre Jan Hus no ano de 1999. Esse simpósio teve apoio de representantes da Igreja Católica na República Tcheca. V. JOÃO PAULO II, Discurso do papa João Paulo II aos participantes no simpósio sobre João Hus. Libreria Editrice Vaticana, 1999. Disponível em <http://www.vatican.va/holy_father/john_paul_ii/speeches/1999/december/documents/hf_jpii_spe_17121999_jan-hus_po.html>. Acesso em 31 dez. 2009.

${ }^{415}$ Ver, por exemplo, artigos da revista Český Časopis Historický, publicada pelo Instituto de História da Academia Ciências da República Tcheca. ŠMAHEL, František. Drobné otázky a záhady v studentském životě mistra Jeronýma Pražského [Questões menores e mistérios na vida estudantil do mestre Jerônimo de Praga]. Český Časopis Historický. Praga: Historický ústav Akademie věd České republiky. 2008. n. 1. pp. 1-18. STOČES, Jiř́i. Rektorská řada předhusitské pražské třífakultní univerzity (do vydání Dekretu kutnohorského). Nové poznatky a otazníky [A sucessão dos reitores Universidade de Praga pré-hussita de três faculdades (até o decreto de Kutna Hora). Pesquisas recentes e questões.] Český Časopis Historický. Praga: Historický ústav Akademie věd České republiky. 2009. n. 3. pp. 533-558. ŠMAHEL, František; NODL, Martin. Kutnohorský dekret po 600 letech. Bilance dosavadního bádání [Seiscentos anos do decreto de Kutná Hora. Estado da arte] Český Časopis Historický. Praga: Historický ústav Akademie věd České republiky. 2009. n. 1. pp. 1-45. ${ }^{416}$ Tim CHODAN, The use and abuse of Jan Hus...

${ }^{417}$ Ver nota acima a respeito do discurso do papa João Paulo II.
} 
de "reflexões pessoais" entre sua produção e o modo como o estudo histórico é tratado no oeste do Canadá:

Esta é uma questão irritante porém maravilhosa em Alberta: qual é, realmente, a utilidade do conhecimento histórico? Talvez até mesmo a palavra utilidade não seja a mais adequada para atribuir o sentido correto da pergunta. Quão ‘bom' é o conhecimento histórico para a cultura que o cultiva e valoriza? (.... $)^{418}$

E, mais à frente, "confessa" o porquê de ter escrito seu trabalho:

E eu confesso que esta tese, embora eu tenha me esforçado muito para pesquisá-la, foi, na verdade, um instrumento pelo qual eu explorei esta questão 'albertana'. Pois em meu estágio preliminar em Praga, antes de eu iniciar a pós-graduação, eu estava assolado pela presença da história tcheca. Lá era um lugar no qual a história era realmente pensada como algo importante. (Eu não consigo lembrar, por exemplo, de um único momento no qual um tcheco tenha me perguntado qual a utilidade de uma graduação em história.) Lá era um lugar no qual a história foi utilizada. Como? Eu me perguntava.

É o uso futuro da história que influencia sua utilidade presente. Esta é a principal resposta que a história tcheca traz para Chodan à pergunta sobre a utilidade do conhecimento histórico. Ele não faz essa recomendação, apenas sugere que essa questão 'albertana' não faz sentido na história tcheca em virtude dos usos que os historiadores fizeram do passado, sendo Jan Hus o caso exemplar. É nesse contexto que este autor produziu sua tese.

Para ele, "o passado tcheco foi pensado como algo para o qual a nação deve voltar de algum modo" e, nesse sentido, a nação é como um "pai mítico" que fala por intermédio de seus "filhos bons, fiéis, verdadeiros etc." 419 . Sua conclusão, para o caso de Hus, é que a história tcheca foi construída com vistas a uma mudança social em busca de um futuro diferente do momento em que se escreveu a narrativa histórica.

Jan Hus assume uma posição na história tcheca de figura que representa essa voz do pai-nação, não apenas por causa de sua história pessoal, mas também porque a história da nação tcheca foi marcada por diversos momentos nos quais o controle estatal não era tcheco. O movimento nacionalista de meados do século XIX precisou, para tornar-se viável, justificar o presente como "uma aberração" e o passado como "uma representação da nação verdadeira" 420 .

\footnotetext{
418 ibidem, p. 112. As duas citações seguintes foram retiradas das páginas 114 e 115.

${ }^{419}$ ibidem, pp. 3 e 4.

${ }^{420}$ ibidem, p. 7.
} 
Chodan propõe observar a história tcheca em três ${ }^{421}$ momentos diferentes de "uma luta política contínua pelo controle do significado de Hus como um símbolo cultural” ${ }^{\natural 22}$ que ele apresenta, metaforicamente, como "os meios, o instrumento e o martelo" para se forjar a nação tcheca do futuro.

O primeiro, os meios, é o período da formação do pensamento nacionalista tcheco, aproximadamente de 1848 a 1869. O segundo, o instrumento, é a virada do século, com um florescimento desse nacionalismo bem como sua diversificação, entre 1895 e 1915 . E o terceiro, o martelo, é o "sequestro" comunista da figura de Hus após a Segunda Guerra Mundial, de 1945 a 1948.

A análise de como nesses períodos a imagem de Hus foi reelaborada fornecerá materiais para que possamos observar a presença desse legado na Boêmia/Morávia especialmente nos séculos XIX e XX. Faremos uma breve contextualização da história tcheca dos Hussitas até meados do século XX para iluminar os espaços-tempos que a obra de Chodan discute. ${ }^{423}$

De 1447 a 1471, a Boêmia vive um período de disputas pelo poder real, com forte atuação dos Utraquistas. No entanto, em 1462, o rei Jorge de Podebrady é excomungado e a Compactata declarada nula e inválida pelo papa Paulo II. Em 1485, a Compactata é novamente reafirmada pelo acordo de Kutná Horá entre Católicos e Utraquistas. Em 1490, Vladislau II, da Polônia, é eleito rei da Hungria e reúne sob seu controle a Boêmia, a Morávia, a Silésia e a Lusátia. Em 1508, Vladislau II emite um decreto de perseguição da União dos Irmãos, grupo formado anos antes e que deu continuidade ao legado Hussita dos grupos anteriores, mas que nunca esteve protegido pela Compactata. No entanto, esse decreto não foi aplicado tão rigidamente.

Em 1517, Martinho Lutero publicou suas teses reformadoras na Alemanha, o que ampliou os conflitos religiosos na Boêmia. Luís II, filho de Vladislau II, tenta mediar esses conflitos, bem como aqueles entre a burguesia crescente e a nobreza possuidora de terras. Não o consegue e morre, em agosto de 1526, durante sua fuga de uma derrota numa batalha contra os turcos.

\footnotetext{
${ }^{421}$ Embora o autor afirme, à página 10, que sua divisão em três períodos não é a única possível e que ele mesmo já vislumbrou outras possibilidades.

422 ibidem, p. 9.

${ }^{423}$ A fonte para essa síntese é CZECHOSLOVAK REGION, HISTORY OF. Encyclopædia Britannica.

Disponível em: <http://www.britannica.com/eb/article-42097>. Acesso em 01 dez. 2007.
} 
Com a morte de Luís II, Ferdinando I, da casa dos Habsburgos, inicia uma dinastia que durará até 1914. Ele perseguiu a União dos Irmãos e, como não obteve sucesso em conseguir um acordo com os Novos Utraquistas, dirigiu seu apoio aos católicos e introduziu a Companhia de Jesus na Boêmia (1556). Pela tradição antipapal e destaque político, a Boêmia torna-se um lugar importante na estratégia da Contra-Reforma. Os católicos ocuparam, com o apoio do então rei Rudolf II, diversos postos de comando em 1600 e perseguiram a União dos Irmãos. O sobrinho do irmão de Rudolf, Ferdinando da Síria, foi coroado em 1617. Os estados protestantes da Boêmia opuseram-se a ele. Em 23 de maio de 1618, dois governadores e um secretário foram julgados e atirados pela janela, o que ficou conhecido como Segunda Defenestração de Praga (lembrando que a primeira ocorrera em 1419). Em 1619, Ferdinando foi deposto, mas no ano seguinte foi recolocado no governo vencendo a batalha de Bilá Horá (Montanha Branca) em 8 de novembro de 1620. Esta batalha foi um marco importante na história tcheca, visto que estabelece o início do absolutismo real, uma época "escura" para os tchecos. $^{424}$

Em 1621, o rei Ferdinando executou 27 líderes boêmios, confiscou terras dos apoiadores dos protestantes e restabeleceu a presença dos Jesuítas na Boêmia (que haviam sido banidos em 1618). Em 1627, promulga um Novo Regime Territorial, que permaneceu válido até 1848. Esse regime estabeleceu, entre outras coisas a hereditariedade do reino, o uso da língua alemã e o catolicismo romano como única religião permitida. Entre as principais consequências dessa mudança estão grande emigração de protestantes, conversões ao catolicismo e crescimento dos Jesuítas. Estes controlavam a produção literária, a educação superior e a formação dos noviços tchecos. O alemão torna-se a língua oficial e o Barroco domina a arquitetura, escultura e pintura e influenciou a literatura, o teatro e a música do período.

No início do século XIX, influenciados por ideias da Revolução Francesa, pela oposição ao regime centralizador do Império Austro-Húngaro, pelas inovações industriais e por um renascimento da cultura tcheca, apoiados por uma aristocracia simpática a estas ideias, surgem acadêmicos, escritores, clérigos e professores que espalharam uma consciência nacionalista no povo. Em 1848, surge um movimento constitucionalista que buscava eleições diretas para a Dieta da Boêmia. O regime do então rei Francisco José impediu o crescimento desse movimento, mas, diante da derrota numa guerra contra a Sardenha promulga, em 1860, um documento que inaugura a era constitucional, permitindo a eleição para a Dieta. Este é o

\footnotetext{
${ }^{424}$ Petra Mocová afirmou-nos pessoalmente que há um ditado popular tcheco, que as pessoas usam quando algo de ruim acontece, que significa "perdi como em Bilá Horá".
} 
pano de fundo do primeiro período da tese de Chodan. Embora extensas, essas informações aqui apresentadas são fundamentais para nossa argumentação, uma vez que a história tcheca é em geral desconhecida para nós.

Em 1874, o Partido Nacional Tcheco se divide em dois grupos, os conservadores e os Jovens Tchecos. Estes apoiavam ideias de progresso na educação, emancipação das influências clericais e melhoria na qualidade de vida. Eles conseguem progressivamente participação política até assumirem a maioria em 1891. Na última década do século XIX, surge o Partido Socialista Nacional, que critica os Jovens Tchecos afirmando que eles se afastaram de suas propostas. Um dos principais líderes desse partido é Tomáš Masaryk. Isto cobre o contexto do segundo período da tese de Chodan.

Em 1914, inicia-se a Primeira Guerra Mundial e, em 1917, a Revolução Russa. Em janeiro 1918, o presidente dos Estados Unidos, Woodrow Wilson publica seus 14 pontos, sendo que o décimo sustenta o livre desenvolvimento autônomo dos povos austro-húngaros. Masaryk vai aos Estados Unidos e de Washington, em 18 de outubro do mesmo ano, simultaneamente a seu apoiador Edvard Beneš em Paris, assina a declaração de independência. Em 28 de outubro o Comitê Nacional de Praga proclama a República, à qual o Conselho Nacional Eslovaco adere dois dias depois. Estava constituída a Tchecoslováquia. Masaryk foi o primeiro presidente e Beneš seu sucessor.

Esse país durou poucos anos. Vinte e um anos depois, em 15 de março de 1939, as tropas alemãs de Hitler ocupam a Boêmia e a Morávia, tornando-os um Protetorado Alemão. O Protetorado permanece durante a guerra e só é extinto em 1945, com a definitiva expulsão do exército alemão de Praga, com apoio das forças soviéticas.

No período pós-guerra, Beneš retorna ao poder e tenta instaurar a liberal democracia que existira na Tchecoslováquia até 1938. Nas eleições de 26 de maio de 1946, o Partido Comunista Tcheco obteve 38,7\% dos votos. Embora não fosse maioria, sob a liderança do premier Gottwald, os membros do partido, aproveitando a desorganização dos partidos nãocomunistas, trabalharam para assumir o poder. Em 20 de fevereiro de 1948, após um conflito a respeito do controle da polícia, os ministros não-comunistas renunciaram. Gottwald recusou-se a fazê-lo e os cargos foram assumidos por ministros do partido comunista. Em 25 de fevereiro de 1948 assume, oficialmente, o governo comunista na Tchecoslováquia. Líderes políticos, intelectuais e administradores deixaram o país. Em 30 de maio, Gottwald é eleito presidente. No outono do mesmo ano, encontra-se com Stalin que lhe dá as diretrizes do novo 
governo. No ano seguinte, conselheiros soviéticos chegam à Tchecoslováquia. Este é o contexto do terceiro período da tese de Chodan. ${ }^{425}$

Do primeiro período que analisa em sua tese, 1848 a 1869, Chodan destaca a figura de František Palacký, historiador tcheco protestante que, em seu livro sobre a história da nação tcheca, escreveu laudatoriamente a respeito de Hus. Ele, em conjunto com outros intelectuais de seu tempo como Karel Havliček e Josef Kajetán Tyl, difundem uma imagem nacionalista do clérigo do século XV. Para Havliček, a nação tcheca deveria reconhecê-lo como "o mais fiel amigo e pai" que ofereceu sua vida "pelo amor à nação tcheca e pela maior verdade de valor humano" ${ }^{\text {426 }}$. Para Tyl, em sua peça de teatro sobre Hus, ele era a luz, o sol, a estrela ou até mesmo "o messias tcheco".

Essa imagem de Hus possibilitou o desenvolvimento de outra ainda maior: a unidade da nação tcheca. Os tchecos referiam-se a ele como "nosso", como se a nação respondesse em unidade aos ataques que ele sofreu. Hus era visto como "filho" ou até mesmo "pai" da nação tcheca. Uma carta enviada para o Národní Listy, jornal de Praga, em 1868, afirmava "seguindo Teu exemplo, santo mártir, nós queremos lutar e nos esforçar, firme e abertamente, por nosso direito e liberdade".

Como símbolo da nação, Hus foi lembrado por seu papel para o desenvolvimento da língua tcheca e, como um Gandhi do século XV, alguém que lutou pela nação sem usar da violência, justamente o que queriam os nacionalistas daquele período. Ainda mais, ele inculcou suas ideias no humanismo e, mais tarde, na Reforma Protestante, no Iluminismo e até mesmo na Revolução Francesa. Suas ideias eram sua contribuição à nação tcheca e a

\footnotetext{
${ }^{425}$ Consideramos importante trazer as informações da história tcheca até o presente, mesmo estando fora do período estudado por Chodan, apresentando a história de um povo que passou por diversos conflitos políticos e culturais para conquistar sua independência. De 1948 até 1968, a Tchecoslováquia viveu sob o governo comunista. Em 1968, o então presidente Antonín Novotný, sob a pressão de manifestações de estudantes e a ação de escritores contrários ao regime, renuncia. É o período da Primavera de Praga, no qual, sob o governo do presidente Ludvík Svoboda (cujo sobrenome coincidentemente significa "Liberdade"), intelectuais propuseram reformas sociais e políticas, cresceram o número de clubes de jovens, escoteiros, igrejas, associações de minorias e de defesa dos direitos humanos. Em 27 de junho de 1968, um documento assinado por diversas pessoas conhecido como Duas Mil Palavras, que pedia a rápida transição para a democracia. A União Soviética, a Alemanha Oriental, a Polônia, a Hungria e a Bulgária, signatárias do Pacto de Varsóvia, invadem a Tchecoslováquia em 20 de agosto do mesmo ano. A partir de então, o país poderia manter seu governo, porém com a presença constante das tropas soviéticas em seu território. Essa situação se manteve até 1989 quando ocorreu a Revolução de Veludo, na qual, manifestações pró-democracia e greves lideradas pelo Fórum Cívico, encerrou o regime comunista na Tchecoslováquia. Václav Havel, principal porta-voz desse movimento, tornouse presidente. Em junho de 1990, foram realizadas novas eleições para o parlamento, com derrota expressiva dos comunistas. Em 1991, as tropas soviéticas saíram do país. As novas eleições parlamentares de 1992 fomentaram o movimento separatista e, como fruto de negociações pacíficas entre os dois grupos, a Assembléia Nacional vota pelo fim da Tchecoslováquia no final daquele ano. Desde 1993, existem a República Tcheca, com territórios que correspondem aproximadamente às regiões da Boêmia e Morávia, e a Eslováquia. Em 2004 a República Tcheca e a Eslováquia integram a União Europeia.

${ }^{426}$ CHODAN, op. cit., p. 20 e pp. 20, 23, 26, 30, 31, 32 para os parágrafos seguintes.
} 
contribuição da nação tcheca para o mundo. Portanto, eles mereciam um lugar de protagonistas na Europa e não de submissos ao Império Austro-Húngaro.

O que percebemos, a partir da leitura de Chodan a respeito desse período nacionalista da história tcheca, se a unirmos com a leitura de Seltzer e dos biógrafos de Hus a respeito dos Hussitas, que apresentamos anteriormente, é que houve um período de adormecimento desse legado na Boêmia/Morávia ${ }^{427}$. Do exílio de Comenius no século XVII ao movimento nacionalista do século XIX, a imagem de Hus estava associada ao do herege, exceto por algumas igrejas que comemoravam o dia seis de julho. No entanto, foi por meio de um historiador protestante, Palacký, que o legado hussita retorna, agora associado a uma imagem nacionalista: Hus morreu pela verdade e pela nação. Se o clérigo da boêmia foi um precursor da Reforma Protestante, esta foi precursora do renascimento de Hus na nação tcheca.

Entendemos que esse suposto adormecimento não significava um esquecimento. $O$ ressurgir hussita em meados do século XIX foi seguido de uma intensa movimentação popular que não foi construída por Palacký e intelectuais que apoiaram suas interpretações. Esse movimento popular pró-Hus foi reconstruído e reinterpretado naquele momento no qual as condições eram favoráveis para tal.

Chodan apresenta o ano de 1868 como o estopim desse movimento. Houve procissões, discursos, publicações no jornal Národní Listy, apresentações teatrais. E tudo começou com a comemoração do aniversário de 70 anos de Palacký, em 14 de junho. No jornal, cartas eram publicadas chamando-o de professor e pai da nação. Em 2 de julho, uma procissão carregando símbolos dos Hussitas, como o cálice, toma as ruas e convida as pessoas para uma peregrinação à Constança. Em 1869, Hus já era o mártir, símbolo da nação tcheca. Foi justamente nesse ano que se decidiu erguer a primeira estátua para Hus e que Palacký publicou seu Documenta, com o Relatio de Mladoňovice, as cartas de Hus e diversos outros documentos importantes do início do século XV, obra que continua sendo importante fonte para Hus e que foi utilizada neste trabalho. A publicação dos escritos de Hus ocorre no auge do fervor nacionalista tcheco. Palacký, que aparece como importante intelectual desse movimento, utiliza o legado hussita para sustentá-lo. ${ }^{428}$

\footnotetext{
${ }^{427}$ ibidem, p. 63, aponta que Tomáš Masaryk, que viria a se tornar o primeiro presidente da Tchecoslováquia, afirma que eles "se perderam" durante a Contra-Reforma.

${ }^{428}$ FERRO, Marc. A história vigiada. São Paulo: Martins Fontes, 1989, p. 56, citando Mona Ozouf, aponta para a existência de uma "função conservadora das comemorações, visto que os projetos de monumentos, o programa das festas, os planos para os desfiles que comemoraram o centenário da Revolução Francesa 'martelam' que aqueles a quem prestamos homenagem são idênticos uns aos outros, 'que somos os mesmos que então, que permaneceremos os mesmos', o que é muito mais um auto de fé do que uma verdade histórica.” Essa
} 
As peças começam a se encaixar. O que supostamente era uma leitura diferente de Hus, entendemos, é a repetição de um mesmo legado, aqui sob a ótica do nacionalismo. Vejamos como ele se reconstrói no segundo período estabelecido por Chodan.

Na virada do século XIX para o XX, a imagem de Hus como símbolo da nação tcheca era bastante forte. Em 1915 já havia 19 estátuas na Boêmia/Morávia. Nesse ano de celebração do aniversário de 500 anos da morte de Hus, multiplicavam-se anúncios de venda de textos sobre ele nos jornais. ${ }^{429}$ Os intelectuais tchecos daquela época associavam sua imagem à nação. Hus era o símbolo de ser tcheco. O historiador Václav Flajšhans utilizava as palavras Hus e tcheco como sinônimas. No jornal Národní Listy, ele escreveu "Hus é, simplesmente, o símbolo de nossa tchequidade ${ }^{430}$ na sua mais bela abrangência." ${ }^{431}$

Uma das figuras principais desse período é Tomáš Masaryk, intelectual que foi um dos líderes do movimento de independência da Tchecoslováquia do Império Austro-Húngaro e se tornou, com o fim da Primeira Guerra Mundial e do Império, o primeiro presidente do país independente. Ele contribuiu para difundir a associação da imagem de Hus com a da modernidade $^{432}$ e do nacionalismo. O povo tcheco era mais avançado que os outros povos, dado que Lutero disse, cem anos depois da morte de Hus, que todos eram Hussitas. O uso da palavra era ao invés de estava foi proposital, visto que o sentido da história tcheca para Masaryk possuía uma "visão arquitetônica", que afetava diretamente o presente e o futuro e deveria ser escrita considerando sua influência. Por isso, como afirma Chodan, Hus era atemporal, ele possuía uma ligação espiritual com a nação.

No início do século XX, houve na Boêmia/Morávia uma discussão sobre o sentido da história tcheca. De um lado, estavam aqueles que pensavam como Masaryk. Do outro, estavam os historiadores inspirados em Jaroslav Goll, que propunha uma abordagem mais estritamente histórica. Supostamente, para os historiadores da escola de Goll, como Josef

característica de auto de fé que o autor apresenta para as comemorações da Revolução Francesa é semelhante aos eventos de comemoração do aniversário de Palacký com relação ao lugar de Hus na sociedade tcheca.

${ }^{429}$ CHODAN, op. cit., p. 65.

${ }^{430}$ Por vezes, certos neologismos exprimem a totalidade de um pensamento e somos obrigados a fazer uso dele. O uso da palavra tcheca češství e da palavra inglesa czechness sustenta o argumento de Chodan da associação entre Hus e a nação tcheca, pois ele representa a "tchequidade", o caráter de ser tcheco em sua plenitude. Como esta frase de Flajšhans é a base do capítulo 2 de Chodan, precisávamos desse neologismo. Eu o construí a partir da palavra "brasilidade" e, pessoalmente, penso ser sonoramente melhor que "tchequismo", cujo sufixo "-ismo" pode remeter a intoxicação/doença (alcoolismo) ou a movimento social/religioso etc. (calvinismo), que não é o caso.

${ }^{431}$ ibidem, p. 59. Publicação de 1908. Vale a pena destacar que Flajšhans também publicou as cartas de Hus, traduzidas (as originais em latim) para o tcheco. Não tivemos acesso a esta edição. A referência bibliográfica é: FLAJŠHANS, Listy husovy.

${ }^{432}$ ibidem, p. 61 e pp. $60,63,71,72,73$ e 75 para os parágrafos seguintes. 
Pekáŕ e Kamil Krofta, essa visão atemporal de Hus não combinava com seu pensamento. No entanto, o que Chodan aponta é que todos valorizavam sua imagem para além da perspectiva histórica, associando-o ao espírito tcheco, àquela tchequidade destacada por Flajšhans.

Outro historiador da escola de Goll merece destaque em nosso trabalho: Václav Novotný. Ele foi um dos mais destacados alunos de Goll e afirmou, em 1915, que Hus foi "um dos homens mais memoráveis na história da humanidade" e "um dos grandes filhos de nossa nação". Chodan afirma que ele, mesmo tentando reconstruir a história de Hus de um ponto de vista "estritamente histórico", fazendo dele "apenas um ser humano", os elogios que Novotný oferece ao clérigo da Boêmia caracterizam-no como "super-herói”. Esse historiador tcheco publicou em 1919 uma biografia de Hus e uma edição de suas cartas em 1920. É esta a edição usada por Matthew Spinka em sua tradução de 1972.

Com estas informações, nós unimos mais algumas peças do quebra-cabeça da história do legado de Hus. As principais fontes de Spinka, com os nomes que ele mais elogia, fazem parte de uma escola de pensamento que buscava um Jan Hus mais histórico. No entanto, essa busca ocorreu num contexto no qual a imagem hussita de Masaryk era o ser tcheco. Não segui-la era ser não-tcheco. E isso era tão forte no pensamento dos intelectuais daquela época que era impossível retratar Hus sem certa apologia. Hus era o educador da nação tcheca. Como sintetizou Chodan "Por meio de Hus os tchecos aprenderam que eles eram éticos, educados, sábios, humanistas, pacíficos, honestos e desejosos de se sacrificarem pela verdade. ${ }^{, 433}$ Hus ensinou os tchecos a serem tchecos em sua plenitude e ele foi para eles um grande mestre, como afirmou o escultor da mais famosa estátua do clérigo da Boêmia na república tcheca, Ladislav Šaloun, no ano da sua inauguração, "Sigamos no caminho que Você nos deixou, Mestre"434.

Outro detalhe que nos interessa destacar deste período da história da república tcheca é o uso de uma das cartas de Hus, "provavelmente um de seus mais famosos escritos", "como um tropo, um apelo para que os tchecos se unissem em tempos difíceis", segundo Chodan. Identificamos essa carta como a de número 73, pastoral, escrita em 10 de junho de 1415 . Aqui, repetiremos o trecho final para que o leiamos, agora, pensando no sentido dela ser relida pelos tchecos às vésperas de sua independência, dentro do contexto nacionalista tendo Hus como o grande educador da nação:

\footnotetext{
${ }^{433}$ ibidem, p. 78.

${ }^{434}$ ibidem, p. 69 e pp. 81, 88, 89, 95-97 para os parágrafos seguintes.
} 
Eu também suplico, em especial a vocês, praguenses, a serem gentis com a Belém visto que o senhor Deus ficará feliz se a Palavra de Deus foi pregada lá. Pois o demônio começou a ficar enfurecido naquele lugar e incitou pastores e cânones contra ele, percebendo que seu reino foi lá arruinado. Confio no senhor Deus que Ele preservará aquele lugar conforme Sua vontade e aumentará seus benefícios em outros mais do que ele fez por mim, este servo inútil. Suplico-lhes também que amem uns aos outros e não permitam que os bons sejam oprimidos pela violência e desejo que cada um de vocês aprenda a verdade.

A última frase deste trecho foi lida por um político, Karel Baxa, numa pequena reunião (tida pelo Národní Listy como tendo "toda a nação presente") organizada pela Associação para a Construção do Memorial de Hus em 6 de julho de 1915. Baxa propõe, e é aplaudido por isso, uma busca de toda a nação por um futuro mais feliz. As palavras de Hus trazem o conforto de que, apesar das perseguições e dos sofrimentos do presente, o futuro será melhor, basta que todos se unam, amem uns aos outros, contra a opressão aos bons, que os tchecos sofrem por não formarem uma nação independente, na bandeira da verdade.

Algumas décadas depois, durante a Segunda Guerra Mundial, a Tchecoslováquia permaneceu como protetorado alemão, sofrendo os horrores daquela guerra. A estátua de Hus ficou coberta pela bandeira nazista e, desde 1938, era proibido celebrar o 6 de julho. Com o fim da guerra, em 1945, a libertação da nação foi marcada pela celebração do dia de Hus. Centenas de milhares de pessoas participaram do evento na praça da cidade velha de Praga e em outras regiões simbolicamente importantes para os tchecos.

Nessa ocasião, um grupo de intelectuais liderados por Zdeněk Nejedlý, associou a imagem de Hus ao projeto comunista. Nejedlý afirmou, em sua obra Hus a naše doba (Hus e o nosso tempo), que "o programa de Hus é, na verdade, o programa socialista dos tempos modernos, o qual, em suas várias modificações, é também o programa de todos os esforços ulteriores para o progresso da humanidade até hoje". E esse programa foi por ele resumido em três pontos: a lei da coletividade, a abolição da propriedade privada e a igualdade entre as pessoas.

Segundo Chodan, esse movimento de apropriação da imagem de Hus no pós-guerra foi um dos principais instrumentos para a instauração do regime comunista na Tchecoslováquia. O clérigo da Boêmia tornou-se o símbolo do programa comunista. Se nas décadas de vinte e trinta surgiu qualquer visão que o visse inserido em seu contexto temporal, no "passado", foi profundamente rechaçada durante a instauração do Comunismo. Os intelectuais desse período afirmavam que foram justamente as leituras a la Pekař, que supostamente liam Hus inserido no século XV, que enfraqueceram a nação tcheca e 
permitiram a invasão alemã. Portanto, elas foram alvo de denúncias, em oposição a uma imagem de Hus como símbolo da identidade tcheca.

Percebemos que, na leitura que Chodan fez desse período do pós-guerra, uma das frases que mais apareciam nos discursos políticos e nos textos dos jornais era "não deixe ninguém separá-los", extraída, como ele afirma, da carta aos fiéis tchecos escrita às vésperas de sua morte. Procuramos pela frase na carta que supomos ser aquela a de número 73 e não encontramos. Mesmo que ela estivesse desta forma na escrita do clérigo da Boêmia, há uma importante diferença de sentido em "não deixar ninguém separá-los" no século XV e no século XX na Boêmia. Enquanto Hus está falando da união em torno de princípios cristãos que estão sendo atacados pelo Anticristo atuando por meio de seus inimigos, os políticos do pós-guerra na Tchecoslováquia estão utilizando esta frase para promover a união em torno dos princípios comunistas.

Se não encontramos a frase citada na carta 73 , procuramos por outras frases que poderiam ser apropriadas de forma semelhante se deslocadas de seu sentido original. Em dois trechos, palavras de Hus poderiam servir como símbolo da revolução comunista. A carta 93 foi escrita para os membros da Universidade de Praga, na qual, logo após a saudação, há uma exortação aos "mestres, bacharéis e estudantes":

Exorto a vocês pelo amor do mais bondoso Jesus, que vocês amem uns aos outros, desenraizem os cismas e promovam a honra de Deus perante todo o resto, guardando-me na memória. Pois eu sempre procurei o avanço da universidade para a honra de Deus, sofri por suas discórdias e excessos e desejei unir nossa ilustre nação em uma só.

Um trecho como este pode ter servido como mote do programa comunista. Para o historiador da educação, o sentido é diverso. No trecho "unir nossa ilustre nação em uma só", Hus se dirige à nação como divisão interna da Universidade. Se destituído de seu sentido original, como era a proposta da crítica comunista à história tcheca, esse trecho oferece uma forte base para o programa não só dos comunistas na Tchecoslováquia, mas de todos os nacionalistas que colaboraram para que a imagem de Hus fosse associada à tchequidade da nação.

A carta 16, para o povo da cidade de Louny, que analisamos anteriormente, possui uma exortação à unidade, pois ela deixará o povo a salvo com Deus. “... suplico-lhes que amem uns aos outros, mantenham-se unidos e não permitam que nada cause a divisão entre os seus. Esta união, trazida pela da fé verdadeira, irá salvá-los quando na presença de Deus.” Na união a salvação. Esta foi a principal proposta comunista na Tchecoslováquia para a imagem 
de Hus. ${ }^{435}$ E o caráter que hoje poderíamos chamar de "religioso" da figura de Hus, ao invés de ser execrado nas bases da perseguição comunista da organização da Igreja, foi o próprio fundamento dessa proposta. O presidente Edvard Beneš, em 1945, disse:

Outra segunda intenção na luta de Hus é o empenho por uma melhor ordem social, que podemos dizer pelo reino de Deus na Terra. Mesmo nesse sentido, nós queremos completar o que a revolução Hussita já começou em nossa nação como um exemplo de progresso social muito além deste mundo. $^{436}$

Percebamos neste trecho, conforme destacou Chodan, o uso do tempo presente na afirmação da luta que Hus travou. Sua luta, seus esforços não ocorreram no passado, estão presentes no momento em que Beneš fez seu discurso. E esse esforço é o de implantar o Reino de Deus na Terra, que virá como um progresso trazido pelos melhores guardiões da herança hussita: os comunistas. É o que afirmava o jornal Rovnost em 1946:

Se, portanto, nós entendermos a aparição de Hus em seu tempo, seu sentido na história da nação, então nós, Comunistas, podemos ser os verdadeiros herdeiros e guardiões de seu legado. Nós vivemos em uma era diferente da de Hus. As condições mudaram, mas a direção da visão de Hus aponta para frente ainda hoje: Hus estaria conosco onde quer que a batalha fosse travada pela verdade, direito, justiça e liberdade humana. (...) Não é por acaso que os principais pensamentos dos políticos comunistas - a identidade entre povo e nação, a elevação cultural da nação, a criação da ordem democrática de um povo, a extinção de todos os privilégios que ainda sobrevivem, a unidade da nação na construção de uma vida melhor - soam tão próximos àqueles pelos quais lutaram os discípulos seguidores de Hus. E é por isso que nós, Comunistas, seremos os mais fiéis e os melhores guardiões da herança de Hus em nosso povo como a grande força moral em nossa história passada e futura. ${ }^{437}$

Surpreendentemente, o legado hussita tornou-se o mote da revolução comunista na Tchecoslováquia, por estar de acordo com os ideais propostos pelos intelectuais e políticos que a engendraram. A morte pela verdade tornou-se a luta pelo comunismo.

Essa apropriação já havia causado uma sensação de estranhamento para Spinka. Como já citamos, ele critica os historiadores tchecos marxistas ao afirmar que eles, justamente por

\footnotetext{
${ }^{435}$ OBERG, op. cit., p. 184 afirma que "Huss sempre pregou o respeito aos superiores e à ordem constituída, desde que estivessem de acôrdo com a palavra de Deus - e basta ler seus escritos, ou as suas cartas que chegaram até nós, para concluirmos que sua mensagem não coincide com a de qualquer agitador social." É uma leitura desse tipo dos escritos de Hus que sustentava essa visão comunista.

${ }^{436}$ CHODAN, op. cit., p. 98.

${ }^{437}$ ibidem, p. 109.
} 
terem escrito trabalhos "dominados pela visão Marxista de história, não se qualificam como pesquisas genuínas e imparciais" "438. Igualmente, Chodan utilizou a expressão "abuso" da figura de Hus no título de sua tese, claramente em referência ao período comunista.

Esse estranhamento surge de um movimento de oposição ao período comunista na Tchecoslováquia, em especial ao período de invasão das tropas soviéticas após a Primavera de Praga. Um exemplo dessa oposição está presente no famoso escritor tcheco radicado na França, Milan Kundera. Em uma de suas obras, afirma sobre o comunismo na Tchecoslováquia:

Em 1945, o Exército russo invadiu a Boêmia, e o país foi mais uma vez chamado de República independente. As pessoas ficaram entusiasmadas com a Rússia, que expulsara os alemães, e, como viam no Partido Comunista Tcheco seu braço fiel, transferiram para ele suas simpatias. Com isso, quando os comunistas se apossaram do poder em fevereiro de 1948, não o fizeram nem com sangue nem pela violência, e sim saudados pelo alegre clamor de cerca de metade do país. Agora, prestem atenção: essa metade, que dava gritos de alegria, era mais dinâmica, mais inteligente, melhor. ${ }^{439}$

A esta última frase, Chodan acrescenta "a metade mais idealista, influenciada, pelo menos em parte, por sua crença no simbolismo de Hus, no progresso e na missão tcheca."440 Decorrente desse estranhamento e para evitar o "esquecimento" apontado por Kundera, entendemos que autores como Spinka ou Chodan esforçam-se para restaurar a imagem de Hus que consideraram maculada pela apropriação comunista.

Nenhuma das "receitas para se cozinhar um ganso" apresentaram a verdade "absoluta" a respeito de Hus. E nenhuma delas poderá jamais fazê-lo. Mas todas as narrativas a respeito do clérigo da Boêmia foram construídas num "lugar de possibilidades historicamente determinadas", como afirma Ginzburg. Sem entrar no mérito da mácula ou não da imagem hussita, o que todas essas diferenças e adições ao legado de Hus mostram é a reiteração e reconstrução de uma memória. Mesmo que o uso que dela foi feito possa ser considerado como totalitário ou opressor, ela reforçou o reconhecimento histórico do papel educativo de Hus. Sua morte e seus escritos foram lidos em temporalidades muito diversas e usados com significados aparentemente diferentes, mas todas elas voltavam ao mesmo ponto: estamos defendendo a verdade, assim como Hus o fez.

\footnotetext{
${ }^{438}$ SPINKA, John Hus at the council of Constance, p. xi.

${ }^{439}$ KUNDERA, Milan. O livro do riso e do esquecimento. Tradução Teresa Bulhões Carvalho da Fonseca. São Paulo: Companhia das Letras, 2008, p. 15.

${ }^{440}$ CHODAN, op cit., p. 110.
} 


\title{
3.4. Um legado perenizado em imagens
}

Com a passagem dos anos, o sujeito histórico Jan Hus, acessível apenas por meio de documentos escritos, passou a ser representado iconograficamente como um mártir. Ginzburg, discutindo o surgimento das imagens de culto cristão ${ }^{441}$, mostra que os evangelhos apresentam grande frequência de "frases nominais com implicações messiânicas", iniciadas por ecce [eis], como "eis o cordeiro de Deus". A partir dos séculos V e VI, surgiram novas "imagens cultuais com conteúdo narrativo escasso ou inexistente" que exerciam a função de imagem de culto. Em movimento semelhante, as representações iconográficas de Hus assumiram um caráter de imagens de culto. Qual o sentido de cobrir sua estátua na praça da cidade velha em Praga durante o Protetorado alemão? É como se ela servisse de representação, no sentido que nos apresenta Ginzburg, de presença corpórea de Hus por meio da estátua. ${ }^{442}$ Até que ponto a sequência do martírio de Hus narrada por Petr de Mladoňovice não serve para associá-lo à Paixão de Cristo? É como se Petr dissesse "Eis Jan Hus", transformando a narrativa numa presença atemporal, na qual deixa de existir a passagem do tempo e fica a permanência da imagem de culto.

Analisar as representações de Hus como mártir em imagens figurativas, utilizando termos de Pierre Francastel ${ }^{443}$, requer instrumentais teóricos adicionais, visto que elas não são redutíveis a imagens verbais e vice-versa. A partir de Francastel, Schmitt afirma:

\begin{abstract}
As respectivas especificidades da imagem e da língua impedem que a primeira seja jamais designada como ilustração de um texto, mesmo no caso de uma miniatura pintada tendo em vista um texto e em relação direta com seu conteúdo. O texto evoca seus significados na sucessão temporal das palavras; a imagem organiza espacialmente a irrupção de um pensamento figurativo radicalmente diferente. Ora, a construção do espaço da imagem e a organização entre as figuras nunca são neutras: exprimem e produzem ao mesmo tempo uma classificação de valores, hierarquias e opções ideológicas. ${ }^{444}$
\end{abstract}

\footnotetext{
${ }^{441}$ GINZBURG, Olhos de madeira, p. 120-121.

${ }^{442}$ ibidem, p. 103.

${ }^{443}$ FRANCASTEL, Pierre. A realidade figurativa. Coleção Estudos. 2a. edição. São Paulo: Editora Perspectiva, 1993, p. 69, por exemplo.

${ }^{444}$ SCHMITT, Jean-Claude. O corpo das imagens: ensaios sobre a cultura visual na idade média. Bauru, SP: EDUSC, 2007, p. 34.
} 
Toda imagem é construção de um sujeito (filtro cultural) que está inserido num tempo, foi obtida por meio de uma técnica e está presente num determinado suporte. ${ }^{445}$ Com o advento da reprodutibilidade técnica ${ }^{446}$, as imagens ganharam um novo status e uma nova e necessária forma de ser lida. Elas podem ser copiadas, modificadas, transmitidas e observadas de tal maneira que os conceitos de veracidade e realidade precisam ser problematizados. No entanto, que diferença, no que tange à veracidade, à realidade e à "interferência" do sujeito no documento, há entre uma fonte escrita e outra figurativa? Se concordarmos com Ginzburg com relação à constante busca pela verdade da parte do historiador, considerando, no entanto, a inevitável distância entre este e o documento, não há menos fidelidade numa fonte só porque ela não está codificada por escrito. ${ }^{447}$ As fontes iconográficas permitem que levantemos indícios de outra ordem que nos permitem confrontar com as fontes escritas.

Ao observarmos imagens de Hus construídas ao longo dos séculos, podemos vislumbrar, por meio de uma linguagem diferente da verbal, a construção do legado educativo de Hus. Além disso, acreditamos ser proveitoso utilizarmos este espaço para apontarmos o lugar que essas imagens podem ocupar numa pesquisa histórica sobre Jan Hus.

A fonte para essas imagens foram os livros sobre Hus e os Hussitas que dispomos, bem como páginas na Internet. Destas últimas, somente utilizamos as imagens cuja fonte pudemos encontrar, procurando, com isso, evitar o problema da perda de informações relevantes para um historiador como seu suporte original e contexto de publicação que a reprodutibilidade digital pode ocasionar. Um simples levantamento a partir do nome de Jan Hus num serviço de busca de imagens na Internet trará uma profusão de repetições e modificações das mesmas imagens. Daquelas que conseguimos obter sua fonte, procuramos a de melhor resolução para reproduzirmos aqui. Elas estão divididas em dois grupos: os rostos e as cenas. No primeiro, estão detalhes de imagens maiores nos quais apresentamos apenas os diversos rostos de Hus. No segundo, estão as imagens inteiras, nas quais poderemos observar quais temas são tratados e o lugar que o clérigo ocupa nessas imagens. Para este segundo grupo, podemos esboçar algumas comparações com a imagem histórica verbal que

\footnotetext{
${ }^{445}$ KOSSOY, Boris. Fotografia e história. $3^{\text {a }}$ edição. São Paulo: Ateliê Editorial, 2009, p. 41, propõe um esquema da materialização documental da imagem fotográfica que é bastante elucidativo com relação ao trabalho de leitura de imagens, propondo pensar a respeito do conteúdo da imagem em relação ao seu contexto de produção e objeto representado. Esse esquema inspirou o trabalho que aqui realizamos de observação das imagens de Hus.

${ }^{446}$ BENJAMIN, Walter. A obra de arte na era de sua reprodutibilidade técnica. In. Magia e técnica: arte e política. Obras escolhidas Vol 1. São Paulo: Brasiliense, 1985, passim.

${ }^{447}$ Ver, por exemplo, GINZBURG, Carlo. Indagações sobre Piero. São Paulo: Paz e Terra, 1989, p. 25-26.
} 
apresentamos anteriormente neste capítulo, construída pelo legado dos historiadores e dos intelectuais e políticos tchecos.

Todas as representações figurativas do rosto de Hus e de suas ações foram construções posteriores, o que tem por consequência o fato de não dispormos de nenhuma expressão de sua feição original. E não apenas porque ele vivia num tempo em que corpo era figurado de forma planificada ${ }^{448}$ (achatada no plano), o que parece, aos nossos olhares de hoje, longe do real. Mesmo se houvesse a possibilidade de termos dele uma fotografia, suporte que nos parece hoje em dia o mais próximo da realidade possível, ela representaria o retrato de um tempo e espaço específicos, filtrados pelo olhar do fotógrafo. ${ }^{449}$

\subsubsection{Os rostos}

Iniciamos com um exercício de observar o rosto de Hus em diferentes representações por causa de um estranhamento que sentimos a partir da comparação das capas de três livros sobre Hus: a edição das cartas de Spinka (1972) e as biografias de David Schaff (2001) e Josef Macek (1963). As imagens presentes em Spinka (figura 14 invertida horizontalmente) e Schaff (figura 15) apresentam dois rostos semelhantes. A imagem na capa da biografia de Macek (figura 13, primeira imagem), contudo é muito diferente. De onde surgiram estes rostos e por que eles são tão diferentes?

As primeiras representações que encontramos do rosto de Hus são ilustrações de manuscritos de décadas bastante posteriores ao período no qual ele viveu. As três primeiras que aqui apresentamos (figura 8) estão presentes no Jenský Kodex (o Códice de Jena), escrito entre 1490 e 1510. Tendo por subtítulo Antithesis Christi et Antichristi, esse manuscrito apresenta textos e iluminuras produzidos por Hussitas no final do século XV. Seu título, "Bohuslaus de [...] sui causa memorie manu propria me fecit", sugere que o texto consiste num memorial e as indicações bibliográficas que encontramos referente ao códice indicam que o autor é Bohuslaus de Kozle, a respeito de quem nada encontramos até o momento. Atualmente, o códice está na Biblioteca do Museu Nacional em Praga. Nele estão presentes três imagens de Hus. Na primeira, Hus está pregando na capela enquanto nas outras duas, ele está na fogueira. A terceira imagem é uma xilogravura.

\footnotetext{
${ }^{448}$ PANOFSKY, Erwin. Significado nas artes visuais. São Paulo: Editora Perspectiva, 1976, capítulo 2, passim.

${ }^{449}$ KOSSOY, op. cit., capítulo 2, passim.
} 

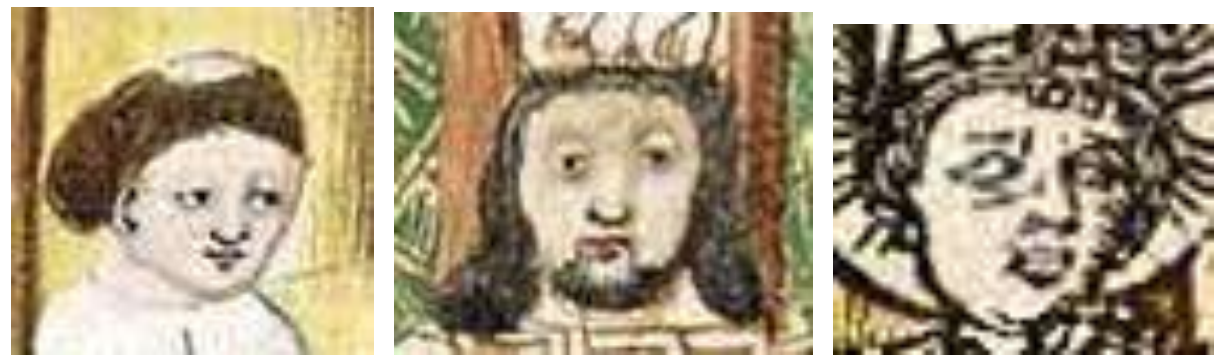

Figura 8. O rosto de Hus no Jeský Kodex

(Fonte: JENSKÝ KODEX [Antithesis Christi et Antichristi]. 1490-1510, 37v, 38r, 41v)

No primeiro, a tonsura está visível na cabeça de Hus. Nos dois seguintes, isso não é possível visto que ele está com o a coroa de papel com desenho de demônios. O tamanho do cabelo é bem diferente. Se pensarmos que ele ficou preso e, na prisão, cabelo e barba cresceram, a diferença entre a primeira e a segunda imagem é coerente. Mas, na terceira, a barba está ausente e o cabelo é curto. Lembremos que sua tonsura foi cortada durante o ritual de deposição em quatro partes. Apenas para termos um elemento de comparação, apresentamos na figura 9 o rosto de Jerônimo de Praga desenhado no mesmo códice, na mesma folha da segunda imagem da figura 8. Observemos a semelhança entre eles.

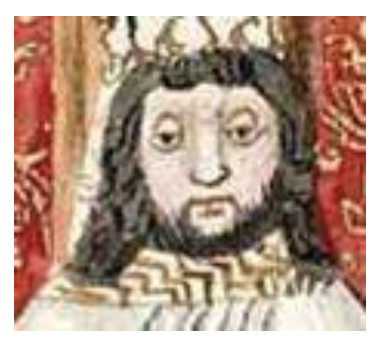

\section{Figura 9. O rosto de Jerônimo de Praga no Jenský Kodex}

(Fonte: JENSKÝ KODEX [Antithesis Christi et Antichristi]. 1490-1510, 38v)

Se compararmos com outra imagem, agora do Cristo e outras pessoas (figura 10), percebemos que não era pelas diferenças faciais que as pessoas eram identificadas. As representações dos rostos nessas imagens não visam uma aproximação com o real observado como esperamos nos dias de hoje obter a partir de uma fotografia. São detalhes, como a presença ou não da barba ou de um objeto como uma coroa, bem como as cores utilizadas para pintar a imagem, que contêm as informações que o artista da época deseja transmitir. 


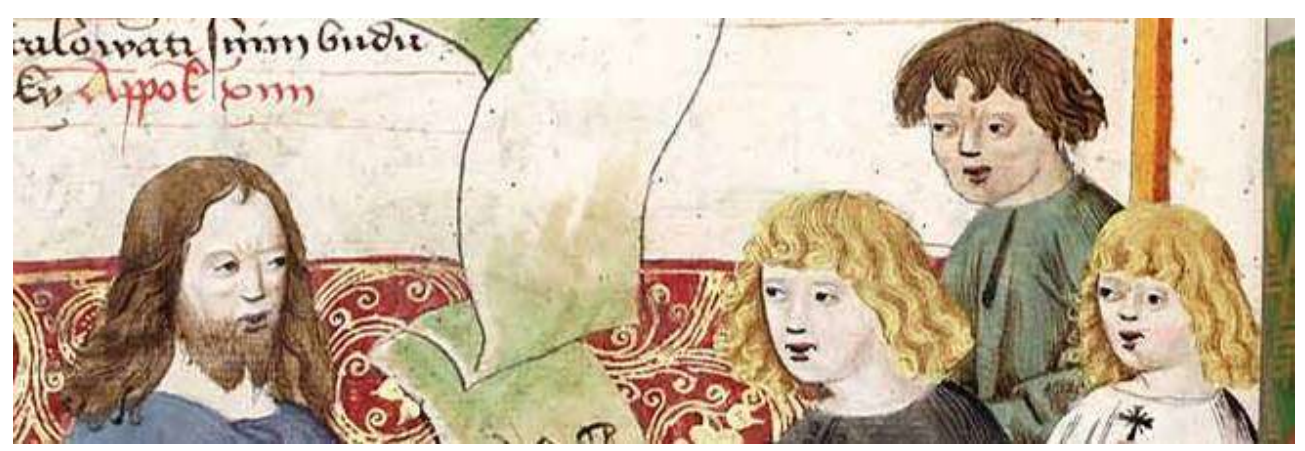

Figura 10. Cristo transmitindo seu sacerdócio, detalhe, Jenský Kodex (Fonte: JENSKÝ KODEX [Antithesis Christi et Antichristi]. 1490-1510, 70v)

As imagens medievais não eram representações do real mas presentificações da realidade. Os artistas que as produziam não pensavam em imitar a realidade ao redor, traduzindo a percepção de seus olhos, mas evocar uma realidade invisível, como afirma Schmitt, que complementa:

As imagens não saberiam 'representar' - no sentido habitual do termo essas realidades. Poderiam no máximo tentar 'torná-las presentes', 'presentificá-las'. A imagem medieval pode, desse modo, ser comparada a uma aparição, a uma epifania, portanto as marcas desta. O uso largamente atestado do dourado, que reflete a luz, não fazia mais do que sublinhar a mediação que a imagem operava entre o visível e o invisível. ${ }^{450}$

Em nosso exercício de traçar as origens do rosto de Hus, podemos, apenas procurar por símbolos que se repitam, entendendo que estas primeiras imagens serviam para provocar uma vivência de lembrança ou de culto e não de representação do real. Outra imagem de Hus, poucas décadas posterior ao Códice de Jena, está presente num livro de orações hussita de 1563. O detalhe do rosto apresentamos na figura 11.

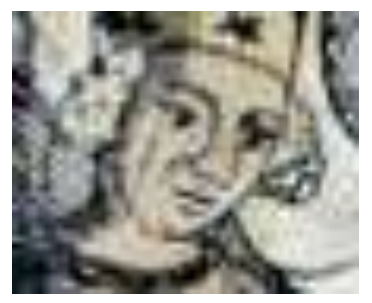

Figura 11. Detalhe do rosto de Jan Hus num livro de orações hussita de 1563 (Fonte: JAN HUS, [Imagem]. Encyclopædia Britannica.)

${ }^{450}$ SCHMITT, op. cit., p. 14. 
Num desenho com traços semelhantes aos do Jenský Kodex, Hus está nesta imagem também sem barba, mas seus cabelos são brancos. Reparemos que, ao contrário das outras, nesta, ele está olhando para baixo. Temos outras imagens de publicações tchecas dos séculos XV e XVI. As figuras 12 e 13 estão presentes no livro do historiador tcheco Josef Macek e apresentam um Hus sem barba e com uma grande tonsura. Nas duas representações da figura 12, Hus tem um rosto cheio. Elas foram publicadas na Crônica do Concílio de Constança escrita por Ulrich de Rosenthal em 1464, sendo, portanto, anteriores ao Códice de Jena. A figura 13 foi extraída de um cancioneiro da cidade de Litoměřice, no norte da Boêmia. Não encontramos mais informações a respeito desses originais, tendo apenas as reproduções que aqui apresentamos.

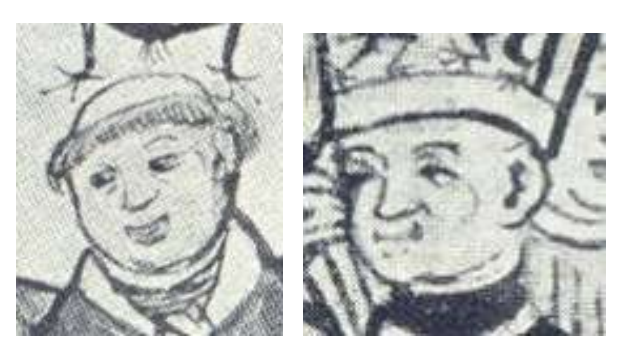

Figura 12. Detalhe do rosto de Jan Hus em duas imagens da crônica de Ulrich de Richental (1464)

(Fonte: MACEK, Jan Hus, p. 96)

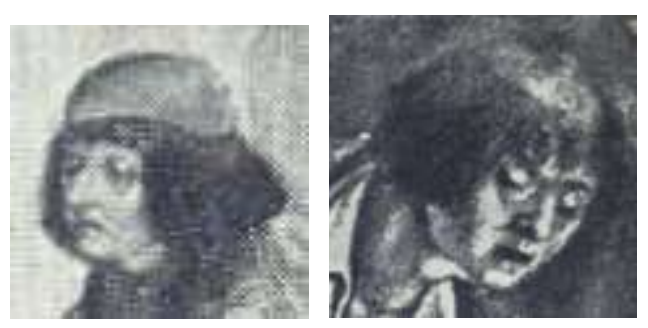

Figura 13. Detalhe do rosto de Jan Hus em duas imagens do Cancioneiro de Litoměřice (século XVI)

(Fonte: MACEK, Jan Hus, p. 32 e 128)

Não há um rosto de Hus que possamos utilizar para identificarmos os principais traços de sua aparência. É um dos infindáveis rostos perdidos na história da humanidade. A feição que hoje conhecemos de Hus também é uma construção histórica. Nem mesmo a barba, presente nas representações posteriores que veremos a seguir, é um elemento de semelhança 
das imagens. O único elemento que reúne todas estas imagens em uma só representação do rosto de Hus é a presença da tonsura. Esta é um símbolo não apenas de sua condição de clérigo, mas um dos marcos de seu martírio, visto que, de acordo com o relato de Petr de Mladoňovice, ela foi cortada durante a cerimônia de deposição de Hus.

A imagem mais utilizada para representar na atualidade a figura de Hus foi produzida algumas décadas depois pelo gravador belga Theodore de Bry (1528-1598), calvinista, que nasceu em Antuérpia, mas se estabeleceu em Frankfurt. Lá, produziu, nos anos finais do século XVI, diversas gravuras de personagens históricos ligados ao movimento da Reforma Protestante. Suas gravuras, bem como outras produzidas por diversos artistas da época, foram colecionadas pelo humanista francês Jean-Jacques Boissard (1553-1598). Os filhos de Theodore de Bry continuaram a produção das gravuras, reunindo 438 retratos em 1664, ano em que tiveram sua primeira publicação em livro. A maior parte das imagens que encontramos de Hus são edições digitais dessa imagem, que apresentamos na figura 14. Ela articula símbolos que foram utilizados pelo artista para representar dados importantes da biografia de Hus. Ele segura um papel com a mão direita e, sobre uma espécie de mesa, está uma pena, representando seus escritos. O gesto da mão esquerda na mesma direção do olhar remete a uma fala, podendo representar tanto sua pregação quanto sua defesa nas audiências do Concílio. Nos cantos superiores, os desenhos remetem à fogueira na qual ele foi queimado.

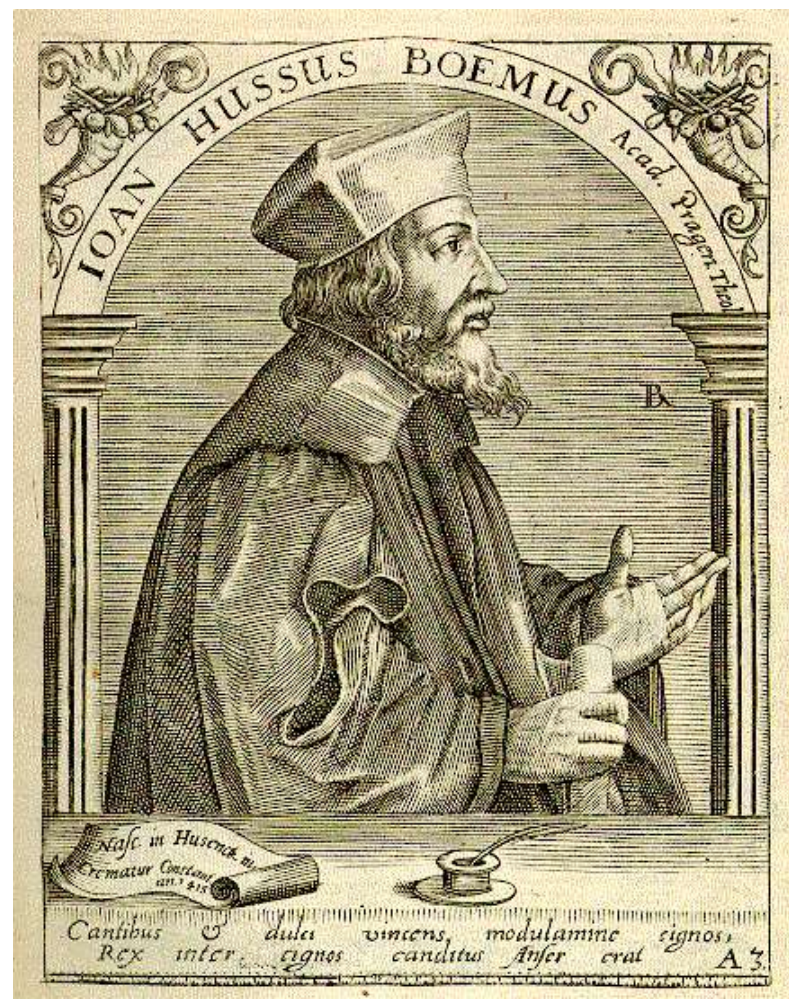

Figura 14. Jan Hus na gravura de Theodore de Bry, editado por J. J. Boissard (Fonte: BOISSARD; BRY, Bibliotheca chalcographica) 
Aqui temos um Hus de barba e cabelos longos e nariz afilado e trajando vestes do período contemporâneo de Bry. Esta imagem é muito semelhante à outra utilizada na capa da biografia de David Schaff, originalmente publicada nos Estados Unidos no início do século XX, porém com reimpressão de $2001 .^{451}$ A imagem da capa do livro de Schaff é a mesma publicada pela revista norte-americana Life em 1901, que aqui reproduzimos na figura 15. Não conseguimos encontrar referências à edição na qual essa imagem foi publicada, visto que ela está disponível no banco de imagens da revista, sem referência direta à sua publicação. Supomos que a imagem seja uma construção derivada da imagem de Boissard.

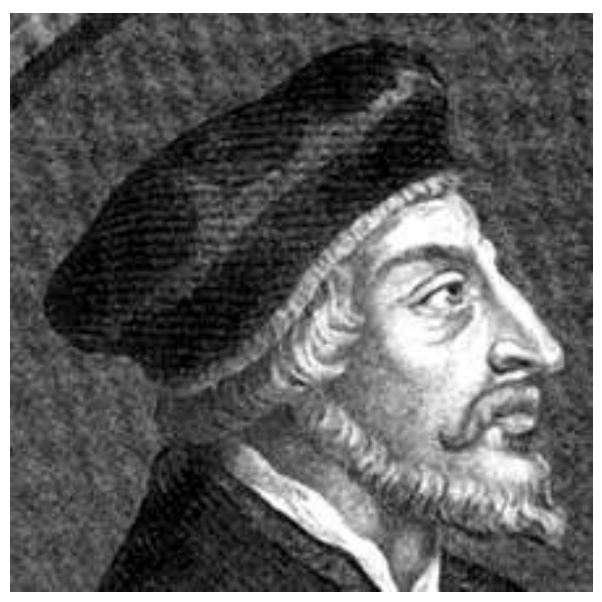

Figura 15. Detalhe do Rosto de Jan Hus na gravura publicada pela revista Life (Fonte: LIFE MAGAZINE, Czech religious reformer John Huss)

Provavelmente anterior à imagem de Theodore de Bry é a gravura de Hans Guldenmundt (figura 16), gravador em madeira alemão que se destacou no início do século XVI. ${ }^{452}$ A gravura é colorida e guarda semelhanças à figura retratada por Bry. A imagem de Guldenmundt pode ter servido de inspiração para a imagem do gravador belga calvinista.

\footnotetext{
${ }^{451}$ SCHAFF, John Huss.

${ }^{452}$ As informações biográficas deste gravador e de Jacques Grandhomme, apresentado a seguir, foram retirados de BRYAN, Michael; STANLEY, George. A biographical and critical dictionary of painters and engravers, from the revival of the art under Cimabue, and the alleged discovery of engraving by Fininguerra, to the present time. Londres: H. G. Bohn, 1849.
} 


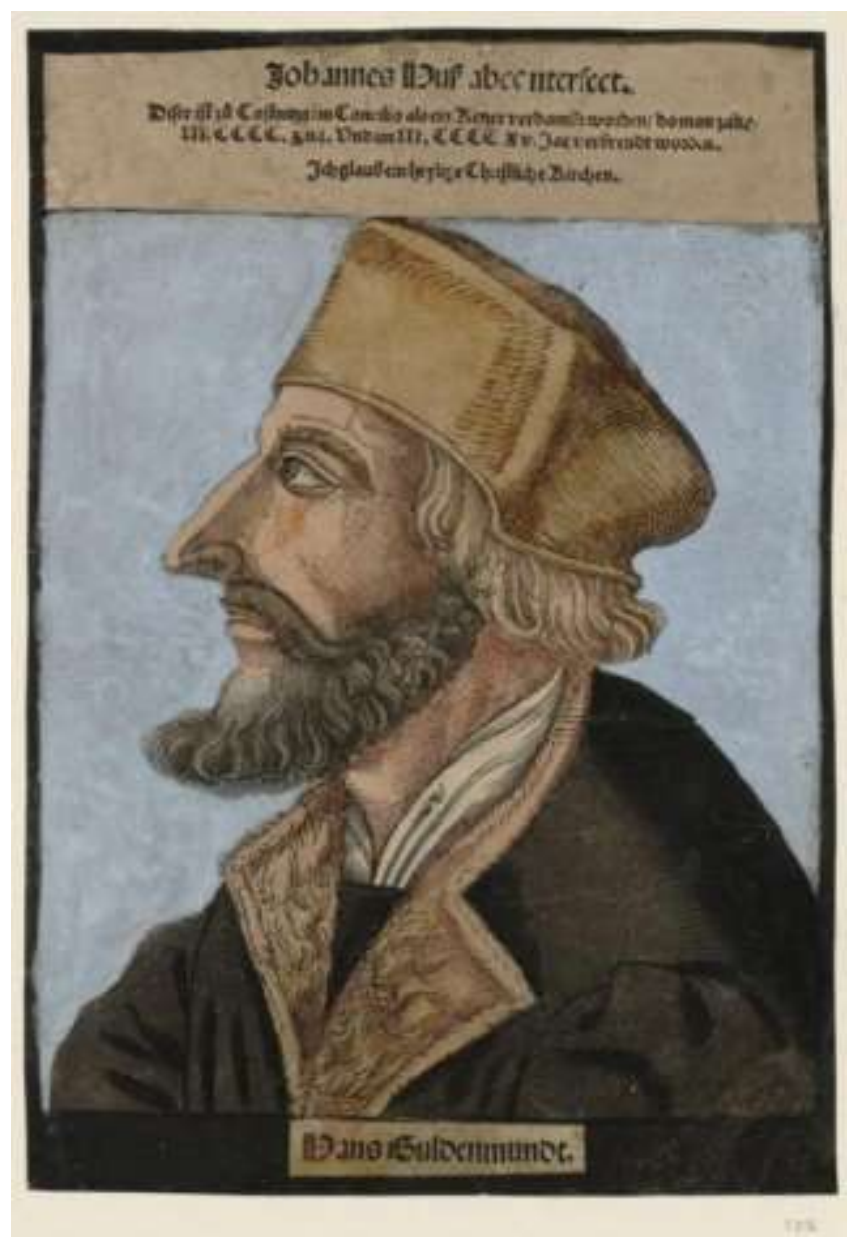

\section{Figura 16. Jan Hus, gravura de Hans Guldenmundt (Fonte: GUNDELMUNDT, Portrait de Jean Huss)}

Ambas as imagens, de Bry e de Guldenmundt, apresentam Hus com nariz e barba pontudos, bigode curvado para trás, destacando-se em relação à barba, cabelos curtos e um barrete. Este consiste uma espécie de boina macia e baixa, recortada para cobrir as orelhas, comum no século $\mathrm{XVI}^{453}$, o que reforça o vínculo temporal da composição da imagem. Os mesmos elementos estão presentes na gravura de Jacques (ou James) Grandhomme (ou Granthomme), gravador alemão nascido em Heidelberg, provavelmente discípulo de Theodore de Bry. Grandhomme destacou-se no início do século XVII, sendo conhecido por sua produção de retratos. Um de seus trabalhos mais importantes é um conjunto de retratos dos doutores e dos reformadores da Igreja, de onde, provavelmente, foi retirada a gravura que apresentamos aqui (figura 17).

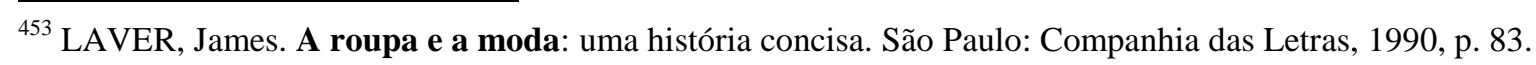




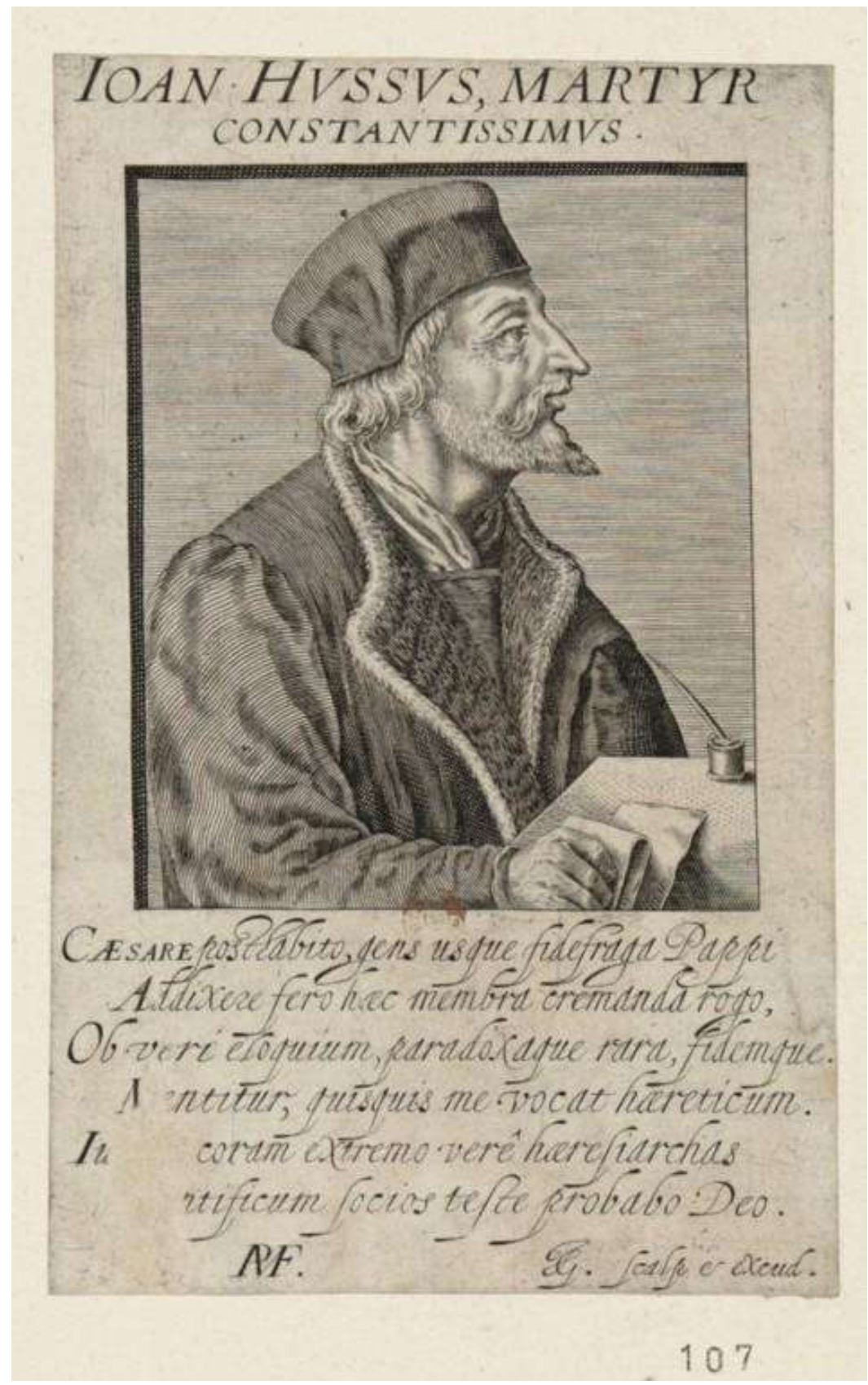

\section{Figura 17. Jan Hus, gravura de Jacques Grandhomme}

\section{(Fonte: GRANDHOMME, Portrait de Joan Hussus, martyr constantissimus)}

Tanto as gravuras de Bry, Guldenmundt e Grandhomme, quanto as iluminuras do Códice de Jena e do Cancioneiro de Litoměrice possuem em comum terem sido publicadas para a divulgação das ideias reformistas. A divulgação dessas imagens de Hus acompanha o movimento de Lutero de publicação dos escritos do clérigo da Boêmia: reiteram o legado do mártir que morreu na fogueira de Constança pela defesa da verdade.

Representações mais modernas do rosto de Hus em obras artísticas guardam semelhanças com as imagens anteriores. Em dois quadros que retratam Jan Hus no Concílio 
de Constança, ele aparece com a cabeça descoberta e com uma fisionomia que faz lembrar tanto as gravuras alemãs quanto as imagens do rosto de Jesus. Um deles foi pintado pelo artista alemão do século XIX, Carl Friedrich Lessing. Produzida já num período mais recente, Hus aparece sem tonsura e com cabelos compridos. O formato do rosto e o tamanho dos cabelos lembram a imagem de Jesus, próxima às suas representações derivadas do Cristo Pantocrátor. O outro quadro foi pintado pelo artista tcheco também do século XIX, Václav Brožík. Este destaca a tonsura, com um cabelo curto e uma barba pontuda e longa, como na figura de Bry e dos outros gravadores renascentistas. A figura 18 mostra o detalhe do rosto, que destacamos desses quadros.

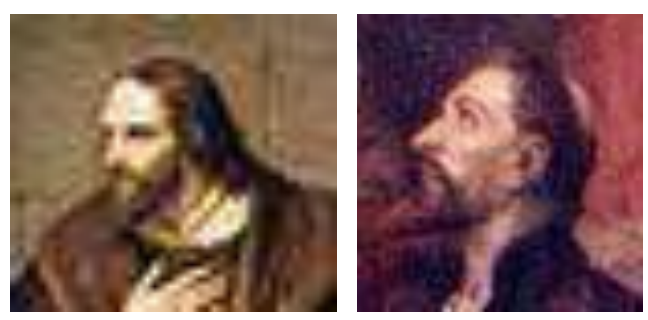

Figura 18. Detalhe do rosto de Jan Hus nos quadros de Carl Friedrich Lessing e Václav Brožík (século XIX)

(Fontes: STÄDEL MUSEUM; RADIO PRAHA)

Por fim, apresentamos o rosto da escultura mais famosa do clérigo da Boêmia, na estátua de Jan Hus da Staroměstské Náměstí, em Praga, esculpida para a celebração de quinhentos anos da sua morte (1915). Foi esta a imagem coberta pelos nazistas. Os detalhes que aqui apresentamos na figura 19 foram extraídos de duas fotos diferentes, que estão entre as de melhor qualidade para impressão que encontramos na Internet. O nariz afilado e a barba pontuda permanecem. O bigode está ausente e o cabelo é curto, tornando essa combinação diferente de todas as outras imagens que apresentamos. Além disso, é a única que foi construída em três dimensões.
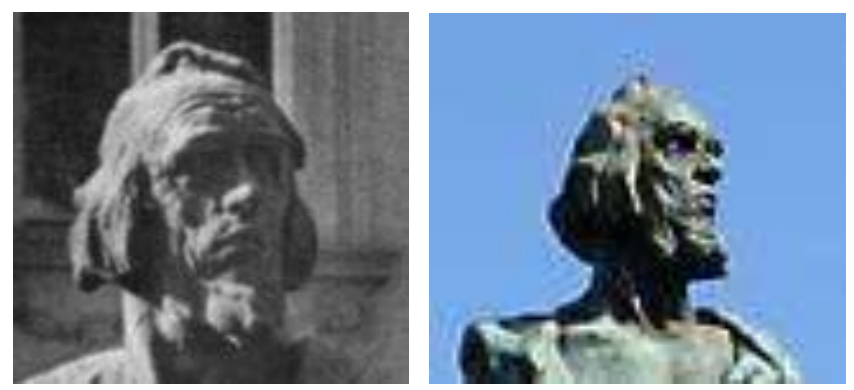

Figura 19. Detalhe do rosto de Jan Hus na estátua da Staroměstské Náměstí em Praga (Fontes: SCHERSCHEL, Statue of Jan Huss in the old City Hall Square; SEAMAN, Jan Hus statue in Prague) 
Os rostos do passado são desconhecidos para nós. No entanto, no esforço de preservação da memória de personagens históricos e de divulgação de suas ideias, podendo até chegar à construção de uma imagem de culto, artistas que nunca viram pessoalmente esses rostos traçaram-lhe as feições. A combinação dessas imagens e sua repetição ao longo do tempo produzem uma imagem figurativa que associamos em nosso pensamento ao nome daquele personagem. No entanto, nosso pensamento plástico, nos termos de Francastel, combina essas imagens e permite associações que também foram construídas por esses artistas. O intelectual que escreve, o mártir de expressão inabalável, o mestre que prega e ensina, que pode lembrar a figura de Jesus, que olha para cima (aos céus) ou para a frente (ao futuro) torna-se presente para aquele que observa estas imagens e seu legado é reiterado sem que seja necessário dizer uma única palavra.

\subsubsection{As cenas}

O mesmo efeito de tornar presente o legado hussita àquele que observa uma representação de Hus é mais fortemente observável se olharmos para a sua figura inteira, colocada num certo arranjo para compor uma cena. Em que cenas sua imagem é representada e de que maneira essa cena reitera o legado do clérigo da Boêmia? As gravuras renascentistas que apresentamos acima em conjunto com as imagens de pensamento construídas pelos editores das cartas hussitas sugerem três categorias que poderemos encontrar nas cenas nas quais Hus é retratado: o intelectual e pregador, o defensor da verdade e o mártir.

A figura 20 é uma das imagens do Códice de Jena. Ela apresenta Jan Hus no púlpito, que pode ser o da Capela de Belém, pregando para a multidão. Essa imagem constrói a figura do Hus como mestre, por isso temos por hipótese ser um manuscrito Hussita. 


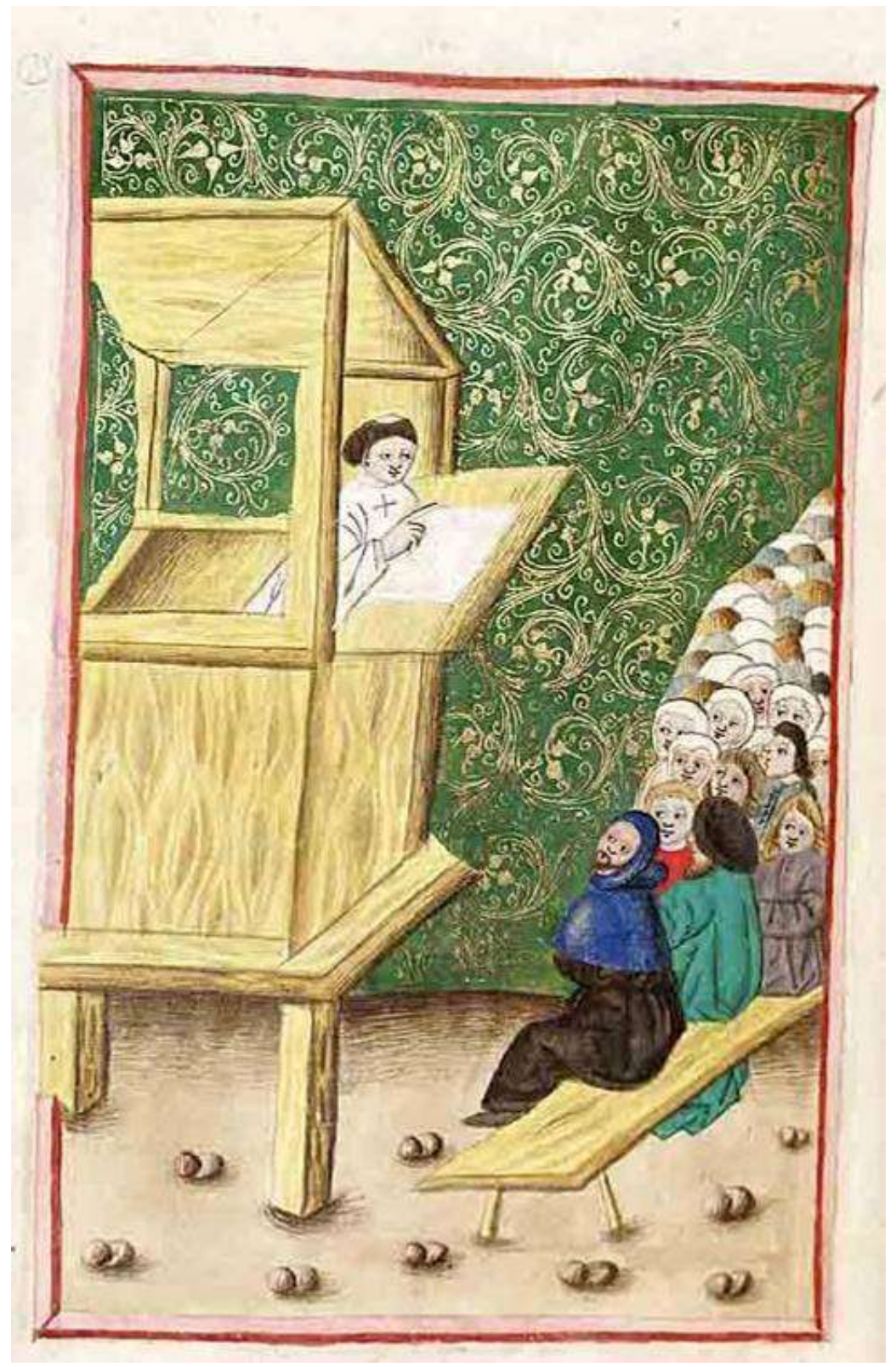

Figura 20. Mestre Jan Hus no Púlpito, Códice de Jena

(Fonte: JENSKÝ KODEX [Antithesis Christi et Antichristi]. 1490-1510, 37v)

No entanto, esta imagem do mestre pregador só ganha força como representação de Jan Hus, porque é acompanhada, no mesmo códice, de outra na qual ele é martirizado (figura 21). É a combinação das duas imagens que constrói a representação completa do educador: o mestre e o mártir. 


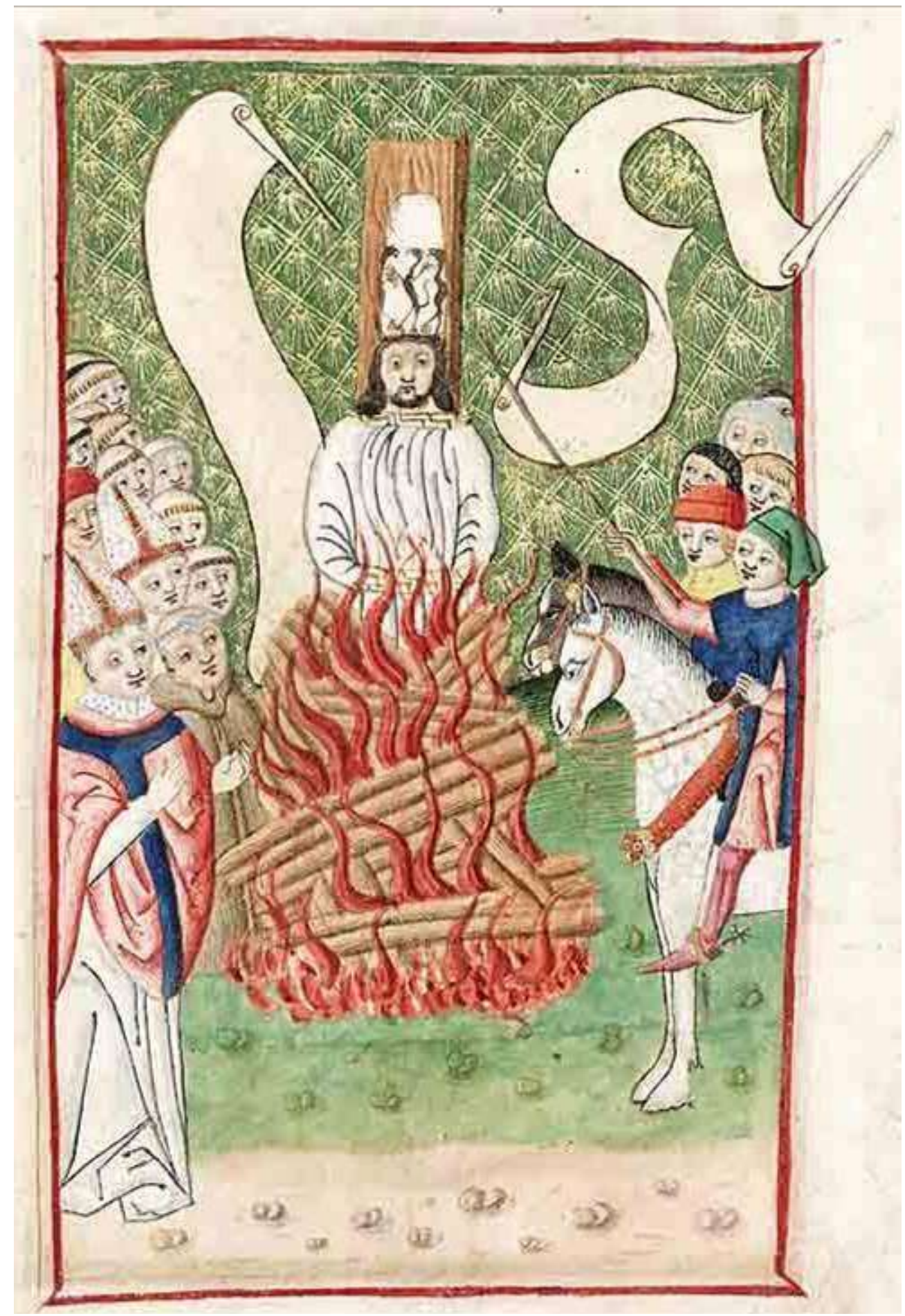

Figura 21. Imolação de Hus no Códice de Jena

(Fonte: JENSKÝ KODEX [Antithesis Christi et Antichristi]. 1490-1510, 38r)

As semelhanças com relação ao traço permitem que tenhamos por hipótese serem ambas produzidas pelo mesmo artista. No entanto, mesmo que elas tenham sido produzidas por pessoas diferentes, a presença de ambas no mesmo códice aponta para a construção da imagem combinada do mestre e do mártir para representar Hus. 
Algumas folhas após a imagem anterior há uma xilogravura da imolação de Hus, inserida no texto do códice e adornada com iluminuras (figura 22). O resultado gráfico é diferente, porém o impacto simbólico é o mesmo.

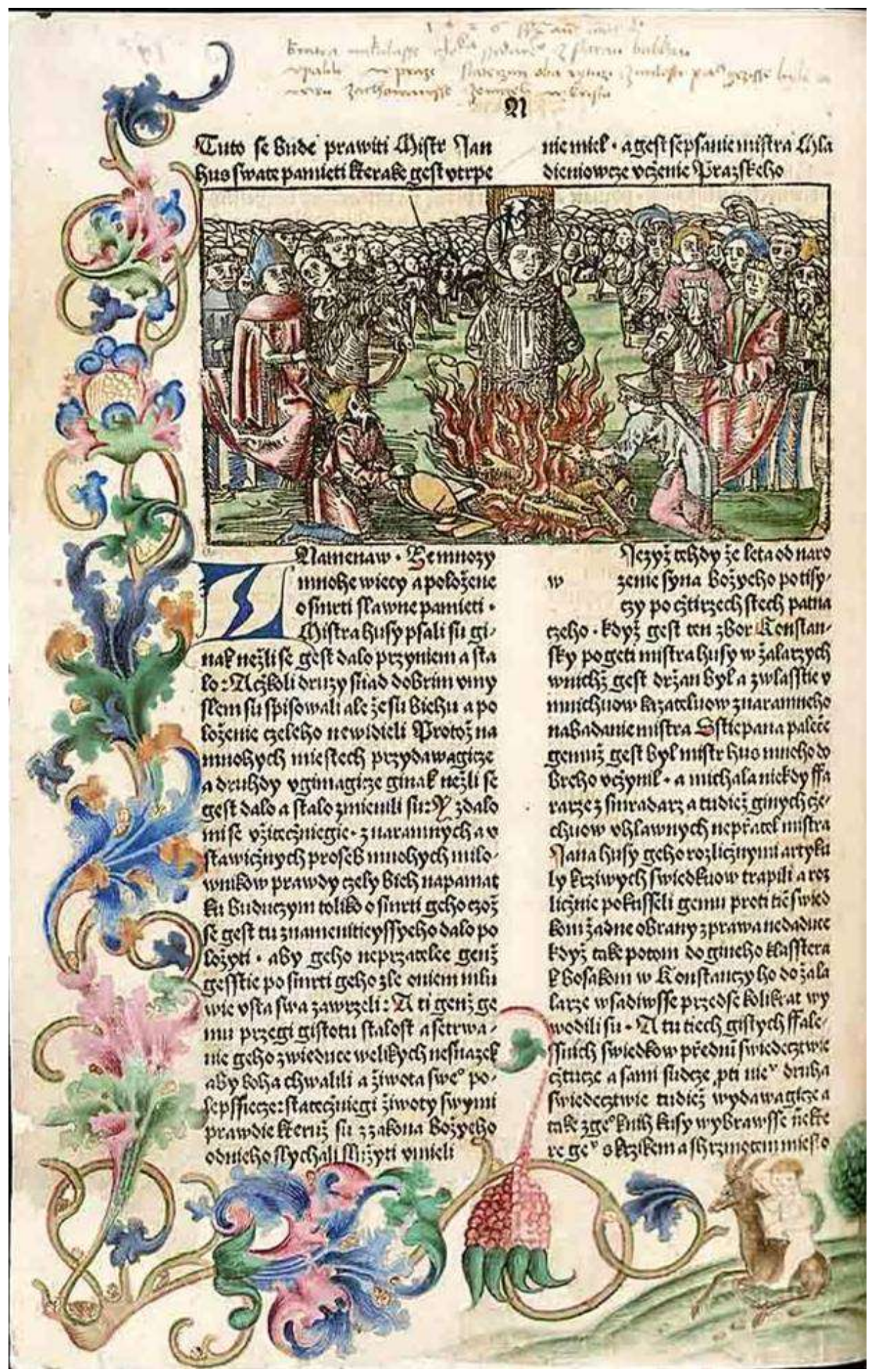

Figura 22. Imolação de Hus no Códice de Jena (xilogravura)

(Fonte: JENSKÝ KODEX [Antithesis Christi et Antichristi]. 1490-1510, 41v) 
Em ambas as figuras do mártir, reconhecemos os elementos apresentados por Petr de Mladoňovice em seu relato. Hus está preso à estaca, com o chapéu de heresiarca que possui desenhos de demônios. À sua volta está a multidão que acompanhava o espetáculo, membros da nobreza (o conde Ludwig do Palatinado?) e os membros do clero que o condenaram. A xilogravura apresenta ainda uma nova figura em relação à primeira imagem de Hus na fogueira: o carrasco. Ele parece estar bombeando ar para estimular o fogo.

Três outras imagens apresentam o momento anterior à imolação: Hus está se defendendo perante o Concílio de Constança. A primeira (figura 23) é do Cancioneiro de Litoměřice, do século XVI e a segunda é o quadro de Carl Friedrich Lessing (figura 24). A terceira é de Václav Brožík (figura 25). As três apresentam Hus no Concílio de Constança. 


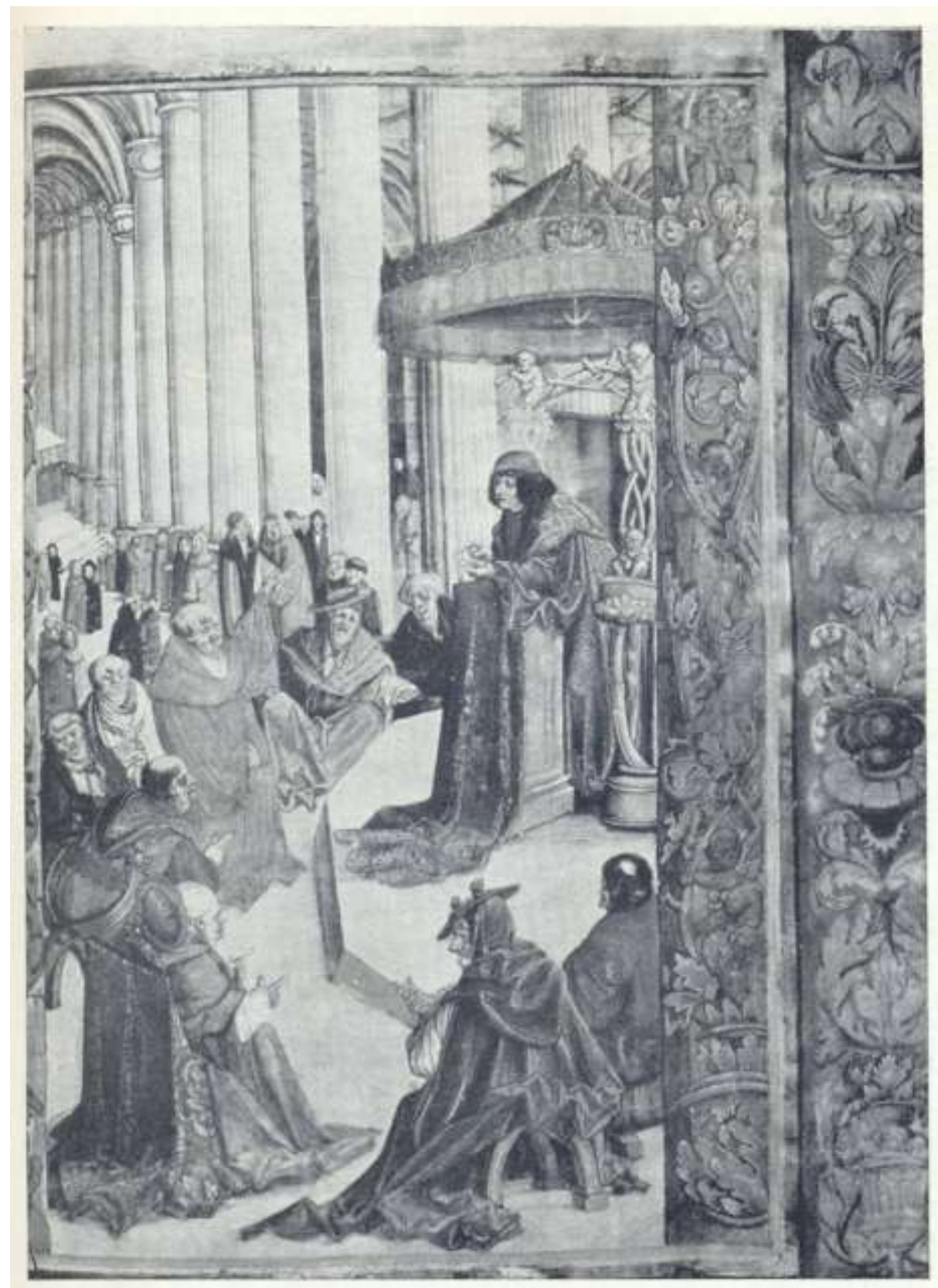

Figura 23. Hus no Concílio de Constança, figura do Cancioneiro de Litoměřice (Fonte: MACEK, Jan Hus, p. 32) 


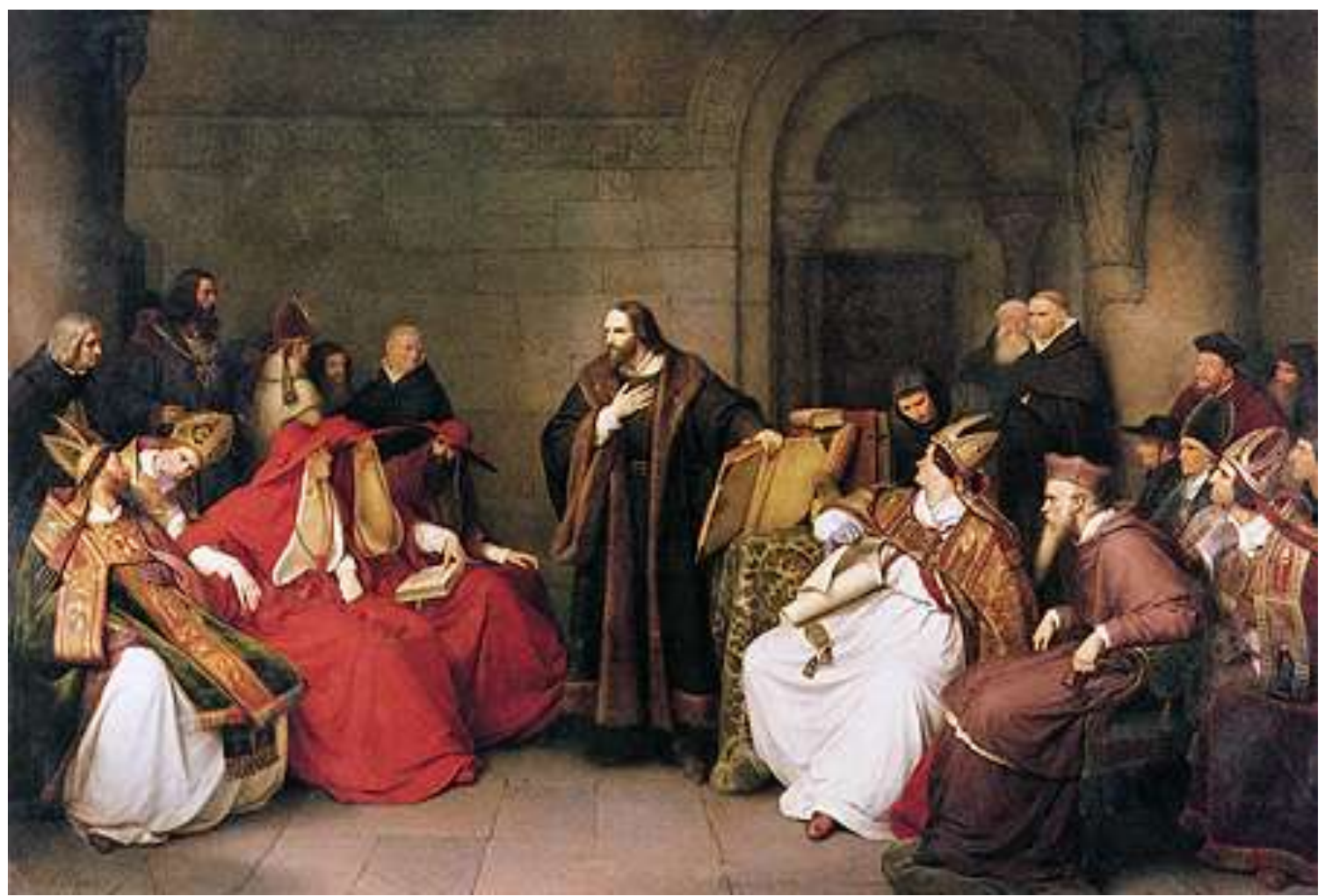

Figura 24. Hus no Concílio de Constança, de Carl Friedrich Lessing (Fonte: STÄDEL MUSEUM)

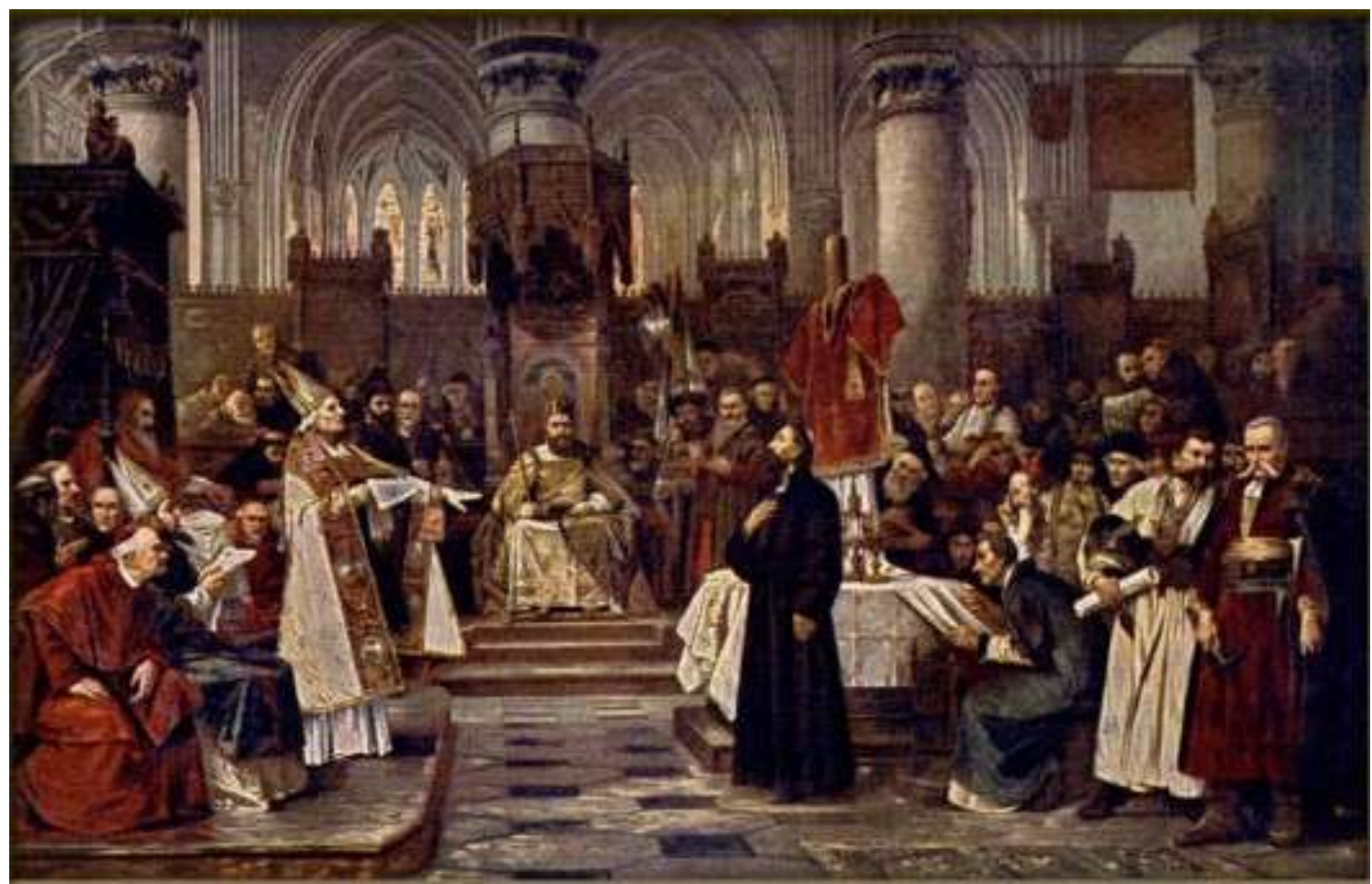

Figura 25. Hus no Concílio de Constança, de Václav Brožík (Fonte: RADIO PRAHA) 
Nas duas primeiras, ele está em posição de destaque em relação às outras pessoas. Na figura 23, ele está acima de todas, tendo apenas anjos mais acima. $\mathrm{Na}$ figura 24, ele está em posição central, formando um X com as imagens dos outros sujeitos, estando acima dos cardeais e do rei e levemente abaixo das pessoas ao fundo. Já na figura 25, ele está abaixo de boa parte dos presentes, inclusive do rei e do cardeal que o acusa. Nesta última, até mesmo a arquitetura do lugar é opressora, ocupando quase metade da imagem e tornando todos pequenos. Essa arquitetura elaborada também está presente na figura 23, tornando a maioria dos presentes pequenos, mas a figura de Hus está em destaque.

O clérigo está se defendendo em duas das imagens, parecendo estar com a palavra (figuras 23 e 24). Já na outra, figura 25, ele está sendo acusado e eleva os olhos aos céus. Notemos a presença dos livros na figura 24. Hus está com o controle deles, segurando um com a mão esquerda enquanto sua mão direita está no coração. Ele parece, por sua posição, declarar que está com a verdade. Os membros da Igreja escutam-no ou conversam entre si.

Na figura 25, Hus também está com a mão direita no coração, mas sua postura é bem diferente da outra. Repare que o papel com a lista das acusações está nas mãos do cardeal e os paramentos de clérigo que Hus vestirá para depois ser despido estão na mesa. O rei pouco participa nessa cena, ao contrário da figura 23 , na qual o rei, sentado no trono no canto inferior esquerdo da figura, está falando (veja as mãos). É nesta figura também que Hus parece estar com um halo em volta de sua cabeça, santificando-o desta forma.

Essas imagens ajudam a compor o imaginário do legado hussita como o defensor da verdade. Mas também reforçam a imagem de santo. Na figura 23, ele está acompanhado de um halo e na figura 24 sua figura assemelha-se, como já afirmamos, à do Cristo. Como Hus morreu como "ser humano", "seguindo o exemplo do Cristo", "empenhado na fidelidade à sua mensagem" $" 454$ ele foi transformado em mártir. Os momentos que antecedem sua martirização devem apresentá-lo como santo. No entanto, como "na Idade Média, a santidade é, sobretudo, uma linguagem do corpo, um discurso da 'carne impassível', para utilizar a expressão feliz de P. Camporesi”, ${ }^{455}$, as representações que maior impacto podem causar naquele que as vê são as que mostram a morte do corpo. Além disso, a base do legado hussita, construído a partir de Petr de Mladoňovice, é a morte pela verdade. É por isso que a maioria das imagens que

\footnotetext{
${ }^{454}$ VAUCHEZ, op. cit., p. 212.

455 ibidem, p. 223.
} 
encontramos refere-se a esse imaginário. Além das figuras 21 e 22, as de número 26, $27^{\mathbf{4 5 6}}$ e 28 estão nesse grupo.

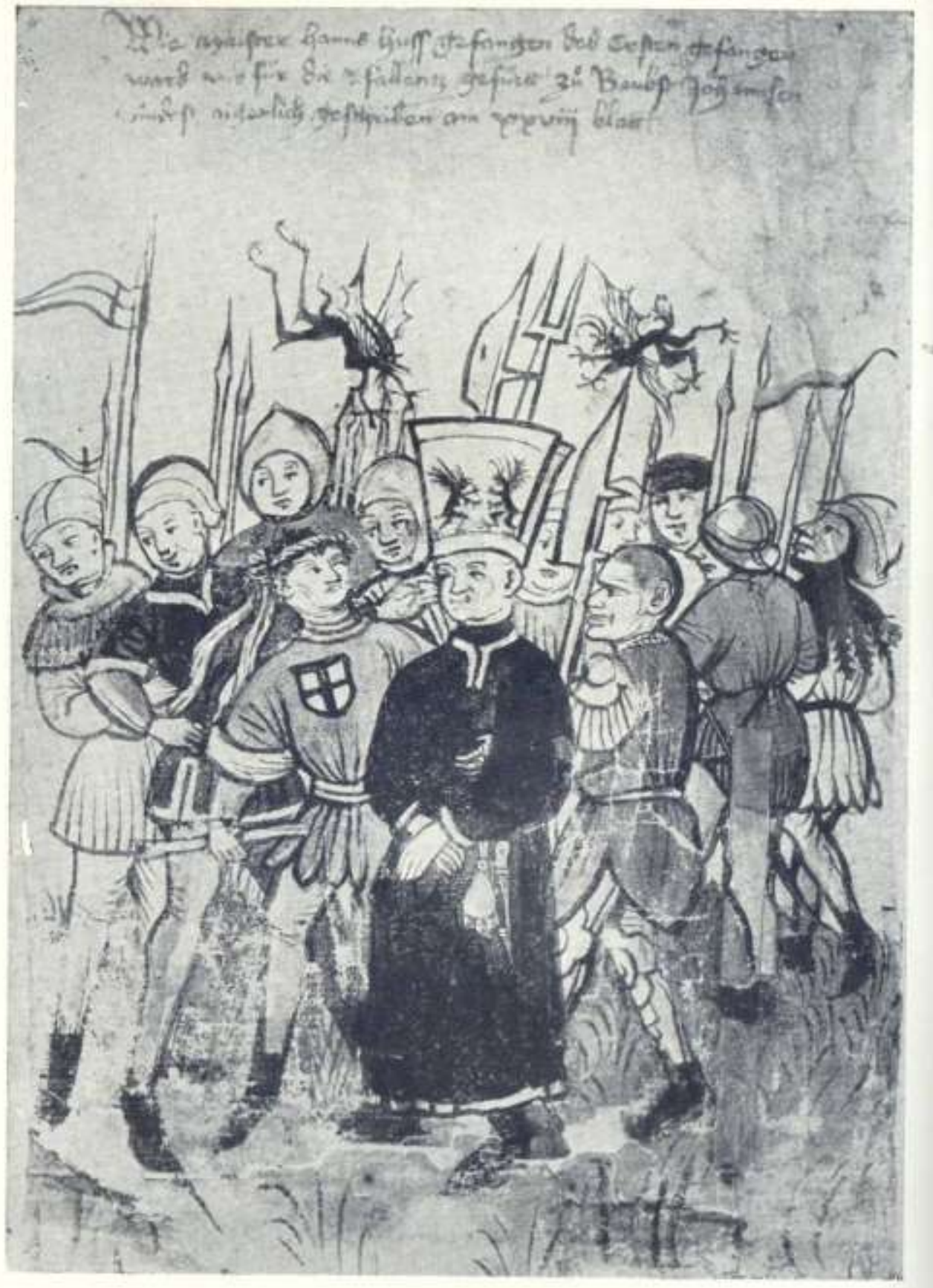

Figura 26. Hus indo para a fogueira, Crônica de Ulrich de Richental

(Fonte: MACEK, Jan Hus, p. 96)

${ }^{456}$ Detalhes desta imagem são reproduzidos em SPINKA, John Hus: a biography, p. 104 e MACEK, op. cit., p. 128. A revista CHRISTIAN HISTORY, ed. 68, Vol. XIX, n. 4, p. 18, indica que esta imagem foi extraída do Códice de Jena. No entanto, como não a encontramos no códice, entendemos que as indicações de Spinka e de Macek estejam corretas e a imagem seja do Cancioneiro de Litoměrice. 


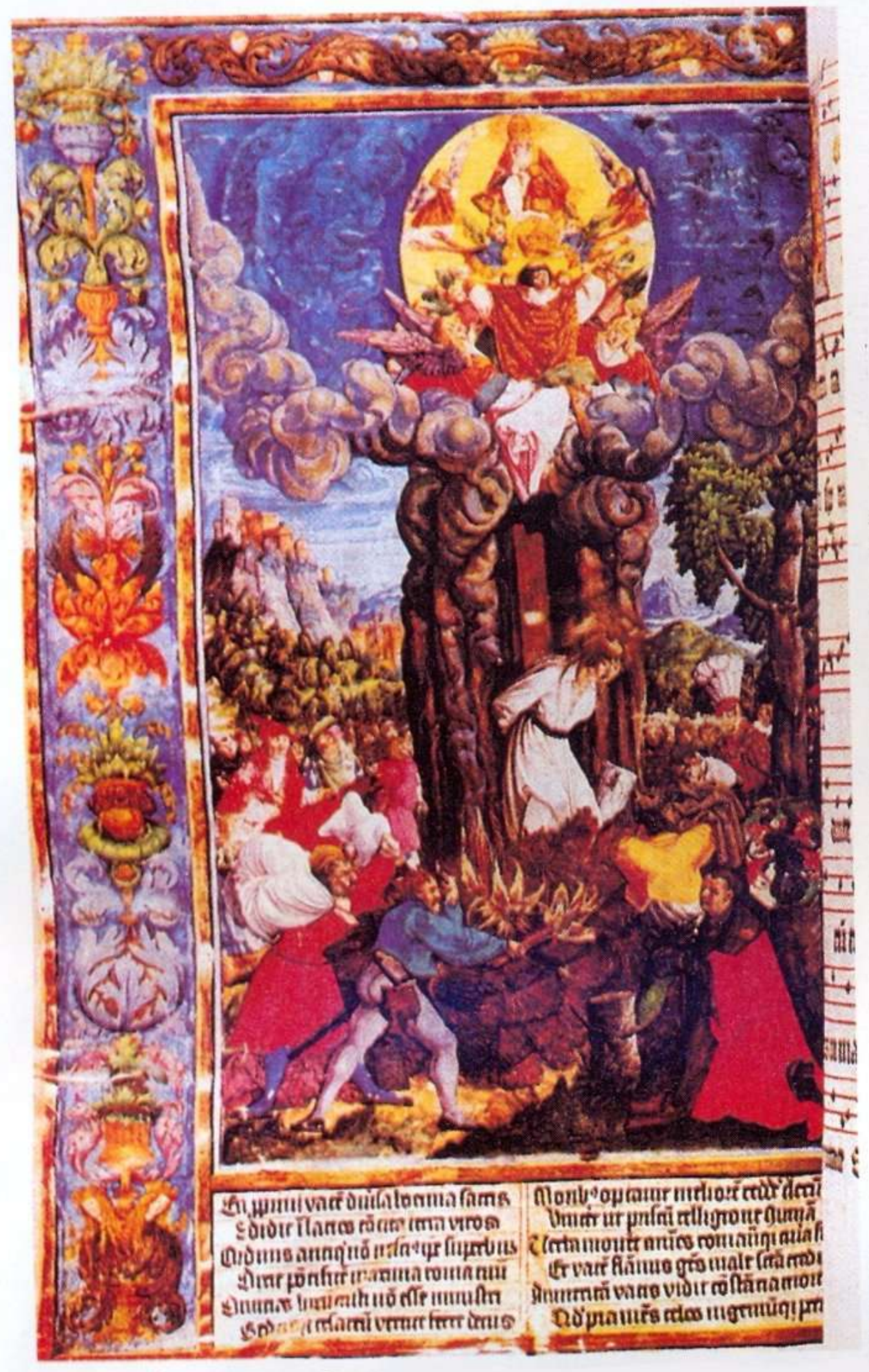

Figura 27. Hus na fogueira, Cancioneiro de Litoměřice

(Fonte: CHRISTIAN HISTORY, ed. 68, Vol. XIX, n. 4, p. 18) 


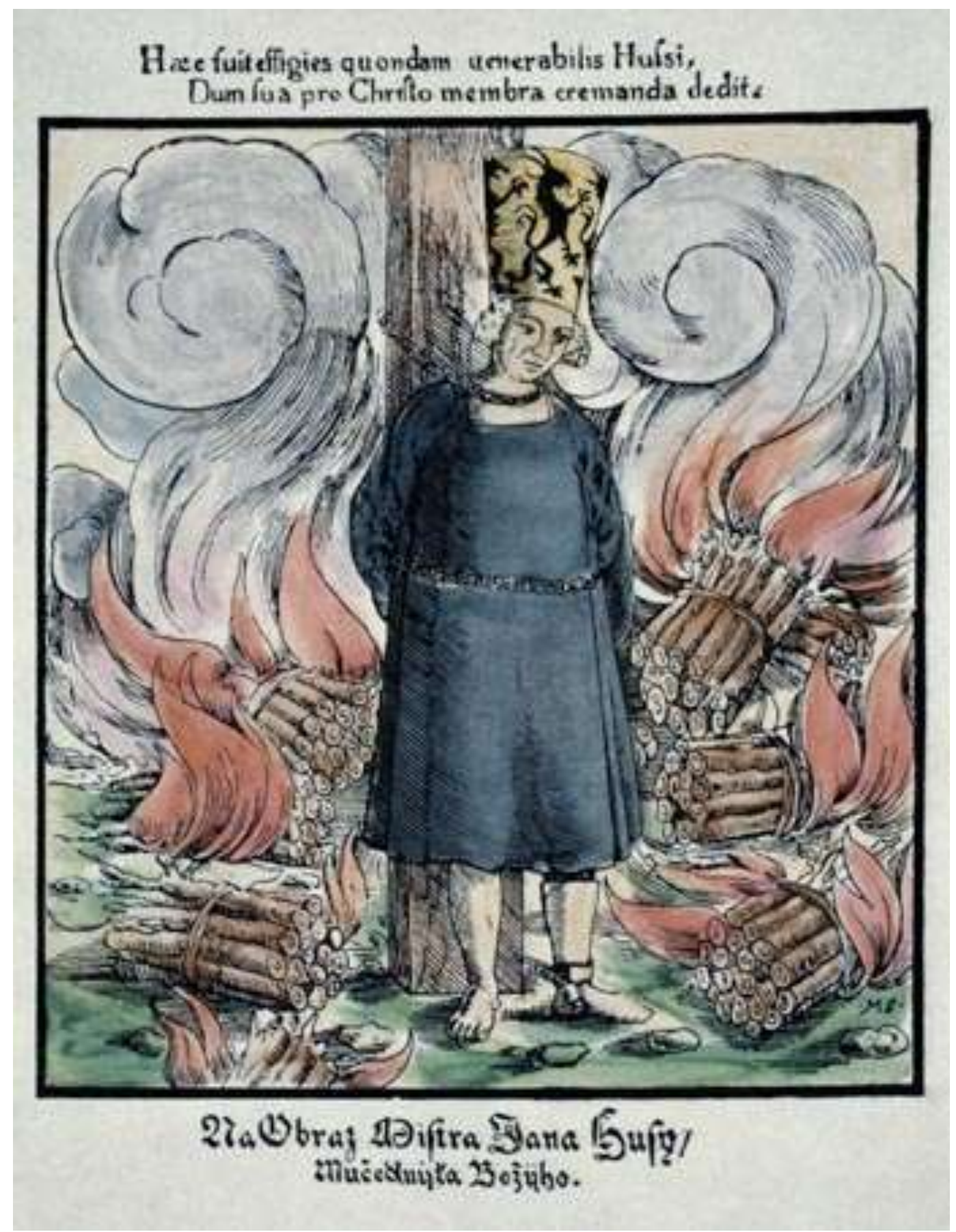

Figura 28. Jan Hus na Fogueira, num livro de orações hussita de 1563

\section{(Fonte: HUS, Jan [Imagem]. Encyclopædia Britannica)}

As cinco imagens, produzidas entre o final do século XV e o XVI, apresentam Hus indo para a fogueira ou já nela e ajudaram a construir a imagem de mártir, especialmente nos primeiros séculos após sua morte, entre os tchecos. A figura 28 é até mesmo legendada com a palavra "mučednický”, mártir, em tcheco. ${ }^{457}$ A figura 27 se diferencia por apresentá-lo com o

\footnotetext{
${ }^{457}$ A legenda inferior completa significa "Na imagem (quadro), Mestre Jan Hus, mártir divino".
} 
corpo caído e sem a coroa de papel com desenhos de demônios ${ }^{458}$, que é destaque nas outras imagens. Petr de Mladoňovice afirmou que Hus disse, quando lhe colocaram a coroa de papel, as seguintes palavras:

"Meu senhor Jesus Cristo, por mim, um infeliz miserável, suportou uma coroa de espinhos muito mais pesada e pungente. Sendo um inocente, foi tido como se merecesse a morte mais vergonhosa. Portanto, eu, um infeliz e pecador, suportarei humildemente esta coroa mais leve, embora difamante, por seu nome e pela verdade." $" 459$

Ela é, portanto, um dos principais símbolos da morte pela verdade. Esta fala de Hus, associando sua coroa à do Cristo, cria um vínculo entre as duas mortes, reforçando o caráter de santificação de sua imolação. ${ }^{460}$ A partir do momento em que Hus é transformado em mártir, essa associação ganha força de comprovação profética.

A morte de Hus foi um evento espetacular, de modo que foi acompanhada por todos. Como já citamos anteriormente, "morrer é, de certa forma, pregar" espetáculo é um reforço da pregação pelo exemplo. A figura 26 mostra o clérigo sendo levado para a fogueira e, seguindo a descrição de Mladoňovice, "quase todos os habitantes da cidade, com armas na mão, acompanharam-no para a morte"462. Sua caminhada também possui simbologias que o transformam em mártir, como o momento em que se ajoelha para rezar. Por isso, ela é tão importante a ponto de ser retratada, como na figura 26. Mais do que isso, ela se torna uma retomada da via-crúcis, na qual o Cristo também caiu de joelhos, também pediu ajuda ao Pai.

O carrasco também está presente na 27. Esta se diferencia das outras por não distinguir claramente as pessoas que estão presentes, além da ausência da coroa de papel. E, mais ainda, o céu está aberto esperando por Hus, como se a fumaça da fogueira o levasse diretamente até as mãos de Deus, de Maria e dos anjos. A figura 28 coloca os feixes de madeira e o fogo separados do corpo de Hus. E, embora a madeira esteja queimando bastante, é como se o fogo

\footnotetext{
${ }^{458}$ Podemos também fazer uma estrapolação temporal do uso da coroa como instrumento de difamação se lembrarmos que na história da educação é comum o imaginário do uso de um "chapéu" para marcar um "aluno burro".

${ }^{459}$ SPINKA, John Hus at the Council of Constance, p. 230-231.

${ }^{460}$ PLINVAL, Georges de; PITTET, Romain. Histoire illustrée de l'eglise. Vol. I. Genève: Éditions de L'Écho Illustré; Paris: Éditions du Cerf, 1946, p. 488, afirmam, após citarem dois nomes de santos nacionais (Joana d'Arc e Caterina de Siena), que a exploração do sentimento nacional é mais dramático em Hus porque é acompanhada da heterodoxia. Para esses autores, Hus é herói de seu povo, defensor de sua língua e campeão da preponderância tcheca na Universidade de Praga e na Igreja da Boêmia.

${ }^{461}$ DUBY, Europa na idade média, p. 146.

${ }^{462}$ ibidem, p. 231.
} 
fosse incapaz de destruir sua imagem. E foi justamente isso o que aconteceu: o fogo, ao invés de destruir, ajudou a construir a imagem do mártir. Não há ninguém mais que possa impedir isso de acontecer, Hus está em posição de destaque. Ele é um símbolo de grandiosidade da verdade. Não é à toa que ele é tão alto na escultura da praça da cidade velha, em Praga (figura 29). De lá, ele olha para o futuro de uma nação, como propuseram os nacionalistas tchecos no início do século XX.

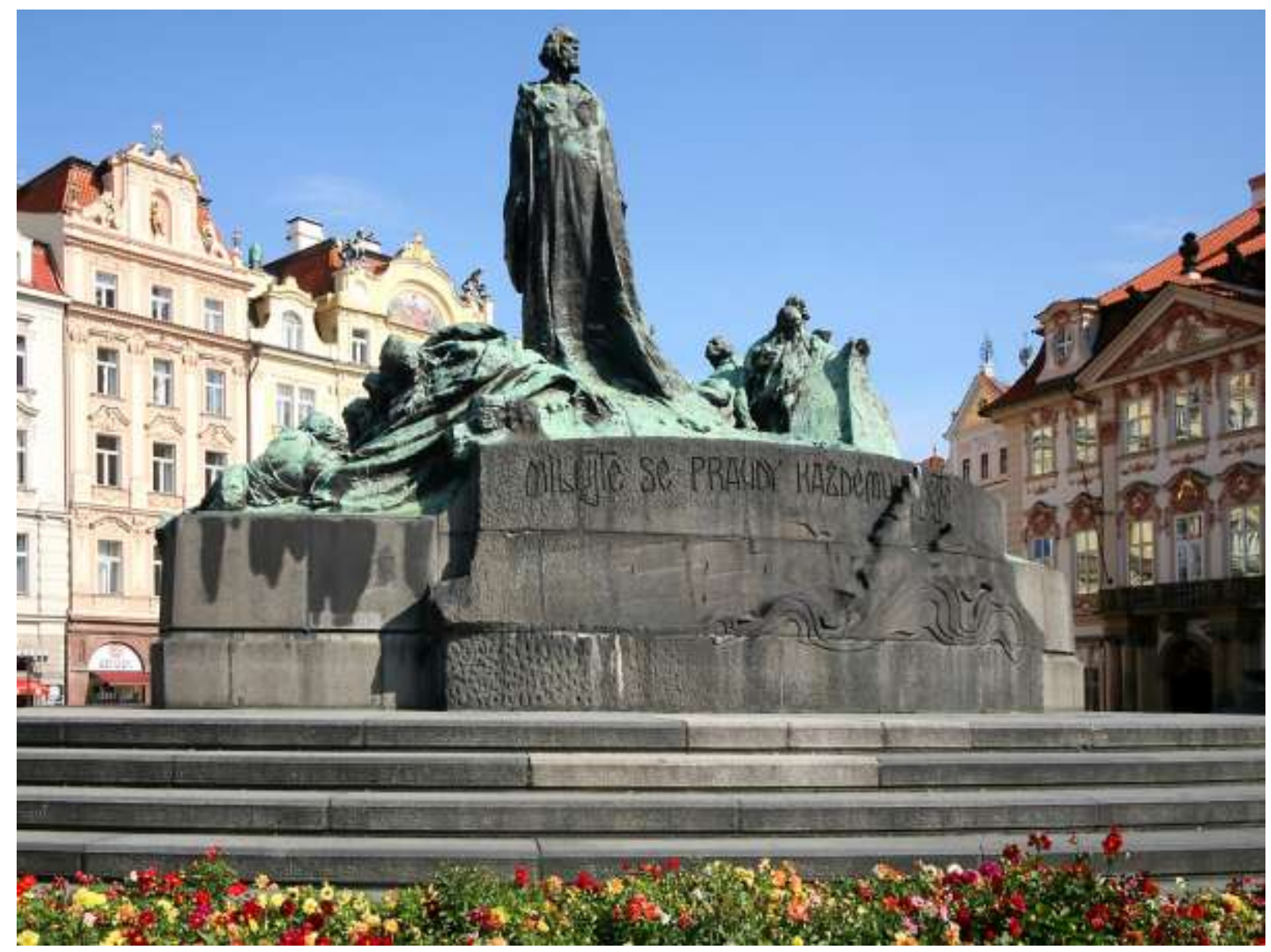

\section{Figura 29. Estátua de Jan Hus na Staroměstské Náměstí em Praga}

(Fonte: SEAMAN, Jan Hus statue in Prague)

$\mathrm{Na}$ base da estátua, juntando a figura e a palavra, quatro frases estão escritas, sendo a primeira de Hus e as outras três retiradas de canções dos Hussitas: "Amem-se uns aos outros e deseje a verdade para todos", "Viva, nação sagrada de Deus, não morra", "Eu acredito que os trovões de ódio cessarão e o governo de seus assuntos voltará às suas mãos, povo tcheco" e "Quem são os guerreiros de Deus e de sua lei”. ${ }^{463}$ É a primeira que aparece na foto. O

\footnotetext{
${ }^{463}$ MULLER, Martin. Jan Hus monument in the middle of the Old Town Square. Disponível em <http://www.prague.cz/jan-hus-monument/>. Acesso em 20 jan. 2010.
} 
monumento reúne uma representação de Hus com as palavras verdade, nação, povo e Deus consolidando os ideais do legado hussita com o nacionalismo tcheco. Ao lado da estátua de Hus estão pessoas que representam os Hussitas, sendo que um deles segura um cálice, aqui como símbolo da dupla comunhão aos leigos ${ }^{464}$. Encontra-se no centro de uma das praças mais famosas da cidade, circundado por prédios históricos que abrigam instituições como a Galeria Nacional [Narodní Galerie] e a Prefeitura e duas igrejas. Uma delas, a igreja de Nossa Senhora Diante de Týn [Matky Boži Před Týnem] foi uma das principais igrejas hussitas até a Batalha de Montanha Branca em 1620. Em 1621, o cálice de ouro que estava na fachada foi fundido para ajudar a fazer a imagem da Virgem que o substituiu até os dias de hoje.

Tanto este monumento na Praça da Cidade Velha, em Praga, quanto o memorial em Constança (figura 7) são espaços para a construção de uma identidade entre aquele que observa e quem está representado. ${ }^{465}$ Aquele que está no monumento é um exemplo a ser seguido. Torna-se uma imagem de culto, que não exerce a função de narrativa, mas presentifica-se aqui e agora. ${ }^{466} \mathrm{~A}$ herança do passado torna-se presente por meio da imagem. As palavras podem receber o predicado de "não-existência", mas a imagem correspondente a elas não: “As imagens, quer representem objetos existentes, inexistentes ou objeto nenhum, são sempre afirmativas. (...) As imagens são o que são."467 O mestre e mártir defensor da verdade, ao ser representado em imagens figurativas, teve seu legado perenizado.

\section{5. $O$ alcance de um legado}

De que maneira Hus é lembrado nos dias de hoje? Quão conhecido ele é? Analisaremos, aqui, uma pequena seleção de materiais acadêmicos e de cultura de massa sobre Hus produzidos nas últimas décadas. Fizemos esta seleção a partir de uma grande quantidade de materiais que encontramos ao longo dos último cinco anos. Eles nos oferecem pistas a respeito do processo contínuo de rememoração do legado hussita até a atualidade. Optamos por fazer uma leitura mais detalhada de alguns materiais ao invés de apresentarmos uma enumeração de muitos, visto que há grande repetição entre eles e pouco trazem de

\footnotetext{
${ }^{464}$ Não nos esqueçamos que, além de símbolo utilizado pelos Hussitas para a dupla comunhão aos leigos, o cálice também é um dos símbolos que aparecem na paixão de Cristo. No evangelho de Lucas (22:42) encontramos Jesus no monte das Oliveiras orando "Pai, se queres, afasta de mim este cálice".

${ }^{465}$ FERRO, op. cit., p. 56.

${ }^{466}$ GINZBURG, Olhos de madeira, p. 118.

${ }^{467}$ ibidem, p. 138.
} 
novidade em relação ao que já apresentamos até aqui. ${ }^{468}$ Por outro lado, as pesquisas acadêmicas que aqui apresentamos, destacam-se por serem únicas em seus contextos. Teremos, ao final deste item, um breve panorama dos espaços, geográfica e culturalmente falando, até onde chegou o legado do clérigo da Boêmia.

\subsubsection{Duas pesquisas}

A tese de Renato Emir Oberg ${ }^{469}$ sobre Hus, defendida na Universidade de São Paulo em 1972, é a única que encontramos sobre o clérigo da Boêmia realizada no Brasil. Ela foi produzida por um pesquisador da década de setenta, que não deu continuidade àquela pesquisa após a defesa. Esse trabalho permite um diálogo com o nosso a respeito da utilização ou não das cartas como documento e da leitura de Hus como educador. ${ }^{470}$

A tese de Oberg consiste num exercício de responder à pergunta "foi Jan Hus injustiçado"? O tema de sua pesquisa, conforme nos disse o autor em conversa pessoal, foi escolhido por seu orientador, Eurípedes Simões de Paula, então professor de História Antiga e Medieval do departamento de História da Faculdade de Filosofia, Letras e Ciências Humanas da Universidade de São Paulo. Percorrendo a lista dos trabalhos orientados por esse professor nas décadas de 60 e 70, encontramos algumas produções na interface religião e história medieval. No entanto, não foram significativos para estabelecermos um padrão que justificasse um trabalho sobre Hus naquele momento. Talvez houvesse para o autor da tese alguma razão pessoal, ligada à sua formação adventista. ${ }^{471}$

Para responder àquela pergunta, o autor analisa documentos da época, biografias e interpretações históricas dos eventos do Concílio de Constança. Pela quantidade de citações e afirmações com base nelas podemos registrar quatro autores que mais influenciaram seu trabalho. O primeiro é o alemão Melchior Vischer, que publicou em 1940 uma biografia sobre o clérigo da Boêmia em Frankfurt. Essa mesma obra foi reeditada em 1955, em Berlim

\footnotetext{
${ }^{468}$ Há diversos sites na Internet, por exemplo, que fazem referência a Hus ou aos Hussitas. Muitos apresentam informações bastante simplificadas, incorrendo, não poucas vezes, em informações equivocadas. Em linhas gerais, o clérigo é visto como reformador e/ou como mártir.

469 OBERG, João Huss, um injustiçado?.

${ }^{470}$ Em conversa pessoal com o autor, fomos informados que ele não deu continuidade àquela pesquisa, tendo dedicado sua vida à ação pastoral. Ele também mostrou-se surpreendido com a proposta de nossa tese, afirmando "Nunca imaginei Hus como um educador".

${ }^{471}$ Não podemos ignorar que houve grande produção de estudos sobre religião da Faculdade de Filosofia, Letras e Ciências Humanas nos anos 70, especialmente em sociologia e antropologia. O autor produziu um trabalho que estava inserido em seu espaço-tempo acadêmico.
} 
Ocidental, após a primeira ter sido confiscada pela Polícia Secreta do Estado em 1941. Oberg dispunha das duas edições ${ }^{472}$.

A segunda fonte é a obra do monge beneditino Paul de Vooght, em suas quatro publicações em língua francesa de 1960 e $1972^{473}$. Esse autor é tão importante para Oberg que são dele as palavras que encerram a tese. Não menos importante é a utilização da obra de Matthew Spinka ${ }^{474}$. Completam, embora não encerrem, as suas influências a biografia escrita pelo Count of Lützow, de $1921^{475}$. Diversos outros textos aparecem, embora com menos frequência, apresentando detalhes que complementam as informações oriundas destas quatro fontes bibliográficas.

Com relação às fontes documentais que utilizou, partiu do Documenta de Palacký ${ }^{476}$, de uma edição de discursos e sermões de Hus, publicada por Anezka Schmidtováa ${ }^{477}$ e traduções de crônicas e documentos referentes ao Concílio de Constança para o inglês e o alemão. Das cartas de Hus, cita algumas, utilizando como base principal a tradução de Workman e Pope ${ }^{478}$, mas também incluindo em algumas citações a referência à tradução francesa de Bonnechose ${ }^{479}$. De Matthew Spinka, teve acesso a cinco obras, mas a coletânea de cartas não está entre elas, provavelmente por ter sido lançada depois de seu contato com esse autor. Não obstante, ele trabalhou com a tradução de parte das cartas que Spinka publicou junto com o relato de Petr de Mladoňovice.

A tese está organizada em quatro partes, numa linha de pensamento que parte do contexto histórico da Europa e da Boêmia e chega até os predecessores de Hus e sua infância. Desta, segue cronologicamente sua biografia, concluindo o último capítulo com sua execução. Poderíamos considerá-la como um estudo biográfico de Jan Hus, tendo por mote justificar que

\footnotetext{
${ }^{472}$ VISCHER, Melchior. Jan Hus: sein leben um sein zeit. 2 vols. Frankfurt am Main: Societäts-Verlag, 1940. Idem, Jan Hus: aufruhr wider papst um reich. Frankfurt am Main: Societäts-Verlag, 1955.

${ }^{473}$ VOOGHT, Paul de. Hussiana. Louvain, Bélgica: Publications Universitaires de Louvain, 1960. Idem, L'Heresie de Jean Huss. Louvain, Bélgica: Publications Universitaires de Louvain, 1960. Idem, Jacobellus de Stribro: premier théologien du hussitisme. Louvain, Bélgica: Publications Universitaires de Louvain, 1972.

${ }^{474}$ Embora cite outras que não utilizamos neste trabalho, as principais referências a Spinka são suas obras, já citadas aqui, John Hus at the Council of Constance e John Hus: a biography.

${ }^{475}$ LÜTZOW, The Count of. The life and times of master John Hus. Londres: Dent \& Sons Ltd.; New York: E. P. Dutton \& Co., 1921.

${ }^{476}$ PALACKÝ, Documenta.

${ }^{477}$ SCHMIDTOVÁ, Anezka (ed.). Iohannes Hus, magister universitatis carolinae, positiones, recommentdationes sermones. Praga: Statní Pedagogicke Nakladatelství, 1958.

${ }^{478}$ WORKMAN; POPE, op. cit.

${ }^{479}$ A edição que aqui citamos é a tradução para o inglês. BONNECHOSE, Letters of John Huss.
} 
as acusações que o levaram à morte eram injustificadas, confrontando as afirmações dos acusadores com a reconstrução da história de vida de Hus e de seu contexto.

Sobre o clérigo da Boêmia, sustenta que ele era um ortodoxo católico, ao contrário de Wyclif e Lutero. Oberg afirma:

Alguns o chamam de reformador, outros de pré-reformador, mas, que fez ele? Wiclif e Lutero desviaram-se do corpo de doutrinas da Igreja e este último serviu de instrumento para um cisma que nunca mais se desfez, e cuja anulação está hoje sendo novamente tentada pelo movimento ecumenista. Huss, porém, não se desviou de ponto algum tido como ortodoxo pela Igreja: cria em tudo o que ela ensinava. ${ }^{480}$

Oberg esforça-se, portanto, ao longo do texto, para mostrar que Hus é quem defendia a ortodoxia católica e, se se afinava com as ideias de Wyclif, era apenas no que tange ao aspecto filosófico dessas ideias, não ao teológico. Eis o segundo aspecto do clérigo da Boêmia que destaca Oberg: ele era defensor do realismo. Oberg destaca:

Não levou muito tempo para ele se tornar um realista convicto, influenciado não só pelo fato de ser ele boêmio, e os boêmios eram quase todos realistas em oposição aos alemães que eram nominalistas, mas especialmente porque o mais estimado de seus mestres, Estanislau de Znojmo, era um dos expoentes do realismo na Universidade. (...) Hus, repetimos, se tornou um realista convicto, não se deixando confundir como aconteceu com seu professor alguns anos mais tarde. Soube sempre e sempre teve a coragem de explicar a harmonia entre suas convicções cristãs e as interpretações filosóficas correspondentes.

Por fim, Hus foi, para Oberg, um injustiçado. Toda a parte IV, que representa cerca de um terço da tese, é dedicada a apresentar o modo como o julgamento foi preparado para que ele não tivesse defesa adequada, o esforço dos acusadores em fazê-lo cair em contradição e a condenação derradeira que parecia simplesmente repetir as acusações, apesar da defesa. Sua conclusão é de que algumas "forças" provocaram o "drama" de Hus:

A luta contra a imoralidade do clero, o problema tcheco-alemão na Universidade e no reino da Boêmia; a perda da coroa imperial por parte de Venceslau bem como os esforços que fazia para reavê-la; a questão da "neutralidade" [em relação aos papas] patrocinada pela Universidade de Paris e que dividiu a Universidade e o sacerdócio de Praga; o 'odium philosophicum' entre nominalistas e realistas; o jogo duplo de Sigismundo feito com o propósito de obter maior fama e maior parcela de poder e, para completar o quadro, um Concílio onde havia doutores que usavam

${ }^{480}$ OBERG, op. cit., p. 293 e pp. 85-86, 299, 105, 274, 276, 277, 293, 300 para as citações seguintes. 
argumentos como o do olho (se Huss tivesse um olho só...), o da freira, e o do livro na cama do santo clérigo; de um Concílio que depôs solene e formalmente um papa, levou outro a abdicar e no momento em que obteve a adesão do rei Fernando de Aragão, não deu mais atenção ao terceiro; de um Concílio que dizia ter recebido sua autoridade diretamente de Deus e por isto era superior a tudo quanto havia na terra; de um Concílio cujos membros falavam dos governantes da Igreja de maneira mais acre que o próprio Huss mas não pensavam em se reformar a si mesmos, pensemos nestes problemas todos e teremos uma explicação facil (sic) para o nome comum de wiclifista que todos concordavam em atribuir àquele que tinha uma palavra de admoestação para qualquer deles.

Esta síntese das forças que levaram o clérigo da Boêmia à condenação mostra que, apesar de Hus se declarar inocente, era inevitável a sua condenação. No entanto, Oberg não apenas construiu uma imagem de Hus como ortodoxo, realista e injustiçado. Em afirmações que faz ao longo do trabalho, o autor nos dá pistas de que ele próprio sustenta a imagem do mártir defensor da verdade. E isso vai se tornando mais claro nos capítulos finais e na conclusão. Vejamos alguns exemplos. Oberg cita, a partir de Paul de Vooght, uma tradição que afirma a passagem de um cometa pelos céus da Boêmia no dia em que Hus foi eleito reitor da capela de Belém. Em seguida, escreve:

Assim seria Huss, com a diferença que, enquanto o cometa atravessou os céus para depois desaparecer sem deixar rasto (sic), Huss deixaria o seu marcado indelevelmente nos anais da História: amigos e inimigos dele se ocuparam por muito tempo, ocupam-se ainda hoje, e dele se ocuparão enquanto houver interêsse pelos movimentos que alteraram os rumos da vida e do pensamento humanos.

Em outro, quando comenta as tentativas que o Concílio promoveu para que Hus voltasse atrás, afirma: “... queriam que Huss semelhantemente se entregasse completamente 'à graça do Concílio', mas a consciência deste homem não permitia que assim o fizesse. Isso não cabia naquela alma sincera que cultivava este dom e andava sempre em busca da verdade." Ou ainda, comentando a carta que Hus escreveu para a Universidade de Praga, número 93, exalta-o:

Admiravel (sic) homem este! está disposto a morrer pelo que julga ser a verdade, mas pede lhe mostrarem o erro ou erros que porventura existam em seus escritos, a fim de que possa abandoná-los. Não julgando isto suficiente, pede á (sic) sua Universidade que continue pesquisando para, caso descubra algum erro no que ele afirmou, abandoná-lo também. Ele não se atribuia (sic) a qualidade de supremo conhecedor da verdade, mas insiste com mestres, bacharéis e estudantes que se entreguem à imensa tarefa de buscála. 
Logo, a seguir, cita esta exaltação de Vischer: "sempre e sempre de novo pelo seu objetivo: Pela Verdade! Pela Verdade! Pela Verdade!" Mais para o final, escreve "Sua luta fora pela verdade e tinha a certeza de que ela um dia triunfaria." E, para concluir sua tese, Renato Oberg faz três citações de Paul de Vooght, sendo que a última é "Assim, desde o dia de sua morte, Huss é considerado como um mártir da religião cristã autêntica."

Não podemos deixar de destacar o valor que esta tese apresenta por ser o primeiro trabalho em língua portuguesa no Brasil sobre Jan Hus. Se hoje, parte importante de nosso trabalho, inclusive com o acesso a determinadas fontes, só foi possível graças ao uso de meios eletrônicos de comunicação e armazenamento, quão grande foi o esforço desse estudioso para reunir fontes que permitissem produzir sua tese no início da década de 70. Há livros a respeito de Hus que, em nosso país, só encontramos em sua biblioteca particular. Provavelmente pela não continuação da pesquisa da parte de seu autor, parece não ter havido repercussão de seu trabalho no meio acadêmico até o momento da realização de nossa tese. Não encontramos qualquer publicação de artigo $^{481}$ ou livro que fizesse menção a ela.

Se Hus foi "o mártir da religião cristã autêntica" para uns, não podemos nos esquecer que ele foi condenado como "heresiarca" e, até onde nós saibamos, não há qualquer revogação desta condenação. Isso significa que, mesmo havendo estudiosos católicos que assumam essa posição de não só defendê-lo como também exaltá-lo, oficialmente, para a Igreja de Roma, ele continua condenado.

Um papa como João Paulo II, que escreveu uma encíclica que permite críticas e sugestões para o aperfeiçoamento do exercício do papado, propondo o ecumenismo e a reconsideração das feridas do passado $^{482}$, abre espaço para uma leitura mais tolerante das ideias de Hus, podendo, inclusive, favorecer uma revisão de sua acusação. Foi também esse papa que, em 1985, escreveu uma encíclica homenageando a vida apostólica de Cirilo e Metódio, que evangelizaram os povos eslavos. ${ }^{483}$ A Igreja surge na Boêmia em virtude da

\footnotetext{
${ }^{481} \mathrm{O}$ próprio autor da tese publicou, antes da defesa, um artigo referente ao papel da reunião de Kutná Horá de 1405 entre os professores da Universidade de Paris e os de Praga como importante ponto de viragem na história de Jan Hus. V. OBERG, Renato Emir. Kutna Hora. Influências morais e políticas no julgamento do mestre João Hus. Revista de História. São Paulo, 1971, nº 85, pp. 33-47.

482 JOÃO PAULO II, Papa. Ut unum sint: carta encíclica do sumo pontífice papa João Paulo II sobre o empenho ecumênico. Libreria Editrice Vaticana, 1995. Disponível em <http://www.vatican.va/holy_father/john_paul_ii/encyclicals/documents/hf_jp-ii_enc_25051995_ut-unumsint_po.html>. Acesso em 22 jan. 2010. Ver especialmente itens 2 e 88-96.

${ }^{483}$ idem. Slavorum apostoli: carta encíclica do sumo pontífice papa João Paulo II para comemorar a obra de evangelização dos santos Cirilo e Metódio no undécimo centenário. Libreria Editrice Vaticana, 1985. Disponível em <http://www.vatican.va/holy_father/john_paul_ii/encyclicals/documents/hf_jp-ii_enc_19850602_slavorumapostoli_po.html>. Acesso em 22 jan. 2010.
} 
ação deste último e de seus discípulos a partir do século IX. Não é, então, estranho descobrir que o primeiro papa eslavo da história ${ }^{484}$ escreveu um discurso sobre Jan Hus, propondo a busca pela verdade histórica de seu julgamento.

Esse discurso foi proferido por ocasião do encerramento do Simpósio Internacional sobre Jan Hus, que ocorreu entre os dias 15 e 18 de dezembro de 1999 na Pontifícia Universidade Lateranense, em Roma. Ele foi organizado pelo Comitê Central do Grande Jubileu do ano de 2000 e pela Conferência Episcopal Tcheca com convidados da Academia de Ciências da República Tcheca e da Universidade de Praga. O objetivo do evento foi estudar a vida e a obra de Hus.

No evento, os convidados discutiram a respeito do contexto social e teológico no qual Hus atuou. Debateram os conceitos de predestinação e remanência para Hus, bem como sua escatologia e a edição de seus escritos. Dedicaram um período do simpósio para o estudo da questão Hus e o Concílio de Constança e outro para sua influência no movimento de reforma da igreja tcheca e na história social e religiosa da Boêmia e da Europa. Deram especial atenção à sua influência no nascimento e desenvolvimento da Reforma Protestante. O evento recebeu a visita do então presidente da República Tcheca, Václav Havel, que presenteou o papa com a árvore de natal do Vaticano daquele ano. ${ }^{485}$

Em seu discurso, Václav Havel afirmou, retomando os temas caros aos nacionalistas tchecos do início do século $\mathrm{XX}$, que

a ligação ardente e intrínseca de Hus com a verdade, a adesão fiel da verdade na mais profunda harmonia com as ações da vida cotidiana, continua a ser, apesar das transformações produzidas através dos séculos e das visões filosóficas e teológicas parciais, um estímulo permanente para a herança espiritual de nosso povo. ${ }^{486}$

\footnotetext{
${ }^{484}$ E o primeiro não-italiano desde Adriano VI (1522-1523), como apontou MCBRIEN, Os papas, p. 390.

${ }^{485}$ Sobre o Simpósio e a visita do presidente Václav Havel, ver: HOLECEK O. M., Frantisek J. Nel nome di Giovanni Hus la riconciliazione fra i cristiani boemi. Revista do Jubileu de 2000. n.10, dez. 1999. Seção Ecumenismo. Disponível em <http://www.vatican.va/jubilee_2000/magazine/documents/ju_mag_01121999_p18_it.html>. Acesso em 22 jan. 2010. BUSOLINI, Dario. Dialogue resumes from the testimony of Jan Hus. Revista do Jubileu de 2000. n. 1, jan. 2000. Seção Themes of the Jubilee. Disponível em <http://www.vatican.va/jubilee_2000/magazine/documents/ju_mag_01012000_p-38_en.html>. Acesso em 22 jan. 2010. RADIO PRAGUE. Czech christmas tree to the vatican. Current Affairs. 15 dez. 1999. Disponível em <http://archiv.radio.cz/english/cur-affrs/15-12-99.html>. Acesso em 22 jan. 2010. JOÃO PAULO II, Papa. Discurso do papa João Paulo II aos peregrinos da República Tcheca vindos a Roma para a entrega da árvore de natal. 18 dez. 1999. Disponível em <http://www.vatican.va/holy_father/john_paul_ii/speeches/1999/december/documents/hf_jpii_spe_18121999_havel_po.html>. Acesso em 22 jan. 2010.

${ }^{486}$ BUSSOLINI, op. cit..
} 
Dos precedentes do evento, encontramos a fala do então Cardeal Arcebispo de Praga, Josef Beran (que havia sido preso pelos nazistas e pelos comunistas ${ }^{487}$ ) durante o Concílio Vaticano II. Aos participantes do concílio, ele se lembrou da figura de Hus e do que ocorreu com este no Concílio de Constança. De algum modo, sua atitude lembra o "aviso salutar" de Lutero ao que se tornou o Concílio de Trento. A figura do clérigo da Boêmia e sua condenação em 1415 participaram nestes dois momentos fundamentais da Igreja. Beran disse:

Em meu país, a Igreja Católica neste momento parece estar sofrendo as expiações pelos defeitos e pecados cometidos nos tempos pregressos em seu nome contra a liberdade religiosa, como (...) a imolação de Jan Hus (...). Então, a história também nos alerta que, neste Concílio, os princípios da liberdade religiosa e da liberdade de consciência devem ser enunciados da forma mais clara e sem quaisquer restrições, o que poderia surgir de motivos oportunistas. Se assim o fizermos, mesmo no espírito de penitência por tais pecados do passado, a autoridade moral de nossa Igreja será amplamente aumentada e todo o mundo irá colher os benefícios. ${ }^{488}$

Em 1990, em visita oficial à então Tchecoslováquia, o papa João Paulo II lembra-se dessa fala de Beran e, num discurso no Castelo de Praga, afirma que "não se pode negar a Hus a integridade de vida pessoal e empenho pela instrução e educação moral da nação". ${ }^{489} \mathrm{Na}$ viagem seguinte à, agora, República Tcheca, retoma a mesma lembrança no seu discurso perante um grupo de representantes de outras confissões. Nele, afirma que uma comissão ecumênica está dando atenção a seu convite para que fosse definido "de modo mais exacto o lugar que Jan Hus ocupa entre os reformadores da Igreja, ao lado de outras famosas figuras reformadoras", com destaque ao envio de um emissário da Santa Sé para um evento sobre Hus em 1993 na cidade de Bayreuth. ${ }^{490}$

\footnotetext{
${ }^{487}$ KERR, Donal A. Christianity, european governments and the cultural identity of non-dominant groups in the 19th and 20th centuries. Revista Cultures and Faith. vol 1, n. 1. 1993. Disponível em $<$ http://www.vatican.va/roman_curia/pontifical_councils/cultr/documents/rc_pc_cultr_01091993_doc_i-1993kling_en.html\#4>. Acesso em 22 jan. 2010.

488 ibidem.

489 JOÃO PAULO II, Papa. Incontro di Giovanni Paolo II con il mondo della cultura. Viagem pastoral para a República Federativa Tcheca e Eslovaca. 21 abr. 1990. Disponível em <http://www.vatican.va/holy_father/john_paul_ii/speeches/1990/april/documents/hf_jpii_spe_19900421_cultura-praga_it.html>. Acesso em 22 jan 2010.

490 idem. Discurso do papa João Paulo II no encontro com os representantes de outras confissões. Viagem apostólica à República Tcheca. 27 abr. 1997. Disponível em <http://www.vatican.va/holy_father/john_paul_ii/speeches/1997/april/documents/hf_jpii_spe_19970427_ecumenico-praga_po.html>. Acesso em 22 jan. 10.
} 
Em seu discurso no evento de $1999^{491}$, João Paulo II inicia agradecendo pela contribuição do simpósio ao trabalho da "Comissão Ecumênica Husovská", constituída pelo cardeal Miloslav Vlk, "com a finalidade de identificar de modo mais preciso o lugar que João Hus ocupa entre aqueles que aspiravam à reforma da Igreja”. O evento, lembremos, foi promovido pelo Comitê Central do Jubileu e pela Conferência Episcopal Tcheca, portanto, a Comissão do Vaticano não o promoveu.

Segue celebrando o fato de haver, no simpósio, participantes não só da República Tcheca como dos países vizinhos e peritos de diferentes confissões religiosas. O próximo passo seria a publicação do trabalho, de acordo com João Paulo II. Até o momento, não conseguimos encontrar tal publicação ou qualquer outra referência bibliográfica a não ser o discurso do papa. Não temos, portanto, como saber quais foram as conclusões do simpósio. Porém, podemos destacar que a permanência e a importância do legado hussita incentivaram a ocorrência de um evento que agregou religiosos e historiadores. Contudo, se continuarmos na leitura do discurso do papa, podemos ir um pouco além e observarmos o modo como o legado hussita também está presente nas palavras da pessoa que representa a posição oficial da Igreja Católica.

João Paulo II afirma o dever de "exprimir profunda tristeza pela cruel morte infligida a João Hus e pela consequente ferida, fonte de conflitos e divisões, que foi desse modo aberta nas mentes e nos corações do povo boêmio". Lembra-se de sua primeira visita a Praga e sustenta que as "feridas dos séculos passados devem ser curadas, mediante um novo olhar prospectivo e a instauração de relações completamente renovadas." O tema do ecumenismo, tão fortemente defendido pelo papa, aparece aqui. É na pesquisa histórica que busque a verdade divina que deve se pautar o trabalho de resgate do que ocorreu com Hus. Essa busca pela verdade histórica pautada na verdade divina é o que o papa considera como "estudo genuinamente científico". Ele justifica:

De fato, é muito difícil alcançar uma análise da história absolutamente objetiva, dado que as convicções, os valores e as experiências pessoais influenciam de maneira inevitável o seu estudo e exposição. Entretanto, isto não significa que não se possa chegar a uma evocação dos eventos históricos, que seja deveras imparcial e, como tal, verdadeira e libertadora. $\mathrm{O}$ vosso próprio trabalho é prova de quanto isto é possível.

\footnotetext{
${ }^{491}$ idem. Discurso do papa João Paulo II aos participantes no simpósio sobre João Hus. Todas as citações seguintes sobre esse discurso partem desta referência. A tradução está em português de Portugal e a adequamos para a atual Reforma Ortográfica.
} 
O estudo histórico imparcial, guardado o fato que há uma inevitável influência subjetiva, é verdadeiro e libertador para João Paulo II. Como a verdade liberta, o trabalho como o do simpósio "está a significar que uma figura como a de João Hus, que foi um grande ponto de controvérsia no passado, pode agora tornar-se um tema de diálogo, de confronto e de aprofundamento comum”. O estudo sobre Hus pode servir como exemplo para a busca da unidade dentro da solidariedade, que é resultante de um "religar-se, de modos novos e criativos, às raízes cristãs comuns e à identidade específica que delas derivou".

Conclui sua fala, dizendo que o trabalho do simpósio

é um serviço importante não só para a figura histórica de João Hus, mas também, de maneira mais geral, para os cristãos e para a sociedade europeia no seu conjunto. Isto porque, afinal, é um serviço à verdade sobre o homem, verdade que a família humana tem necessidade de recuperar, antes de qualquer outra coisa, no alvorecer do terceiro milênio da era cristã. (grifo no original)

E completa, lembrando-se da figura do Cristo ressuscitado, que

encarna de maneira perfeita a verdade sobre o homem, criado à imagem e semelhança de Deus (cf. Gn 1, 26). Oro ardentemente Àquele que é 'o

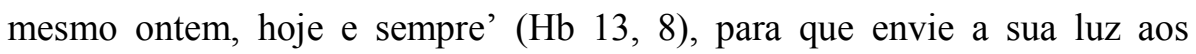
vossos corações. Em penhor de graça e paz n'Ele, invoco sobre vós, sobre as pessoas que vos são queridas e a inteira nação tcheca as abundantes bênçãos do Altíssimo, ao Qual sejam dados louvor, glória, sabedoria e ação de graças nos séculos dos séculos. Amém!

João Paulo II faz, neste discurso, uma relação entre a busca da verdade histórica e a busca da verdade do homem, tendo por base a verdade divina. Aproveita para ressaltar a importância de se resgatar a imagem de Hus, questionando as interpretações históricas que hoje dele temos. Coloca-o na história das igrejas reformadas e destaca a importância de sua revisão para o movimento ecumênico. Embora em nenhum momento faça menção direta aos conceitos hussitas, a busca pela verdade do homem com base na verdade divina é o mote da busca de Jan Hus. Este não é o herege, é alguém que deve ser melhor estudado para ser melhor compreendido. Mais do que isso, João Paulo II, de certa forma, aceita o legado histórico de Hus e usa esse legado para reafirmar as novas posições da Igreja Católica nas décadas posteriores ao Concílio Vaticano II. O mesmo Hus que foi utilizado como representação do cristão verdadeiro no início da Reforma Protestante, foi posto como alguém cuja história deve ser retomada e revista para o fortalecimento do movimento de reunião das igrejas cristãs. 


\subsubsection{Três meios textuais de divulgação histórica}

Jan Hus foi destaque de uma coleção que circulou no Brasil na década de setenta, voltada à divulgação histórica para o grande público. A coleção Grandes Personagens da História Universal, da Editora Abril Cultural ${ }^{492}$ propunha-se a narrar os momentos mais importantes da história do mundo através da vida de 59 personagens. Ricamente ilustrado, o fascículo número 27 possui 16 páginas de tamanho pouco maior que ofício, cobertas por uma capa de quatro páginas que deveria ser destacada para compor um Dicionário Enciclopédico dos contemporâneos dos grandes personagens.

Na primeira página da capa do fascículo, como observamos na figura 30, encontramos a reprodução de uma imagem de Hus provavelmente oriunda de algum códice do século XV ou XVI, que não sabemos qual é pela ausência de indicação. Este, aliás, é um dos problemas do fascículo, que não apresenta qualquer referência bibliográfica ao texto escrito e nem identifica a origem de todas as imagens.

Nas páginas seguintes da capa, encontramos uma linha do tempo contemplando a vida de Hus, seus antecedentes históricos e seus sucessores. Além disso, acompanha essa linha um conjunto de pequenas biografias de personagens contemporâneos embora não necessariamente relacionados a Hus. São eles: Ibn Khaldun, Érico da Pomerânia, Wyclif, Gutenberg, Chaucer, Tamerlão e Sigismundo.

Nesta linha do tempo, encontramos algumas incorreções históricas, talvez oriundas do excesso de síntese que esse tipo de texto apresenta. Por exemplo, em 1409, Hus "aproveita a ocasião [de ser reitor da Universidade] para 'boemizá-la', com apoio do Rei Venceslau”. Colocado desta forma, parece que o clérigo foi o responsável pela nacionalização da universidade, enquanto ele foi apenas um dos personagens desse momento, além do fato de ele ter se tornado reitor após o decreto de Kutná Horá. Nesse sentido, David Schaff ${ }^{493}$, por exemplo, afirmou que Hus guardou "a honra, ou o estigma" de ser o autor principal da mudança da Universidade, embora ele o negasse. Ou então, no ano de 1414, que ele foi à Constança, munido de um salvo-conduto, o que não ocorreu, visto que ele insistia em solicitálo durante a viagem.

\footnotetext{
${ }^{492}$ ABRIL S.A. CULTURAL E INDUSTRIAL. João Hus. Coleção Grandes Personagens da História Universal. 20p. São Paulo: Editora Abril Cultural, 1971. Dos autores indicados no fascículo, sabemos apenas que Heloísa Goulart Jahn é tradutora e que Cassiano Marcondes Rangel Filho defendeu sua tese em História no ano de 1969 na então Faculdade de Filosofia, Ciências e Letras da Universidade de São Paulo.
}

${ }^{493}$ SCHAFF, op. cit., p. 82-83. 


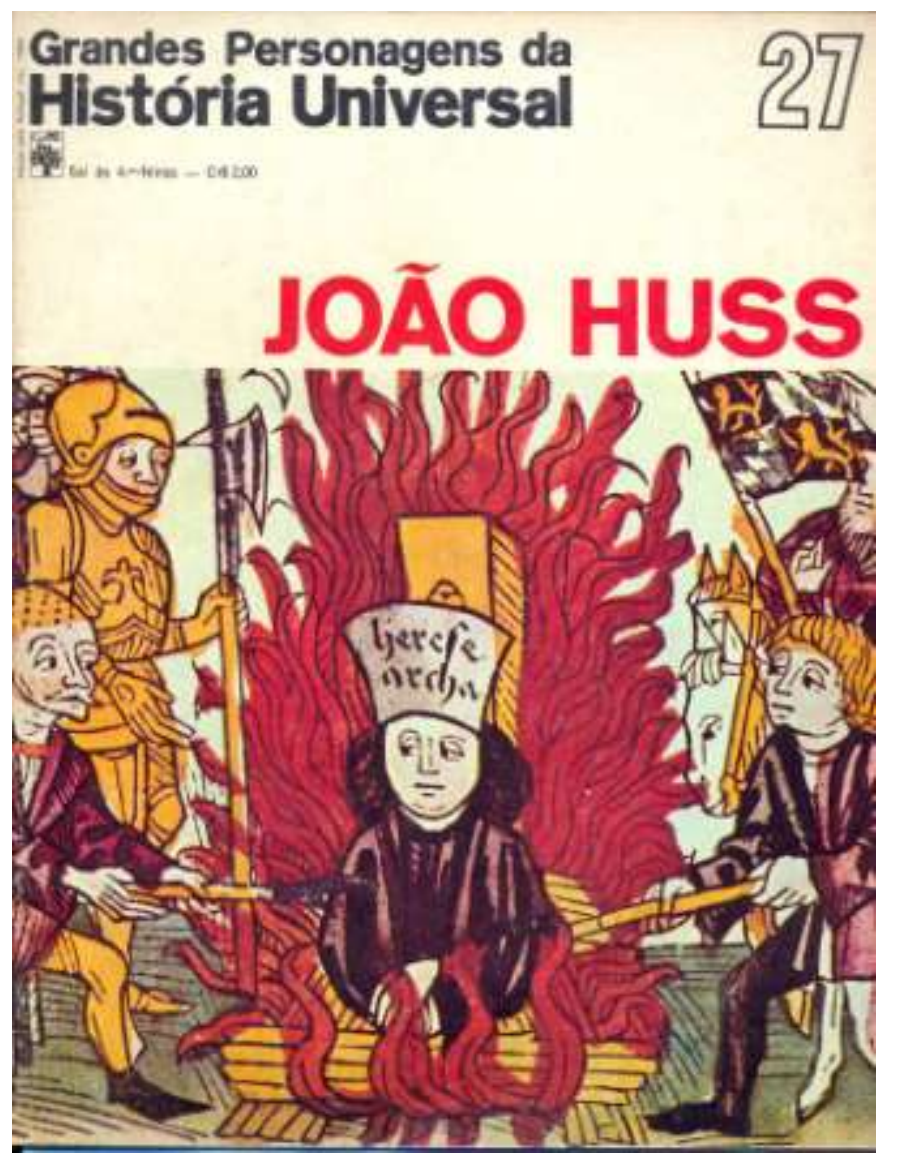

\section{Figura 30. Capa do fascículo 27}

\section{(Fonte: Coleção Grandes Personagens da História Universal)}

Outra destas incorreções aparece no texto, na página 389, na qual consta a afirmação "Huss estabelecera que os fiéis, da mesma forma que os padres, deviam receber a comunhão tanto pela hóstia como pelo vinho." ${ }^{494}$ Desta forma, dá a entender que este foi um preceito estabelecido por Hus, sendo que foi, como as cartas e outras fontes que utilizamos indicam, uma proposição com a qual ele concordava, mas sua tradição já remontava a seus predecessores.

O texto introdutório é uma narrativa romanceada de um encontro entre Hus e os guardas reais, responsáveis por transmitir-lhe a ordem do Rei Venceslau para que deixasse Praga por conta do Interdito de 1412. Ele é chamado de "Padre João", o que causa um efeito de intimidade para quem lê. Após essa narrativa, é apresentado o contexto da Boêmia daquele ano e a crise do século XIV, com a peste negra e o cisma papal. Introduzem Wyclif, para estabelecer, mais adiante, uma ligação direta entre ele e Hus.

Tecem, então, uma breve biografia de Hus, comparando sua vida com as condições de trabalho dos servos nos feudos e a quantidade de impostos que os tchecos pagavam aos

${ }^{494}$ ABRIL CULTURAL, op. cit., p. 389 e pp. 381-384, 387, 389 e 395 para os parágrafos seguintes. 
alemães. Continuam com a vida sacerdotal do clérigo, suas relações com o arcebispo, com os reis e com os papas, mencionando a nacionalização da Universidade de Praga e as excomunhões que sofreu.

Apresentam seu exílio, a partir do conflito com a venda de indulgências pelo Papa João XXIII e sintetizam em poucas linhas seu julgamento, condenação e execução:

Conduzido à assembléia do concílio, Huss tenta falar, mas não pode. Sua voz é abafada pela gritaria dos presentes. Na segunda sessão, Huss concorda em retratar-se quanto a um problema puramente teológico, mas recusa aceitar o princípio de que o papa é a cabeça da Igreja. Intimado a fazer uma retratação completa diante do perjuro Sigismundo, Huss se nega e ouve sua condenação à morte. Tenta falar novamente, mas é proibido. Finalmente, ajoelha em prece silenciosa e deixa-se levar pelos guardas, sob os impropérios do público. Poucas horas depois - o tempo para juntar a madeira - é queimado vivo. Quando as chamas se tornaram longas línguas de fogo envolvendo seu corpo, ouviu-se o professor de filosofia entoar o Kyrie Eleison. Suas cinzas foram espalhadas ao vento ou jogadas no Ródano [Reno], para que não pudessem servir de relíquias.

Uma síntese como esta, num texto de divulgação para o grande público, está sujeita a incoerências, especialmente se comparadas a documentos como as cartas de Hus e o Relatio de Mladoňovice, que entendemos serem pouco conhecidos até hoje. No entanto, se entrarmos por este caminho de análise, deixamos de perceber o principal dessa produção: a imagem de Hus que tenta retratar.

Ele é o "camponês que deu certo" e, seguindo a heresia de Wyclif, lutando contra a hierarquia da Igreja, pregou e morreu pelo nacionalismo e a pobreza do clero. Vejamos neste trecho, como estas ideias aparecem reunidas:

Huss continua as pregações, cada vez mais inflamadas, suscitando entusiasmo ainda maior dos tchecos. Agora já pede abertamente a expropriação dos bens da Igreja e que os padres vivam segundo a regra evangélica. Mas exige, sobretudo, que se faça justiça aos boêmios.

As questões teológicas e a busca pela verdade não aparecem. Os motivos da ação de Hus são basicamente a exploração econômica, o nacionalismo e um retorno a uma vida de pobreza. As seis páginas seguintes são dedicadas aos Hussitas, com grande destaque a Jan Žižka. A conclusão do texto liga Hus a Lutero:

Ainda decorreriam noventa anos, até que, numa manhã de vento, um padre alemão atravessasse a praça e afixasse duas fôlhas na porta da igreja do Castelo de Wittenberg. Era um violento ataque à venda de indulgências, à 
simonia. Poucos anos mais tarde, êsse mesmo padre - Martinho Lutero diria: 'Éramos todos hussitas, mas não sabíamos disso'.

Citam a republicação dos livros de Hus, os soldados de Müntzer e os anabatistas e terminam afirmando que a cavalaria de Cromwell lia Wyclif e Hus nas vésperas das batalhas e que os escritos destes foram para a América por meio dos puritanos. O fascículo apresenta ainda um mapa da expansão hussita na Europa. Nesta conclusão, eles reforçam a imagem de Hus precursor da Reforma.

Das ilustrações, destacamos uma gravura do século XVI, guardada na Biblioteca Nacional da Áustria.

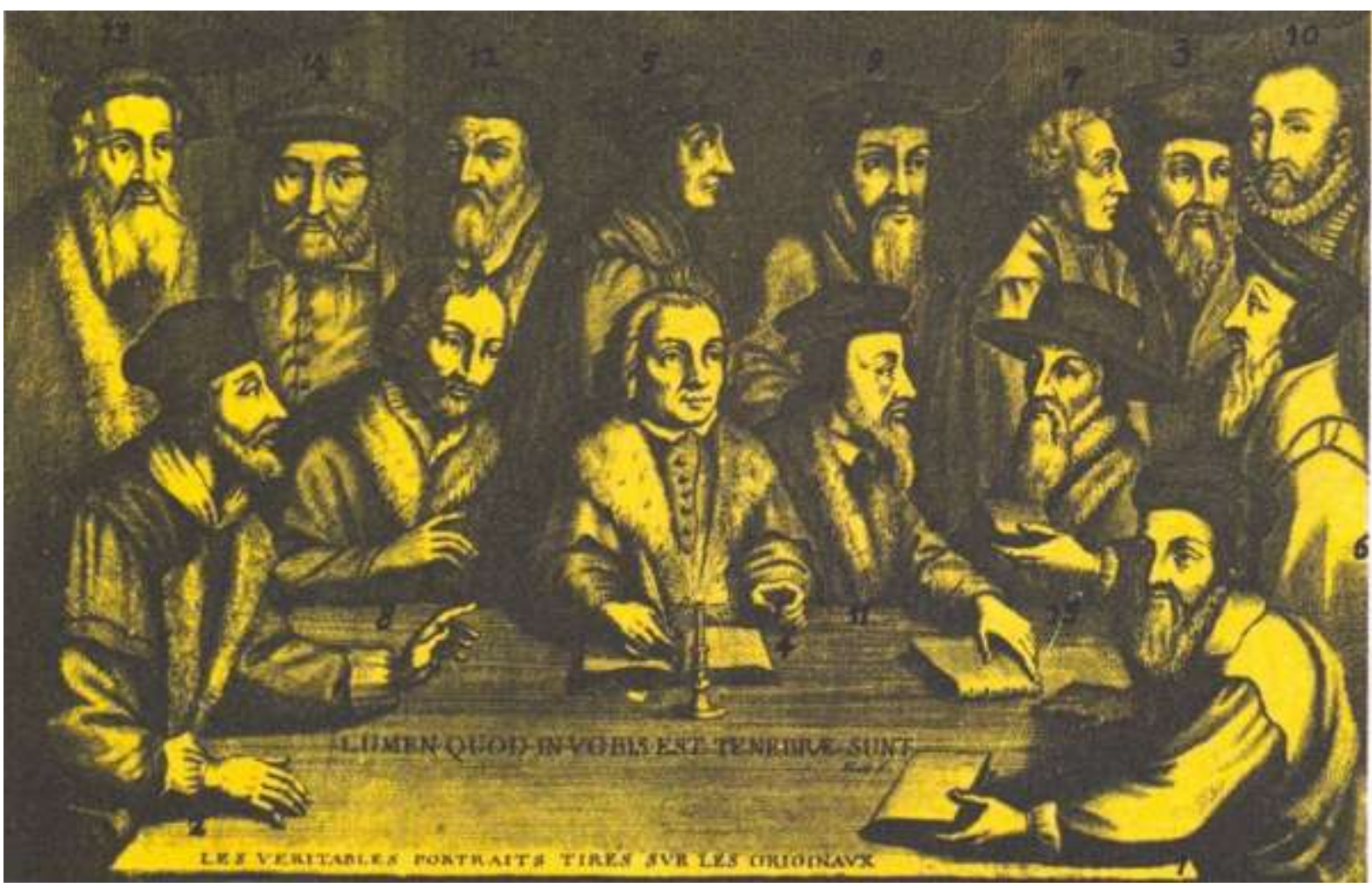

Figura 31. Os pensadores da tradição protestante, gravura do século XVI

(Fonte: Coleção Grandes Personagens da História Universal, fascículo 27)

A figura 31, extraída do fascículo, apresenta quinze personagens da tradição protestante, a saber, em pé, da esquerda para a direita, Bullinger, Jerônimo Zanchi, Knox, Zwinglio, Pedro Vermilli, Bucer, Jerônimo de Praga, Bernardo Occhini, Oecolampade, sentados, Jan Hus, Melanchthon, Lutero, Calvino, Bese, Wyclif. Vejamos com que expoentes da Reforma Hus está sentado, bem como sua posição de destaque à mesa, tanto pelo espaço que ocupa quando pela postura corporal. Ele é o único que está falando. E Wyclif, sentado na outra ponta da mesa, parece estar entregando seus escritos a Hus e não a Lutero (sentado no centro). $\mathrm{O}$ autor da imagem parece estabelecer uma linha de ligação entre Wyclif, Hus e 
Lutero, compondo um triângulo cujo vértice superior é o reformador alemão. Destaquemos, também, que a imagem de Hus desta gravura é idêntica à de Theodore de Bry, apresentada neste trabalho como figura 14. A frase escrita na base da imagem dos pensadores da tradição protestante, ao afirmar que os personagens foram apresentados com suas feições verdadeiras, extraídas de originais, reforça o caráter de fidedignidade que as gravuras de Bry conquistaram. A imagem de Hus composta por Theodore de Bry ganhou o status de original.

Na figura 31 aparecem apenas personagens ligados à Igreja, o que reforça a leitura do clérigo da Boêmia como precursor da Reforma. Não há figuras leigas ligadas à nobreza ou ao povo. Lembrando-nos das redes de relações de Hus que traçamos a partir das cartas, entendemos que essa imagem ressalta apenas seu lugar de intelectual. As outras ilustrações do fascículo apresentam-no sozinho, ao lado de Jerônimo de Praga ou sendo levado à fogueira. A reprodução destas imagens, como é o caso da capa, acrescenta ao texto o legado do mártir. Visto que este material é destinado ao grande público, vendido em bancas de jornal, visando a divulgação histórica, ele deixa para aquele que o lê a memória do mártir precursor da reforma protestante. Os editores do fascículo mostram ao público brasileiro que Hus é um líder religioso e, ao fazê-lo, ignoram o educador.

Esse material foi publicado no mesmo ano em que Renato Oberg defendeu sua tese. Entendemos que não há ligação entre os dois trabalhos. No entanto, ambos apontam para a o mesmo legado hussita construído por Petr de Mladoňovice, Lutero e pelos seguidores deste. Essa construção de séculos atrás chegou, no início da década de setenta no Brasil, preservando suas principais ideias. Se não aprendemos a respeito de Jan Hus pelo currículo praticado na escola brasileira, materiais como essa coleção da Abril Cultural possuem um papel importante na formação de nossa compreensão a respeito do clérigo da Boêmia.

Se aqui no Brasil não é comum conhecer a Jan Hus nos estudos históricos que fazemos na escola, com certeza ele é um personagem que frequenta os programas escolares na República Tcheca. Por meio de nosso curso de língua tcheca ${ }^{495}$, tivemos acesso a dois livros de história tcheca para crianças, ambos publicados já no século XXI. São materiais de divulgação histórica voltados para crianças. Como será o Jan Hus desses livros?

O primeiro deles, Obrázky z českých dějin a pověstí [Histórias e Lendas Tchecas Ilustradas], possui duas páginas com quadrinhos dedicadas à vida de Hus. As imagens apresentam Hus pregando e os erros do clero que ele denunciava. Em seguida, apresenta o

${ }^{495}$ Agradecemos à Petra Mocová pelo empréstimo destes materiais. 
movimento contra as indulgências e a morte dos três jovens tchecos ${ }^{496}$ que seguiram seus ensinamentos. Depois, ele sai para o exílio, com a promessa do salvo-conduto de Sigismundo. Ao chegar a Constança é preso e condenado. No antepenúltimo quadro, ele está escrevendo e no penúltimo ele ora enquanto é queimado.

Como podemos ver na figura 32, ele aparece em sete quadros: pregando (em dois), viajando, preso, sendo condenado, escrevendo e morrendo na fogueira rezando. Os outros clérigos são gordos, aparecendo, inclusive, comendo num banquete. Sigismundo está com aquilo que as crianças costumam chamar de "cara de mal".
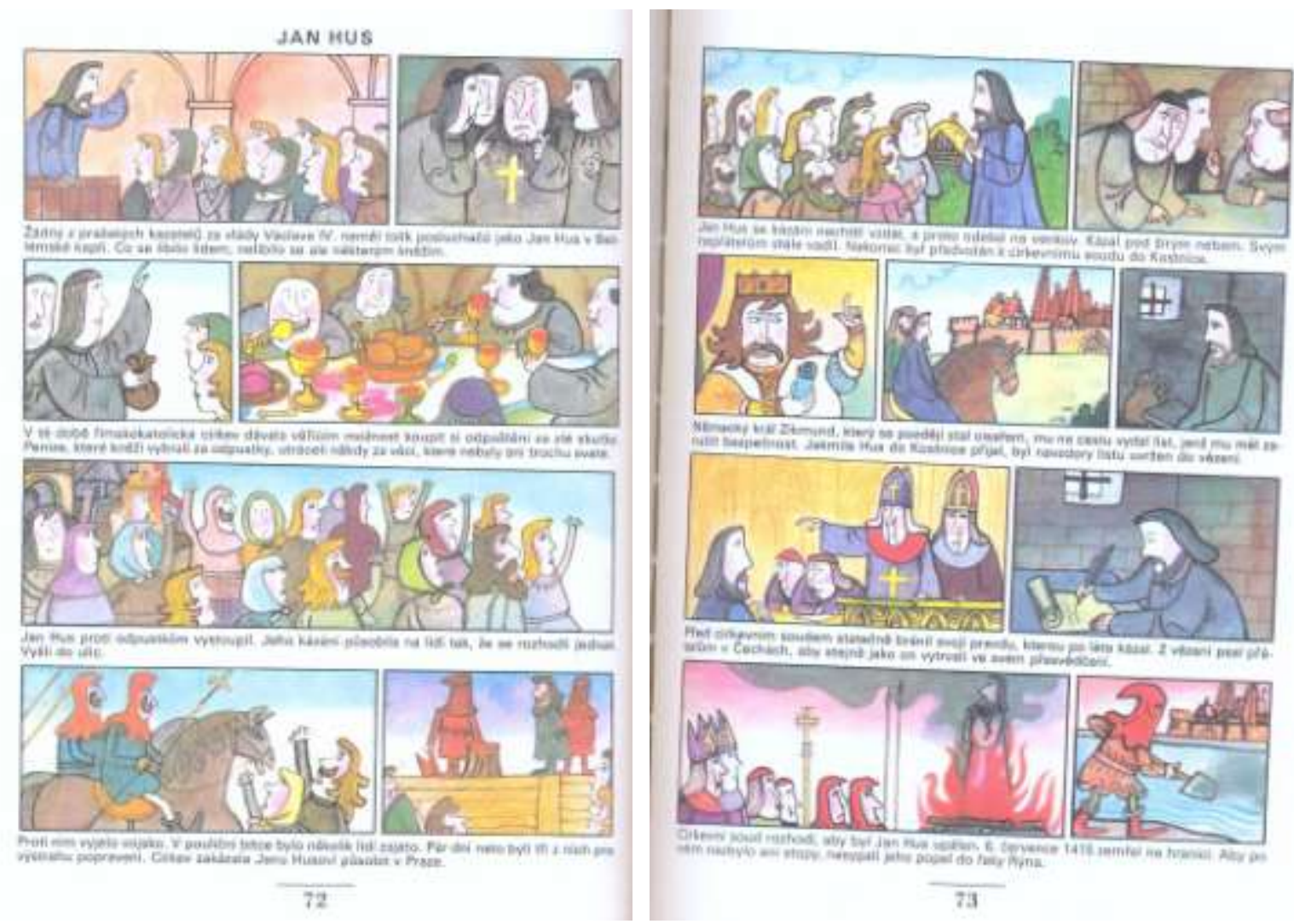

Figura 32. Jan Hus, do livro de história ilustrada tcheca para crianças (Fonte: ČERNÝ; ZÁTKA; ADLA; KALOUSEK, Obrázky z českých dějin a pověstí)

\footnotetext{
${ }^{496}$ Em julho de 1412, três jovens, Martin, Jan e Stašek, reclamaram contra a venda de indulgências em três igrejas. Eles foram condenados à morte. Na companhia de mestres, bacharéis e estudantes, Hus, afirmando ser mais culpado que os jovens, porque fora do clérigo que eles ouviram aqueles ensinamentos, pediu para que eles fossem absolvidos. Ao receber a resposta afirmativa dos magistrados, Hus voltou para casa. Poucas horas depois, os três jovens foram decapitados. Isso gerou um grande movimento em Praga, chegando Hus a defini-los como santos e exortou o povo, em seus sermões, a seguir o exemplo deles. V. SPINKA, John Hus: a biography, pp. 154-155 e SCHAFF, John Hus, pp. 124-125.
} 
Com relação ao texto, seu conteúdo é, resumidamente, o seguinte. ${ }^{497}$ Durante o governo de Venceslau IV não havia nenhum pregador com mais fiéis que Hus. Isso não agradava à Igreja. A Igreja Católica Romana vendia indulgências. Com o dinheiro desta venda, gastavam em coisas "nem um pouco santas". Jan Hus pregou contra as indulgências, o que levou o povo às ruas, impressionados com sua pregação. Outra vez o povo saiu às ruas e vários foram presos. Numa das revoltas, três foram executados e a Igreja interditou Hus e ele não podia mais pregar em Praga. Jan Hus não podia deixar de pregar e continuou a fazê-lo debaixo do céu, no campo. Por fim, foi convidado a um tribunal religioso em Constança. O rei alemão Sigismundo, que mais tarde seria imperador, prometeu um salvo conduto. Hus foi a Constança. Apesar do salvo-conduto, foi preso. Diante do tribunal da igreja defendeu sua verdade que por anos pregou. Da prisão, escreveu para seus amigos tchecos, para que, como ele, mantivessem sua convicção. O tribunal da Igreja decidiu que ele seria queimado e em 6 de julho de 1415 ele morreu na fogueira. Para que não sobrassem vestígios, suas cinzas foram jogadas no rio Reno.

Percebemos, no texto, a presença do Hus pregador influente, sem igual no reino, diante de uma igreja que fazia coisas "nem um pouco santas". Ele defendeu sua verdade e escreveu para que os seus amigos fossem tão convictos quanto ele. Hus é valorizado por sua pregação, por sua convicção e por sua escrita. Morreu como um santo, basta vermos a postura como ele está na fogueira. Assemelha-se a algumas imagens de santos católicos em postura de oração. Seja por meio do texto, seja pela imagem, ele foi um personagem de destaque para o povo, que era aclamado e ouvido com atenção. Sendo este um livro para crianças, transformando as afirmações em prescrições, temos: Hus é alguém que deve ser ouvido com atenção, um exemplo a ser seguido de combater os erros e não desistir jamais. É um herói nacional, um homem a ser reverenciado.

Outra obra que trata Hus quase como um mártir é o livro Dějiny udatného českého národa a pár bezvýzamných světových událostí (História do bravo povo tcheco e alguns eventos mundiais insignificantes), de Lucie Seifertová. O próprio título do livro, ao utilizar a palavra insignificante, já aponta para o tom de humor com o qual irá ilustrar a história e selecionar as curiosidades que comporão os eventos mundiais. As páginas possuem dobraduras, fazendo saltar para fora delas determinadas partes da ilustração. Elas não são

\footnotetext{
${ }^{497}$ Escrevemos de modo a cada frase corresponder a um quadrinho. Este trecho é mais uma tradução livre do que literal. Mas tomamos o cuidado de não mudar as ideias do texto, especialmente nas frases que comentaremos a seguir.
} 
encadernadas, mas ligadas pelas laterais, em formato de sanfona, podendo ser abertas numa grande linha do tempo da história tcheca ou mundial (frente e verso da linha do tempo).

No capítulo 12, Boži bojovníci [Guerreiros de Deus], as Guerras Hussitas e os fatos correlatos estão retratados. Como não é um texto corrido apresentado sequencialmente, não há nada melhor que ver a ilustração completa, que aqui apresentamos como figura 33.

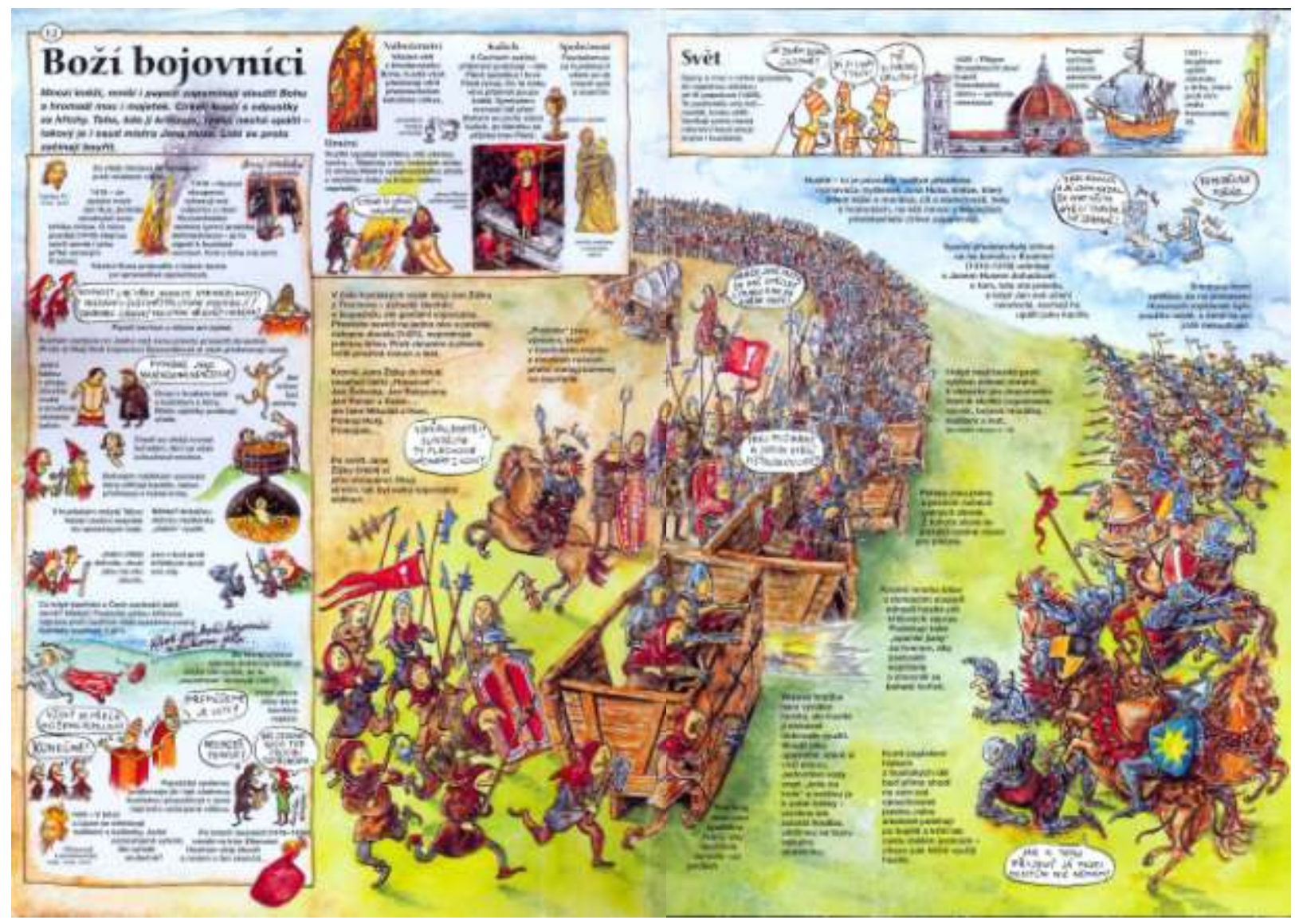

Figura 33. "Guerreiros de Deus", no livro História do bravo povo tcheco (Fonte: SEIFERTOVÁ, Dějiny...)

A imagem apresenta os Hussitas (no centro da ilustração), liderados por Jan Žižka (ao centro, num cavalo), lutando contra o exército cruzado (à direita da ilustração). Nas caixas (topo e esquerda), pequenos textos dão informações sobre o contexto. O primeiro texto escrito, logo abaixo do título, apresenta o contexto daquele período:

Multiplicam clérigos, monges e papas que se esquecem de servir a Deus e acumulam muitas propriedades. A igreja negocia indulgências com os 
pecadores. Quem critica isto prefere se deixar queimar - tal é o destino do mestre Jan Hus. As pessoas, por isso, começaram a se rebelar. ${ }^{498}$

Logo abaixo, aparece o ano de 1415 seguido do texto: "É queimado o mestre Jan Hus, porque não revogaram sua crítica à Igreja. Logo mais tarde (1416) morre do mesmo jeito seu amigo Jerônimo de Praga." Ao lado deste texto, está o desenho de Hus na fogueira, que podemos ver mais atentamente na figura 34 (que apresenta alguns detalhes da imagem).

Na caixa superior direita, de título Svět [Mundo], temos uma ilustração com os três papas brigando pela igreja. O primeiro diz "Eu conheço Deus pessoalmente!", o segundo "Eu o trato por "você'!” e o terceiro “A mim, ele preferiu (se apegou) mais!". Esse diálogo também está destacado na figura 34. Mas o detalhe que mais chama a nossa atenção está no céu, à direita. Lá encontramos Jan Hus e Jesus Cristo conversando a respeito da guerra. Hus diz "Outra batalha (guerra). E eu que preguei que acima de tudo a verdade vence, sem armas!" e Jesus completa "Foi o que eu sempre disse...".

Eis Jan Hus, no céu, conversando com Jesus Cristo, descontente com as guerras Hussitas, defendendo a verdade acima de tudo dentro de um mundo confuso e perdido. É o mesmo legado aqui repetido, da boca de alguém que está em lugar de destaque. Mais do que isso, Hus foi santificado e seu sofrimento foi deslocado de sua individualidade para o coletivo. Foi o povo que sofreu pelos problemas da Igreja com seus três papas e o clérigo da Boêmia foi o mártir, tal qual o Cristo, que morreu no lugar do povo.

\footnotetext{
${ }^{498}$ SEIFERTOVÁ, Lucie. Dějiny udatného českého národa a pár bezvýzamných světových událostí. República Tcheca: Petr Prchal; Euromedia Group k. s.; Knizni klub, 2003, p. 12. A referência é a mesma para todas as citações seguintes deste livro.
} 
Mnozí kněží, mniši i papeži zapomínají sloužit Bohu a hromadí moc i majetek. Církev kupčí s odpustky za hříchy. Toho, kdo ji kritizuje, raději nechá upálit takový je i osud mistra Jana Husa. Lidé se proto začínají bouritit.

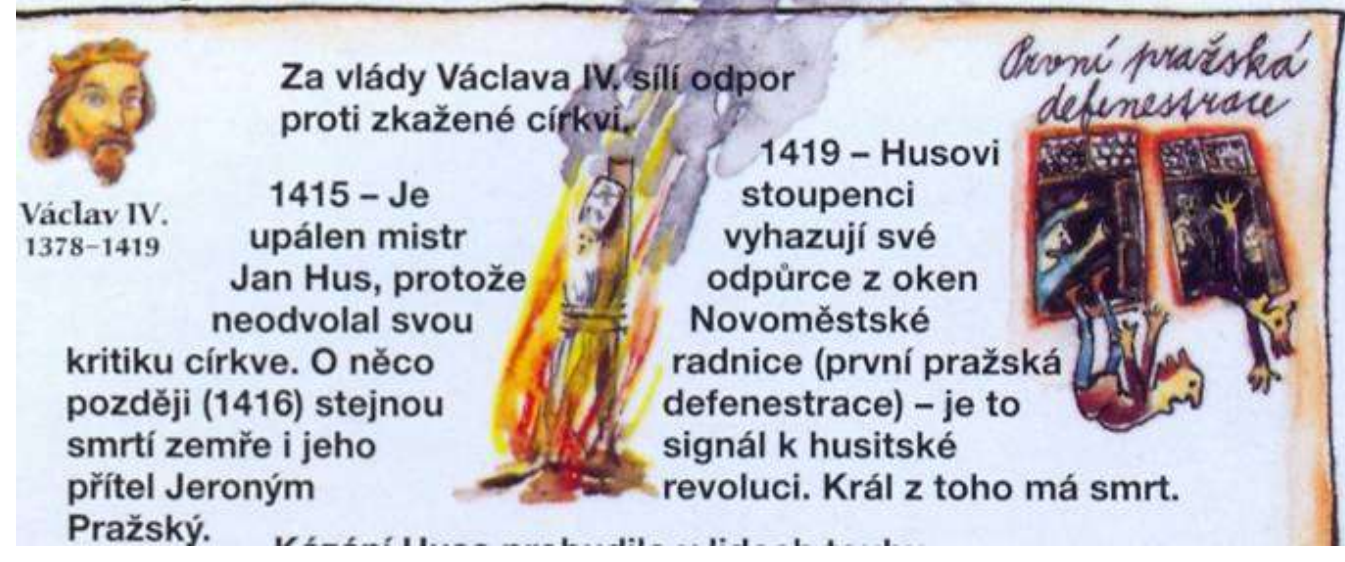
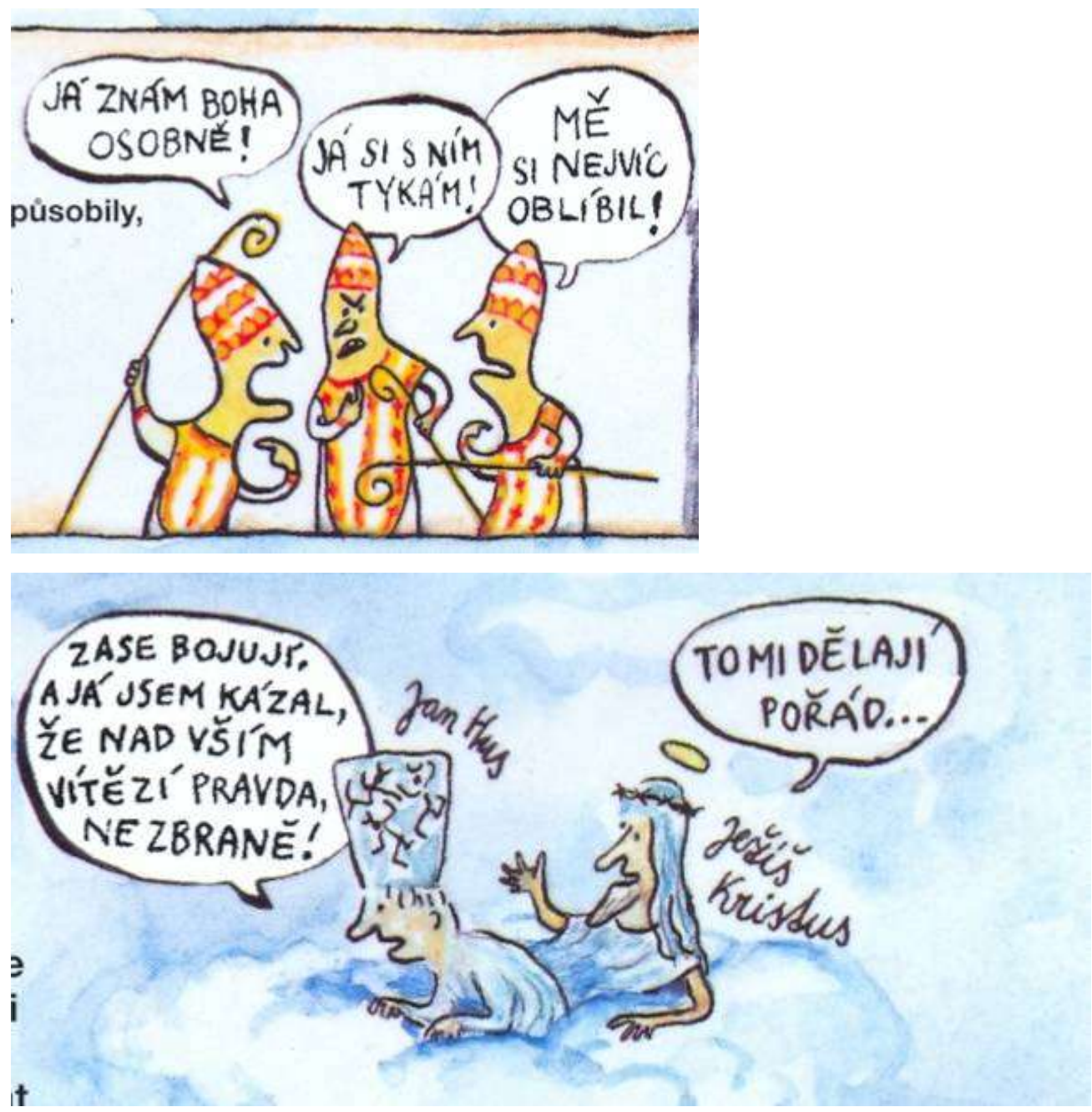

Figura 34. Detalhes da imagem anterior

(Fonte: SEIFERTOVÁ, Dějiny...) 
Estes são apenas dois exemplos que chegaram até nossas mãos de como Jan Hus aparece em livros atuais de história tcheca para crianças. Eles não são suficientes para determinar o padrão desse tipo de livro, mas estão em conformidade com o legado hussita que observamos ser reiterado pelos historiadores tchecos dos séculos anteriores. Eles indicam que há muito desse legado presente por lá nos dias de hoje.

Há um aspecto que pode agregar os dois livros tchecos para crianças e a coleção brasileira de grandes personagens da história: os três são materiais que as editoras e as escolas denominam "paradidáticos". Há uma intenção educativa da parte de quem edita esses materiais e de quem porventura os recomende ou compre. As informações históricas neles presentes são formativas, tanto na forma genérica de "aprender com a nossa história" quanto, no caso de Hus, na apreensão de sua imagem. Ele é o líder religioso, o precursor da Reforma, o herói nacional e, até mesmo, o mártir santificado. Mais do que isso, porém, na História do bravo povo tcheco, ele é o mestre defensor da verdade em meio a um tumultuoso contexto histórico. Nesse sentido, seu legado é educativo.

\subsubsection{Uma canção}

Se o legado de Hus faz parte do imaginário tcheco, é possível encontrá-lo no campo da cultura midiática, como filmes e música. Lembremos do concurso realizado pela Česká Televize para eleger o melhor tcheco de todos os tempos. Nesse concurso, um ator apresentou durante spots de um minuto o clérigo queimado na fogueira de Constança. E não foi este seu único aparecimento na TV. Documentários históricos e filmes, produzidos ou não na época comunista, retrataram e divulgaram sua imagem. No campo da música, encontramos desde a regravação de hinos Hussitas por um cantor de rock, como no caso da canção Kdož jste boží bojovníci [Vós que sois os guerreiros de Deus] ${ }^{499}$, quanto menções a Hus ou aos Hussitas em canções populares. Selecionamos um exemplo de uma destas canções. De nome sugestivo, Husita, a música do cantor tcheco Jaromir Nohavica, foi gravada em seu primeiro álbum Darmoděj, de $1988 .^{500}$

Nohavica é um cantor bastante conhecido na República Tcheca que apresenta músicas que misturam folclore, cultura pop e crítica política. A música Husita foi composta às

\footnotetext{
${ }^{499}$ LANDA, Daniel. Kdož jste boží bojovníci. In: LANDA, Daniel. Best of Daniel Landa 2. EMI, 2004. CD Faixa 10.

${ }^{500}$ NOHAVICA, Jaromir. Husita. In: NOHAVICA, Jaromir. Darmoděj. Praga: Panton, 1988. LP Faixa 7. Texto da música disponível em <http://www.nohavica.cz/cz/tvorba/texty/husita.htm>. Acesso em 23 jan. 2010.

Tradução para o inglês e trecho do áudio disponíveis na página.
} 
vésperas da Revolução de Veludo, possivelmente representando o espírito de uma época de transição entre o comunismo e a democracia. A letra descreve o sentimento e o pensamento de um guerreiro Hussita diante de uma cruzada, provavelmente personificando os jovens revolucionários do presente. Ele era um camponês e agora não é mais. É um menino Hussita. Ele vê os cruzados se aproximando e olha para as garotas que ficam e acenam, enquanto o capitão grita "às armas". Aproxima-se de uma delas, Maria. Chegando ao final da música, ele vê o exército cruzado se aproximando e olha para a grama na qual ele e Maria estarão no dia seguinte, dando a entender que mortos. E termina com uma saudação à história "Viva a história".

No site do músico, há uma tradução para o inglês da letra desta canção. Essa tradução, no entanto, apresenta, em nosso entendimento, palavras diferentes das que utilizaríamos numa tradução "literal" do texto da música tcheco para o inglês. Parece-nos uma adaptação do sentido para manter a sonoridade na língua traduzida. Nessa tradução, o último verso guarda o sentido de toda a música: "Let history judge all we've done" [Que a história julgue tudo o que fizemos]. Este é o recado que Nohavica deixa por sua música: "Valeu a pena? Que a história julgue".

Utilizando o recurso de relembrar uma parte da história tcheca, o compositor talvez tenha questionado a perpetuação desse símbolo da tchequidade ou, mais ainda, o momento político no qual vivia, próximo ao fim do comunismo na Tchecoslováquia. A força que Hus e os Hussitas possuem como símbolo de um momento importante na história do povo é retomada como instrumento de crítica social e afirmação da juventude revolucionária contemporânea.

O que esta música, os livros de história tcheca para crianças, a coleção brasileira de história mundial, o discurso do papa num simpósio sobre Hus e a tese de Renato Oberg possuem em comum? Todos relembram o legado hussita que foi construído ao longo dos séculos pelo esforço de personagens como Petr de Mladoňovice e Martinho Lutero e de historiadores como František Palacký, que viam em Hus um sujeito suficientemente importante para ser rememorado. O clérigo da Boêmia chega até os dias de hoje, no Brasil, como alguém que propôs uma reforma na Igreja antes de Lutero e, na República Tcheca, como um herói nacional, símbolo que contém os valores que merecem o destaque de aparecerem na bandeira do presidente. Suas representações figurativas reforçam o caráter de mártir e, às vezes, até de santo atribuído a ele. Ainda que não se destaque o caráter de mestre, essas representações fazem parte de um legado que é educativo na medida em que não apenas serve para relembrar como foi a vida de Hus, mas, principalmente, para, por meio dessa 
lembrança, propor a defesa da verdade. Nicolau Sevcenko, em seu prefácio às cartas de Václav Havel, lembra-se de Hus:

Praga: esse nome por si só é um emblema do inconformismo, da revolta e da autonomia. Uma das primeiras e das mais possantes vozes heterodoxas, dentre as fundadoras da modernidade, era de lá. Jan Hus, reitor da Universidade de Praga, educador e teólogo reformista, proclamou já no início do século $\mathrm{XV}$, a emancipação política em relação ao Império e a emancipação espiritual em relação à Igreja de Roma. Com mais de um século de antecedência a Lutero e a Calvino, que sempre se declararam inspirados por ele, Hus, através de seus célebres sermões em língua tcheca, constituiria o primeiro movimento de renovação e resistência cultural, no coração da Europa ainda presa aos rigores da aristocracia feudal. Levado preso diante do Concílio de Constança, transformado em Tribunal Imperial, ele foi condenado, constrangido e torturado para que abjurasse suas convicções. Sem que jamais renegasse suas ideias e crenças, no entanto, Jan Hus foi queimado vivo em praça pública em 1415.

E, logo em seguida, dá o tom do impacto do legado hussita: "Sua morte desencadeou uma reação autonomista que nunca mais refluiu." ${ }^{, 501}$ No entanto, mais do que relembrar seu legado, aqueles que desenharam, falaram, escreveram ou cantaram sobre Hus levaram adiante a proposta educativa do clérigo da Boêmia, recriando dentro de seus espaços-tempos novas formas de se utilizar da figura de Hus para educar.

${ }^{501}$ HAVEL, Cartas a Olga, p. 9. Grifos nossos. 


\section{Conclusão: o educador pela História da Educação}

Nesta tese, partimos da percepção que o historiador da educação designa quem é e quem não é educador na história e questionamos a possibilidade de repensar o lugar que Jan Hus nela ocupa. Inspirados metodologicamente pela questão da distância do historiador de suas fontes, com base nas ideias de Ginzburg, olhamos para uma documentação inédita para a História da Educação que permitiria um encontro com essa figura do passado: as cartas de Hus. Encontramos diversas publicações dessas cartas e enfrentamos o desafio de comparar essas edições e construir uma versão em português para os textos hussitas.

Descobrimos que essas cartas estão impregnadas de uma padrão retórico típico do período e exercem uma função de acordo com a expectativa, da parte dele, remetente, de receber ou não uma resposta de seu destinatário. Igualmente, observamos que Hus correspondeu-se com uma ampla base sócio-cultural que favoreceu a defesa de seus pensamentos por meio da aceitação e propagação das ideias hussitas. O clérigo da Boêmia teve a intenção de influenciar essas pessoas por meio da escrita de cartas, o que esteve claro pelo rol de motivações que identificamos nesses escritos: trabalho intelectual, aconselhamento, refutação às acusações, defesa da verdade e continuidade da tarefa pastoral. Percebemos, então, que as cartas preservavam uma intenção educativa.

Jan Hus, diante de seu exílio, enfrentou a necessidade de continuar sua tarefa pastoral, compensando a distância que o separava da Capela de Belém. Sua intenção educativa encontrou nessa prática de escrever cartas pastorais um meio de manter sua ação educativa. Construiu um padrão de escrita que passou a impregnar suas cartas pastorais e seguiu esse padrão, com algumas variações, até as vésperas de sua morte. Diante desta, então iminente, tentou preservar sua memória, visto que preservar sua vida já não era mais possível.

Sua ação educativa não ocorreu, porém, apenas por meio das cartas pastorais. Ela também esteve presente na relação mestre-discípulo, o que constatamos a partir da existência e do conteúdo das cartas para Martin de Volyně. Uma característica que destacamos nestas cartas é a transmissão que Hus quis fazer de seu legado.

O legado hussita foi recebido, relembrado e recriado por seus seguidores. O primeiro indício desse processo encontramos na reedição das cartas de Hus em diferentes espaçostempos. A construção desse legado iniciou-se com o pedido do clérigo da Boêmia, explícito em sua correspondência, para que preservasse sua memória e com a aceitação desse pedido da parte de Petr de Mladoňovice, secretário do nobre Jan de Chlum, amigo de Hus. Petr, em seus 
registros, especialmente em sua narrativa da condenação e morte de Hus, ajudou a formar a imagem do clérigo como mártir e mestre defensor da verdade. Martinho Lutero apoiou essa imagem e divulgou os escritos e as cartas hussitas, consolidando a figura de Hus como de um educador por seu exemplo de vida e de morte.

Como rememorar é acrescentar, cada novo editor dos escritos de Hus, especialmente de suas cartas, ajudou na manutenção dessa imagem de mestre e mártir, embora a adequando a seu contexto. Émile de Bonnechose considerou Hus o defensor da liberdade de consciência. Workman e Pope ressaltaram o aspecto de precursor da Reforma Protestante. Matthew Spinka colocou Hus no lugar de ligação entre o pensamento medieval e a Reforma. Da mesma forma, historiadores e políticos tchecos, ao relembrarem Hus, ajudaram a construir a imagem de herói nacional, símbolo do ser tcheco. Percebemos, ao observarmos a rememoração que todos esses sujeitos fizeram de Hus, que relembrar esse clérigo do século XV teve um fim educativo.

Nesse sentido, a morte de seu corpo não impediu a divulgação de suas ideias, como esperavam os membros do Concílio de Constança que o condenaram como heresiarca. Pelo contrário, desencadeou a construção e transmissão de um legado imortal, visto que perenizado nas representações iconográficas de Hus ao longo dos séculos e ainda presente nos debates acadêmicos e religiosos e nas produções artísticas e culturais da atualidade.

Um historiador da educação que trabalhasse com as fontes com as quais trabalhamos e observasse as práticas de escrita e transmissões de um legado que aqui vislumbramos poderia não encontrar em Hus o educador? Pode uma figura como esta estar ausente na História da Educação? A julgar pela historiografia acessível em língua portuguesa, a resposta é pouco favorável e o legado hussita parece desaparecido. Vejamos alguns exemplos de como Hus é retratado na área, a partir de alguns dos manuais que circulam com certa frequência pela Faculdade de Educação da Universidade de São Paulo, instituição para a qual apresentamos este trabalho.

Mario Alighiero Manacorda é um pedagogo italiano do século XX, professor de história da pedagogia em diversas universidades italianas. Seu livro "História da Educação: da Antiguidade aos nossos dias" consiste numa proposta de um "rápido passeio histórico pela educação 'através dos textos"”. ${ }^{502}$ No capítulo VII, referente à educação nos séculos XVI e XVII, propõe ver nos movimentos de reforma da Igreja "a iniciativa mais avançada de novos

${ }^{502}$ MANACORDA, op. cit., p. 5. 
modelos de instrução popular e moderna". É nesse sentido que ele apresenta Wyclif e Hus, inserindo-os na base desses movimentos:

Tradicionalmente os movimentos heréticos promoveram a difusão da instrução a fim de que cada um pudesse ler e interpretar pessoalmente a Bíblia, sem a mediação do clero. Na Inglaterra, John Wycliffe (1320-1384) auspiciara que cada um se tornasse um teólogo e na Boêmia, Jan Hus (13741415) dera uma contribuição concreta à instrução, codificando a ortografia tcheca e redigindo um silabário, em que as frases de conteúdo religioso eram apresentadas em ordem alfabética (ABC de Hus). ${ }^{503}$

Hus e Wyclif são apresentados como exemplos de movimentos heréticos que abrem espaço para o crescimento das escolas comunais, opondo-se às instituições eclesiásticas e suas hierarquias. Manacorda cita, logo em seguida, uma frase de Enea Silvio Piccolomini, em visita à Boêmia, referindo-se aos hussitas: "aquela infiel progênie humana pelo menos tem uma boa qualidade: ama a instrução”. Esta mesma frase é citada por Howard Kaminsky em seu artigo sobre a visita de Enea Piccolomini aos Taboritas. ${ }^{504}$ Enea Piccolomini aponta que, nesta visita, observou a grande quantidade de estudantes e cidadãos que acompanhavam sua discussão com um sacerdote taborita e que conheciam o latim. Isso confirma a importância dada à instrução na região da Boêmia oriunda do movimento reformador do qual Hus foi um dos principais representantes. Embora não tenhamos informações do uso da cartilha de Hus, essa relação entre a proposta de sua elaboração e o reconhecimento do futuro papa Pio II de que a Boêmia "amava a instrução" feita por Manacorda é um forte indício do impacto da figura de Hus na educação.

Paul Monroe foi um pesquisador em história da educação norte-americano, que se destacou no primeiro quartel do século XX por sua produção escrita a partir do Teachers College da Universidade de Columbia. A obra traduzida no Brasil com o título "História da Educação" é um manual voltado para a Escola Normal, resumido a partir de uma obra mais ampla intitulada "A text-book in the history of education", publicada em 1905. Um dos objetivos de sua obra é "preocupar-se mais com tendências educacionais do que com homens" 505. É dentro desta perspectiva que aparecerá o nome de Hus.

\footnotetext{
503 ibidem, p. 194.

${ }^{504}$ KAMINSKY, Howard. Pius Aeneas among the Taborites. Church History. set. 1959, vol. 28, n. 3, pp. 281 309, p. 290.

${ }^{505}$ MONROE, Paul. História da educação. Sétima Edição. São Paulo: Companhia Editoria Nacional, 1968, p. xxi.
} 
No capítulo dedicado à Idade Média, quando discute a Universidade Medieval, Monroe destaca a influência política das primeiras universidades. Em sua posição, elas "forneceram o primeiro exemplo de organização puramente democrática", visto que lá era possível o livre exame de assuntos políticos, eclesiásticos e teológicos. E, embora houvesse inclinação das simpatias universitárias para as classes privilegiadas, "frequentemente ela se fez intérprete do povo humilde na oposição ao rei ou ao sacerdócio."

Igualmente, elas tiveram papel social de destaque, tornando-se um grande "Estado", destacando o papel da Universidade de Paris na resolução do Cisma Papal e do Cativeiro Babilônio (período no qual o papado estava em Avignon). No entanto, mais do que uma instituição de influência política e uma nova estrutura de poder social, além do Estado, da Igreja e da nobreza, a Universidade influenciou a vida intelectual, oferecendo um espaço privilegiado para essa atividade e fomentando o nascimento de um novo espírito intelectual:

... foi em relação à vida intelectual, restrita, formal e pobre como era, que se exerceu a maior influência da universidade. Os interesses intelectuais se viam cristalizados agora numa grande instituição, reconhecida como de categoria quase igual à da Igreja, à do Estado e à da nobreza. Estes interesses e esta organização institucional estavam tão reduzidos no século XV que possuíam pouco mais do que uma vida formal. Ainda assim a universidade, mesmo nessa época, foi um retiro para os raros gênios que mantiveram acesa a chama da verdadeira vida intelectual, guardando o lar para o novo espírito intelectual que estava por vir. Por mais hostil que tivesse sido, durante estes séculos, à inovação, ao radicalismo e ao racionalismo, a universidade manteve vivo o espírito de inquérito conservando o espírito de especulação; dela é que vieram Rogério Bacon, Dante, Petrarca, Wycliffe, Huss, Copérnico, - os homens que introduziram o espírito moderno. ${ }^{507}$

Este é o único trecho em sua obra, além do quadro síntese do período ${ }^{508}$, no qual lemos o nome de Hus. O clérigo da Boêmia é citado como um dos homens que introduziram o espírito moderno, ao lado de figuras como Roger Bacon, Dante, Petrarca e Copérnico.

O historiador espanhol Lorenzo Luzuriaga, escreveu um livro sobre a "História da Educação e da Pedagogia" e destaca, na introdução que sua obra não é um "trabalho erudito ou de investigação" mas uma "obra essencialmente didática". ${ }^{509}$ No capítulo sobre educação religiosa reformada protestante, logo no primeiro parágrafo, ele cita Hus:

\footnotetext{
506 ibidem, p. 133.

507 ibidem, p. 134.

508 ibidem, p. 382-383. Quadro do Desenvolvimento da Educação nos séculos XIV a XVI.

${ }^{509}$ LUZURIAGA, Lorenzo. Historia da educação e da pedagogia. Nona edição. São Paulo: Companhia Editora Nacional, 1977, p. Xv.
} 
A reforma religiosa começa, como se sabe, na Alemanha, no século XVI. Já antes haviam surgido movimentos reformistas ou de protesto contra a Igreja, por cuidar-se que ela se havia desviado das primitivas crenças. Assim aconteceu com os movimentos de alguns humanistas, como Erasmo e Thomas Morus e antes com o de Wycliffe na Inglaterra e o de Huss na Boêmia. Mas esses movimentos ficaram localizados e foram extintos. Em compensação, o de Lutero e seus partidários pronto se estendeu não apenas pela Alemanha, mas pela maior parte do centro e norte da Europa.

Hus é apresentado como representante de um movimento religioso de reforma ou protesto contra a Igreja. Não há qualquer menção à sua contribuição seja para a educação, seja para a Reforma. Ele parece isolado até mesmo de Lutero.

Frederick Eby, professor de história e filosofia da educação na Universidade do Texas, em seu livro sobre a "História da Educação Moderna"510, por sua especialização temática, apresenta em seu início uma síntese dos antecedentes da Reforma. Nela, cita Hus duas vezes, uma em relação à Reforma e outra como base do movimento da União dos Irmãos, que ele, ou as tradutoras para o português, denomina Irmãos Boêmios. Mesmo tendo associado à Hus o verbo ensinar, o clérigo é apresentado por Eby como formador de um movimento religioso e esta é sua contribuição para a área:

Um alto grau de cultura existia na Boêmia, muito antes do despertar ter ocorrido na Alemanha, e a primeira universidade naquela parte da Europa foi fundada em Praga, já em 1348. Aí João Huss estudou, ensinou e disseminou as doutrinas radicais que conduziram ao seu martírio, mas não obstante estabeleceu o grupo protestante. ${ }^{511}$

Outros livros fazem referências semelhantes às de Eby e Luzuriaga ou não fazem qualquer menção a Hus, como é o caso da obra de $\mathrm{Cambi}^{512}$. A única exceção é o trabalho dos historiadores franceses Mialaret e $\mathrm{Vial}^{513}$, que organizaram textos de diferentes historiadores especializados em regiões e períodos específicos, numa obra que se propõe a traçar uma "História Mundial da Educação". Desta maneira, eles tentam atingir espaços-tempos da História da Educação que não estariam presentes numa obra de concepção mais abrangente. É de se esperar, portanto, que Hus esteja presente, por haver um capítulo dedicado

\footnotetext{
${ }^{510}$ EBY, Frederick. História da educação moderna: teoria, organização e práticas educacionais. 2a. edição. Porto Alegre: Editora Globo, 1976.

${ }^{511}$ ibidem, p. 84.

${ }^{512}$ CAMBI, op. cit..

${ }^{513}$ MIALARET; VIAL, op. cit.
} 
especificamente ao mundo eslavo no período medieval ${ }^{514}$. E, de fato, neste há um item com pouco mais de uma página para descrever o "hussitismo". A autora relaciona Hus a Wyclif:

No momento em que o Estado checo atinge o apogeu do seu desenvolvimento, a Universidade de Praga, à imagem da Sorbonne que a havia inspirado na sua estrutura e no ensino, transforma-se num centro revolucionário. $\mathrm{O}$ clero oferece aos professores a oportunidade de manifestarem do cimo da sua cátedra o seu descontentamento para com a cúria romana e de criticarem severamente, quer a vida eclesiástica em geral, quer muitas instituições dependentes da Igreja em particular. Já no tempo de Venceslau o elemento nacional checo havia adquirido grande importância na Universidade de Praga. Mestres e estudantes, na sua maior parte, haviam-se declarado partidários da filosofia de vanguarda de Wyclif, em oposição aos docentes alemães que combatiam por princípio e se mantinham apegados ao ponto de vista tradicional e conservador. A partir de então, João Huss (13691415) transformou-se numa das grandes figuras nacionais checas ao defender a doutrina de Wyclif. ${ }^{515}$

A autora, então, afirma o papel central que o movimento que denominou de "hussitismo" teve no mundo eslavo e nas Universidades da Europa Central. Ela utiliza essa expressão para o desenvolvimento das ideias que partiram de Hus. Cita que o Concílio de Constança julgou e mandou para a fogueira Hus e que essa atitude não "pôs termo à 'heresia'", pois as ideias hussitas se espalharam por diversas regiões do entorno, chegando até a França. Em seguida, destaca a relação de Hus com a língua tcheca:

Instaurando a língua literária checa na base de um dialecto praguense, Huss fixou nele a ortografia mercê de regras que se mantiveram em vigor até aos nossos dias. Graças a João Huss, a literatura tcheca enriqueceu-se e adquiriu uma importância que ultrapassou amplamente a de Wyclif na literatura inglesa.

Essa relação de Hus com a língua tcheca inseria-se no contexto da época de valorização do vernáculo em relação ao latim, inclusive nos cultos religiosos. Denis relaciona o uso do vernáculo à difusão das ideias hussitas, afirmando que estas ganharam terreno por causa daquele. Mais à frente, em seu texto, destaca o papel das "correntes de pensamento, laico ou religioso, que compreenderam o facto e procederam para que, em matéria de educação, a língua materna fosse o fundamento de todo o conhecimento."

Esta menção à Hus era mais do que esperada num capítulo que tratasse especificamente do mundo eslavo no volume dedicado ao período "das origens a 1515". Não

\footnotetext{
${ }^{514}$ Escrito pela historiadora francesa Marcelle Denis.

${ }^{515}$ MIALARET.; VIAL, op. cit., p. 296 e pp. 297 e 298 para as citações seguintes.
} 
é possível, no entanto, encontrar nesta obra outro lugar para Jan Hus que não seja estar inserido no mundo eslavo. O fato de ele não aparecer em várias outras obras pode significar justamente isso: sua atuação restringe-se ao mundo eslavo e, mais especificamente, ao povo tcheco. Por outro lado, este capítulo pode justamente ter sido escrito por causa de Hus. Como o mundo eslavo está em destaque no primeiro volume, talvez seja este um indício de que a figura de Hus seja a principal contribuição da Boêmia para a história da educação medieval.

Denis relaciona Hus a Wyclif de foram direta, trazendo para ambos uma atuação na educação no que diz respeito à valorização do vernáculo. Ela lembra, inclusive, do trabalho de Hus de reforma da ortografia tcheca. Mostra, porém, que há uma expansão das ideias de Hus atingindo outras regiões da Europa, ao afirmar que "a progressão das ideias hussitas atingia não só a Morávia e a Eslováquia, mas também a Alemanha, a França e a região magiar.” Ela também afirma que a tradição de "nacionalização do culto divino", com o uso da língua local para a celebração, que possui uma de suas raízes em Hus, perpetua-se, sob a influência de Lutero, nos Irmãos Morávios do século XV.

O capítulo termina com uma ilustração de Hus. A ausência de assinatura e a forma como ela foi apresentada, em semelhança a outras ao longo do livro, leva-nos à conclusão que a figura é uma produção desta edição e exerce a função de vinheta. A escolha do editor e do ilustrador do modo como representar Hus é diferenciada das imagens que analisamos no capítulo três. Nesta, o educador está escrevendo (figura 35).

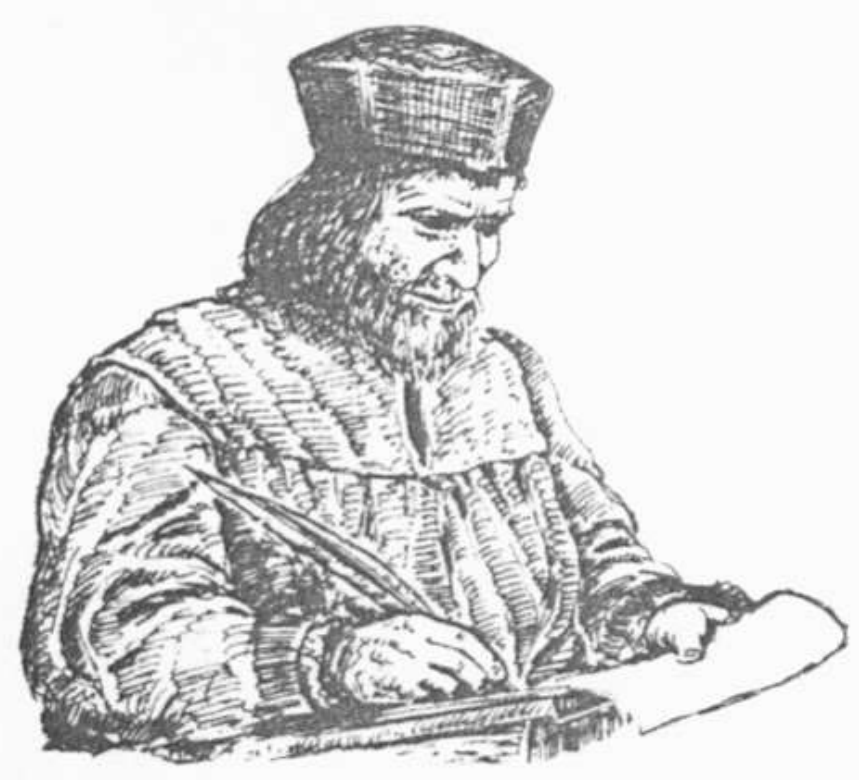

Figura 35. Jan Hus escrevendo

(Fonte: MIALARET; VIAL, História Mundial da Educação, vol. I, p. 298) 
Embora a vestimenta, o cabelo e a barba remetam a algumas das representações que encontramos nas imagens apresentadas anteriormente, há uma característica que a diferencia das outras: ela foi publicada num livro de História da Educação de produção contemporânea. É esta atualidade que dá força para o legado educativo do educador-pregador manifestando-se por meio da escrita. É um exemplo da força do legado hussita reconhecida por uma historiadora francesa de nossos dias dedicada ao estudo da educação no mundo eslavo.

Nossa pergunta formulada antes de observarmos estes exemplos está respondida: sim, um historiador da educação ao analisar as práticas do clérigo da Boêmia poderá encontrar o educador. Por que, então, no caso da historiografia da área, a presença de Jan Hus é mais uma exceção do que uma regra? Por que, nas obras de História da Educação que observamos, personagens como Lutero e Comenius recebem um destaque muito maior do que o educador tcheco do início do século XV? Teriam personagens como Hus sido silenciados na história? ${ }^{516}$

A relevância de cada personagem, dada pelo historiador, situa-o hierarquicamente na história. O historiador pode fazê-lo grande ou pequeno. É o que percebemos no caso de Hus, inspirados por uma proposta de Hilsdorf em uma disciplina do curso de Pedagogia da Faculdade de Educação da Universidade de São Paulo. Parte do currículo desse curso, a disciplina "História de Educação Moderna e Contemporânea: Os Pedagogos 'Menores"” é um exercício metodológico de apresentar e interpretar nomes de pedagogos importantes, mas feitos "menores" pela História da Educação. ${ }^{517}$

\footnotetext{
${ }^{516}$ FERRO, op. cit., p. 15, quando pensa na escrita da história, também se preocupa com esta questão: "Os mesmos personagens históricos mudam de sentido conforme a legitimidade muda de signo, de foco e conforme é definida sucessivamente na França, pelos juristas, pela Igreja, pela nação. Isso ocorre com Joana d'Arc através dos tempos. No século $\mathrm{XV}$, próximos dos juristas, os historiadores oficiais praticamente ignoram a Donzela e, na Annales de Gilles, nem mesmo se faz alusão a seu processo. Afinal, o triunfo do rei não poderia ser acompanhado da ajuda de uma santa ou de uma feiticeira; o serviço do rei exige a laicização da heroína e que seu papel seja, assim, diminuído - o rei 'permite' a Joana ajudá-lo em seu combate; os homens do rei souberam tramar, pois compreendiam como o rei poderia aproveitar a vinda de Joana, vinda que transformaram num milagre. A versão religiosa nasce mais tarde, quando a Igreja fortalece sua aliança com o Estado e quer encarnálo. A partir de então, o processo e o bispo Cauchon incomodam os católicos que, com frequência, reduzem o seu papel; esmagar os ingleses, torná-los responsáveis pela morte de Joana é uma versão mais popular. Com a Revolução Francesa e a visão laica da história, as 'vozes' que Joana ouve incomodam os narradores; suprime-se São Miguel e escreve-se que Joana achava que ouvia vozes. Há outra mudança após 1904: para fortalecer a Entente cordial com os ingleses, restitui-se o papel de vilão a Cauchon; para salvar a honra da Igreja, admite-se a possibilidade da intervenção de um monge que, no momento da morte de Joana, lhe estende a Cruz. Tais versões exprimem ao mesmo tempo a visão das diferentes instâncias e instituições que controlam o discurso sobre a história, as suas necessidades sucessivas - e as necessidades de um compromisso."
}

${ }^{517}$ HISTÓRIA DA EDUCAÇÃO MODERNA E CONTEMPORÂNEA: OS PEDAGOGOS "MENORES". Disponível em <http://sistemas2.usp.br/jupiterweb/obterDisciplina?sgldis=EDF0662\&verdis=2>. Acesso em 24 jan. 2010. Participei da turma de 2003 desta disciplina, ministrada pela professora Maria Lucia Spedo Hilsdorf. 
Esse exercício consiste numa exploração da bibliografia em busca de pedagogos que não foram consagrados pela história. ${ }^{518} \mathrm{Em}$ contraposição aos considerados "grandes pedagogos", eles foram chamados pela docente de pedagogos "menores". Essas expressões não significam um juízo de valor a respeito do trabalho que eles realizaram ou da qualidade de sua obra, mas sim do lugar que ocupam na produção historiográfica. Aqueles que são consagrados pela história entram num círculo vicioso: há mais conhecimento sobre eles porque há mais trabalhos a seu respeito e vice-versa. Em oposição a este círculo, estão aqueles personagens que por serem menos citados, possuem menos pesquisa a seu respeito e uma produção de conhecimento menor, que os mantêm nesse lugar.

Esses pedagogos "menores", em referência aos "grandes pedagogos", são aqueles que podem ser identificados como seus inspiradores, colaboradores, mestres, antecessores, companheiros, da mesma geração, da mesma filiação de ideias, contrapositores, executores ou desenvolvedores das propostas desses. No entanto, as informações a respeito de suas obras e biografias são menos acessíveis. Seria Jan Hus um desses pedagogos “menores”?

A disponibilidade de informações e a produção de conhecimento a respeito dos sujeitos são diretamente proporcionais ao seu "sucesso" historiográfico. Se este trabalho fosse sobre Lutero, nossas fontes seriam quantitativamente maiores que as que tivemos acesso numa pesquisa sobre Hus. Se nossa pesquisa fosse sobre Jerônimo de Praga, amigo de Hus também condenado pelo Concílio de Constança, essas fontes seriam ainda menores. Se quiséssemos, então, estudar a vida e a obra de Martin de Volyně, discípulo de Hus para quem escreveu duas cartas, talvez nem conseguíssemos.

Esta não é, contudo, apenas uma questão de disponibilidade de fontes, como também de acesso a elas. Afirmar que Jan Hus é um pedagogo "menor" não teria o mesmo caráter se esta tese fosse escrita na República Tcheca. Lá, é provável que os trabalhos na área de história da educação dediquem um espaço maior de texto a falar a respeito de Hus do que aqui. Talvez esse clérigo do século XV continue como um pedagogo “menor", porém com mais materiais disponíveis. Para termos outro exemplo do impacto do espaço-tempo de onde se escreve a história, basta imaginar como seria para um pesquisador tcheco estudar a figura de Tiradentes ou retratar o educador Anísio Teixeira. Este, um dos grandes nomes na História da Educação brasileira, talvez fosse um pedagogo "menor" se estudado fora do Brasil.

O uso dessa categoria serve como instrumento teórico-metodológico para pensarmos a respeito de nossa concepção de História da Educação, especialmente de uma história dos

\footnotetext{
${ }^{518}$ Uma referência para os nomes desses "grandes pedagogos" é CHATEAU, Jean. Grandes pedagogistas. São Paulo: Nacional, 1978.
} 
sujeitos educadores. À luz das leituras que fizemos de Ginzburg, propomos três aspectos a serem considerados. Em primeiro lugar, sempre há outros sujeitos, sem os quais o personagem histórico que estudamos simplesmente não existiria, seja porque eles dialogaram, porque um divulgou a ideia do outro, ou porque o apoiou perante opositores e assim ao infinito das possibilidades do convívio humano. Esta foi a proposta do curso, ao estudarmos Jácopo Sadoleto em referência a Erasmo no século XVI, Ratichius [Ratke] em referência a Comenius no século XVII ou Helvetius em referência a Rousseau no século XVIII. Quanto mais nos aproximamos da figura de Hus na historiografia, procurando por textos dedicados a estudar o clérigo da Boêmia, mais outros nomes aparecem, como Jerônimo de Praga, Mathias de Janow (antecessor, que propôs, entre outras coisas, a comunhão frequente dos leigos) ou Jakoubek de Stř́bro (companheiro, que introduziu a dupla comunhão e a levou adiante após a morte de Hus). A cada novo nome, a vida de Hus e seu contexto se ressignificam.

Em segundo lugar, o nosso olhar amplia o tamanho do que estamos observando. $O$ olhar histórico funciona como uma lente de aumento que permite visualizarmos mais detalhes do objeto do qual nos aproximamos. Tuchman, a respeito da diferença entre um fato noticiado e um fato não-noticiado, afirma:

Raramente o desastre é tão generalizado quanto parece no registro histórico. $\mathrm{O}$ fato de estar registrado dá-lhe a aparência de constância e onipresença, quando o mais provável é que tenha sido esporádico, tanto no tempo como no espaço. Além disso, a persistência da normalidade costuma ser maior do que o efeito da perturbação (...) Isso levou-me a formular a Lei de Tuchman: 'O fato de ser noticiado multiplica em cinco a dez vezes (ou qualquer outro número que o leitor prefira) a extensão aparente de qualquer fato deplorável. $^{519}$

O que a autora propõe com sua "Lei de Tuchman" é a existência de uma relação entre a construção de uma narrativa histórica e a leitura dos acontecimentos por parte do historiador. Tendemos a confundir história com realidade quando lemos uma narrativa histórica. Ginzburg, comentando a disponibilidade ou não de documentos inquisitoriais, salienta que

De um modo mais geral, a difusão de um fenômeno, quem sabe até documentado de maneira fragmentária, não pode ser assumida como um indício de sua importância histórica. Uma leitura aprofundada de um pequeno número de documentos, mesmo se ligados a um nível circunscrito

${ }^{519}$ TUCHMAN, op. cit., p. xvii. 
de crenças, pode ser muito mais esclarecedora do que uma enorme quantidade de documentos repetitivos. ${ }^{520}$

O historiador italiano fez este comentário mais geral como síntese das possibilidades de se apreender algo da cultura dos interrogados pela Inquisição a partir dos documentos produzidos pelos inquisidores, como fez no seu estudo sobre o moleiro Menocchio, no livro "O queijo e os vermes". Para ele, nós podemos recorrer a uma "comparação mais ampla do que estava à disposição dos inquisidores". É justamente essa possibilidade de fazermos novas leituras dos documentos que permite, ao mesmo tempo, construirmos nossa narrativa histórica a partir de uma documentação escassa. Este é o exercício que nos propomos nesta tese. No nosso caso, por olharmos detalhadamente para a correspondência de Hus, proporcionamos a emergência da figura de um educador do século XV. Isso não significa que seu impacto na história da educação tenha sido tão grande quanto o de Lutero e Comenius, por exemplo. O que nos leva ao terceiro aspecto dessa categoria.

Não estudamos um sujeito historiograficamente tratado como "menor" para que ele passe a ser "grande". Talvez uma descoberta mude nossa interpretação dos fatos, como, por exemplo, a confirmação da existência de uma carta escrita pela concubina que Santo Agostinho cita em suas "Confissões" mostraria o lado mais humano de um santo. ${ }^{521}$ Isso poderia mudar nossa visão desse grande Padre da Igreja. Mas, em geral, o que o estudo de um sujeito fornece é uma compreensão mais detalhada de um período, fato ou contexto histórico, das condições e consequências de determinada ideia ou até mesmo da vida e obra de outro sujeito. Quando Ginzburg estudou o moleiro Menocchio, não estava propondo atribuir-lhe um lugar na história. Queria "reconstruir um fragmento do que se costuma denominar 'cultura das classes subalternas' ou ainda 'cultura popular'" pelo estudo de um indivíduo que, mesmo sendo um caso-limite, pode ser representativo e "pesquisado como um microcosmo de um estrato social inteiro num determinado período histórico" ${ }^{522}$. O mesmo podemos afirmar a respeito da história família Platter, registrada por Le Roy Ladurrie. ${ }^{523}$

Em nosso caso, o estudo de uma figura como Jan Hus, suscitou para além da observação da emergência de um educador no século XV e o desenvolvimento de seu legado,

\footnotetext{
${ }^{520}$ GINZBURG, O fio e os rastros, p. 293.

${ }^{521}$ A inspiração para este exemplo veio da obra GAARDER, Jostein. Vita brevis: a carta de Floria Emilia para Aurelio Agostinho. Tradução de Pedro Maia Soares. São Paulo: Companhia das Letras, 1997.

${ }^{522}$ GINZBURG, Carlo. O queijo e os vermes. São Paulo: Companhia das Letras, 1987, p. 25.

${ }^{523}$ LE ROY LADURIE, Emmanuel. O mendigo e o professor: a saga da família Platter no século XVI. Tomo I. Rio de Janeiro: Rocco, 1999.
} 
uma questão a respeito de seu lugar como um educador "menor". Será que podemos reconhecer e propor para esse educador a consolidação de um lugar na historiografia da educação, a partir do modelo do clérigo que educa por meio de cartas, dentro de um movimento considerado herético e que contribui para a difusão de uma moral cristã e do uso da língua vernacular?

\section{O fim é o começo}

Eis o lugar de Hus na História da Educação que encontramos: um lugar à sombra dos grandes nomes e movimentos da educação. Ao elaborarmos este trabalho, iluminamos um pedaço dessa sombra para observarmos outros detalhes de modo a entendermos as questões que perpassam as discussões do início do século XV. E esse destaque coloca Hus em outro lugar. Só que não no lugar de um grande educador do período, de modo que os manuais didáticos mereçam ser reescritos. É a nossa leitura sobre como a história dos sujeitos educadores é construída que muda.

Ao percebermos que há personagens que recebem pouco espaço na área, entendemos que os grandes nomes não fizeram nada sozinhos e o trabalho com cartas ofereceu-nos uma leitura concreta e irrefutável da presença dos outros sujeitos. Se temos na história da leitura o reconhecimento da existência de leitores para os livros, no estudo da recepção destes, as cartas são documentos excelentes para observarmos como as ideias são elaboradas e as práticas justificadas no diálogo com outros sujeitos. A defesa da verdade, por exemplo, foi uma construção que apareceu na correspondência hussita. Partiu de uma presença mais esporádica, como na troca de correspondência com o lolardo Richard Wyche, ganhou mais força a partir do exílio, aparecendo nas cartas pastorais e se tornou mais intensa nas cartas do fim de sua vida. Mas ela só existiu porque havia sujeitos que concordavam com a posição que Hus assumiu, como Wyche, outros que discordavam dela, como o Pater que o aconselhou a se submeter ao Concílio e aqueles que a questionavam, como os membros do Concílio.

As cartas para Martin de Volyně mostram não apenas que houve uma relação muito próxima entre ele e Hus, como também outros sujeitos que foram fundamentais para a vida do clérigo da Boêmia. Do mesmo modo, a necessidade de escrever cartas para substituir a presença física na Capela de Belém e continuar educando surgiu porque havia um interlocutor coletivo: as pessoas que frequentavam a capela. Mas só houve essa interlocução por meio de cartas em tcheco (a maioria) porque um membro da nobreza financiou anos antes a construção daquela capela para a pregação em tcheco, porque o arcebispo que primeiro apoiava Hus, deixou de apoiá-lo e passou a persegui-lo. Igualmente, porque dois professores da 
Universidade de Praga (Štěpán Páleč e Stanislav de Znojmo), após terem permanecido presos, decidiram não mais apoiar as ideias reformistas e estiveram no concílio acusando Hus. Isso sem contar que Hus exilou-se a partir da sugestão do rei Venceslau IV, após a questão da venda de indulgências pelo papa João XXIII. A lista de eventos interrelacionados não tem fim e nosso trabalho, como historiador, é selecionar nesse meio aqueles que compõem o contexto de nossa narrativa.

As fontes para o estudo de Jan Hus só estão disponíveis porque Petr de Mladoňovice guardou as cartas e escreveu seu Relatio e, no século seguinte, Lutero leu e publicou os escritos de Hus. O que seria do trabalho dos historiadores sem a publicação do Documenta de Palacký? Ou então, do reforço da associação entre Hus e a tchequidade da nação por Masaryk? Será que hoje estaríamos fazendo um trabalho sobre este personagem sem a obra de Matthew Spinka? Cada sujeito que de alguma forma divulgou, discutiu ou combateu as ideias de Hus ajudou a construí-las historicamente. Num estudo sobre um pedagogo "menor" como Hus, novos sujeitos apareceram e podem fazer parte do trabalho de outros historiadores que os pesquisem à sombra do clérigo da Boêmia.

Além disso, a partir do momento em que fizemos este levantamento sobre o uso educativo das cartas por Hus e sobre a reiteração do legado educativo por discípulos, seguidores e historiadores (alguns dos quais também discípulos e seguidores), cada leitor deste trabalho saberá mais a respeito do próprio clérigo da Boêmia. Por consequência, poderá saber mais do período no qual viveu. Mas esse saber é apenas uma parte da história, a parte que selecionamos como historiadores.

O Concílio de Constança durou quatro anos e nós só comentamos o julgamento de Hus, a condenação de Jerônimo de Praga, a deposição de João XXIII e a eleição do novo papa, Martinho V. Quantas outras discussões ocorreram naquela reunião que não estavam relacionadas a estas questões? Uma grande reunião de esforços foi necessária para que esse concílio desse um fim no Cisma Papal, o que o Concílio de Pisa (1409) não conseguiu. As principais mudanças na Igreja, com relação ao poder papal, que ocorreram no Concílio Vaticano II poderiam já ter ocorrido no Concílio de Constança. ${ }^{524}$ No entanto, sem estas outras informações, parece que o principal trabalho dessa reunião foi a condenação dos hereges.

\footnotetext{
${ }^{524}$ V. SPINKA, John Hus at the Council of Constance. O autor mostra o quanto o movimento conciliarista propunha uma reforma da Igreja que questionava o poder supremo do papa e poderia levar a uma postura mais democrática dessa instituição.
} 
Martin de Volyně recebeu grande destaque neste trabalho por ser discípulo de Hus e este ter-lhe dirigido duas importantes cartas. Historicamente importantes. Mas não encontramos registros da participação posterior desse personagem no desenvolvimento das ideias hussitas. Tanto ele pode ter sido um importante "articulador dos bastidores" quanto ele pode ter feito pouco em relação ao que lhe pediu Hus. Igualmente, destaquemos que possuímos apenas duas cartas escritas para ele, enquanto há diversas para Jan de Chlum e Petr de Mladoňovice. Em Martin, nós destacamos a figura do discípulo pelo valor da carta escrita pelo mestre. No entanto, seu nome entra para a história como o de qualquer outro personagem anônimo que teve um contato de destaque com alguém famoso.

Se olharmos para a frase de Lutero "todos somos hussitas" e o destaque que os biógrafos de Hus dão a ela, parece-nos que o contato com os escritos do clérigo da Boêmia e a divulgação destes pelo reformador alemão são eventos importantes e fundamentais na vida deste. No entanto, "um homem com o temperamento de Lutero, se abre um livro, nele apenas lê um pensamento, o seu. Não apreende nada que não traga em si próprio"525 e "durante trinta anos" Lutero fez uma “incrível produção de livros, panfletos, sermões e cartas; calcula-se que publicava à média de uma obra por quinzena" ${ }^{, 526}$. Não é possível, portanto, afirmarmos que Hus tenha sido tão central e importante na vida de Lutero. O fato de ele ter demonstrado empolgação com os escritos do reformador tcheco a ponto de publicar suas cartas para dar um aviso salutar ao concílio vindouro não significa muito dentro dessa profusão de publicações.

Igualmente, este trabalho diferencia-se por apresentar o estudo sobre um personagem inserido na região da Boêmia, local pouco explorado pela historiografia europeia. Passamos, por meio dele, a conhecer mais sobre essa região, sua história, língua e cultura. Isso não significa que ela teve um tamanho impacto sobre a Europa que mereça a revisão dessa historiografia. Renato Oberg, no primeiro capítulo de sua tese, faz uma revisão da história da Europa nos final da Idade Média. Ele escreveu, basicamente, sobre França e Inglaterra. Se os Hussitas não tivessem sido derrotados na Guerra dos Trinta Anos, em $1620^{527}$ e a coroa da Boêmia não tivesse se tornado hereditária dos Habsburgos, talvez a história fosse diferente e hoje conheceríamos mais sobre a região. Mas hipóteses sobre o que poderia acontecer na história beiram o infinito e quando olhamos para um detalhe, ele parece maior do que

\footnotetext{
${ }^{525}$ Lucien Febvre apud BARBOSA, Luciane Muniz Ribeiro. Igreja, estado e educação em Martinho Lutero: uma análise das origens do direito à educação. 2007. 239p. + anexos. Dissertação (Mestrado em Educação). Faculdade de Educação da Universidade de São Paulo, 2007, p. 54.

${ }^{526}$ Geoffrey Elton apud ibidem, p. 57.

${ }^{527}$ Ver, por exemplo, SCHAFF, John Huss, p. 333-334.
} 
realmente é. Isso, porém, não o invalida, porque ele pode trazer à luz novas interpretações históricas.

A afirmação de Manacorda "os movimentos heréticos promoveram a difusão e a instrução a fim de que cada um pudesse ler e interpretar pessoalmente a Bíblia, sem a mediação do clero"528 ganha novos contornos quando, estudando Hus, entendemos que ser considerado herege não significa necessariamente estar contrário ao pensamento da época. $\mathrm{Ou}$ que, além da Universidade, ele se relacionou com o pensionato da Capela de Belém, que viria a se tornar o colégio secundário dos tempos modernos, segundo Hilsdorf ${ }^{529}$. Além disso, como interpretar a afirmação de Manacorda que a finalidade dos movimentos heréticos era que cada um pudesse ler a Bíblia "sem a mediação do clero" perante as cartas pastorais de Hus? Com certeza, essas cartas serviam de mediação entre o povo e a Bíblia. Assim, um estudo das cartas hussitas faz com que leiamos com mais cuidado a generalização de Manacorda, entendendo que isso não significava a ausência do clero, mas uma aproximação maior do povo das ideias contidas nas escrituras.

No que diz respeito à escrita da história, entendemos, a partir da realização deste trabalho, que há espaço para uma História da Educação que não tenha a instituição escolar como elemento central na investigação. Para além de uma pesquisa sobre a história do pensamento educativo, este estudo apresentou duas interfaces: as práticas educativas nãoescolares (como pelo meio de cartas escritas no século XV) e as relações entre educação e religião.

Com relação à primeira interface, pudemos observar que um sujeito, partindo de uma necessidade de distanciamento de seus educandos, utilizou cartas para educar. Isso abre um precedente para que os estudos de cartas na história da educação não sejam apenas vistas como uma prática cultural que permitam compreender melhor os sujeitos estudados ou as relações destes com seus interlocutores. Ou então, como uma fonte para compreender as ideias de um sujeito. Mas também como um instrumento de educação: escrever para educar.

Com isso não estamos invalidando esses outros estudos, nem afirmando que o estudo sobre as cartas de Hus resumiu-se apenas a vê-las como instrumento. Nós observamos também as cartas hussitas como prática cultural do século XV, na medida em que elas serviram de meio de comunicação à distância, debate intelectual e defesa pública de ideias. Também entendemos melhor a figura de Hus por suas cartas, bem como conhecemos mais a

\footnotetext{
${ }^{528}$ MANACORDA, op. cit., p. 194.

${ }^{529}$ HILSDORF, $O$ aparecimento da escola moderna
} 
respeito de seus interlocutores. Igualmente, compreendemos um pouco da visão de mundo hussita e o debate desta com a cultura dos intelectuais de sua época. No entanto, o principal aspecto que procuramos desenvolver foi o uso da correspondência como um instrumento educativo utilizado pelo educador Jan Hus para dar continuidade à ação que iniciara na Capela de Belém.

Ainda na primeira interface, temos a proposta de utilizarmos as edições das cartas como um meio de observarmos o reconhecimento de um legado educativo e, por esse reconhecimento, um meio de o educando assumir o lugar do educador. As edições e traduções das cartas, acompanhadas dos movimentos políticos e culturais de resgate da figura de Hus, foram meios de reconhecimento de sua herança educativa, baseada principalmente na defesa da verdade. Mas, na medida em que os epistolários e os discursos utilizaram dessa herança, os sujeitos responsáveis por eles colocaram-se no lugar de novos defensores da verdade. Só que, ao invés de o fazerem com a morte na fogueira, fizeram-no com o uso da palavra (e da imagem visual, se incluirmos as representações figurativas de Hus).

No que diz respeito à segunda interface deste estudo, as relações entre educação e religião, ela foi o mote transversal a toda discussão. Para um sujeito como Hus, sacerdote católico, chefe de uma capela, formado em teologia e professor de uma universidade medieval, todos os aspectos de sua vida eram religiosos. É impossível separar o religioso do educador. Afirmar que determinada prática desse clérigo é religiosa é abrir o precedente para a possibilidade de uma prática que não seja religiosa. Para um sujeito que morreu defendendo sua visão de mundo, utilizou a Bíblia como autoridade para julgar suas ações, afirmou ter certeza da ação do Anticristo nos eventos ao seu redor, isso não existe. Foi nesse sentido que, ao vermos em Hus uma intenção de promover em seus interlocutores uma transformação para melhor, apontamos para sua intenção educativa e não para uma intenção religiosa.

Por fim, vislumbramos que o estudo de pedagogos "menores" permite ampliarmos as possibilidades de nossa escrita da História da Educação inspirada na proposta de Carlo Ginzburg de um constante movimento entre o plano geral e o detalhe. Um trabalho como este, ao observar a figura de Jan Hus, dirige nossa atenção para um detalhe histórico da transição entre a escolástica e o humanismo ou da disputa entre realismo e nominalismo ou do impacto educativo das ideias reformistas da Igreja. Para esse "detalhe", demos grande visibilidade de modo que ele permita termos mais subsídios para entendermos o espaço-tempo educativo no qual ele atuou.

A leitura da correspondência hussita não traz referências à temática humanista de retorno às tradições clássicas, acrescentando-as à Igreja e seus comentadores. Nem referências 
diretas a uma educação integral do homem (coração, corpo e mente). Estas, talvez com algum esforço, consigamos inferir a partir de seus escritos, mas isso seria, em nossa opinião, querer encontrar algo que não está presente. Além disso, comparando os escritos de Hus com a definição que apresentamos a seguir, concluímos que ele, definitivamente, não é um humanista:

o humanista encontra nos antigos a mesma atitude de 'interrogação racional do homem acerca do homem, do mundo e das coisas (Garin, 'O Filósofo e o Mago', p. 127) que lhe permite superar, enquanto filósofo, a prática dos intelectuais medievais escolásticos que punham em foco o homem na sua relação com o divino, e tinham como fontes a Revelação e a teologia. Humanista é aquele que, no interior da sua relação com o divino, 'renasce' pela busca de uma verdade captada e interrogada por um homem na direção e em benefício de outro homem. ${ }^{530}$

O Hus que esta tese propõe é um intelectual medieval escolástico, pois a essência de suas cartas é a defesa da Verdade, entendida na relação com a divindade, tendo a Bíblia como referência principal. Isto situa o clérigo da Boêmia em seu período e não como um antecipador da modernidade. Razão e fé eram os pilares da Escolástica. Portanto, valorizar a razão na compreensão das questões de fé não era nenhuma novidade.

Podemos, sim, destacar sua relação com o uso da língua vernacular como um elemento que o coloca à frente de seu tempo. Mas isso seria fazer uma leitura teleológica da história, como se a redução progressiva do uso do latim estivesse programada para acontecer. Se esse uso teve grande impacto na educação dos séculos seguintes, como propõe Manacorda ao citar o clérigo da Boêmia num capítulo sobre os séculos XVI e XVII, ele não foi uma inovação hussita, visto que outros já o propuseram. Basta lembrarmos-nos de Wyclif ou da construção da Capela de Belém. Nesse sentido, usar a língua vernacular era uma inovação de seu próprio tempo, concomitante com a nacionalização que crescia na Europa.

Morrer pela verdade é para poucos, mas remonta a períodos bem mais distantes como o de Sócrates. Não é o diálogo Críton, de Platão, uma grande defesa da Verdade e da Justiça? Ou a Apologia de Sócrates comparável à Relatio de Petr de Mladoňovice no que diz respeito à construção de um mártir? Se Hus não foi um grande inovador nas questões do pensamento e o uso da língua vernacular e a defesa da verdade não são originais dele, significa que toda a empolgação de seus biógrafos é à toa? Hus não foi um grande pensador de seu tempo, com inovações que impactaram a Europa. Ele teve, sim, um papel de destaque na história do povo

\footnotetext{
${ }^{530}$ HILSDORF, Maria Lúcia Spedo. Pensando a educação nos tempos modernos. São Paulo: Editora da Universidade de São Paulo, 1998, p.13.
} 
tcheco e sua imagem foi utilizada como símbolo de um movimento que durou pelas décadas seguintes. Não queremos, de forma alguma, descaracterizar sua grandeza pessoal. Isso já afirmamos anteriormente. Em que ele se destaca e diferencia é que foi um dos poucos que levaram suas ideias até a morte pela fogueira, transformando-se em mártir. Trouxe um exemplo de firmeza moral que educa mais do que mil palavras e só é possível com a sua morte em defesa da verdade, seu primeiro legado.

Mas o principal é que Hus pode ser visto como um sujeito que representa o educador do século XV. Não o grande educador, mas um educador do período, como ensinam Verger e Le Goff. E a pesquisa com as cartas permitiu-nos observar algumas facetas desse educador que permitem afirmá-lo como tal.

Em primeiro lugar, ele está numa posição ambígua entre o antigo e o moderno. Em seu caso, isso se exprime pelo uso de um pensamento escolástico, que remete aos séculos anteriores, e que vemos em suas cartas escritas em latim para o arcebispo Zbyněk, por exemplo. Mas, ao mesmo tempo, ele valoriza o uso do tcheco em suas cartas ao povo, apoiando a proposta de pregação no vernáculo que começa a aparecer no século XIV, mas só vai se consolidar nos séculos XVI e XVII. Isso é típico de um século que foi tradicionalmente marcado como o de transição entre a Idade Média e a Idade Moderna. Estudar Hus é, portanto, estudar um pouco de ambas.

Em segundo lugar, ele é um intelectual. De formação na Universidade, chegou a ser professor de filosofia antes de estudar teologia. Ele atuou na Universidade, tendo inclusive ocupado o cargo de reitor pelo período regular de seis meses no ano de 1409. Usa a escrita e a fala como seus instrumentos de trabalho e, consequentemente, de defesa de ideias. Suas primeiras cartas apresentam essa característica, mas os vários tratados que escreveu é que a corroboram.

Em terceiro lugar, ele é chefe da Capela de Belém e nela existe um pensionato para estudantes, que ajudou a fundar. Se este pensionato se tornará o colégio secundário, de orientação humanista, não temos informações detalhadas a respeito. Sabemos, apenas, por exemplos nas cartas, da relação entre Hus e seus discípulos, como Martin de Volyně. Mas a proximidade entre eles dá ocasião para pensarmos no papel das capelas e outras modalidades de local de culto e dos pensionatos nelas abertos como origem dessas futuras instituições educativas.

Por último, embora sua prática educativa esteja nos espaços institucionalizados para o ensino, Universidade e Igreja, Hus utilizou a escrita de cartas para educar. As cartas foram escritas no modelo de seu tempo, mas quantos utilizaram delas para educar? Não é uma 
resposta que aqui tenhamos buscado, até porque não nos interessa a questão da originalidade ou não desta prática. O que o exemplo do clérigo da Boêmia mostra, porém, é uma possibilidade de ação educativa não escolar do período. Se outros não o fizeram, poderiam têlo feito. Mas para isso, precisariam ter vivido uma biografia semelhante à dele neste traço peculiar: Hus foi um educador que reiterou na correspondência e na vida, dedicação e firmeza moral. E isso, acreditamos, são características de todos aqueles que podem ser chamados de educadores, não importa o período em que viveram. Nisso, ele é um representante de um educador de qualquer século.

Ao colocarmos o ponto final nesta tese, perguntamo-nos a respeito do lugar que ela ocupa no contexto que apresentamos. Na medida em que cada nova publicação é um reconhecimento do legado educativo de Hus, no final das contas, este trabalho volta-se para si mesmo. Sua escrita é um novo reconhecimento do educador Hus, uma nova reiteração da defesa da verdade. Nós tivemos o cuidado de escrever um trabalho que não tivesse um caráter de militância em defesa de Hus e nem de louvação à sua imagem, como vimos em vários dos materiais com os quais trabalhamos. Buscamos o rigor metodológico. Mas será que nas entrelinhas não há indícios de uma paixão pelo objeto de investigação? Se buscamos um distanciamento das fontes que nos permitisse uma leitura de estranhamento, nunca pretendemos que nossa subjetividade estivesse anulada. Talvez no fundo estejamos repetindo "Lembre-se do Ganso!".

Então, "mementote aucae vos amici mei". 


\title{
Referências Bibliográficas*
}

\author{
Fontes Primárias, Escritos de Hus e Biografias
}

BONNECHOSE, Émile de. (ed.) Letters of John Hus: written during his exile and imprisonment, with Martin Luther's preface and containing a general view of the works of Huss. Tradução para o inglês de Campbell Mackenzie. Edimburgo: William Whyte \& Co, 1846.

BONNECHOSE, Émile de. The reformers before the reformation: the fifteenth century, John Hus and the Council of Constance. Tradução para o inglês de Campbel Mackenzie. New York: Harper and Brothers, 1844.

BONNECHOSE, Émile de. Les réformateurs avant la réforme (XVe siècle): Jean Hus et le Concile de Constance. 2a ed. Paris: Au Comptoir des Imprimeurs-Unis, 1847.

DE VOOGHT, Paul; PILNY, Josepha. Um classique de la littérature spirituelle: la "Dcerka" de Jean Huss. Revue d'histoire de la spiritualité. Tomo 48, v. 3, n. 191, p. 275-314, 1972.

FLAJŠHANS, Václav. (ed.) Listy husovy. Praga: J. Otto, s/d. (-)

HÖFLER, K Geschichtschreiber der husitischen bewegung in Böhmen In: Fontes rerum austriacarum. Viena, 1865. (-)

HUS, Jan. Opera omnia. Tomus IV. Opera bohemica minora. Praga: Academia, 1985. (-)

HUS, Jan. Ortographia bohemica (Ortografie česká). Edição de Aloys Vojtěch Šembera. Tiskem Leopolda Sommra, 1857.

HUS, Johannes; HIERONYMUS. Historia et monumenta Joannis Hus et Hieronymi Pragensis confessorum Christi. Frankfurt: Joannes Montanus et Ulricus Neuberus, 1558. (-)

HUSS, John. The Church. Trad. David Schaff. Nova Iorque: Charles Scribner's Sons, 1915. Reimpressão Westport, Connecticut: Greenwood Press, 1976.

LUTERO, Martinho. Epistolæ quaedam piissimae et eruditissimae Iohannis Hus, quæ solæ satis declarant papistarum pietates, esse Satanæ furias. Wittemberg: Officina Ioannis Lufft, 1537.

MACEK, Josef. Jan Hus. Praga: Svodobné Slovo, 1963.

MAREŠ, Bohumil Karel. Lisy husovy. 2a ed. Praga: Samostatnost, 1901. (-)

\footnotetext{
*Aqui, apresentamos a relação, organizada por tipo de referência, de todas as fontes e obras que foram citadas. Por questão de legibilidade e facilidade no acesso às referências, repetimos o nome do autor em todas as ocorrências. As obras marcadas com (-) são aquelas que não tivemos acesso, apenas indicações de sua existência.
} 
NOVOTNÝ, Václav. M. Jana Husi Korespondence a dokumenty. Praga: Komise pro vydávání pramenů náboženského hnutí českého, 1920. (-)

PALACKÝ, Franciscus. Documenta mag. Joannis Hus: vitam, doctrinam, causam in constantiensi concilio actam at controversias de religione in Bohemia annis 1403-1418 motas. Praga: Sumptibus Friderici Tempsky, 1869.

RYBA, Bohumil. Sto listů M. Jana Hus. Praga: Jan Laichter, 1949. (-)

SCHAFF, David S. John Huss: his life, teachings and death after five hundred years. Eugene, Oregon: Wipf and Stock Publishers, 2001. Publicação original: Nova York: Charles Scribner \& Co, 1915.

SCHMIDTOVÁ, Anezka (ed.). Iohannes Hus, magister universitatis carolinae, positiones, recommentdationes sermones. Praga: Statní Pedagogicke Nakladatelství, 1958. (-)

SPINKA, Matthew. John Hus at the Council of Constance. New York \& London: Columbia University Press, 1965.

SPINKA, Matthew. John Hus: a biography. Princetown, New Jersey, EUA: Princetown University Press, 1968.

SPINKA, Matthew (ed.). The letters of John Hus. Manchester, USA: Manchester University Press, 1972.

ŠEMBERA, Aloys Vojtěch (ed.) Ortographia bohemica (Ortografie česká). Tiskem Leopolda Sommra, 1857.

WORKMAN, Herbert B.; POPE, R. Martin. The letters of John Hus: with introductions and explanatory notes. Londres: Hodder and Stoughton, 1904.

\section{Livros e Capítulos}

A BÍBLIA DE JERUSALÉM. 6a impressão. Nova Edição, Revista. São Paulo: Edições Paulinas, 1993.

ALIGHIERI, Dante. A divina comédia. Tradução e notas de Italo Eugenio Mauro. São Paulo: Editora 34, 1998.

ALVES, Fábio, MAGALHÃES, Célia, PAGANO, Adriana. Traduzir com autonomia: estratégias para o tradutor em formação. $2^{a}$ edição. São Paulo: Contexto, 2003.

BARRACLOUGH, Geoffrey. Europa: uma revisão histórica. Tradução de Affonso Blacheyre. Rio de Janeiro: Zahar Editores, 1964.

BASTOS, Maria Helena Camara; CUNHA, Maria Teresa Santos; MIGNOT, Ana Chrystina Venancio (orgs.). Destinos das letras: história, educação e escrita epistolar. Passo Fundo: UPF, 2002. 
BENJAMIN, Walter. A obra de arte na era de sua reprodutibilidade técnica. In. Magia e técnica: arte e política. Obras escolhidas Vol 1. São Paulo: Brasiliense, 1985.

BORGES, Vavy Pacheco. Desafios da memória e da biografia: Gabrielle Brune-Sieler, uma vida (1874-1940) In: BRESCIANI, Stella; NAXARA, Márcia. Memória e (res)sentimento: indagações sobre uma questão sensível. Campinas: Editora da Unicamp, 2001.

BROCCHIERI, Mariateresa Fumagalli Beonio. O intelectual. In: LE GOFF, Jacques (dir.). O homem medieval. Tradução de Maria Jorge Vilar de Figueiredo. Lisboa: Editorial Presença, 1989.

BRYAN, Michael; STANLEY, George. A biographical and critical dictionary of painters and engravers, from the revival of the art under Cimabue, and the alleged discovery of engraving by Fininguerra, to the present time. Londres: H. G. Bohn, 1849.

BURKE, Peter; HSIA, R. Po-chia. (orgs.) A tradução cultural nos primórdios da Europa moderna. São Paulo: Editora Unesp, 2009.

CAGLIARI, Luiz Carlos. Alfabetizando sem o bá-bé-bi-bó-bu. São Paulo: Scipione, 1998.

CAMBI, Franco. História da pedagogia. São Paulo: Editora Unesp, 1999.

CASAGRANDE, Carla. A mulher sob custódia. In: DUBY, Georges; PERROT, Michelle (dir.). História das mulheres no ocidente. Volume 2: A Idade Média. Porto: Edições Afrontamento, 1990.

CASTILLO GÓMEZ, Antonio (coord.). Historia de la cultura escrita: del próximo oriente antiguo a la sociedad informatizada. Gijón, Astúrias, Espanha: Ediciones Trea, S. L., 2001.

CHATEAU, Jean. Grandes pedagogistas. São Paulo: Nacional, 1978.

COLLODI, Carlo. As aventuras de Pinóquio. São Paulo: Iluminuras, 1899. Disponível parcialmente em: <http://books.google.com.br/books?id=KmDakW_sISEC>. Acesso em: 15 nov. 2009.

ČERNÝ, Jiř́i; ZÁTKA, Pavel; ADLA, Zdeněk;KALOUSEK, Jiří. Obrázky z českých dějin a pověstí. Praga: Albatros Nakladatelství, 2007.

DAUPHIN, Cécile; POUBLAN, Daniéle. Maneiras de escrever, maneiras de viver: cartas familiares no século XIX. In: BASTOS, Maria Helena Camara; CUNHA, Maria Teresa Santos; MIGNOT, Ana Chrystina Venancio (orgs.). Destinos das letras: história, educação e escrita epistolar. Passo Fundo: UPF, 2002.

DENIS, Marcelle. O mundo eslavo. In: MIALARET, Gaston; VIAL, Jean (dir). História mundial da educação. Volume I: das origens a 1515. Porto, Portugal: Rés Editora, s/d.

DUBY, Georges. Europa na idade média. São Paulo: Martins Fontes, 1988.

DUBY, Georges. Tempo das catedrais: a arte e a sociedade, 980-1420. Lisboa: Editora Estampa, 1979. 
EBY, Frederick. História da educação moderna: teoria, organização e práticas educacionais. 2a. edição. Porto Alegre: Editora Globo, 1976.

FALBEL, Nachman. Heresias medievais. São Paulo: Editora Perspectiva, 1976.

FERRO, Marc. A história vigiada. São Paulo: Martins Fontes, 1989.

FOXE, John. O livro dos mártires. Tradução de Almiro Pizetta. São Paulo: Mundo Cristão, 2005.

FRANCASTEL, Pierre. A realidade figurativa. Coleção Estudos. 2a. edição. São Paulo: Editora Perspectiva, 1993.

FREITAS, Marcos Cezar. Por quem os sinos dobram? In: BASTOS, Maria Helena Camara; CUNHA, Maria Teresa Santos; MIGNOT, Ana Chrystina Venancio (orgs.). Destinos das letras: história, educação e escrita epistolar. Passo Fundo: UPF, 2002.

FRITZER, Gottfried. O que Lutero realmente disse. Rio de Janeiro: Editora Civilização Brasileira, 1971.

GAARDER, Jostein. Vita brevis: a carta de Floria Emilia para Aurelio Agostinho. Tradução de Pedro Maia Soares. São Paulo: Companhia das Letras, 1997.

GALVÃO, Walnice Nogueira; GOTLIB, Nádia Batella (orgs.). Prezado senhor, prezada senhora: estudos sobre cartas. São Paulo: Companhia das Letras, 2000.

GINZBURG, Carlo. O queijo e os vermes. São Paulo: Companhia das Letras, 1987.

GINZBURG, Carlo. Indagações sobre Piero. São Paulo: Paz e Terra, 1989.

GINZBURG, Carlo. Mitos, emblemas e sinais: morfologia e história. São Paulo: Companhia das Letras, 1989.

GINZBURG, Carlo. Olhos de madeira: nove reflexões sobre a distância. São Paulo: Companhia das Letras, 2001.

GINZBURG, Carlo. Nenhuma ilha é uma ilha: quatro visões da literatura inglesa. São Paulo: Companhia das Letras, 2004.

GINZBURG, Carlo. O fio e os rastros: verdadeiro, falso, fictício. São Paulo: Companhia das Letras, 2006.

GOLDMANN, Lucien. Correspondance de Martin de Barcos, abbé de Saint-Cyran, avec les abbesses de Port-Royal et les principaux personnages du groupe janséniste. Paris:

Presses universitaires de France, 1956.

GOLDMANN, Lucien. Dialética e cultura. São Paulo: Paz e Terra, 1967.

GUSDORF, Georges. De l'histoire des sciences a l'histoire de la pensée. Les sciences humaines et la pensée occidentale, vol. I. Paris: Payot, 1966.

GUSDORF, Georges. Professores para quê? Tradução de João Bénard da Costa e António Ramos Rosa. 2.a edição. Lisboa: Moraes editores, 1970. 
HAVEL, Václav. Cartas a Olga. São Paulo: Estação Liberdade, 1992.

HILSDORF, Maria Lúcia Spedo. Pensando a educação nos tempos modernos. São Paulo: Editora da Universidade de São Paulo, 1998.

HILSDORF, Maria Lúcia Spedo. O aparecimento da escola moderna. Belo Horizonte: Autêntica, 2006.

HOUAISS, Antônio. Dicionário eletrônico Houaiss. Rio de Janeiro: Objetiva, s/d.

HUIZINGA, Johan. O declínio da Idade Média. Tradução de Augusto Abelaira São Paulo: Verbo; EDUSP, 1978.

INFANTES, VÍCTOR. De las primeras letras: cartillas españolas para enseñar a leer de los siglos XV y XVI: preliminar y edición facsímil de 34 obras. Salamanca: Ediciones Universidad de Salamanca, 1998.

KLAPISCH-ZUBER, Christiane. Introdução. In: DUBY, Georges; PERROT, Michelle (dir.). História das mulheres no ocidente. Volume 2: A Idade Média. Porto: Edições Afrontamento, 1990.

KOSSOY, Boris. Fotografia e história. $3^{\text {a }}$ edição. São Paulo: Ateliê Editorial, 2009.

KOWALSKÁ, Eva. A língua como meio de transferência de valores culturais. In: BURKE, Peter; HSIA, R. Po-chia. (orgs.) A tradução cultural nos primórdios da Europa moderna. São Paulo: Editora Unesp, 2009.

KUHN, Thomas. O caminho desde a estrutura. São Paulo: Editora Unesp, 2006.

KUNDERA, Milan. O livro do riso e do esquecimento. Tradução Teresa Bulhões Carvalho da Fonseca. São Paulo: Companhia das Letras, 2008.

LAUAND, Luiz Jean. O xadrez na Idade Média. São Paulo: Perspectiva; Editora da Universidade de São Paulo, 1988.

LAUAND, Luiz Jean (org.). Oriente \& ocidente: Idade Média: cultura popular estudos e traduções. Vol. 7. São Paulo: Centro de Estudos Árabes/DLO-FFLCH-USP; Edix edições, 1995.

LAUAND, Luiz Jean. Medievália: filosofia, teatro e pedagogia. Série Acadêmica. São Paulo: Hottopos, 1997.

LAVER, James. A roupa e a moda: uma história concisa. São Paulo: Companhia das Letras, 1990.

LE GOFF, Jacques. Para um novo conceito de Idade Média: tempo, trabalho e cultura no ocidente. Lisboa: Editorial Estampa, 1980.

LE GOFF, Jacques. Maravilhoso e o quotidiano no ocidente medieval. Lisboa: Edições 70, 1985. 
LE GOFF, Jacques (dir.). O homem medieval. Tradução de Maria Jorge Vilar de Figueiredo. Lisboa: Editorial Presença, 1989.

LE GOFF, Jacques. Os intelectuais na Idade Média. Tradução de Marcos de Castro. Rio de Janeiro: José Olympio, 2003.

LE GOFF, Jacques; SCHMITT, Jean-Claude (coord.). Dicionário Temático do Ocidente Medieval. Coordenação da Tradução Hilário Franco Júnior. Bauru, SP: Edusc, 2006.

LE ROY LADURIE, Emmanuel. O mendigo e o professor: a saga da família Platter no século XVI. Tomo I. Rio de Janeiro: Rocco, 1999.

LIMA, Henrique Espada. A micro-história italiana: escalas, indícios e singularidades. Rio de Janeiro: Civilização Brasileira, 2006.

LÜTZOW, The Count of. The life and times of master John Hus. Londres: Dent \& Sons Ltd.; New York: E. P. Dutton \& Co., 1921. (-)

LUZURIAGA, Lorenzo. Historia da educação e da pedagogia. São Paulo: Companhia Editora Nacional, 1969.

MACIEL, Francisca Izabel Pereira. Cartas pedagógicas: fragmentos de um discurso. In: BASTOS, Maria Helena Camara; CUNHA, Maria Teresa Santos; MIGNOT, Ana Chrystina Venancio (orgs.). Destinos das letras: história, educação e escrita epistolar. Passo Fundo: UPF, 2002.

MALATIAN, Teresa. Cartas: narrador, registro e arquivo. In: PINSKY, Carla Bassanezi; LUCA, Tania Regina de (orgs.). O historiador e suas fontes.São Paulo: Editora Contexto, 2009.

MANACORDA, Mario Alighiero. História da educação. São Paulo: Cortez/Autores Associados, 1989.

MCBRIEN, Richard P. Os papas: de São Pedro a João Paulo II. Tradução Barbara Theoto Lambert. São Paulo: Edições Loyola, 2000.

MIALARET, Gaston; VIAL, Jean (dir). História mundial da educação. Volume I: das origens a 1515. Porto, Portugal: Rés Editora, s/d.

MIGNOT, Ana Chrystina Venâncio. Artesãos da palavra: cartas a um prisioneiro político tecem redes de ideias e afetos. In: BASTOS, Maria Helena Camara; CUNHA, Maria Teresa Santos; MIGNOT, Ana Chrystina Venancio (orgs.). Destinos das letras: história, educação e escrita epistolar. Passo Fundo: UPF, 2002.

MIRANDA, Tiago C. P. dos Reis. A arte de escrever cartas: para a história da epistolografia portuguesa no século XVIII. In: GALVÃO, Walnice Nogueira; GOTLIB, Nádia Batella (orgs.). Prezado senhor, prezada senhora: estudos sobre cartas. São Paulo: Companhia das Letras, 2000.

MONGELLI, Lênia Márcia. Retórica: a virtuosa elegância do bem dizer. In: MONGELLI, L. M. (coord.) Trivium e quadrivium: as artes liberais na Idade Média. Cotia: Íbis, 1999. 
MONROE, Paul. História da educação. São Paulo: Companhia Editoria Nacional, 1939.

MORAES, Elaine Robert. A cifra e o corpo: as cartas de prisão do marquês de Sade. In: GALVÃO, Walnice Nogueira; GOTLIB, Nádia Batella (orgs.). Prezado senhor, prezada senhora: estudos sobre cartas. São Paulo: Companhia das Letras, 2000.

MORAES, Marcos Antonio de. "Orgulho de jamais aconselhar": Mário de Andrade e os moços. In: GALVÃO, W. N. \& GOTLIB, N. B. Prezado senhor, prezada senhora: estudos sobre cartas. São Paulo: Companhia das Letras, 2000, p. 289.

NÓVOA, António (org.). Vidas de Professores. Porto: Porto Editora, 1992.

NUNES, Ruy Afonso da Costa. História da Educação na Idade Média. São Paulo: Editora Pedagógica e Universitária Ltda. Editora da Universidade de São Paulo, 1979.

OPTIZ, Claudia. O quotidiano da mulher no final da Idade Média (1250-1500). In: DUBY, Georges; PERROT, Michelle (dir.). História das mulheres no ocidente. Volume 2: A Idade Média. Porto: Edições Afrontamento, 1990.

PANOFSKY, Erwin. Significado nas artes visuais. São Paulo: Editora Perspectiva, 1976.

PLINVAL, Georges de; PITTET, Romain. Histoire illustrée de l'eglise. Vol. I. Genève: Éditions de L’Écho Illustré; Paris: Éditions du Cerf, 1946.

PORTAL, Roger. Os eslavos: povos e nações. Lisboa: Edições Cosmos, 1968.

PUTZGER, F. W. Historischer weltatlas. Bielefeld, Berlin, Hannover: Velhagen \& Klasing, 1965.

SCHMITT, Jean-Claude. O corpo das imagens: ensaios sobre a cultura visual na idade média. Bauru, SP: EDUSC, 2007.

SEIFERTOVÁ, Lucie. Dějiny udatného českého národa a pár bezvýzamných světových událostí. República Tcheca: Petr Prchal; Euromedia Group k. s.; Knizni klub, 2003.

TIN, Emerson (org.). A arte de escrever cartas. Campinas: Editora da Unicamp, 2005.

TUCHMAN, Barbara W. Um espelho distante: o terrível século XIV. Tradução de Waltensir Dutra. Rio de Janeiro: José Olympio, 1990.

VAUCHEZ, André. O santo. In: LE GOFF, Jacques (dir.). O homem medieval. Tradução de Maria Jorge Vilar de Figueiredo. Lisboa: Editorial Presença, 1989.

VERGER, Jacques. Homens e saber na idade média. Tradução de Carlota Botto. Bauru, SP: EDUSC, 1999.

VISCHER, Melchior. Jan Hus: sein leben un sein zeit. 2 vols. Frankfurt am Main: SocietätsVerlag, 1940. (-)

VISCHER, Melchior. Jan Hus: aufruhr wider papst un reich. Frankfurt am Main: SocietätsVerlag, 1955. (-) 
VOOGHT, Paul de. Hussiana. Louvain, Bélgica: Publications Universitaires de Louvain, 1960. (-)

VOOGHT, Paul de. L'Heresie de Jean Huss. Louvain, Bélgica: Publications Universitaires de Louvain, 1960. (-)

VOOGHT, Paul de. Jacobellus de Stribro: premier théologien du hussitisme. Louvain, Bélgica: Publications Universitaires de Louvain, 1972. (-)

\section{Teses e dissertações}

BARBOSA, Luciane Muniz Ribeiro. Igreja, estado e educação em Martinho Lutero: uma análise das origens do direito à educação. 2007. 239p. + anexos. Dissertação (Mestrado em Educação). Faculdade de Educação da Universidade de São Paulo, 2007.

CASTRO, Roberto Carlos Gomes de. Demóstenes educador. 2003. 153 f. Dissertação (Mestrado em Educação). Faculdade de Educação da Universidade de São Paulo, 2003.

CAUVILlA, Waldir. Alceu Amoroso Lima e a democracia: em busca da proporção. 2000. 238 f. Tese (Doutorado em Educação). Faculdade de Educação da Universidade de São Paulo, 2000.

CAVICCHIOLI, Maria de Lourdes Silva Barros. A cultura clássica e o magistério de Paulo de Tarso. 2005. 118 f. Dissertação (Mestrado em Educação). Universidade Estadual de Maringá, 2005.

CHODAN, Tim. The use and abuse of Jan Hus as an historical figure in czech culture or cooking your own goose: three czech recipes. 1999. 133 f. Dissertação (Master of Arts em História) - Department of History and Classics, Faculty of Graduate Studies and Research, University of Alberta. Edmonton, Alberta, Canadá, 1999.

DIAS, Marcia Hilsdorf. Professores da escola normal de São Paulo (1846-1890): a história não escrita. 2002. 290 f. Dissertação (Mestrado em educação). Faculdade de Educação da Universidade de São Paulo, 2002.

DIAS, Maria Aparecida Lima. O espírito da educação: Maria Lacerda de Moura (19181935). 1999. 219 f. Dissertação (Mestrado em Educação). Faculdade de Educação da Universidade de São Paulo, 1999.

FARIA, Vera Lúcia Boechat. Combati o bom combate: retórica nos discursos de Paulo. 2008. 84 f. Dissertação (Mestrado em Letras). Universidade Vale do Rio Verde, Três Corações, 2008.

GONÇALVES, Tânia. João Cruz Costa educador: contribuições ao debate sobre a filosofia como formação cultural. 2004. 119 f + anexos. Dissertação (Mestrado em Educação).

Faculdade de Educação da Universidade de São Paulo, 2004.

LIMA, Raymundo de. A educação no Brasil: o pensamento e a atuação de José Mario Pires Azanha. 2005. 296 f. Tese (Doutorado em Educação). Faculdade de Educação da Universidade de São Paulo, 2005. 
LOUREIRO, Noemi Paulichenco. Anna Bagby, educadora batista (1902-1919). 2006. 100 f. + anexos. Dissertação (Mestrado em Educação). Faculdade de Educação da Universidade de São Paulo, 2006.

MORAIS, Maria Helena de Jesus Silva. Da pedagogia que "pegou de galho" a uma pedagogia cristã nova e brasileira: Theobaldo Miranda Santos (1904-1971) e seus manuscritos didáticos. 2004. 86 f. + anexos. Dissertação (Mestrado em Educação). Faculdade de Educação da Universidade de São Paulo, 2004.

OBERG, Renato Emir. João Huss, um injustiçado? 1972. 2 vol. 400 p.Tese (Doutorado em História). Faculdade de Filosofia, Letras e Ciências Humanas da Universidade de São Paulo. Departamento de História, 1973.

SELTZER, Joel Daniel. Framing faith, forging a nation: czech vernacular historiography and the Bohemian Reformation, 1430-1530. 2005. 309 f. Tese (Doutor em Filosofia). Faculty of the Graduate School, Yale University, Yale, EUA, 2005.

SILVA, Antonio Ozaí da. Maurício Tragtenberg e a pedagogia libertária. 2004. 226 f. Tese (Doutorado em Educação). Faculdade de Educação da Universidade de São Paulo, 2004.

ZANATTA, Regina Maria. Jonathas Serrano e a escola nova no Brasil: raízes católicas na concepção progressista. 2005. 201 f. Tese (Doutorado em Educação). Faculdade de Educação da Universidade de São Paulo, 2005.

\section{Páginas na Internet ${ }^{531}$}

AQUINO, Tomás de. The summa theologica of St. Thomas Aquinas. 2a. ed. Traduzido para o inglês pelos Fathers of the English Dominican Province, 1920. Edição Online de 2008. Disponível em <http://www.newadvent.org/summa>. Acesso em 26 dez. 09.

ASSIS, Francisco de. Carta aos fiéis II. Disponível em <http://www.franciscanos.org.br/v3/carisma/fontesfran/word/CARTA\%20AOS\%20FIÉIS\%2 0I.doc>. Acesso em 26 dez. 09.

BOISSARD, Jean-Jacques; BRY, Theodore de. Bibliotheca chalcographica, hoc est virtute et eruditione clarorum virorum imagines. Heidelberg: Clemens Ammon, 1669. Disponível em <http://www.uni-mannheim.de/mateo/desbillons/aport.html>. Acesso em 20 jan. 2010.

BUSOLINI, Dario. Dialogue resumes from the testimony of Jan Hus. Revista do Jubileu de 2000. n. 1, jan. 2000. Seção Themes of the Jubilee. Disponível em

<http://www.vatican.va/jubilee_2000/magazine/documents/ju_mag_01012000_p38_en.html>. Acesso em 22 jan. 2010.

CATÃO, Andrea; Folha Online. Lembo ironiza FHC e diz que escrever cartas é "coisa de velho". Disponível em <http://www1.folha.uol.com.br/folha/brasil/ult96u82810.shtml>. Acesso em 02 nov. 2009.

\footnotetext{
${ }^{531}$ A maior parte das referências aqui presentes não são textos escritos originalmente para a Internet, mas republicações de originais de outras fontes.
} 
CONCÍLIO VATICANO II. Dignitatis humanae: declaração sobre a liberdade religiosa. Disponível em

<http://www.vatican.va/archive/hist_councils/ii_vatican_council/documents/vatii_decl_19651207_dignitatis-humanae_po.html>. Acesso em 16 jan. 2010.

CZECH LANGUAGE. Encyclopaedia Britannica. Disponível em <http://www.britannica.com/eb/article-9028459>. Acesso em 01 dez. 2007.

CZECHOSLOVAK REGION, HISTORY OF. Encyclopædia Britannica. Disponível em: <http://www.britannica.com/eb/article-42097>. Acesso em 01 dez. 2007.

ČESKÁ TELEVIZE. Největší čech: o projektu. Disponível em $<$ http://www.ceskatelevize.cz/specialy/nejvetsicech/oprojektu_top100>. Acesso em 06 jun. 2010.

FOLHA ONLINE. Vaticano diz que escuridão e perna da cama foram causas de queda do papa. Disponível em <http://www1.folha.uol.com.br/folha/mundo/ult94u600926.shtml>. Acesso em 02 nov. 2009.

FORTESCUE, Adrian. Kyrie Eleison. The Catholic Encyclopedia. Vol. 8. New York: Robert Appleton Company, 1910. Disponível em: 〈http://www.newadvent.org/cathen/08714a.htm〉. Acesso em 17 mar. 2010.

GRANDHOMME, Jacques. Portrait de Joan Hussus, martyr constantissimus: [estampe]. Disponível em <http://gallica.bnf.fr/ark:/12148/btv1b84001450>. Acesso em 6 set. 2010.

GUNDELMUNDT, Hans. Portrait de Jean Huss: [estampe]. Disponível em <http://gallica.bnf.fr/ark:/12148/btv1b8400144k>. Acesso em 6 set. 2010.

HISTÓRIA DA EDUCAÇÃO MODERNA E CONTEMPORÂNEA: OS PEDAGOGOS “MENORES". USP: Júpiter Sistema de Graduação. Informações da Disciplina. Disponível em <http://sistemas2.usp.br/jupiterweb/obterDisciplina?sgldis=EDF0662\&verdis=2>. Acesso em 24 jan. 2010.

HISTORY OF THE FLAG OF THE CZECH. Disponível em <http://www.czechgallery.com/flag/index.html>. Aceso em 29 mar.2010.

HOLECEK O. M., Frantisek J. Nel nome di Giovanni Hus la riconciliazione fra i cristiani boemi. Revista do Jubileu de 2000. n.10, dez. 1999. Seção Ecumenismo. Disponível em <http://www.vatican.va/jubilee_2000/magazine/documents/ju_mag_01121999_p-18_it.html>. Acesso em 22 jan. 2010.

HUS, Jan. [Imagem]. Encyclopædia Britannica. Disponível em <http://www.britannica.com/eb/art-75633>. Acesso em 01 dez. 2007.

JENSKÝ KODEX [Antithesis Christi et Antichristi]. 1490-1510. Disponível em <http://www.manuscriptorium.com/Site/ENG/free_documents.asp>. Acesso em 19 jan. 2010.

JOÃO PAULO II, Papa. Slavorum apostoli: carta encíclica do sumo pontífice papa João Paulo II para comemorar a obra de evangelização dos santos Cirilo e Metódio no undécimo centenário. Libreria Editrice Vaticana, 1985. Disponível em 
<http://www.vatican.va/holy_father/john_paul_ii/encyclicals/documents/hf_jpii_enc_19850602_slavorum-apostoli_po.html>. Acesso em 22 jan. 2010.

JOÃO PAULO II, Papa. Incontro di Giovanni Paolo II con il mondo della cultura. Viagem pastoral para a República Federativa Tcheca e Eslovaca. 21 abr. 1990. Disponível em <http://www.vatican.va/holy_father/john_paul_ii/speeches/1990/april/documents/hf_jpii_spe_19900421_cultura-praga_it.html>. Acesso em 22 jan 2010.

JOÃO PAULO II, Papa. Ut unum sint: carta encíclica do sumo pontífice papa João Paulo II sobre o empenho ecumênico. Libreria Editrice Vaticana, 1995. Disponível em <http://www.vatican.va/holy_father/john_paul_ii/encyclicals/documents/hf_jpii_enc_25051995_ut-unum-sint_po.html>. Acesso em 22 jan. 2010.

JOÃO PAULO II, Papa. Discurso do papa João Paulo II no encontro com os representantes de outras confissões. Viagem apostólica à República Tcheca. 27 abr. 1997. Disponível em <http://www.vatican.va/holy_father/john_paul_ii/speeches/1997/april/documents/hf_jpii_spe_19970427_ecumenico-praga_po.html>. Acesso em 22 jan. 10.

JOÃO PAULO II, Papa. Discurso do papa João Paulo II aos participantes no simpósio sobre João Hus. Libreria Editrice Vaticana, 1999. Disponível em <http://www.vatican.va/holy_father/john_paul_ii/speeches/1999/december/documents/hf_jpii_spe_17121999_jan-hus_po.html>. Acesso em 31 dez. 2009.

JOÃO PAULO II, Papa. Discurso do papa João Paulo II aos peregrinos da República Tcheca vindos a Roma para a entrega da árvore de natal. 18 dez. 1999. Disponível em <http://www.vatican.va/holy_father/john_paul_ii/speeches/1999/december/documents/hf_jpii_spe_18121999_havel_po.html>. Acesso em 22 jan. 2010.

JOÃO XXIII, Papa. Pacem in terris: carta encíclica do sumo pontífice papa João XXIII a paz de todos os povos na base da verdade, justiça, caridade e liberdade. Disponível em <http://www.vatican.va/holy_father/john_xxiii/encyclicals/documents/hf_jxxiii_enc_11041963_pacem_po.html>. Acesso em 16 jan. 2010.

KARLSSON. Hussenstein. (Fotografia). 18 jul.2007. Disponível em <http://www.panoramio.com/photo/5245602>. Acesso em 28 mar.2010

KERR, Donal A. Christianity, european governments and the cultural identity of nondominant groups in the 19th and 20th centuries. Revista Cultures and Faith. vol 1, n. 1. 1993. Disponível em <http://www.vatican.va/roman_curia/pontifical_councils/cultr/documents/rc_pc_cultr_010919 93_doc_i-1993-kling_en.html\#4>. Acesso em 22 jan. 2010.

LAUAND, Luiz Jean. Deus Ludens - o lúdico no pensamento de Tomás de Aquino e na pedagogia medieval. Disponível em <http://www.hottopos.com/notand7/jeanludus.htm>. Acesso em 22 dez. 2009.

LAUAND, Luiz Jean. 500 provérbios portugueses antigos: educação moral, mentalidade e linguagem. Disponível em < http://www.hottopos.com/vdletras4/jeans2.htm>. Acesso em 25 dez. 2009. 
LAUAND, Luiz Jean. Et Pilo sua Umbra... Inscrições em Relógios de Sol. Disponível em <http://www.hottopos.com/mirand5/et_pilo_sua_umbra.htm>. Acesso em 28 ago. 2010.

LIFE MAGAZINE. Czech religious reformer John Huss (Jan Hus). Disponível em $<$ http://images.google.com/hosted/life/l?imgurl=dd0d56e9bec28108\&q=jan\%20hus\%20sourc e:life\&prev=/images $\% 3 \mathrm{Fq} \% 3 \mathrm{Djan} \% 2 \mathrm{Bhus} \% 2 \mathrm{~B}$ source:life $\% 26 \mathrm{hl} \% 3 \mathrm{Dpt}-\mathrm{BR}>$. Acesso em 20 jan. 2010.

MING, John. Concupiscence. The Catholic Encyclopedia. Vol. 4. New York: Robert Appleton Company, 1908. Disponível em <http://www.newadvent.org/cathen/04208a.htm>. Acesso em 19 dez. 2009.

MULLER, Martin. Jan Hus monument in the middle of the Old Town Square. Disponível em <http://www.prague.cz/jan-hus-monument/>. Acesso em 20 jan. 2010.

RADIO PRAGUE. Czech christmas tree to the vatican. Current Affairs. 15 dez. 1999. Disponível em <http://archiv.radio.cz/english/cur-affrs/15-12-99.html>. Acesso em 22 jan. 2010.

RADIO PRAHA. Václav Brozík y sus monumentales pinturas con temas históricos. Disponível em <http://www.radio.cz/es/rubrica/personalidades/vaclav-brozik-y-susmonumentales-pinturas-con-temas-historicos>. Acesso em 22 jan. 2010.

REPÚBLICA TCHECA. Ministério das Relações Exteriores. The national emblems of the czech republic. Disponível em: <http://www.czech.cz/en/czech-republic/politics/thenational-emblems-of-the-czech-republic>. Acesso em: 02 nov. 2009.

SCHERSCHEL, Frank. Statue of Jan Huss in the old City Hall Square. Fotografia tirada em maio de 1956. Disponível em

$<$ http://images.google.com/hosted/life/l?imgurl=401 ee20d01a2233f\&q=John $\% 20 \mathrm{Huss} \% 20$ so urce:life\&prev=/images $\% 3 \mathrm{Fq} \% 3 \mathrm{DJ}$ ohn $\% 2 \mathrm{BHuss} \% 2 \mathrm{~B}$ source:life $\% 26 \mathrm{hl} \% 3 \mathrm{Dpt}-\mathrm{BR}>$. Acesso em 20 jan. 2010.

SEAMAN, Richard. Jan Hus statue in Prague. In: European Travel Wallpaper. Disponível em <http://www.richard-seaman.com/Wallpaper/Travel/Europe/index.html>. Acesso em 20 jan. 2010.

SPINKA, Matthew; BARTOŠ, František M. Jan Hus. Encyclopaedia Britannica. Disponível em <http://www.britannica.com/eb/article-9041616>. Acesso em 01 dez. 2007.

STÄDEL MUSEUM. Carl Friedrich Lessing: Johann Hus zu Konstanz. Disponível em $<$ http://www.staedelmuseum.de/sm/index.php?StoryID=337\&ObjectID=464>. Acesso em 20 jan. 2010.

\section{Artigos e trabalhos em anais de congressos}

FEDRIGO, Fabiana de Souza. Francisco de Paula Santander e a exposição de seus projetos para a América independente: entre a memória e a autobiografia. In: XXV Simpósio Nacional de História da Associação Nacional de História - Anpuh, 2009, Universidade Federal do Ceará, Fortaleza. História e ética: simpósios temáticos e resumos. Fortaleza: Editora, 2009. 
GASTAUD, Carla Rodrigues. Práticas epistolares: cartas de amor no século XX. In: XXV Simpósio Nacional de História da Associação Nacional de História - Anpuh, 2009, Universidade Federal do Ceará, Fortaleza. História e ética: simpósios temáticos e resumos. Fortaleza: Editora, 2009.

HANSEN, João Adolfo. O nu e a luz: cartas jesuíticas do Brasil. Nóbrega - 1549-1558. Revista do Instituto de Estudos Brasileiros. 1995, n. 38, pp. 87-119.

KAMINSKY, Howard. Pius Aeneas among the Taborites. Church History. set. 1959, vol. 28, n. 3, pp. 281-309.

MORAES, Maria Rita Salzano. O que (se) passa na tradução? O que (ultra)passa a tradução? Literal. Escola de Psicanálise de Campinas. jan-jun 2002, nº 5, pp. 169-178.

OBERG, Renato Emir. Kutna Hora. Influências morais e políticas no julgamento do mestre João Hus. Revista de História. São Paulo, 1971, nº 85, pp. 33-47.

OLIVEIRA, Alessandra Ramos. Equivalência: sinônimo de divergência. Cadernos de Tradução. Universidade Federal de Santa Catarina. jan-jun 2007, nº 19, pp. 97-114.

OLIVEIRA, Iranilson Buriti de. A pena de Belisário: narrativas de nordeste nas correspondências de Belisário Penna. In: XXV Simpósio Nacional de História da Associação Nacional de História - Anpuh, 2009, Universidade Federal do Ceará, Fortaleza. História e ética: simpósios temáticos e resumos. Fortaleza: Editora, 2009.

SHELL, Deise Cristina. 'Yo, rebelde hasta la muerte': as cartas de Lope de Aguirre e a escrita de si. In: XXV Simpósio Nacional de História da Associação Nacional de História - Anpuh, 2009, Universidade Federal do Ceará, Fortaleza. História e ética: simpósios temáticos e resumos. Fortaleza: Editora, 2009.

SPINKA, Matthew. Religious movements in Czechoslovakia. The journal of religion. Chicago: University of Chicago Press. nov 1923, vol. 3, n. 6, pp. 616-631.

SPINKA, Matthew. Slavic translations of the scriptures. The journal of religion. Chicago: University of Chicago Press. out 1933, vol. 13, n. 4, pp. 415-432.

SPINKA, Matthew. Peter Chelčický: the spiritual father of the Unitas Fratrum. Church history. Cambridge University Press; American Society of Church History. dez. 1943, vol. 12, n. 4, pp. 271-291.

SPINKA, Matthew. Fiftieth (thirty-fourth annual) meeting of the American Society of Church History. Church history. Cambridge University Press; American Society of Church History. mar. 1941, vol. 10, n. 1, pp. 60-67.

SPINKA, Matthew. Comenian pansophic principles. Church history. Cambridge University Press; American Society of Church History. jun. 1953, vol. 22, n. 2, pp. 155-165.

SPINKA, Matthew. Paul Kravař and the Lollard-Hussite relations. Church history.

Cambridge University Press; American Society of Church History. mar. 1956, vol. 25, n. 1, pp. 16-26. 
STOČES, Jiří. Rektorská řada předhusitské pražské tř́fakultní univerzity (do vydání Dekretu kutnohorského). Nové poznatky a otazníky [A sucessão dos reitores Universidade de Praga pré-hussita de três faculdades (até o decreto de Kutna Hora). Pesquisas recentes e questões.] Český Časopis Historický. Praga: Historický ústav Akademie věd České republiky. 2009. n. 3. pp. 533-558.

ŠMAHEL, František. Drobné otázky a záhady v studentském životě mistra Jeronýma Pražského [Questões menores e mistérios na vida estudantil do mestre Jerônimo de Praga]. Český Časopis Historický. Praga: Historický ústav Akademie věd České republiky. 2008. n. 1. pp. 1-18.

ŠMAHEL, František; NODL, Martin. Kutnohorský dekret po 600 letech. Bilance dosavadního bádání [Seiscentos anos do decreto de Kutná Hora. Estado da arte] Český Časopis Historický. Praga: Historický ústav Akademie věd České republiky. 2009. n. 1. pp. $1-45$.

WADDINGTON, Charles. Nécrologie: M. E. de Bonnechose. Bulletin historique et littéraire. Paris: Société de l'histoire du protestantisme français. 1875, ano 24, p. 144.

\section{Outros meios}

ABRIL S.A. CULTURAL E INDUSTRIAL. João Hus. Coleção Grandes Personagens da História Universal. 20p. São Paulo: Editora Abril Cultural, 1971.

CHRISTIAN HISTORY (Magazine). 50p. Estados Unidos da América: Christianity Today, Inc., 2000. Edição 68. Vol. XIX, n. 4. ISSN 0891-9666.

NOHAVICA, Jaromir. Husita. In: NOHAVICA, Jaromir. Darmoděj. Praga: Panton, 1988. LP Faixa 7. Texto da música disponível em <http://www.nohavica.cz/cz/tvorba/texty/husita.htm>. Acesso em 23 jan. 2010.

LANDA, Daniel. Kdož jste boží bojovníci. In: LANDA, Daniel. Best of Daniel Landa 2. EMI, 2004. CD Faixa 10.

\section{Nossos trabalhos}

AGUIAR, Thiago Borges de. O abecedário de Hus: o passo tcheco no caminho para as primeiras cartilhas européias. In: Simpósio Internacional "Livro Didático: Educação e História", 2007, São Paulo. Anais do Simpósio Internacional "Livro Didático: Educação e História", São Paulo: Faculdade de Educação da Universidade de São Paulo, 2007.

AGUIAR, Thiago Borges de. Como se constrói um educador na história da educação. In: VII Semana da Educação - 40 anos da Faculdade de Educação, 50 anos da Escola de Aplicação: conquistas e desafios, 2009, Faculdade de Educação da Universidade de São Paulo. ANAIS. No prelo.

AGUIAR, Thiago Borges de. A necessidade de escrever para educar na correspondência de Jan Hus. In: XXV Simpósio Nacional de História da Associação Nacional de História - 
Anpuh, 2009, Universidade Federal do Ceará, Fortaleza. Anais do XXV Simpósio Nacional de História: por uma est(ética) da beleza na História. Fortaleza: Anpuh, 2009.

LEONARDI, Paula; BALASSIANO, Ana Luiza Grillo; AGUIAR, Thiago Borges de. Uma leitura da inserção da obra de Carlo Ginzburg em periódicos brasileiros de história da educação. In: IX Congresso Iberoamericano de História da Educação Latino-americana, 2009, Universidade do Estado do Rio de Janeiro. Anais do IX Congresso Iberoamericano de História da Educação Latino-Americana: Educação, Autonomia e Identidades na América Latina. Rio de Janeiro: Quartet Editora, 2009. 


\section{Apêndice 1. Cartas de Hus por edição.}

\begin{tabular}{|c|c|c|c|c|c|c|}
\hline $\begin{array}{l}\text { Neste } \\
\text { Trabalho }\end{array}$ & $\begin{array}{l}\text { Monumenta } \\
(1558 ; 1715): \\
\text { páginas }\end{array}$ & $\begin{array}{l}\text { Bonnechose } \\
\text { (1846) }\end{array}$ & $\begin{array}{l}\text { Documenta } \\
(1869)\end{array}$ & $\begin{array}{l}\text { Workman \& } \\
\text { Pope (1904) }\end{array}$ & $\begin{array}{l}\text { Korespondence } \\
\text { (1920) }\end{array}$ & $\begin{array}{l}\text { Spinka } \\
\text { (1972) }\end{array}$ \\
\hline 1 & $(?)$ & ausente & ausente & ausente & 1 & 1 \\
\hline 2 & $(?)$ & ausente & ausente & ausente & 6 & 2 \\
\hline 3 & (?) & ausente & ausente & ausente & 7 & 3 \\
\hline 4 & $(?)$ & ausente & ausente & ausente & 8 & 4 \\
\hline 5 & $(?)$ & ausente & ausente & ausente & 9 & 5 \\
\hline 6 & ausente & ausente & 3 & i.II & 10 & 6 \\
\hline 7 & ausente & ausente & 1 & $\overline{\text { i.I }}$ & 11 & 7 \\
\hline 8 & $(?)$ & ausente & pp.155-163 & ausente & 12 & 8 \\
\hline 9 & ausente & ausente & 2 & i.III & 13 & 9 \\
\hline 10 & $(?)$ & ausente & ausente & ausente & 18 & 10 \\
\hline 11 & i.93b; 117 & II & 4 & i.IV & 20 & 11 \\
\hline $11 a^{532}$ & $(?)$ & $\mathrm{XV}$ & ausente & pp. 32-34 & 22 & Ap 1 \\
\hline 12 & $(?)$ & ausente & ausente & ausente & 23 & 12 \\
\hline 13 & $(?)$ & ausente & ausente & ausente & 25 & 13 \\
\hline 14 & $(?)$ & ausente & ausente & ausente & 27 & 14 \\
\hline 15 & ausente & ausente & 6 & i.VI & 24 & 15 \\
\hline 16 & i.100b;125 & XIV & 5 & i.V & 16 & 16 \\
\hline 17 & i.94;119 & $\mathrm{V}$ & 8 & i.VIII & 28 & 17 \\
\hline 18 & ausente & ausente & 9 & i.IX & 31 & 18 \\
\hline 19 & i.92;117 & I & 10 & i.X & 32 & 19 \\
\hline 20 & ausente & ausente & 12 & ii.XII & 35 & 20 \\
\hline 21 & $(?)$ & ausente & ausente & ausente & 36 & 21 \\
\hline 22 & ausente & ausente & 7 & i.VII & 39 & 22 \\
\hline 23 & ausente & ausente & 14 & ii.XIV & 41 & 23 \\
\hline 24 & ausente & ausente & 13 & ii.XIII & 42 & 24 \\
\hline 25 & i.93; 117 & III & 15 & ii.XV & 47 & 25 \\
\hline 26 & ausente & 2.VIII & 16 & iii.XVI & 48 & 26 \\
\hline 27 & i.95;119 & VI & 17 & iii.XVII & 49 & 27 \\
\hline 28 & i.97;121 & VII & 19 & iii.XIX & 50 & 28 \\
\hline $28 a$ & $(?)$ & ausente & ausente & ausente & 46 & Ap 2 \\
\hline 29 & i.98;122 & IX & 23 & iii.XXIII & 53 & 29 \\
\hline
\end{tabular}

${ }^{532}$ Os números sublinhados referem-se às cartas da correspondência passiva de Hus. 


\begin{tabular}{|c|c|c|c|c|c|c|}
\hline $\begin{array}{l}\text { Neste } \\
\text { Trabalho }\end{array}$ & $\begin{array}{l}\text { Monumenta } \\
\text { (1558;1715): } \\
\text { páginas }\end{array}$ & $\begin{array}{l}\text { Bonnechose } \\
\text { (1846) }\end{array}$ & $\begin{array}{l}\text { Documenta } \\
\text { (1869) }\end{array}$ & $\begin{array}{l}\text { Workman \& } \\
\text { Pope (1904) }\end{array}$ & $\begin{array}{l}\text { Korespondence } \\
\text { (1920) }\end{array}$ & $\begin{array}{l}\text { Spinka } \\
\text { (1972) }\end{array}$ \\
\hline 30 & i.94;118 & IV & 26 & iii.XXVI & 52 & 30 \\
\hline 31 & ausente & ausente & 11 & ii.XI & 54 & 31 \\
\hline 32 & i. $98 ; 123$ & XI & 21 & iii.XXI & 55 & 32 \\
\hline 33 & ausente & ausente & 30 & iii.XXX & 58 & 33 \\
\hline 34 & ausente & ausente & $\begin{array}{l}29+ \\
28\end{array}$ & $\begin{array}{l}\text { iii.XXIX + } \\
\text { iii.XXVIII }\end{array}$ & 60 & 34 \\
\hline $34 a$ & ausente & ausente & 25 & iii.XXV & 57 & Ap 3 \\
\hline 35 & ausente & ausente & 27 & iii.XXVII & 63 & 35 \\
\hline 36 & ausente & ausente & 31 & iii.XXXI & 67 & 36 \\
\hline 37 & i. $99 ; 124$ & XIII & 18 & iii.XVIII & 69 & 37 \\
\hline 38 & i. $98 ; 123$ & $\mathrm{X}$ & 20 & iii.XX & 70 & 38 \\
\hline 39 & i. $99 ; 124$ & XII & 22 & iii.XXII & 71 & 39 \\
\hline 40 & i. $97 ; 122$ & VIII & 24 & iii.XXIV & 72 & 40 \\
\hline 41 & ausente & ausente & 32 & iii.XXXII & 74 & 41 \\
\hline 42 & $\begin{array}{l}\text { i. } 2 \\
\text { ausente }\end{array}$ & ausente & $\begin{array}{l}33 \\
34^{533}\end{array}$ & $\begin{array}{l}\text { nota às pp. } \\
140-141 \text { e nota } \\
1\end{array}$ & 76 & 42 \\
\hline 43 & i. 283 & ausente & 35 & $\begin{array}{l}\text { nota às pp. } \\
141-142\end{array}$ & 78 & 43 \\
\hline 44 & ausente & ausente & 36 & iv.XXXIII & 81 & 44 \\
\hline 45 & i. $57 ; 72$ & $2 . I$ & 38 & iv.XXXV & 86 & 45 \\
\hline 46 & i. $57 ; 72$ & 2.II & 37 & iv.XXXIV & 87 & 46 \\
\hline 47 & (?) & ausente & ausente & ausente & 89 & 47 \\
\hline 48 & i. $57 ; 73$ & $2 . I I I$ & 39 & iv.XXXVI & 93 & 48 \\
\hline$\underline{48 a}$ & i. $58 ; 73$ & $2 . I V$ & 42 & pág. $162+$ & (?) & ausente \\
\hline 49 & i. 59 & $2 . I X$ & 92 & Ap. A & 95 & 49 \\
\hline 50 & i. $58 ; 74$ & $2 . \mathrm{V}$ & 40 & iv.XXXVII & 96 & 50 \\
\hline 51 & i. $58 ; 74$ & $2 . \mathrm{VI}$ & 41 & iv.XXXVIII & 97 & 51 \\
\hline 52 & i. $58 ; 75$ & 2.VII & 43 & iv.XXXIX & 100 & 52 \\
\hline 53 & i.72;91 & ausente & 45 & v.XLI & 103 & 53 \\
\hline 54 & i. $74 ; 94$ & $2 . \mathrm{XV}$ & 50 & v.XLV & 104 & 54 \\
\hline$\underline{55}$ & i.72;91 & 2.XXVI & 46 & pág. 169+ & 105 & 55 \\
\hline 56 & i.72;91 & 2.XXVII & 51 & v.XLVI & 106 & 56 \\
\hline
\end{tabular}

${ }^{533}$ A versão presente em [spk] relaciona-se com a versão "tcheca" apresentada por [wpo] na nota 1 da página 140. No Documenta, de Palacký, há duas versões diferentes (apresentadas por [wpo]), uma em latim e outra em tcheco. A primeira numeração apresentada é a em latim e a segunda em tcheco. 


\begin{tabular}{|c|c|c|c|c|c|c|}
\hline $\begin{array}{l}\text { Neste } \\
\text { Trabalho }\end{array}$ & $\begin{array}{l}\text { Monumenta } \\
\text { (1558;1715): } \\
\text { páginas }\end{array}$ & $\begin{array}{l}\text { Bonnechose } \\
\text { (1846) }\end{array}$ & $\begin{array}{l}\text { Documenta } \\
\text { (1869) }\end{array}$ & $\begin{array}{l}\text { Workman \& } \\
\text { Pope (1904) }\end{array}$ & $\begin{array}{l}\text { Korespondence } \\
\text { (1920) }\end{array}$ & $\begin{array}{l}\text { Spinka } \\
\text { (1972) }\end{array}$ \\
\hline 57 & i. $74 ; 94$ & 2.XIII & 47 & v.XLII & 108 & 57 \\
\hline 58 & i.60;76 & 2.XI & 44 & v.XL & 109 & 58 \\
\hline 59 & i.71;90 & $2 . X$ & 48 & v.XLIII & 110 & 59 \\
\hline 60 & i.72;92 & 2.XIX & 49 & v.XLIV & 111 & 60 \\
\hline 60a & i. $71 ; 90$ & 2.XXI & 53 & pág. 191+ & 115 & Ap 4 \\
\hline 61 & $\begin{array}{l}\text { i.73;93 } \\
\text { i. } 71 ; 90\end{array}$ & $\begin{array}{l}\text { 2.XII + } \\
2 . \mathrm{XX}\end{array}$ & $\begin{array}{l}57 \\
52\end{array}$ & $\begin{array}{l}\text { v.XLVII + } \\
\text { v.XLVIII }\end{array}$ & 114 & 61 \\
\hline 62 & i.71;91 & 2.XXII & 54 & v.XLIX & 116 & 62 \\
\hline$\underline{62 a}$ & i.73;93 & 2.XXIII & 55 & pág. 196+ & (?) & ausente \\
\hline 63 & i.73;93 & 2.XXIV & 56 & v.L & 118 & 63 \\
\hline 64 & i. $75 ; 95$ & 2.XVII & 58 & v.LI & 120 & 64 \\
\hline 65 & i. $75 ; 95$ & 2.XVI & 59 & 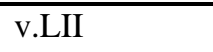 & 121 & 65 \\
\hline 66 & (?) & ausente & ausente & ausente & ausente & 66 \\
\hline 67 & ausente & ausente & 68 & vi.LXI & 122 & 67 \\
\hline 68 & i.69;88 & 2.XXIX & 63 & vi.LIV & 124 & 68 \\
\hline 69 & i.69;88 & 2.XXX & 66 & vi.LVIII & 125 & 69 \\
\hline 70 & i. $68 ; 87$ & 2.XXXIII & 67 & vi.LIX & 126 & 70 \\
\hline 71 & i. $70 ; 90$ & 2.XXXV & 69 & vi.LXII & 127 & 71 \\
\hline 72 & i.69;88 & 2.XXV & 60 & vi.LIII & 128 & 72 \\
\hline 73 & i.60;76 & 2.XXXVI & 71 & vi.LXIV & 129 & 73 \\
\hline 74 & i. $65 ; 83$ & 2.XXXIV & 72 & vi.LXV & 130 & 74 \\
\hline 75 & i. $68 ; 87$ & 2.XXXII & 70 & vi.LXIII & 131 & 75 \\
\hline 76 & i.66;84 & 2.XXXVIII & 73 & vi.LXVI & 132 & 76 \\
\hline 77 & (?) & ausente & ausente & ausente & 133 & 77 \\
\hline 78 & i. $70 ; 89$ & 2.XLI & 75 & vi.LXVII & 136 & 78 \\
\hline$\underline{79}$ & i. $70 ; 89$ & 2.XLII & 76 & pág. 240 & 137 & 79 \\
\hline 80 & i.70;90 & 2.XLIV & 77 & vi.LXVIII & 138 & 80 \\
\hline 81 & i.63;81 & 2.XVIII & 78 & vi.LXIX & 139 & 81 \\
\hline 82 & i. $64 ; 82$ & 2.XXXVII & 79 & vi.LXX & 140 & 82 \\
\hline 83 & i. $62 ; 80$ & 2.XXXIX & 80 & vi.LXXI & 141 & 83 \\
\hline 84 & (?) & ausente & ausente & ausente & 142 & 84 \\
\hline 85 & i.67;86 & 2.XL & 84 & vi.LXXV & 143 & 85 \\
\hline 86 & i. $67 ; 85$ & 2.XLIV & 82 & vi.LXXIII & 145 & 86 \\
\hline 87 & i.61;78 & 2.XLVII & 83 & vi.LXXIV & 147 & 87 \\
\hline 88 & (?) & ausente & ausente & ausente & 149 & 88 \\
\hline 89 & i. $68 ; 86$ & 2.XLIII & 61 & vi.LX & 150 & 89 \\
\hline
\end{tabular}




\begin{tabular}{|c|c|c|c|c|c|c|}
\hline $\begin{array}{l}\text { Neste } \\
\text { Trabalho }\end{array}$ & $\begin{array}{l}\text { Monumenta } \\
(1558 ; 1715): \\
\text { páginas }\end{array}$ & $\begin{array}{l}\text { Bonnechose } \\
(\mathbf{1 8 4 6 )}\end{array}$ & $\begin{array}{l}\text { Documenta } \\
(\mathbf{1 8 6 9 )}\end{array}$ & $\begin{array}{l}\text { Workman \& } \\
\text { Pope (1904) }\end{array}$ & $\begin{array}{l}\text { Korespondence } \\
\text { (1920) }\end{array}$ & $\begin{array}{l}\text { Spinka } \\
\text { (1972) }\end{array}$ \\
\hline 90 & i. $64 ; 82$ & 2.LV & 88 & vi.LXXIX & 152 & 90 \\
\hline 91 & i.60;77 & 2.L & 85 & vi.LXXVI & 153 & 91 \\
\hline 92 & i.63;80 & 2.LIV & 81 & vi.LXXII & 154 & 92 \\
\hline 93 & i.63;80 & 2.XLVIII & 87 & vi.LXXVIII & 155 & 93 \\
\hline 94 & i.62;79 & 2.XLIX & 86 & vi.LXXVII & 156 & 94 \\
\hline 95 & $(?)$ & ausente & ausente & ausente & 159 & 95 \\
\hline 96 & i. $66 ; 84$ & 2.XXVIII & 62 & vi.LVI & 160 & 96 \\
\hline 97 & $\begin{array}{l}\text { i. } 64 ; 82+ \\
\text { i. } 65 ; 83\end{array}$ & $\begin{array}{l}\text { 2.LIII + } \\
\text { 2.LII }\end{array}$ & $\begin{array}{l}89+ \\
90\end{array}$ & $\begin{array}{l}\text { vi.LXXX + } \\
\text { vi.LXXXI }\end{array}$ & 161 & 97 \\
\hline 98 & ausente & ausente & ausente & pág. 275+ & 162 & 98 \\
\hline 99 & i.65;84 & 2.XLV & 64 & vi.LV & 163 & 99 \\
\hline 100 & i. $65 ; 83$ & $\begin{array}{l}2 . \mathrm{LI}+ \\
2 . \mathrm{LVI}\end{array}$ & 91 & vi.LXXXII & 164 & 100 \\
\hline 101 & i. $62 ; 79$ & 2.XXXI & 65 & vi.LVII & 165 & 101 \\
\hline
\end{tabular}




\section{Apêndice 2. Tradução de duas cartas de Hus ${ }^{534}$}

\section{Carta 27}

Mestre Jan Hus, um clérigo ${ }^{535}$ e servo do Senhor Jesus, na esperança de sê-lo ${ }^{536}$, para todos os que amam a Deus verdadeiramente ${ }^{537}$, confessam sua lei, esperam que o Salvador apareça e com ele desejam viver para sempre. Graça e paz de Deus nosso Pai e do Senhor Jesus Cristo, que se entregou a si mesmo à morte ${ }^{538}$ pelos nossos pecados a fim de nos livrar deste mundo mau ${ }^{539}$ e da danação eterna, segundo a vontade de Deus Pai, a quem a glória para sempre. Amém. ${ }^{540}$

Meus bem-amados, fiquei sabendo do zelo e do progresso de vocês na palavra de Deus, o que agradeço a Ele com alegria ${ }^{541}$. Rezo para que nosso pai ${ }^{542}$ lhes dê a perfeita compreensão $^{543}$, de modo que, reconhecendo os artifícios e fraudes ${ }^{544}$ do Anticristo e de seus mensageiros ${ }^{545}$, vocês não se permitam o desvio da Sua ${ }^{546}$ verdade. $^{547}$

E tenho certeza que Ele, em sua misericórdia, completará em vocês o bom trabalho ${ }^{548}$ que começou ${ }^{549}$ e não permitirá que ${ }^{550}$ se extraviem de Sua verdade. Muitos ${ }^{551}$ a abandonaram

\footnotetext{
${ }^{534}$ As abreviaturas utilizadas nas notas de tradução são as seguintes: [nt] Nota do tradutor; [spk] Edição das cartas de Hus de Matthew Spinka; [bon] Edição das cartas de Hus de Émile de Bonnechose; [wpo] Edição das cartas de Hus de Workman e Pope; [bib] Bíblia de Jerusalém

535 [nt] substantivo presente apenas em [spk].

${ }^{536}$ [nt] "in hope", presente em todos os originais. Depois de vasculhar todas as fontes que dispunha não encontrei uma expressão idiomática que tivesse diferente sentido. O que me parece essa expressão, e que tentei transmitir no aposto incluído, é que Hus espera ser um servo de Jesus, digno, humilde ou mesmo verdadeiro, por exemplo. A expressão "assim espero", acho negativa demais para este trecho da carta.

${ }^{537}$ [nt] advérbio presente apenas em [spk].

538 [nt] ao sacrifício, para [wpo], como uma vítima, para [bon].

${ }^{539}$ [nt] preocupante, para [wpo], de aflições, para [bon].

${ }^{540}$ [spk] Paráfrase de Gl 1:3-5 [wpo] Paráfrase de Gl 1:4-5.

${ }^{541}[\mathrm{nt}]$ aposto presente apenas em [spk].

${ }^{542}$ [nt] há uma grande repetição da palavra "Deus" ou "Ele". Aqui, tentei uma substituição.

543 [nt] a iluminação, para [bon].

$544[\mathrm{nt}]$ as duas palavras aparecem apenas em [wpo]. Em [spk] aparece apenas a primeira, artifícios, enquanto em [bon] apenas a segunda, fraudes.

${ }^{545}$ [nt] ministros, para [wpo] e para [bon]. A palavra ministros, porém, pode trazer outro sentido que pode estar implícito nas palavras de Hus: pertencentes ao clero.

${ }^{546}$ [nt] "God" deste trecho não está presente em [bon].

${ }^{547}$ [nt] Não há quebra de parágrafo para [spk] neste momento.

${ }^{548}$ [nt] trabalho de regeneração, para [bon]
} 
por medo do perigo ${ }^{552}$, aterrorizados mais por alguns pobres infelizes do que por Deus todo poderoso, que tem o poder de matar e de dar a vida, de $\operatorname{condenar}^{553}$ e de $\operatorname{salvar}^{554}$, de resguardar seus servos fiéis da tentação ${ }^{555}$ e de lhes dar a vida eterna de imensa alegria em troca de um breve instante ${ }^{556}$ de sofrimento.

Não se aflijam, portanto, meus bem-amados, nem sintam medo ${ }^{557}$ se alguns de vocês são testados por Deus que permite que os ministros ${ }^{558}$ do Anticristo lhe aterrorizem com sua tirania $^{559}$. Pois Deus Pai diz a cada um de seus filhos ${ }^{560}$ nos provérbios de Salomão, terceiro capítulo: "Não te assustará o terror imprevisto, nem o ataque dos maus sobre você ${ }^{561}$. Pois o senhor ficará ao teu lado ${ }^{562}$ e guardará o teu pé da armadilha." ${ }^{, 563} \mathrm{E}$, por meio do profeta ${ }^{564}$ Davi, ele diz a respeito de cada um de Seus servos que sofrer por Sua causa ${ }^{565}$ : "na angústia ${ }^{566}$ estarei com ele, eu o livrarei e o glorificarei" ${ }^{\circ 67}$.

${ }^{549}$ [spk] Fl 1:6 [bib] "e tenho plena certeza de que aquele que começou em vós a boa obra há de levá-la à perfeição até o dia de Cristo Jesus."

${ }^{550}[\mathrm{nt}]$ retirei o "vocês" na revisão.

${ }^{551}$ [spk] Hus faz alusão a Stanislav de Znojmo e Stephen Páleč, que abandonaram o movimento reformista.

552 [nt] "do perigo" não presente em [spk].

${ }^{553}$ [nt] destruir, para [wpo] e [bon].

${ }^{554}$ [spk] Ti 4:12 [bib] "Só há um legislador e juiz, a saber, aquele que pode salvar e destruir. Tu, porém, quem és para julgares o teu próximo?"

555 [nt] de grandes e graves perigos, para [wpo] e [bon]. Tentação parece-me uma interpretação de [spk].

${ }^{556}$ [nt] um minuto, para [spk]. Não me pareceu usual em português.

557 [nt] terror, para [wpo] e [bon].

558 [nt] servos, para [spk]. Utilizei a versão ministros, de [wpo] e [bon], porque a palavra servo em português possui um uso mais voltado a um ser passivo, diferente do que está implícito nesta frase a respeito da ação dos que os estão testando.

559 [nt] aterrorizam com intimidações, para [spk] e implícito na tradução escolhida.

${ }^{560}$ [nt] para um de seus servos, para [wpo] e semelhante a este em [bon]. Parece-me que [spk] faz interpretações "teológicas" em sua tradução. No caso: o que Deus disse para um de seus servos, diz para todos os seus filhos.

${ }^{561}$ [nt] a diferença entre a tradução da [bib] e a versão em inglês levou-me à opção de aproximar-me da última semelhante nos três tradutores - nas partes muito divergentes. Transcrevo os versículos da [bib] Pr 3:25-26: "não te assustará o terror imprevisto, nem a desgraça que cai sobre os ímpios. Pois Iahweh ficará ao teu lado e guardará o teu pé da armadilha."

${ }^{562}$ [nt] a transcrição bíblica termina aqui com “etc.” para [wpo].

563 [spk] e [wpo] Pr 3:25-26.

${ }^{564}$ [nt] epíteto não presente em [spk].

565 [nt] " a respeito de cada um de Seus servos que sofrer por Sua causa” presente apenas em [spk]. Não é comum esse tipo de explicação prévia nas citações de Hus.

${ }^{566}$ [nt] no dia do seu julgamento, para [bon].

${ }^{567}$ [spk] S1 91:15 [wpo] S1 90:15. Ver nota 229 (fora) 
Sabendo disso, meus queridos irmãos, "tende por motivo de grande alegria", com diz São Tiago, “o serdes submetidos a múltiplas provações, pois sabeis que a vossa fé, bem provada, leva à perseverança; mas é preciso que a perseverança produza uma obra perfeita, a fim de serdes perfeitos e íntegros sem nenhuma deficiência." ${ }^{, 568}$ E mais adiante ele diz: "Bemaventurado o homem que suporta com paciência a provação! Porque, uma vez provado, receberá a coroa da vida, que o Senhor prometeu aos que o amam."

Permaneçam, então, firmes na verdade que vocês aprenderam ${ }^{570}$ : tudo o que fizerem, façam-no como filhos de Deus. Acreditem, pois se o Cristo venceu ${ }^{571}$ vocês também vencerão. Lembrem-se daquele que resistiu à perseguição pelos pecadores e vocês não falharão em suas boas resoluções ${ }^{572}$. E também, "rejeitando todo fardo e o pecado que nos envolve, corramos com perseverança para o certame que nos é proposto, com os olhos fixos naquele que é o autor e realizador da fé, Jesus, que, em vez da alegria que lhe foi proposta, suportou a cruz, desprezando a vergonha, e se assentou à direita do trono de Deus."

Ele, o criador, o rei e o senhor de todo o mundo, sem que fosse necessário à sua divindade, fez-se humilde na humanidade. Isento de pecados ${ }^{574}$, ministrou fielmente a nós pecadores mesmo suportando fome, sede, frio, calor, cansaço ${ }^{575}$, falta de sono, trabalho duro na pregação ${ }^{576}$. Sofreu grandes insultos nas mãos dos bispos $^{577}$, sacerdotes e escribas que o chamaram de "glutão e beberrão", ${ }^{578}$ um louco possuído pelo demônio ${ }^{579}$, um sedutor e blasfemo $^{580}$, afirmando "este homem não vem de Deus"581. Declararam-no culpado de

\footnotetext{
${ }^{568}$ [spk] e [wpo] Tg 1:2-4 [nt] também citado na carta 1.V ou i.VIII ou I.17 (nota 191). Tanto [wpo] quanto [bon] apresentam paciência no lugar de perseverança.

${ }^{569}$ [spk] e [wpo] Tg 1:12. [nt] Não há quebra de parágrafo aqui para [wpo] nem para [bon].

${ }^{570}$ [nt] conhecem, para [wpo], o texto de [bon] não apresenta esta expressão, terminando em "firme na verdade".

${ }^{571}$ [nt] superar, conquistar.

${ }^{572}$ [nt] desejos, para [spk] e [wpo]. A versão de [bon] ofereceu uma palavra que resolveu minha dúvida com relação ao uso de desejo e ao sentido do trecho.

573 [spk] e [wpo] Hb 12:1-2.

574 [nt] culpa, para [spk]. Escolhi o termo "pecado" pelo contexto da frase e ligação "estética" com a palavra pecador que aparece em seguida.

575 [nt] "sorrow", para [spk], o que representa, até onde eu entendo, certa dor ou tristeza.

${ }^{576}$ [nt] a versão de [spk] apresenta algumas palavras que parecem fora do trecho e não estão presentes nas outras traduções. São elas: "in prayer, night watching" e mais à frente "flight”. De certa maneira, elas estão incorporadas no contexto das outras versões.

577 [wpo] Episcopis; o leitor notará isso.

${ }^{578}$ [spk] e [wpo] Mt 11:19.

${ }^{579}$ [wpo] Mt 11:18 [nt] embora eu não concorde, por não se referir a Jesus, mas a João.

${ }^{580}$ [nt] estes dois últimos adjetivos estão presentes apenas em [spk].
} 
heresia, excomungaram-no, conduziram-no para fora da cidade e o crucificaram como um homem maldito ${ }^{582}$.

Se os sacerdotes fizeram isso com aquele que curou todas as doenças por suas palavras, que sem dinheiro e sem preço ${ }^{583}$, expulsou os demônios, ressuscitou os mortos ${ }^{584}$, ensinou a lei de Deus em nada lhes prejudicando e que não pecou, a não ser pelo fato de ter exposto as maldades dos que o perseguiram, por que vocês estranham que os mensageiros ${ }^{585}$ do Anticristo de hoje, que são mais avarentos, mais tendentes à fornicação, mais cruéis e astutos do que os Fariseus ${ }^{586}$, perseguem Seus servos com calúnias, excomunhões, prisões e mortes $?^{587}$

Lembrem-se do que nosso rei, mestre, pai, amado irmão, criador supremo e Redentor misericordioso ${ }^{588}$ disse: "Se o mundo vos odeia, sabei que, primeiro, me odiou a mim. Se fôsseis do mundo, o mundo amaria o que era seu; mas, porque não sois do mundo e minha escolha vos separou do mundo, o mundo, por isso, vos odeia. Lembrai-vos da palavra que vos disse: O servo não é maior que seu senhor. Se eles me perseguiram, também vos perseguirão; se guardaram minha palavra, também guardarão a vossa. Mas tudo isso eles farão contra vós, por causa do meu nome, porque não conhecem quem me enviou."

Observem que aqui nós temos a profecia de nosso Salvador ${ }^{590}$ que seus eleitos sofreriam perseguição pelo mundo, por homens maus que não conhecem a Deus Pai e ao Senhor Jesus verdadeiramente. Embora eles digam que conhecem a Deus, por seus maus atos negam-no, como disse São Paulo para Tito. ${ }^{591592}$ Suas obras são visíveis: avareza, simonia, orgulho excessivo ${ }^{593}$ e fornicação, abandono e desprezo da Palavra de Deus, colocando suas

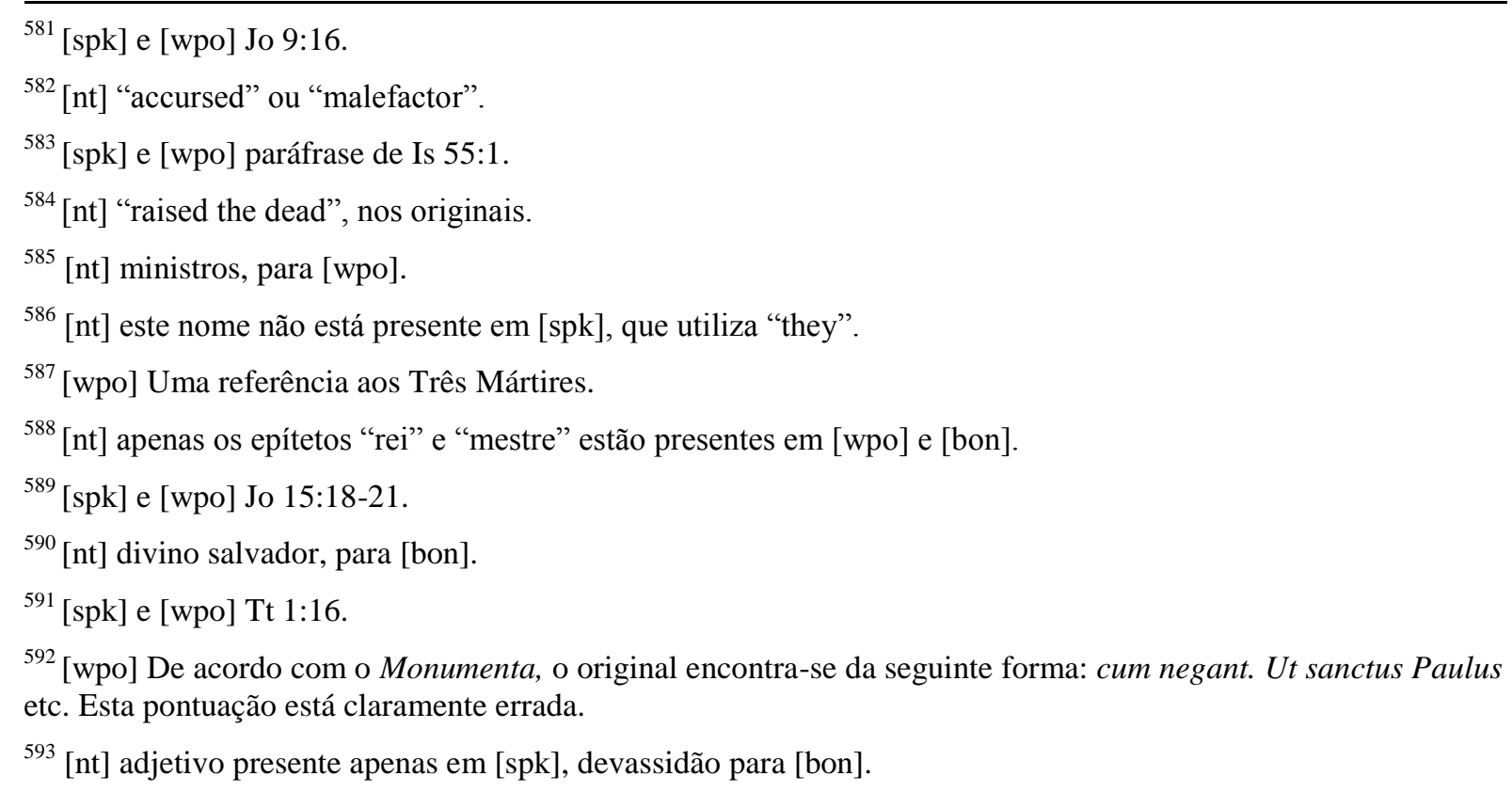


tradições acima da Sua lei e repudiando a humildade, a pobreza, a castidade ${ }^{594}$ e os sofrimentos $^{595}$ de Jesus. ${ }^{596}$

Os maus, portanto, não pararão de perseguir e os fiéis membros de Jesus não deixarão de sofrer ${ }^{597}$ enquanto continuar, neste mundo, a batalha entre o Cristo e o Anticristo. Pois disse São Paulo: “todos os que quiserem viver com piedade em Cristo Jesus serão perseguidos. Quanto aos homens maus e impostores, eles progredirão no mal, enganando e sendo enganados."

São Paulo quer dizer que todos os homens bons sofrerão em nome do Cristo Jesus, mas os homens maus continuarão a errar e a seduzir aos outros, satisfazendo, assim, seus desejos de agirem no mal ${ }^{599}$ para sua própria destruição. Destes, o Salvador profetizou, como um aviso para todos os eleitos ${ }^{600}$ : "Eis que eu vos envio como ovelhas entre lobos. Por isso, sede prudentes como as serpentes e sem malícia como as pombas. Guardai-vos dos homens: eles vos entregarão aos sinédrios e vos flagelarão em suas sinagogas... O irmão entregará o irmão à morte e o pai entregará o filho. Os filhos se levantarão contra os pais e os farão morrer. E sereis odiados por todos por causa do meu nome. Aquele, porém, que perseverar até o fim, esse será salvo. Quando vos perseguirem numa cidade, fugi para a outra. E se vos perseguirem nesta, tornais a fugir para a terceira. ${ }^{\circ 01}$ Porém, essa perseguição continuará até o dia do Julgamento. ${ }^{602}$ Ele continua: "Em verdade vos digo que não acabareis de percorrer as cidades de Israel até que venha o Filho do Homem. Não existe discípulo superior ao mestre, nem servo superior ao seu senhor. Basta que o discípulo se torne como o mestre e o servo como o seu senhor. Se chamaram Belzebu ao chefe da casa, quanto mais chamarão assim aos seus familiares! Não tenhais medo deles, portanto."603

Assim disse o Salvador para seus futuros ${ }^{604}$ discípulos de modo que eles pudessem escapar de tais armadilhas, confortando-os e os ensinando ${ }^{605}$ a reconhecerem os lobos

\footnotetext{
${ }^{594}[\mathrm{nt}]$ temperança, para [wpo] e [bon].

${ }^{595}$ [nt] amor, para [wpo] e [bon].

${ }^{596}$ [spk] e [wpo] Gl 5:19.

597 [nt] a expressão "e os fiéis membros de Jesus não deixarão de sofrer" está presente apenas em [spk].

${ }^{598}$ [spk] e [wpo] 2Tm 3:12-13.

${ }^{599}$ [nt] "agirem no mal" presente apenas em [wpo] e [bon].

${ }^{600}$ [nt] "como um aviso para todos os eleitos" presente apenas em [spk].

${ }^{601}$ [spk] e [wpo] Mt 10:16-17;21-23. [nt] observar referência à nota 136.

${ }^{602}$ [nt] O trecho que segue, continuando a citação até o final do parágrafo, não está presente em [bon].

${ }^{603}$ [spk] e [wpo] Mt. 10:23-26.

${ }^{604}[\mathrm{nt}]$ adjetivo presente apenas em [spk].
} 
famintos por meio de suas ações. Estes querem devorar o mundo inteiro com sua avareza. ${ }^{606}$ Ensinou, também, que os falsos profetas não concordam, em ações e em escritos ${ }^{607}$, com os verdadeiros profetas. Há falsos cristos que se dizem os principais discípulos do Cristo quando, na realidade ${ }^{608}$, eles são os seus principais inimigos. Eles fariam de tudo, com prazer ${ }^{609}$, para asfixiar a palavra de Deus porque é contrária ao seu orgulho, avareza, simonia, fornicação ${ }^{610}$ etc.

Primeiro, eles atacaram todas as capelas e locais de adoração ${ }^{611}$ para evitar que a Palavra de Deus fosse pregada nesses lugares ${ }^{612}$, mas o Cristo não permitiu tal crime. ${ }^{613}$ Agora, eu soube que eles decidiram destruir a Capela de Belém ${ }^{614}$ e proibiram a pregação nas igrejas onde sua iniquidade é denunciada. ${ }^{615}$ Mas eu confio em Deus que eles não obterão sucesso. Eles já espalharam suas armadilhas, com intimações e excomunhões, ${ }^{616}$ contra Ganso $^{617}$ e já pegaram muitos outros ${ }^{618}$. Mas, mesmo sendo o ganso um pássaro preguiçoso, doméstico e que não voa alto, suas redes já começaram a rasgar. Portanto, muitos outros pássaros que voam mais alto até Deus, com suas palavras ${ }^{619}$ e com suas vidas, irão, agora, despedaçá-las. Eles lançaram suas ameaças ${ }^{620}$ e suas excomunhões ${ }^{621}$ como a imagem de uma

\footnotetext{
${ }^{605}$ [nt] encorajando suas mentes, para [wpo].

${ }^{606}$ [nt] aqui há quebra de parágrafo para [wpo] e [bon].

${ }^{607}$ [wpo] Scripturis, no original. Ou se trata de uma licença (uso livre) ou uma versão errada de scriptis, ou talvez tenha sido atraído, se assim podemos dizer, pela precedente prophetis.

${ }^{608}$ [nt] em suas obras, para [wpo] e [bon].

${ }^{609}$ [nt] expressão presente apenas em [spk].

${ }^{610}$ [nt] e insubordinação, para [wpo].

611 [nt] "e locais de adoração" presente apenas em [wpo] e [bon].

${ }^{612}$ [spk] esta é uma referência à proibição do Papa Alexandre V, de 20 de dezembro de 1409, por meio da qual a pregação em todos os lugares exceto paróquias, catedrais e igrejas monásticas fosse proibida. Ver o meu livro John Hus: a biography, p. 107.

${ }^{613}$ [wpo] pelo parágrafo que se segue nós pudemos inferir a data. [nt] em relação a eventos descritos na página 79 de [wpo].

${ }^{614}$ [spk] a ordem papal para fazê-lo chegou a Praga antes do final de setembro de 1412.

${ }^{615}$ [nt] lugares onde a palavra de Deus é ensinada, para [wpo] e [bon].

${ }^{616}$ [nt] anátemas, para [wpo] e [bon].

${ }^{617}$ [bon] Hus, aqui, faz uma alusão ao seu próprio nome que significa Ganso, na região da Boêmia. [spk] Também pode ser entendido como "ganso", visto que é isso que seu nome significa. [nt] [bon] utilizou a expressão "simple bird", [wpo] utilizou "Goose" e [spk] "Hus". Preferi seguir a proposta de [wpo] por manter a "dúvida" e não utilizar uma auto-referência em terceira pessoa.

${ }^{618}$ [nt] "e agora esperam por alguns de vocês", na versão de [wpo].

${ }^{619}$ [nt] esta proposta tenta abarcar a dúvida de [spk] e as opções de [bon] e [wpo]. Para [spk], há uma palavra duvidosa, que ele apresenta entre colchetes (estaria ausente no original?): "escritos". Para [bon] e [wpo], é "voam mais alto com a Palavra de Deus...".
} 
ave de caça ${ }^{622}$ e atiraram uma flecha da aljava do Anticristo quando impediram os serviços $\operatorname{divinos}^{623}$ e a adoração. No entanto, quanto mais eles tentam esconder sua maldade ${ }^{624}$, mais eles a revelam. Quanto mais eles desejam ser livres, mais trabalho eles têm. ${ }^{625}$ Quanto mais eles se esforçam por espalhar suas tradições como redes, mais elas se rompem. E, na busca pela paz no mundo, eles a perderam junto com a paz espiritual. Querendo prejudicar aos outros, eles se machucam ainda mais. ${ }^{626}$

Eles padecem o mesmo destino dos sacerdotes e altos sacerdotes ${ }^{627}$ judeus, que perderam o que procuraram preservar e caíram na sua própria armadilha, tentando subjugar por completo $^{628}$ a verdade que sempre vence. Só que a verdade que eles quiseram eliminar tem a propriedade de brilhar mais forte sempre que se tenta apagá-la e de subir mais alto sempre que se tenta rebaixá-la, mesmo que às vezes caia ${ }^{629}$.

Os altos sacerdotes, os sacerdotes, os escribas, os fariseus ${ }^{630}$, Herodes, Pilatos e os cidadãos de Jerusalém ${ }^{631}$ condenaram a verdade, crucificaram-na e a puseram no túmulo ${ }^{632}$. Mas ela ressurgiu ${ }^{633}$ e conquistou a todos eles. E, no lugar de um único pregador, enviou doze e mais outros ${ }^{634} \cdot{ }^{635}$ Essa mesma verdade deu a Praga, no lugar de um fraco e medroso ganso,

\footnotetext{
${ }^{620}[\mathrm{nt}]$ "redes de ameaças", nos originais. Porém, removi a palavra rede para evitar repetições.

${ }^{621}$ [nt] idem nota 344.

${ }^{622}$ [nt] como uma armadilha de madeira, para [spk], como um falcão de madeira, para [wpo].

${ }^{623}$ [nt] a palavra de Deus, para [wpo] e [bon]. Parece-me que [spk] tenta interpretar mais e trazer o texto para os dias de hoje.

${ }^{624}$ [nt] sua verdadeira natureza, para [wpo] e [bon].

${ }^{625}$ [nt] esta frase (liberdade/trabalho) está presente apenas em [spk].

${ }^{626}$ [nt] eles falham bastante, para [wpo].

${ }^{627}$ [nt] bispos, para [spk]. Não utilizei sua sugestão por comparação com a nota 304.

${ }^{628}$ [nt] concordo com a sugestão de [spk] para substituir dois verbos: "overcome" e "crush", para [wpo] e "stifle" e "put down", para [bon]. Minha escolha por "subjugar", com sentido figurado, pois ela se refere a pessoa, foi para evitar os sentidos positivos de conquistar e sobrepujar, claramente ausentes na intenção das palavras de Hus.

${ }^{629}[\mathrm{nt}]$ "mesmo que às vezes caia" presente apenas em [spk].

${ }^{630}$ [nt] mestres, para [spk]. Também vale a mesma opção referida na nota 354.

${ }^{631}$ [nt] aqui [spk] incluiu "a comunidade", que achei muito estranho no contexto e, por isso, não acrescentei ao texto.

${ }^{632}$ [nt] embora tanto [spk] quanto [wpo] tenham utilizado o masculino, em referência a Jesus, seu nome está distante no texto. Pareceu-me forçado escrever "mataram-No", como sugeriram os tradutores mencionados. A interpretação de [bon] ofereceu uma versão clara e bonita para este trecho.

633 [nt] "subiu novamente", nos originais.

${ }^{634}$ [nt] "e mais outros" presente apenas em [spk]. [bon] inclui "da Palavra" a pregadores.

${ }^{635}$ [nt] [wpo] e [bon] realizam quebra de parágrafo aqui.
} 
muitas águias e falcões ${ }^{636}$, que possuem olhos aguçados, voam grandes alturas pela graça de Deus e habilmente capturam todos ${ }^{637}$ os outros pássaros para o rei ${ }^{638}$, senhor Jesus, que lhes dará a força e a todos os seus fiéis. Pois ele disse: "E eis que eu estou convosco todos os dias, até a consumação dos séculos ${ }^{639}$ !" ${ }^{640}$ Se Ele, o verdadeiro Deus ${ }^{641}$, o mais poderoso e seguro defensor, o rei e o mais generoso doador ${ }^{642}$ está conosco, quem nos vencerá na batalha ${ }^{643}$ ? Que medo nos separará dele? Ou que morte? ${ }^{644}$ O que nós perderemos se perdermos por Ele a riqueza, os amigos, a honra, o mundo ${ }^{645}$ e esta vida pobre? Com certeza, nós seremos libertados desta infelicidade, receberemos fortuna cem vezes mais esplêndida, amigos muito mais queridos e alegria mais perfeita, coisas que a morte não roubará de nós. Pois quem morre pelo Cristo, conquista, fica livre de todo o tormento e goza a eterna bem-aventurança. Que Jesus Cristo, o Salvador, conduza nós e os fiéis ${ }^{646}$ a tudo isso.

Escrevo-lhes esta carta, meus queridos irmãos e amadas irmãs, para que vocês se mantenham firmes na verdade que aprenderam. Não temam as intimações e não venham menos do que antes para ouvirem a Palavra de Deus por causa das ameaças cruéis que eles fazem. Pois “o Senhor é fiel ${ }^{647}$, e há de fortalecer-vos e guardar-vos do mal. ${ }^{648,, 649}$

Por último, suplico-lhes, meus bem-amados, que rezem por aqueles que proclamam a verdade de Deus em sua graça. Rezem, também, por mim, para que eu possa escrever e pregar

\footnotetext{
${ }^{636}$ [spk] Hus tem em mente Jakoubek de Strríbo, Nicholas e Peter de Dresden e os outros reformistas. [nt] observe o termo "reformista" de [spk].

${ }^{637}$ [nt] pronome presente apenas em [wpo].

${ }^{638}$ [nt] título presente apenas em [spk].

639 [nt] "do mundo", nas versões em inglês.

${ }^{640}$ [spk] e [wpo] Mt 28:20.

${ }^{641}$ [nt] "Se Deus", simplesmente, para [bon].

${ }^{642}$ [nt] "o rei e o mais generoso doador" presente apenas em [spk].

${ }^{643}$ [nt] [wpo] escolheu outra tradução: “quem, em sua maldade, seria capaz de nos vencer?” Sua justificativa pela escolha da palavra maldade ("malice") está justificada na nota que traduzimos a seguir. [wpo] No original, militia sua. Na versão do Monumenta encontramos malitia sua e a seguimos por causa do sua. Se não o fizéssemos, algo como "nesta guerra" estaria melhor.

${ }^{644}$ [spk] Reminiscência de Rm 8:38-39.

645 [nt] as honras do mundo, para [wpo] e [bon] no lugar de "a honra, o mundo". Não incluí o adjetivo "infeliz" que qualifica a palavra "mundo" para [spk], pois me pareceu "contaminação" pela pobreza da vida e desnecessária nesse contexto.

${ }^{646}[\mathrm{nt}]$ "e os fiéis" presente apenas em [spk].

${ }^{647}$ [wpo] Hb 10:23 [nt] embora haja a menção à fidelidade do senhor neste trecho, a citação de [spk] (nota 376) é mais precisa.

${ }^{648}$ [nt] Na [bib] a última palavra é "Maligno", porém, como a nota à esta palavra afirma que pode ser também "mal" e, nas versões em inglês está "evil", sem artigo e minúsculo, optei pela segunda opção.

${ }^{649}$ [spk] 2Ts 3:3.
} 
ainda mais contra as maldades do Anticristo e, quando for necessário ${ }^{650}$, que Deus me coloque na frente de batalha para defender sua verdade. ${ }^{651}$

Tenham certeza que eu não hesito entregar minha pobre vida ${ }^{652}$ pela verdade de Deus perante o perigo ou a morte, pois nada falta para nós em Sua palavra ${ }^{653}$ e, dia após dia, a verdade evangélica se espalha mais. No entanto, eu desejo viver por aqueles que sofrem a violência e precisam da pregação da Palavra de Deus, para que a maldade do Anticristo possa ser exposta e os devotos escapem dela. É por isso que eu estou pregando em outros lugares e exercendo o ministério para todos, sabendo que assim a vontade de Deus se realiza em mim, mesmo que eu morra ou caia doente pelas mãos do Anticristo ${ }^{654}$. Se eu for para Praga, os meus inimigos, que não servem a Deus e impedem os outros de servi-lo, com certeza, prepararão armadilhas para mim e perseguirão a vocês. Contudo, rezemos a Deus para que, se houver entre eles alguns dos escolhidos, que estes voltem-se para o conhecimento da verdade. ${ }^{655}$

Que Deus lhes dê a compreensão e a perseverança naquilo que eu thes escrevi e que Ele realize seus desejos em todo o bem ${ }^{656}$, pelos méritos de Jesus Cristo, que sofreu por nós ${ }^{657}$ a morte mais vergonhosa e cruel. Ele nos deixou seu exemplo ${ }^{658}$ para que nós soframos igualmente de acordo com Sua vontade. Amém.

$$
*_{-} *_{-} *
$$

\section{Carta 28}

Para todos os fiéis e zelosos pelo Senhor Jesus Cristo e por Sua palavra que vivem na cidade de Praga. Mestre Jan Hus, servo de Deus ${ }^{659}$, um sacerdote inútil, deseja-lhes ${ }^{660}$ perseverança no amor a Deus.

\footnotetext{
${ }^{650}$ [nt] "que é tão necessário", para [bon].

${ }^{651}$ [nt] não há quebra de parágrafo para [bon] aqui.

${ }^{652}$ [nt] corpo, para [wpo] e [bon].

${ }^{653}$ [nt] "a palavra de Deus não necessita de nós”, para [wpo], ou seja, ela se espalha sem que precisemos intervir.

${ }^{654}$ [nt] "morra pelas mãos do Anticristo ou na cama da doença", para [wpo].

${ }^{655}$ [nt] não há quebra de parágrafo para [bon] aqui.

${ }^{656}$ [nt] com toda bênção, para [wpo], que seu coração seja digno de todas estas bênçãos, para [bon].

${ }^{657}$ [spk] 1Pd 2:21.

${ }^{658}$ [wpo] 1Pd 2:21. [bib] "Com efeito, para isto é que fostes chamados, pois que também Cristo sofreu por vós, deixando-vos um exemplo, a fim de que sigais os seus passos."

${ }^{659}$ [nt] epíteto ausente em [wpo].
} 
Meus bem-amados, ${ }^{661}$ suplico-lhes, com toda a força de meu coração, ${ }^{662}$ que não abandonem a verdade que aprenderam e cujo conhecimento lhes foi generosamente concedido pelo misericordioso Salvador. Tenho certeza que o senhor levará à perfeição a obra que iniciou em vocês, seus escolhidos ${ }^{663}$, e dará a perseverança perante as tentações. ${ }^{664}$ Eu mesmo dependo da misericordiosa bondade de nosso Salvador, embora posso, neste momento, dizer com o apóstolo: "pois para mim o viver é Cristo e o morrer é lucro. Mas, se o viver na carne me dá a ocasião de trabalho frutífero, não sei bem o que escolher. Sinto-me num dilema: o meu desejo é partir e ir estar com Cristo, pois isso me é muito melhor, mas o permanecer na carne é mais necessário por vossa causa." ${ }^{665}$ Isto escreveu o apóstolo Paulo para os Filipenses, quando confinado a uma prisão em Roma. ${ }^{666}$

Da mesma maneira, digo-lhes, meus bem-amados, embora eu não esteja preso, preferia morrer com ${ }^{667}$ Cristo e estar com ele. No entanto, eu anseio trabalhar com vocês pela sua salvação. "O que escolher, não sei" ${ }^{\prime 668}$, espero pela misericórdia de Deus. De fato, temo que muitos males sejam cometidos contra vocês ${ }^{669}$, que os fiéis sofram e os maus, por isso, percam suas almas. Estes se alegram enquanto exigem não apenas que a Palavra de Deus seja silenciada em mim, mas também que o lugar dessa palavra, Belém, seja fechada com barras de madeira ${ }^{670}$. Permitirá o Deus onipotente que eles levem a cabo sua intenção? ${ }^{671}$ Porém, se Ele permitir que os criminosos causem sofrimento com seus atos, tal qual fizeram em Belém, onde ele nasceu, e em Jerusalém, onde ele nos redimiu, ${ }^{672}$ vamos, ainda assim, louvá-lo em

\footnotetext{
${ }^{660}[\mathrm{nt}]$ suplica, para [bon].

${ }^{661}$ [nt] Queridos amigos, para [wpo].

${ }^{662}$ [nt] com forte desejo, para [spk] e [wpo]; trecho ausente em [bon].

${ }^{663}$ [spk] Fl 1:6.

${ }^{664}$ [nt] todo este trecho está escrito na primeira pessoa do plural em [bon]. Por exemplo: "estou convencido que ele nos dará a perseverança e a força perante as tentações".

${ }^{665}$ [spk] Fl 3:21-24. [wpo] Fl 1:21-24. [nt] Está correto o apontamento de [wpo], ou seja, capítulo 1.

${ }^{666}$ [nt] não há mais quebra de parágrafo para [wpo] até o final do texto.

${ }^{667}$ [nt] por, para [wpo] e [bon].

${ }^{668}$ [wpo] ibidem [Fl. 1:21-24]

${ }^{669}$ [nt] surjam entre vocês, para [wpo] e [bon].

${ }^{670}$ [wpo] fuste. Para mais informações sobre o acidente, veja p. 79. [nt] a palavra latina refere-se à parte superior de um abesto (árvore).

${ }^{671}$ [nt] dar-lhes-á o que estão pedindo, para [wpo], se Deus não consentir, seus esforços serão em vão, para [bon].

${ }^{672}$ [nt] [bon] insere, aqui, o seguinte trecho: "que foram vistas soterradas até suas bases".
} 
sua graça, fazendo-nos humildes perante seu poder. Esse poder ${ }^{673}$, que está com aqueles que o amam, liberta os que sofrem em seu nome e reserva o fogo eterno para aqueles que o insultam.

Portanto, meus bem-amados ${ }^{674}$, suplico-lhes que não se entreguem ${ }^{675}$ ao cansaço, mas rezem ${ }^{676}$ para que o Salvador nos dê a perseverança para seguir o que for bom. ${ }^{677}$ Confiemos em sua imensa bondade, para que ele liberte Sua palavra e nos ajude contra o Anticristo, que eu guerrearei com a ajuda de suas preces e, se o Cristo assim desejar, tendo a Palavra de Deus como minha arma. ${ }^{678}$

A paz e o amor, o progresso em tudo o que for bom e a vida eterna em glória no outro mundo ${ }^{679}$ são o que desejo, de nosso Senhor Jesus Cristo, a vocês. Amém.

$$
*_{-} *_{-} *
$$

\footnotetext{
${ }^{673}$ [nt] as referências seguintes, para [wpo], são para Ele e não para Seu poder.

${ }^{674}$ [nt] queridos amigos no Senhor, para [wpo]. [bon] inicia com "para nós".

${ }^{675}$ [nt] "fail", nos originais.

${ }^{676}[\mathrm{nt}]$ implorem, para [wpo].

${ }^{677}$ [nt] na fé, para [bon].

${ }^{678}$ [nt] contra quem ele profetizou em suas santas Escrituras, para [bon]. A carta termina aqui, para [bon].

${ }^{679}$ [nt] daí em diante, para [spk].
} 